— Influência dos agentes climáticos de degradação no comportamento higrotérmico de fachadas em Brasília

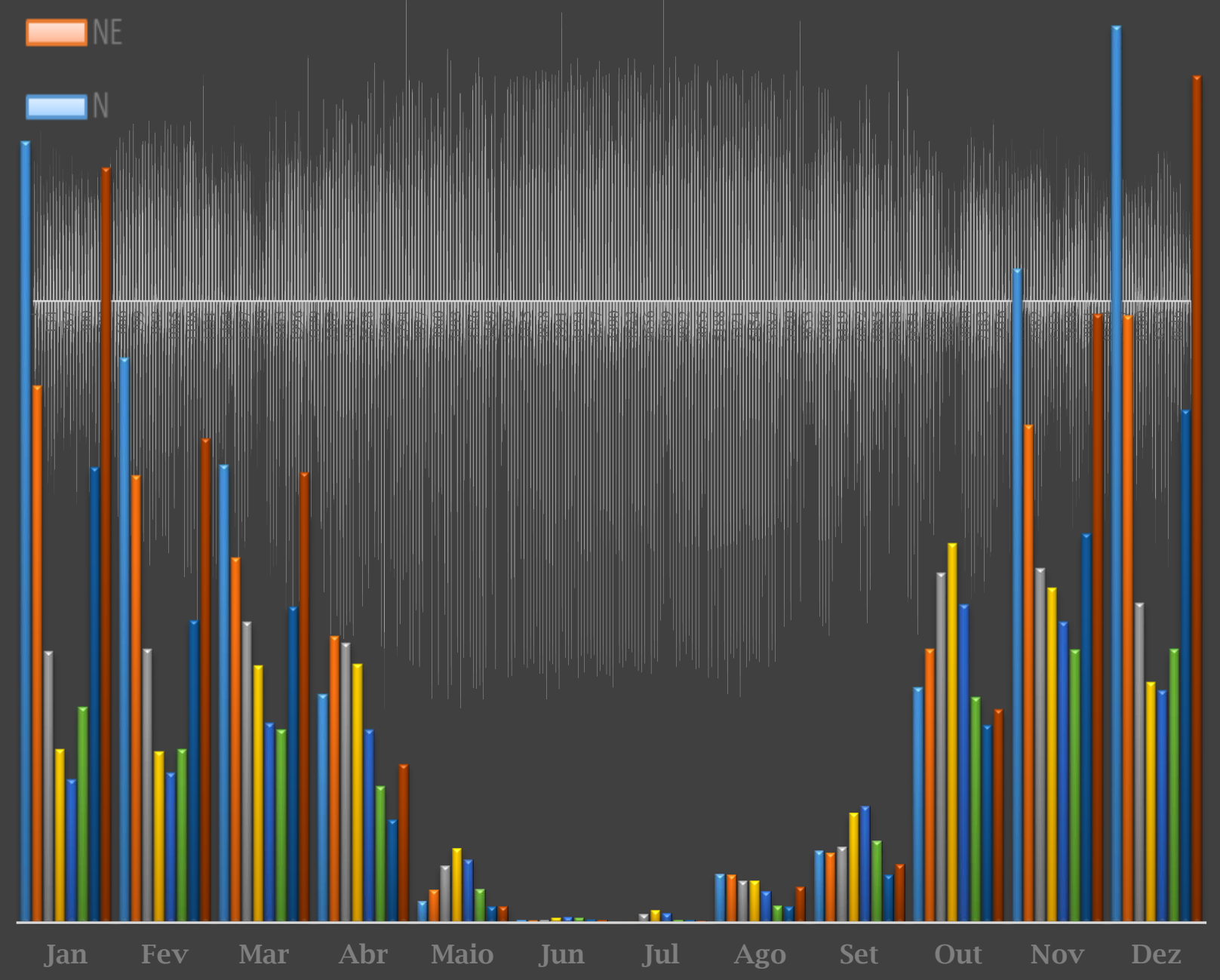




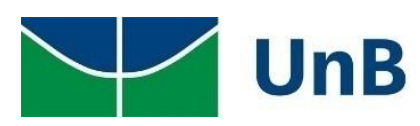

UNIVERSIDADE DE BRASÍLIA

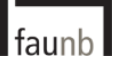

FACULDADE DE ARQUITETURA E URBANISMO

PROGRAMA DE PESQUISA E PÓS-GRADUAÇÃo EM ARQUITETURA E URBANISMO

Tese de Doutorado

INFLUÊNCIA DOS AGENTES CLIMÁTICOS DE DEGRADAÇÃO NO COMPORTAMENTO HIGROTÉRMICO DE FACHADAS EM BRASÍLIA

VANDA ALICE GARCIA ZANONI

ORIENTADOR: PROF. DR. JOSÉ MANOEL MORALES SÁNCHEZ COORIENTADOR: PROF. DR. ELTON BAUER

BRASÍLIA 


\section{INFLUÊNCIA DOS AGENTES CLIMÁTICOS DE DEGRADAÇÃO NO COMPORTAMENTO HIGROTÉRMICO DE FACHADAS EM BRASÍLIA}

Tese de Doutorado apresentada como requisito obrigatório para a obtenção do grau de Doutor pelo Programa de Pesquisa e Pós-Graduação em Arquitetura e Urbanismo da Faculdade de Arquitetura e Urbanismo da Universidade de Brasília.

Área de concentração:

Tecnologia, Ambiente e Sustentabilidade

Orientador: Prof. Dr. José Manoel Morales Sánchez Coorientador: Prof. Dr. Elton Bauer

\section{BRASÍLIA}


Ficha catalográfica elaborada automaticamente com os dados fornecidos pelo(a) autor(a):

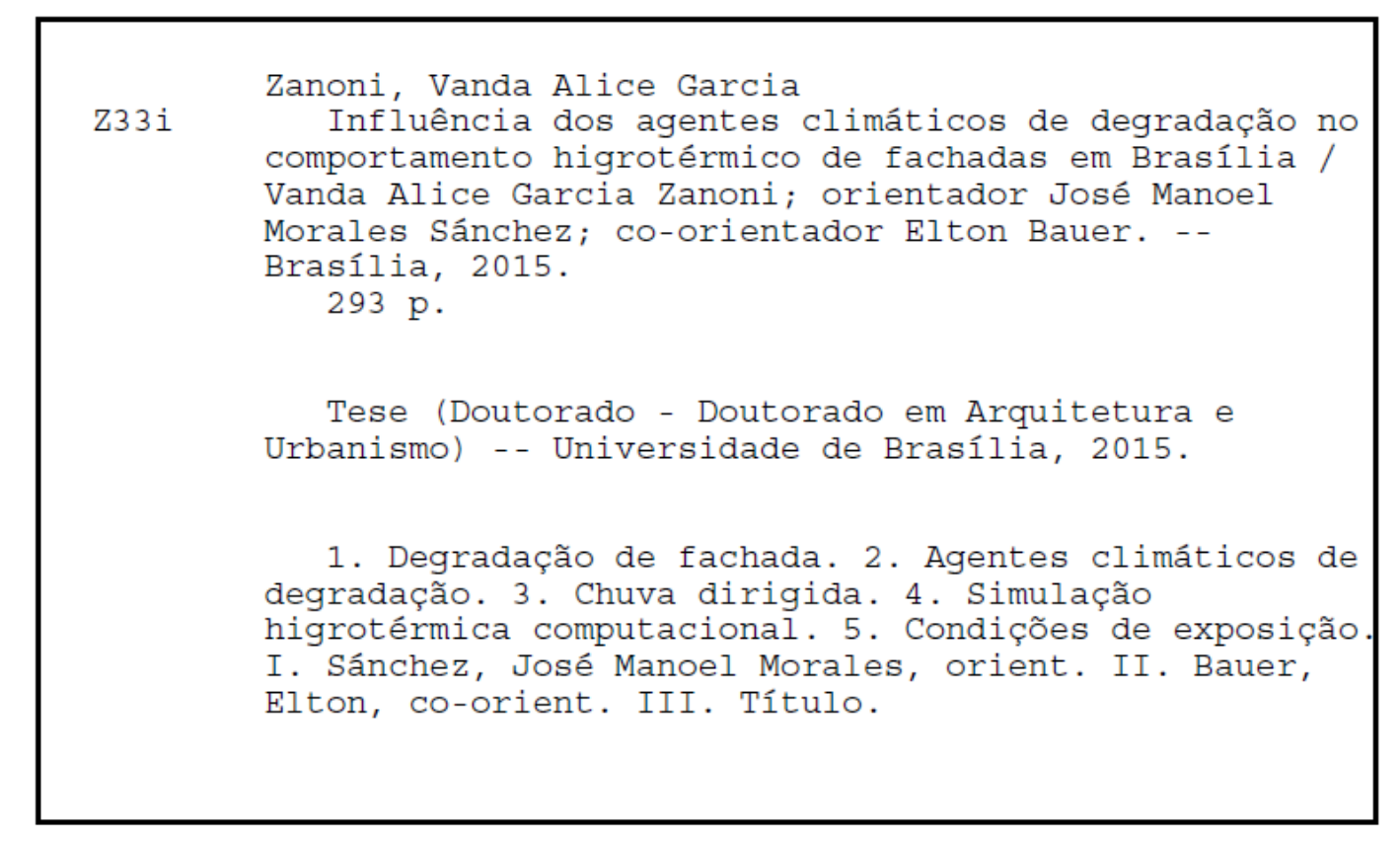

\section{REFERÊNCIA BIBLIOGRÁFICA}

ZANONI, V.A.G. (2015). Influência dos agentes climáticos de degradação no comportamento higrotérmico de fachadas em Brasília. Tese de Doutorado em Arquitetura e Urbanismo. Programa de Pós-Graduação da Faculdade de Arquitetura e Urbanismo da Universidade de Brasília, Brasília, DF, 293 p. 
Brasília, 03 de dezembro de 2015

Tese de Doutorado defendida no Programa de Pós-Graduação da Faculdade de Arquitetura e Urbanismo da Universidade de Brasília e aprovada pela Banca Examinadora constituída pelos membros:

Orientador

Prof. Dr. José Manoel Morales Sánchez

Departamento de Tecnologia da Arquitetura e Urbanismo

Faculdade de Arquitetura e Urbanismo FAU-UnB

Coorientador

Prof. Dr. Elton Bauer

Departamento de Engenharia Civil e Ambiental

Faculdade de Tecnologia FT-UnB

Examinador Interno

Profa. Dr. ${ }^{a}$ Cláudia Naves David Amorim Departamento de Tecnologia da Arquitetura e Urbanismo

Faculdade de Arquitetura e Urbanismo FAU-UnB

Examinador Externo

Profa. Dr. ${ }^{a}$ Eliane Kraus de Castro

Departamento de Engenharia Civil e Ambiental

Faculdade de Tecnologia FT-UnB

Examinador Externo

Profa. Dr. ${ }^{\text {a }}$ Maryangela Geimba de Lima

Divisão de Engenharia Civil

Instituto Tecnológico de Aeronáutica - ITA

Examinador Externo

Prof. Dr. Ercio Thomaz

Instituto de Pesquisas Tecnológicas - IPT 


\section{AGRADECIMENTOS}

Por tantas bênçãos que recebo na minha vida, obrigada Senhor!

Aos meus orientadores, prof. Sanchez e prof. Bauer, mais do que agradecimentos, a minha eterna gratidão, respeito e admiração.

Aos membros participantes da minha banca de defesa, pela honrosa presença e contribuições.

À profa. Cláudia Amorim, pelas oportunidades proporcionadas e apoio incondicional.

Ao Laboratório de Ensaio de Materiais - LEM da FT-UNB, pela disponibilização do programa de simulação computacional WUFI que foi patrocinado pelo engenheiro Paulo Henrique Vasconcelos da CiaImper Companhia da Impermeabilização.

Ao IPT - Instituto de Pesquisas Tecnológicas do Estado de São Paulo, em especial, aos pesquisadores Osmar Becere e Alexandre Cordeiro, agradeço imensamente a forma carinhosa e amiga com que me receberam, a oportunidade do aprendizado e das trocas de conhecimento durante o período de convívio.

À Dra. Selma Regina Maggiotto, professora de Agroclimatologia da UNB, pela generosidade e disponibilidade na instalação e controle da estação meteorológica automática portátil utilizada nas medições in situ na SQN 214.

Ao INMET-Instituto Nacional de Meteorologia e à equipe técnica e de funcionários, em especial, aos Dr. Antônio Divino Moura, Francisco de Assis Diniz e Andrea Ramos, pela logística para as minhas medições de chuva dirigida in situ, pelo acesso ao arquivo de dados meteorológicos horários de Brasília e por tantos esclarecimentos e apoio recebido.

Ao Prof. Maurício Roriz (in memorian), pela generosidade enriquecedora nas conversas e e-mails. À Sara Freitas, ao Prof. Vasco, ao Lamberts e ao Jorge de Brito, pelas valiosas contribuições.

Ao Prof. Albert Schiaveto de Souza, pela facilitação no aprendizado da Anova three way e no acesso ao Sigma Plot.

Ao bolsista Renan Filgueiras, pela grande ajuda nas macros das minhas planilhas eletrônicas. À bolsista Raissa Gramacho, pelos redesenhos fofos.

Aos meus queridos amigos e colegas da FAU-UNB, em especial, Márcio Buson, Janes, Caio, Daniel, Luna, Márcio Buzar, Oscar, Mônica, Cristiane, Carolina, Ricardo, Elane, Fernanda, Luciana, Ivan e Jaime, pelas boas conversas e ombro amigo.

Aos meus queridos amigos do PPG-FAU, PECC FT-UNB e LEM-FT, em especial, Luciana Azevedo, Katia Miller, Nazaré, Matheus, Maria Cláudia, Washington, Elier, Jéssica, Marcos, Roger, Samara e Flávio, pelo compartilhamento do conhecimento e solidariedade nas boas conversas.

À minha família e amigos (de lá e daqui) sempre solidários e presentes, meu amor incondicional. Aos meus pais Izabel e João, a quem devo tudo o que sou. 
"A maior ríqueza do homem é sua incompletude. Nesse ponto sou abastado. “ Manoel de Barros

"Um sonho que se sonha só, é só um sonho que se sonha só, mas sonho que se sonha junto é realidade. " 


\section{RESUMO}

Esta tese enquadra-se nos estudos da durabilidade e degradação de fachada, especialmente relacionados às condições de exposição da edificação, com ênfase nas ações externas de origem climática como agentes de degradação. Nos estudos sobre degradação de fachadas, as variações higrotérmicas estão entre os principais mecanismos responsáveis pelo envelhecimento natural das edificações. Existe uma importante barreira para o avanço nos estudos da durabilidade e degradação de fachadas relacionada à falta de dados disponíveis para análises mais detalhadas do envelhecimento natural decorrente dos agentes climáticos e mecanismos de degradação em sistemas de fachada. O objetivo geral desta tese foi avaliar a influência dos agentes climáticos de degradação no comportamento higrotérmico dos sistemas porosos de vedação vertical (alvenaria de bloco cerâmico e revestimento com argamassa), na cidade de Brasília-DF, com base na ação e interação entre os agentes externos de origem climática e o elemento de fachada, em cada uma das oito principais orientações, ao longo dos períodos seco e chuvoso do ano. Por meio da ferramenta computacional para simulação higrotérmica WUFI Pro 5.3, foram feitos os estudos do comportamento higrotérmico do sistema poroso de fachada. Com os resultados, foi possível estabelecer uma relação entre dose e resposta, com base nos agentes e mecanismos de degradação relacionados às variações higrotérmicas do sistema construtivo estudado. Os resultados mostraram que as fachadas sofrem influência das ações climáticas em diferentes graus de intensidade e frequência, dependendo das propriedades higrotérmicas dos componentes e das variações cíclicas e sazonais dos agentes climáticos que afetam o comportamento higrotérmico. $O$ teor de umidade total do elemento de fachada e a amplitude térmica na superfície da fachada mostraram-se indicadores eficazes para avaliar as condições de exposição aos agentes climáticos de degradação nas principais orientações de fachada (N, NO, L, SE, $\mathrm{S}, \mathrm{SO}, \mathrm{O}$ e NO). Entre as contribuições da tese, destacam-se os estudos realizados com o arquivo climático de 13 anos de dados horários medidos pela estação automática A001-Brasília. Destacam-se, também, os resultados do programa experimental de medições de chuva dirigida in situ, que permitiram quantificar coeficientes de chuva dirigida para as condições urbanas da cidade de Brasília.

Palavras-chave: Degradação de fachada. Agentes climáticos. Chuva dirigida. Simulação higrotérmica computacional. Variações higrotérmicas. Condições de exposição. 


\begin{abstract}
This thesis is part of the studies of durability and degradation of façade, especially related to exposure conditions of the building, with emphasis on climatic actions of external origin as degradation agents. In studies on façades degradation, the hygrothermal variations are among the main mechanisms responsible for the natural aging of the buildings. There is a major barrier to the advance in the study of durability and degradation of façade systems. This barrier refers to the lack of data available for a more detailed analysis of the natural aging, as results of climatic agents and degradation mechanisms. The overall objective of this thesis was to evaluate the influence of climatic degradation agents in the hygrothermal behavior of porous vertical systems (ceramic block masonry and facing by mortar), in Brasília-DF, based on the action and interaction among agents external climate origin and façade element, in each of the eight main orientations façade over the dry and rainy seasons of the year. Through computational tool for hygrothermal simulation WUFI Pro 5.3, there have been studies of hygrothermal behavior of the porous facade system. With the results, it was possible to establish a relationship between dose and response, based on the agents and degradation mechanisms related to hygrothermal variations of building system studied. The results showed that the facades are influenced climate actions in different degrees of intensity and frequency, depending on the hygrothermal properties of the components and the cyclical and seasonal variations in climatic agents that affect the hygrothermal behavior. The total moisture content of the facade element and the temperature range on the facade surface proved to be effective facadeindicators to assess the conditions of exposure to climatic degradation agents in the main orientations facade (N, NO, L, SE, S, SO, O and NO). Among the contributions of the thesis, we highlight the studies of the climate file with 13 years of hourly data measured by automatic station A001-Brasilia. Noteworthy are also the results of the experimental program of driving rain measurements addressed in situ, which allowed quantify driving rain coefficients directed to urban conditions of the city of Brasilia.
\end{abstract}

Keywords: Façade degradation. Climatic agents. Driving Rain. Hygrothermal computer simulation. Hygrothermal variations. Exposure conditions. 


\section{LISTA DE FIGURAS}

Figura 1.1 Campo conceitual do contexto temático da tese de pesquisa.

Figura 1.2 Curvas de degradação: evolução dos danos em função da idade para as

Figura 1.3 Organização das fases de desenvolvimento dos trabalhos de tese e etapas dos 16

$\begin{array}{llr}\text { Figura } 1.4 & \text { Estrutura da tese. } & 17\end{array}$

Figura 2.1 Média diária da irradiância solar global $\left(\mathrm{Wh} / \mathrm{m}^{2}\right)$ para Brasília. 26

Figura 2.2 Média diária da irradiância solar global $\left(\mathrm{Wh} / \mathrm{m}^{2}\right)$ para Brasília. 26

Figura 2.3 Média diária mensal da irradiância solar global $\left(\mathrm{Wh} / \mathrm{m}^{2}\right)$ para Brasília. 27

Figura 2.4 Umidade relativa (\%): frequência de ocorrência da série 2001-2013 para Brasília. 32

Figura 2.5 Frequência de ocorrência da umidade relativa (\%) da série 2001-2013 para 32

Figura 2.6 Umidade relativa (\%) da série 2001-2013 para Brasília: média mensal e por faixa 33

Figura 2.7 Perfil diário da pressão atmosférica (hPa) no verão e no inverno, em Brasília. $\quad 34$

Figura 2.8 Perfil anual das temperaturas horárias máximas e mínimas em ${ }^{\circ} \mathrm{C}$, registradas pela 36 estação automática de superfície A001-Brasília no ano de 2013.

Figura 2.9 Histogramas para as temperaturas horárias da série 2001 - 2013 para Brasília: a) 37

Temperatura média do ar $\left({ }^{\circ} \mathrm{C}\right)$; b) Temperatura máxima $\left({ }^{\circ} \mathrm{C}\right)$; c) Temperatura mínima $\left({ }^{\circ} \mathrm{C}\right)$.

Figura 2.10 Perfil diário da temperatura máxima $\left({ }^{\circ} \mathrm{C}\right)$ e da umidade relativa $(\%)$ para um dia 38 de inverno (24/07/2009), em Brasília.

Figura 2.11 Frequência de ocorrência por faixa de variação da amplitude térmica $\left({ }^{\circ} \mathrm{C}\right)$, em 39 Brasília.

Figura 2.12 Frequência de ocorrência (\%) por faixa de variação da média mensal da amplitude 39 térmica (AT em ${ }^{\circ} \mathrm{C}$ ) da série 2001-2013 para Brasília.

Figura 2.13 Irradiância solar após os efeitos atenuantes da atmosfera.

Figura 2.14 Gráficos das Normais Climatológicas 1961-1990 para as cidades de Brasília, São Paulo e Porto Alegre: a) nebulosidade; b) precipitação.

Figura 2.15 Nebulosidade: média mensal em Brasília.

Figura 2.16 Frequência de ocorrência (\%) da nebulosidade, conforme classificação da 43

Figura 2.17 Componentes da radiação solar. $\quad 44$

Figura 2.18 Composição da radiação global em função da nebulosidade: a) sob mesma 46

Figura 2.19 Média anual da radiação solar global horizontal diária $\left(\mathrm{kWh} / \mathrm{m}^{2}\right.$.dia), para o 47

Brasil.

Figura 2.20 Comportamento dos ventos ausentes e calmos ao longo das horas do dia para a 51 série 2001-2013 - Brasília.

Figura 2.21 Comportamento dos ventos ausentes e calmos ao longo dos meses do ano para a 51 série 2001-2013 - Brasília.

Figura 2.22 Frequência de ocorrência da velocidade dos ventos da série 2001-2013 - Brasília.

Figura 2.23 Frequência de ocorrência da direção dos ventos da série 2001-2013 - Brasília.

Frequencia de ocorrencia da direção dos ventos da série 2001-2013 - Brasília. Velocidade média mensal dos ventos em cada direção e mês do ano da série 53 2001-2013 - - Brasília.

Figura 2.26 Média mensal da velocidade do vento da série 2001-2013 - Brasília. 53

Figura 2.27 Média anual da velocidade do vento da série 2001-2013 para cada direção, em 53

Figura 2.28 Frequência de ocorrência dos ventos da série 2001-2013 - Brasília. 55

Figura 2.29 Composição da média mensal do vento da série 20011-2013 para Brasília, a partir 55 da contribuição de cada média mensal da velocidade do vento conforme a sua direção.

Figura 2.30 Frequência da velocidade dos ventos diurnos e noturnos (\%) nos períodos seco e chuvoso, em relação às classes de velocidade (m/s), da série 20011-2013 para 
Brasília.

Figura 2.31 Médias mensais das temperaturas das Normais Climatológicas 1961-1990 para

Brasília.

Figura 2.32 Médias mensais das temperaturas da série 2001-2013 para Brasília.

Figura 2.33 Médias mensais da velocidade do vento:

60

Normais Climatológicas 1961-1990 e série 2001-2013 para Brasília.

Figura 2.34 Médias mensais da precipitação (mm): Normais Climatológicas 1961-1990 e série 2001-2013 para Brasília.

Figura 2.35 Média mensal da umidade relativa do ar (\%): Normais Climatológicas do Brasil 1961-1990 e série 2001-2013 para Brasília.

Figura 2.36 Exemplo dos dados climáticos de irradiância solar global horizontal diária (Wh/m²), para o mês de abril da série 2001-2013 para Brasília: a) antes do tratamento, mostrando os dados horários espúrios ou inconsistentes; b) resultado depois dos dados tratados.

Figura 2.37 Exemplo dos dados climáticos de irradiância solar global horizontal diária (Wh/m²), para o mês de abril da série 2001-2013 para Brasília: a) antes do tratamento, mostrando uma sequência de dados horários espúrios; b) resultado depois dos dados tratados.

Figura 2.38 Irradiância solar global horizontal horária $\left(\mathrm{Wh} / \mathrm{m}^{2}\right)$, após a remoção de dados nulos e espúrios, em 13 anos de dados horários registrados pela estação A001Brasília.

Figura 2.39 Ciclo diário da irradiância solar global horizontal horária $\left(\mathrm{Wh} / \mathrm{m}^{2}\right)$ - mês de janeiro de 2013, em Brasília.

Figura 2.40 Irradiância solar global horizontal diária $\left(\mathrm{Wh} / \mathrm{m}^{2}\right)$ para 13 anos de dados registrados pela estação A001-Brasília ( 365 dias x 13 anos $=4745$ médias diárias).

Figura 2.41 Irradiância solar global horizontal diária $\left(\mathrm{Wh} / \mathrm{m}^{2}\right)$, após a remoção de valores abaixo da faixa limite de $2000 \mathrm{Wh} / \mathrm{m}^{2}$, para 13 anos de dados registrados pela estação A001-Brasília.

Figura 2.42 Média diária mensal da irradiância global horizontal $\left(\mathrm{kWh} / \mathrm{m}^{2}\right.$.dia): comparação entre dois arquivos climáticos de Brasília.

Figura 2.43 Média mensal diária da irradiância global horizontal $\left(\mathrm{kWh} / \mathrm{m}^{2}\right.$.dia) entre arquivos climáticos para Brasília.

Figura 2.44 Série 2001-2013 - Brasília: Intensidade de chuva dirigida (mm/ano).

Figura 2.45

Figura 2.46

Figura 2.47

TMY-EPW/ANTAC: Intensidade de chuva dirigida (mm/ano) para Brasília.

Unidades climáticas do Brasil: Climas Zonais (macroclima).

Figura 2.48

Escalas espaciais do clima no contexto de Brasília - DF.

Mapa para o Brasil: a) média anual da temperatura do ar $\left({ }^{\circ} \mathrm{C}\right)$; b) total anual da precipitação (mm).

Figura 3.1 Gráfico das médias mensais da precipitação no plano horizontal para Brasília, nos períodos 1961-1990, 1991-2000, 2001-2010 e 2001-2013.

Figura 3.2 Îndice de Chuva Dirigida - mensal para Brasília, nos períodos 1961-1990, 19912000, 2001-2010 e 2001-2013.

Figura 3.3 Situação geográfica do edifício na superquadra do Plano Piloto de Brasília: a) Plano Piloto; b) Superquadra.

Figura 3.4

Figura 3.5 Intensidade de chuva dirigida $\left(1 / \mathrm{m}^{2}\right)$ em Brasília: método ASHRAE. Intensidade de chuva dirigida $\left(1 / \mathrm{m}^{2}\right)$ em Brasília: método WUFI.

Figura 3.6 Intensidade de chuva dirigida $\left(1 / \mathrm{m}^{2}\right)$ em Brasília: método ISO 15927-3.

Figura 3.7 Intensidade de chuva dirigida em Brasília, conforme três métodos de dimensionamento.

Figura 3.8 Comparação entre três métodos de quantificação de chuva dirigida para a cidade de Brasília.

Figura 3.9 Dispositivo para medição de chuva em campo aberto, projetado em 1937 por Norwegian Building Research Institute.

Figura 3.10 Dispositivo para medição de chuva dirigida, projetado por National Research Council Canada.

Figura 3.11 Dispositivo para medição de chuva dirigida projetado pelos pesquisadores da Universidade do Porto (FEUP). 
Figura 3.12 Dispositivo para medição de chuva dirigida.

Figura 3.13 Dispositivo para medição de chuva dirigida.

Figura 3.14 Pluviômetro de báscula com contador de pulso.

Figura 3.15 a) Dispositivo de medição de chuva dirigida; b)dimensionamento do coletor; c) aparato no Campus da Swiss Federal Laboratories de Ciência dos Materiaise Tecnologia (APEM) em Dübendorf, Suiça.

Figura 3.16 Aparato de coleta de chuva dirigida em Brasília: a) bandeja coletora; b) recipiente coletor protegido pelo recipiente protetor (caixa térmica de isopor com tampa); c) provetas para medição.

Figura 3.17 Plano Piloto de Brasília: localização do Instituto de Meteorologia-INMET no Sudoeste e da SQN 214 na Asa Norte.

Figura 3.18 Sede do INMET em Brasília: localização dos aparatos de mediação de chuva dirigida.

Figura 3.19 Aparatos de coleta de chuva dirigida na sede do INMET em Brasília: 1-Fachada Noroeste; 2-Fachada Norte; 3- Fachada Nordeste; 4- Fachada Leste.

Figura 3.20 Bloco H - SQN 214 - Asa Norte - Brasília.

Figura 3.21 Posicionamento da estação meteorológica portátil na cobertura do Bloco H - SQN 214 em Brasília.

Figura 3.22 Cobertura do bloco H na SQN 214 em Brasília: a) torre da caixa d'água; b) posicionamento dos aparatos.

Figura 3.23 Bloco H - SQN 214 em Brasília: a) posicionamento nas paredes Leste e Norte em relação ao vértice; b) posicionamento da estação meteorológica portátil e dos dois aparatos na parede Norte.

Figura 3.24 Análise comparativa entre as medianas das amostras coletadas na Sede de do INMET, na SQN e os dados da série 2001-2013 da estação automática de superfície A001 em Brasília.

Figura 3.25 Coeficiente de chuva dirigida: amostra coletada na sede do INMET em Brasília, nas fachadas Norte, Nordeste, Leste e Noroeste.

Figura 3.26 Coeficiente de chuva dirigida: amostras coletadas nas fachadas Norte e Leste, na SQN 214 em Brasília.

Figura 3.27 Resultado do teste não paramétrico Wilcoxon para as duas amostras da fachada Norte na SQN 214.

Figura 3.28 Coeficiente de chuva dirigida: amostra coletada no Bloco H-SQN 214, fachadas Norte e Leste, em Brasília.

Figura 4.1 Estágios de umidificação e teor de umidade de um material. 136

$\begin{array}{lll}\text { Figura 4.2 Isotermas de Equilíbrio. } & 137\end{array}$

Figura 4.3 Curvas de transferência da água na fase líquida: absorção e redistribuição.

Figura 4.4 Expressões para resistência térmica do componente $(R t)$ e do sistema como um 146 todo $(R T)$.

$\begin{array}{lll}\text { Figura 4.5 } & \text { Etapas da fixação das moléculas de vapor de água nos poros. } & 148\end{array}$

$\begin{array}{llr}\text { Figura 4.6 } & \text { Fluxo de calor por condução. } & 152\end{array}$

Figura 4.7 Fluxo de calor por convecção.

$\begin{array}{llr}\text { Figura } 4.8 & \text { Espectro eletromagnético da radiação solar. } & 153\end{array}$

$\begin{array}{llr}\text { Figura 4.9 } & \text { Fluxo de radiação emitido pela superfície. } & 154\end{array}$

Figura 4.10 Balanço energético na fachada. 155

Figura 5.1 Limites toleráveis de resistência à difusão do vapor de água e do coeficiente de 187 absorção de água.

Figura 5.2 Esquema da metodologia empregada para a etapa simulação higrotérmica.

Figura 6.1 Média mensal da umidade relativa do ar e montante mensal de chuva dirigida 200

Figura 6.2 Representação gráfica do teor de umidade $\left(\mathrm{em} \mathrm{kg} / \mathrm{m}^{3}\right)$ das camadas do sistema SC1: a) Revestimento com argamassa A1 com capilaridade $A_{\text {valor }}=1,0 \mathrm{~kg} / \mathrm{m}^{2} \sqrt{\mathrm{h}}$; b) Base de alvenaria B1 (porosidade alta e densidade de massa aparente baixa).

Figura 6.3 Representação gráfica do teor de umidade $\left(\mathrm{em} \mathrm{kg} / \mathrm{m}^{3}\right)$ das camadas do sistema SC2: a) Revestimento com argamassa A3 com capilaridade $A_{\text {valor }}=2,5 \mathrm{~kg} / \mathrm{m}^{2} \sqrt{\mathrm{h}}$; b) Base de alvenaria B3 (porosidade baixa e densidade de massa aparente média).

Figura 6.4 Representação gráfica do teor de umidade $\left(\mathrm{em} \mathrm{kg} / \mathrm{m}^{3}\right)$ das camadas do sistema SC3: a) Revestimento com argamassa A2 com capilaridade $A_{\text {valor }}=0,1 \mathrm{~kg} / \mathrm{m}^{2} \sqrt{\mathrm{h}}$; 
Figura 6.5

Figura 6.6

Figura 6.7

Figura 6.8

Figura 6.9

Figura 6.10

Figura 6.11

Figura 6.12

Figura 6.13

Figura 6.14

Figura 6.15

Figura 6.16

Figura 6.17

Figura 6.18

Figura 6.19

Figura 6.20

Figura 6.21

Figura 6.22 b) Base de alvenaria B1 (porosidade alta e densidade de massa aparente baixa). Representação gráfica do teor de umidade $\left(\mathrm{em} \mathrm{kg} / \mathrm{m}^{3}\right)$ das camadas do sistema SC4: a) Revestimento com argamassa A1 com capilaridade $A_{\text {valor }}=1,0 \mathrm{~kg} / \mathrm{m}^{2} \sqrt{\mathrm{h}}$; b) Base de alvenaria B2 (porosidade baixa e densidade de massa aparente alta). Representação gráfica do teor de umidade $\left(\mathrm{em} \mathrm{kg} / \mathrm{m}^{3}\right)$ das camadas do sistema SC5: a) Revestimento com argamassa A2 com capilaridade $A_{\text {valor }}=0,1 \mathrm{~kg} / \mathrm{m}^{2} \sqrt{\mathrm{h}}$;

b) Base de alvenaria B2 (porosidade baixa e densidade de massa aparente alta). Representação gráfica do teor de umidade $\left(\mathrm{em} \mathrm{kg} / \mathrm{m}^{3}\right)$ das camadas do sistema SC6: a) Revestimento com argamassa A4 com capilaridade $A_{\text {valor }}=10,0 \mathrm{~kg} / \mathrm{m}^{2} \sqrt{\mathrm{h}}$; b) Base de alvenaria B1 (porosidade alta e densidade de massa aparente baixa). Representação gráfica do teor de umidade $\left(\mathrm{em} \mathrm{kg} / \mathrm{m}^{3}\right.$ ) das camadas do sistema SC7: a) Revestimento com argamassa A4 com capilaridade $A_{\text {valor }}=10,0 \mathrm{~kg} / \mathrm{m}^{2} \sqrt{\mathrm{h}}$;

b) Base de alvenaria B2 (porosidade baixa e densidade de massa aparente alta).

Comparação entre as médias do teor de umidade nas fachadas - período chuvoso.

Comparação entre as médias do teor de umidade nas fachadas - período seco.

Comparação entre as médias do teor de umidade dos sistemas construtivos período chuvoso.

Comparação entre as médias do teor de umidade dos sistemas construtivos período seco.

Irradiância solar na superfície da fachada e temperatura do ar exterior.

Variações de temperatura para $\Delta \mathrm{T}_{\mathrm{ch}}>8^{\circ} \mathrm{C}$, para intervalo de tempo de 1 hora.

Variações de temperatura para $\Delta \mathrm{T}_{\mathrm{ch}}>8^{\circ} \mathrm{C}$, para intervalo de tempo de 2 hora.

Variações de temperatura para $\Delta \mathrm{T}_{\mathrm{ch}}>15^{\circ} \mathrm{C}$, para intervalo de tempo de 2 hora.

Variações de temperatura para $\Delta \mathrm{T}_{\mathrm{ch}}>20^{\circ} \mathrm{C}$, para intervalo de tempo de 2 hora.

Comportamento das variações térmicas nos períodos seco e chuvoso.

Média da amplitude térmica na superfície da fachada no período chuvoso.

Média da amplitude térmica na superfície da fachada no período seco.

Média da amplitude térmica na superfície da fachada no período seco.

Média da amplitude térmica na superfície da fachada no período chuvoso.

\section{LISTA DE TABELAS}

Tabela 2.1

Tabela 2.2

Tabela 2.3

Tabela 2.4

Tabela 2.5

Tabela 2.6

Tabela 2.7

Tabela 2.8

Tabela 2.9

Tabela 2.10

Tabela 2.11

Tabela 2.12

Tabela 2.13

Tabela 2.14

Tabela 2.15

Tabela 2.16
Percentual de dados nulos dos arquivos climáticos de dados horários da série 2001 2013 registrados pelo INMET na estação automática de superfície A001 - Brasília. Precipitação (mm) da série 2001-2013 para Brasília.

Média mensal da umidade relativa do ar (\%) por período, em Brasília.

Frequência de ocorrência por faixa de umidade relativa (\%), em Brasília. Distribuição das horas com umidade relativa acima de 75\%UR, em Brasília.

Valores horários das temperaturas da série 2001-2013: Estação A001 do INMET, em Brasília - DF.

Amplitude térmica (AT) da série 2001-2013 para Brasília: médias mensais e frequência de ocorrência.

diárias em $\mathrm{kWh} / \mathrm{m}^{2}$ para Brasília.

Média mensal da Nebulosidade da série 2001-2013 para Brasília.

Condição de céu e frequência de ocorrência de nebulosidade da série 2001-2013 para Brasília.

Médias diárias da Irradiância Solar Global Horizontal - $I g \mathrm{em} \mathrm{Wh} / \mathrm{m}^{2}$.dia da série 2001-2013 para Brasília.

Direção predominante dos ventos.

Brasília.

Média mensal da velocidade do vento (m/s) da série 2001-2013 - Brasília. 
chuvoso e seco, para cada direção.

Tabela 2.17 Médias mensais das temperaturas $\left({ }^{\circ} \mathrm{C}\right)$ - Normais Climatológicas do Brasil 1961-

1990 para Brasília.

Tabela 2.18 Médias mensais das temperaturas - Série 2001-2013 para Brasília.

Tabela 2.19 Normais Climatológicas do Brasil 1961-1990: Ventos (m/s) para Brasília.

Tabela 2.20 Diferenças percentuais $(\%)$ entre as médias mensais da velocidade do vento $(\mathrm{m} / \mathrm{s})$

da série 2001-2013 e as Normais Climatológicas 1961-1990 para Brasília.

Tabela 2.21 Precipitação $(\mathrm{mm})$ para Brasília.

Tabela 2.22 Umidade relativa do ar (\%) para Brasília.

Tabela 2.23 Estatística descritiva dos arquivos climáticos TMY-EPW/ANTAC e série 20012013 para a variável Irradiância Global Horizontal para Brasília.

Tabela 2.24 Resultados estatísticos dos testes de hipótese: Teste T para duas amostras.

Tabela 2.25 Diferenças entre as médias mensais diárias da Irradiância Global Horizontal $\left(\mathrm{kWh} / \mathrm{m}^{2}\right)$ para Brasília.

Tabela 2.26 Médias mensais diárias da Irradiância Global Horizontal (Wh/m²), nos períodos seco e chuvoso, em Brasília.

Tabela 2.27 Diferenças entre as médias mensais diárias da Irradiância Global Horizontal $\left(\mathrm{Wh} / \mathrm{m}^{2}\right)$, no período chuvoso, em Brasília.

Tabela 2.28 Diferenças entre as médias mensais diárias da Irradiância Global Horizontal $\left(\mathrm{Wh} / \mathrm{m}^{2}\right)$, no período seco, em Brasília.

Tabela 2.29 Dados de nebulosidade e precipitação da série 2001-2013 para Brasília.

Tabela 2.30 Quantificação da ocorrência mensal de focos ativos de queimada detectados por satélite de referência, no período de 2001 a 2013, no Distrito Federal.

Tabela 2.31 Médias mensais das variáveis climáticas da série 2001-2013 registradas pela estação automática de superfície A001 do INMET em Brasília-DF.

Tabela 3.1 Índice de Chuva Dirigida ( $\left.\mathrm{m}^{2} / \mathrm{s}\right)$ obtidos por Estrela (2010) na localidade das estações meteorológicas 83377 e Estação 83378 - aeroporto, ambas situadas em Brasília-DF.

Tabela 3.2 Índice de Chuva Dirigida - período 1961-1990. Estação: 83377 - Brasília-DF.

Tabela 3.3 Índice de Chuva Dirigida - período 2001-2013. Estação automática de superfície A001- INMET - Brasília-DF.

Tabela 3.4 Índice de Chuva Dirigida - período 1991-2000. Vento (graus) - Primeira Predominância. Aeródromo Presidente Juscelino Kubitschek - Brasília-DF.

Tabela 3.5 Índice de Chuva Dirigida -período 1991-2000. Vento (graus) - Segunda Predominância. Aeródromo Presidente Juscelino Kubitschek - Brasília-DF.

Tabela 3.6 Índice de Chuva Dirigida - período 2001-2010. Vento (graus) - Primeira Predominância. Aeródromo Presidente Juscelino Kubitschek - Brasília-DF.

Tabela 3.7 Índice de Chuva Dirigida - período 2001-2010. Vento (graus) - Segunda Predominância. Aeródromo Presidente Juscelino Kubitschek - Brasília-DF.

Tabela 3.8 Método ASHRAE: média mensal da intensidade de chuva dirigida $\left(R b v \mathrm{em} 1 / \mathrm{m}^{2}\right)$, em Brasília.

Tabela 3.9 Método WUFI: média da mensal da intensidade de chuva dirigida $\left(R w d r \mathrm{em} 1 / \mathrm{m}^{2}\right)$, em Brasília.

Tabela 3.10 Método ISO 15927-3: média da mensal da intensidade de chuva dirigida ( Iws em $\left.1 / \mathrm{m}^{2}\right)$, em Brasília.

Tabela 3.11 Relação de eventos horários de precipitação horizontal nos meses de fevereiro e março, em Brasília

Tabela 3.12 Apresentação da amostra coletada na Sede do INMET e na estação automática de superfície A001 em Brasília.

Tabela 3.13 Apresentação da amostra coletada na estação portátil e na cobertura do Bloco H, SQN 214 - Brasília.

Tabela 3.14 Montantes de chuva dirigida obtidos em Brasília.

Tabela 3.15 Coeficientes e fatores de ajustes aplicados aos modelos analíticos de referência para quantificação da chuva dirigida em Brasília.

Tabela 6.1 Teor de umidade $\left(\mathrm{kg} / \mathrm{m}^{2}\right)$ : resultados da ANOVA de três vias para as interações entre orientações de fachada, períodos do ano e sistemas construtivos.

Tabela 6.2 Amplitude térmica na superfície exterior $\left({ }^{\circ} \mathrm{C}\right)$ : resultados da ANOVA de três vias para as interações entre orientações de fachada, períodos do ano e sistemas construtivos. 


\section{LISTA DE QUADROS}

Quadro 1.1 Agentes, ação e efeitos em ETICS - External Thermal Insulation Composite 6

System.

Quadro 2.1 Grau de intensidade da precipitação. $\quad 29$

Quadro 2.2 Valores absolutos das temperaturas da série 2001-2013/INMET Estação A001- 37

Brasília - DF.

Quadro 2.3 Classificação da nebulosidade. $\quad 40$

Quadro 2.4 Valores de Albedo. $\quad 46$

Quadro 2.5 Escala anemométrica Beaufort - velocidade equivalente na altura padrão de $10 \quad 49$

Quadro 2.6 Dados dos dias típicos de projeto para Brasília. $\quad 57$

Quadro 2.7 Apresentação dos parâmetros para dias típicos de verão e de inverno 58

e das médias da série 2001-2013 para Brasília.

Quadro 2.8 Resultado do estudo comparativo dos arquivos climático de Brasília: TMY/EPW-

ANTAC e Série 2001 - 2013 com dados horários medidos pelo INMET, em

Brasília.

Quadro 2.9 Extensões das escalas do clima.

Quadro 2.10 Dimensões das escalas temporais e espaciais do clima.

Quadro 3.1 Nível de exposição à chuva dirigida. 90

Quadro 3.2 Categorias do terreno e parâmetros para cálculo de Cr. 94

Quadro 3.3 Comprimento efetivo, $L_{\mathrm{e}}$. 95

$\begin{array}{llr}\text { Quadro } 3.4 & \text { Fator } W . & 95\end{array}$

Quadro 3.5 Valores do Fator de Obstrução $O$. 96

Quadro 3.6 Valores do fator de exposição Fe. $\quad 97$

Quadro 3.7 Valores do fator de deposição $F d . \quad 97$

Quadro 3.8 $\quad$ Altura do edifício e respectivo coeficiente $R_{2} .98$

Quadro 3.9 Faixas de agressividade propostas para o Índice de Chuva Dirigida mensal. 99

Quadro 3.10 Nível de exposição à chuva dirigida. $\quad 104$

Quadro 3.11 Matriz de análise da chuva dirigida para a cidade de Brasília-DF: Índices de Chuva 105 Dirigida mensais $(I C D)$ e as direções de vento mais agressivas.

Quadro 3.12 Apresentação dos resultados da quantificação de chuva dirigida pelo 108 método ASHRAE 160, no contexto de Brasília-DF.

Quadro 3.13 Apresentação dos resultados da quantificação de chuva dirigida pelo 109 método WUFI, no contexto de Brasília-DF.

Quadro 3.14 Apresentação dos resultados da quantificação de chuva dirigida pelo 110 método ISO 15927-3, no contexto de Brasília-DF.

Quadro 3.15 Determinação do coeficiente de chuva dirigida $(\alpha)$ para a amostra da 127 Sede do INMET em Brasília.

Quadro 3.16 Determinação do coeficiente de chuva dirigida $(\alpha)$ para a amostra do 130

Quadro 4.1 Absortância $(\alpha)$ para radiação solar (ondas curtas) e emissividade $(\mathcal{E}) \quad 143$ para radiações à temperaturas comuns (onda longas).

Quadro 4.2 Expressões e valores para o coeficiente superficial de transmissão por convecção (hc).

Quadro 4.3 Expressões para o coeficiente superficial de transmissão por radiação $(h r)$

Quadro 4.4 Resistência térmica superficial interna e externa. 145

$\begin{array}{ll}\text { Quadro 4.5 Natureza dos agentes de degradação. } & 159\end{array}$

Quadro 5.1 Modelos higrotérmicos e abrangência das propriedades dos materiais. 178

Quadro 5.2 Dados de entrada para o programa computacional higrotérmico WUFI. 180

Quadro 5.3 Dados de saída fornecidos pelo programa higrotérmico WUFI. 181

Quadro 5.4 Base de referência: propriedades higrotérmicas de argamassas e tijolos. 183

Quadro 5.5 Classificação do coeficiente de capilaridade dados pela ABNT NBR 13281. 185

Quadro 5.6 Faixas de referência das propriedades higrotérmicas dos materiais para simulação 187 computacional. 
Quadro 5.7 Componentes selecionados para as simulações higrotérmicas computacionais. 189

Quadro 5.8 Propriedades higrotérmicas das argamassas selecionadas. 190

Quadro 5.9 Propriedades higrotérmicas dos blocos cerâmicos selecionados. 193

Quadro 5.10 Estrutura analítica para a fase de pó-processamento. 196

Quadro 6.1 Variações do sistema construtivo de fachada para os estudos higrotérmicos. 199

Quadro 6.2 Comportamento do teor de umidade total - média mensal $\left(\mathrm{kg} / \mathrm{m}^{2}\right)$. 201

Quadro 6.3 Comportamento do teor de umidade total: máxima média diária do mês $\left(\mathrm{kg} / \mathrm{m}^{2}\right) . \quad 202$

Quadro 6.4 Comparação entre as médias do teor de umidade nos períodos seco e chuvoso. 210

Quadro 6.5 Comportamento da máxima temperatura superficial exterior mensal $\left({ }^{\circ} \mathrm{C}\right) . \quad 216$

Quadro 6.6 Comportamento da máxima amplitude térmica mensal na superfície exterior $(\Delta \mathrm{T} \quad 218$ em ${ }^{\circ} \mathrm{C}$ ).

Quadro 6.7 Frequência de ocorrência da máxima amplitude térmica mensal na superfície 220

Quadro 6.8 Comportamento das variações térmicas na superfície da fachada para intervalo de 225

$\begin{array}{lll}\text { Quadro 6.9 } & \text { tempo de } 2 \text { horas, considerando todos os eventos de um ano climático típico. } & 229\end{array}$ períodos seco e chuvoso. 


\section{SUMÁRIO}

1. INTRODUÇÃO 1

1.1. CONTEXTUALIZAÇÃO DO TEMA

1.2. ENQUADRAMENTO DA PESQUISA 4

1.3. PROBLEMATIZAÇÃO E QUESTÕES DE PESQUISA 11

$\begin{array}{lll}1.4 . & 12\end{array}$

$\begin{array}{ll}\text { 1.4.1. Objetivo geral } & 12\end{array}$

1.4.2. Objetivos específicos 12

$\begin{array}{lll}\text { 1.5. JUSTIFICATIVA } & 14\end{array}$

1.6. METODOLOGIA 15

1.7. ESTRUTURA DA TESE 16

2. AGENTES CLIMÁTICOS DE DEGRADAÇÃO DE FACHADA 19

2.1. CONSIDERAÇÕES INICIAIS 19

2.2. ARQUIVOS CLIMÁTICOS E FORMAS DE OBTENÇÃO 20

2.3. NORMAIS CLIMATOLÓGICAS 20

2.3.1. Estações meteorológicas e tipos de dados meteorológicos 22

2.4. ARQUIVOS CLIMÁTICOS DE DADOS HORÁRIOS PARA SIMULAÇÃO 24

2.4.1. Ano Climático de Referência (TRY - Test Reference Year) 24

2.4.2. Ano Meteorológico Típico (TMY - Typical Meteorological Year) 25

2.4.3. Metodologia da ISO15927-4 para um ano climático 25

2.4.4. Arquivos de ano climático disponíveis para Brasília 26

2.5. ESTUDO DAS VARIÁVEIS CLIMÁTICAS PARA BRASÍLIA 28

2.6. PRECIPITAÇÃO 29

2.7. UMIDADE RELATIVA DO AR 30

2.8. PRESSÃO ATMOSFÉRICA 34

2.9. TEMPERATURA DO AR 35

2.10. AMPLITUDE TÉRMICA 37

2.11. NEBULOSIDADE 40

2.12. RADIAÇÃO SOLAR GLOBAL HORIZONTAL 43

2.13. VENTO 48

2.14. DIA TÍPICO 56

2.14.1. Análise dos parâmetros de Brasília para os dias típicos de verão e de inverno 58

2.15. ANÁLISE DA SÉRIE 2001-2013 À LUZ DAS NORMAIS CLIMATOLÓGICAS 59

2.16. COMPARAÇÃO ENTRE ARQUIVOS CLIMÁTICOS DE IRRADIÂNCIA SOLAR 64 PARA BRASÍLIA

2.16.1. Conclusões sobre a comparação entre os arquivos climáticos de irradiância solar 73

2.17. REPRESENTATIVIDADE DO ARQUIVO CLIMÁTICO TMY-EPW/ANTAC 74

2.18. ESCALAS DO CLIMA 76

2.19. BRASÍLIA E O CLIMA LOCAL 79

2.20. ANÁLISE E CARACTERIZAÇÃO DAS VARIÁVEIS CLIMÁTICAS DE 81

2.21. CONSIDERAÇÕES FINAIS DO CAPÍTULO 82

ENCARTE 1 
3. ESTUDOS SOBRE CHUVA DIRIGIDA

3.1. $\quad$ CONSIDERAÇÕES INICIAIS 87

3.2. $\quad$ CHUVA DIRIGIDA 87

3.3. ÍNDICE DE CHUVA DIRIGIDA (ICD) 89

3.4. MÉTODOS DE QUANTIFICAÇÃO DE CHUVA DIRIGIDA 91

3.4.1. Método da ISO 15927-3 93

3.4.2. Método da ANSI/ASHRAE Standard 160

3.4.3. Método do WUFI 97

3.5. ESTUDOS BRASILEIROS SOBRE A CHUVA DIRIGIDA 98

3.6. DETERMINAÇÃO DO ÍNDICE DE CHUVA DIRIGIDA PARA BRASÍLIA 101

3.6.1. Apresentação e análise dos resultados do estudo sobre ICD para Brasília 101

3.6.2. Conclusões do estudo sobre ICD direcional-mensal para Brasília 105

3.7. COMPARAÇÃO ENTRE TRÊS MÉTODOS SEMI-EMPÍRICOS PARA 106

QUANTIFICAÇÃO DA CHUVA DIRIGIDA NAS FACHADAS EM BRASÍLIA

3.7.1. Conclusões do estudo comparativo entre os métodos de quantificação 111

3.8. MÉTODOS EXPERIMENTAIS PARA MEDIÇÃO DE CHUVA DIRIGIDA 113

3.8.1. Dispositivos para medição in situ $\quad 114$

3.8.2. Precisão e erro nas medições $\quad 115$

3.8.3. Referenciais metodológicos para quantificação da chuva dirigida a partir das medições 118

3.9. PROGRAMA EXPERIMENTAL PARA MEDIÇÃO IN SITU DE CHUVA 119 DIRIGIDA NA CIDADE DE BRASÍLIA-DF

$\begin{array}{ll}\text { 3.9.1. Objetivos do programa experimental } & 120\end{array}$

3.9.2. Descrição do aparato de coleta de chuva dirigida $r$

3.9.3. Localização dos aparatos de coleta de chuva dirigida $\quad 121$

3.9.4. Apresentação e discussão dos resultados do programa experimental de chuva dirigida 125

$\begin{array}{ll}\text { 3.9.5. Conclusões do programa experimental } & 131\end{array}$

3.10. CONSIDERAÇÕES FINAIS DO CAPÍTULO 133

4. COMPORTAMENTO HIGROTÉRMICO E DEGRADAÇÃO DE FACHADA 135

4.1. CONSIDERAÇÕES INICIAIS 135

4.2. PROPRIEDADES HIGROTÉRMICAS RELACIONADAS AO TRANSPORTE DE 135 CALOR E MASSA

4.2.1. Teor de umidade - W 135

4.2.2. Isotermas de Equilíbrio (Curvas Higroscópicas) 137

4.2.3. Coeficiente de transferência de água líquida - DW [m²/s] 138

4.2.4. Coeficiente de absorção de água líquida (coeficiente de capilaridade) $-\mathrm{A}_{\text {valor }}\left[\mathrm{kg} / \mathrm{m}^{2} \cdot \mathrm{h}^{1 / 2}\right] \quad 139$

4.2.5. Coeficiente de Permeabilidade $-\delta[\mathrm{kg} / \mathrm{m} . \mathrm{s} . \mathrm{Pa}] \quad 139$

4.2.6. Permeância ao vapor de água $-w\left[\mathrm{~kg} / \mathrm{m}^{2}\right.$.s.Pa $] \quad 140$

4.2.7. Fator de resistência à difusão do vapor de água - $\mu[-] \quad 140$

4.2.8. $\quad$ Espessura da camada de ar de difusão equivalente - Sd [m] 141

4.2.9. Porosidade aberta $-\varepsilon\left[\mathrm{m}^{3} / \mathrm{m}^{3}\right] \quad 141$

4.2.10. Densidade de massa $-\rho\left[\mathrm{kg} / \mathrm{m}^{3}\right] \quad 141$

4.2.11. Condutividade térmica - $\lambda(\mathrm{W} / \mathrm{m} . \mathrm{K}) \quad 142$

4.2.12. Calor especifico - c [J/kg.K] 142

4.2.13. Capacidade térmica - C $\left[\mathrm{kJ} / \mathrm{m}^{2} . \mathrm{K}\right] \quad 142$

4.2.14. Coeficiente de absorção (absortância) - $\alpha[-] \quad 142$

4.2.15. Emissividade - E [-] 143

4.2.16. Coeficiente superficial de transmissão de calor - h [W/m².K] 144

4.2.17. Resistência térmica superficial - Rs [m².K/W] 145 
4.2.18. Resistência térmica total $-\mathrm{R}_{\mathrm{T}}\left[\mathrm{m}^{2} . \mathrm{K} / \mathrm{W}\right] \quad 146$

4.2.19. Transmitância térmica - U [W/m².K] 146

4.3. MECANISMOS DE TRANSPORTE DE MASSA (UMIDADE) 147

4.3.1. Transporte de umidade por difusão de vapor de água $\quad 147$

4.3.2. Transporte de umidade por capilaridade 149

4.3.3. Transporte convectivo de ar no meio poroso $r$

4.4. UMIDIFICAÇÃO E SECAGEM 151

4.5. MECANISMOS DE TRANSPORTE DE CALOR 152

4.5.1. Fluxo de calor por condução $-q c d\left[\mathrm{~W} / \mathrm{m}^{2}\right] \quad 152$

4.5.2. Fluxo de calor por convecção $-q c v\left[\mathrm{~W} / \mathrm{m}^{2}\right] \quad 152$

4.5.3. Fluxo de calor por radiação - $\operatorname{qrad}\left[\mathrm{W} / \mathrm{m}^{2}\right] \quad 153$

4.5.4. Balanço energético na superfície da fachada 154

4.6. RADIAÇÃO SOLAR INCIDENTE NA FACHADA 156

4.7. TEMPERATURA NA SUPERFÍCIE DA FACHADA 156

4.7.1. Temperatura Equivalente (Temperatura Sol-Ar) 157

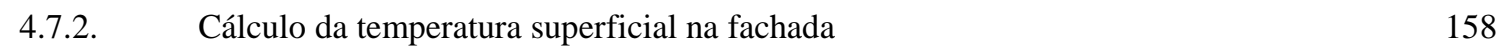

4.8. AGENTES E MECANISMOS DE DEGRADAÇÃO DE FACHADA 159

4.8.1. Movimentações térmicas nas fachadas 160

$\begin{array}{ll}\text { 4.8.2. } & 161\end{array}$

4.8.3. Choque térmico $\quad 162$

4.8.4. Umidade nas construções $\quad 163$

4.8.5. Movimentações higroscópicas 165

4.8.6. Condensações superficiais ou intersticiais 166

4.8.7. A ação do vento como agente de degradação da fachada 167

4.9. MANIFESTAÇÕES PATOLÓGICAS NAS FACHADAS DECORRENTES DOS 168

$\begin{array}{llr}\text { 4.9.1. } & \text { Fissuras } & 169\end{array}$

$\begin{array}{lr}\text { 4.9.2. Descolamento } & 169\end{array}$

$\begin{array}{ll}\text { 4.9.3. Destacamento } & 171\end{array}$

$\begin{array}{lr}\text { 4.9.4. Eflorescência } & 171\end{array}$

$\begin{array}{ll}\text { 4.9.5. Manchas } & 171\end{array}$

4.9.6. Perda da cor (desbotamento) 172

4.9.7. Deterioração de componentes de base orgânica 172

$\begin{array}{ll}\text { 4.9.8. Degradação biológica } & 173\end{array}$

4.10. CONSIDERAÇÕES FINAIS DO CAPÍTULO $\quad 173$

5. PROCEDIMENTOS METODOLOGICOS: ETAPA SIMULAÇÃO 175 HIGROTÉRMICA COMPUTACIONAL
CONSIDERAÇÕES INICIAIS

$\begin{array}{llr}\text { 5.1. } & \text { CONSIDERAÇÕES INICIAIS } & 175 \\ \text { 5.2. } & \text { WUFI - PROGRAMA DE SIMULAÇÃO COMPUTACIONAL DO } & 175\end{array}$

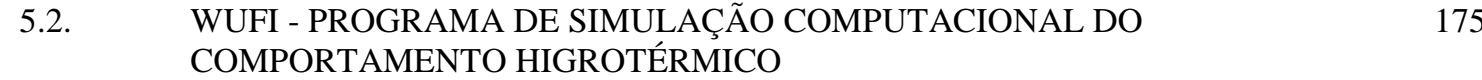

5.2.1. Considerações sobre o programa WUFI $\quad 177$

$\begin{array}{ll}\text { 5.2.2. Dados de entrada do programa WUFI } & 179\end{array}$

$\begin{array}{lr}\text { 5.2.3. Dados de saída do programa WUFI } & 180\end{array}$

5.2.4. Pós-processamento $\quad 182$

5.3. PROCEDIMENTOS PARA A SELEÇÃO DOS MATERIAIS PARA AS 182

5.4. APRESENTAÇÃO DOS COMPONENTES E SISTEMA CONSTRUTIVO 188

$\begin{array}{llr}\text { 5.4.1. } & \text { SELECIONADOS E SUAS PROPRIEDADES HIGROTÉRMICAS } & 189\end{array}$ 
5.4.2. Caracterização dos blocos cerâmicos 192

5.5. ESTRUTURA DE ANÁLISE E ESQUEMA DA METODOLOGIA EMPREGADA 194

5.6. PROCEDIMENTOS PARA ANÁLISE ESTATÍSTICA, APRESENTAÇÃO E 196

$\begin{array}{ll}\text { 5.7. } & \text { DISCUSSÁO DOS RESULTADOS } \\ \text { CONSIDERAÇÕES FINAIS DO CAPÍTULO } & 197\end{array}$

6. RESULTADOS DOS ESTUDOS HIGROTÉRMICOS 199

6.1. CONSIDERAÇÕES INICIAIS 199

6.2. ANÁLISE DO COMPORTAMENTO DO TEOR DE UMIDADE INFLUENCIADO 200

6.3. TEOR DE UMIDADE: ANÁLISE DAS INTERAÇÕES ENTRE SISTEMAS 207

CONSTRUTIVOS, ORIENTAÇÕES DE FACHADA E PERÍODOS DO ANO
6.4. ANÁLISE DO COMPORTAMENTO DA TEMPERATURA SUPERFICIAL EXTERNA INFLUENCIADO PELAS PROPRIEDADES DO SISTEMA DE FACHADA

6.5. ANÁLISE DO COMPORTAMENTO DA AMPLITUDE TÉRMICA NA SUPERFÍCIE DA FACHADA INFLUENCIADO PELAS PROPRIEDADES DO SISTEMA DE FACHADA

6.6. CHOQUE TÉRMICO

6.6.1. Análise das frequências de ocorrência dos eventos de variação térmica com intervalos de tempo de 1 hora e 2 horas

6.6.2. Análise do comportamento da variação térmica considerando resfriamento ou aquecimento da superfície da fachada durante os períodos do ano

6.7. AMPLITUDE TÉRMICA NA SUPERFÍCIE EXTERIOR: ANÁLISE DAS INTERAÇÕES ENTRE SISTEMAS CONSTRUTIVOS, ORIENTAÇÕES DE FACHADA E PERÍODOS DO ANO

6.8. CONSIDERAÇÕES FINAIS DO CAPÍTULO 233

ENCARTE 2 237

ENCARTE $3 \quad 239$

ENCARTE $4 \quad 241$

ENCARTE 5

7. CONCLUSÕES DA TESE 245

7.1. CONSIDERAÇÕES INICIAIS 245

7.2. OBJETIVOS ALCANÇADOS E CONTRIBUIÇÕES DA TESE 246

7.3. RESPONDENDO ÀS QUESTÕES DE PESQUISA 251

7.4. SUGESTÕES PARA TRABALHOS FUTUROS 253

REFERÊNCIAS

$\begin{array}{lr}\text { APENNDICE A } & 269\end{array}$

$\begin{array}{lr}\text { APÊNDICE B } & 277\end{array}$

APÊNDICE C 286 


\section{CAPÍTULO I}

\section{INTRODUÇÃO}

\subsection{CONTEXTUALIZAÇÃO DO TEMA}

A temática desta tese enquadra-se nos estudos da durabilidade e degradação de fachada, especialmente relacionados às condições de exposição da edificação, com ênfase no tema ações externas de origem climática como agentes de degradação.

A durabilidade ${ }^{1}$ passou a ser considerada como uma das exigências do usuário, desde 2013, com a aprovação do conjunto de normas de desempenho ${ }^{2}$. Uma das premissas impostas é que "as condições de exposição do edifício devem ser especificadas em projeto, a fim de possibilitar uma análise da Vida Útil de Projeto (VUP) e da durabilidade do edifício e seus sistemas" (ABNT, 2013a).

As condições de exposição da envoltória do edifício constituem-se em um conjunto de ações que afetam a sua durabilidade. As ações externas de origem climática estão entre os principais agentes de degradação que, agindo sobre o edifício, contribuem para reduzir o seu desempenho ao longo do tempo de vida útil, pois aceleram os mecanismos de envelhecimento natural que atuam nas fachadas (JERNBERG, 2004a; ABNT, 2013a).

Apesar de a influência dos agentes climáticos de degradação no processo de envelhecimento natural das edificações, as normas de desempenho ainda tratam esses fenômenos de forma geral e muito incipiente, quando comparados às normas internacionais. A chuva dirigida é um exemplo que ilustra bem essa situação. Mesmo constituindo-se como uma das principais fontes de umidificação das fachadas, a chuva dirigida não é mencionada em nenhuma norma brasileira.

Os sistemas de vedação vertical externo (SVVE) da envoltória edificada são constituídos pelas fachadas, que definem a volumetria da edificação. Influenciando e sendo influenciados pelo desempenho do conjunto edificado, os SVVE interagem com os demais componentes, elementos e subsistemas da edificação, como as estruturas, coberturas, esquadrias, instalações, pisos, entre outros (ABNT, 2013b).

\footnotetext{
${ }^{1}$ Segundo a NBR15575-1, são três as exigências dos usuários: Segurança, Habitabilidade e Sustentabilidade. A Sustentabilidade é uma exigência expressa por três fatores: durabilidade, manutenibilidade e impacto ambiental (ABNT, 2013a).

${ }^{2} \mathrm{O}$ conjunto de normas de desempenho foi publicada em 2013 pela ABNT - Associação Brasileira de Normas Técnicas e engloba seis partes: a) NBR15575-1; b) NBR15575-2; c) NBR15575-3; d) NBR15575-4; e) NBR15575-5; f) NBR15575-6.
} 
As fachadas exercem importantes funções para a durabilidade dos edifícios, entre elas, a estanqueidade à água. Considera-se como requisito de desempenho que as fachadas, seus elementos, componentes e junções, devem ser estanques à infiltração de água proveniente das chuvas ou de outras fontes de umidade. Outra importante função da fachada é proteger os ambientes interiores do clima exterior. Responsável pela proteção do edifício perante os agentes externos, os sistemas de fachada devem constituir-se em uma camada reguladora das cargas térmicas que agem na superfície da envoltória (OLIVEIRA, 2009; ABNT, 2013b).

Portanto, para responder às solicitações impostas pelas condições de exposição, as fachadas devem ser capazes de minimizar os impactos negativos das cargas higrotérmicas que atuam sobre a envoltória do edifício, mantendo o desempenho e a vida útil esperados. Nos estudos sobre degradação de fachadas, as variações higrotérmicas estão entre os principais mecanismos responsáveis pelo envelhecimento natural das edificações.

Segundo Bauer et al. (2011), as variações térmicas que ocorrem nas superfícies das fachadas na cidade de Brasília, devido à alta amplitude térmica, provocam tensões que atuam diretamente nos processos de degradação dos sistemas de revestimento externo, ocasionando danos decorrentes da fadiga térmica, expansões e retrações, entre outros, ao longo da vida útil do edifício.

A exposição à umidade é um fator preponderante nos processos de degradação, sendo considerada a maior fonte de problemas nos edifícios em todo o mundo (LOURENÇO, 2006; SILVA et al., 2011; 2013).

De acordo com Thomaz e Del Mar (2013), a vida útil é a métrica temporal da durabilidade, correspondente ao período de tempo em que o edifício e suas partes ou seus componentes mantém o desempenho requerido, desde que as condições de uso, exposição e manutenção especificadas sejam atendidas.

A durabilidade é a expressão qualitativa da capacidade do edifício e suas partes de desempenhar suas funções, ao longo do tempo de vida útil, quando expostos às condições normais de uso. Ou seja, a variação do desempenho é uma das medidas da durabilidade da edificação ou de suas partes (ABNT, 2013a).

Segundo John e Sato (2006), a durabilidade não é uma propriedade inerente de um material ou componente, mas o resultado da interação entre o material e o ambiente que o cerca, incluindo aspectos de microclima. 
Para Lichtenstein (1986), os agentes agressivos interagem com o edifício, produzindo um leque de fenômenos físicos, químicos e biológicos; alguns destes podem causar manifestações patológicas e, como consequência, queda de desempenho.

John et al., (2001) esclarece que a durabilidade não é uma qualidade intrínseca de um material, mas é um atributo que depende mais do conhecimento do que dos próprios recursos, portanto, o conhecimento dos agentes de degradação dos materiais permite tomar decisões de projeto que proporcionam maior proteção ao componente, aumentando a sua vida útil, mesmo quando mantidas as condições de exposição.

Para Hans e Chevalier (2005), a falta de conhecimento sobre cenários de degradação de componentes da construção dificulta ainda mais a avaliação da durabilidade e, portanto, ainda existe uma forte necessidade de melhorar modelos, experimentações e estudos de casos.

As fachadas estão expostas às ações externas de origem climática e, dependendo da sua orientação, sofrem influências de diferentes intensidades. Haagenrud (2004) alerta que a existência de efeitos sinérgicos (por exemplo, os efeitos dos ciclos de molhagem e secagem) levantam sérias dúvidas quanto a caracterizar os agentes climáticos pelo seu valor médio ou por valores limites. Como alternativa, até que se saiba mais sobre o efeito individual de cada agente climático no processo de degradação, é recomendável que as séries temporais de cada um dos agentes climáticos sejam monitoradas e caracterizadas, simultaneamente.

Neste contexto, o eixo condutor que delimita a abrangência deste trabalho é o estudo da influência das ações externas de origem climática na degradação de fachada. A Figura 1.1 sintetiza o campo conceitual do contexto deste estudo.

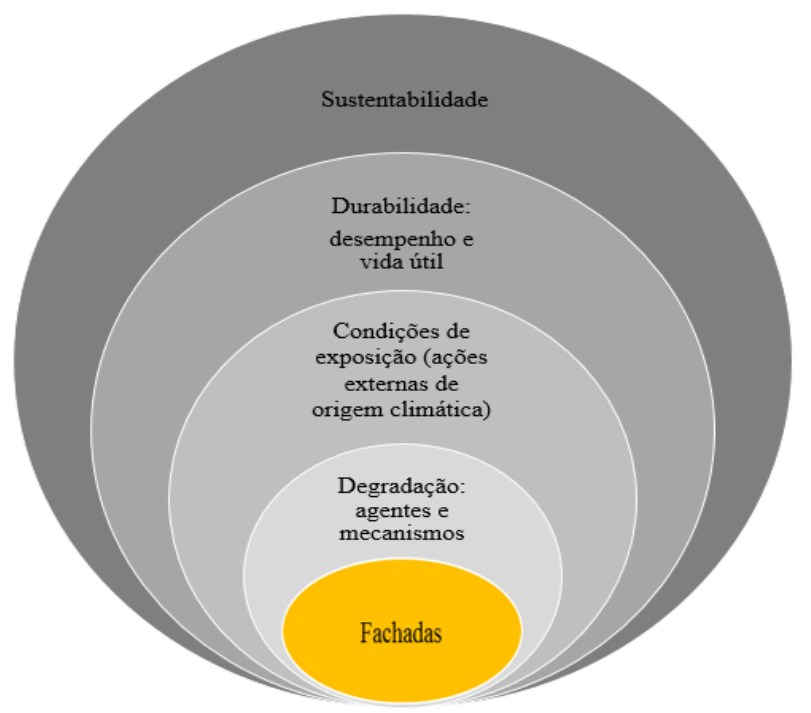

Figura 1.1 - Campo conceitual do contexto temático da tese de pesquisa. 


\subsection{ENQUADRAMENTO DA PESQUISA}

O comportamento higrotérmico do edifício refere-se ao campo conceitual da física das construções que estuda o transporte de calor, ar e massa nos seus componentes (CIB W040, 2012). Para o estudo do comportamento higrotérmico do sistema de vedação vertical e seu revestimento é necessário conhecer os mecanismos de transporte de calor e massa e as propriedades higrotérmicas dos componentes constituintes da fachada.

O estudo dos mecanismos de transporte de umidade em meios porosos é bastante complexo. Segundo Mendes (1997) e Santos (2009), a complexidade está relacionada à dificuldade em se definir modelos que representem a estrutura de poros dos materiais, as propriedades higrotérmicas e os mecanismos simultâneos de transporte de calor e massa. Santos (2009) relata que são escassos os trabalhos que abordam a natureza multidimensional do fenômeno de transporte de calor, ar e umidade em elementos de edificações. Nos seus estudos, os autores citados buscam simplificar os modelos para que seja possível, com as técnicas atuais, representar as situações reais por meio da simulação computacional, viabilizando assim os avanços nas pesquisas do comportamento higrotérmico dos sistemas construtivos.

Segundo Mendes (1997), nas paredes das edificações, os gradientes de temperatura e umidade e os fenômenos de transferência de calor e umidade ocorrem simultaneamente e são altamente interdependentes. No entanto, a difusão de calor através da envoltória da edificação, em programas de simulação térmica em sistemas computacionais como o DOE-2, realizam o cálculo do consumo de energia de edificações, normalmente considerando o calor transferido através da envoltória puramente por condução. Segundo o autor, isto é verdade quando se trata de materiais não porosos, mas em construção civil os materiais usados são, comumente, porosos.

Uma das metas de Mendes (1997), entre outras, é o fortalecimento do estudo do comportamento higrotérmico dos materiais de construção com vistas às decisões de adoção de política de conservação de energia, predições das condições internas de cargas e níveis de conforto, além do modelamento acoplado de calor e umidade para estimar graus de degradação e deterioração de componentes de edificação.

O grupo de pesquisa da física das construções da Universidade do Porto (FEUP) utiliza alguns programas de simulação higrotérmica (CONDENSA, WUFI, HAM-Tools, hygIRC-ID, entre outros) como ferramentas para estudar o comportamento higrotérmico das edificações. Segundo 
Freitas (1992), os estudos e medições dos fluxos higrotérmicos e os potenciais de transporte de umidade e calor são difíceis de serem medidos, até em condições de laboratório.

As simulações computacionais podem ser uma ferramenta necessária para avaliar as condições de exposição às cargas higrotérmicas, de acordo com as diferentes orientações ou tipo de superfície (KÜNZEL, 1994; ASHRAE, 2009). Sobre esta abordagem, alguns estudos dos pesquisadores da FEUP mostram a complexidade das condições locais atuantes na superfície da fachada e a sinergia entre os agentes de degradação (RAMOS, 2007; BARREIRA, 2010; DELGADO et al., 2010; FREITAS, 2011). Nestes estudos, os autores adotaram programas de simulação higrotérmica computacional como ferramenta de processamento e análise das condições de exposição.

Integrado ao grupo de pesquisa da FEUP, os pesquisadores brasileiros Santos et al. (2014) e Almeida et al. (2014) desenvolvem trabalhos sobre o comportamento higrotérmico do gesso brasileiro. A pesquisa de Santos et al. (2014) está focada na avaliação dos perigos de degradação dos sistemas de paredes exteriores em gesso, em decorrência das ações higrotérmicas para o contexto do Nordeste do Brasil, especificamente da região do Araripe-PE, que é um polo produtor de gesso. Procedimentos experimentais e analíticos permitiram caracterizar o material e alimentar o programa higrotérmico de simulação computacional WUFI (2013). As simulações foram realizadas para duas diferentes zonas climáticas e condições de exposição: Petrolina (Brasil) e Porto (Portugal). O estudo demonstra que os problemas de durabilidade podem surgir devido às diferenças na ação higrotérmica, dependendo das características de cada localidade.

Bruno Daniotti e seu grupo de pesquisa do Politecnico di Milano, na Itália, estudam os ETICs (External Thermal Insulation Composite System) por meio de simulações higrotérmicas com o WUFI (2013). Entre os estudos realizados, destacam-se as pesquisas de choque térmico em ETICS, para 4 orientações (N, S, L e O), em algumas cidades com diferentes climas da Europa (Nantes, Barcelona, Milão, Zurique, entre outros). Um dos objetivos das pesquisas é estudar soluções para minimizar a ocorrência de congelamento ou condensações nos materiais.

A frequência de ocorrência de choques térmicos está associada a certos tipos de clima e a determinados teores de água nos componentes. Os pesquisadores analisaram as temperaturas de superfície da fachada para os sistemas em ETICs, considerando intervalos de $5^{\circ} \mathrm{C}$ (variando de $-5^{\circ} \mathrm{C}$ a $+70^{\circ} \mathrm{C}$ ) e contando o número de eventos para cada intervalo. Foram simuladas diversas situações para absortância, variando entre 0,1 e 0,9 . Um dos objetivos do estudo foi 
identificar para quais absortâncias (valor relacionado à cor) ocorria o menor risco de congelamento (DANIOTTI et al., 2014).

Nos estudos dos pesquisadores, as mudanças bruscas de temperatura ocorreram combinadas com chuva forte e aconteceram tanto com um súbito arrefecimento (pancada de chuva ou tempestade) ou um aquecimento repentino (parada da chuva com abertura de forte insolação). Para a análise do choque térmico foram consideradas as diferenças de temperatura da superfície entre dois passos de tempo (ou seja, uma hora), contando as variações bruscas de temperatura ao longo de um ano (DANIOTTI et al., 2008). Os autores constataram que o número absoluto de eventos de choque térmico por ano foi mais elevado em contextos mais úmidos. Nas regiões onde os teores de umidade foram menos elevados, os eventos não foram tão frequentes (DANIOTTI et al., 2014).

Em Daniotti et al. (2012), é apresentada uma análise dos modos de falha nos sistemas ETICS, baseada na degradação relacionada com os processos de envelhecimento natural, excluindo assim, erros de concepção e de construção (isto é, manifestações patológicas de origem construtiva). O Quadro 1.1 mostra os principais agentes, ações, efeitos e parâmetros ambientais que influenciam a degradação dos sistemas ETICS, sintetizando as variáveis pesquisadas por Daniotti et al. (2012).

Quadro 1.1 - Agentes, ação e efeitos em ETICS - External Thermal Insulation Composite System.

\begin{tabular}{|c|c|c|c|}
\hline Agente & Ação & Efeito & Parâmetros ambientais \\
\hline $\begin{array}{l}\text { Choque térmico - } \\
\text { no inverno, resfriamento da } \\
\text { superfície durante a noite / } \\
\text { rápido aquecimento durante o } \\
\text { dia }\end{array}$ & $\begin{array}{l}\text { Degradação devido as } \\
\text { deformações por contrações e } \\
\text { expansões que geram tensões } \\
\text { de tração ou de compressão }\end{array}$ & $\begin{array}{l}\text { Fissuras, esfoliação, } \\
\text { descolamento e enrugamento }\end{array}$ & $\begin{array}{l}\text { - Temperaturas máximas e } \\
\text { mínimas, exposição à radiação, } \\
\text { nebulosidade e chuva, que } \\
\text { levam às variações na } \\
\text { temperatura da superfície }\end{array}$ \\
\hline $\begin{array}{l}\text { Umidade - } \\
\text { de origem meteorológica ou } \\
\text { pela condensação intersticial } \\
\text { e/ou superficial }\end{array}$ & $\begin{array}{l}\text { Aumento do volume com o } \\
\text { congelamento, formação de } \\
\text { colônias biológicas, deposição } \\
\text { de poeira e transporte de sais }\end{array}$ & $\begin{array}{l}\text { Diminuição da resistência dos } \\
\text { materiais, rompimento do } \\
\text { revestimento, abaulamento, } \\
\text { enrugamento e crescimento } \\
\text { biológico }\end{array}$ & $\begin{array}{l}\text { - Chuva e vento (índice de } \\
\text { chuva dirigida) e temperaturas } \\
\text { para avaliar as condições de } \\
\text { congelamento ou } \\
\text { superaquecimento da superfície }\end{array}$ \\
\hline Radiação ultra-violeta & $\begin{array}{l}\text { Fragilização das ligações } \\
\text { covalentes do acabamento }\end{array}$ & $\begin{array}{l}\text { Propagação de fissuras } \\
\text { superficiais, variação cromática }\end{array}$ & $\begin{array}{l}\text { - Nebulosidade, intensidade da } \\
\text { radiação solar e poluição } \\
\text { ambiental }\end{array}$ \\
\hline Vento & $\begin{array}{l}\text { Pressão positiva-negativa sobre } \\
\text { o edifício, mudança da direção } \\
\text { da chuva, transporte de } \\
\text { poluição }\end{array}$ & $\begin{array}{l}\text { Destacamento, deslocamento, } \\
\text { deposição de partículas e } \\
\text { abrasão da superfície }\end{array}$ & - Velocidade e direção do vento \\
\hline $\begin{array}{l}\text { Algas e colônias de } \\
\text { microorganismos }\end{array}$ & Ações mecânicas e química & $\begin{array}{l}\text { Crescimento biológico na } \\
\text { superfície, degradação da } \\
\text { camada de revestimento }\end{array}$ & $\begin{array}{l}\text { - Alta umidade relativa, } \\
\text { temperaturas intermediárias, } \\
\text { precipitação, nebulosidade }\end{array}$ \\
\hline
\end{tabular}

Fonte: Daniotti et al. (2012).

Esta linha de pesquisa conduzida pelo grupo do Politecnico di Milano (DANIOTTI et al., 2013) refere-se aos estudos da perda de desempenho para avaliar a durabilidade de componentes de construção, estudando os modos de falha que podem ocorrer ao longo do tempo, muitas vezes 
resultantes da ação repetida de vários agentes indutores de tensões cíclicas, como a fadiga térmica. Para isso, foram realizadas simulações de transporte de calor e umidade com o programa de simulação higrotérmica computacional WUFI.

O grupo de pesquisa ligado ao Laboratório de Ensaios de Materiais da Universidade de Brasília - LEM-UnB vem desenvolvendo uma linha de investigação voltada à quantificação da degradação em sistemas de revestimento de fachada, baseada em levantamentos e medições de campo. Entre as principais contribuições e trabalhos já concluídos destacam-se:

- Antunes (2010): Estudo de manifestações patológicas em revestimento de fachada em Brasília: sistematização da incidência de casos;

- Silva (2014): Avaliação quantitativa da degradação e vida útil de revestimentos de fachada - aplicação ao caso de Brasília/DF.

Os trabalhos citados tratam de procedimentos para a quantificação da degradação, baseados no banco de dados do acervo técnico de inspeções prediais do laboratório LEM-UnB, compreendendo levantamento de campo, mapeamento de manifestações patológicas, registro fotográfico e diagnósticos, entre outros.

Silva (2014) sistematizou uma metodologia para quantificar a degradação de sistemas de revestimento cerâmico em fachada. A metodologia de quantificação baseia-se em levantamentos de campo e mapeamentos de danos (BAUER et al., 2014; BAUER et.al, 2015a); fornece subsídios para o cálculo de um índice de degradação denominado Fator Geral de Danos (FGD); e permite obter curvas de degradação para estimativa de vida útil a partir dos índices de degradação obtidos por meio de um método de cálculo analítico (SILVA, 2014). Segundo a autora, principalmente no Brasil, as pesquisas com enfoque quantitativo da degradação e vida útil das fachadas são muito incipientes.

As curvas de degradação são representações gráficas que demonstram a queda do desempenho, ou seja, a evolução da degradação, ao longo do tempo (BAUER et al., 2015b; FRANCINETE et al., 2015).

A degradação é um fenômeno progressivo e, caso não haja as devidas manutenções, as curvas de degradação representam a evolução da degradação do elemento ao longo da sua vida útil e refletem a velocidade com que o edifício ou suas partes perdem sua capacidade funcional, ou seja, deixam de atender aos requisitos de desempenho exigidos (SHOHET et al., 1999; FLORES-COLEN, 2002; LACASSE; SJOSTROM, 2003; HOVDE; MOSER, 2004; GASPAR; BRITO, 2008; DANIOTTI; CECCONI, 2010a). 
A Figura 1.2 mostra as curvas de degradação desenvolvidas por Silva (2014), baseadas em 90 amostras de fachadas com revestimento cerâmico, na cidade de Brasília. A determinação do Fator Geral de Danos (FGD) foi feita em função de várias variáveis (ver Silva, 2014), entre elas, as orientações de fachada que foram classificadas em quatro quadrantes (Norte, Sul, Leste e Oeste). As curvas de degradação mostraram tendências diferenciadas para o comportamento do edifício, ao longo da vida útil, dependendo da orientação.

Os resultados mostraram que as fachadas de Brasília com orientações nos quadrantes Oeste e Norte apresentaram, notadamente, os maiores índices de degradação do que nos quadrantes Leste e Sul (Figura 1.2). Os resultados do FGD permitiram comprovar a influência da orientação das fachadas na evolução e aceleração da degradação, pois permitiram identificar com precisão os diferentes níveis de degradação em relação à idade, evidenciando maior intensidade de degradação para os edifícios com idades superiores a 10 anos. Nos processos evolutivos da degradação, Silva (2014) obteve o maior valor para o Fator Geral de Danos nas fachadas orientadas para o quadrante Oeste.

Na Figura 1.2, as curvas de degradação representam o Fator Geral de Danos em função da idade do edifício, para os quatro principais quadrantes.

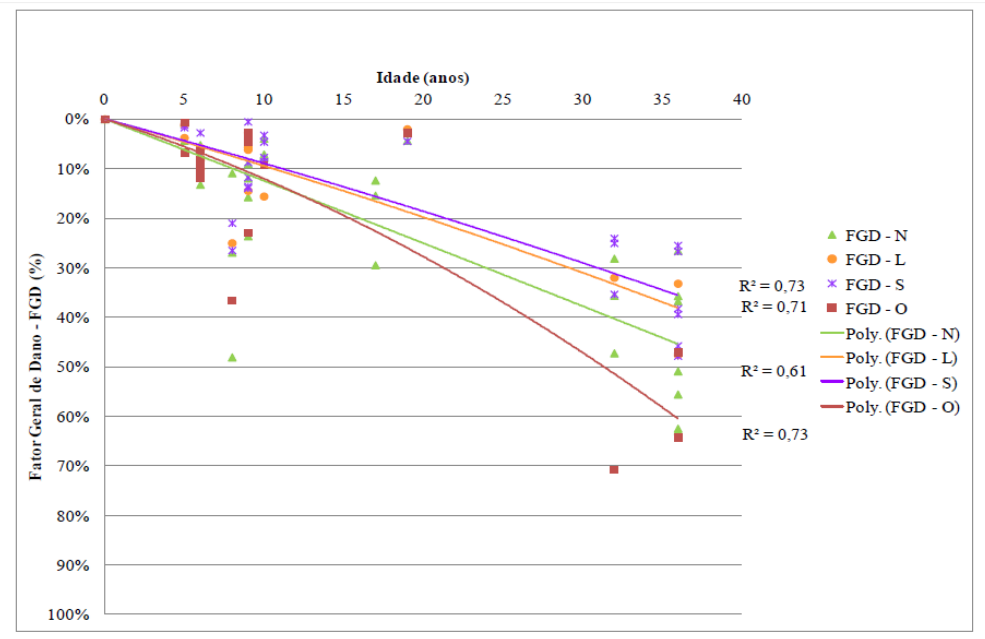

Fonte: Silva (2014).

Figura 1.2 - Curvas de degradação: evolução dos danos em função da idade para as orientações nos quadrantes Norte, Sul, Leste e Oeste.

Existem lacunas nos estudos de degradação do ambiente construído relacionadas à falta de dados disponíveis para uma análise mais detalhada do envelhecimento natural nos sistemas de revestimento poroso de fachada, principalmente em decorrência dos agentes e mecanismos de degradação de origem climática e os efeitos sinérgicos dos fenômenos (HOVDE; MOSER, 2004; JERNBERG et. al., 2004b). 
Segundo a ISO ${ }^{3}$ 15686-2 Buildings and constructed assets - Service life planning: Service life prediction procedures (BS, 2012), dados sobre o envelhecimento natural das edificações, decorrentes da exposição a longo prazo, podem ser obtidos por meio de quatro categorias:

- Exposição em estações de envelhecimento natural;

- Inspeção em edifícios;

- Exposição em edifícios experimentais;

- Exposição nas condições de uso (condições normais de uso, mas com monitoramento). Pela metodologia proposta pela ISO 15686-2 (BS, 2012), quando se deseja avaliar a degradação por meio da exposição de curta duração, o método indicado é o ensaio acelerado. Atualmente, tanto no âmbito nacional como no âmbito internacional, vem sendo desenvolvidas muitas pesquisas voltadas para os ensaios acelerados como método para avaliar a degradação de materiais e componentes (JERNBERG, 2004a; DANIOTTI et al., 2010b).

John e Sato (2006) alertam que existem diferenças significativas na evolução do comportamento mecânico entre amostras expostas nos diferentes sítios de ensaio de envelhecimento natural e dessas com o envelhecimento acelerado. Para os autores, isso mostra a importância de incluir, nos estudos de durabilidade, o envelhecimento natural a longo prazo avaliado em campo, além dos ensaios acelerados.

Para que os resultados dos ensaios acelerados sejam representativos das condições reais do ambiente de exposição do edifício e do seu envelhecimento natural, é necessário um dimensionamento dos tempos de cada ciclo de envelhecimento para que os ensaios acelerados correspondam ao comportamento das séries temporais e dos efeitos sinérgicos dos agentes climáticos de degradação (DANIOTTI et al., 2010a; NICOLELLA; DE PASCALE, 2008).

O grupo de pesquisa do Instituto Tecnológico de Aeronáutica-ITA desenvolve pesquisas relacionadas ao mapeamento dos agentes de degradação dos materiais de construção. Essas pesquisas buscam integrar informações sobre dados ambientais em mapas de agressividade, baseados na distribuição da temperatura e amplitude térmica do ar, umidade relativa do ar, vento, chuva dirigida (precipitação associada ao vento), com ênfase para os agentes ambientais ${ }^{4}$ e mecanismos que afetam a durabilidade das estruturas de concreto armado, entre outros, chuva

\footnotetext{
${ }^{3}$ A série ISO 15686 constitui-se de um conjunto de normas com 11 partes, sob o título geral Buildings and constructed assets - Service life planning, publicada pela British Standard (BS).

${ }^{4}$ Nesta tese, os agentes climáticos são as variáveis relacionadas ao clima. Quando essas variáveis estão associadas à qualidade do ar da área de localização, inclusive poluentes e contaminantes decorrentes de áreas marinhas e industriais, é usado o termo "agentes ambientais".
} 
ácida, corrosividade atmosférica, poluentes e contaminantes agressivos (LIMA; MORELLI, 2005; LIMA et al., 2006; LIMA, 2005; MORELLI, 2008).

Segundo Morelli (2008), as condições ambientais no entorno da edificação durante sua vida útil são um desafio recente que ainda demanda um grande esforço em pesquisa para a melhoria do conhecimento sobre a durabilidade e degradação do ambiente construído. O autor desenvolveu uma metodologia para caracterizar os agentes de degradação através de mapas temáticos, com o auxílio de Sistema de Informação Geográfica (SIG), em escalas regionalizadas e escalas locais.

Para Lima (2005), as normas brasileiras não consideram a variação sazonal e espacial da intensidade e/ou concentração dos agentes de degradação. No entanto, esse conhecimento é fundamental para a realização de projetos e especificações de materiais para fachadas.

Comparativamente com as normas internacionais, são incipientes as exigências das normas brasileiras quanto aos aspectos relacionados com a durabilidade e vida útil das edificações. Somente a partir de 2003 a NBR 6118-Projeto de Estruturas de Concreto: Procedimento passou a contemplar exigências quanto às condições de exposição ambiental para as estruturas de concreto armado. Segundo Helene (2004), na década de 90 houve um fortalecimento do movimento nacional e internacional para a introdução do conceito de vida útil no projeto das estruturas de concreto. A NBR 6118 classifica a agressividade do ambiente em quatro escalas de agressividade (fraca, moderada, forte e muito forte), associadas ao tipo de ambiente (rural, submersa, urbana, marinha, industrial e respingos de maré), sendo que os contaminantes e poluentes presentes no ar compõe o critério chave da classificação quanto à agressividade (HELENE, 2004; ABNT, 2014).

A partir de 2013, com a aprovação do conjunto de normas de desempenho NBR 15575, requisitos e critérios relacionados à durabilidade e vida útil foram estendidos para os outros subsistemas da edificação, além das estruturas de concreto armado.

No entanto, enquanto o conjunto de normas de desempenho traz exigências associadas ao transporte de calor para os estudos de comportamento térmico, conforme o zoneamento bioclimático estabelecido pela NBR 15220-3 (ABNT, 2005c), verifica-se a ausência de requisitos e critérios relacionados ao comportamento higrotérmico e às condições de exposição associadas à sinergia entre os agentes climáticos de degradação. Ou seja, as exigências quanto ao desempenho térmico restringem-se às características e propriedades térmicas dos materiais 
e/ou componentes construtivos, sem levar em consideração os fenômenos simultâneos relacionados ao transporte de massa (umidade) e a sinergia entre eles.

Em suma, com base no enquadramento exposto, delimita-se o foco de interesse desta tese nos estudos sobre a caracterização das condições de exposição das fachadas aos agentes climáticos, considerando, simultaneamente, os fenômenos de calor e umidade por meio de simulação higrotérmica computacional.

\subsection{PROBLEMATIZAÇÃO E QUESTÕES DE PESQUISA}

No enquadramento da pesquisa de tese foi possível perceber que existe uma importante barreira para o avanço nos estudos da durabilidade e degradação de fachadas relacionada à falta de dados disponíveis para análises mais detalhadas do envelhecimento natural decorrente dos agentes climáticos e mecanismos de degradação, em sistemas de fachada. No Brasil, os estudos relacionados ao comportamento higrotérmico dos sistemas porosos de fachada associados ao comportamento dos agentes climáticos de degradação são bastante incipientes.

Uma lacuna observada nos estudos brasileiros sobre degradação é a quantificação dos agentes climáticos de degradação que atuam nas fachadas das edificações, de acordo com a localização, clima e orientação, associando as condições de exposição com o comportamento higrotérmico dos componentes de fachada, objetivando explicar os fatores que afetam, em diferentes intensidades, o envelhecimento natural das oito principais orientações de fachada (Norte - N, Nordeste - NE, Leste - L, Sudeste - SE, Sul - S, Sudoeste - SO, Oeste - O e Noroeste - NO).

Outra lacuna encontrada nos estudos brasileiros foi a ausência de pesquisas relacionadas às medições de chuva dirigida in situ. Inclusive, não foi encontrada nenhuma publicação brasileira abordando a quantificação dos montantes de chuva dirigida por meio de métodos semiempíricos. Os trabalhos sobre chuva dirigida no Brasil são baseados nos Índices de Chuva Dirigida - ICD (ver Capítulo III) que é um indicador do nível de severidade das condições de exposição a campo aberto, mas não quantifica o montante de chuva que é projetada pelo vento em cada orientação de fachada, nos diferentes contextos urbanos.

Observou-se que, mesmo quando determinadas fachadas são classificadas em condições de exposição mais severa em relação aos agentes climáticos de degradação (radiação solar, chuva dirigida, temperaturas, entre outros), as explicações ou justificativas apresentam lacunas sobre 
as interações entre os agentes climáticos e a influência no comportamento higrotérmico das fachadas, considerando as variações cíclicas e sazonais, ao longo do ano.

Partindo da problematização apresentada, são colocadas as seguintes questões de pesquisa:

1) Qual é a influência dos agentes climáticos no comportamento higrotérmico dos sistemas porosos de fachada, considerando as principais orientações, ao longo dos períodos do ano?

2) Qual a resposta higrotérmica do sistema poroso de fachada mediante a ação e interação entre os agentes climáticos de degradação e a fachada, considerando as intensidades, as frequências de ocorrência e o comportamento cíclico e sazonal dos fenômenos climáticos?

\subsection{OBJETIVOS}

\subsubsection{Objetivo Geral}

O objetivo geral desta tese é avaliar a influência dos agentes climáticos de degradação no comportamento higrotérmico dos sistemas porosos de vedação vertical (alvenaria de bloco cerâmico e revestimento com argamassa), na cidade de Brasília-DF, com base na ação e interação entre os agentes externos de origem climática e o elemento de fachada, em cada uma das oito principais orientações, ao longo dos períodos seco e chuvoso do ano.

\subsubsection{Objetivos Específicos}

$\rightarrow$ a) Objetivos específicos relacionados aos estudos dos arquivos e agentes climáticos:

- Caracterizar as variáveis climáticas em seu comportamento cíclico e sazonal ao longo do ano, com base nos estudos dos valores médios, mínimos, máximos e frequências de ocorrência, utilizando o arquivo de dados da série 2001-2013 (INMET, 2014) ${ }^{5}$, com registros de dados horários da estação automática de superfície A001-Brasília-DF;

- Estabelecer uma base referencial para a seleção de dados climáticos e análise de sensibilidade, por meio de estudos comparativos entre diversas fontes e arquivos de dados climáticos;

- Selecionar um arquivo climático para os estudos por meio de simulação computacional;

\footnotetext{
${ }^{5} \mathrm{O}$ arquivo climático de dados horários da série 2001-2013 foi fornecido pelo INMET, de forma gratuita, conforme regulamenta a Lei da Transparência. A Lei 12.527/2011 da Presidência da República (conhecida como Lei da Transparência) assegura e regulamenta o direito fundamental de acesso à informação.
} 
- Sistematizar os principais resultados dos estudos sobre os arquivos e variáveis climáticas em um cenário representativo das condições de exposição às ações externas de origem climática, para as fachadas das edificações na cidade de Brasília.

\section{$\rightarrow$ b) Objetivos específicos relacionados aos estudos sobre chuva dirigida:}

- Apresentar os principais conceitos e métodos semi-empíricos disponíveis para quantificação de chuva dirigida;

- Quantificar os montantes de chuva dirigida por meio de modelos analíticos, aplicando os principais métodos semi-empíricos em estudos para determinação da chuva dirigida, no contexto da cidade de Brasília, e apresentar uma análise comparativa dos resultados obtidos;

- Propor um método para medição de chuva dirigida in situ, de baixo custo e simples aplicação;

- Quantificar a chuva dirigida e determinar um coeficiente de chuva dirigida para Brasília, por meio de um programa experimental para medição de chuva dirigida in situ;

- Selecionar um método semi-empírico para quantificação de chuva dirigida, visando aos estudos por meio de simulação higrotérmica computacional.

$\rightarrow$ c) Objetivos específicos relacionados aos estudos do comportamento higrotérmico por meio da simulação higrotérmica computacional:

- Conceituar as propriedades higrotérmicas, os mecanismos de transporte de calor e umidade e os agentes e mecanismos de degradação, visando aos estudos por meio do programa computacional de simulação higrotérmica WUFI Pro 5.3 Fraunhofer - IBP (WUFI, 2013);

- Selecionar e qualificar os dados de entrada para as simulações higrotérmicas;

- Selecionar e caracterizar os componentes de fachada para as simulações higrotérmicas com base em suas propriedades higrotérmicas;

- Estabelecer procedimentos metodológicos para o estudo e quantificação dos fenômenos higrotérmicos em fachada, por meio de programa computacional de simulação higrotérmica;

- Quantificar, por meio da simulação higrotérmica, os eventos que induzem às variações higrotérmicas, resultantes da ação simultânea dos agentes climáticos de degradação, das características do edifício, do ambiente e do clima, que mais afetam o comportamento higrotérmico diferenciado dos sistemas de fachada, em cada uma das oito principais orientações (N, NE, L, SE, S, SO, O e NO). 
- Analisar as variáveis respostas das simulações higrotérmicas, a saber, teor de umidade, temperatura superficial externa e amplitude térmica na superfície da fachada, com base na caracterização quantitativa do comportamento higrotérmico das fachadas;

- Analisar o comportamento diferenciado ao envelhecimento natural das oito principais orientações de fachada (N, NE, L, SE, S, SO, O e NO), estabelecendo cenários referenciais das condições de exposição de fachada, considerando a ação e interação entre os agentes climáticos de degradação e o comportamento higrotérmico dos sistemas porosos em fachada;

- Avaliar o potencial de uso da simulação higrotérmica computacional, quando aplicada aos estudos relacionados à degradação de fachada.

\subsection{JUSTIFICATIVA}

Dando prosseguimento às temáticas das linhas de pesquisa do laboratório LEM-UnB e do Núcleo de Tecnologia da Construção e Sistemas Estruturais do PPG-FAU, esta tese busca contribuir com os estudos integrados sobre os agentes climáticos de degradação, as condições de exposição das fachadas e o comportamento higrotérmico dos sistemas porosos de fachada.

Segundo Haagenrud (2004), a caracterização dos agentes climáticos pelo seu valor médio ou por valores limites não são suficientes para compreender os efeitos sinérgicos que levam ao envelhecimento natural. As variáveis climáticas possuem comportamento cíclico e sazonal, portanto, é preciso ter conhecimento do comportamento das séries temporais de cada um dos agentes climáticos e da ação simultânea, no processo de degradação.

Justifica-se, assim, a necessidade de compreender a resposta do edifício à ação e interação dos agentes climáticos e dos fenômenos higrotérmicos, como um passo importante na caracterização das fachadas.

Conforme já apresentados, os trabalhos de Antunes (2010) e Silva (2014) mostraram que os agentes climáticos influenciam a degradação e citam a sinergia entre eles como uma das causas do processo de envelhecimento natural, mas não quantificaram os efeitos sinérgicos e simultâneos do calor e da umidade atuantes nas fachadas da cidade de Brasília.

Partindo da premissa que a orientação da fachada é um fator essencial para o diagnóstico da degradação dos sistemas de revestimentos porosos, visando às ações de manutenção e retroalimentação de projetos e especificações, esta pesquisa de tese avança no entendimento 
multidisciplinar e integrado sobre como os agentes climáticos afetam de forma diferenciada a vida útil das fachadas na cidade de Brasília e qual a resposta higrotérmica dos sistemas de fachada com alvenaria revestida com argamassa, perante as condições de exposição aos agentes de degradação de origem climática.

A importância deste estudo justifica-se, também, pelo seu caráter pioneiro em quantificar os coeficientes de chuva dirigida para a cidade de Brasília.

Enfim, entre as principais contribuições desta tese, enfatiza-se o aprofundamento do conhecimento sobre a caracterização quantitativa das ações e interações entre os agentes climáticos de degradação e o comportamento higrotérmico de fachada, considerando a abordagem simultânea dos fenômenos de calor e umidade, por meio da aplicação de métodos de simulação computacional higrotérmica nos estudos de fachada para as condições locais de Brasília.

Visando melhor compreender os fenômenos da degradação e os possíveis cenários de degradação resultante da cinética e interação dos fenômenos higrotérmicos atuantes nas fachadas, este estudo contribui para a formulação de requisitos de projeto de fachada e retrofit, quanto aos aspectos relacionados à durabilidade e vida útil.

\subsection{METODOLOGIA}

Para os estudos sobre o comportamento higrotérmico dos sistemas de fachada, a abordagem da pesquisa foi delimitada para os sistemas de vedação vertical e seu revestimento, especificamente, para as vedações verticais em alvenaria de tijolo cerâmico com revestimento em argamassa, considerada como um sistema poroso.

Para contextualizar os estudos, considerou-se as fachadas dos edifícios localizados na cidade de Brasília-DF, na zona bioclimática 4. As oito principais orientações de fachada consideradas foram: Norte - N, Nordeste - NE, Leste - L, Sudeste - SE, Sul - S, Sudoeste - SO, Oeste - O e Noroeste - NO.

O desenvolvimento desta tese foi estruturado em quatro fases, cujo conteúdo foi organizado em capítulos. Cada fase da pesquisa foi estruturada em várias etapas de procedimentos metodológicos que se constituíram em um roteiro executivo para alcançar os objetivos geral e específicos da tese, conforme apresentado na Figura 1.3. 

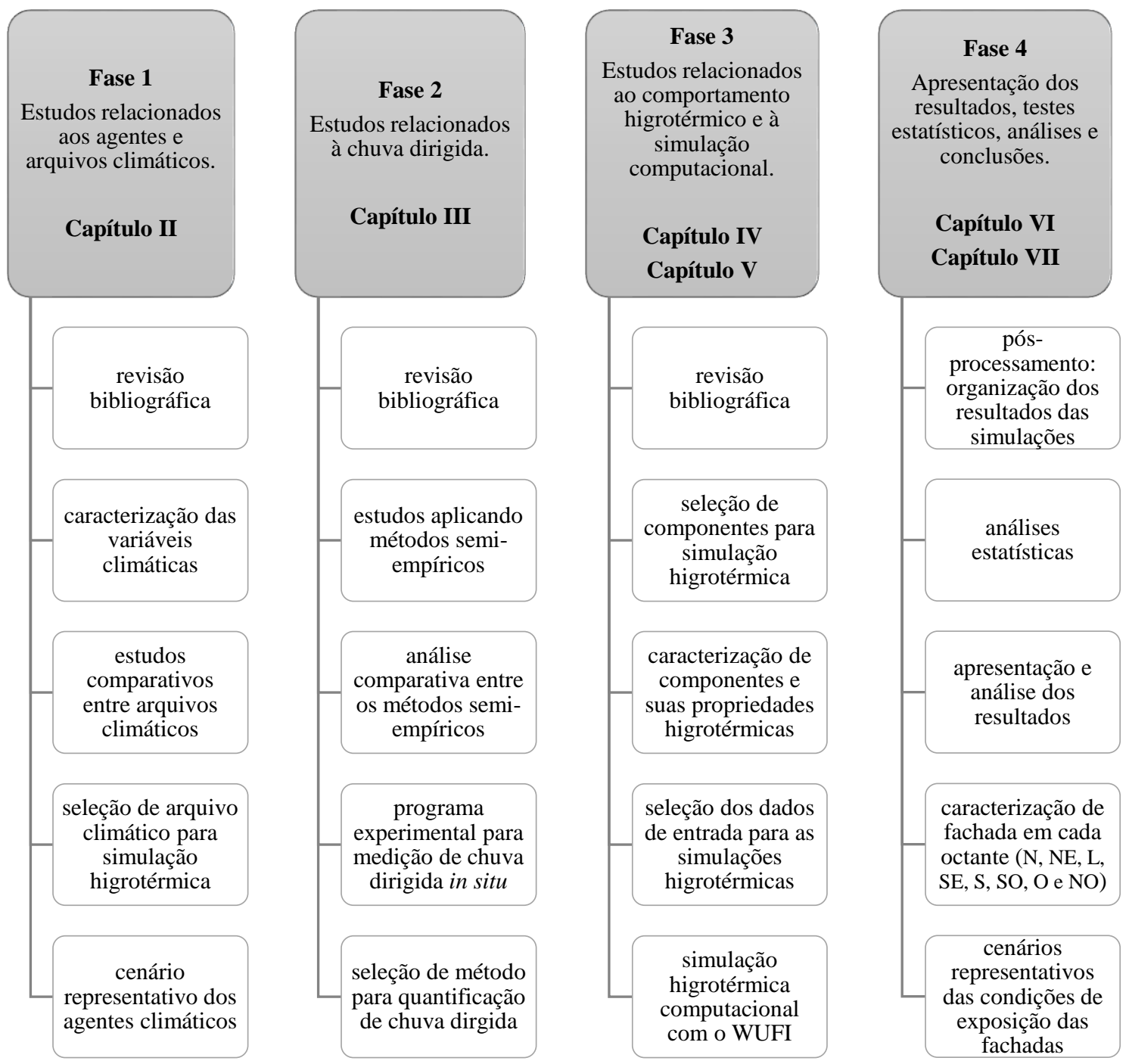

Figura 1.3 - Organização das fases de desenvolvimento dos trabalhos de tese
e etapas dos procedimentos metodológicos.

Em linhas gerais, foram adotadas as seguintes estratégias de pesquisa: levantamento bibliográfico e documental; pesquisa exploratória; programa experimental in situ; estudos comparativos e simulação computacional. Em cada fase da pesquisa, os métodos de procedimentos buscaram atender as especificidades dos objetivos de cada etapa. Quando necessário e pertinente, foi inserido um melhor detalhamento dos procedimentos metodológicos no próprio escopo do respectivo capítulo.

\subsection{ESTRUTURA DA TESE}

Esta tese está estruturada em 8 capítulos e seus encartes, mais referências e apêndices, conforme síntese apresentada na Figura 1.4. 


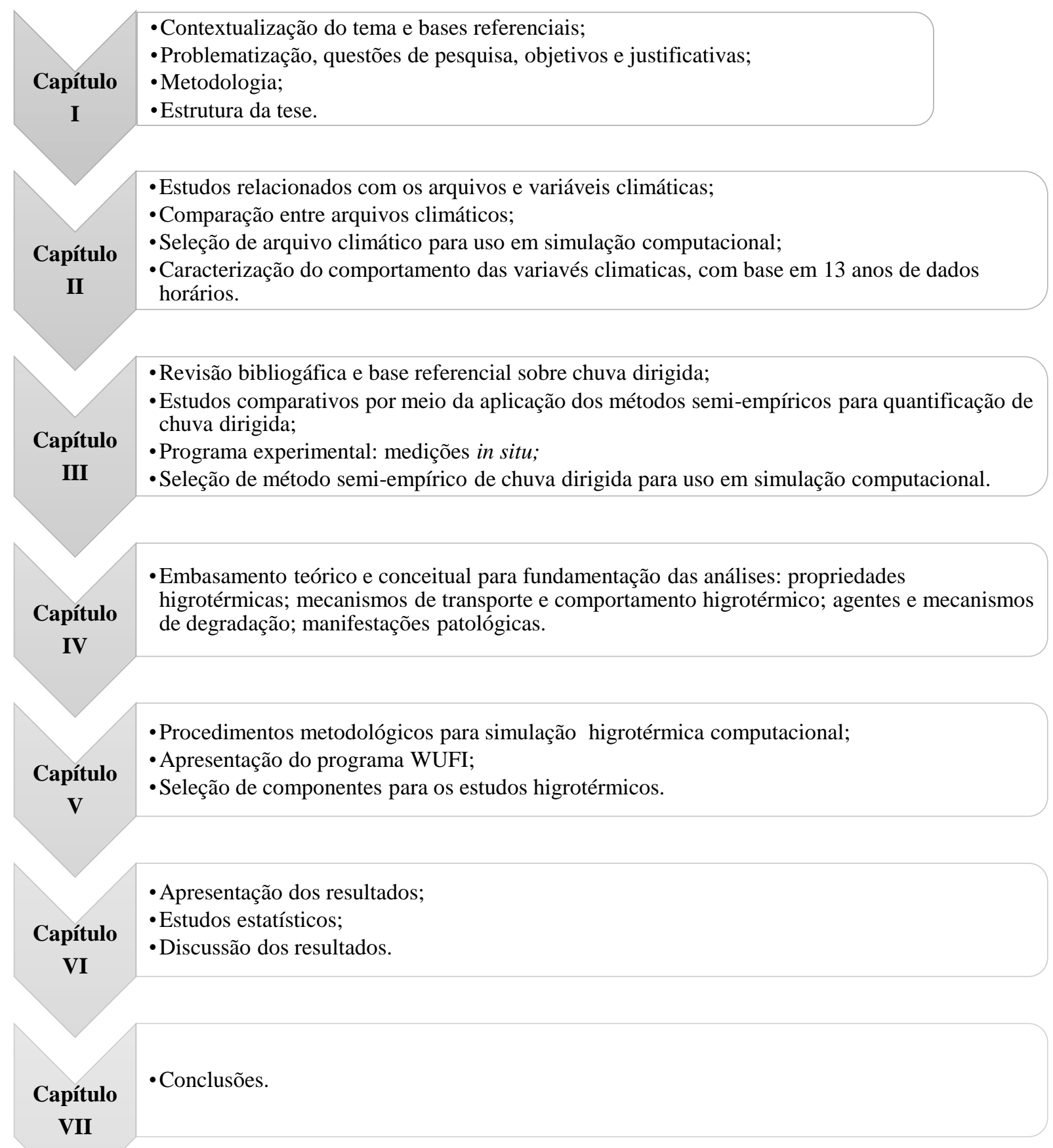

Figura 1.4 - Estrutura da tese.

Na Introdução, o tema é contextualizado e são estabelecidas as bases bibliográficas referenciais. O objetivo geral e os objetivos específicos são definidos com base nos problemas enunciados e nas questões de pesquisa que são os eixos condutores dos procedimentos metodológicos e análises. As justificativas apresentadas delimitam a abordagem da tese e a suas contribuições. Em linhas gerais, são apresentados os procedimentos metodológicos para atingir os objetivos da pesquisa. 
O Capítulo II trata das variáveis climáticas e dos arquivos de dados climáticos. Além da revisão bibliográfica, este capítulo apresenta os estudos comparativos realizados entre alguns arquivos climáticos existentes para a cidade de Brasília, visando à seleção do arquivo mais representativo para os estudos higrotérmicos por meio de simulação computacional. Este capítulo traz uma importante contribuição que é a caracterização das variáveis climáticas para Brasília, a partir de uma base de dados horários com 13 anos de dados medidos em estação automática de superfície.

O Capítulo III apresenta os estudos sobre chuva dirigida. Além da revisão bibliográfica, são apresentados os estudos onde foram aplicados os métodos semi-empíricos para quantificação de chuva dirigida para Brasília. Considerando a ausência de dados sobre medições in situ de chuva dirigida no Brasil e a necessidade de selecionar um método de quantificação de chuva dirigida para ser utilizado nos estudos higrotérmicos por meio de simulação computacional, este capítulo apresenta o programa experimental realizado em Brasília. Essa é uma importante contribuição inédita da tese.

Por meio da revisão bibliográfica, o Capítulo IV apresenta a base teórica para os estudos sobre a degradação de fachada e o comportamento higrotérmico dos sistemas porosos de vedação vertical (alvenaria revestida com argamassa). Especificamente, este capítulo aborda as propriedades higrotérmicas dos materiais, os mecanismos de transporte de calor e massa, os agentes e mecanismos de degradação, preparando assim, a base conceitual para os estudos por meio de simulações higrotérmicas computacionais, embasando a seleções dos componentes construtivos e a análise dos resultados.

O Capítulo V trata dos aspectos metodológicos para os estudos por meio das simulações higrotérmicas computacionais; apresenta o programa WUFI como uma ferramenta computacional para simulação higrotérmica e, de forma mais detalhada e justificada, os procedimentos metodológicos para a etapa de simulações e análise de resultados. Neste capítulo são estabelecidos os critérios e a seleção dos componentes de fachada utilizados nas simulações. O Capítulo VI apresenta os resultados e análises das simulações computacionais e os estudos estatísticos aplicados aos resultados. Apresenta, também, as discussões e respostas às questões de pesquisa que esclarecem os problemas levantados à luz dos conceitos, dos referenciais teóricos e dos resultados obtidos ao longo dos capítulos. Enfim, é apresentado o Capítulo VII com as conclusões da tese, os objetivos alcançados, as principais contribuições e sugestões para trabalhos futuros. 


\section{CAPÍtULO II}

\section{AGENTES CLIMÁTICOS DE DEGRADAÇÃO DE FACHADA}

\subsection{CONSIDERAÇÕES INICIAIS}

Neste capítulo são apresentados os estudos relacionados às variáveis climáticas e aos arquivos de dados climáticos. Um dos objetivos deste capítulo foi caracterizar as variáveis climáticas em seu comportamento cíclico e sazonal ao longo do ano, com base nos estudos dos valores médios, mínimos, máximos e frequências de ocorrência. Para isso, foram utilizados 13 anos de dados horários medidos no período de 2001 a 2013, registrados pelo INMET na estação automática de superfície A001-Brasília (que entrou em funcionamento em maio de 2000). Neste trabalho, esse arquivo de dados climáticos foi denominado como série 2001-2013 do INMET.

Outro importante objetivo deste capítulo foi a seleção de um ano climático, visando aos estudos por meio de simulação higrotérmica computacional. Para atingir este objetivo, foram feitos estudos comparativos entre alguns arquivos de dados climáticos para Brasília, estabelecendo uma base referencial para a seleção de dados e análise de sensibilidade ${ }^{1}$.

Neste caso, para compreender melhor as características e o comportamento dos agentes climáticos para a cidade de Brasília, foram analisados os seguintes arquivo climáticos: série 2001-2013 do INMET; Normais Climatológicas do Brasil 1961-1990 (INMET, 2009); parâmetros climáticos para os dias típicos de verão e inverno, apresentados pela NBR155751(ABNT, 2013); e arquivo climático TMY da base EPW/ANTAC (RORIZ, 2012) que é um ano climático típico com 8760 horas, configurado para simulação computacional.

Enfim, este capítulo contém um conjunto de informações sobre as variáveis climáticas e os arquivos climáticos de forma a caracterizar os agentes climáticos de degradação para a cidade de Brasília, buscando estabelecer uma base necessária para a análise de sensibilidade dos resultados das simulações higrotérmicas para os estudos de degradação de fachada. Os resultados deste capítulo são sistematizados em um cenário representativo das condições de exposição das edificações às ações dos agentes climáticos de degradação, na cidade de Brasília.

\footnotetext{
${ }^{1}$ Análise de sensibilidade é um termo definido pela ISO 15686-5 - Buildings and constructed assets - Sevice-life planning. Parte 5 - Lifecycle costing (BS, 2008a) e refere-se aos testes de resultado de uma análise, alterando um ou mais parâmetros do valor inicial (test of the outcome of an analysis by altering one or more parameters from initial value).
} 


\subsection{ARQUIVOS CLIMÁTICOS E FORMAS DE OBTENÇÃO}

Os arquivos climáticos são conjuntos de dados climatológicos que podem ser obtidos, basicamente, por meio das seguintes fontes de dados: estações meteorológicas, imagens de satélites, métodos semi-empíricos ou modelos numéricos.

As estações meteorológicas registram dados reais, medidos por equipamentos. Uma das mais importantes bases de dados obtidos por medições em estações de superfície são as Normais Climatológicas do Brasil fornecidas pelo INMET. A obtenção de dados, a partir de estações meteorológicas de superfície em áreas tão extensas como o Brasil, exige grande investimento em equipamentos e logística, o que nem sempre é possível em todo o território nacional. A confiabilidade na coleta e transmissão, assim como a eficiência na manutenção, são fundamentais para a qualidade do dado registrado.

Os métodos semi-empíricos e os modelos numéricos constituem-se em métodos importantes para obtenção de dados, pois depois de validados são de baixo custo para aplicação. Os métodos experimentais são fundamentais para validarem os dados obtidos por meio de métodos semiempíricos e numéricos, muito embora as medições in situ possam conter erros significativos (BLOCKEN; CARMELIET, 2004).

Os modelos numéricos que estimam os fenômenos físicos pela parametrização dos processos estão sendo cada vez mais aperfeiçoados e validados, ampliando o uso de ferramentas computacionais de simulação. Inclusive, com o crescimento da produção e uso de programas computacionais de simulação, os modelos numéricos tornam-se cada vez mais acessíveis e fundamentais para viabilizar o amplo uso de ferramentas computacionais. Programas computacionais para geração de dados sintéticos são recursos de baixo custo e consomem menos tempo, além de permitirem obter dados com uma variação horária necessária para utilização em programas de simulação. No entanto, é recomendado que sejam continuamente validados por dados reais (BLOCKEN; CARMELIET, 2004; KRENZINGER; BUGS, 2010).

\subsection{NORMAIS CLIMATOLÓGICAS}

O principal arquivo climático no Brasil são as Normais Climatológicas fornecidas pelo Instituto Nacional de Meteorologia (INMET) que seguem os procedimentos padronizados mundialmente pela Organização Meteorológica Mundial (OMM) para a obtenção e validação dos dados coletados. 
A Organização Meteorológica Mundial (OMM) é responsável pelo aperfeiçoamento de conceitos, procedimentos gerais e técnicas estatísticas adequadas ao cálculo das Normais Climatológicas.

Os procedimentos padronizados para a determinação das normais permitem estabelecer referências básicas para comparações, tornando mais úteis os dados climáticos coletados em experimentos quando comparados com valores normais padronizados.

A OMM define Normais Climatológicas Padronizadas como valores médios calculados para um período relativamente longo e uniforme, compreendendo no mínimo três décadas consecutivas, representando padrões climatológicos normais como médias de dados climatológicos calculados para períodos consecutivos de 30 anos.

As décadas consecutivas estabelecidas pela OMM para a obtenção das Normais Climatológicas são 1901-1930, 1931-1960, 1961-1990, 1991-2020, etc. (INMET, 2009).

As Normais Climatológicas Provisórias são definidas pela OMM como médias de curto período, baseadas em observações que se estendem sobre um período mínimo de 10 anos. As Normais Provisórias são utilizadas quando a estação não esteve em operação durante o período de 30 anos ou os dados ainda não estão disponíveis, ou ainda, quando se detecta ausências de informações por escassez ou má qualidade de dados nas Normais Climatológicas Padronizadas (INMET, 2009).

As Normais Climatológicas do Brasil 1961-1990 foram publicadas pela primeira vez em 1992 pelo Departamento Nacional de Meteorologia do Ministério da Agricultura e Reforma Agrária, hoje denominado Instituto Nacional de Meteorologia (INMET). Esta publicação reunia dados de 209 estações meteorológicas brasileiras e 12 variáveis meteorológicas e, por muito tempo, foi usada como uma importante fonte de dados para os trabalhos relacionados aos estudos climáticos no Brasil.

No entanto, como consequência técnico-científica do aperfeiçoamento dos conceitos, metodologias e ferramentas computacionais que fundamentam os estudos meteorológicos, inclusive com a incorporação de recomendações da OMM, o INMET decidiu-se pela revisão e ampliação das informações da publicação de 1992. Isso foi possível graças à implantação do SIM - Sistema de Informações Meteorológicas do INMET, no final do ano 2000.

O SIM consiste em um banco de dados relacional que permitiu centralizar e organizar, eficientemente, o acervo de dados meteorológicos digitalizados e criou as condições objetivas para uma revisão sistemática das Normais 1961-1990 em 2009. As Normais Climatológicas 
1961-1990 de 1992 abrangiam 209 estações meteorológicas. Em 2009, para a revisão e ampliação das normais climatológicas, foram computadas 414 estações meteorológicas de superfície e as variáveis meteorológicas foram ampliadas para um conjunto de 26 variáveis (INMET, 2009).

As Normais Climatológicas são importantes, pois consolidam séries representativas daquele período. Os procedimentos padronizados para a determinação das Normais permitem estabelecer referências básicas para comparações, tornando mais úteis os dados climáticos coletados em observações reais quando comparados com valores normais padronizados no mundo todo.

\subsubsection{Estações meteorológicas e tipos de dados meteorológicos}

O INMET possui estações meteorológicas de superfície convencionais e automáticas em todo o Brasil. Em Brasília, são duas estações meteorológicas convencionais de superfície e uma estação automática, funcionando simultaneamente. São elas:

- Estações meteorológicas convencionais em Brasília:

○ Código 83377: longitude $47,92^{\circ} \mathrm{W}$; latitude $15,78^{\circ} \mathrm{S}$; altitude $1159,54 \mathrm{~m}$. Bairro Sudoeste;

○ Código 83378: longitude 47,92 ${ }^{\circ} \mathrm{W}$; latitude $15,87^{\circ} \mathrm{S}$; altitude $1060 \mathrm{~m}$. Local: Aeroporto.

- Estação meteorológica automática A001 em Brasília:

○ Código 86715 : longitude $47,92^{\circ} \mathrm{W}$; latitude $15,78^{\circ} \mathrm{S}$; altitude $1161 \mathrm{~m}$. Bairro Sudoeste.

Uma estação meteorológica convencional é composta de vários equipamentos isolados que registram, continuamente, os dados meteorológicos (pressão atmosférica, temperatura, umidade relativa do ar, precipitação, radiação solar, direção e velocidade do vento, etc.), que são lidos e anotados por um técnico observador, a cada intervalo, e enviados para um centro coletor por um meio de comunicação (telefone, e-mail, etc.). Uma estação meteorológica de superfície automática é composta de uma unidade de memória central (data logger), ligada a vários sensores dos fenômenos meteorológicos, que integraliza automaticamente a cada hora, os valores registrados minuto a minuto. As informações meteorológicas são representativas da área em que a estação meteorológica está localizada.

As Normais Climatológicas Padronizadas da série 1961-1990 para Brasília trazem a referência da Estação Meteorológica Convencional de Brasília-DF que possui o código sinótico 83377, com valores registrados em três horários de observação, às 12 UTC, 18 UTC e 24UTC, respectivamente 9h, 15h e 21h, no horário oficial de Brasília. 
Em sua série 1961-1990, as Normais Climatológicas não apresentam dados de radiação solar, somente apresentam horas de insolação. Os dados horários de radiação solar passaram a ser registrados pelas estações automáticas do INMET a partir de maio de 2000.

Estações sinóticas realizam simultaneamente, independentemente de sua localização geográfica, observações em horários padronizados internacionalmente pela OMM. Os horários padrão para fins sinóticos são 00:00(ou 24:00) UTC, 06:00 UTC, 12:00 UTC e 18:00 UTC.

A unidade de tempo UTC (Coordinated Universal Time ou Tempo Universal Coordenado) corresponde ao fuso horário de referência a partir do qual se calculam todas as outras zonas horárias. Para Brasília, na transformação de UTC para hora local, basta subtrair 3 horas.

Para a obtenção das Normais Climatológicas da série 1961-1990, com base em dados de observações sinóticas em estações convencionais de superfície, o INMET classificou as variáveis em grupos (RAMOS et al., 2010).

As variáveis do grupo I são aquelas associadas aos valores diários, como temperatura, pressão atmosférica, umidade relativa do ar, nebulosidade e intensidade do vento. No cômputo dos valores diários, foi calculada a média aritmética simples dos valores registrados nos três horários de observação sinótica (12, 18 e 24 UTC).

As variáveis do grupo II são aquelas associadas a valores acumulados no período de interesse, como precipitação, evaporação e insolação. Os valores acumulados foram resultados da soma de todos os valores diários disponíveis para aquele mês ou aquele ano, sendo considerados apenas meses completos, isto é, meses sem nenhum dado faltante. Para as variáveis dos grupos II, a normal anual foi computada como a soma dos 12 valores mensais.

As variáveis do grupo III correspondem àquelas que representam eventos observados em um período como o mês ou o ano, entre elas estão os dias com chuva acima de determinado limiar, ou períodos do mês com dias consecutivos sem chuva.

Para variáveis em quaisquer dos três grupos, a normal é considerada padronizada se o número de anos para os quais se dispõe de valores for igual a 30 anos. Se o número de anos for inferior a 30, mas igual ou superior a 10 anos, é uma normal provisória. Caso o número de anos seja inferior a 10, o valor não é considerado.

A estação automática A001 está em funcionamento em Brasília desde maio do ano 2000, sendo a primeira estação automática de superfície no Brasil para coleta de dados horários pelo INMET. 
As estações meteorológicas automáticas (EMA) coletam dados de minuto a minuto. A cada hora, as medidas são integralizadas e disponibilizadas para serem transmitidas, via satélite ou telefonia celular, para a sede do INMET, em Brasília. O conjunto de dados recebidos é validado através de um sistema de controle da qualidade (eliminação de erros grosseiros) e armazenado em um banco de dados. Por meio da Internet, os dados meteorológicos são disponibilizados em tempo real e, também, os arquivos de dados horários dos últimos 3 meses.

Para acessar arquivos de dados de períodos mais longos, é necessário solicitar ao INMET. Os arquivos climáticos são disponibilizados gratuitamente e o INMET alerta que as informações (dados meteorológicos) das estações automáticas são dados brutos e ainda não passaram por um processo de consistência (validação). Ou seja, esses arquivos podem conter dados nulos (NULL) e dados espúrios.

\subsection{ARQUIVOS CLIMÁTICOS DE DADOS HORÁRIOS PARA SIMULAÇÃO}

Para as simulações computacionais, em geral, é necessário que o arquivo climático seja representativo do local e contenha um ano completo de 365 dias com 8760 dados horários. No caso dos anos bissextos, o dia 29 de fevereiro deve ser descartado.

Metodologias específicas permitem tratar os dados de uma série de 30 anos (10 anos, no mínimo) para compor um ano completo que representa um ano climático médio, de referência ou típico de um determinado local. Os dados selecionados devem representar a série de padrões climáticos que normalmente seria encontrada em um conjunto de dados de vários anos.

Um ano climático, típico ou de referência, consiste em um ano de dados climáticos horários apresentados em um formato padronizado para as 8.760 horas do ano.

Neste caso, há diversas metodologias para a sua obtenção, entre elas o Test Reference Year (TRY), o Typical Meteorological Year (TMY), o método normatizado pela ISO15927-4, entre outras.

\subsubsection{Ano Climático de Referência (TRY - Test Reference Year)}

O Test Reference Year (TRY) consiste em um ano real com dados climáticos horários, contendo informações climáticas para as 8.760 horas do ano, apresentados em um formato padronizado, conforme necessário para as simulações de desempenho das edificações (LAMBERTS et al., 2011). 
O TRY é gerado a partir de dados de temperatura. A metodologia para a formação de um Ano Climático de Referência - TRY consiste em eliminar do banco de dados os anos de temperaturas médias mensais extremas (altas ou baixas), até que se obtenha apenas um ano de dados médios. O TRY seleciona o ano mais representativo entre vários anos (GOULART, 1993; GOULART et al.,1998).

\subsubsection{Ano Meteorológico Típico (TMY - Typical Meteorological Year)}

O Typical Meteorological Year (TMY) é uma das metodologias para se obter um ano típico. Diferentemente do TRY que seleciona o ano mais representativo entre vários anos, o TMY seleciona os meses mais representativos de vários anos distintos para compor um ano típico.

A metodologia para obtenção de um TMY baseia-se na variável temperatura e consiste em excluir sucessivamente os meses mais quentes e mais frios, até que reste apenas um, considerado como o mês típico do local. O TMY é formado por 12 meses reais, podendo ser, estes meses, de diferentes anos, desde que o mês selecionado seja representativo dos mesmos meses observados no período de 30 anos (de preferência) ou, no mínimo, 10 anos (AKUTSU, 1998).

\subsubsection{Metodologia da ISO15927-4 para um ano climático}

A ISO15927-4 Hygrothermal performance of buildings - Calculation and presentation of climatic data - Part 4: Hourly data for assessing the annual energy use for heating and cooling (BS, 2005) normatiza a seleção de informações meteorológicas para avaliação energética de longo prazo para edificações.

A norma parte da premissa que a correta simulação do desempenho do edifício depende não apenas dos valores médios das variáveis meteorológicas, mas também das distribuições de frequência desses e da correlação entre eles.

A ISO 15927-4 especifica um método para a construção de um ano de referência de valores horários de dados meteorológicos adequados para avaliar o desempenho anual para os estudos energéticos, ou seja, não contempla situações extremas.

Para a determinação do ano de referência, a metodologia contempla as médias diárias das variáveis climáticas temperatura de bulbo seco, radiação solar e umidade, considerando pelo menos, 10 anos de dados horários. 
A partir de análises estatísticas e dos valores das medianas e, considerando o menor desvio padrão da velocidade do vento, é feita a seleção do melhor mês para ser incluído no ano de referência (BS, 2005).

\subsubsection{Arquivos de ano climático disponíveis para Brasília}

Visando aos estudos de projetos e avaliações energéticas de edificações, Goulart et al. (1998) organizou arquivos climático do tipo TRY (Test Reference Year) para 14 cidades brasileiras, com dados horários do período 1961 - 1970.

Carlo e Lamberts (2005), com vistas ao processamento de arquivos climáticos para simulação de desempenho energético de edificações, realizaram uma revisão e correção de dados dos arquivos climáticos TRY, inserindo dados de radiação e compilando arquivos em formatos para consulta compatíveis com os dois programas computacionais de simulação de desempenho térmico, o DOE 2.1-E e o EnergyPlus, muito utilizados para a etiquetagem Procel-Edifica.

Como não havia arquivos de dados horários medidos de irradiância solar, os autores recorreram aos métodos de cálculo para estimar os valores de irradiação solar global horizontal horária (CARLO; LAMBERTS, 2005).

A Figura 2.1 mostra os resultados das comparações efetuadas pelos autores entre os diferentes métodos de cálculo testados para determinar a irradiação. Observa-se que os valores resultantes são muito dependentes do método semi-empírico adotado.

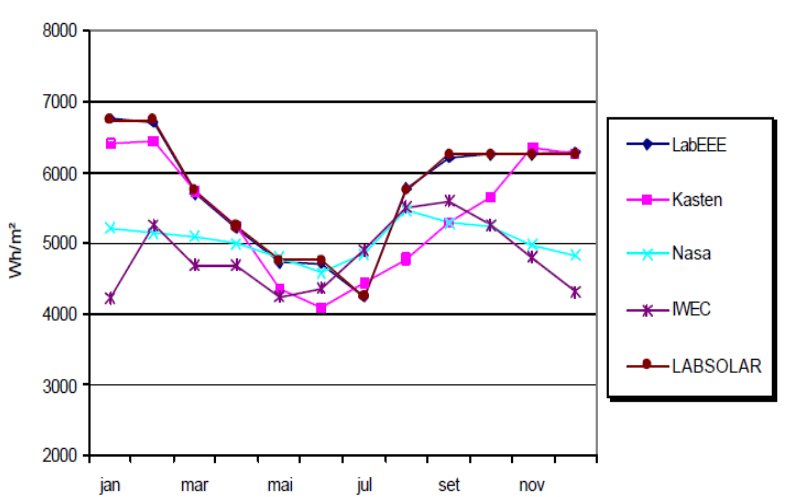

Fonte: Carlo; Lamberts (2005).

Figura 2.1 - Média diária da irradiância solar global $\left(\mathrm{Wh} / \mathrm{m}^{2}\right)$ para Brasília.

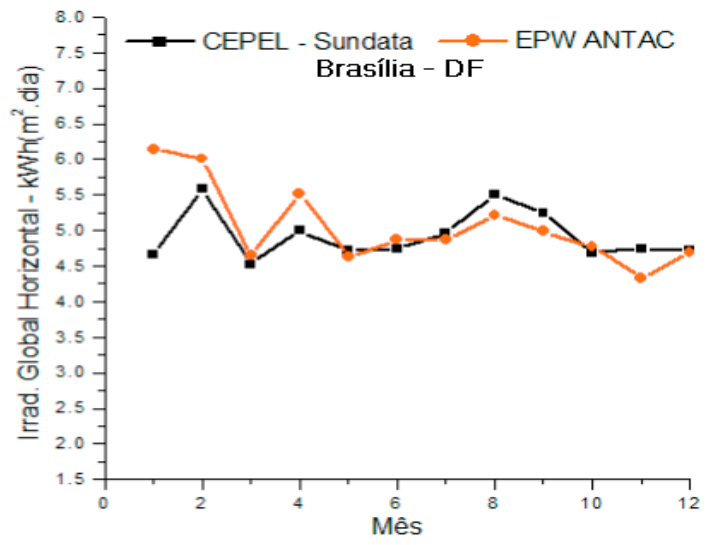

Fonte: Roriz (2012).

Figura 2.2 - Média diária da irradiância solar global $\left(\mathrm{Wh} / \mathrm{m}^{2}\right)$ para Brasília.

Em 2012, Roriz organizou um conjunto de arquivos climáticos TMY que foram disponibilizados como arquivos da base EPW-ANTAC. Para o arquivo climático TMY para Brasília, Roriz (2012) utilizou 10 anos de dados horários (2001 a 2010) medidos pelo INMET. 
A Figura 2.2 mostra uma comparação entre o arquivo climático EPW-ANTAC gerado para Brasília e a base de dados do CEPEL-Sundata, usada como referencial de comparação por Roriz (2012). Segundo o autor, observa-se boa correspondência entre as duas bases de dados.

Em 2015, Scheller et al. publicaram um relatório contendo uma análise comparativa entre o Atlas SWERA, o Atlas IRENA e mais três arquivos climáticos utilizados nas simulações termoenergética de edificações para climas brasileiros, identificados como TRY (Test Reference Year), TMY da base SWERA (Solar and Wind Energy Resource Assessment) e TMY (Typical Meteorological Year) da base EPW/ANTAC, elaborado por Roriz (2012) com 10 anos de dados do INMET. Para as 15 cidades analisadas, entre elas Brasília, os autores concluíram que os arquivos climáticos analisados possuem imprecisões e baixa qualidade (SCHELLER et al., 2015).

A partir dos dados de irradiância solar global apresentados no relatório de Scheller et al. (2015), para a cidade de Brasília, a Figura 2.3 mostra a representação gráfica dos arquivos comparados pelos pesquisadores.

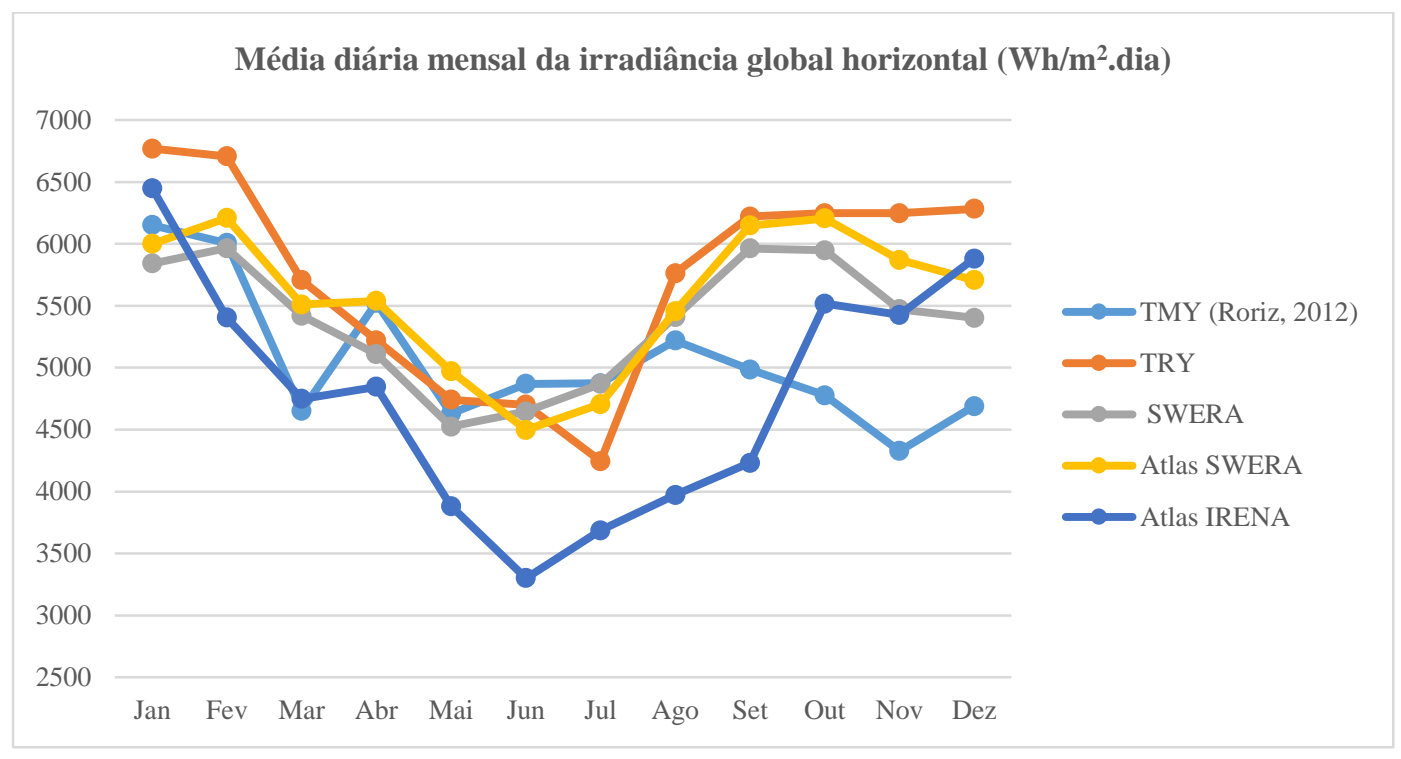

Fonte dos dados: Scheller et al. (2015).

Figura 2.3 - Média diária mensal da irradiância solar global (Wh/m²) para Brasília.

Para simulações de desempenho termo-energético em Brasília, os arquivos climáticos que mais se destacam são: arquivo climático TRY-1962_05CSV; arquivo climático TMY-SWERA com dados do projeto SWERA (Solar and Wind Energy Resource Assessment) e arquivo climático TMY-EPW/ANTAC com 10 anos de dados do INMET (Scheller et al., 2015).

Para as simulações computacionais higrotérmicas por meio do programa WUFI, é necessária a utilização de um arquivo climático que contenha dados de precipitação. Neste caso, a opção é 
pelo uso do arquivo TMY da base EPW-ANTAC (RORIZ, 2012) que contempla tal variável, utilizada para a quantificação de chuva dirigida. No entanto, para ser usado nesta tese, foi preciso averiguar a sua representatividade (essa discussão é apresentada na seção 2.16).

\subsection{ESTUDO DAS VARIÁVEIS CLIMÁTICAS PARA BRASÍLIA}

Para caracterizar as variáveis climáticas para Brasília, visando aos estudos de degradação por meio de simulações computacionais e a necessidade de uma base de referência para a análise de sensibilidade, foi obtido no INMET um arquivo climático com dados horários referentes aos anos de 2001 a 2013, correspondendo aos registros consecutivos de 13 anos de dados climáticos horários pela estação meteorológica automática de superfície, código A001- Brasília (doravante referenciado como arquivo climático da série 2001-2013/INMET).

A Tabela 2.1 mostra as variáveis climáticas contempladas pela série 2001-2013/INMET para os estudos desta tese, as quantidades de horas registradas pelos arquivos e os respectivos percentuais de dados nulos.

Tabela 2.1 - Percentual de dados nulos dos arquivos climáticos de dados horários da série 2001-2013 registrados pelo INMET na estação automática de superfície A001- Brasília.

\begin{tabular}{lccc}
\hline \multicolumn{1}{c}{ Variáveis climáticas } & Série 2001-2013 & $\begin{array}{c}\text { Horas com dados } \\
\text { nulos (h) }\end{array}$ & \% de dados nulos \\
\hline \hline Temperatura do ar $\left({ }^{\circ} \mathrm{C}\right)$ & 113880 & 4221 & 3,71 \\
Temperatura do ponto de orvalho $\left({ }^{\circ} \mathrm{C}\right)$ & 113880 & 4221 & 3,71 \\
Umidade relativa do ar $(\%)$ & 113880 & 4226 & 3,71 \\
Temperatura máxima $\left({ }^{\circ} \mathrm{C}\right)$ & 113880 & 4465 & 3,92 \\
Temperatura mínima $\left({ }^{\circ} \mathrm{C}\right)$ & 113880 & 4466 & 3,92 \\
Temperatura máxima do ponto de orvalho $\left({ }^{\circ} \mathrm{C}\right)$ & 113880 & 4462 & 3,92 \\
Temperatura mínima do ponto de orvalho $\left({ }^{\circ} \mathrm{C}\right)$ & 113880 & 4461 & 3,92 \\
Umidade relativa máxima do ar $(\%)$ & 113880 & 4466 & 3,92 \\
Umidade relativa mínima do ar $(\%)$ & 113880 & 4467 & 3,76 \\
Pressão atmosférica $(\mathrm{hPa})$ & 113880 & 4279 & 4,28 \\
Vento-velocidade $(\mathrm{m} / \mathrm{s})$ & 113880 & 4869 & 4,28 \\
Vento-direção $($ graus) & 113880 & 4873 & 10,65 \\
Radiação global horizontal $\left(\mathrm{Wh} / \mathrm{m}^{2}\right)$ & 113880 & 12125 & 3,81 \\
Precipitação (mm) & 113880 & 4343 & 4,49 \\
Vento, rajada máxima $(\mathrm{m} / \mathrm{s})$ & 113880 & 5118 & 4,00 \\
Pressão atmosférica máxima $(\mathrm{hPa})$ & 113880 & 4555 & 4,00 \\
Pressão atmosférica mínima $(\mathrm{hPa})$ & 113880 & 4555 & - \\
Nebulosidade $($ variando de $1 \mathrm{a} 10)$ & $14231 * *$ & - & \\
\hline
\end{tabular}

** Diariamente, a variável nebulosidade é obtida visualmente por um observador, nos três horários sinóticos. 
Esses arquivos foram fornecidos como dados brutos, por não terem passados, ainda, por um processo de consistência (validação). Por isso, são arquivos que podem apresentar dados nulos (NULL) e eventuais dados espúrios (valores fora da faixa limite característica da variável climática em análise). Para verificar a representatividade estatística desses arquivos, foi feito um levantamento dos dados nulos (Tabela 2.1). Observa-se que a quantidade de dados nulos apresentados pelos arquivos está abaixo de 5\%, com exceção da radiação solar que apresenta cerca de $10 \%$.

Baseado nas orientações e informações obtidas durante às consultas feitas aos técnicos e especialistas da área, considerando o tamanho da amostra (13 anos de dados horários) e o percentual de dados nulos (10\% ou menos), foi tomada a decisão de não preencher os dados nulos da série 2001-2013, mantendo assim os arquivos somente com os dados medidos válidos, sem incorrer em risco de cometer alterações no comportamento dos dados reais.

Para melhor embasar a caracterização das variáveis climáticas da série 2001-2013, as análises estatísticas são apresentadas no Apêndice A e foram utilizadas nos estudos de comportamento e análises comparativas.

\subsection{PRECIPITAÇÃO}

A precipitação é o conjunto de partículas líquidas ou sólidas que caem das nuvens em forma de chuva, chuvisco, neve, granizo, nevoeiro, bruma, geada e orvalho. A precipitação é medida em milímetros (mm) por meio de pluviômetro: uma lâmina de $1 \mathrm{~mm}$ de espessura corresponde a 1 litro de água em uma superfície plana horizontal de um metro quadrado. A intensidade da precipitação é o volume de água que cai na unidade de tempo. As medições podem ser registradas em milímetros por hora (INMET, 1999).

O Quadro 2.1 apresenta uma classificação dos tipos de precipitação (chuva e chuvisco), suas intensidades e características.

Quadro 2.1 - Grau de intensidade da precipitação.

\begin{tabular}{|c|l|l|}
\hline Classificação & \multicolumn{1}{|c|}{ Intensidade e características } \\
\hline \hline $\begin{array}{l}\text { Chuva ou chuvisco } \\
\text { inapreciável (inap) }\end{array}$ & \multicolumn{2}{|c|}{ Precipitação cuja quantidade não consegue ser acumulada. } \\
\hline Chuvisco & \multicolumn{2}{|c|}{ Precipitação até 1,0 mm por hora } \\
\hline Chuva fraca & $\begin{array}{l}\text { Precipitação de 1,1 mm por } \\
\text { hora até 5,0 mm por hora ou, } \\
\text { no máximo, 0,8 mm em 10 } \\
\text { minutos. }\end{array}$ & $\begin{array}{l}\text { As gotas de chuva são bem destacadas; os pingos nos } \\
\text { telhados são fracos; as poças de água formam-se } \\
\text { lentamente; as superfícies secas levam cerca de dois } \\
\text { minutos para se umedecerem; fios de água correm } \\
\text { nas sarjetas das ruas. }\end{array}$ \\
\hline
\end{tabular}




\begin{tabular}{|c|l|l|}
\hline \multicolumn{2}{|c|}{ Quadro 2.1 - Grau de intensidade da precipitação. } \\
\hline Classificação & \multicolumn{2}{|c|}{ Intensidade e características } \\
\hline \hline Chuva moderada & $\begin{array}{l}\text { Precipitação de } 5,1 \mathrm{~mm} \text { por } \\
\text { hora até } 60,0 \mathrm{~mm} \text { por hora } \\
\text { ou, no máximo, 6,0 mm em } \\
10 \text { minutos. }\end{array}$ & $\begin{array}{l}\text { As gotas de chuva são bem identificadas e ao } \\
\text { encontrarem superfícies duras provocam borrifos; o } \\
\text { escoamento das águas nas calhas dos telhados vai de } \\
\text { um terço a mais da metade da sua capacidade; a } \\
\text { queda das chuvas nos telhados provoca ruídos } \\
\text { assemelhados a desde um simples chiado até o bater } \\
\text { de tambores. }\end{array}$ \\
\hline Chuva forte & $\begin{array}{l}\text { Precipitação acima de } 60,0 \\
\text { mm por hora ou de 10,0 mm } \\
\text { em 10 minutos. }\end{array}$ & $\begin{array}{l}\text { A chuva cai torrencialmente e todas as demais } \\
\text { características são mais acentuadas que as indicadas } \\
\text { para chuva moderada. }\end{array}$ \\
\hline Fonte: INMET (1999). & \multicolumn{2}{|l}{} \\
\hline
\end{tabular}

As chuvas em Brasília ocorrem de setembro a abril, ou seja, maio, junho, julho e agosto são os meses mais secos do ano.

Na série 2001-2013 foi identificado que os seis meses mais chuvosos do ano (outubro, novembro, dezembro, janeiro, fevereiro e março) correspondem a 85,15\% do total de precipitação em 13 anos de dados analisados. Consequentemente, 14,85\% do total da precipitação correspondem aos seis meses mais secos (abril, maio, junho, julho, agosto e setembro).

Na Tabela 2.2 são apresentadas as intensidades de precipitação em cada mês do ano.

Tabela 2.2 - Precipitação (mm) da série 2001-2013 para Brasília.

\begin{tabular}{lccccccccccccc}
\hline & Jan & Fev & Mar & Abr & Mai & Jun & Jul & Ago & Set & Out & Nov & Dez & Período \\
\hline \hline $\begin{array}{l}\text { Período chuvoso } \\
\text { 2216,0 }\end{array}$ & 164,2 & 187,9 & & & & & & & 138,7 & 220,8 & 242,2 & $\mathbf{1 . 1 6 9 , 8}$ \\
Período seco & & & & 132,0 & 18,5 & 2,1 & 2,4 & 15,2 & 33,8 & & & & $\mathbf{2 0 4 , 0}$ \\
\hline & & & & & & & & & & & Anual & $\mathbf{1 . 3 7 3 , 8}$ \\
\hline
\end{tabular}

Fundamentado na forte sazonalidade demarcada pelos percentuais de precipitação, foi possível subdividir equitativamente os meses do ano em dois períodos de igual tamanho temporal, caracterizados como períodos seco e chuvoso. Para fins metodológicos, essa divisão fez-se necessária para que os estudos de degradação ao envelhecimento natural das edificações pudessem ser feitos em dois diferentes períodos bem característicos, mas com o mesmo espaço temporal.

\subsection{UMIDADE RELATIVA DO AR}

A umidade relativa do ar é uma variável climática que exprime a quantidade de vapor de água na atmosfera. O elemento água existe na atmosfera sob três estados: sólido, líquido e gasoso. A 
umidade ou vapor de água presente na atmosfera é o estado gasoso do elemento água e apresenta-se misturado com o ar seco. A proporção de umidade da atmosfera, expressa em percentagem $(\%)$, pode aumentar devido à evaporação, ou pode diminuir devido à condensação (mudanças de estado).

As medições de umidade relativa envolvem equipamentos que associam as leituras das temperaturas de bulbo seco (temperatura do ar) com as temperaturas de bulbo úmido. A temperatura do ponto de orvalho é outra variável climática associada à umidade relativa (INMET, 1999).

Os processos evaporativos e de evapotranspiração que regulam a umidade relativa do ar são influenciados pelo regime de ventos, ciclo hidrológico, topografia, ocupação urbana, presença de vegetação, lagos, rios, mares, entre outros. Ao longo do dia, quando a temperatura se eleva, a umidade relativa do ar fica mais baixa.

Como Brasília está localizada no Planalto Central, em uma região de Cerrado e longe das grandes massas de água, a umidade relativa do ar está fortemente ligada à sazonalidade da precipitação e aos ciclos diários de temperatura, além do armazenamento e transporte de vapor de água nas camadas superiores da atmosfera.

Segundo Cavalcante et al. (2008), desde o final da década de 30 já se sabe que a precipitação não depende simplesmente da evaporação e evapotranspiração local, depende também do armazenamento de vapor de água na atmosfera e seu transporte pela circulação geral.

Para melhor caracterizar a umidade relativa do ar, foram calculadas as médias mensais com base na série 2001-2013, com 13 anos de dados horários medidos pelo INMET, conforme apresentado na Tabela 2.3.

Tabela 2.3- Média mensal da umidade relativa do ar (\%) por período, em Brasília.

\begin{tabular}{|c|c|c|c|c|c|c|c|c|c|c|c|c|c|}
\hline & Jan & Fev & Mar & Abr & Mai & Jun & Jul & Ago & Set & Out & Nov & Dez & Período \\
\hline Período chuvoso & $78 \%$ & $75 \%$ & $77 \%$ & & & & & & & $63 \%$ & $76 \%$ & $77 \%$ & $74 \%$ \\
\hline Período seco & & & & $73 \%$ & $67 \%$ & $63 \%$ & $55 \%$ & $47 \%$ & $48 \%$ & & & & $59 \%$ \\
\hline & & & & & & & & & & & \multicolumn{2}{|c|}{ Média Anual } & $67 \%$ \\
\hline
\end{tabular}

Baseado na forte sazonalidade demarcada pelos percentuais de precipitação que configuram dois períodos de igual tamanho temporal, caracterizados como períodos seco e chuvoso (ver seção 2.6), a variável umidade relativa do ar foi, também, caracterizada mensalmente e nos períodos seco e chuvoso, definidos pelo regime de chuva. Como já foi dito, para fins metodológicos, essa divisão fez-se necessária para que os estudos de degradação ao 
envelhecimento natural das edificações pudessem ser feitos em dois diferentes períodos bem característicos, mas com o mesmo espaço temporal.

Importante frisar que os dados de umidade relativa em estudo referem-se aos valores horários da umidade relativa do ar, não envolvendo a variável climática URmáxima ou URmínima (ver na Tabela 2.1, algumas variáveis meteorológicas medidas pelo INMET).

A Figura 2.4 mostra a frequência de ocorrência da umidade relativa do ar da série 2001-2013, de um total de 109654 horas analisadas, com intervalo de classe variando de 5\%UR.

A média anual é de $67 \%$ UR e cerca de $39 \%$ das horas possuem umidade relativa acima de 75\%UR. A frequência no intervalo de classe $95 \%$ UR é a mais alta da série, correspondendo a cerca de $12 \%$ da amostra.

Visando analisar as frequências de ocorrência da umidade relativa da série 2001-2013 por período, a Figuras 2.5-a mostra o período chuvoso e a Figura 2.5-b mostra o período seco, com intervalo de classe variando de 5\%UR.

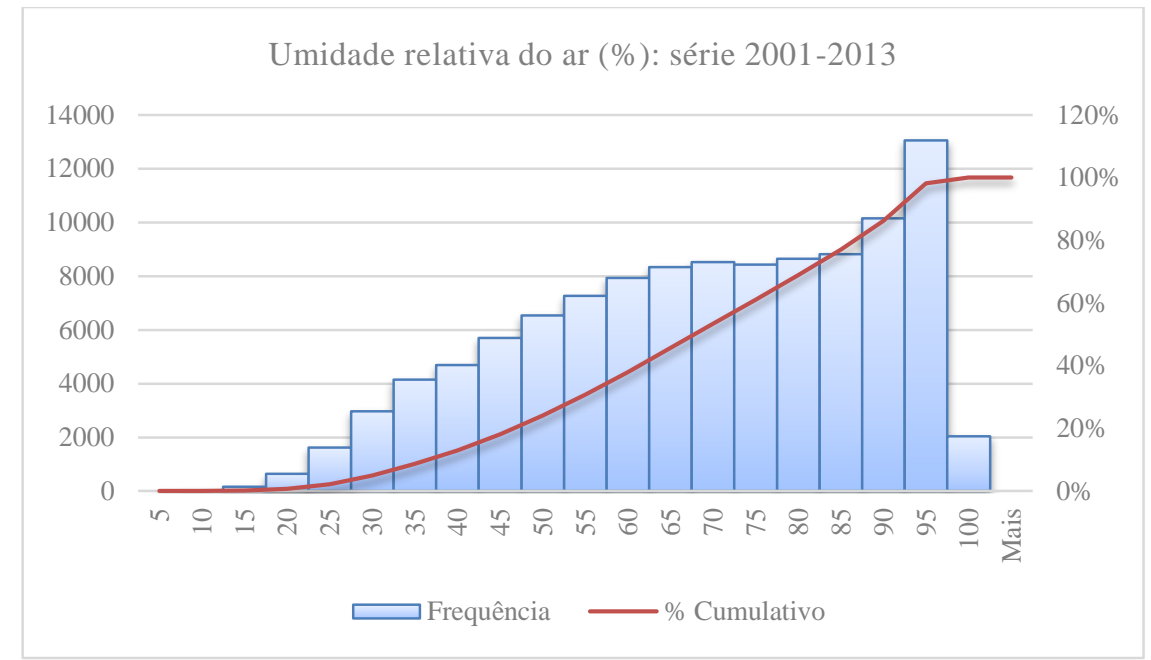

Figura 2.4 - Umidade relativa (\%): frequência de ocorrência da série 2001-2013 para Brasília.
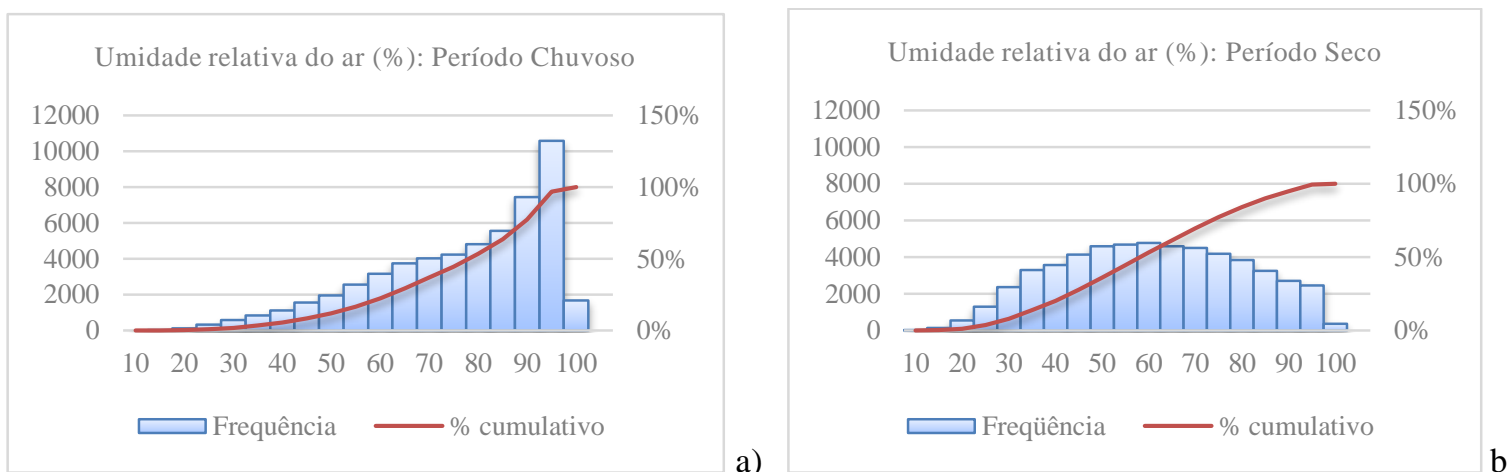

Figura 2.5 - Frequência de ocorrência da umidade relativa (\%) da série 2001-2013 para Brasília: a) período chuvoso; b) período seco. 
A Tabela 2.4 e a Figura 2.6 apresentam as faixas de ocorrência da umidade relativa do ar para a série 2001-2013, com três níveis de classificação propostos para esta tese (crítico, satisfatório, alto). A Tabela 2.5 mostra a distribuição dessas horas para o período noturno ( $18 \mathrm{~h}$ até $6 \mathrm{~h}$ ) e para o período diurno (6h até $18 \mathrm{~h})$, nos períodos seco e chuvoso.

\begin{tabular}{|c|c|c|c|}
\hline & $\mathrm{UR} \leq \mathbf{3 0} \%$ & $30 \%<\mathrm{UR} \leq 75 \%$ & $\mathrm{UR}>75 \%$ \\
\hline בJan & 0,02 & 3,0 & 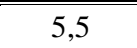 \\
\hline Fev & 0,02 & 3,0 & 4,0 \\
\hline Mar & 0,02 & 3,0 & 5,0 \\
\hline Abr & 0,01 & 5,0 & 4,0 \\
\hline Mai & 0,04 & 5,0 & 3,0 \\
\hline Jun & 0,13 & 6,0 & 2,0 \\
\hline Jul & 0,53 & 7,0 & 1,0 \\
\hline Ago & 1,46 & 7,0 & 0,0 \\
\hline Set & 1,87 & 6,0 & 1,0 \\
\hline Out & 0,83 & 5,0 & 3,0 \\
\hline Nov & 0,02 & 3,0 & 5,0 \\
\hline Dez & 0,05 & 3,0 & 5,5 \\
\hline Total & $5 \%$ & $56 \%$ & $39 \%$ \\
\hline
\end{tabular}

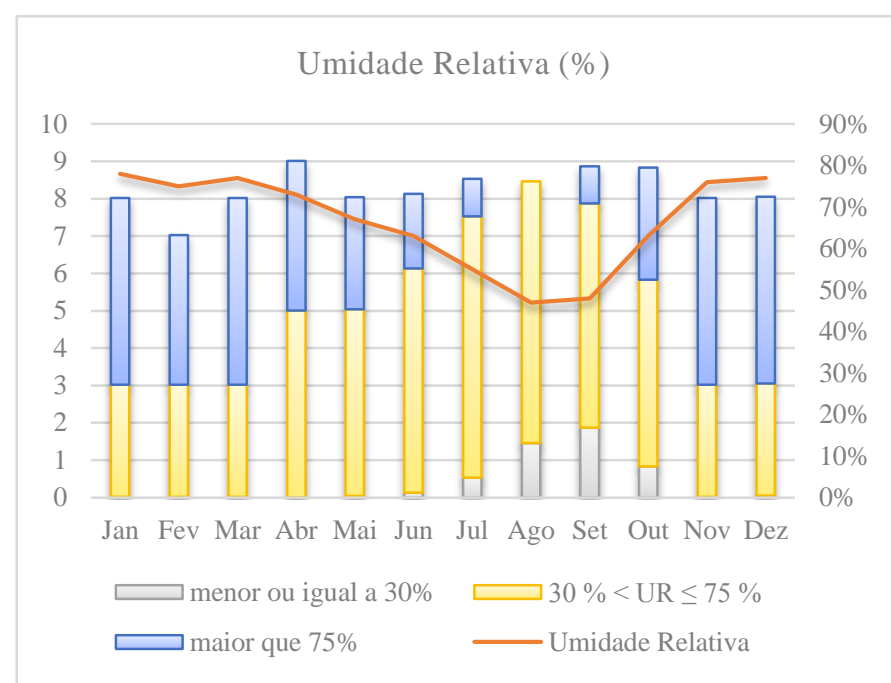

Figura 2.6 - Umidade relativa (\%) da série 2001-2013 para Brasília: média mensal e por faixa de frequência.

Tabela 2.5 - Distribuição das horas com umidade relativa acima de 75\% UR, em Brasília.

\begin{tabular}{cccc}
\hline & Período chuvoso & Período seco & Total \\
\hline \hline Noturno & $46 \%$ & $19 \%$ & $\mathbf{6 5 \%}$ \\
Diurno & $24 \%$ & $11 \%$ & $\mathbf{3 5 \%}$ \\
\hline Total no período & $70 \%$ & $30 \%$ & $\mathbf{1 0 0 \%}$ \\
\hline
\end{tabular}

A cidade de Brasília, mesmo sendo caracterizada pelas baixas taxas de umidade relativa do ar, apresenta uma média anual de 67\%UR, com cerca de 39\% das horas da série 2001-2013 com umidade relativa acima de $75 \%$ UR, conforme mostra a Figura 2.4.

No período chuvoso, a média da umidade relativa do ar é de $74 \%$ UR, e no período seco é de $59 \%$ UR.

Investigando as faixas de frequência para a série 2001-2013 (Tabela 2.4 e Figura 2.6), a umidade relativa do ar foi classificada em três níveis de ocorrência:

- Crítico UR $\leq 30 \%$ - 5\% das horas possuem umidade relativa abaixo ou igual a 30\%;

- Satisfatório 30\%<UR $\leq 75 \%$ - 56\% das horas possuem umidade relativa entre $30 \%$ e $75 \%$;

- Alto UR $>75 \%$ - 39\% das horas possuem umidade relativa acima de $75 \%$. 
Observa-se que é baixa a frequência de ocorrência da umidade relativa no nível crítico, concentrando-se nos meses de agosto e setembro. As horas de umidade relativa classificadas como nível alto variam ao longo dos meses do ano, mas ocorrem em todos os meses, com exceção do mês de agosto.

Como já citado, considerando uma amostra de 109654 horas analisadas na série 2001-2013, cerca de $39 \%$ dessas horas possuem umidade relativa acima de $75 \%$ UR, sendo que $28 \%$ estão no período chuvoso e $11 \%$ estão no período seco. Considerando somente as horas com umidade relativa do ar acima de $75 \% \mathrm{UR}$, cerca de $65 \%$ dessas horas estão concentradas no período noturno.

\subsection{PRESSÃO ATMOSFÉRICA}

A pressão atmosférica é uma variável climática que corresponde ao peso da coluna de ar da camada atmosférica sobre um determinado ponto. A unidade que mede a pressão atmosférica é hPa ou mm de mercúrio, que corresponde a 9,80665 m/s² a $0^{\circ} \mathrm{C}$ (INMET, 1999).

A pressão atmosférica depende da altitude do lugar. Nas altitudes elevadas a pressão é menor, pois a camada de ar atmosférico é menos espessa. As variações de temperatura ocasionam modificações na densidade do ar, resultando em movimentos verticais e horizontais que acarretam, por essas razões, alterações da pressão atmosférica. As variações da pressão atmosférica são sensíveis às condições do tempo, havendo queda acentuada da pressão em tempo chuvoso com vento e elevação da pressão nos períodos de melhora do tempo.

A Figura 2.7 representa o comportamento da pressão do ar ao longo das 24 horas do dia, em um perfil de um dia de verão e de um dia de inverno.

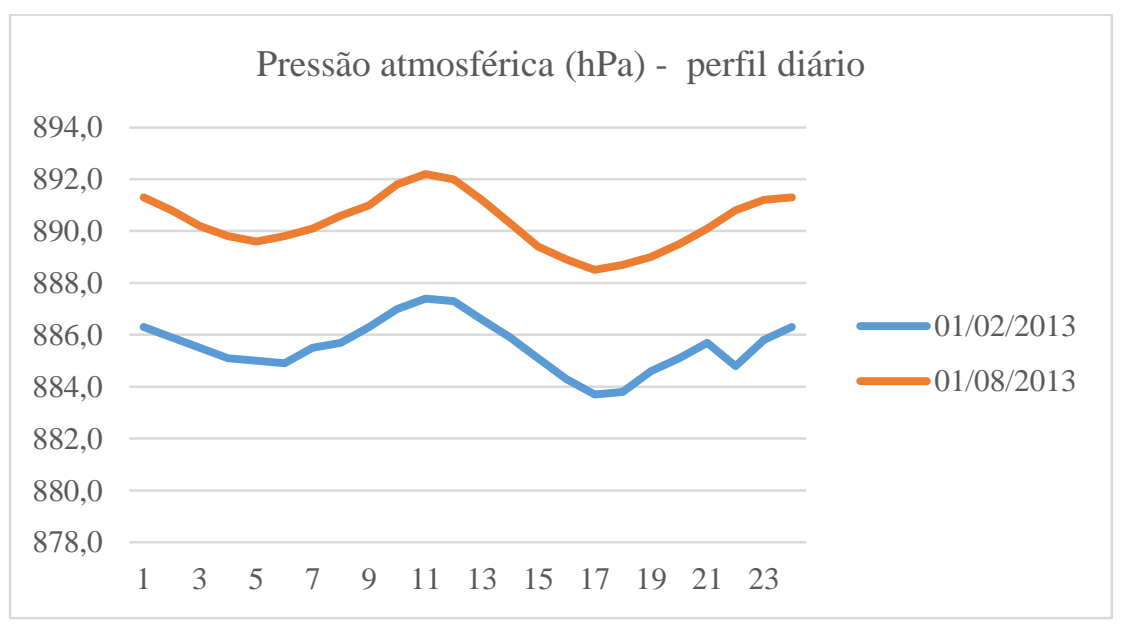

Figura 2.7 - Perfil diário da pressão atmosférica (hPa) no verão e no inverno, em Brasília. 
Na média, as pressões atmosféricas possuem comportamento sazonal, diferenciando-se no inverno e no verão. Ao longo do dia, apresentam comportamento senoidal, com dois máximos e dois mínimos. As pressões máximas são registradas, aproximadamente, às 10 e 22 horas local e, as mínimas, ocorrem às 4 e 16 horas local.

Para Brasília, com base na série 2001-2013, a média anual encontrada para a pressão atmosférica do ar é de $887,15 \mathrm{hPa}$.

\subsection{TEMPERATURA DO AR}

A temperatura é uma variável climática que indica a quantidade de calor que existe no ar. Apesar de o Sol ser a principal fonte de calor da Terra, não é a radiação solar que determina diretamente a temperatura do ar, visto que o ar é transparente a todos os comprimentos de onda. A temperatura do ar é resultado dos efeitos da radiação solar sobre as superfícies da Terra e do balanço energético. A radiação solar atinge o solo e as superfícies, aquecendo-os. O calor liberado pelo solo e superfícies aquecidos, por convecção, aquecem o ar.

Segundo Lamberts et al. (2011), neste balanço energético estão envolvidos a radiação solar incidente, o coeficiente de absorção das superfícies receptoras da radiação solar, a condutividade e a capacidade térmica do solo, que determinam a transmissão de calor por condução, as perdas por evaporação, convecção e radiação.

A temperatura do ar pode ser expressa em valores médios (horários, diários, mensais e anuais), valores extremos (máxima e mínima) e amplitude térmica.

A temperatura média do ar é uma variável climatológica obtida pela média das temperaturas verificadas em um período específico de tempo. A temperatura máxima e a temperatura mínima, respectivamente, são resultantes das médias das máximas temperaturas e das mínimas temperaturas, em um determinado período. A temperatura máxima absoluta e a temperatura mínima absoluta são, respectivamente, a mais alta das temperaturas máximas e a mais baixa das temperaturas mínimas, observadas em um determinado período (INMET, 1999).

A temperatura do ar tem um comportamento cíclico diário. As temperaturas mais baixas acontecem um pouco antes do nascer do sol, vai elevando-se ao longo do dia, atingindo os valores máximos cerca de duas horas após a passagem do sol pelo meridiano do observador. Então, a temperatura da terra começa a diminuir. A partir deste momento, o balanço começa a ser negativo: a energia perdida, especialmente por radiação em direção às altas camadas da 
atmosfera, é maior que a recebida. A variação diária de temperatura é maior nos trópicos e decresce em direção aos polos.

A Figura 2.8 mostra um perfil anual das variáveis climáticas temperatura horária máxima e temperatura horária mínima, para o ano de 2013, registradas pela estação automática de superfície A001-Brasília.

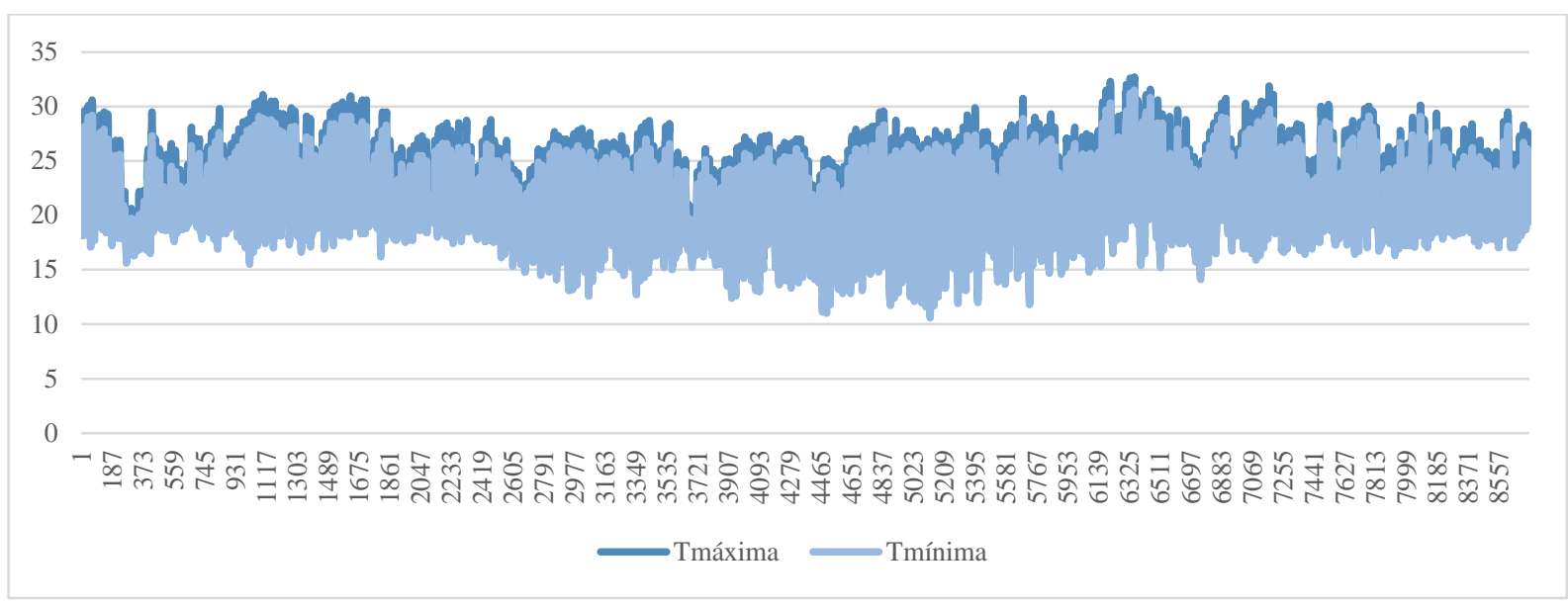

Figura 2.8 - Perfil anual das temperaturas horárias máximas e mínimas em ${ }^{\circ} \mathrm{C}$, registradas pela estação automática de superfície A001-Brasília no ano de 2013.

A Tabela 2.6 mostra as médias estatísticas das temperaturas do arquivo climático da série 20012013, para as três variáveis climáticas registradas. Observa-se que as diferenças não são muito acentuadas.

Tabela 2.6 - Valores horários das temperaturas da série 2001-2013: Estação A001 do INMET, em Brasília - DF.

\begin{tabular}{cccc}
\hline & $\begin{array}{c}\text { Temperatura do ar } \\
\left({ }^{\circ} \mathbf{C}\right)\end{array}$ & $\begin{array}{c}\text { Temperatura Máxima } \\
\left({ }^{\circ} \mathbf{C}\right)\end{array}$ & $\begin{array}{c}\text { Temperatura Mínima } \\
\left({ }^{\circ} \mathbf{C}\right)\end{array}$ \\
\hline \hline Média & 21,2 & 21,9 & 20,6 \\
Mediana & 20,7 & 21,4 & 20,1 \\
Moda & 19,1 & 19,4 & 19,1 \\
Mínimo & 9,1 & 9,4 & 8,8 \\
Máximo & 34,9 & 35,3 & 34,4 \\
\hline
\end{tabular}

Na cidade de Brasília, a temperatura horária mínima absoluta acontece na madrugada, pouco antes do nascer do sol, e a temperatura horária máxima absoluta ocorre no meio da tarde.

Ao longo do ano, o comportamento das temperaturas máxima e mínima (ilustrado na figura 2.8, como exemplo) permite compreender as amplitudes térmicas do ar que ocorrem diariamente.

O Quadro 2.2 mostra os valores absolutos máximos e mínimos das temperaturas. 
Quadro 2.2 - Valores absolutos das temperaturas da série 2001-2013/INMET, Estação A001- Brasília - DF.

\begin{tabular}{|cccc|}
\hline & $\begin{array}{c}\text { Temperatura do ar } \\
\left({ }^{\circ} \mathbf{C}\right)\end{array}$ & $\begin{array}{c}\text { Temperatura Máxima } \\
\left({ }^{\circ} \mathbf{C}\right)\end{array}$ & $\begin{array}{c}\text { Temperatura Mínima } \\
\left({ }^{\circ} \mathbf{C}\right)\end{array}$ \\
\cline { 2 - 4 } Mínima horária & $8,9^{\circ} \mathrm{C}$ em $24 / 07 / 2004$ às $7 \mathrm{~h}$ & $9,4^{\circ} \mathrm{C}$ em $24 / 07 / 2004$ às $7 \mathrm{~h}$ & $8,8^{\circ} \mathrm{C}$ em $24 / 07 / 2004$ às $7 \mathrm{~h}$ \\
Máxima horária & $34,9^{\circ} \mathrm{C}$ em $28 / 10 / 2008$ às $14 \mathrm{~h}$ & $35,3^{\circ} \mathrm{C} \mathrm{em} 28 / 10 / 2008$ às $15 \mathrm{~h}$ & $34,4^{\circ} \mathrm{C}$ em $28 / 10 / 2008$ às $15 \mathrm{~h}$ \\
\hline \hline & Máxima Absoluta da série 2001-2013: $35,3^{\circ} \mathrm{C} \mathrm{em} 28 / 10 / 2008$ às 15 horas \\
& Mínima Absoluta da série 2001-2013: $8,8^{\circ} \mathrm{C} \mathrm{em} 24 / 07 / 2004$ às 7 horas \\
\hline
\end{tabular}

As Figuras 2.9-a, 2.9-b e 2.9-c representam, respectivamente, os histogramas das temperaturas médias, máximas e mínimas.

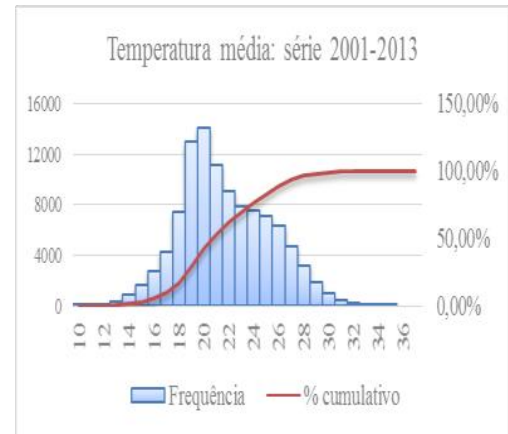

a)

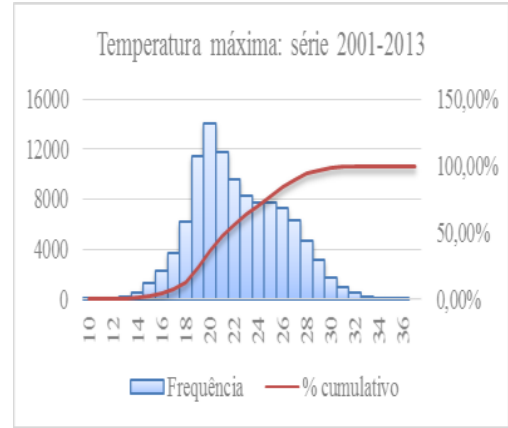

b)

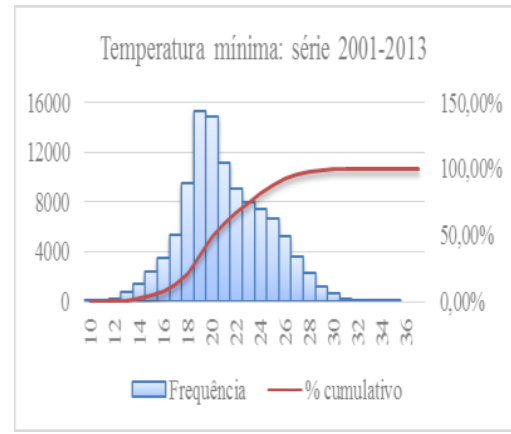

c)

Figura 2.9 - Histogramas para as temperaturas horárias da série 2001 - 2013 para Brasília: a) Temperatura média do ar $\left({ }^{\circ} \mathrm{C}\right)$; b) Temperatura máxima $\left({ }^{\circ} \mathrm{C}\right)$; c) Temperatura mínima $\left({ }^{\circ} \mathrm{C}\right)$.

As temperaturas representadas pelos histogramas ilustram o clima ameno da cidade de Brasília que possui muitas horas do ano na zona de conforto ${ }^{2}$. Segundo Lamberts, et al. (2013), Brasília possui $43,6 \%$ de horas do ano em zona de conforto térmico e 56,3\% em horas de desconforto, sendo distribuídas em $15,2 \%$ decorrente do calor e $41,1 \%$ devido ao frio.

Considerando a frequência de ocorrência da série 2001-2013, para os histogramas com intervalo de classe variando de $1{ }^{\circ} \mathrm{C}$, observa-se que menos de $1 \%$ das temperaturas máximas horárias ocorrem com valores acima de $31{ }^{\circ} \mathrm{C}$ e, menos de $1 \%$ das temperaturas mínimas horárias ocorrem com valores abaixo de $14^{\circ} \mathrm{C}$.

\subsection{AMPLITUDE TÉRMICA}

A amplitude térmica é uma variável que mede a flutuação térmica diária, obtida pela diferença entre a temperatura horária máxima absoluta e a temperatura horária mínima absoluta

\footnotetext{
${ }^{2}$ Baseado na carta bioclimática apresentada pela NBR 15220-3 (ABNT, 2005) que classifica as zonas bioclimáticas conforme metodologia adaptada do Diagrama Psicométrico de Givoni.
} 
registradas naquele dia. Isto é, a diferença entre a máxima e a mínima temperatura, ao longo de 24 horas de um dia, chama-se amplitude térmica (INMET, 1999).

A umidade influencia a amplitude térmica. Quando o ar está muito úmido, a amplitude térmica é pequena. Quando o ar está muito seco, as temperaturas máximas e mínimas podem ser mais acentuadas. Ou seja, a amplitude térmica é uma variável que depende da umidade do ar. Climas mais secos possuem amplitudes maiores e, por outro lado, climas mais úmidos possuem amplitudes menores.

A Figura 2.10 mostra o comportamento da umidade relativa do ar e da temperatura máxima em um dia de inverno, para a cidade de Brasília.

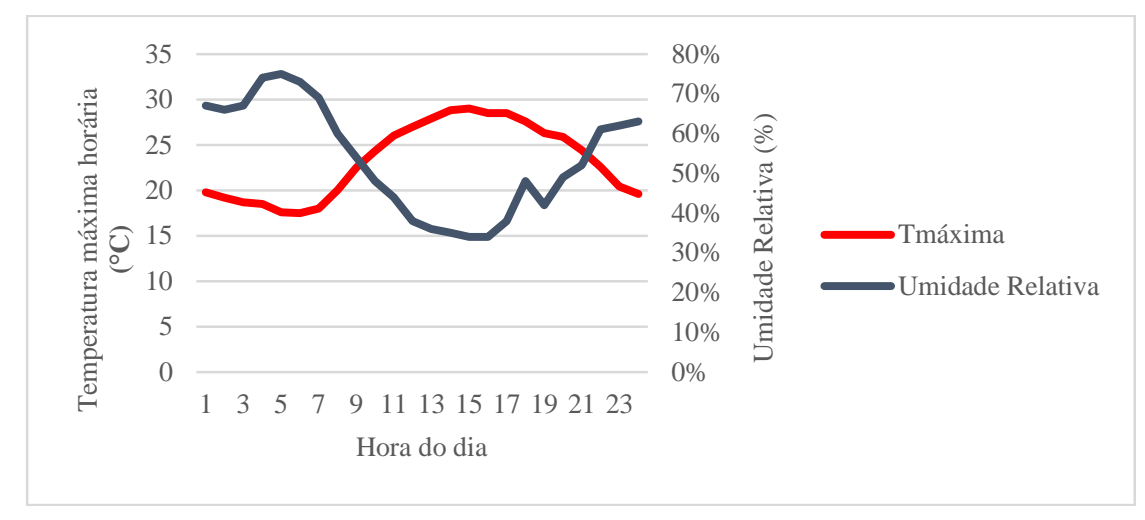

Figura 2.10 - Perfil diário da temperatura máxima $\left({ }^{\circ} \mathrm{C}\right)$

e da umidade relativa (\%) para um dia de inverno (24/07/2009), em Brasília.

O cálculo da amplitude térmica diária da série 2001-2013 foi feito pela diferença entre a máxima temperatura horária e a mínima temperatura horária para cada dia válido da amostra. Ou seja, utilizou-se a máxima e a mínima absoluta das 24 horas de cada dia.

Para se obter o valor da amplitude térmica representativa de cada mês, foi feita a média aritmética simples com todas as amplitudes térmica dos dias correspondentes ao mês em questão.

A Tabela 2.7 mostra as médias mensais da amplitude térmica e os valores máximos mensais, organizados nos períodos seco e chuvoso, inclusive as médias por período, obtidos da série 2001-2013. Mostra, também, a frequência por faixa de variação das amplitudes térmicas, em percentuais de contribuição para a média mensal.

As faixas de variação da amplitude térmica foram definidas, após um estudo estatístico das frequências de ocorrência e com base em parâmetro dado pela NBR 6118. Buscou-se classificar em três faixas que fossem mais representativas das condições de exposição das edificações: $\mathrm{AT}<10^{\circ} \mathrm{C} ; 10^{\circ} \mathrm{C} \leq \mathrm{AT}<15^{\circ} \mathrm{C}$ e $\mathrm{AT} \geq 15^{\circ} \mathrm{C}$. 
A Figura 2.11 apresenta os percentuais totais de ocorrência para cada faixa de amplitude térmica. A Figura 2.12 apresenta a contribuição de cada faixa de amplitude térmica na composição da média mensal.

Tabela 2.7 - Amplitude térmica (AT) da série 2001-2013 para Brasília:

Médias mensais e frequência de ocorrência.

\begin{tabular}{|c|c|c|c|c|c|c|c|}
\hline & \multicolumn{2}{|c|}{ Período chuvoso } & \multicolumn{2}{|c|}{ Período seco } & \multicolumn{3}{|c|}{ Frequência por faixa de variação da amplitude térmica diária } \\
\hline & $\begin{array}{c}\text { ATmédia } \\
\text { Mensal }\end{array}$ & ATmax & $\begin{array}{c}\text { ATmédia } \\
\text { Mensal }\end{array}$ & ATmax & $\mathrm{AT}<10^{\circ} \mathrm{C}$ & $10^{\circ} \mathrm{C} \leq \mathrm{AT}<15^{\circ} \mathrm{C}$ & $\mathrm{AT} \geq 15^{\circ} \mathrm{C}$ \\
\hline Jan & $8,5^{\circ} \mathrm{C}$ & $14,3^{\circ} \mathrm{C}$ & & & $5,2 \%$ & $4,5 \%$ & $0,2 \%$ \\
\hline Fev & $9,1^{\circ} \mathrm{C}$ & $14,3^{\circ} \mathrm{C}$ & & & $1,9 \%$ & $6,4 \%$ & $0,6 \%$ \\
\hline Mar & $9,0^{\circ} \mathrm{C}$ & $14,3^{\circ} \mathrm{C}$ & & & $2,6 \%$ & $6,9 \%$ & $0,4 \%$ \\
\hline Abr & & & $9,4^{\circ} \mathrm{C}$ & $14,2^{\circ} \mathrm{C}$ & $6,4 \%$ & $2,3 \%$ & $0,0 \%$ \\
\hline Mai & & & $10,6^{\circ} \mathrm{C}$ & $16,2^{\circ} \mathrm{C}$ & $4,7 \%$ & $3,0 \%$ & $0,0 \%$ \\
\hline Jun & & & $11,2^{\circ} \mathrm{C}$ & $18,3^{\circ} \mathrm{C}$ & $2,1 \%$ & $5,1 \%$ & $0,4 \%$ \\
\hline Jul & & & $12,0^{\circ} \mathrm{C}$ & $16,9^{\circ} \mathrm{C}$ & $2,2 \%$ & $5,4 \%$ & $0,4 \%$ \\
\hline Ago & & & $12,1^{\circ} \mathrm{C}$ & $17,6^{\circ} \mathrm{C}$ & $5,4 \%$ & $2,5 \%$ & $0,0 \%$ \\
\hline Set & & & $11,7^{\circ} \mathrm{C}$ & $17,8^{\circ} \mathrm{C}$ & $5,1 \%$ & $2,6 \%$ & $0,0 \%$ \\
\hline Out & $10,5^{\circ} \mathrm{C}$ & $16,1^{\circ} \mathrm{C}$ & & & $2,2 \%$ & $5,3 \%$ & $0,4 \%$ \\
\hline Nov & $8,8^{\circ} \mathrm{C}$ & $14,3^{\circ} \mathrm{C}$ & & & $3,5 \%$ & $4,0 \%$ & $0,2 \%$ \\
\hline Dez & $8,6^{\circ} \mathrm{C}$ & $14,2^{\circ} \mathrm{C}$ & & & $5,4 \%$ & $2,5 \%$ & $0,0 \%$ \\
\hline Total & $9,0^{\circ} \mathrm{C}$ & $14,5^{\circ} \mathrm{C}$ & $11,1^{\circ} \mathrm{C}$ & $16,8^{\circ} \mathrm{C}$ & $47 \%$ & $50 \%$ & $3 \%$ \\
\hline & & & & & Valores aprox & pelo arredondamen & asas decimais. \\
\hline
\end{tabular}

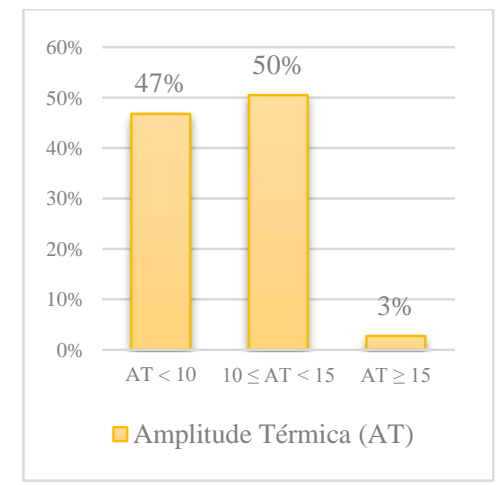

Figura 2.11 - Frequência de ocorrência por faixa de variação da amplitude térmica $\left({ }^{\circ} \mathrm{C}\right)$ em Brasília.

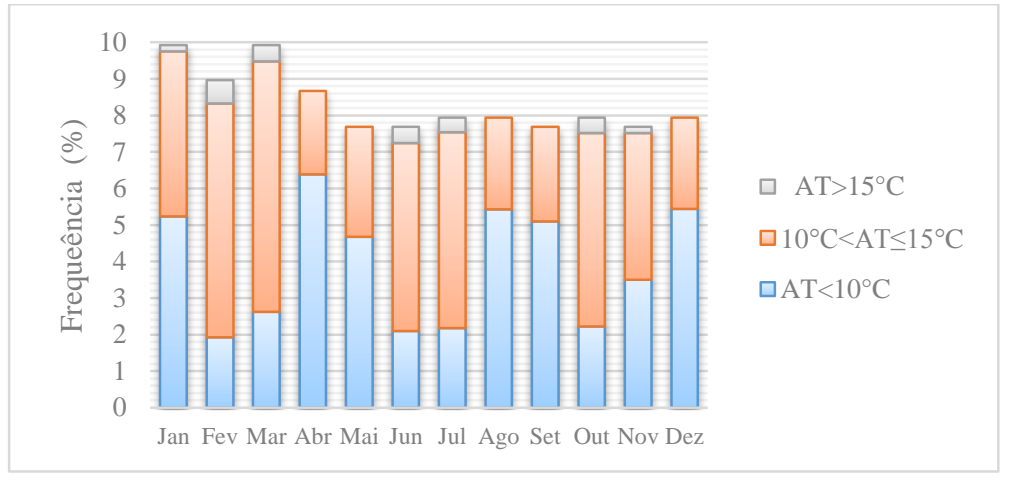

Figura 2.12 - Frequência de ocorrência (\%) por faixa de variação da média mensal da amplitude térmica $\left(\mathrm{AT}\right.$ em $\left.{ }^{\circ} \mathrm{C}\right)$ da série 20012013 para Brasília.

Na série 2001-2013, observa-se que cerca de 50\% da amostra referem-se à amplitude térmica diária maior ou igual a $10^{\circ} \mathrm{C}$ e menor que $15^{\circ} \mathrm{C}$. Somente cerca de $3 \%$ da amostra possuem amplitude térmica igual ou maior que $15^{\circ} \mathrm{C}$.

As máximas amplitudes térmicas diárias, no período chuvoso, variam entre $14,2^{\circ} \mathrm{C}$ e $16,1^{\circ} \mathrm{C}$. No período seco, as máximas amplitudes térmicas diárias variam entre $14,2^{\circ} \mathrm{C}$ e $18,3^{\circ} \mathrm{C}$. O mês de junho é aquele onde foi observado o maior valor $\left(18,3^{\circ} \mathrm{C}\right)$. Quanto às médias mensais, elas 
variam entre $8,5^{\circ} \mathrm{C}$ e $12,1^{\circ} \mathrm{C}$. Os meses que sofreram as maiores amplitudes térmicas foram julho e agosto (em torno de $12^{\circ} \mathrm{C}$ ). Verifica-se que as máximas amplitudes térmicas diárias e as maiores médias mensais correspondem ao período seco.

\subsection{NEBULOSIDADE}

A nebulosidade é uma variável climática que indica a fração do céu coberta pelas nuvens. A obtenção da nebulosidade é feita por meio da observação visual, mesmo quando a estação é automática. Isto é, esta variável não é computada pela estação automática A001 de Brasília. A nebulosidade é uma porção de céu encoberto que varia de 1/8 a 8/8. Para a representação dos dados climatológicos, adota-se a nebulosidade em décimos (variando de 0 a 10 décimos), proporcionalmente aos octais observados. Para a condição de céu claro, sem nuvens, a situação é zero. Para registrar a variável nebulosidade, o INMET faz 3 observações visuais diárias, nos horários sinóticos 12 UTC, 18 UTC e 24 UTC, (INMET, 2009).

O Quadro 2.3 apresenta a classificação da nebulosidade de acordo com a condição de céu.

Quadro 2.3 - Classificação da nebulosidade.

\begin{tabular}{|cl|}
\hline Condição de céu & Classificação \\
\hline \hline 0 a 3,9 & Céu claro (baixa nebulosidade) \\
4,0 a 6,9 & Céu parcialmente nublado (média nebulosidade) \\
7,0 a 10,0 & Céu encoberto (alta nebulosidade) \\
\hline
\end{tabular}

Fonte: Baseado em Wollmann e Sartori (2006a).

As nuvens exercem grande influência no balanço radioativo da Terra. $\mathrm{O}$ topo das nuvens é o mais importante refletor da radiação solar. Para a condição de céu encoberto, a irradiação global horizontal (que atinge a superfície da Terra) comparada com a irradiação solar extraterrestre (presente no topo da atmosfera) sofre uma grande atenuação em função da umidade mais elevada e da maior quantidade de nuvens. Nos dias de céu claro e com menor teor de umidade, grande parte da irradiação solar incidente no topo da atmosfera atinge a superfície da terra (PEREIRA; NUNES, 2013).

Segundo a NBR-15220-3 (ABNT, 2005c), a irradiância solar refere-se à taxa de radiação incidente sobre um corpo, por unidade de área de superfície.

A irradiância solar extraterrestre é a energia disponível em uma dada latitude, sem que sejam considerados os efeitos atenuantes da atmosfera (SENTELHAS; ANGELOCCI, 2009).

A Figura 2.13 representa a atenuação da irradiância solar extraterrestre $\left(Q_{0}\right)$, após sofrer os processos de absorção e difusão pela atmosfera. Outros aspectos conceituais relacionados com a radiação solar são abordados na seção 2.12 deste capítulo. 


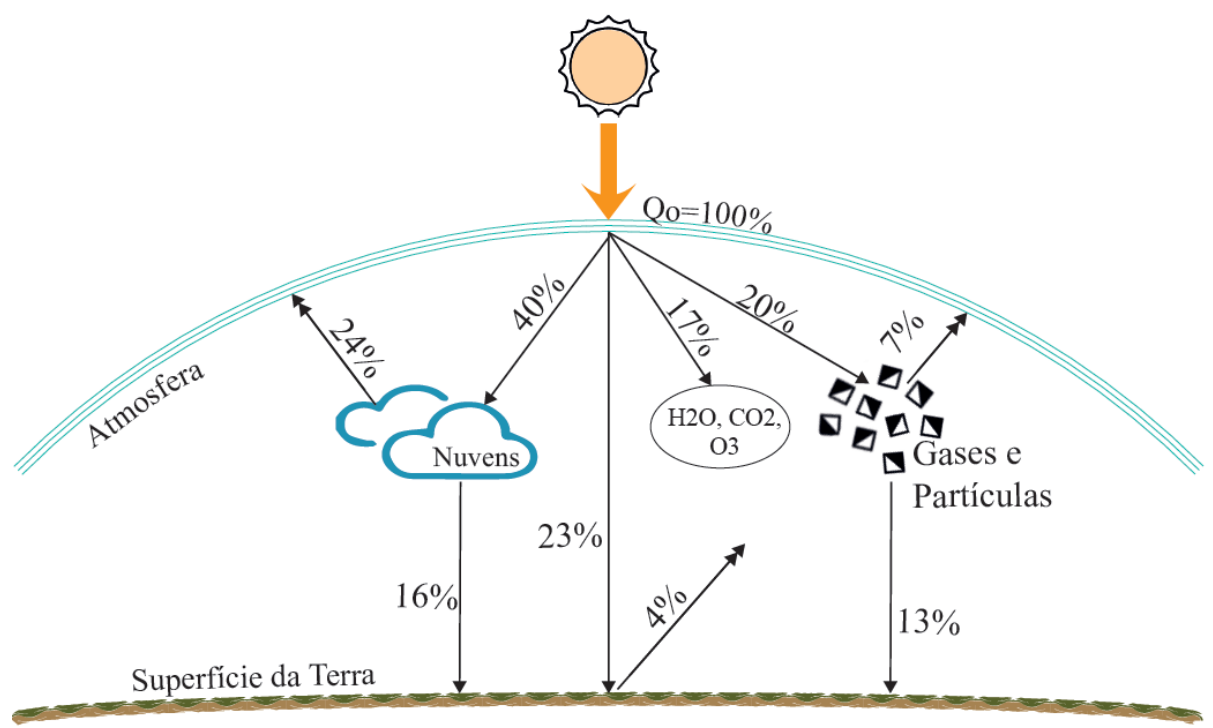

Fonte: Baseado em Sentelhas; Angelocci (2009).

Figura 2.13 - Irradiância solar após os efeitos atenuantes da atmosfera.

A Tabela 2.8 apresenta os valores da irradiância solar extraterrestre e da irradiância solar global horizontal, para a cidade de Brasília.

Tabela 2.8 - Irradiância solar extraterrestre $\left(Q_{0}\right)$ e irradiância solar global horizontal (Ig): Médias diárias em $\mathrm{kWh} / \mathrm{m}^{2}$ para Brasília.

\begin{tabular}{ccccccccccccc}
\hline & Jan & Fev & Mar & Abr & Mai & Jun & Jul & Ago & Set & Out & Nov & Dez \\
\hline $\mathbf{Q}_{\mathbf{0}}$ & 11,43 & 11,28 & 10,79 & 9,76 & 8,51 & 7,51 & 7,31 & 8,00 & 9,21 & 10,33 & 11,08 & 11,37 \\
Ig & 5,15 & 5,38 & 5,15 & 5,05 & 4,84 & 4,77 & 5,01 & 5,64 & 5,71 & 5,33 & 4,9 & 5,05 \\
\hline
\end{tabular}

Fonte da Irradiância solar extraterrestre: http://www.cresesb.cepel.br/sundata/index.php\#sundata (TIBA et al., 2001) Fonte da irradiância solar global horizontal: série 2001-2013/INMET.

A nebulosidade está relacionada com a evaporação. Nos meses frios, a radiação é menor, portanto a evaporação é menor, formando menos nuvens e tornando o céu mais limpo do que no verão. Nos dias de muita nebulosidade não faz tanto frio como nos dias com luz do sol. A barreira de nuvens impede tanto a penetração como a saída da radiação solar. Quanto maior a evaporação, maior é a formação de nuvens. Quando concentradas, atuam como uma barreira, refletindo para a estratosfera grande parte da radiação solar extraterrestre, por outro lado, diminuindo a quantidade de calor que a crosta terrestre perde por irradiações para a estratosfera (MOOJEN et al, 2012).

Na visão de Tubelis e Nascimento (1980), a nebulosidade não possui um comportamento regular ao longo do ano, mas depende da época do ano em que determinados processos de formação de nuvens atuam. Segundo os autores, os cursos anuais da nebulosidade e precipitação são similares. A precipitação acompanha as flutuações da nebulosidade ao longo do ano, pois dela se origina e é diretamente proporcional a ela. 
No entanto, Wollmann e Sartori (2010) alertam que o aumento da nebulosidade não implica, necessariamente, em aumento da pluviosidade. O aumento da nebulosidade implica em diminuição da taxa de radiação solar e de insolação que atingem a superfície terrestre.

Para algumas cidades, o comportamento da nebulosidade ao longo do ano tem forte relação com o comportamento da precipitação, mas nem sempre esta relação é estabelecida, conforme pode ser visto nas Figuras 2.14-a e 2.14-b. Observando as curvas de nebulosidade e precipitação para as cidades de Brasília, São Paulo e Porto Alegre, constata-se que os cursos mais similares entre a precipitação e a nebulosidade são os de Brasília.

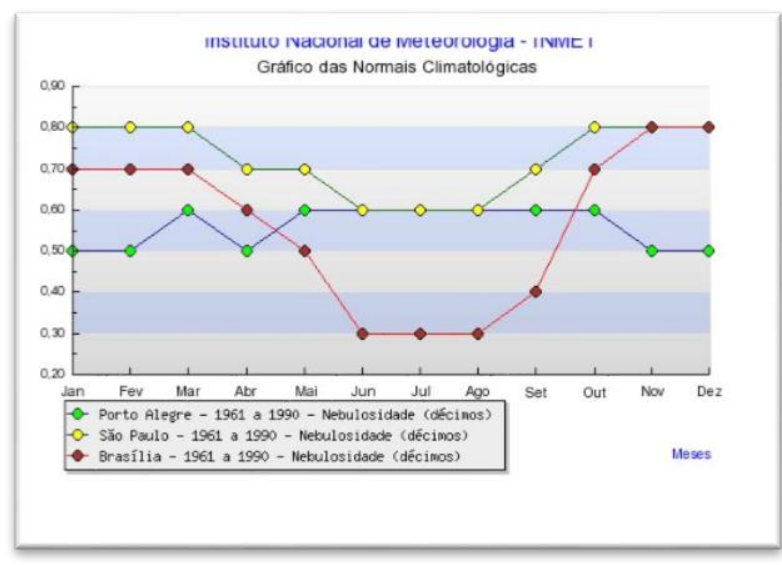

a)

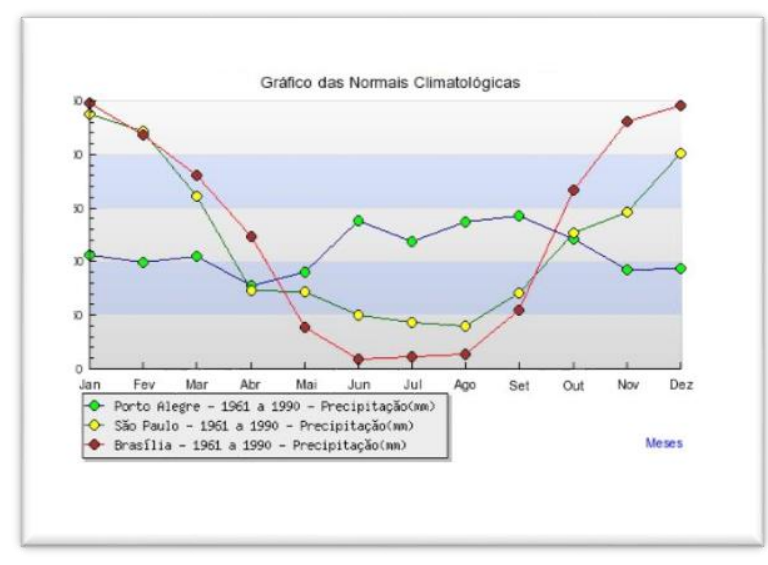

b)

Fonte: http://www.inmet.gov.br/portal.

Figura 2.14 - Gráficos das Normais Climatológicas 1961-1990 para as cidades de Brasília, São Paulo e Porto Alegre: a) nebulosidade; b) precipitação.

A Tabela 2.9 mostra as médias mensais da nebulosidade por período e o valor sinótico medido às $15 \mathrm{~h}$ local, calculados com base no arquivo climático da série 2001-2013. A Figura 2.15 representa o perfil anual das médias mensais da nebulosidade apresentadas na Tabela 2.9.

Tabela 2.9 - Média mensal da Nebulosidade da série 2001-2013 para Brasília.

\begin{tabular}{cccc}
\multicolumn{3}{c}{ Brasília. } \\
\hline & $\begin{array}{c}\text { Período } \\
\text { chuvoso }\end{array}$ & $\begin{array}{c}\text { Período } \\
\text { seco }\end{array}$ & $\begin{array}{c}\text { Média mensal } \\
\text { às 15 horas }\end{array}$ \\
\hline Jan & 8,1 & & 8,4 \\
Fev & 7,5 & & 8 \\
Mar & 7,3 & & 8 \\
Abr & & 6,0 & 7,1 \\
Mai & & 4,8 & 6,1 \\
Jun & & 3,5 & 4,7 \\
Jul & & 3 & 4 \\
Ago & & 2,8 & 3,6 \\
Set & & 4,4 & 5,3 \\
Out & 6,6 & & 7,2 \\
Nov & 8 & & 8,3 \\
Dez & 8 & & 8,4 \\
\hline Total & $\mathbf{7 , 6}$ & $\mathbf{4 , 1}$ & $\mathbf{6 , 6}$ \\
\hline Anual & & $\mathbf{5 , 8}$ & \\
\hline
\end{tabular}

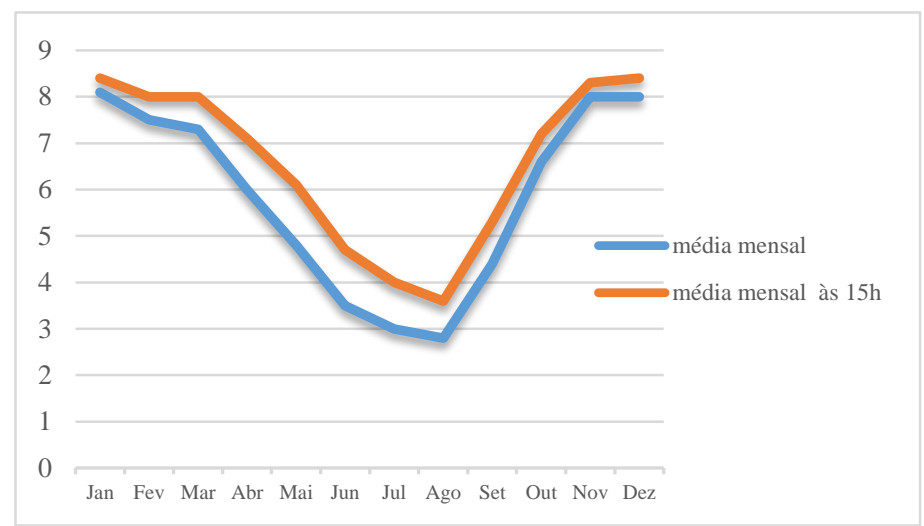

Figura 2.15 - Nebulosidade: média mensal, em Brasília. 
Como já mencionado, observa-se na Figura 2.15 que a nebulosidade é menor no período seco. O valor da nebulosidade, medido no horário sinótico correspondente às $15 \mathrm{~h}$ local, é maior que a média observada. Ou seja, em média, o período da tarde registra maior índice de nebulosidade que o período da manhã ou da noite.

A Figura 2.16 mostra a frequência de ocorrência da nebulosidade de acordo com a faixa de classificação dada para a condição de céu, apresentada na Tabela 2.10.

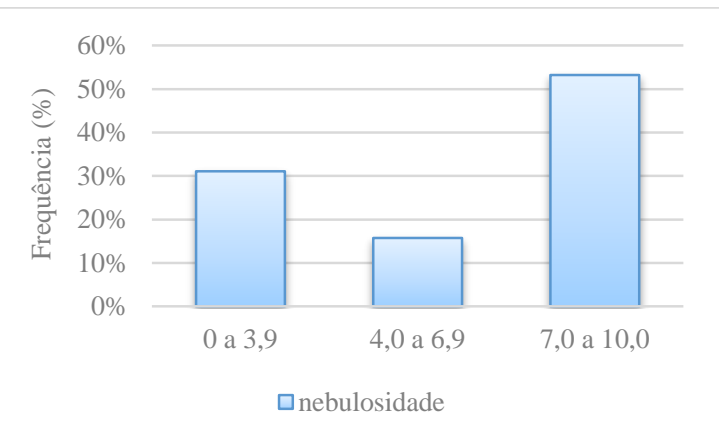

Figura 2.16 - Frequência de ocorrência $(\%)$ da nebulosidade, conforme classificação da condição de céu, em Brasília.
Tabela 2.10 - Condição de céu e frequência de ocorrência de nebulosidade da série 2001-2013 para Brasília.

\begin{tabular}{cc}
\hline Condição de céu & Frequência \\
\hline Céu claro - 0 a 3,9 & $31,1 \%$
\end{tabular}

Céu parcialmente nublado - 4,0 a $6,9 \quad 15,7 \%$

Céu encoberto - 7,0 a 10,0 53,2\%

A série 2001-2013 apresenta cerca de 53\% de registros de nebulosidade para a condição de céu encoberto, típico de período chuvoso, quando as médias mensais da nebulosidade apresentam valores de 7 ou mais décimos.

Cerca de 31\% dos registros de nebulosidade da série 2001-2013 correspondem à condição de céu claro, onde os valores de nebulosidade são da ordem de 0 a 3,9 décimos. No período seco, as médias mensais da nebulosidade dos meses junho, julho e agosto apresentam esta característica.

\subsection{RADIAÇÃO SOLAR GLOBAL HORIZONTAL}

A radiação solar emitida pelo Sol atinge o globo terrestre na forma de ondas eletromagnéticas curtas, concentradas na região do espectro eletromagnético compreendido entre comprimentos de ondas de $0,2 \mu \mathrm{m}$ e $0,3 \mu \mathrm{m}$. Varia continuadamente ao longo do ano devido à distância TerraSol e de acordo com o ângulo zenital, que é o ângulo de incidência dos raios solares.

Os comprimentos de onda emitidos pelas componentes da radiação oriunda do Sol são considerados ondas curtas e os comprimentos de onda emitidos pela Terra são considerados ondas longas. As fontes de baixa temperatura (por exemplo, o edifício) emitem radiação térmica 
de onda longa com comprimento de onda compreendido entre 3,0 $\mu \mathrm{m}$ e 100,0 $\mu \mathrm{m}$. Quanto maior a temperatura da fonte, menor o comprimento de onda (DUFFIE; BECKMAN, 1980). Seguindo a lei do inverso do quadrado da distância, à medida que a Terra se afasta do Sol ocorre a redução da irradiância solar extraterrestre. As distâncias máximas e mínimas verificadas na trajetória solar correspondem, respectivamente, aos solstícios de inverno (22/06) e de verão $(22 / 12)$.

O ângulo zenital formado entre o zênite local e os raios solares incidentes no plano do observador varia de acordo com a latitude, época do ano e hora do dia. Pela Lei do Cosseno de Lambert, quanto maior o ângulo zenital, maior é a inclinação dos raios solares e, portanto, maior é a área para a mesma quantidade de energia distribuída, resultando em uma menor concentração de irradiância solar. Por isso, as irradiâncias são máximas, próximo ao meio-dia do horário solar local, e mínimas, ao nascer e pôr do sol (SENTELHAS; ANGELOCCI, 2009).

A Figura 2.17 ilustra as componentes direta, difusa e refletida da radiação global horizontal.

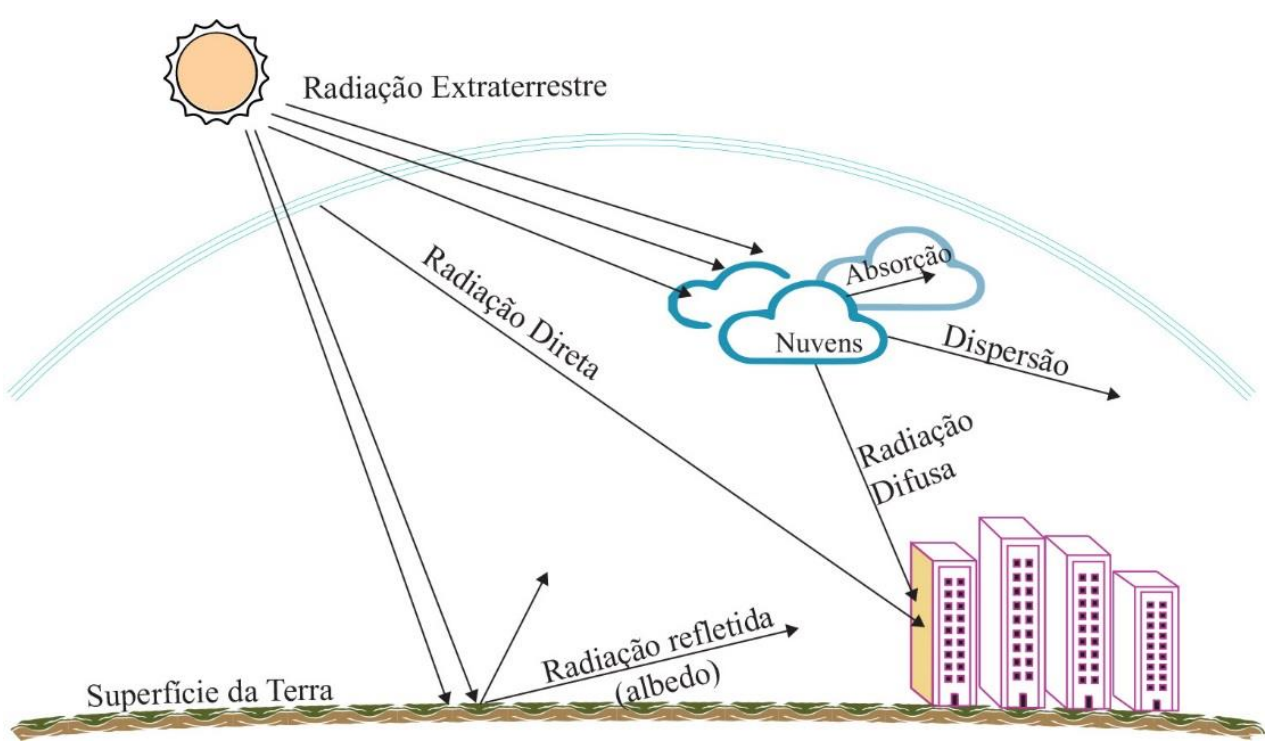

Figura 2.17 - Componentes da radiação solar.

A radiação global horizontal que incide na superfície terrestre é constituída pelas componentes direta e difusa.

A radiação global direta, advinda da parcela da radiação extraterrestre que atravessa a atmosfera e incide diretamente sobre as superfícies, é determinada pela Lei do Cosseno de Lambert.

A radiação global difusa é resultado dos sucessivos processos de difusão, reflexão e absorção que depende das nuvens e das partículas da atmosfera, sendo refletida na abóbada celeste e nas nuvens e re-irradiada para a terra. Para a condição de céu claro, sem nuvens, a radiação direta 
é uma parcela maior do que a difusa, mas se o céu está muito nublado, a radiação difusa pode apresentar-se em uma parcela maior que a parcela direta (LAMBERTS, et al. 2011).

Como já citado, a radiação solar sofre a influência das diferentes latitudes, épocas do ano e horas do dia, de acordo com o ângulo zenital e a posição do sol (altura solar e azimute). Mas, além dessas variações temporais e espaciais decorrentes da trajetória do sol e da geometria da insolação, os valores da irradiância solar global na superfície horizontal sofrem variações em razão das condições de transparência atmosférica, tais como, nebulosidade, tipos de nuvens, aerossóis (conjunto de partículas sólidas ou líquidas suspensas em um gás), vapor de água, poeira, fumaça, entre outros, que acarretam a variação da camada ou perfil atmosférico a ser atravessado pela radiação solar.

$\mathrm{O}$ índice de transparência da atmosfera $(\mathrm{Kt})$ engloba todos os elementos que interferem na transparência atmosférica e é calculado como a razão entre a radiação solar global que chega à superfície horizontal e a radiação solar extraterrestre no topo da atmosfera, portanto, é um número adimensional (QUERINO et al., 2011; HAAG, 2012).

A camada de nuvens presente na atmosfera e sua espessura influenciam as reflexões. A maior parte das reflexões da radiação solar pelas nuvens se faz diretamente ao espaço, sendo assim, considerada como energia perdida sob o ponto de vista da superfície terrestre. Porém, uma parte é refletida pela superfície inferior das camadas de nuvem mais elevada, sendo irradiada de volta para a Terra (INCROPERA, DEWITT, 2003).

Segundo Moojen et al. (2012), a composição da radiação solar global para cada possibilidade de cobertura de nuvem pode ser representada como na Figura 2.18-a. Observa-se que, para céu limpo, a parcela difusa representa $20 \%$ da radiação global enquanto a parcela direta é responsável pelos outros $80 \%$. Porém, quando a cobertura de nuvens é máxima, a radiação difusa passa a ser a mais relevante, sendo responsável por $90 \%$ da radiação global. Com o aumento da nebulosidade, a radiação difusa passa a ter maior contribuição na radiação global horizontal (MOOJEN et al., 2012).

Segundo Incropera e Dewitt (2003), a contribuição da parcela difusa pode variar de, aproximadamente, $10 \%$ da radiação solar global em dias claros até $100 \%$ em dias completamente nublados. Para Fu e Rich (2000), em condições de céu limpo, a proporção da radiação difusa em relação à radiação global atinge valores típicos de $20 \%$.

O gráfico da Figura 2.18-b, segundo Moojen et al. (2012), também apresenta a composição da radiação global, contudo, a referência utilizada é a radiação global para céu claro. Observa-se 
que, com o aumento da nebulosidade, a radiação global sofre declínio. É importante ressaltar que, embora a participação da radiação difusa aumente com a nebulosidade, o valor bruto desta parcela atinge seu valor máximo para cobertura de $70 \%$ e, a partir deste valor, começa a decrescer (MOOJEN et al., 2012).

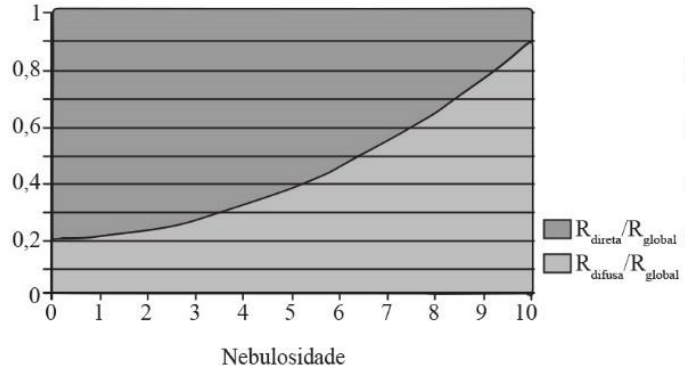

a)

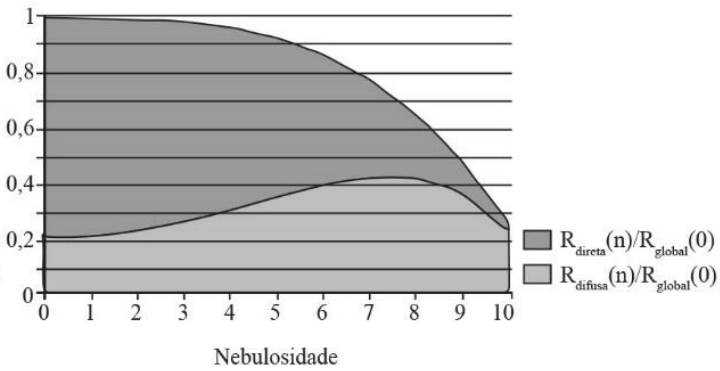

b)

Fonte: Moojen et al. (2012).

Figura 2.18 - Composição da radiação global em função da nebulosidade: a) sob mesma nebulosidade; b) em relação à condição de céu claro.

Albedo é a relação entre a radiação refletida e a incidente e representa o poder refletor da superfície, ou seja, é a fração da radiação incidente que é devolvida à atmosfera (LEIVAS, et $a l ., 2007)$. As condições de nebulosidade influenciam a radiação solar e o albedo.

Esse coeficiente de reflexão solar (variável unidimensional) varia de acordo com a composição da superfície terrestre. Quanto maior for o albedo, maior é a reflexão da luz solar, mais brilhante são as zonas adjacente e maior é a radiação difusa pelas superfícies (DOMUS, 2013).

O albedo é característico do tipo de superfície e está associado à cor do material. Quanto mais escuro, maior é a absorção e, portanto, mais baixa é a taxa de reflexão, consequentemente, mais baixo é o albedo (SILVA, 2013), conforme mostra o Quadro 2.4. A Terra tem albedo médio de 0,35 ou $35 \%$, sendo o valor sobre um corpo d'água menor do que sobre a vegetação.

Quadro 2.4 - Valores de Albedo.

\begin{tabular}{|cc|}
\hline SUPERFÍCIE TERRESTRE & ALBEDO \\
\hline \hline Asfalto & 0,15 \\
Concreto & 0,30 \\
Grama & 0,25 \\
Tijolo & $0,20-0,40$ \\
Água & $0,10-0,20$ \\
Neve & $0,80-0,90$ \\
\hline
\end{tabular}

Fonte: DOMUS (2013).

Como o albedo depende da componente direta da radiação solar incidente, é normal que se apresente uma redução nos seus valores quando a nebulosidade altera a componente espectral incidente na superfície, deixando-a mais rica em radiação difusa (QUERINO, 2004). 
Dias com nebulosidade aumenta a componente difusa da radiação, consequentemente diminui o albedo. As variações temporais nos valores do albedo estão associadas, principalmente, ao ângulo de elevação solar e às condições de nebulosidade (LEIVAS et al., 2007).

Apesar de as diferentes características climáticas observadas no Brasil, os valores de irradiação solar global incidente em qualquer região do território brasileiro apresentam boa uniformidade (Figura 2.19), com médias diárias relativamente altas em todo país (4200-6700 Wh/m²). Os maiores valores de irradiação global ocorrem no norte do Estado da Bahia, próximo à fronteira com o Estado do Piauí. Essa área apresenta um clima semiárido, com baixa precipitação ao longo do ano (aproximadamente $300 \mathrm{~mm} / \mathrm{ano}$ ), e a média anual de cobertura de nuvens mais baixa do Brasil. Os menores valores de irradiação solar global ocorrem no litoral norte de Santa Catarina, caracterizado pela precipitação bem distribuída ao longo do ano (PEREIRA et al., 2006).

A Figura 2.19 apresenta o mapa da radiação solar global horizontal para o Brasil. Observa-se que Brasília está entre as regiões com maior índice de radiação solar global horizontal.

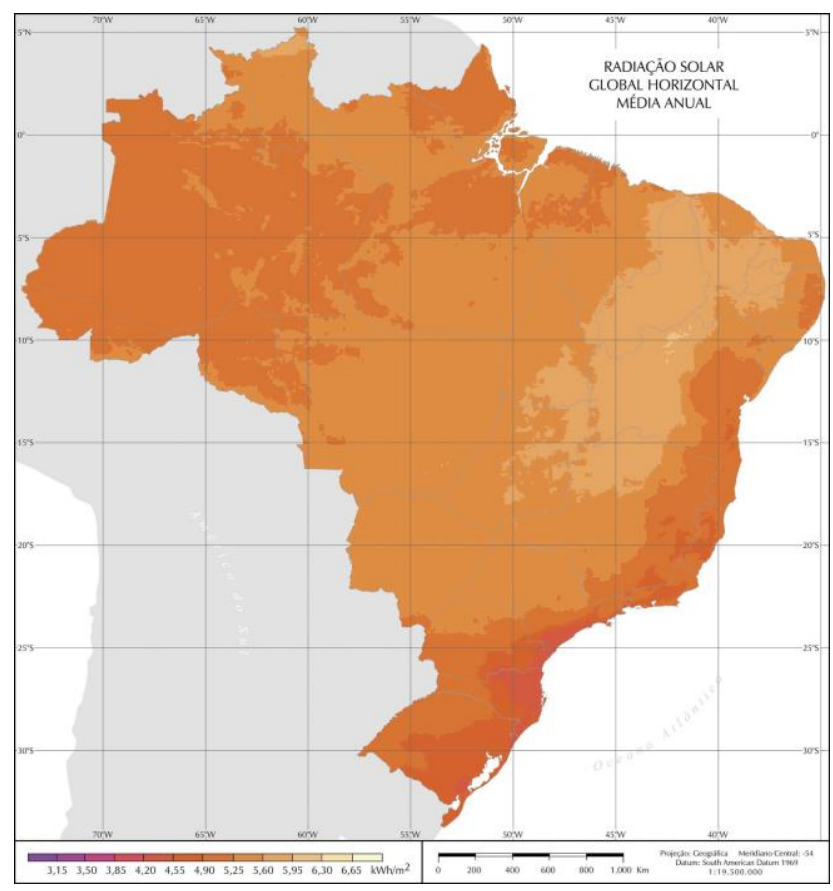

Fonte: Pereira et al. (2006).

Figura 2.19 - Média anual da radiação solar global horizontal diária $\left(\mathrm{kWh} / \mathrm{m}^{2}\right.$.dia), para o Brasil.

Nas Normais Climatológicas 1961-1990 não consta registro de radiação solar, somente de horas de insolação. Desde 2000, a estação automática de superfície A001-Brasília tem registrado dados de radiação solar global horizontal. 
Segundo o INMET (1999), a radiação solar é uma das variáveis climatológicas mais difíceis de serem obtidas com confiabilidade e precisão por meios automáticos. No arquivo climático da série 2001-2013, a variável radiação solar global é aquela que apresenta maior quantidade de dados nulos ou espúrios (ver Tabela 2.1).

Com base na série 2001-2013, foram quantificadas as médias diárias mensais da irradiância solar global horizontal para a cidade de Brasília. A Tabela 2.11 apresenta essas médias diárias para cada mês e a média diária para os períodos seco e chuvoso.

Tabela 2.11 - Médias diárias da Irradiância Solar Global Horizontal - Ig em Wh/m².dia, da série 2001-2013 para Brasília.

\begin{tabular}{cccc}
\hline \multicolumn{2}{c}{ PERÍODO CHUVOSO } & \multicolumn{2}{c}{ PERÍODO SECO } \\
\hline \hline Jan & 5152,9 & Abr & 5050,4 \\
Fev & 5378,1 & Mai & 4837,9 \\
Mar & 5152,9 & Jun & 4768,5 \\
Out & 5326,8 & Jul & 5007,2 \\
Nov & 4895,6 & Ago & 5635,5 \\
Dez & 5047,5 & Set & 5708,0 \\
\hline Média & $\mathbf{5 1 5 8 , 9}$ & Média & $\mathbf{5 1 6 7 , 9}$ \\
\hline
\end{tabular}

Considerando a importância da variável radiação solar para os estudos de durabilidade e degradação de fachada, na seção 2.16 deste capítulo é apresentado um estudo comparativo entre os arquivos climáticos de irradiância solar para a cidade de Brasília.

No Capítulo IV desta tese é discutido o fenômeno da radiação solar global que incide na superfície vertical da edificação e sua influência no comportamento higrotérmico da fachada.

\subsection{VENTO}

Os ventos (movimento do ar) são originados pelo aquecimento diferenciado da atmosfera, que causa diferenças de pressão, e influenciados pelo movimento de rotação da Terra. As forças que atuam no movimento do ar são: forças dos gradientes de pressão, força de Corioles, força centrífuga, forças de atrito e força da gravidade. Como resultado, o vento sofre variação espaçotemporal, tanto em velocidade (intensidade) quanto em direção.

O Quadro 2.5 apresenta a Escala Anemométrica Internacional de Beaufort que relaciona a velocidade dos ventos e as manifestações ou danos provocados na ambiência observada. 
Quadro 2.5 - Escala anemométrica Beaufort - velocidade equivalente na altura padrão de 10 metros acima de um terreno plano e descoberto.

\begin{tabular}{|c|c|c|c|c|}
\hline $\begin{array}{c}\text { Escala } \\
\text { Beaufort }\end{array}$ & Categoria & \multicolumn{2}{|c|}{ Velocidade do Vento } & Indicações Visuais na Superfície Terrestre \\
\hline 00 & CALMA & $0,0-0,2$ & $<1$ & $\begin{array}{l}\text { Não se nota o menor deslocamento nos mais leves } \\
\text { objetos. Folhas de árvores sem movimento. A } \\
\text { fumaça sobe verticalmente. }\end{array}$ \\
\hline 01 & ARAGEM & $0,3-1,5$ & $1-5$ & $\begin{array}{l}\text { A direção do vento é indicada pelo desvio da } \\
\text { fumaça, mas não pelos cata-ventos. }\end{array}$ \\
\hline 02 & BRISA LEVE & $1,6-3,3$ & $6-11$ & $\begin{array}{l}\text { Sente-se o vento no rosto. Folhas das árvores são } \\
\text { levemente agitadas. Cata-ventos comuns são } \\
\text { agitados. }\end{array}$ \\
\hline 03 & BRISA FRACA & $3,4-5,4$ & $12-19$ & $\begin{array}{l}\text { Bandeiras leves começam a se estender. As folhas } \\
\text { das árvores e os pequenos arbustos ficam em } \\
\text { movimento. }\end{array}$ \\
\hline 04 & BRISA MODERADA & $5,5-7,9$ & $20-28$ & $\begin{array}{l}\text { Movem-se os pequenos galhos das árvores, poeira } \\
\text { e pedaços de papéis. }\end{array}$ \\
\hline 05 & BRISA FORTE & $8,0-10,7$ & $29-38$ & $\begin{array}{l}\text { Árvores pequenas e folhagem oscilam. Surgem } \\
\text { ondas com cristas nas superfícies dos lagos. }\end{array}$ \\
\hline 06 & VENTO FRESCO & $10,8-13,8$ & $39-49$ & $\begin{array}{l}\text { Galhos grandes das árvores são agitados. Ouve-se } \\
\text { o assovio produzido pelo vento ao passar pelos } \\
\text { fios telegráficos. Torna-se difícil usar o guarda- } \\
\text { chuva. }\end{array}$ \\
\hline 07 & VENTO FORTE & $13,9-17,1$ & $50-61$ & $\begin{array}{l}\text { Árvores inteiras oscilam. Torna-se difícil } \\
\text { caminhar contra o vento. }\end{array}$ \\
\hline 08 & VENTANIA & $17,2-20,7$ & $62-74$ & $\begin{array}{l}\text { Galhos de árvores são quebrados. Impossível } \\
\text { andar contra o vento. }\end{array}$ \\
\hline 09 & VENTANIA FORTE & $20,8-24,4$ & $75-88$ & $\begin{array}{l}\text { Ocorrem pequenos danos em edificações } \\
\text { (chaminés e telhas são arrancadas). }\end{array}$ \\
\hline 10 & TEMPESTADE & $24,5-28,4$ & $89-102$ & $\begin{array}{l}\text { Árvores são derrubadas. Danos consideráveis nas } \\
\text { edificações. }\end{array}$ \\
\hline 11 & $\begin{array}{l}\text { TEMPESTADE } \\
\text { VIOLENTA }\end{array}$ & $28,5-32,6$ & $103-117$ & Ocorrem grandes destruições. \\
\hline $12-17$ & FURACÃO/TORNADO & $>32,7$ & $>118$ & Fenômenos extremos. \\
\hline
\end{tabular}

Fonte: Baseado em INMET (1999) e CEPAGRI (2015).

O regime de ventos, isto é, o seu comportamento estatístico ao longo do dia, pode ser estudado em várias escalas: escala planetária, escala local e escala do edifício. O conhecimento do regime de ventos na escala local pode ser obtido pelo seu comportamento cíclico (periodicidade do movimento da série ao longo dos anos) e pela sua sazonalidade (picos repetitivos em intervalos iguais de tempo dentro da série, geralmente inferior a um ano) (SILVA, 1999; MORETTIN; TOLOI, 2006; PEREIRA; PAIS; SALES, 1986).

O comportamento livre dos ventos corresponde ao regime local dos ventos se o terreno fosse perfeitamente liso (sem rugosidade), plano e livre de obstáculos.

Para fins de comparação entre as estações meteorológicas, a Organização Meteorológica Mundial (OMM) recomenda procedimentos padronizados para os registros do vento como uma variável meteorológica: 
- velocidade em $\mathrm{m} / \mathrm{s}$;

- direção (em graus ou azimute);

- média horária em 24 leituras diárias;

- período de integração da média horária - 10 minutos;

- altura para instalação dos sensores - 10 metros;

- rugosidade do terreno onde são instalados os sensores - plano e sem obstáculos;

- rajada - vento máximo registrado no período de uma hora, caracterizado por aumento brusco de curta duração da velocidade do vento, geralmente acompanhado por mudanças de direção.

Visando caracterizar o regime de ventos de Brasília na escala local, com base no arquivo climático da série 2001-2013, com 13 anos de dados medidos pelo INMET na estação automática de superfície A001-Brasília, buscou-se determinar as médias das velocidades e quantificar a frequência de ocorrência para cada direção dos ventos em cada mês do ano, assim como o comportamento nos períodos seco e chuvoso, noturno e diurno e de calmaria.

Na série 2001-2013 foram considerados válidos 109000 horas de dados de direção e velocidade dos ventos, correspondente a cerca de $96 \%$ dos dados registrados. Ou seja, foram descartados cerca de $4 \%$ correspondentes aos dados nulos do arquivo climático (ver Tabela 2.1).

A direção do vento da série 2001-2013 é dada em graus, variando de 1 a 360. O valor máximo encontrado para a velocidade do vento foi de $10,4 \mathrm{~m} / \mathrm{s}$, estando compatível com o range previsto para esta variável climática, para a cidade de Brasília. A média anual encontrada foi de $2,45 \mathrm{~m} / \mathrm{s}$, semelhante à mediana da amostra.

As horas com velocidade de vento igual a 0,00 foram consideradas horas com ventos ausentes.

Neste trabalho, entende-se por calmaria o período que compreende as horas com ventos ausentes (velocidade igual a zero) mais as horas com ventos classificados como calmos, com velocidade de 0 a 0,2 m/s, conforme escala anemométrica Beaufort (Quadro 2.5).

A Figura 2.20 mostra a distribuição das horas de calmaria (para ventos ausentes e na faixa de 0-0,2 m/s), ao longo das 24 horas do dia, cuja frequência foi tomada da série 2001-2013. Observa-se que entre $10 \mathrm{~h}$ e $18 \mathrm{~h}$ é o período do dia com menos horas de calmaria.

As horas de calmaria concentram-se mais durante a noite, aumentando pela madrugada até o amanhecer. Ao longo do dia, o aquecimento do solo aquece o ar que se desloca ascendentemente, originando gradientes de temperatura e pressão que aumentam a velocidade 
dos ventos diurnos, nas horas mais quentes do dia. À noite, como esse gradiente térmico é menor, a velocidade do vento também é menor (MUNHOZ; GARCIA, 2008; BITTENCOURT; CANDIDO, 2010).

A Figura 2.21 mostra a distribuição das horas de calmaria nos meses do ano. O mês de agosto é o mês com menos horas de calmaria. Observa-se que os meses do período chuvoso possuem mais horas de calmaria que os meses mais secos, principalmente os meses da estação de inverno.

A análise da série 2001-2013 permitiu identificar que 1,9\% da amostra são de ventos ausentes (velocidade igual a 0,00 ). Ao longo do ano, quando considerado todas as horas do período de calmaria (para ventos de $0-0,2$ ), o percentual é de $3 \%$. O mês de agosto possui $0,10 \%$ das horas de calmaria do ano enquanto que o mês de abril possui $0,37 \%$.

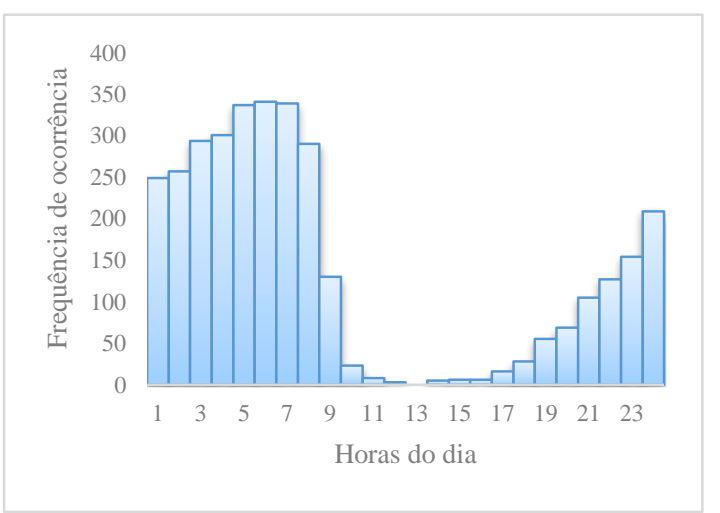

Figura 2.20 - Comportamento dos ventos ausentes e calmos ao longo das horas do dia para a série 2001-2013 - Brasília.

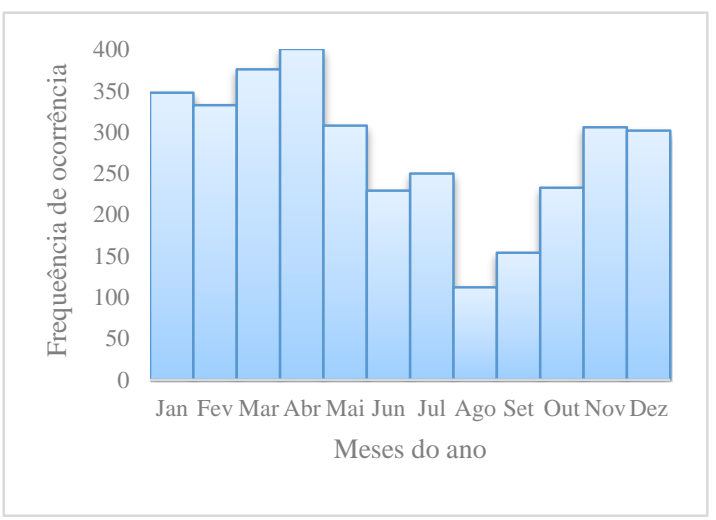

Figura 2.21 - Comportamento dos ventos ausentes e calmos ao longo dos meses do ano para a série 2001-2013 - Brasília.

As Figuras 2.22 e 2.23 apresentam, respectivamente, as frequências de ocorrência para a velocidade e para a direção dos ventos horários, inclusive as horas de calmaria $(0-0,2 \mathrm{~m} / \mathrm{s})$.

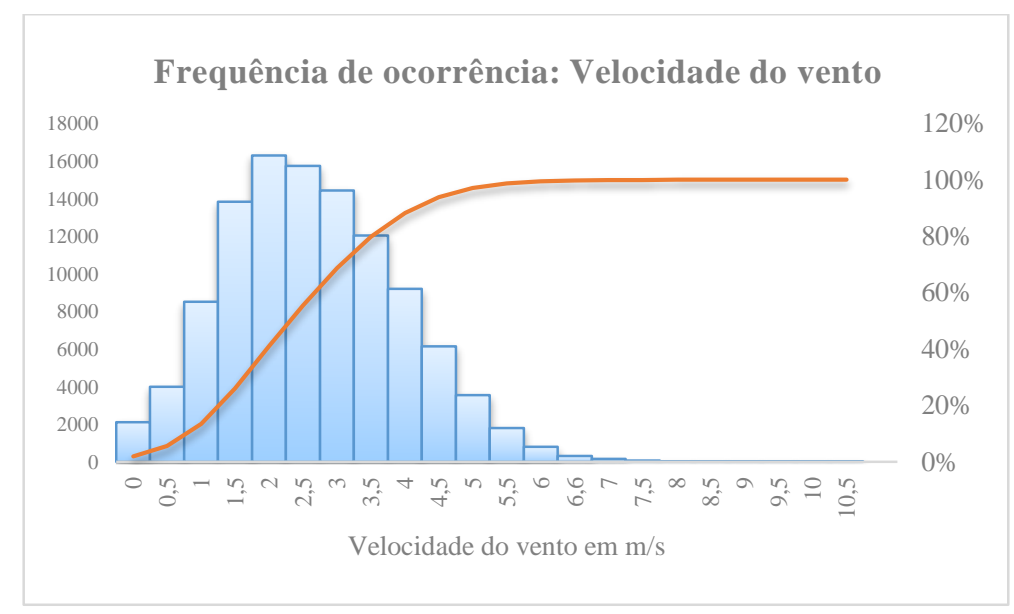

Figura 2.22 - Frequência de ocorrência da velocidade dos ventos da série 2001-2013 - Brasília. 


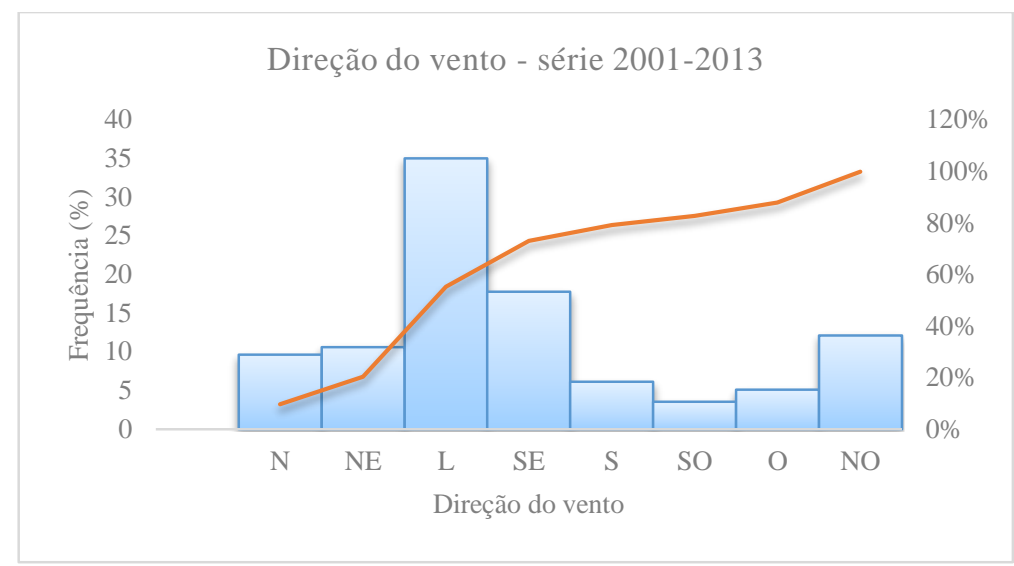

Figura 2.23 - Frequência de ocorrência da direção dos ventos da série 2001-2013 - Brasília.

A Figura 2.24 mostra a frequência de ocorrência dos ventos (em \%) para cada mês do ano e para cada direção do vento. A Tabela 2.12 apresenta a frequência de ocorrência anual dos ventos para cada direção. Assim, é possível verificar que a direção Leste $(34,62 \%)$, seguida pela Sudeste $(17,26 \%)$ são as direções predominantes de vento quando considerado o total no ano.

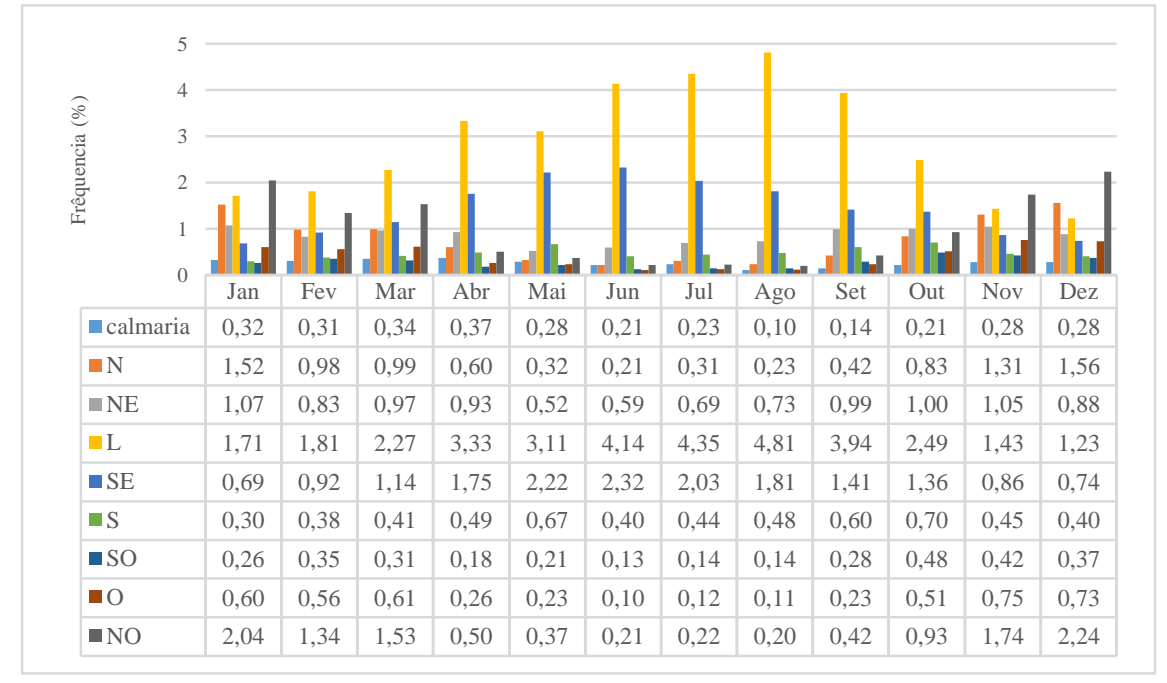

Figura 2.24 - Frequência de ocorrência da direção dos ventos
Tabela 2.12 - Direção predominante dos ventos.

\begin{tabular}{cc}
\hline Direção & $\begin{array}{c}\text { Frequência } \\
(\%)\end{array}$ \\
\hline \hline Calmaria & $3,08 \%$ \\
N & $9,28 \%$ \\
NE & $10,24 \%$ \\
L & $34,62 \%$ \\
SE & $17,26 \%$ \\
S & $5,72 \%$ \\
SO & $3,27 \%$ \\
O & $4,81 \%$ \\
NO & $11,73 \%$ \\
\hline Total & $\mathbf{1 0 0 \%}$ \\
\hline
\end{tabular}
da série 2001-2013 - Brasília.

A Figura 2.25 mostra a média mensal da velocidade do vento para cada direção em cada mês do ano. Assim, associando as Figuras 2.24 e 2.25, é possível relacionar para cada mês e direção qual a velocidade média e com que frequência ela ocorre.

A Tabela 2.13 apresenta a velocidade média anual do vento para cada direção. Assim, é possível identificar que a direção Leste é aquela que apresenta a maior média anual de velocidade de vento $(3,57 \mathrm{~m} / \mathrm{s})$ seguida pela direção Nordeste $(2,69 \mathrm{~m} / \mathrm{s})$. 


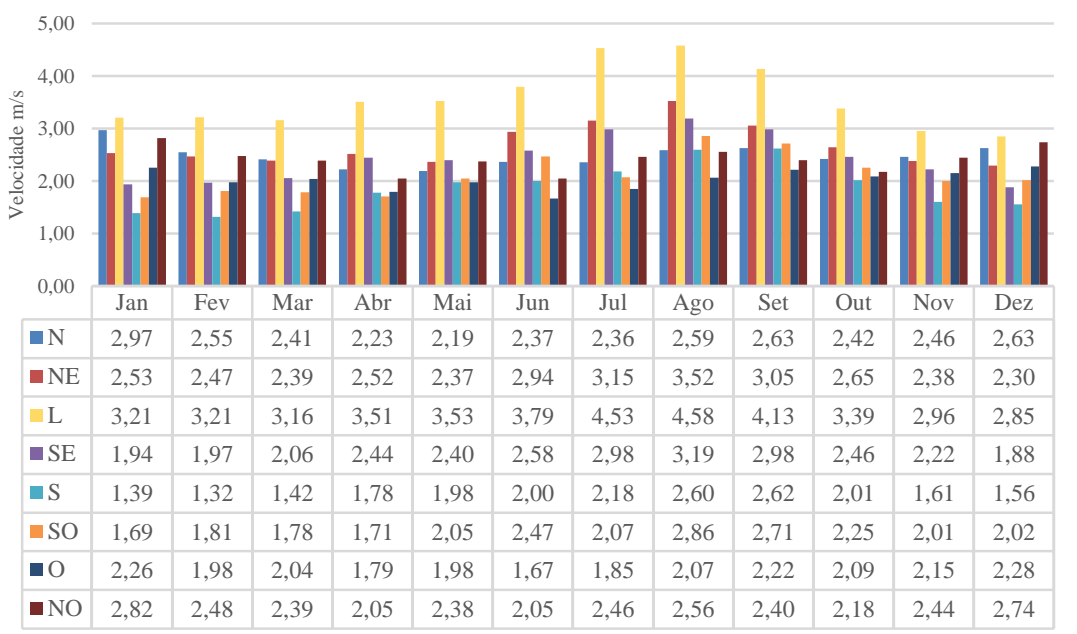

Tabela 2.13 - Velocidade dos ventos $(\mathrm{m} / \mathrm{s})$.

\begin{tabular}{cc}
\hline Direção & $\begin{array}{c}\text { Velocidade } \\
\text { média }\end{array}$ \\
\hline \hline $\mathrm{N}$ & 2,48 \\
$\mathrm{NE}$ & 2,69 \\
$\mathrm{~L}$ & 3,57 \\
$\mathrm{SE}$ & 2,43 \\
$\mathrm{~S}$ & 1,87 \\
$\mathrm{SO}$ & 2,12 \\
$\mathrm{O}$ & 2,03 \\
NO & 2,41 \\
\hline Total & $\mathbf{2 , 4 5}$ \\
\hline
\end{tabular}

Figura 2.25 - Velocidade média mensal dos ventos em cada direção e mês do ano da série 2001-2013 - Brasília.

Com base nos dados das Figuras 2.24 e 2.25, a Tabela 2.14 mostra a média mensal da velocidade do vento e uma indicação das direções predominantes, cuja classificação foi efetuada simplesmente com base nos maiores percentuais de frequência de ocorrência da direção dos ventos da série 2001-2013.

Tabela 2.14 - Média mensal da velocidade do vento e direção predominante da série 2001-2013 - Brasília.

\begin{tabular}{ccccccccccccc}
\hline & Jan & Fev & Mar & Abr & Mai & Jun & Jul & Ago & Set & Out & Nov & Dez \\
\hline \hline Média mensal da velocidade & 2,42 & 2,26 & 2,23 & 2,25 & 2,34 & 2,47 & 2,66 & 2,95 & 2,82 & 2,43 & 2,3 & 2,32 \\
Direção $-1^{\text {a }}$ predominância & NO & L & L & L & L & L & L & L & L & L & NO & NO \\
Direção $-2^{\text {a }}$ predominância & L & NO & NO & SE & SE & SE & SE & SE & SE & SE & L & N \\
\hline
\end{tabular}

As médias mensais da velocidade do vento são apresentadas no gráfico da Figura 2.26, mostrando que, no período seco, a velocidade é maior. A Figura 2.27 apresenta as médias anuais da velocidade para cada direção (já mostradas na Tabela 2.13).

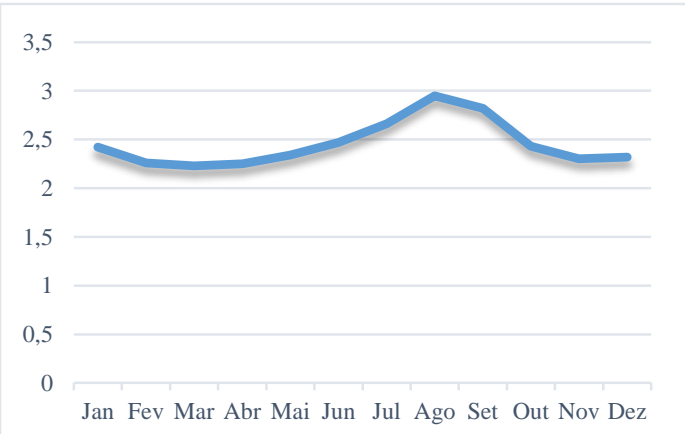

Figura 2.26 - Média mensal da velocidade do vento $(\mathrm{m} / \mathrm{s})$ da série 2001-2013 - Brasília.

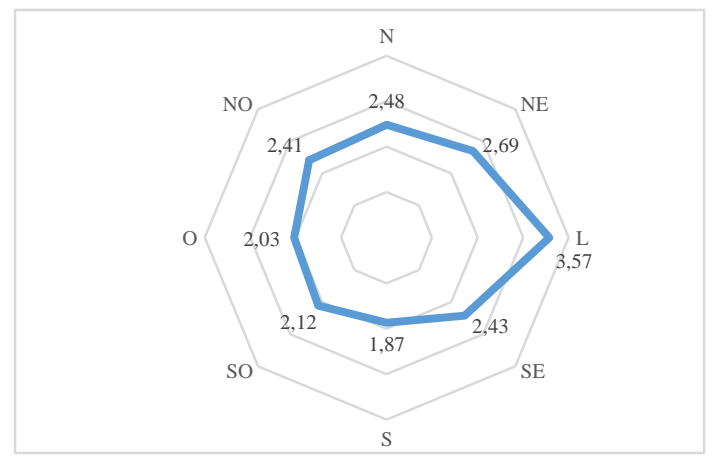

Figura 2.27 - Média anual da velocidade do vento (m/s) da série 2001-2013 para cada direção, em Brasília. 
Para calcular as médias mensais da velocidade do vento, foram analisadas duas situações: a) média simples excluindo os valores 0,$00 ; 0,1$ e 0,2 correspondentes ao período de calmaria; b) média simples incluindo todos os dados da amostra.

A Tabela 2.15 mostra os resultados e o percentual correspondente à diferença entre as médias. Observa-se que a diferença entre as médias é pequena (3\% de diferença entre as médias anuais).

Tabela 2.15 - Média mensal da velocidade do vento $(\mathrm{m} / \mathrm{s})$ da série 2001-2013 - Brasília.

\begin{tabular}{|c|c|c|c|c|c|c|c|c|c|c|c|c|c|}
\hline & Jan & Fev & Mar & Abr & Mai & Jun & Jul & Ago & Set & Out & Nov & Dez & Ano \\
\hline $\begin{array}{l}\text { Velocidades de } 0,3-10,4 \\
\text { (sem dados horários de } \\
\text { calmaria) }\end{array}$ & 2,51 & 2,35 & 2,32 & 2,35 & 2,43 & 2,53 & 2,73 & 2,99 & 2,87 & 2,49 & 2,38 & 2,4 & 2,53 \\
\hline $\begin{array}{l}\text { Velocidades de } 0-10,4 \mathrm{~m} / \mathrm{s} \\
\text { (com todos os dados } \\
\text { horários) }\end{array}$ & 2,42 & 2,26 & 2,23 & 2,25 & 2,34 & 2,47 & 2,66 & 2,95 & 2,82 & 2,43 & 2,3 & 2,32 & 2,45 \\
\hline Diferença entre as médias & $3,5 \%$ & $3,8 \%$ & $3,8 \%$ & $4,2 \%$ & $3,7 \%$ & $2,3 \%$ & $2,5 \%$ & $1,3 \%$ & $1,7 \%$ & $2,4 \%$ & $3,3 \%$ & $3,3 \%$ & $3 \%$ \\
\hline
\end{tabular}

Na metodologia do INMET (2009) para o cálculo das Normais Climatológicas 1961-1990, a composição da média mensal da velocidade dos ventos considerou todos os valores da amostra. Para Bittencourt e Candido (2010), nos estudos de conforto ambiental, os ventos de calmaria não devem entrar na composição das médias, pois mascaram a velocidade média. Os autores justificam que a análise do potencial do vento ao longo do dia e do ano permite identificar a disponibilidade e a velocidade real dos ventos nos períodos de interesse para adotar a ventilação natural como estratégia de resfriamento. Uma alta velocidade do vento no período de inverno pode causar desconforto, assim como uma baixa velocidade do vento no verão pode inviabilizar o uso da ventilação natural como estratégia de resfriamento dos espaços arquitetônicos.

Neste trabalho de tese, visando aos estudos de degradação, considera-se que a média da velocidade dos ventos deve incluir todos os valores da amostra, inclusive os valores das horas de calmaria, pois assim, o comportamento médio dos ventos torna-se mais representativo para os estudos do envelhecimento natural das edificações.

No entanto, deve-se estar atento ao regime dos ventos, considerando as variações mensais e sazonais, inclusive os períodos de calmaria que afetam, por exemplo, os processos de secagem e molhagem.

Para os estudos relacionados ao desempenho das edificações e à ação do envelhecimento natural ao longo da vida útil, a média anual pode mascarar o comportamento sazonal do vento. Importante compreender o comportamento livre dos ventos correspondente ao regime local nos períodos característicos do ano (no caso de Brasília, seco e chuvoso), antes de se considerar a média anual como um indicador. 
Investigando a frequência de ocorrência dos ventos (Tabela 2.16), constata-se que no período seco predominam principalmente os ventos na direção Leste enquanto que no período chuvoso, há uma mudança na direção dos ventos, passando a predominar os ventos incidentes na direção Noroeste, seguida pela Norte, além da direção Leste, conforme mostra a Figura 2.28.

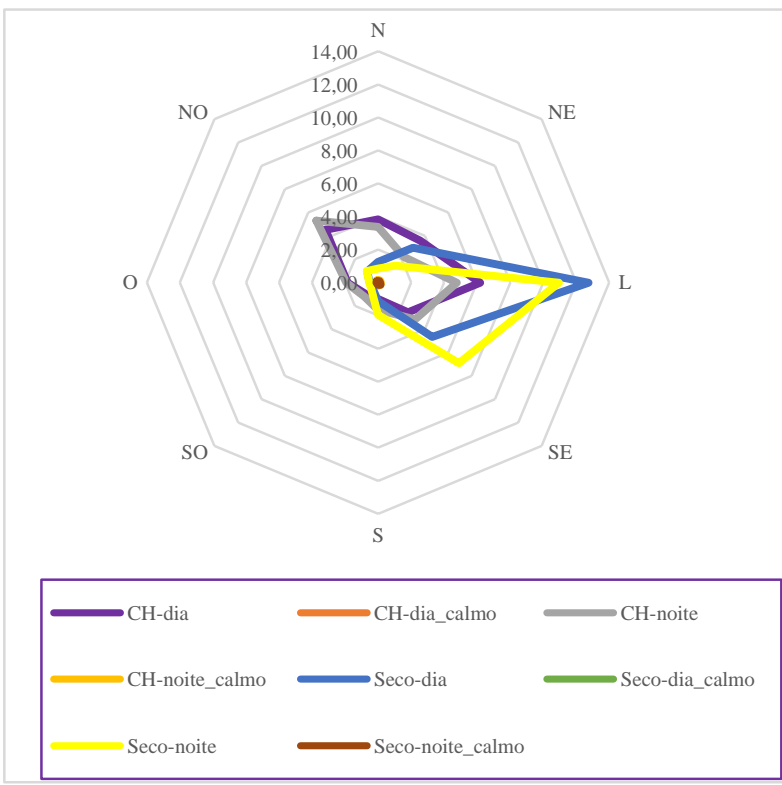

Figura 2.28 - Frequência de ocorrência dos ventos da série 2001-2013 - Brasília.
Tabela 2.16 - Frequência de ocorrência dos ventos da série 2001-2013 - Brasília, nos períodos chuvoso e seco, para cada direção.

\begin{tabular}{c||cc||cc}
\hline \multicolumn{1}{l||}{} & \multicolumn{2}{c||}{ Período chuvoso } & \multicolumn{2}{c}{ Período seco } \\
\hline \hline & $\begin{array}{c}\% \text { de } \\
\text { horas }\end{array}$ & $\begin{array}{c}\% \text { de } \\
\text { horas }\end{array}$ & $\begin{array}{c}\% \text { de } \\
\text { horas }\end{array}$ & $\begin{array}{c}\% \text { de } \\
\text { horas }\end{array}$ \\
& diurnas & noturnas & diurnas & noturnas \\
\hline N & 3,81 & 3,37 & 1,26 & 0,84 \\
NE & 3,60 & 2,19 & 3,00 & 1,45 \\
L & 6,17 & 4,76 & 12,74 & 10,95 \\
SE & 2,55 & 3,16 & 4,65 & 6,90 \\
S & 0,99 & 1,65 & 1,12 & 1,95 \\
SO & 1,00 & 1,19 & 0,49 & 0,59 \\
O & 1,84 & 1,92 & 0,52 & 0,53 \\
NO & 4,51 & 5,31 & 0,95 & 0,97 \\
\hline Total & $\mathbf{2 4 , 4 8}$ & $\mathbf{2 3 , 5 5}$ & $\mathbf{2 4 , 7 2}$ & $\mathbf{2 4 , 1 8}$ \\
\hline Calmaria & $\mathbf{0 , 4 1}$ & $\mathbf{1 , 3 3}$ & $\mathbf{0 , 3 7}$ & $\mathbf{0 , 9 6}$ \\
\hline
\end{tabular}

A Figura 2.29 representa a contribuição de cada média mensal da velocidade do vento em determinada direção na composição da média mensal geral. Observa-se que os ventos são bem distribuídos em todas as direções, havendo uma intensidade maior na direção Leste durante os meses da estação de inverno.

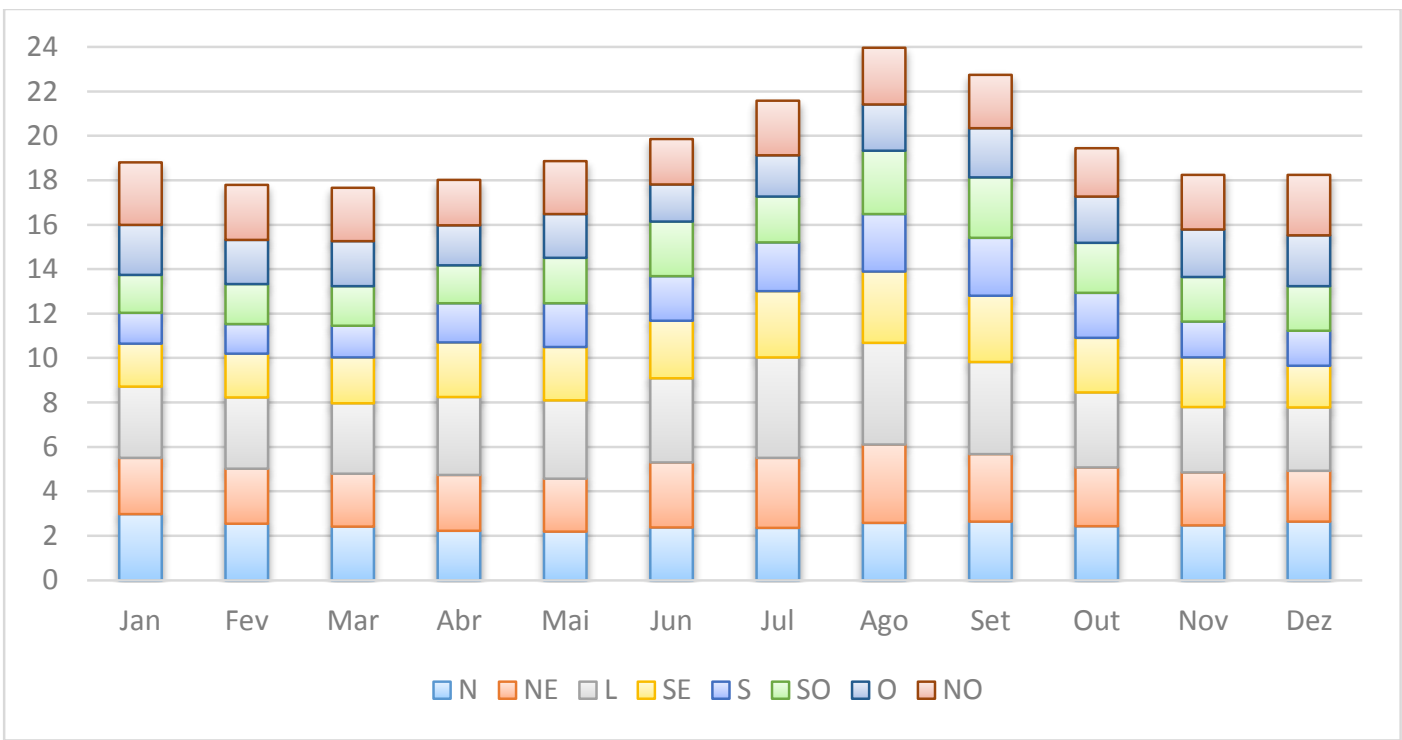

Figura 2.29- Composição da média mensal do vento da série 20011-2013 para Brasília, a partir da contribuição de cada média mensal da velocidade do vento conforme a sua direção. 
A Figura 2.30 apresenta a frequência de ocorrência nos períodos seco e chuvoso por classe de velocidade durante as horas noturnas e diurnas.

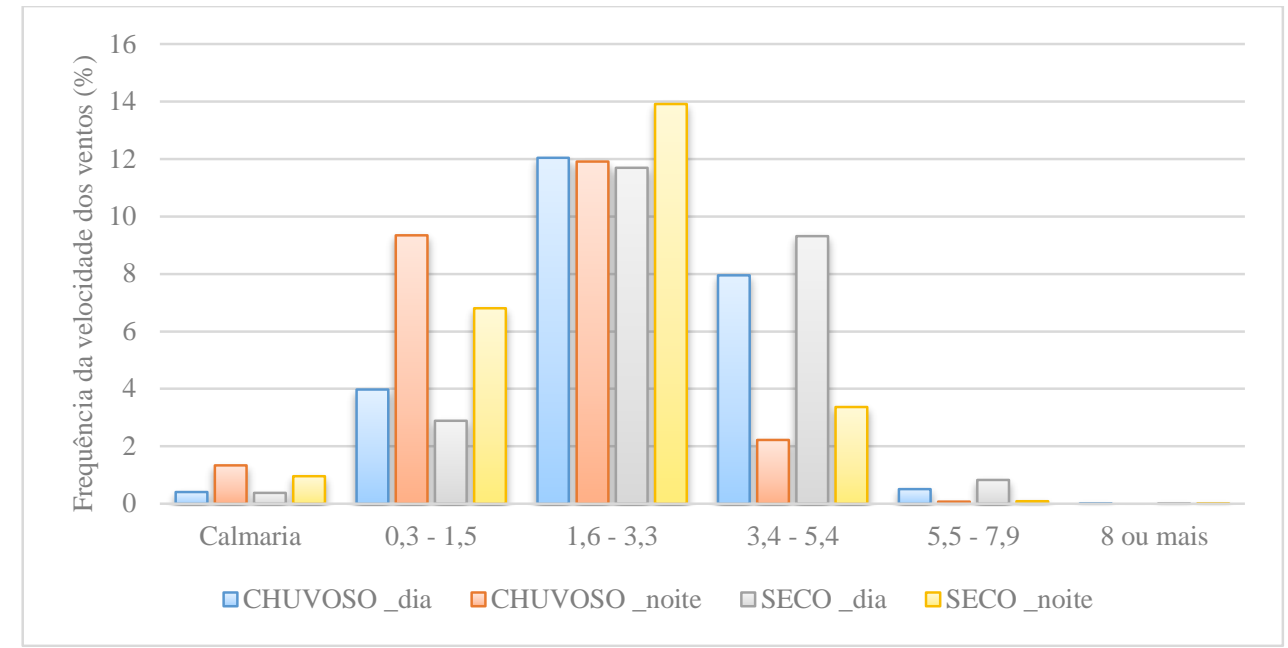

Figura 2.30 - Frequência da velocidade dos ventos diurnos e noturnos (\%) nos períodos seco e chuvoso, em relação às classes de velocidade $(\mathrm{m} / \mathrm{s})$, da série 20011-2013 para Brasília.

A classe de velocidade de 1,6-3,3 apresenta a maior predominância para os períodos noturno e diurno, tanto no período seco como no chuvoso. Nesta classe de velocidade, ocorrem cerca de $50 \%$ dos ventos.

A segunda classe de velocidade predominante é de 3,4-5,4 para os ventos diurnos nos períodos seco e chuvoso, sendo que, nesta classe, ocorrem cerca de $23 \%$ dos ventos. Na classe de $0,3-$ 1,5 ocorrem cerca de $23 \%$ dos ventos, principalmente os ventos noturnos.

Para a velocidade de vento de $5,5 \mathrm{~m} / \mathrm{s}$ ou mais, a frequência é menor do que $2 \%$. Os ventos de calmaria correspondem a $3 \%$ da amostra.

\subsection{DIA TÍPICO}

Para os estudos de desempenho térmico, frequentemente são usados dados de um dia típico de projeto, para o período de verão ou de inverno (AKUTSU, 1998).

A NBR 15575-1 define dia típico como um dia real caracterizado pelas variáveis temperatura do ar, umidade relativa do ar, velocidade do vento, radiação solar incidente em superfície horizontal para o dia mais quente do ano (dia típico de verão) ou para o dia mais frio do ano (dia típico de inverno), segundo a média do período dos últimos 10 anos (ABNT, 2013a).

Existem várias metodologias para determinação dos dias típicos de projeto (GOULART, 1993;

AKUTSU; VITTORINO, 1998; SIQUEIRA et al.; 2005). Segundo Thomaz e Del Mar (2013), 
para os dias típicos de verão e de inverno, são tomadas, respectivamente, as médias dos dias mais quentes e mais frios, observados em um número representativo de anos.

A NBR 15575-1 apresenta dados para os dias típicos de projeto para várias cidades brasileiras. O Quadro 2.6 mostra os dados de um dia típico de projeto para Brasília, recomendados para a avaliação de desempenho térmico de edificações (ABNT NBR 15575-1: 2013a).

A cidade de Brasília está inserida na zona bioclimática 4, conforme classificação do zoneamento bioclimático brasileiro recomendado pela NBR 15220-3 Desempenho térmico de edificações - Parte 3: Zoneamento bioclimático brasileiro e diretrizes construtivas para habitações unifamiliares de interesse social (ABNT, 2005c).

A metodologia utilizada para a classificação do zoneamento bioclimático baseou-se nas seguintes variáveis climáticas: médias mensais das temperaturas máximas; médias mensais das temperaturas mínimas; e nas médias mensais das umidades relativas do ar. Os dados utilizados para as médias foram obtidos das Normais Climatológicas 1961-1990 (ABNT, 2005c).

Quadro 2.6 - Dados dos dias típicos de projeto para Brasília.

\begin{tabular}{|c|c|c|c|c|c|}
\hline UF & Cidade & $\begin{array}{c}\text { Zona } \\
\text { bioclimática }\end{array}$ & Latitude & Longitude & Altitude (m) \\
\hline DF & Brasília & 4 & $15.78 \mathrm{~S}$ & $47.93 \mathrm{~W}$ & 1160 \\
\hline \multicolumn{7}{|c|}{ DADOS DE DIAS TÍPICOS DE PROJETO } \\
\hline $\begin{array}{c}\text { Temperatura } \\
\text { máxima diária }\left({ }^{\circ} \mathrm{C}\right)\end{array}$ & $\begin{array}{c}\text { Temperatura } \\
\text { mínima diária }\left({ }^{\circ} \mathrm{C}\right)\end{array}$ & $\begin{array}{c}\text { Amplitude diária de } \\
\text { temperatura }\left({ }^{\circ} \mathrm{C}\right)\end{array}$ & $\begin{array}{c}\text { Radiação solar } \\
(\mathrm{Wh} / \mathrm{m} 2)\end{array}$ & $\begin{array}{c}\text { Nebulosidade } \\
(\text { Décimos })\end{array}$ \\
\hline $\begin{array}{c}\text { Dia típico de } \\
\text { verão }\end{array}$ & 31,2 & 12,5 & 4625 & 4 \\
\hline $\begin{array}{c}\text { Dia típico de } \\
\text { inverno }\end{array}$ & & 10,0 & 12,2 & 4246 & 3 \\
\hline
\end{tabular}

Fonte: NBR 15575-1 (ABNT, 2013a).

Segundo a NBR 15575-1, para as avaliações por medição, o dia tomado para análise deve corresponder a um dia típico de projeto, de verão ou de inverno, precedido por pelo menos um dia com características semelhantes. A norma recomenda, como regra geral, trabalhar com uma sequência de três dias e analisar os dados do terceiro dia, especificamente com base nos valores da temperatura do ar exterior medidos no local.

Para Sorgato e Marinoski (2012), um "dia de projeto" para verão ou inverno representa condições diferentes de um "dia típico" de verão ou inverno. Os autores alertam que um dia típico é facilmente encontrado em uma situação real, pois representa condições médias que podem ocorrer com maior frequência, enquanto que um "dia de projeto" é aquele usado para as 
simulações computacionais na fase de projeto, para avaliar o desempenho de edificações e representam condições extremas mais severas e, portanto, raramente ocorrerá na realidade.

\subsubsection{Análise dos parâmetros de Brasília para os dias típicos de verão e de inverno}

Para analisar os parâmetros recomendados pela NBR 15575-1 para os dias típicos de verão e de inverno, foi organizado o Quadro 2.7 que apresenta, além dos dias típicos, as médias da série 2001-2013 obtidas para as respectivas variáveis.

Quadro 2.7 - Apresentação dos parâmetros para dias típicos de verão e de inverno e das médias da série 20011-2013 para Brasília.

\begin{tabular}{|cccccc|}
\hline & & $\begin{array}{c}\text { Temperatura } \\
\text { máxima/mínima } \\
\text { diária }\left({ }^{\circ} \mathrm{C}\right)\end{array}$ & $\begin{array}{c}\text { Amplitude } \\
\text { térmica }\left({ }^{\circ} \mathrm{C}\right)\end{array}$ & $\begin{array}{c}\text { Radiação solar } \\
\left(\mathrm{Wh} / \mathrm{m}^{2}\right)\end{array}$ & $\begin{array}{c}\text { Nebulosidade } \\
(\text { Décimos })\end{array}$ \\
\hline \hline $\begin{array}{c}\text { Condição de } \\
\text { Verão }\end{array}$ & $\begin{array}{c}\text { Dia típico da } \\
\text { NBR 15575-1 }\end{array}$ & 31,2 & 12,5 & 4.625 & 4 \\
\cline { 2 - 6 } & $\begin{array}{c}\text { Média da } \\
\text { série 2001-2013 }\end{array}$ & 21,9 & 9,0 & 5.159 & 3 \\
\hline $\begin{array}{c}\text { Dia típico da } \\
\text { NBR 15575-1 } \\
\text { inverno }\end{array}$ & $\begin{array}{c}\text { Média da } \\
\text { série 2001-2013 }\end{array}$ & 10,0 & 12,2 & 4.246 & 4 \\
\hline
\end{tabular}

Para a condição de verão, a temperatura máxima diária recomendada para um dia típico é de $31,2^{\circ} \mathrm{C}$. Na série $2001-2013$, a temperatura $31,2^{\circ} \mathrm{C}$ está no intervalo de classe correspondente a 0,42\% da amostra. A frequência de ocorrência das temperaturas máximas da série 2001-2013, com valores acima de $31,0^{\circ} \mathrm{C}$, corresponde a $1,5 \%$ das temperaturas máximas da amostra.

Para a condição de inverno, a temperatura mínima diária recomendada para um dia típico é de $10,0^{\circ} \mathrm{C}$. Na série $2001-2013$, a temperatura $10,0^{\circ} \mathrm{C}$ está no intervalo de classe correspondente a $0,03 \%$ da amostra, que compreende a faixa de frequência de ocorrência das menores temperaturas mínimas.

A amplitude térmica de $12,5^{\circ} \mathrm{C}$, para um dia típico de verão, e a amplitude térmica de $12,2^{\circ} \mathrm{C}$, para um dia típico de inverno, são valores acima das médias dos períodos da série 2001-2013, respectivamente $9,0^{\circ} \mathrm{C}$ e $11,1^{\circ} \mathrm{C}$. No entanto, os valores estipulados pela norma de desempenho para os dias típicos estão dentro da faixa $10^{\circ} \mathrm{C} \leq \mathrm{AT}<15^{\circ} \mathrm{C}$, que correspondem a $50 \%$ da amplitude térmica diária da série 2001-2013.

Analisando as médias mensais da irradiância solar global horizontal dos dias típicos, para verão e para inverno, observa-se que estes valores apresentados pela norma de desempenho são subestimados em relação às médias mensais da irradiância solar global horizontal obtidas da 
série 2001-2013. A discussão sobre esses valores comparativamente com outros arquivos climáticos é apresentada na seção 2.16 deste capítulo.

Para a condição de verão, a nebulosidade recomendada para um dia típico é de 4 décimos. Na série 2001-2013, a nebulosidade correspondente ao período em questão é de 7 décimos. Para a condição de inverno, a nebulosidade recomendada para um dia típico é de 3 décimos. Na série 2001-2013, a nebulosidade correspondente ao período em questão é de 4 décimos. Observa-se que a nebulosidade apresentada pela NBR 15575-1, para o dia típico na condição de verão, está subestimada.

Um dia típico deve representar as condições mais significativas que podem ocorrer em um dia de verão ou de inverno. Sendo representativo, o dia típico permite quantificar os níveis de exigência na avaliação de desempenho.

No entanto, para os estudos sobre a degradação decorrente do envelhecimento natural das edificações, ao longo do tempo, é necessário considerar o comportamento sazonal e cíclico das variáveis climáticas. Por isso, simulações considerando um ano climático representam melhor as condições de exposição aos agentes de degradação e os processos de envelhecimento natural das edificações.

\subsection{ANÁLISE DA SÉRIE 2001-2013 À LUZ DAS NORMAIS CLIMATOLÓGICAS 1961-1990}

As Normais Climatológicas do Brasil 1961-1990 (INMET, 2009) foram obtidas por meio de metodologia própria, conforme recomendações da OMM, para dados registrados por estações convencionais de superfície. Os dados meteorológicos utilizados para a cidade de Brasília foram dados sinóticos, correspondente a três registros diários, medidos pela Estação Convencional 83377 de Brasília - DF.

A série 2001-2013 foi obtida pela Estação Automática de Superfície A001- Brasília do INMET, com registros horários dos dados.

Portanto, quando se pretende analisar a série 2001-2013 a luz das Normais Climatológicas, fazse uma ressalva quanto às diferenças metodológicas que envolveram a obtenção desses dois arquivos de dados. Neste caso, o objetivo desta seção de estudo é apresentar os valores das principais variáveis destes dois arquivos, estabelecendo uma base de comparação e referência para a análise do comportamento cíclico e sazonal das variáveis climáticas de interesse. 
A Tabela 2.17 apresenta as temperaturas publicadas pelas Normais Climatológicas 1961-1990, resultado de médias compensadas (conforme metodologia utilizada para o cálculo das médias diárias da temperatura do ar das normais padronizadas), baseadas em 3 registros diários de dados sinóticos (INMET, 2009).

Tabela 2.17 - Médias mensais das temperaturas $\left({ }^{\circ} \mathrm{C}\right)$ - Normais Climatológicas do Brasil 1961-1990 para Brasília.

\begin{tabular}{|c|c|c|c|c|c|c|c|c|c|c|c|c|c|}
\hline & Jan & Fev & Mar & Abr & Mai & Jun & Jul & Ago & Set & Out & Nov & Dez & Ano \\
\hline Temperatura Máxima & 26,9 & 26,7 & 27,1 & 26,6 & 25,7 & 25,2 & 25,1 & 27,3 & 28,3 & 27,5 & 26,6 & 26,2 & 26,6 \\
\hline $\begin{array}{l}\text { Temperatura } \\
\text { Compensada }\end{array}$ & 21,2 & 21,3 & 21,5 & 20,9 & 19,6 & 18,5 & 18,3 & 20,3 & 21,7 & 21,6 & 21,1 & 21,0 & 20,6 \\
\hline Temperatura Mínima & 17,4 & 17,4 & 17,5 & 16,8 & 15,0 & 13,3 & 12,9 & 14,6 & 16,0 & 17,4 & 17,5 & 17,5 & 16,1 \\
\hline
\end{tabular}

Fonte: INMET (2009).

A Tabela 2.18 traz as médias simples das temperaturas mensais da série 2001-2013, com 13 anos de dados horários medidos pela estação automática de superfície A001 do INMET.

Tabela 2.18 - Médias mensais das temperaturas - Série 2001-2013 para Brasília.

\begin{tabular}{cccccccccccccc}
\hline & Jan & Fev & Mar & Abr & Mai & Jun & Jul & Ago & Set & Out & Nov & Dez & Ano \\
\hline \hline Temperatura Máxima & 22,2 & 22,5 & 22,3 & 22,1 & 20,9 & 20,0 & 20,3 & 21,7 & 23,6 & 23,3 & 22,1 & 22,1 & $\mathbf{2 1 , 3}$ \\
Temperatura média do ar & 21,6 & 21,8 & 21,7 & 21,5 & 20,2 & 19,4 & 19,5 & 21,0 & 22,9 & 22,7 & 21,5 & 21,5 & $\mathbf{2 1 , 9}$ \\
Temperatura Mínima & 21,0 & 21,2 & 21,1 & 20,9 & 19,6 & 18,7 & 18,8 & 20,3 & 22,2 & 22,0 & 20,9 & 20,9 & $\mathbf{2 0 , 7}$ \\
\hline
\end{tabular}

As Figuras 2.31 e 2.32 representam as médias mensais das temperaturas compensadas/ médias, máximas e mínimas do ar das séries 1961-1990 e 2001-2013, respectivamente.

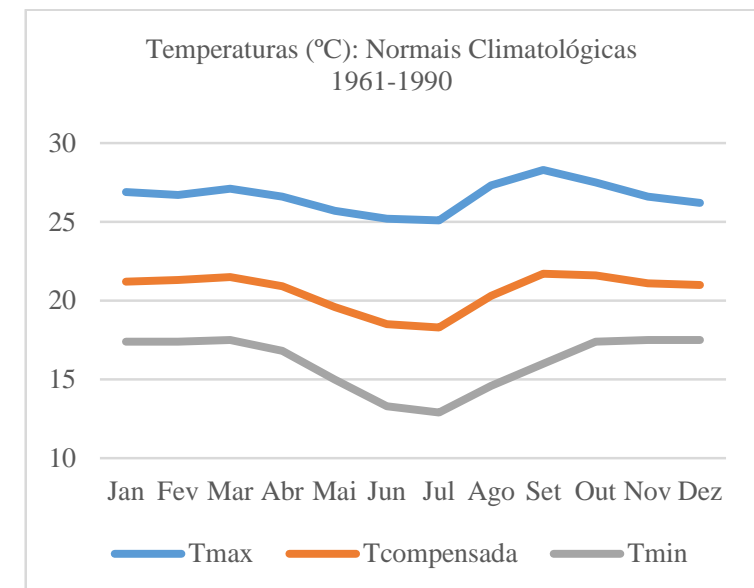

Figura 2.31 - Médias mensais das temperaturas das Normais Climatológicas 1961-1990 para Brasília.

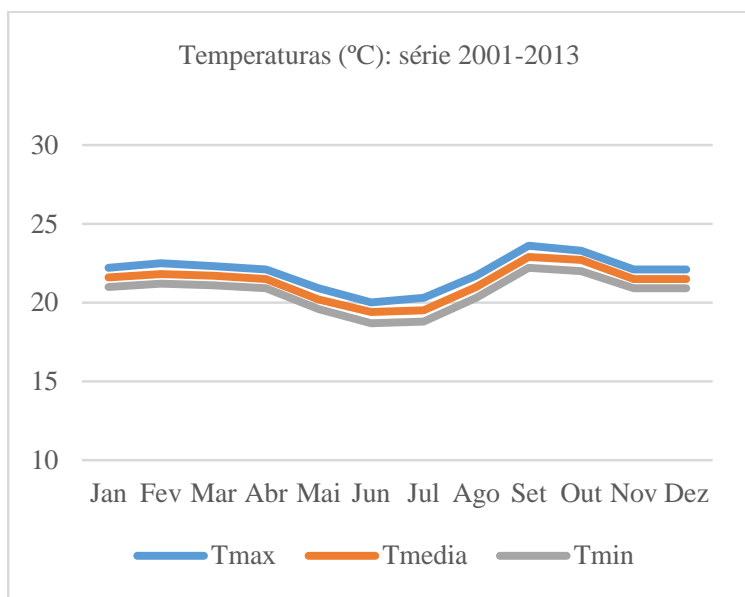

Figura 2.32 - Médias mensais das temperaturas da série 2001-2013 para Brasília.

Analisando as temperaturas da série 2001-2013, verifica-se que as médias das temperaturas máximas são menores que aquelas obtidas pelas Normais Climatológicas 1961-1990, enquanto que as temperaturas mínimas são maiores. A média anual da temperatura do ar da série 2001- 
2013 é maior que a média compensada das Normais Climatológicas 1961-199. Considerando as médias anuais das duas séries, as temperaturas máximas apresentam uma diferença de $5,3^{\circ} \mathrm{C}$ e as mínimas de $4,6^{\circ} \mathrm{C}$, enquanto que as temperaturas médias do ar diferem em $1,3^{\circ} \mathrm{C}$.

A Tabela 2.19 apresenta as médias mensais e anuais da intensidade dos ventos $(\mathrm{m} / \mathrm{s})$ e direções resultantes e predominantes, publicados pelas Normais Climatológicas 1961-1990 (INMET, 2009).

Tabela 2.19- Normais Climatológicas do Brasil 1961-1990: Ventos (m/s) para Brasília.

\begin{tabular}{|c|c|c|c|c|c|c|c|c|c|c|c|c|c|}
\hline Vento $(\mathrm{m} / \mathrm{s})$ & Jan & Fev & Mar & Abr & Mai & Jun & Jul & Ago & Set & Out & Nov & Dez & Ano \\
\hline Intensidade & 2,54 & 2,43 & 2,23 & 2,37 & 2,43 & 2,61 & 2,89 & 3,00 & 2,83 & 2,53 & 2,39 & 2,53 & 2,56 \\
\hline Direção & 16 & 39 & 65 & 92 & 102 & 99 & 98 & 94 & 93 & 70 & 26 & 3 & 76 \\
\hline Resultante & $\mathrm{N}$ & $\mathrm{NE}$ & $\mathrm{NE}$ & E & $\mathrm{E}$ & E & E & E & E & $\mathrm{NE}$ & $\mathrm{NE}$ & $\mathrm{N}$ & E \\
\hline $\begin{array}{c}\text { Direção } \\
\text { Predominante }\end{array}$ & Calmo & Calmo & Calmo & E & E & E & E & E & E & Calmo & Calmo & Calmo & \\
\hline
\end{tabular}

Fonte: INMET (2009).

A Tabela 2.20 mostra as diferenças percentuais entre as Normais Climatológicas 1961-1990 e a série 2001-2013. A Figura 2.33 ilustra o comportamento da velocidade do vento ao longo do ano.

Tabela 2.20 - Diferenças percentuais (\%) entre as médias mensais da velocidade do vento (m/s) da série 2001-2013 e as Normais Climatológicas 1961-1990 para Brasília.

\begin{tabular}{cccccccccccccc}
\hline & Jan & Fev & Mar & Abr & Mai & Jun & Jul & Ago & Set & Out & Nov & Dez & Ano \\
\hline \hline Normais Climatológicas & 2,54 & 2,43 & 2,23 & 2,37 & 2,43 & 2,61 & 2,89 & 3,00 & 2,83 & 2,53 & 2,39 & 2,53 & $\mathbf{2 , 5 6}$ \\
$\quad$ Série 2001-2013 & 2,42 & 2,26 & 2,23 & 2,25 & 2,34 & 2,47 & 2,66 & 2,95 & 2,82 & 2,43 & 2,3 & 2,32 & $\mathbf{2 , 4 5}$ \\
Diferença entre as séries (\%) & $5 \%$ & $8 \%$ & $0 \%$ & $5 \%$ & $4 \%$ & $6 \%$ & $9 \%$ & $2 \%$ & $0 \%$ & $4 \%$ & $4 \%$ & $9 \%$ & $\mathbf{4 \%}$ \\
\hline
\end{tabular}

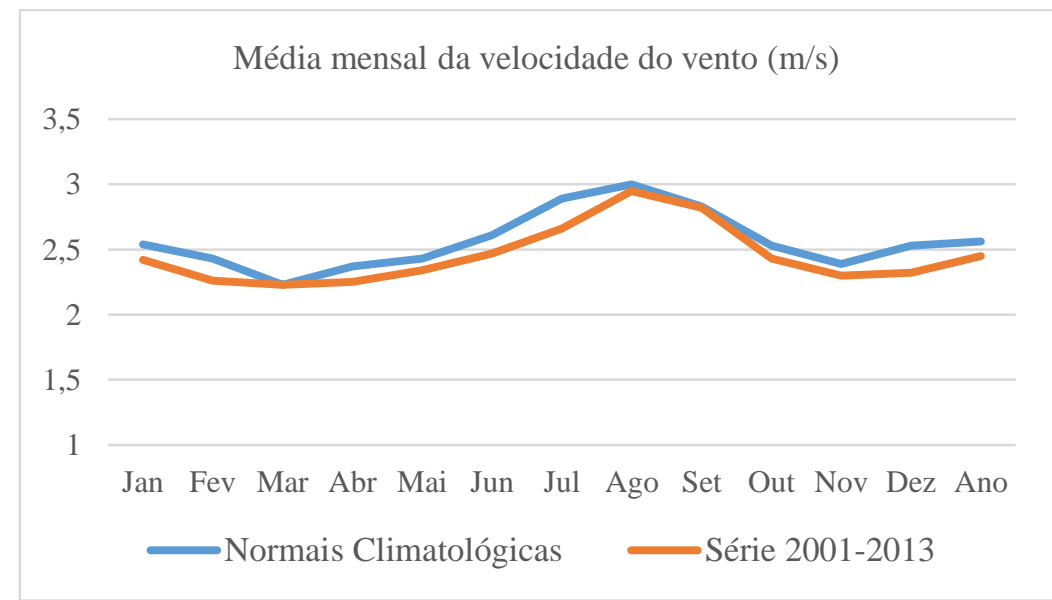

Figura 2.33 - Médias mensais da velocidade do vento: Normais Climatológicas 1961-1990 e série 2001-2013 para Brasília.

Nas Normais Climatológicas 1961-1990, a média mensal da velocidade do vento variou de 2,23 a 3,00 m/s. De acordo com a metodologia de revisão e ampliação das Normais Climatológicas 1961-1990, computadas pelo INMET em 1992 e consolidadas em 2009, a faixa (direção) de 
maior frequência relativa dos ventos é aquela cuja frequência é superior a 20\%. Caso não haja uma faixa predominante, a classificação dada é "calmo".

Observa-se que nos meses do período chuvoso (outubro a março) não há predominância de vento em uma determinada direção. Nestes casos, verifica-se a denominação calmo. Quando considerado a direção resultante dos ventos, o período foi caracterizado pelas direções Norte e Nordeste. Os meses do período seco (abril a setembro) foram caracterizados pelas direções resultantes e predominantes dos ventos no quadrante Leste.

Observando as diferenças percentuais entre as séries apresentadas pela Tabela 2.20, constatase que as médias mensais da velocidade do vento da série 2001-2013 são menores que as médias mensais das Normais Climatológicas.

A Tabela 2.21 mostra os valores mensais e anual para a precipitação em ambos os arquivos em discussão. Verifica-se que a precipitação na série 2001-2013 foi menos intensa do que na série 1961-1990. A Figura 2.34 ilustra o comportamento da precipitação ao longo do ano.

\begin{tabular}{ccc}
\multicolumn{3}{c}{ Tabela $\begin{array}{c}\text { 2.21 - Precipitação (mm) } \\
\text { para Brasília. }\end{array}$} \\
\multicolumn{3}{c}{ Normais } \\
1961-1990 & Série \\
$\mathbf{2 0 0 1 - 2 0 1 3}$ \\
\hline \hline Jan & 247,4 & 216,0 \\
Fev & 217,5 & 164,2 \\
Mar & 180,6 & 187,9 \\
Abr & 123,8 & 132,0 \\
Mai & 38,6 & 18,5 \\
Jun & 8,7 & 2,1 \\
Jul & 11,1 & 2,4 \\
Ago & 13,9 & 15,2 \\
Set & 55,2 & 33,8 \\
Out & 166,6 & 138,7 \\
Nov & 231,1 & 220,8 \\
Dez & 246,0 & 242,2 \\
\hline Ano & $\mathbf{1 5 4 0 , 6}$ & $\mathbf{1 3 7 4 , 1}$ \\
\hline & & \\
\hline
\end{tabular}

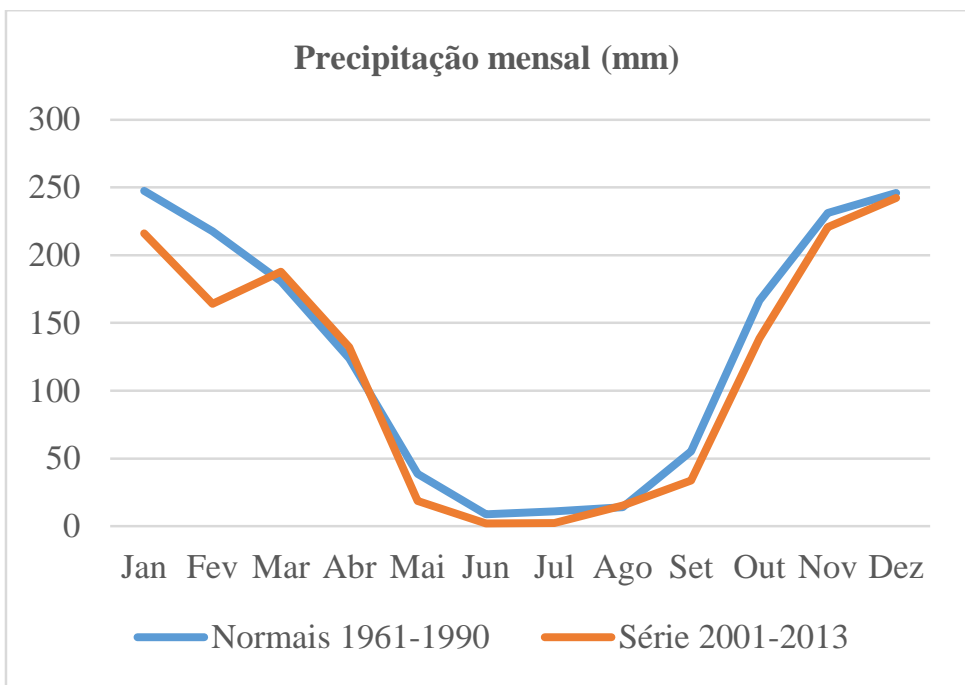

Figura 2.34 - Médias mensais da precipitação (mm): Normais Climatológicas 1961-1990 e série 2001-2013 para Brasília.

A Tabela 2.22 apresenta as médias mensais da umidade relativa do ar nas Normais Climatológicas 1961-1990 e na série 2001-2013. A Figura 2.35 ilustra o comportamento da variável climática ao longo do ano nas duas séries analisadas.

Tabela 2.22 - Umidade relativa do ar (\%) para Brasília.

\begin{tabular}{cccccccccccccc}
\hline & Jan & Fev & Mar & Abr & Mai & Jun & Jul & Ago & Set & Out & Nov & Dez & Ano \\
\hline \hline $\begin{array}{c}\text { Normais } \\
\mathbf{1 9 6 1 - 1 9 9 0}\end{array}$ & $76 \%$ & $77 \%$ & $76 \%$ & $75 \%$ & $68 \%$ & $61 \%$ & $56 \%$ & $49 \%$ & $53 \%$ & $66 \%$ & $75 \%$ & $79 \%$ & $\mathbf{6 8 \%}$ \\
$\begin{array}{c}\text { Série } \\
\mathbf{2 0 0 1 - 2 0 1 3}\end{array}$ & $78 \%$ & $75 \%$ & $77 \%$ & $73 \%$ & $67 \%$ & $63 \%$ & $55 \%$ & $47 \%$ & $48 \%$ & $63 \%$ & $76 \%$ & $77 \%$ & $\mathbf{6 7 \%}$ \\
\hline
\end{tabular}


Observa-se na Tabela 2.22 que as médias mensais da umidade relativa do ar das Normais Climatológicas 1961-1990 e da série 2001-2013 apresentam pequenos desvios. Como pode ser observado da Figura 2.35, o comportamento das séries é bastante similar.

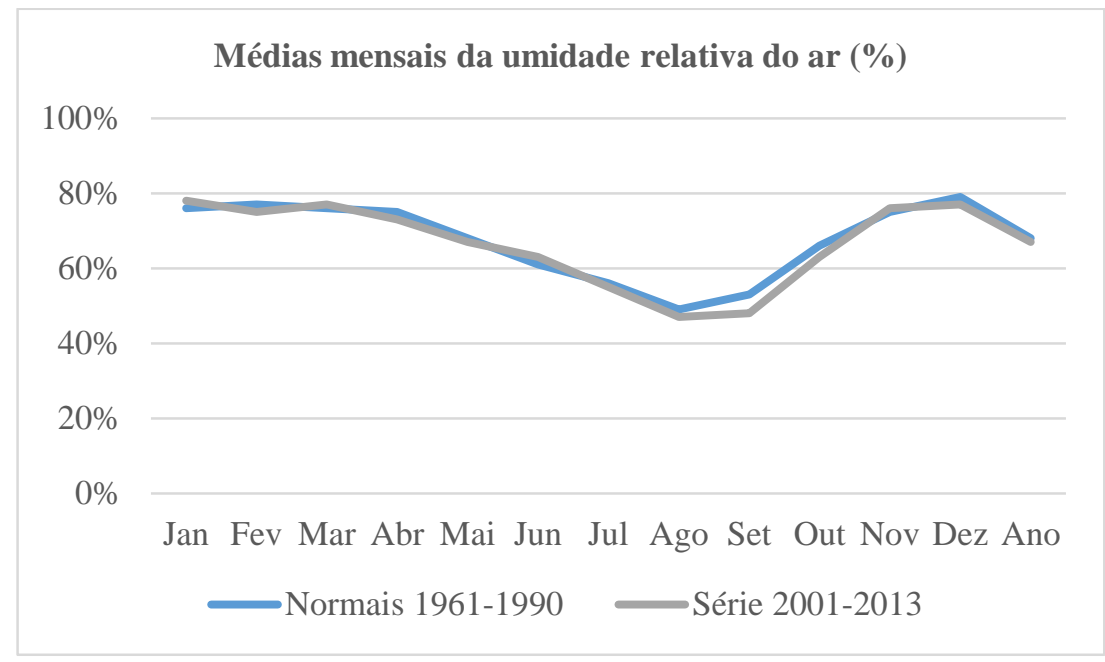

Figura 2.35 - Média mensal da umidade relativa do ar (\%):

Normais Climatológicas do Brasil 1961-1990 e série 2001-2013 para Brasília.

As Normais Climatológicas do Brasil 1961-1990 (INMET, 2009) não publicaram dados de radiação solar, que passou a ser registrado somente a partir do ano 2000.

Nesta seção, algumas variáveis climáticas da série 2001-2013 foram analisadas à luz das Normais Climatológicas 1961-1990. Foram observadas diferenças entre os dados das séries em questão.

No entanto, é prematuro associar as diferenças encontradas entre os dois arquivos de dados como consequência dos efeitos da urbanização, desmatamento ou mudanças climáticas, apesar de que as alterações climáticas que estão ocorrendo no mundo todo sinalizam que será cada vez mais comum a ocorrência de eventos extremos (PBMC, 2014).

Os valores obtidos nas duas séries analisados resultaram de tratamentos estatísticos diferenciados, portanto, ao comparar os parâmetros publicados pelas Normais Climatológicas com as médias simples obtidas da série 2001-2013 para Brasília, pode-se incorrer em erro, por estar comparando resultados obtidos por diferentes metodologias.

As diferenças nos resultados devem ser avaliadas com cautela, considerando que as metodologias utilizadas são próprias de cada uma das séries. Somente em 2020 estará concluída a nova série de registros do INMET para as Normais Climatológicas 1991-2020 (30 anos). 
No entanto, mesmo havendo diferenças entre os valores das médias mensais, a análise efetuada permitiu concluir que existe forte correspondência entre os valores das variáveis das séries analisadas, e que a série 2001-2013 possui um comportamento sazonal similar às Normais Climatológica 1961-1990, ao longo do ano.

\subsection{COMPARAÇÃO ENTRE ARQUIVOS CLIMÁTICOS DE IRRADIÂNCIA SOLAR PARA BRASÍLIA}

O principal objetivo do estudo apresentado nesta seção foi comparar a irradiância global horizontal diária do arquivo climático TMY da base de dados EPW/ANTAC (RORIZ, 2012) com o arquivo climático da série 2001-2013 do INMET, cujos dados horários foram registrados pela estação automática A001 - Brasília.

O ano climático TMY da base EPW/ANTAC foi gerado a partir dos valores médios de temperatura, portanto, pode não ser representativo para outros parâmetros climáticos como a radiação solar, por exemplo.

O estudo comparativo entre os dois arquivos climáticos visou verificar a representatividade da irradiância solar global, justificando assim a seleção do arquivo climático TMY para as simulações computacionais higrotérmicas, realizadas neste trabalho de tese.

Para analisar as diferenças entre o ano climático TMY - EPW/ANTAC e a série 20012013/INMET, foi adotada a mesma metodologia de análise comparativa das diferenças entre as médias utilizada por Scheller et al. (2015), quando compararam cinco arquivos climáticos utilizados em simulações termo-energéticas (ver Figura 2.3).

Em 2015, Scheller et al. publicaram um relatório contendo uma análise comparativa entre o Atlas SWERA, o Atlas IRENA e mais três arquivos climáticos utilizados nas simulações termoenergética de edificações para climas brasileiros, identificados como TRY (Test Reference Year), SWERA (Solar and Wind Energy Resource Assessment) e TMY (Typical Meteorological Year) da base EPW/ANTAC (este último, objeto de análise desta seção de estudo).

A estação automática A001-Brasília entrou em funcionamento em maio de 2000 e foi a primeira estação automática de superfície do INMET. Os dados do ano 2000 estão incompletos e, portanto, foram descartados. Foi considerada a série 2001-2013, portanto, 13 anos de dados registrados. 
O INMET tem como norma padrão realizar controle da qualidade dos dados antes da sua publicação. Mesmo assim, o INMET alerta que esses arquivos climáticos contêm dados que ainda não foram consolidados, isto é, estão disponíveis para o público em geral, mas ainda não sofreram o tratamento necessário para se tornarem dados das Normais Climatológicas como série representativa de dados climáticos padronizados.

A série 2001-2013, com 13 anos de dados, possui 113880 horas de registros de radiação solar, isto é, são 8760 horas registradas por ano. Verificou-se que cerca de 10,65\% dos dados registrados de radiação solar são nulos (NULL).

Para identificar dados espúrios, foram verificados os valores extremos. Conforme teste de range apresentado por Pittigliani (2000), podem ser considerados como dados inconsistentes de radiação solar os valores acima de $1355 \mathrm{~W} / \mathrm{m}^{2}$. O critério de Pittigliani (2000) foi adotado por Roriz (2012) para a revisão do TMY - EPW/ANTAC.

Mas, para este estudo, foi considerado o critério proposto por Zahumenský (2004) para a WMOWorld Meteorological Organization que adota como dados suspeitos os valores para radiação solar que não estejam entre 0 e $1600 \mathrm{~W} / \mathrm{m}^{2}$, quando registrados por estações climáticas automáticas (AWS- Automatic Weather Stations).

Além disso, devem ser considerados dados suspeitos as variações horárias (diferenças entre dois registros horários consecutivos) acima de $800 \mathrm{~W} / \mathrm{m}^{2}$ (WMO, 2007). Esses critérios são adotados pelo INMET, com base nos manuais da WMO.

Em 13 anos de dados horários, foram encontrados cerca de $0,8 \%$, de valores de irradiância solar acima de $1600 \mathrm{Wh} / \mathrm{m}^{2}$, que podem ser considerados como dados espúrios. Esses valores foram removidos do arquivo climático da série 2001-2013/INMET.

A Figura 2.36 exemplifica uma situação antes e depois do tratamento de dados horários espúrios ocorridos nos registros do mês de abril da série 2001-2013.

A Figura 2.37 exemplifica uma situação, antes e depois do tratamento, onde os dados espúrios ocorrem em uma sequência de registros horários, no mês de abril da série 2001-2013.

A Figura 2.38 mostra 13 anos de dados horários de irradiância solar global horizontal, após serem removidos os valores horários que não atenderam aos critérios estabelecidos para o controle da qualidade. A Figura 2.39 mostra a irradiância solar global horizontal do mês de janeiro, ilustrando o ciclo diário, com os picos de radiação que ocorrem por volta do meio dia. 
a) Antes do tratamento

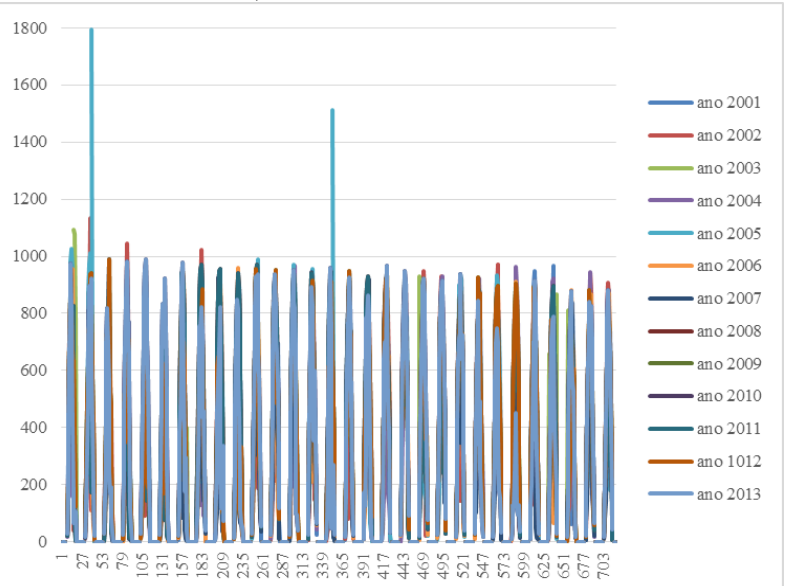

b) Depois do tratamento

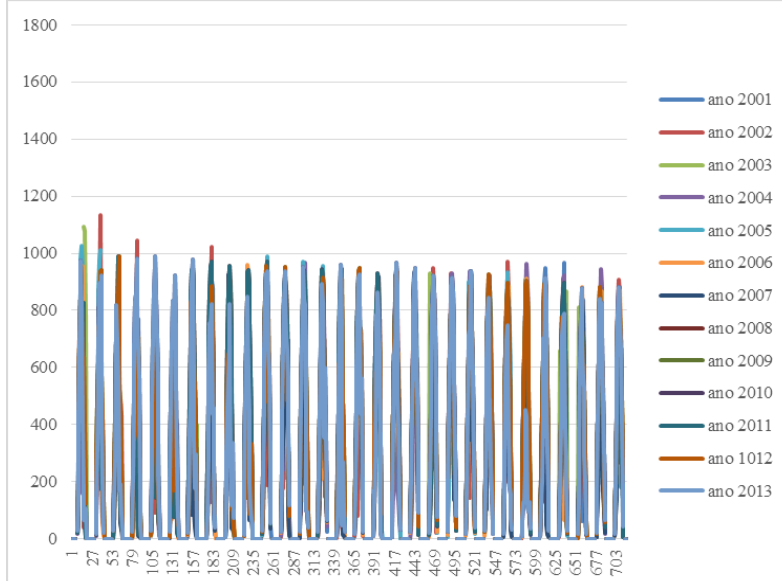

Figura 2.36 - Exemplo dos dados climáticos de irradiância solar global horizontal diária $\left(\mathrm{Wh} / \mathrm{m}^{2}\right)$, para o mês de abril da série 2001-2013 para Brasília: a) antes do tratamento, mostrando os dados horários espúrios ou inconsistentes; b) resultado depois dos dados tratados.

a) Antes do tratamento

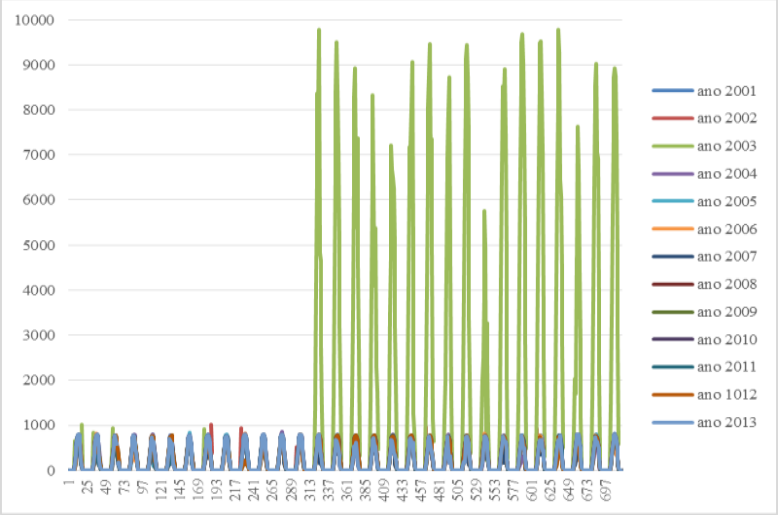

b) Depois do tratamento

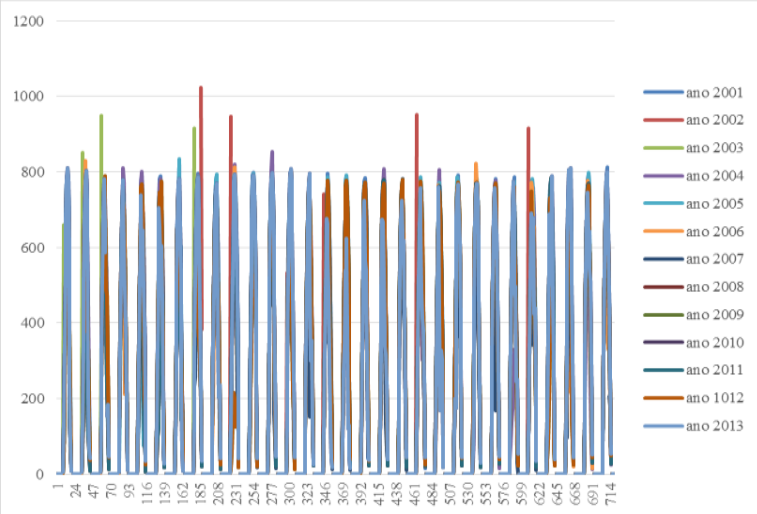

Figura 2.37 - Exemplo dos dados climáticos de irradiância solar global horizontal diária $\left(\mathrm{Wh} / \mathrm{m}^{2}\right), \mathrm{para} 0$ mês de abril da série 2001-2013 para Brasília: a) antes do tratamento, mostrando uma sequência de dados horários espúrios; b) resultado depois dos dados tratados.

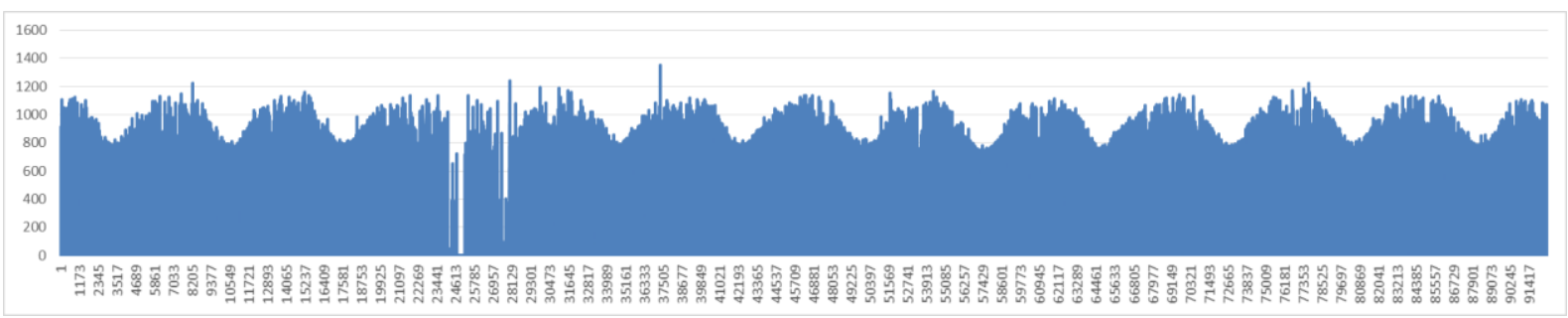

Figura 2.38 - Irradiância solar global horizontal horária (Wh/m2), após a remoção de dados nulos e espúrios, em 13 anos de dados horários registrados pela estação A001-Brasília.

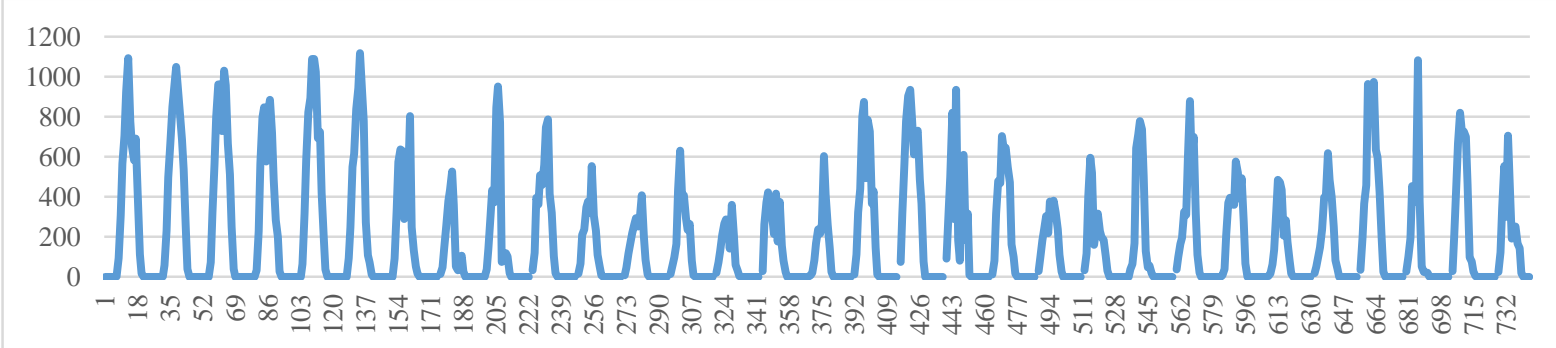

Figura 2.39 - Ciclo diário da irradiância solar global horizontal horária $\left(\mathrm{Wh} / \mathrm{m}^{2}\right)$ - 744 horas do mês de janeiro de 2013, em Brasília. 
Após esse primeiro controle da qualidade dos dados, foi feita a média diária da irradiação solar para os 4745 dias da série 2001-2013. Essas médias diárias geraram o gráfico da Figura 2.40.

Avaliando os extremos superiores da série, não foi observado nenhum valor acima de 9000 $\mathrm{Wh} / \mathrm{m}^{2}$. Ao avaliar os extremos inferiores, observou-se que sequências de valores nulos ou removidos pelo controle da qualidade afetavam as médias diárias. Por isso, foi feita uma verificação da série, identificando a faixa de valores que alteravam o comportamento esperado, estabelecendo como valor de corte as médias diárias abaixo de 2000Wh/m² (ver Figura 2.40).

A Figura 2.41 mostra o resultado final obtido para a série, após os controles da qualidade para erros grosseiros. No geral, foram encontrados cerca de $13 \%$ de valores considerados espúrios para as médias diárias. Após o tratamento dos dados, cerca de $87 \%$ das médias diárias foram consideradas aprovadas. Optou-se por não interpolar ou preencher sequências de dados nulos ou lacunas deixadas por dados espúrios.

A Figura 2.40 mostra os valores médios diários da irradiância solar global horizontal para 13 anos de dados da série 2001-2013 medidos pela estação automática de superfície A001 do INMET, antes do controle da qualidade. A Figura 2.41 apresenta os valores médios diários da irradiância solar global horizontal após o controle da qualidade que removeu todos os valores médios diários abaixo da faixa limite de $2000 \mathrm{Wh} / \mathrm{m}^{2}$.

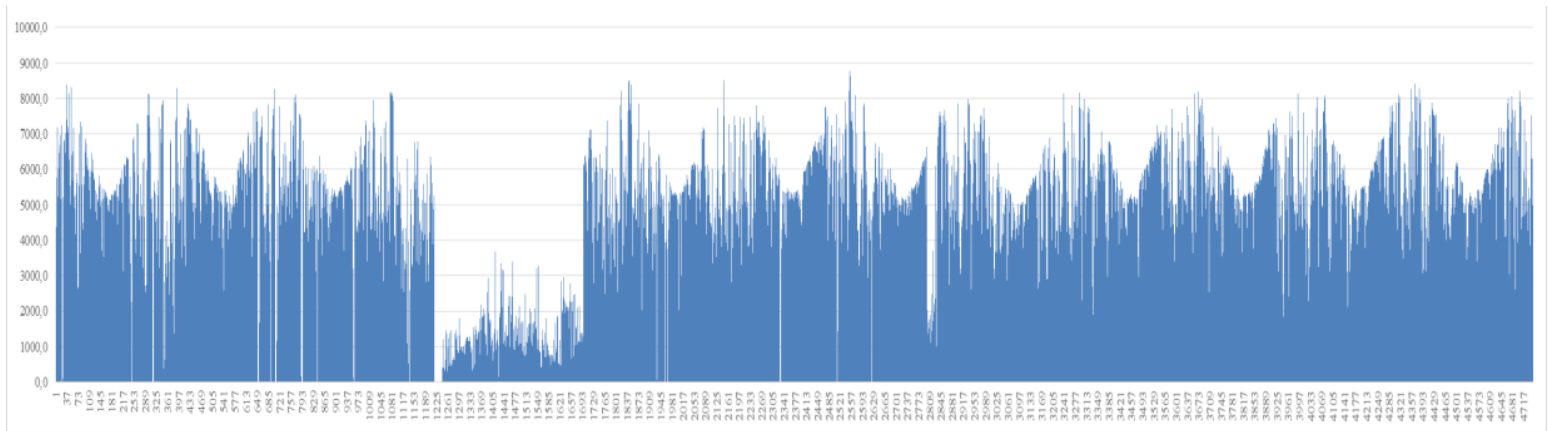

Figura 2.40 - Irradiância solar global horizontal diária $\left(\mathrm{Wh} / \mathrm{m}^{2}\right)$ para 13 anos de dados registrados pela estação A001-Brasília (365 dias x 13 anos = 4745 médias diárias).

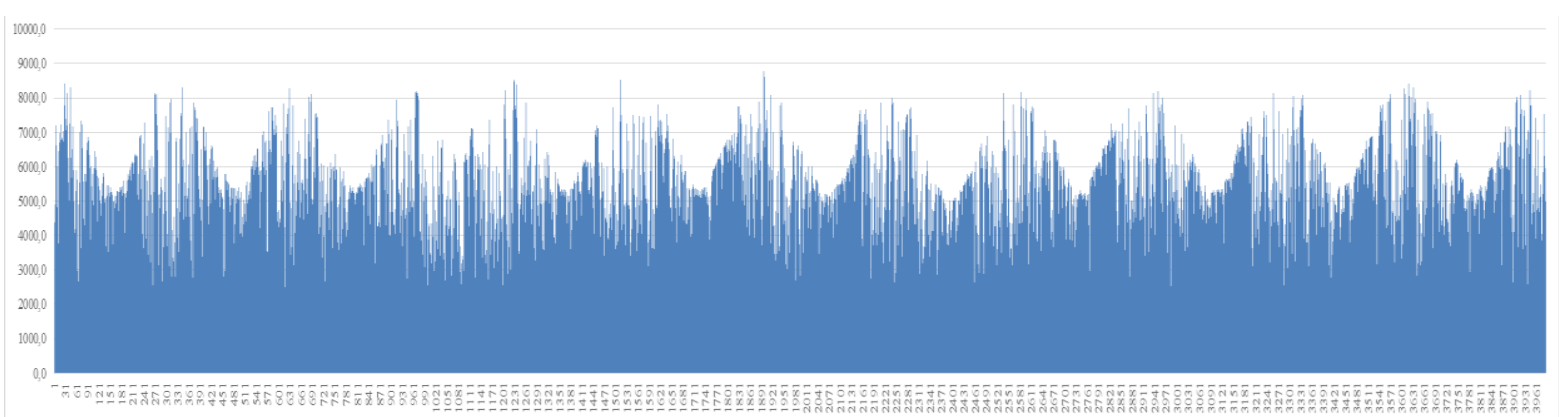

Figura 2.41 - Irradiância solar global horizontal diária $\left(\mathrm{Wh} / \mathrm{m}^{2}\right)$, após a remoção de valores abaixo da faixa limite de $2000 \mathrm{Wh} / \mathrm{m}^{2}$, para 13 anos de dados registrados pela estação A001-Brasília. 
A Tabela 2.23 apresenta a estatística descritiva do ano climático TMY da base de dados EPW/ANTAC (RORIZ, 2012) e do arquivo climático da série 2001-2013/INMET para a variável irradiância global horizontal. Para as análises comparativas, os arquivos foram agrupados por ano e por período (seco e chuvoso). A Tabela 2.24 apresenta os resultados dos testes T realizados para duas amostras com variâncias diferentes (para os grupos período anual e chuvoso) e variâncias equivalentes (grupo período seco).

Tabela 2.23 - Estatística descritiva dos arquivos climáticos TMY-EPW/ANTAC e série 2001-2013 para a variável Irradiância Global Horizontal para Brasília.

\begin{tabular}{c|cc|cc|cc}
\hline & $\begin{array}{c}\text { TMY } \\
\text { Anual }\end{array}$ & $\begin{array}{c}\text { Série 2001-2013 } \\
\text { Anual }\end{array}$ & $\begin{array}{c}\text { TMY } \\
\text { Chuvoso }\end{array}$ & $\begin{array}{c}\text { Série 2001- } \\
\text { 2013 Chuvoso }\end{array}$ & $\begin{array}{c}\text { TMY } \\
\text { Seco }\end{array}$ & $\begin{array}{c}\text { Série 2001-2013 } \\
\text { Seco }\end{array}$ \\
\hline \hline Média & 5,06 & 5,16 & 5,10 & 5,16 & 5,01 & 5,17 \\
\hline Desvio padrão & 0,56 & 0,29 & 0,77 & 0,17 & 0,31 & 0,40 \\
\hline Variância da amostra & 0,318 & 0,088 & 0,599 & 0,031 & 0,097 & 0,164 \\
\hline Curtose & 0,078 & $-0,384$ & $-1,720$ & $-0,659$ & 0,338 & $-1,784$ \\
\hline Assimetria & 0,990 & 0,666 & 0,806 & $-0,180$ & 0,694 & 0,700 \\
\hline Observações & 12 & 12 & 6 & 6 & 6 & 6 \\
\hline
\end{tabular}

Tabela 2.24 - Resultados estatísticos dos testes de hipótese: Teste T para duas amostras.

\begin{tabular}{|c|c|c|c|c|c|c|}
\hline & $\begin{array}{c}\text { TMY } \\
\text { Anual }\end{array}$ & $\begin{array}{c}\text { Série 2001-2013 } \\
\text { Anual }\end{array}$ & $\begin{array}{c}\text { TMY } \\
\text { Chuvoso }\end{array}$ & $\begin{array}{c}\text { Série 2001-2013 } \\
\text { Chuvoso }\end{array}$ & $\begin{array}{l}\text { TMY } \\
\text { Seco }\end{array}$ & $\begin{array}{c}\text { Série 2001- } \\
2013 \\
\text { Seco } \\
\end{array}$ \\
\hline & \multicolumn{2}{|c|}{ Variâncias diferentes } & \multicolumn{2}{|c|}{ Variâncias diferentes } & \multicolumn{2}{|c|}{ Variâncias equivalentes } \\
\hline Média & 5,06 & 5,16 & 5,10 & 5,16 & 5,01 & 5,17 \\
\hline Variância & 0,318 & 0,088 & 0,599 & 0,031 & 0,097 & 0,164 \\
\hline Observações & 12 & 12 & 6 & 6 & 6 & 6 \\
\hline Variância agrupada & & & & & 0,130 & \\
\hline $\mathrm{gl}$ & 17 & & 6 & & 10 & \\
\hline Stat $\mathrm{t}$ & $-0,569$ & & $-0,179$ & & $-0,726$ & \\
\hline $\mathrm{P}(\mathrm{T}<=\mathrm{t})$ uni-caudal & 0,288 & & 0,4315707 & & 0,242 & \\
\hline t crítico uni-caudal & 1,739 & & 1,9431803 & & 1,812 & \\
\hline $\mathrm{P}(\mathrm{T}<=\mathrm{t})$ bi-caudal & 0,576 & & 0,863 & & 0,484 & \\
\hline t crítico bi-caudal & 2,109 & & 2,446 & & 2,228 & \\
\hline
\end{tabular}

Foram verificadas as normalidades das amostras para $\mathrm{P}_{\text {valor }}>0,05$, constatando que as amostras são oriundas de uma distribuição normal, possibilitando aplicar os testes para variância e selecionar os testes de hipótese. Para as amostras correspondentes ao período anual e período chuvoso, os testes rejeitaram a hipótese de igualdade de variância. Para o período seco, as evidências estatísticas não mostraram diferenças significativas entre as variâncias.

Baseado nas variâncias das amostras, para o período anual e período chuvoso, foi aplicado o Teste T: duas amostras presumindo variâncias diferentes. Para o período seco foi aplicado o Teste T: duas amostras presumindo variâncias equivalentes. Observa-se que $P_{\text {valor }}>0,05$, 
mostrando que não existem evidências estatísticas de diferenças significativas entre as médias dos dois arquivos analisados, quando consideradas a média do grupo anual e as médias dos grupos período seco e período chuvoso.

Nem sempre a média anual é um bom indicador para a análise do comportamento sazonal das séries temporais. Por esta razão, foi efetuada uma análise dos desvios entre as médias mensais diárias da irradiância global horizontal do ano climático TMY e da série 2001-2013.

A Tabela 2.25 apresenta as médias mensais da irradiância solar global horizontal dos dois arquivos analisados, os desvios entre as médias mensais e as respectivas diferenças percentuais. As médias mensais foram obtidas pela média aritmética simples, considerando todas as médias diárias do respectivo mês.

Tabela 2.25 - Diferenças entre as médias mensais diárias da Irradiância Global Horizontal $\left(\mathrm{kWh} / \mathrm{m}^{2}\right)$ para Brasília.

\begin{tabular}{|c|c|c|c|c|}
\hline & $\begin{array}{c}\text { TMY } \\
\text { EPW-ANTAC } \\
(\mathbf{1})\end{array}$ & $\begin{array}{c}\text { Série 2001-2013 } \\
\text { (INMET) } \\
(2)\end{array}$ & $\begin{array}{c}\text { Diferenças entre as } \\
\text { séries } 1 \text { e } 2 \\
\left(\mathbf{k W h} / \mathbf{m}^{2} . \text { dia }\right)\end{array}$ & $\begin{array}{c}\text { Diferenças } \\
\text { percentual entre as } \\
\text { séries } 1 \text { e } 2 \\
(\%) \\
\end{array}$ \\
\hline Janeiro & 6,15 & 5,15 & 1,00 & 16,26 \\
\hline Fevereiro & 6,01 & 5,38 & 0,63 & 10,48 \\
\hline Março & 4,65 & 5,15 & $-0,50$ & $-10,75$ \\
\hline Abril & 5,52 & 5,05 & 0,47 & 8,51 \\
\hline Maio & 4,63 & 4,84 & $-0,21$ & $-4,54$ \\
\hline Junho & 4,87 & 4,77 & 0,10 & 2,05 \\
\hline Julho & 4,88 & 5,01 & $-0,13$ & $-2,66$ \\
\hline Agosto & 5,22 & 5,64 & $-0,42$ & $-8,05$ \\
\hline Setembro & 4,99 & 5,71 & $-0,72$ & $-14,43$ \\
\hline Outubro & 4,78 & 5,33 & $-0,55$ & $-11,51$ \\
\hline Novembro & 4,33 & 4,90 & $-0,57$ & $-13,16$ \\
\hline Dezembro & 4,69 & 5,05 & $-0,36$ & $-7,68$ \\
\hline Total & 60,72 & 61,98 & $-1,26$ & $-2,08$ \\
\hline
\end{tabular}

A Figura 2.42 representa graficamente as médias mensais diárias da irradiância global horizontal dos dois arquivos climáticos utilizados para as comparações.

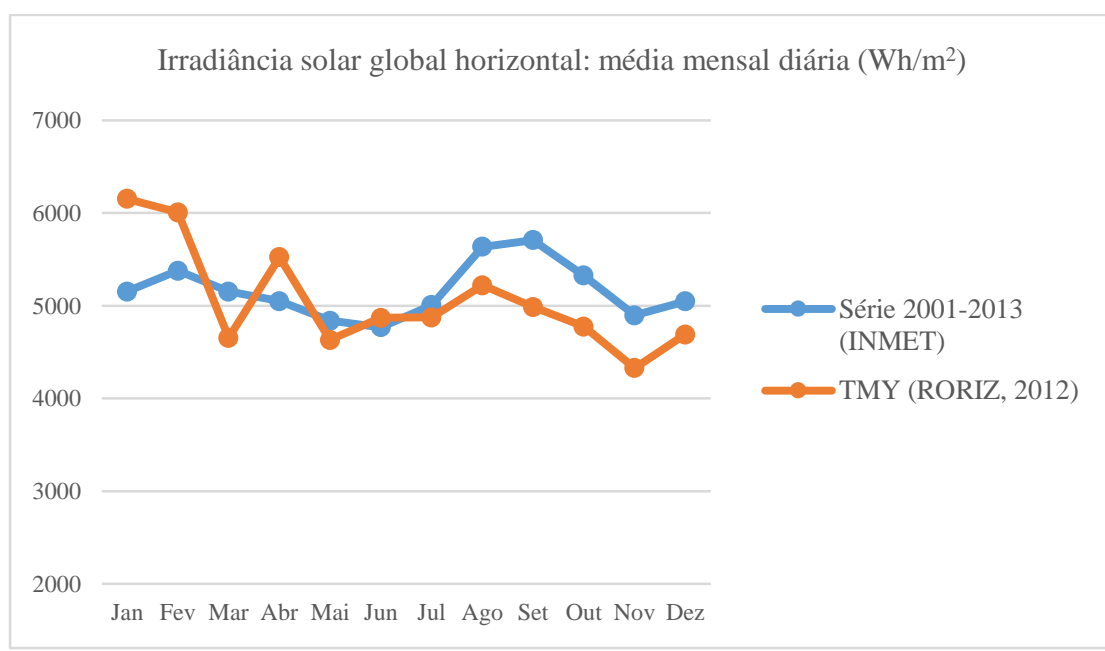

Figura 2.42 - Média diária mensal da irradiância global horizontal (Wh/m².dia): Comparação entre dois arquivos climáticos para Brasília. 
A Tabela 2.26 mostra as médias diárias mensais da irradiância global horizontal, para os períodos seco e chuvoso, da série 2001-2013 medidos pelo INMET, comparativamente com os dados do arquivo climático TMY (RORIZ, 2012) e os valores apresentados no relatório de Scheller et al. (2015) para os arquivos climáticos Atlas SWERA, Atlas IRENA, TRY e SWERA.

Tabela 2.26 - Médias mensais diárias da Irradiância Global Horizontal $\left(\mathrm{Wh} / \mathrm{m}^{2}\right)$, nos períodos seco e chuvoso, em Brasília.

\begin{tabular}{|c|c|c|c|c|c|c|c|c|c|c|c|c|c|}
\hline \multicolumn{7}{|c|}{ PERÍODO CHUVOSO } & \multicolumn{7}{|c|}{ PERÍODO SECO } \\
\hline & $\begin{array}{c}{ }^{1} \text { Série } \\
2001-2013\end{array}$ & TMY $^{2}$ & TRY $^{3}$ & SWERA $^{3}$ & $\begin{array}{c}\text { Atlas } \\
\text { SWERA }^{3}\end{array}$ & $\begin{array}{c}\text { Atlas } \\
\text { IRENA }^{3}\end{array}$ & & $\begin{array}{c}{ }^{1} \text { Série } \\
2001- \\
2013\end{array}$ & $\mathbf{T M Y}^{2}$ & TRY $^{3}$ & SWERA $^{3}$ & $\begin{array}{c}\text { Atlas } \\
\text { SWERA }^{3}\end{array}$ & $\begin{array}{c}\text { Atlas } \\
\text { IRENA }^{3}\end{array}$ \\
\hline Jan & 5152,9 & 6152 & 6769,8 & 5841,6 & 6000,8 & 6450 & Abr & 5050,4 & 5523,8 & 5220,5 & 5110,6 & 5539,5 & 4846 \\
\hline Fev & 5378,1 & 6007,6 & 6706,5 & 5964,2 & 6208,6 & 5405 & Mai & 4837,9 & 4631,1 & 4741 & 4523,8 & 4971,8 & 3882 \\
\hline Mar & 5152,9 & 4652,9 & 5708,1 & 5419,8 & 5510,5 & 4749 & Jun & 4768,5 & 4870 & 4701,6 & 4645,9 & 4497,9 & 3301 \\
\hline Out & 5326,8 & 4776,1 & 6247,4 & 5947,8 & 6205,8 & 5517 & Jul & 5007,2 & 4875 & 4244,8 & 4869,5 & 4705,8 & 3686 \\
\hline Nov & 4895,6 & 4327,6 & 6248 & 5471,6 & 5869,9 & 5427 & Ago & 5635,5 & 5219,3 & 5762,9 & 5409,3 & 5456,8 & 3972 \\
\hline Dez & 5047,5 & 4688,8 & 6283,8 & 5402,4 & 5707,8 & 5880 & Set & 5708 & 4986,3 & 6220,6 & 5964,1 & 6148,5 & 4231 \\
\hline Média & 5158,9 & 5100,8 & 6327,2 & 5674,5 & 5917,2 & 5571,3 & Média & 5167,9 & $\mathbf{5 0 1 7 , 5}$ & 5148,5 & 5087,2 & 5220,0 & 3986,3 \\
\hline
\end{tabular}

Fonte: (1) INMET (2014); (2) RORIZ (2012); (3) SCHELLER et al. (2015).

As Tabelas 2.27 e 2.28 mostram, respectivamente, as diferenças entre as médias dos arquivos climáticos nos períodos chuvoso e seco.

Tabela 2.27 - Diferenças entre as médias mensais diárias da Irradiância Global Horizontal (Wh/m2), no período chuvoso, em Brasília.

\begin{tabular}{|c|c|c|c|c|c|c|}
\hline $\begin{array}{l}\text { PERÍODO } \\
\text { CHUVOSO }\end{array}$ & $\begin{array}{c}{ }^{1} \text { Série 2001- } \\
2013\end{array}$ & TMY $^{2}$ & TRY $^{3}$ & SWERA $^{3}$ & $\begin{array}{c}\text { Atlas } \\
\text { SWERA }^{3}\end{array}$ & $\begin{array}{c}\text { Atlas } \\
\text { IRENA }^{3}\end{array}$ \\
\hline Série 2001-2013 & 0,00 & & & & & \\
\hline TMY & $-58,13$ & 0,00 & & & & \\
\hline TRY & 1168,30 & 1226,43 & 0,00 & & & \\
\hline SWERA & 515,60 & 573,73 & $-652,70$ & 0,00 & & \\
\hline Atlas SWERA & 758,27 & 816,40 & $-410,03$ & 242,67 & 0,00 & \\
\hline Atlas IRENA & 412,37 & 470,50 & $-755,93$ & $-103,23$ & $-345,90$ & 0,00 \\
\hline
\end{tabular}

Fonte: (1) INMET (2014); (2) RORIZ (2012); (3) SCHELLER et al. (2015).

Tabela 2.28 - Diferenças entre as médias mensais diárias da Irradiância Global Horizontal (Wh/m2), no período seco, em Brasília.

\begin{tabular}{|c|c|c|c|c|c|c|}
\hline PERÍODO SECO & $\begin{array}{c}{ }^{1} \text { Série 2001- } \\
2013 \\
\end{array}$ & TMY $^{2}$ & TRY ${ }^{3}$ & SWERA $^{3}$ & $\begin{array}{c}\text { Atlas } \\
\text { SWERA }^{3} \\
\end{array}$ & $\begin{array}{c}\text { Atlas } \\
\text { IRENA }^{3} \\
\end{array}$ \\
\hline Série 2001-2013 & 0,00 & & & & & \\
\hline TMY & $-150,33$ & 0,00 & & & & \\
\hline TRY & $-19,35$ & 130,98 & 0,00 & & & \\
\hline SWERA & $-80,72$ & 69,62 & $-61,37$ & 0,00 & & \\
\hline Atlas SWERA & 52,13 & 202,47 & 71,48 & 132,85 & 0,00 & \\
\hline Atlas IRENA & $-1181,58$ & $-1031,25$ & $-1162,23$ & $-1100,87$ & $-1233,72$ & 0,00 \\
\hline
\end{tabular}


A Figura 2.43 mostra as médias diárias mensais da irradiância global horizontal da série 20012013, medidos pelo INMET, comparativamente com os dados do ano climático TMY (RORIZ, 2012) e dos arquivos climáticos Atlas SWERA, Atlas IRENA, TRY e SWERA, obtidos do relatório de Scheller et al. (2015).

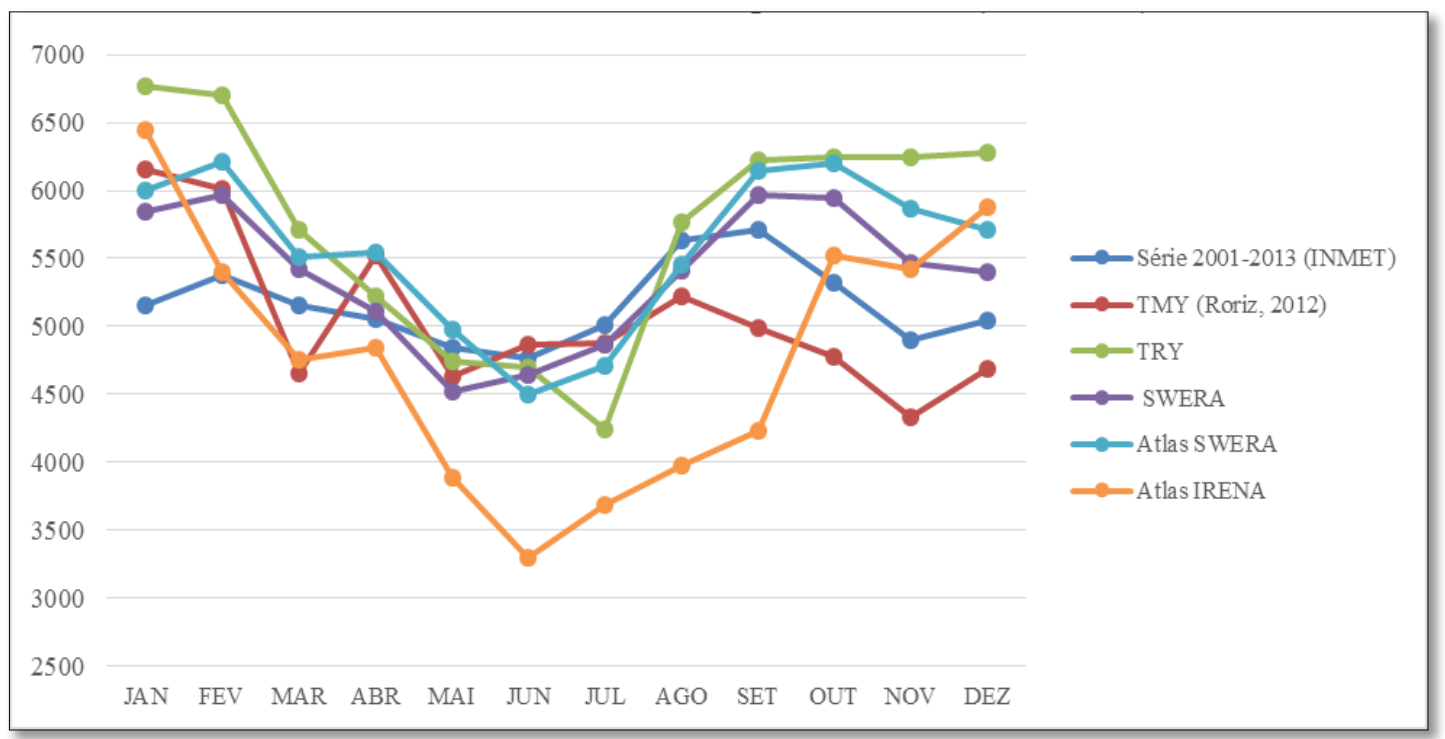

Figura 2.43 - Média mensal diária da irradiância global horizontal $\left(\mathrm{Wh} / \mathrm{m}^{2}\right.$.dia) entre arquivos climáticos para Brasília.

Analisando os desvios entre as médias diárias das irradiâncias dos arquivos estudados, inclusive aqueles publicados por Scheller et al., (2015), verifica-se que, no período chuvoso, a menor diferença está entre os arquivos climáticos TMY e a série 2001-2013/INMET. Com exceção do Atlas IRENA, no período seco, são baixos os valores das diferenças, quando comparados com o período chuvoso.

Essas discrepâncias entre os arquivos podem ser melhor visualizadas no comportamento das curvas da média mensal diária da irradiância global horizontal, apresentadas na Figura 2.43.

Comparando o comportamento do ano meteorológico típico TMY da base EPW/ANTAC e da série 2001-2013/INMET, é possível observar que:

a) em maio, junho e julho, que são os meses mais secos e de menor nebulosidade (Tabela 2.29), os valores de irradiância solar global dos dois arquivos analisados apresentam desvios similares; no período seco, as variâncias das médias dos arquivos são equivalentes (Tabela 2.24);

b) em agosto e setembro, aumentam os desvios entre as médias dos meses analisados; dentro do período seco, esses meses possuem baixa nebulosidade, mas são os meses com os maiores índices de focos de queimadas no Distrito Federal (Tabela 2.29 e Tabela 2.30); 
c) os meses mais chuvosos, que compreendem os meses mais quentes do ano (outubro a março) e com maior nebulosidade, existe uma maior discrepância dos desvios entre as médias mensais dos dois arquivos analisados; para o período chuvoso, as variâncias das médias dos dois arquivos apresentam-se diferentes (Tabela 2.24).

A irradiância solar global horizontal está fortemente relacionada com a nebulosidade e sofre influência do índice de transparência ou transmissividade atmosférica (Kt), dado pela razão entre a irradiância solar global e a irradiância solar que chega ao topo da atmosfera.

O Kt varia de acordo com as condições de céu (nebulosidade, aerossóis na atmosfera, particulados decorrentes das queimadas, etc.). Os valores mais discrepantes observados nos arquivos podem ser decorrentes da maior imprevisibilidade do Kt.

Tabela 2.29 - Dados de nebulosidade e precipitação da série 2001-2013 para Brasília.

\begin{tabular}{c|cc|c|cc}
\hline \multicolumn{3}{|c|}{ PERÍODO CHUVOSO } & \multicolumn{3}{c}{ PERÍODO SECO } \\
\hline & Nebulosidade & Precipitação & & Nebulosidade & Precipitação \\
\hline \hline Jan & 8,1 & 216 & Abr & 6 & 132 \\
Fev & 7,5 & 164,2 & Mai & 4,8 & 18,5 \\
Mar & 7,3 & 187,9 & Jun & 3,5 & 2,1 \\
Out & 6,6 & 138,7 & Jul & 3 & 2,4 \\
Nov & 8 & 220,8 & Ago & 2,8 & 15,2 \\
Dez & 8 & 242,2 & Set & 4,4 & 33,8 \\
\hline Média & $\mathbf{7 , 6}$ & $\mathbf{1 1 6 9 , 8 ~} \mathbf{~ m m}$ & Média & $\mathbf{4 , 1}$ & $\mathbf{2 0 4 , 0 ~} \mathbf{~ m m}$ \\
\hline
\end{tabular}

Fonte: INMET (2014).

Tabela 2.30 - Quantificação da ocorrência mensal de focos ativos de queimada detectados por satélite de referência, no período de 2001 a 2013, no Distrito Federal.

\begin{tabular}{cccccccccccccc}
\hline & Jan & Fev & Mar & Abr & Mai & Jun & Jul & Ago & Set & Out & Nov & Dez & Ano \\
\hline \hline Máximo mensal & 2 & 4 & 2 & 8 & 23 & 21 & 85 & 159 & 196 & 16 & 4 & 2 & $\mathbf{5 0 5}$ \\
Média mensal & 0,38 & 0,77 & 0,23 & 1,23 & 4,31 & 6,23 & 25,85 & 50,77 & 53,00 & 6,77 & 0,38 & 0,38 & $\mathbf{1 5 0 , 3 0}$ \\
Mínimo mensal & 0 & 0 & 0 & 0 & 0 & 0 & 3 & 16 & 5 & 0 & 0 & 0 & $\mathbf{0}$ \\
Total & $\mathbf{5}$ & $\mathbf{1 0}$ & $\mathbf{3}$ & $\mathbf{1 6}$ & $\mathbf{5 6}$ & $\mathbf{8 1}$ & $\mathbf{3 3 6}$ & $\mathbf{6 6 0}$ & $\mathbf{6 8 9}$ & $\mathbf{8 8}$ & $\mathbf{5}$ & $\mathbf{5}$ & $\mathbf{1 9 5 4}$ \\
\hline
\end{tabular}

Fonte: INPE (2012).

As análises estatísticas mostraram que não existem evidências estatisticamente significativas de diferenças entre o ano climático TMY e a série 2001-2013, quando analisadas as médias por período. Mas, quando analisadas as diferenças entre as médias, mês a mês (Tabela 2.25 e Figura 2.42), são encontradas discrepâncias entre eles. As diferenças são maiores nos meses chuvosos do que nos meses secos.

Para os estudos de degradação, baseados na interação entre os agentes climáticos de degradação e as fachadas, a estratégia de comparar os arquivos climáticos por período do ano torna-se um 
procedimento satisfatório, considerando a compensação das diferenças entre os meses, desde que o objetivo seja o estudo do envelhecimento natural das edificações ao longo da sua vida útil. Como Brasília é uma cidade com um período seco e um período chuvoso bastante característicos, essa comparação por períodos mostra-se como um recurso viável para analisar a representatividade dos arquivos climáticos (ZANONI et al., 2015a; 2015b).

A representatividade de um arquivo climático pode ser afetada pela quantidade de anos utilizada para compor o ano climático de referência. É recomendada uma amostra com, no mínimo, 10 anos de dados de registros horários. A qualidade dos dados da série analisada também influencia a representatividade do arquivo climático (DIN EN 15026:2007).

Os primeiros anos de registros de dados horários de Brasília pelo INMET apresentaram muitos dados nulos e espúrios para a radiação solar, consequência de pane nos sensores ou problemas no sinal de satélite, além de ajustes de procedimentos na aquisição e transmissão de dados horários. Por isso, para este estudo, optou-se por selecionar 13 anos de dados do INMET, melhorando assim a representatividade do arquivo base de comparação. Os bancos de dados dos últimos dois anos já se apresentam com menor quantidade de dados nulos ou espúrios (em torno de $5 \%$ ).

A metodologia de controle da qualidade e os procedimentos para tratamento de arquivos de dados meteorológicos, visando à consolidação de dados horários, ainda são pouco difundidas. Os procedimentos para preenchimento de falhas e correção de dados horários espúrios são pouco relatados pelos pesquisadores brasileiros, fora do âmbito da meteorologia.

\subsubsection{Conclusões sobre a comparação entre os arquivos climáticos de irradiância solar}

Este estudo apresentou os resultados de uma análise dos valores de irradiância solar global horizontal visando identificar a representatividade do arquivo climático TMY-EPW/ANTAC, por meio da comparação com a série 2001-2013 registrada pela estação automática A001Brasília do INMET.

Nem sempre a média anual é um bom indicador para avaliar a representatividade de uma série temporal, por isso foram analisados os desvios entre as médias mensais.

Conclui-se que a metodologia para obtenção de um ano meteorológico típico (TMY) seleciona os meses de referência com base nas temperaturas médias. Assim, os arquivos climáticos com 8760 horas, gerados para simulações computacionais a partir dos valores médios de 
temperatura, podem não ser representativos para o parâmetro radiação solar quando analisados mês a mês.

A análise dos desvios entre as médias mensais dos arquivos climáticos permitiu concluir que o TMY da base EPW-ANTAC apresenta valores discrepantes em relação à série 2001-2013 do INMET, principalmente nos meses mais chuvosos.

No entanto, quando analisados os desvios por períodos, verifica-se que no período chuvoso a diferença entre os arquivos climáticos é de cerca de $1,13 \%\left(0,35 \mathrm{kWh} / \mathrm{m}^{2}\right.$.dia), enquanto que no período seco a diferença é cerca de $3 \%\left(0,91 \mathrm{kWh} / \mathrm{m}^{2}\right.$.dia). Quando comparados os desvios das somatórias totais das médias mensais diárias da irradiância solar ao longo do ano, verificase que a diferença é de apenas $2 \%\left(1,26 \mathrm{kWh} / \mathrm{m}^{2}\right.$.dia).

A análise estatística mostrou que não existem evidências de diferenças significativas entre as médias anuais dos dois arquivos analisados, tampouco entre as médias efetuadas por período, mostrando que o arquivo TMY - EPW/ANTAC (RORIZ, 2012), entre todos os arquivos climáticos considerados neste estudo, é suficientemente representativo para a variável irradiância solar global horizontal, visando aos estudos de degradação de fachadas em Brasília por meio de simulação computacional higrotérmica. Inclusive, este arquivo possui a vantagem de conter dados de precipitação.

\subsection{REPRESENTATIVIDADE DO ARQUIVO CLIMÁTICO TMY- EPW/ANTAC PARA USO EM SIMULAÇÕES HIGROTÉRMICAS}

A seção 2.16 deste trabalho mostrou que o arquivo TMY da base EPW/ANTAC (RORIZ, 2012) é o mais representativo entre os arquivos climáticos para Brasília, disponíveis para as simulações computacionais, em relação à variável climática radiação solar global horizontal.

A metodologia para a seleção deste ano climático é baseada nos meses com as temperaturas mais representativas da série considerada. Por isso, a análise realizada na seção 2.16 foi importante, pois permitiu averiguar a representatividade da irradiação solar.

Para analisar outros parâmetros climáticos, o Quadro 2.8 organiza os principais dados obtidos da série 2001-2013 e do ano climático TMY/EPW-ANTAC, já apresentados em seções anteriores. Observa-se que as variáveis climáticas temperatura do ar, umidade relativa e pressão atmosférica apresentam forte similaridade entre os dois arquivos climáticos. 
O comportamento da chuva dirigida em relação à cada orientação de fachada é resultado da ação do vento sobre a precipitação. Os gráficos da chuva dirigida apresentados nas Figuras 2.44 e 2.45 permitem associar a precipitação com a velocidade e direção do vento.

A Figura 2.44 foi obtida por meio de métodos semi-empíricos (ver Capítulo III sobre os estudos de chuva dirigida), usados para calcular a intensidade da chuva dirigida com dados da série 2001-2013.

Observa-se que o resultado é fortemente correspondente com a Figura 2.45, obtida do programa WUFI, a partir da leitura do ano climático TMY.

Quadro 2.8 - Resultado do estudo comparativo dos arquivos climático de Brasília: TMY/EPW-ANTAC e Série 2001 - 2013 com dados horários medidos pelo INMET, em Brasília.

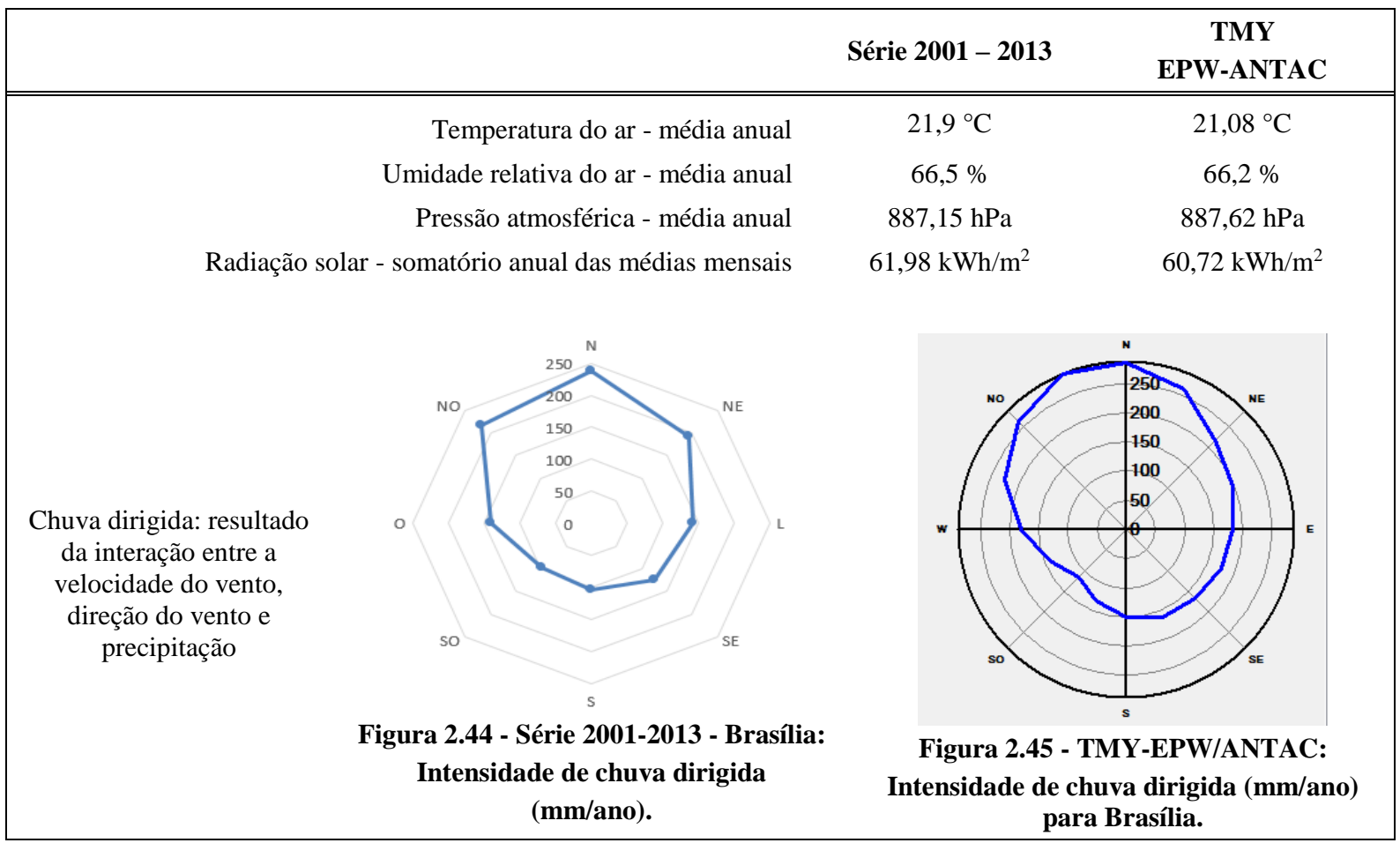

Portanto, analisando os dois arquivos climáticos com base nos valores médios anuais, constatase que o ano climático TMY é fortemente representativo para as variáveis climáticas que mais influenciam o comportamento higrotérmico das fachadas.

Dessa forma, o ano climático TMY/EPW-ANTAC (RORIZ, 2012) é o arquivo recomendado para as simulações computacionais do comportamento higrotérmico de fachadas, visando aos estudos de degradação das edificações. 


\subsection{ESCALAS DO CLIMA}

Os termos clima e tempo possuem diferentes significados na meteorologia. Enquanto o tempo é o estado físico momentâneo das condições atmosféricas em um determinado local, o clima refere-se ao comportamento médio da atmosfera, baseado nos eventos de tempo, em observações contínuas durante um determinado período, em uma certa localidade (REBOITA et al., 2012; INMET, 2014).

O estudo do clima pode ser feito em diferentes escalas espaciais: macroclima, mesoclima e microclima.

O Brasil é um país continental, de grandes dimensões territoriais, compreendido entre dois trópicos, com extensas regiões litorâneas, de floresta, de cerrado, entre outras paisagens e relevos.

Portanto, dimensões métricas da escala espacial podem não ser representativas quando comparadas com as classificações de outros países ou continentes ou, mesmo quando comparadas entre as regiões do próprio Brasil.

Para exemplificar o exposto, os Quadro 2.9 e 2.10 exemplificam duas importantes fontes de referência que apresentam classificações bastante distintas para as escalas espaciais do clima.

Quadro 2.9 - Extensões das escalas do clima.

\begin{tabular}{|c|c|c|}
\hline Clima & $\begin{array}{c}\text { Extensão } \\
\text { horizontal }\end{array}$ & Extensão vertical \\
\hline Clima regional (regional climate) & $1-200 \mathrm{~km}$ & $1 \mathrm{~m}-100 \mathrm{~km}$ \\
\hline Clima local (local climate) & $100 \mathrm{~m}-10 \mathrm{Km}$ & $0,1 \mathrm{~m}-1 \mathrm{~km}$ \\
\hline Clima na superfície ou próximo à superfície da edificação & $0.01 \mathrm{~m}-100 \mathrm{~m}$ & $0.01 \mathrm{~m}-10 \mathrm{~m}$ \\
\hline
\end{tabular}

Fonte: DURACRETE (1999) apud Lencioni; Lima; Morelli (2006).

Quadro 2.10 - Dimensões das escalas temporais e espaciais do clima.

\begin{tabular}{|c|c|c|c|c|c|}
\hline $\begin{array}{c}\text { Ordem de } \\
\text { grandeza }\end{array}$ & Subdivisões & $\begin{array}{c}\text { Escala } \\
\text { horizontal }\end{array}$ & Escala vertical & $\begin{array}{c}\text { Temporalidade } \\
\text { das variações } \\
\text { mais } \\
\text { representativas }\end{array}$ & Exemplificação espacial \\
\hline Macroclima & $\begin{array}{c}\text { Clima zonal } \\
\text { Clima regional }\end{array}$ & $>2000 \mathrm{~km}$ & $3 \mathrm{~km} \mathrm{a} 12 \mathrm{~km}$ & $\begin{array}{c}\text { Algumas semanas } \\
\text { a vários decênios }\end{array}$ & $\begin{array}{c}\text { O globo, um hemisfério, } \\
\text { oceano, continente, } \\
\text { mares, etc. }\end{array}$ \\
\hline Mesoclima & $\begin{array}{c}\text { Clima regional } \\
\text { Clima local } \\
\text { Topoclima }\end{array}$ & $\begin{array}{c}2.000 \mathrm{~km} \text { a } 10 \\
\mathrm{~km}\end{array}$ & $12 \mathrm{~km}$ a $100 \mathrm{~m}$ & $\begin{array}{c}\text { De várias horas a } \\
\text { alguns dias }\end{array}$ & $\begin{array}{c}\text { Região natural, } \\
\text { Montanha, região } \\
\text { metropolitana, cidade, } \\
\text { etc. }\end{array}$ \\
\hline Microclima & $\begin{array}{c}10 \mathrm{~km} \text { a alguns } \\
\text { metros }\end{array}$ & Abaixo de $100 \mathrm{~m}$ & De minutos ao dia & $\begin{array}{c}\text { Bosque, uma rua, uma } \\
\text { edificação/casa, etc. }\end{array}$ \\
\hline
\end{tabular}

Fonte: Baseado em Mendonça; Danni-Oliveira (2007, p. 23). 
Segundo Haagenrud (2004), não existe um consenso sobre a definição exata das diferentes escalas, mas para relacionar os fatores de degradação e seus efeitos em funções dose-resposta, é necessário caracterizar e mapear os fatores de degradação mais relevantes levando em conta as diferentes escalas geográficas do clima. Segundo o autor, as escalas geográficas para avaliar a exposição ambiental das edificações para os estudos de durabilidade, podem ser classificadas em macroclima, mesoclima, clima local e microclima.

No âmbito deste trabalho, entende-se que o macroclima abrande uma grande área de extensão territorial, fortemente influenciado pelos fatores climáticos globais (latitude, altitude, maritimidade e continentalidade, relevo, massas de ar, entre outros). A Figura 2.46 mostra as unidades climáticas do Brasil e suas subdivisões, que podem ser identificadas pelos seus macroclimas. Segundo a classificação do IBGE, os Climas Zonais do Brasil são identificados como Clima Equatorial; Clima Tropical-Zona Equatorial; Clima Tropical-Nordeste Oriental; Clima Tropical-Brasil Central e Clima Temperado.

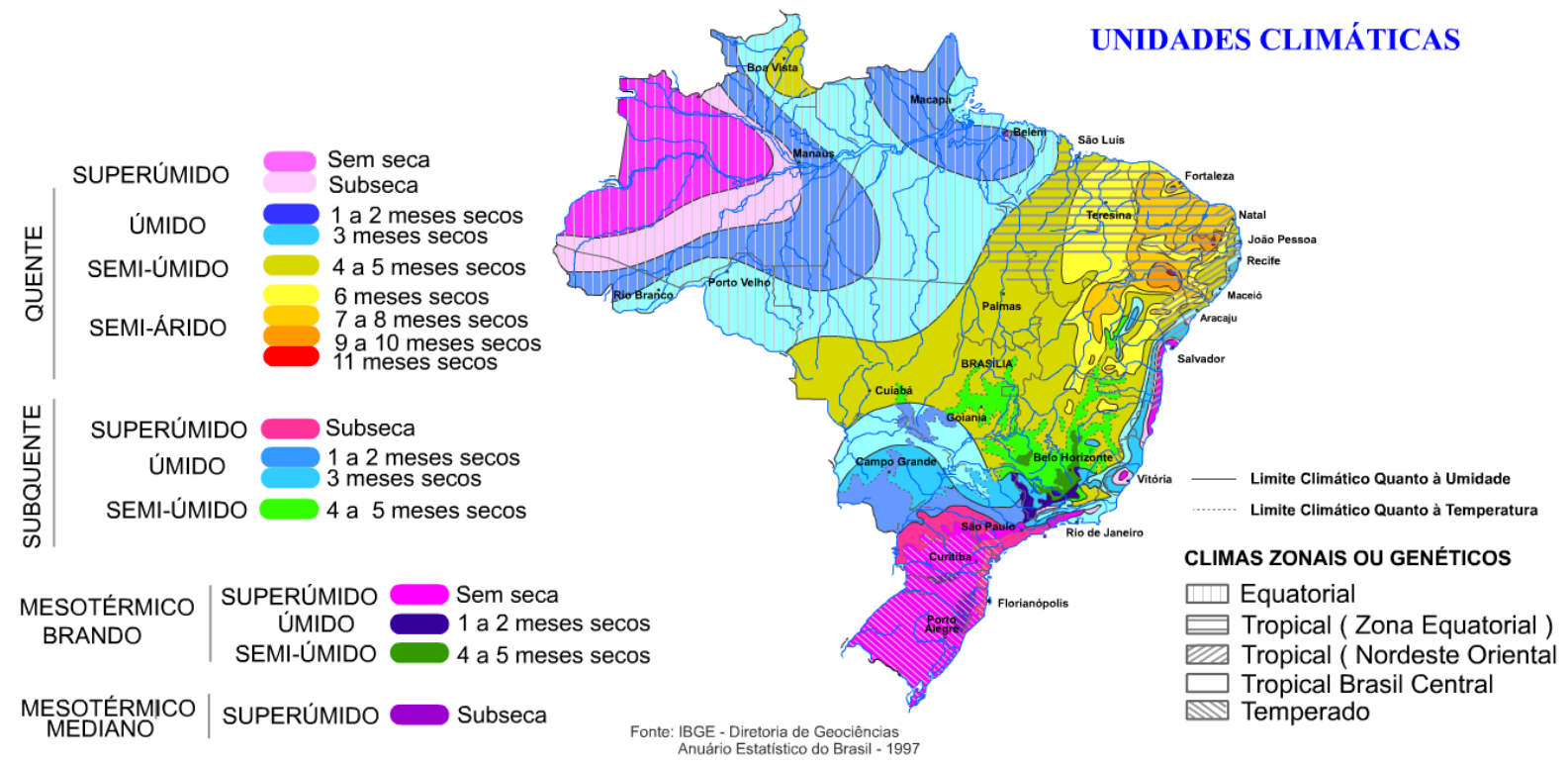

Fonte: IBGE (2015).

Figura 2.46 - Unidades climáticas do Brasil: Climas Zonais (macroclima).

O mesoclima possui uma escala intermediária entre o macro e o microclima. As características da região são fortemente influenciadas pelos fatores climáticos locais (relevo, vegetação, tipo de superfície do solo, tipo de ocupação urbana, entre outros). As subdivisões do macroclima, apresentados na Figura 2.46 com base na temperatura e regime de chuvas tem forte relação com a escala mesoclimática, configuradas pelos aspectos específicos da localização como área litorânea, área agrícola, floresta, área metropolitana, etc. 
O mesoclima pode ser definido como clima local, quando a configuração é dada pelos aspectos específicos da localização. Quando a configuração é definida pelo relevo, o termo usado é topoclima (MENDONÇA; DANNI-OLIVEIRA, 2007).

O microclima é o clima na pequena escala, que se verifica no entorno da edificação em um ponto restrito da escala intra-urbana, e depende dos fatores climáticos locais, tais como topografia, vegetação, revestimento do solo, massa edificada, sombreamento, efeito das edificações no fluxo dos ventos, entre outros (ROMERO, 2000; ROMERO, 2011).

Para os estudos de durabilidade, quando o objetivo é a degradação e a vida útil, o que interessa é o clima e não as condições meteorológicas.

Segundo Lima e Morelli (2005), o microclima é o que rege os processos de degradação. No entanto, são poucos os estudos desenvolvidos que utilizam dados oriundos de medições na superfície do edifício ou em seu entorno.

Em geral, os estudos de degradação utilizam os dados fornecidos pelas estações meteorológicas. Neste caso, a modelagem realizada com este tipo de abordagem leva a modelos pouco precisos, uma vez que esses dados podem ser representativos do macro ou mesoclima e não do microclima (LIMA; MORELLI, 2005).

A Figura 2.47 representa as diferentes escalas climáticas, contextualizando a localização da cidade de Brasília nas diferentes escalas geográficas e sua escala local.

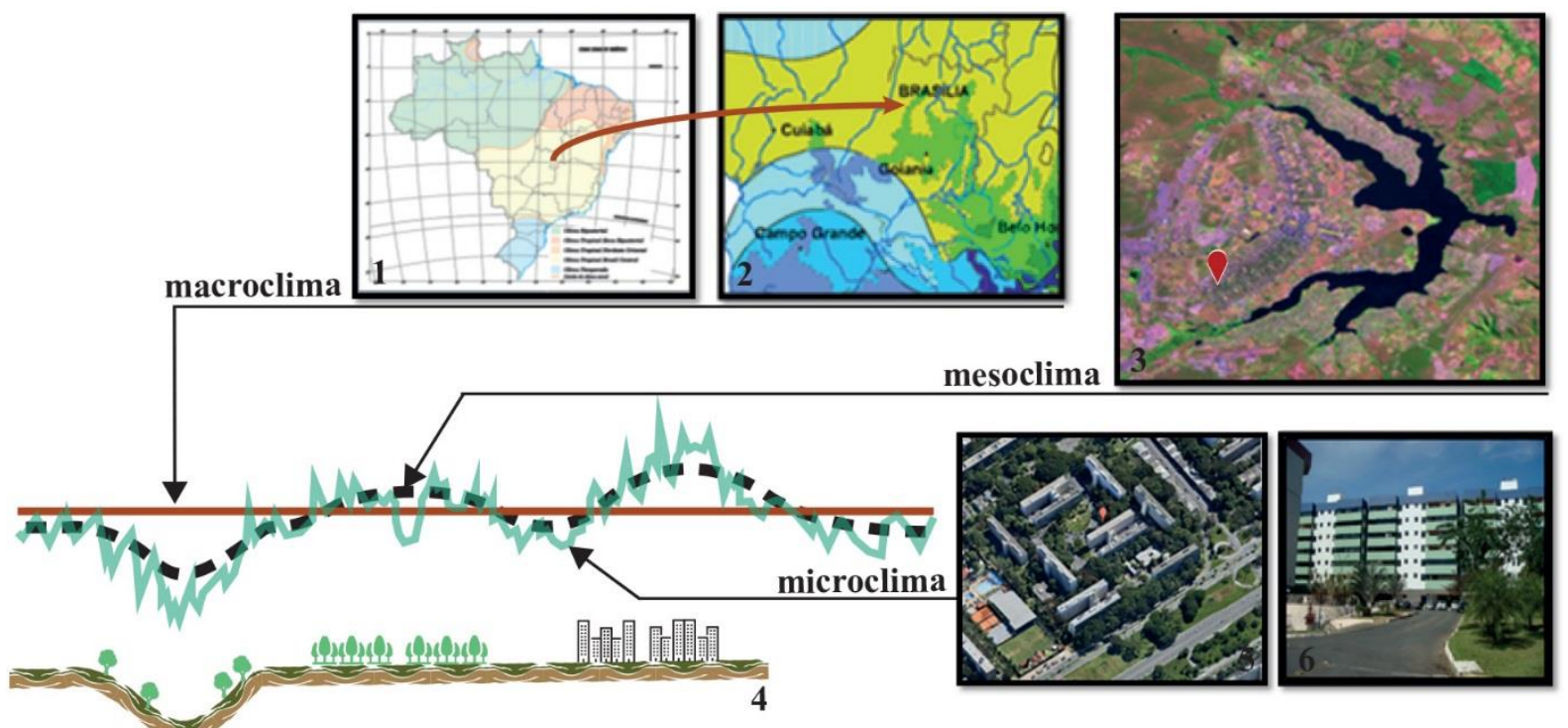

Fonte do gráfico: baseados em DURACRETE (1999) apud Lima; Morelli, Lencioni (2006). Composição das imagens inspirada em HAAGENRUD (2004).

Figura 2.47 - Escalas espaciais do clima no contexto de Brasília - DF. 
No âmbito deste trabalho, pelas premissas expostas e baseado em Haagenrud (2004), a escala adotada para os estudos é a escala do mesoclima, identificada pela sua subdivisão como clima local, considerando o raio de abrangência de monitoramento da estação meteorológica com registro de dados climáticos padronizados.

\subsection{BRASÍLIA E O CLIMA LOCAL}

A cidade de Brasília-DF está localizada na latitude $15,78^{\circ}$ Sul, longitude $47,92^{\circ}$ Oeste e altitude média de $1.160 \mathrm{~m}$.

De acordo com a classificação de Köppen, o clima da cidade de Brasília caracteriza-se como Clima Tropical (A) com inverno seco (W). A cidade possui forte sazonalidade das chuvas, com duas estações bem distintas (ALVARES et al., 2013).

Situada no Planalto Central do Brasil, a cidade de Brasília está localizada em um sítio convexo, aberto a todas as influências dos ventos predominantes (ROMERO, 2000).

As Figuras 2.48-a e 2.48-b mostram, respectivamente, a situação de Brasília para a temperatura média anual e precipitação anual em relação às outras regiões do Brasil.
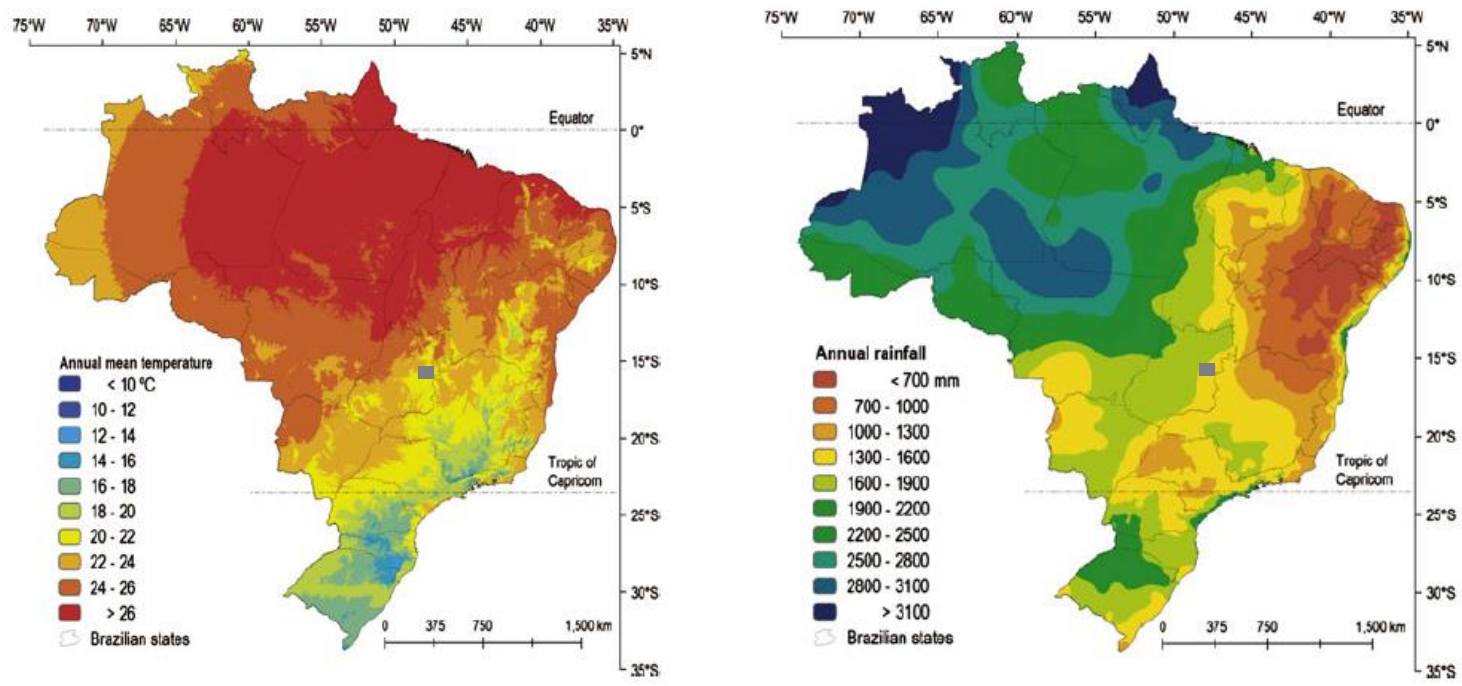

Fonte: Alvares et al. (2013).

Figura 2.48 - Mapa para o Brasil: a) média anual da temperatura do ar $\left({ }^{\circ} \mathrm{C}\right)$; b) total anual da precipitação $(\mathbf{m m})$.

O período chuvoso, sob a influência da Massa Equatorial Continental, compreende a primavera e o verão. A condição de tempo, em geral, apresenta-se nublado, evoluindo à tarde para encoberto com pancadas de chuvas e trovoadas, e ventos de rajadas moderadas a fortes. $\mathrm{O}$ período seco, que se entende pelo outono e inverno, com predomínio da Massa Equatorial 
Atlântica, apresenta boas condições de tempo em todo o Planalto Central, com sucessivos dias de céu claro pela manhã e à noite, nublado à tarde, com forte incidência de névoa seca, especialmente ao final do inverno (SALES; REBELLO; SILVA, 2010; AMORIM; BRAGA, 2004).

De acordo com o arquivo climático da série 2001-2013, com registros de 13 anos de dados horários medidos na estação automática de superfície A001 do INMET, as variáveis climáticas para a cidade de Brasília são apresentadas na Tabela 2.31, resultados que sintetizam as médias mensais e anual calculadas ao longo deste capítulo.

Tabela 2.31 - Médias mensais das variáveis climáticas da série 2001-2013 registradas pela estação automática de superfície A001 do INMET, em Brasília-DF.

\begin{tabular}{cccccccccccccc}
\hline & Jan & Fev & Mar & Abr & Mai & Jun & Jul & Ago & Set & Out & Nov & Dez & Ano \\
\hline \hline TBS & 21,6 & 21,8 & 21,7 & 21,5 & 20,2 & 19,4 & 19,5 & 21,0 & 22,9 & 22,7 & 21,5 & 21,5 & $\mathbf{2 1 , 2}$ \\
Tmax & 22,2 & 22,5 & 22,3 & 22,1 & 20,9 & 20,0 & 20,3 & 21,7 & 23,6 & 23,3 & 22,1 & 22,1 & $\mathbf{2 1 , 9}$ \\
Tmin & 21,0 & 21,2 & 21,1 & 20,9 & 19,6 & 18,7 & 18,8 & 20,3 & 22,2 & 22,0 & 20,9 & 20,9 & $\mathbf{2 0 , 6}$ \\
AT & 8,5 & 9,1 & 9,0 & 9,4 & 10,6 & 11,2 & 12,0 & 12,1 & 11,7 & 10,5 & 8,8 & 8,6 & $\mathbf{1 0 , 1}$ \\
Ig & 5,15 & 5,38 & 5,15 & 5,05 & 4,84 & 4,77 & 5,01 & 5,64 & 5,71 & 5,33 & 4,90 & 5,05 & $\mathbf{5 , 1 7}$ \\
UR & $78 \%$ & $75 \%$ & $77 \%$ & $73 \%$ & $67 \%$ & $63 \%$ & $55 \%$ & $47 \%$ & $48 \%$ & $63 \%$ & $76 \%$ & $77 \%$ & $\mathbf{6 7 \%}$ \\
Precip & 216,0 & 164,2 & 187,9 & 132,0 & 18,5 & 2,1 & 2,4 & 15,2 & 33,8 & 138,7 & 220,8 & 242,2 & $\mathbf{1 . 3 7 3 , 8}$ \\
Nebulos & 8 & 8 & 7 & 6 & 5 & 4 & 3 & 3 & 4 & 7 & 8 & 8 & $\mathbf{6}$ \\
Vento- & 2,42 & 2,26 & 2,23 & 2,25 & 2,34 & 2,47 & 2,66 & 2,95 & 2,82 & 2,43 & 2,30 & 2,32 & $\mathbf{2 , 4 5}$ \\
veloc & & & & & & & & & & & & & L \\
Vento - & NO & $\mathrm{L}$ & $\mathrm{L}$ & $\mathrm{L}$ & $\mathrm{L}$ & $\mathrm{L}$ & $\mathrm{L}$ & $\mathrm{L}$ & $\mathrm{L}$ & $\mathrm{L}$ & $\mathrm{NO}$ & $\mathrm{NO}$ & - \\
dir & & & & & & & & & & & & &
\end{tabular}

Legenda

Variáveis climáticas e unidades de medida da Tabela 2.31

\begin{tabular}{ccc}
\hline TBS & Temperatura de Bulbo Seco $\left({ }^{\circ} \mathrm{C}\right)$ & Média mensal \\
Tmax & Temperatura máxima $\left({ }^{\circ} \mathrm{C}\right)$ & Média mensal \\
Tmin & Temperatura mínima $\left({ }^{\circ} \mathrm{C}\right)$ & Média mensal \\
$\mathbf{A T}$ & Amplitude Térmica $\left({ }^{\circ} \mathrm{C}\right)$ & Média mensal \\
Ig & Irradiância solar global horizontal & Média diária mensal \\
UR & $\left(\mathrm{kWh} / \mathrm{m}^{2}\right.$. dia $)$ & Média mensal \\
Precipitação & Umidade Relativa do ar $(\%)$ & Acumulada mensal \\
Nebulosidade & Precipitação $(\mathrm{mm})$ & Média mensal \\
Vento-veloc & Nebulosidade $($ décimos $)$ & Média mensal \\
Vento-dir & Velocidade do vento $(\mathrm{m} / \mathrm{s})$ & Média mensal \\
\hline
\end{tabular}




\subsection{ANÁLISE E CARACTERIZAÇÃO DAS VARIÁVEIS CLIMÁTICAS DE BRASÍLIA PARA OS ESTUDOS DE DEGRADAÇÃO DE FACHADA}

Nesta seção são sintetizadas as principais análises apresentadas neste capítulo, considerando a série 2001-2013 de dados horários para a cidade de Brasília.

Em geral, os ventos são bem distribuídos em todas as direções, havendo baixa quantidade de horas de calmaria (3\%). No entanto, $50 \%$ dos ventos horários são caracterizados como brisa leve (velocidade entre 1,6 e $3,3 \mathrm{~m} / \mathrm{s}$ ).

Nos meses secos, a velocidade dos ventos é maior, principalmente em agosto. Em janeiro, novembro e dezembro que são os meses mais chuvosos, a direção dos ventos de Noroeste predomina sobre a Leste. Outra direção que aparece em segunda predominância no período chuvoso é a Norte. Os ventos de Leste predominam de fevereiro a outubro.

O regime de chuvas caracteriza bem o ano, em dois períodos: seco e chuvoso. Cerca de $85 \%$ do total acumulado da precipitação anual está concentrada em 6 meses do período chuvoso. Nos meses com maior precipitação, a umidade relativa do ar é mais elevada.

Apesar de a cidade de Brasília caracteriza-se como uma cidade de clima seco devido ao longo período de estiagem durante o ano, cerca de $39 \%$ das horas do ano possuem alta umidade relativa do ar (acima de 75\%UR) e estão mais concentradas no período chuvoso. Por isso, a umidade em fachada é um fator importante a ser investigado nos processos de degradação das edificações. Somente 5\% das horas do ano possuem umidade relativa crítica, igual ou abaixo a $30 \%$ UR e estão mais concentradas em agosto e setembro.

O período chuvoso integra os meses de primavera e verão, cujas temperaturas são mais elevadas que as temperaturas no outono e inverno. Os meses com temperaturas mais baixas são junho e julho. Os meses mais quentes do ano são setembro e outubro, coincidindo com o final do período da longa estiagem, quando começa o início das chuvas. Apesar de as temperaturas serem elevadas em todo o Brasil, por sua característica de país tropical, Brasília apresenta cerca de $1,5 \%$ das horas com temperaturas máximas acima de $30^{\circ} \mathrm{C}$, e menos de $1 \%$ das temperaturas mínimas horárias ocorrem com valores abaixo de $14^{\circ} \mathrm{C}$.

A radiação solar é alta durante todo o ano, com médias diárias mensais acima de $4700 \mathrm{Wh} / \mathrm{m}^{2}$. No período chuvoso, apesar de maior nebulosidade (em média 7,6 décimos), a radiação é alta devido à trajetória do sol mais próxima da Terra. No inverno seco, apesar do Sol estar mais distante da Terra, os dias de céu claro devido à baixa nebulosidade (em média, 4,1 décimos) favorece a radiação solar direta. O Sol é a maior fonte de energia da Terra, portanto afeta as 
temperaturas do ar. Apesar de a radiação solar não ser diretamente o fator determinante da temperatura do ar, observa-se que o comportamento da radiação solar global ao longo do ano, possui forte correspondência com a curva da variação média mensal da temperatura do ar.

Embora a média anual da amplitude térmica do ar ser de $10,1^{\circ} \mathrm{C}$, cerca de $53 \%$ das amplitudes térmicas diárias ocorrem com valores iguais ou acima de $10^{\circ} \mathrm{C}$.

Por isso a cidade de Brasília pode ser considerada uma cidade com altas amplitudes térmicas, distribuídas durante todo o ano, sendo que as máximas amplitudes térmicas ocorrem no período seco, que compreende os meses mais frios. À noite, a temperatura cai, e ao longo do dia, a temperatura se eleva, fazendo cair a umidade relativa do ar. Nesses meses, a velocidade de vento é maior, principalmente os ventos com a direção Leste.

Neste sentido, a cidade de Brasília, pelas características amplamente exploradas neste capítulo, pode ser estudada em dois períodos bem definidos, delineando assim dois cenários característicos, representativos dos períodos seco e chuvoso. No Encarte 1, fixado no final deste capítulo, é apresentado o cenário referente ao clima local de Brasília, caracterizado pela intensidade, frequência e comportamento das principais variáveis climáticas. Essa forma de representação é uma síntese das pesquisas apresentadas neste capítulo. Constituem-se em uma base de referência do clima local da cidade de Brasília, visando à análise de sensibilidade dos resultados dos estudos produzidos para esta tese, por meio das simulações higrotérmicas computacionais com o programa WUFI.

\subsection{CONSIDERAÇÕES FINAIS SOBRE O CAPÍTULO}

Este capítulo abordou os aspectos relacionados às variáveis climáticas e aos arquivos climáticos para a cidade de Brasília. Buscou-se caracterizar as variáveis climáticas como agentes de degradação de origem climática, visando aos estudos de degradação por meio de simulação computacional do comportamento higrotérmico de fachadas.

Para os estudos de degradação, além das médias mensais, é necessário analisar a frequência de ocorrência das variáveis climáticas e a ação temporal simultânea.

A utilização de apenas um dia típico de verão e de inverno, ou um dia de dados máximos, mínimos ou dados extremos, mostrou-se inexpressivo para representar as condições de exposição da edificação, visando aos estudos do envelhecimento natural das edificações, a longo prazo. 
Por outro lado, para os estudos da degradação, a média anual das variáveis climáticas nem sempre é o melhor indicador. Para a cidade de Brasília, ao se fazer a média anual com base nas médias mensais, descaracteriza-se a forte sazonalidade e os picos mensais que existem em algumas variáveis climáticas, por exemplo, a precipitação, a nebulosidade e a umidade relativa. Para os estudos de degradação na cidade de Brasília, a periodicidade bem definida pelos períodos seco (6 meses) e chuvoso (6 meses) pode ser adotada como os ciclos de exposição às condições climáticas que afetam o envelhecimento natural das fachadas. Alerta-se que, para estudos similares em outras localidades, deve-se proceder analises para identificar a caracterização mensal, sazonal, anual, ou outro período de tempo que melhor represente o comportamento dos dados climáticos do local a estudar.

Todos os estudos apresentados neste capítulo tiveram como base de análise o arquivo climático da série 2001-2013, com 13 anos de dados horários registrados pelo INMET na estação automática de superfície A001-Brasília.

Sobre este arquivo de dados horários de Brasília, apesar de estar disponível ao público em geral, não foi encontrada nenhuma publicação com estudos de caracterização de suas variáveis climáticas, com a abrangência que foi desenvolvida neste capítulo. Por isso, foi necessário analisar a frequência de ocorrência, o comportamento e as médias mensais das variáveis à luz das Normais Climatológicas, como fonte referencial para validar as análises e caracterizações da série 2001-2013, aqui apresentadas.

No contexto brasileiro, somente a NBR15575-1 faz referência a dados climáticos para estudos de desempenho. A análise dos parâmetros para dias típicos de projeto apresentados pela NBR15575-1(ABNT, 2013a), à luz da série 2001-2013/INMET, permitiu concluir que os valores estabelecidos pela norma de desempenho são direcionados para as simulações computacionais na área de desempenho termo-energético, mas não são representativos para serem utilizados nos estudos de degradação das edificações. Com exceção do parâmetro amplitude térmica, os outros parâmetros (temperaturas máxima e mínima, radiação solar e nebulosidade) não correspondem aos valores médios obtidos pela série 2001-2013 para a cidade de Brasília.

Para os estudos de degradação de fachadas por meio de programas de simulação computacional, é preciso selecionar, como dado de entrada, um arquivo climático que represente um ano de 8760 horas de dados climáticos característicos do clima local. Essa abordagem é vantajosa, em relação à utilização de apenas um dia típico de verão e de inverno, ou um dia de dados máximos, 
mínimos ou dados extremos, quando se deseja realizar simulações representativas do comportamento cíclico ou sazonal que afetam o envelhecimento natural das edificações, a longo prazo.

Conhecer como o arquivo de dados foi gerado, quais foram as bases de dados que o alimentou e a representatividade desses dados, quando comparados com o contexto climático em estudo, são condições essenciais para a validação dos resultados simulados.

O estudo do arquivo climático da série 2001-2013 para Brasília permitiu obter um conjunto de informações para a caracterização das variáveis climáticas e seus comportamentos cíclicos e sazonais, garantindo assim a base necessária para a análise de sensibilidade dos resultados dos estudos de simulação higrotérmica, inclusive a verificação da representatividade do arquivo climático TMY da base EPW/ANTAC (RORIZ, 2012) para Brasília-DF.

Entre os principais arquivos de ano climático disponíveis para Brasília, as análises das frequências de ocorrência e do comportamento cíclico e sazonal das médias permitiram identificar que o arquivo climático TMY da base EPW/ANTAC (RORIZ, 2012) é a melhor opção para os estudos de degradação higrotérmica por meio de simulações computacionais.

Este capítulo traz uma contribuição pioneira que é a caracterização das variáveis climáticas para Brasília, a partir de uma base de dados horários com 13 anos de dados medidos em estação automática de superfície. No Encarte 1, as principais variáveis climáticas, caracterizadas pela intensidade, frequência de ocorrência e comportamento cíclico e sazonal, são sintetizadas em um cenário referente ao clima local de Brasília. 


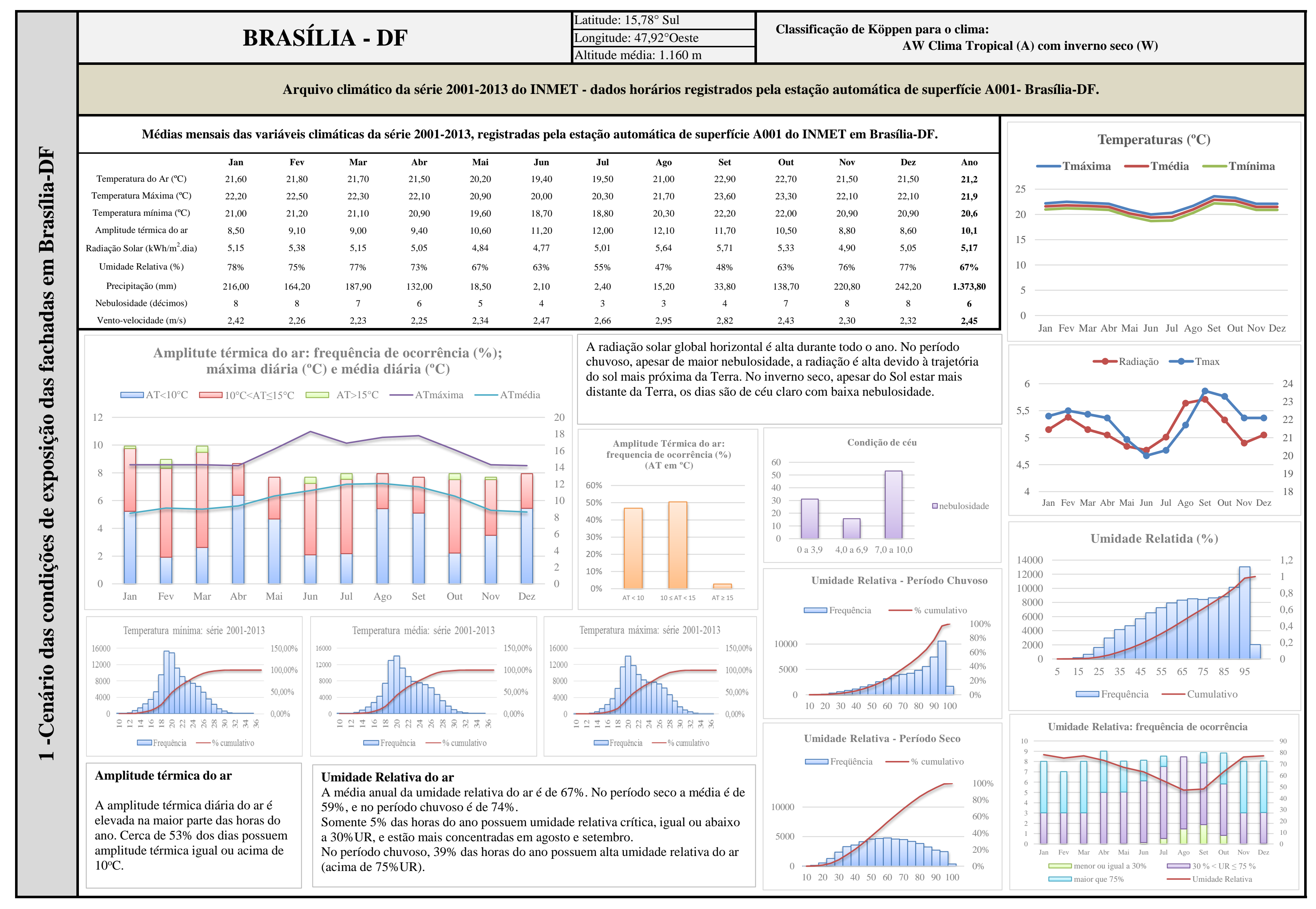




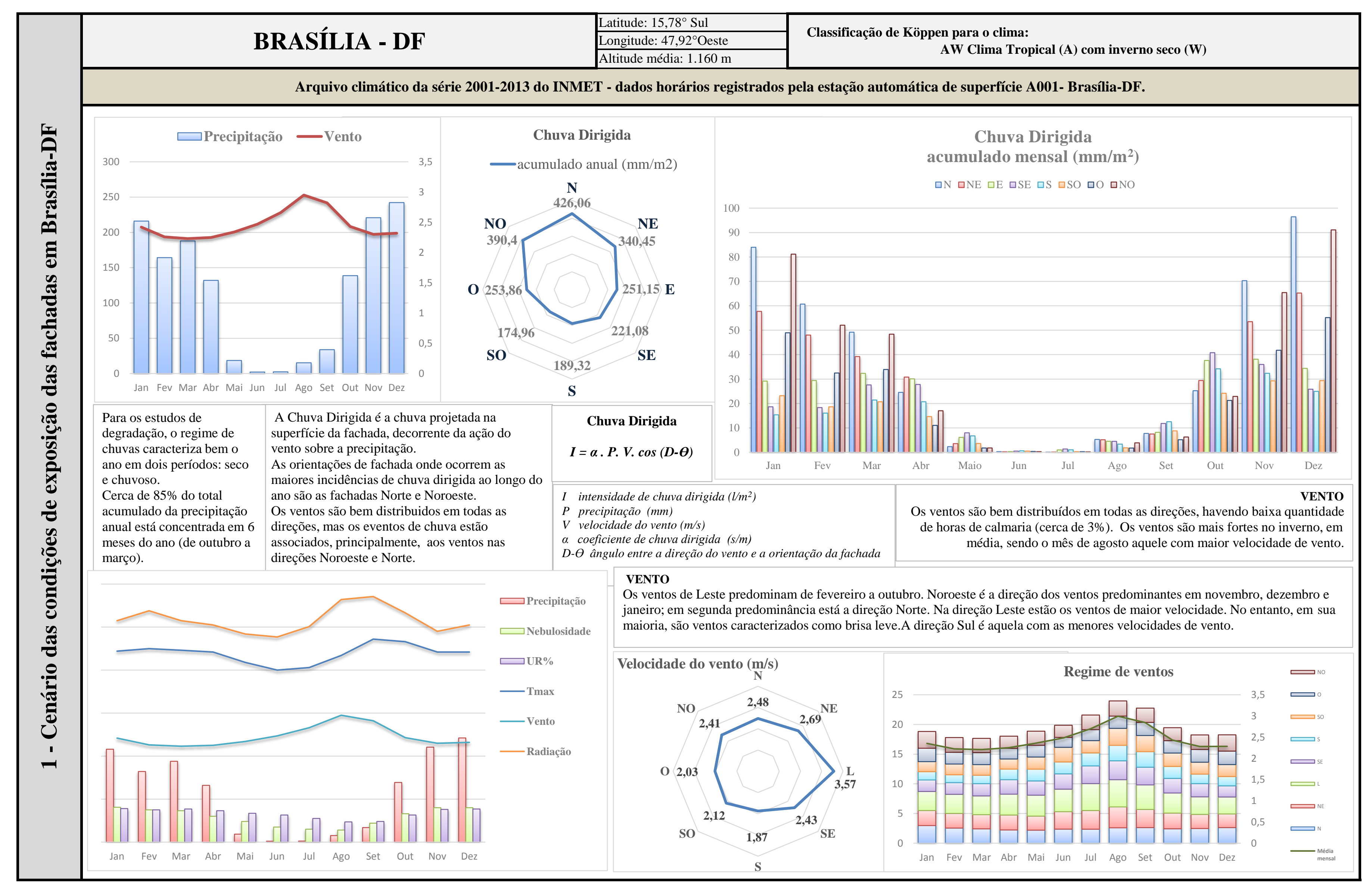




\section{CAPÍTULO III}

\section{ESTUDOS SOBRE CHUVA DIRIGIDA}

\subsection{CONSIDERAÇÕES INICIAIS}

Neste capítulo são abordados os principais conceitos e métodos semi-empíricos de quantificação de chuva dirigida, assim como os resultados obtidos nos estudos analíticos aplicados ao contexto da cidade de Brasília-DF.

Além disso, é apresentado o programa experimental de medição de chuva dirigida in situ, realizado em Brasília, que permitiu determinar coeficientes de chuva dirigida para embasar as análises comparativas e a seleção de um método semi-empírico representativo para a quantificação de chuva dirigida em fachadas, no contexto urbano estudado.

Durante estes estudos, não foi encontrada nenhuma referência sobre medições de chuva dirigida realizadas em fachadas brasileiras, portanto os resultados obtidos e a metodologia adotada são importantes contribuições pioneiras deste trabalho de tese.

\subsection{CHUVA DIRIGIDA}

Chuva dirigida (driving rain ou wind-driven rain - WDR) é a chuva projetada na superfície da fachada, decorrente da ação do vento sobre a precipitação. Sem o vento, a chuva cairia verticalmente e pouco molharia as paredes (BAUER, 1987; PEREZ, 1988).

Os estudos de chuva dirigida são compostos por duas partes: (1) avaliação da chuva dirigida incidente na fachada (instante antes do impacto das gotas de chuva sobre a superfície vertical); (2) avaliação da resposta do edifício para a chuva dirigida (após o impacto das gotas de chuva) (BLOCKEN; DEROME; CARMELIET, 2013).

A primeira parte dos estudos compreende o movimento e distribuição das gotas de chuva que caem das nuvens e são levadas pelo vento até colidir com a fachada do edifício. A intensidade da chuva dirigida é governada por uma ampla gama de parâmetros: geometria urbana, geometria e altura do edifício, detalhamento da fachada do edifício, tamanho, distribuição e velocidade das gotas de chuva, além de todos os parâmetros meteorológicos relevantes, tais como a intensidade da precipitação e a velocidade e direção do vento. A interação destes parâmetros produz distintos padrões de chuva dirigida nas fachadas. 
A segunda parte dos estudos de chuva dirigida consiste na investigação dos processos físicos que ocorrem na microescala, durante e após o impacto da chuva dirigida sobre a fachada do edifício. Inclui-se os fenômenos que ocorrem na superfície, tais como respingo, ressalto, adesão, espalhamento, formação de filme, escoamento, evaporação, absorção das gotas de chuva e distribuição da umidade na parede. Estes processos também são regulados por todos os parâmetros que influenciam a intensidade da chuva dirigida na fachada, mas também por parâmetros adicionais, tais como as propriedades e características do material da superfície, incluindo permeabilidade, porosidade, rugosidade, tensão superficial e sujidade da superfície. Na escala de uma gota de chuva, também são parâmetros importantes o diâmetro, a velocidade e o ângulo de impacto de cada gota, individualmente. A ampla gama dos parâmetros que influenciam o fenômeno indica a complexidade dos processos físicos das águas de chuva nas fachadas dos edifícios.

Para avaliar a chuva dirigida incidente nas paredes da fachada (instante antes do impacto das gotas de chuva), os estudos de intensidade de chuva dirigida são realizados a partir de três métodos: (1) métodos experimentais (medições in situ ou em laboratório), (2) métodos semiempíricos e (3) métodos numéricos - simulações numéricas baseadas em Dinâmica dos Fluidos Computacional (Computational Fluid Dynamics - CFD) (BLOCKEN; CARMELIET, 2010). O termo semi-empírico refere-se aos métodos que usam equações de cálculo embasadas teoricamente na física das construções e com uso de coeficientes que são determinados a partir de medições experimentais in situ.

Para Blocken e Carmeliet (2010), atualmente os três métodos mais utilizados e que estão mais avançados são o método semi-empírico da norma ISO 15927-3 (BS, 2009), o método semiempírico SB-Straube e Burnett (STRAUBE, 2010) e os métodos de simulações numéricas baseadas em Dinâmica dos Fluidos Computacional. Os autores consideram que os métodos experimentais que se utilizam de medições são demorados, caros e propensos ao erro. Além disso, as medições feitas nas fachadas de um prédio em particular têm aplicabilidade limitada para outras fachadas de outros prédios, em outros locais. Esta consciência tem levado pesquisadores a desenvolver métodos de cálculo que foram progressivamente melhorados, ao longo dos anos.

Freitas (2011) realizou um estudo comparativo entre diversos métodos semi-empíricos disponíveis para quantificar os montantes de chuva dirigida em edificações. Entre os mais conhecidos e utilizados, foram comparados os seguintes métodos: Lacy (1965); Henriques 
(1992); SB-Straube e Burnett (1997); WUFI (2013); ASHRAE 160 (2009); ISO 15927-3 (BS, 2009), entre outros.

Após avaliar esses métodos, Freitas (2011) concluiu que, entre outros, a aplicação das diferentes equações semi-empíricas conduz a diferentes quantidades de chuva dirigida. Alguns métodos avaliam as condições de exposição do edifício em campo aberto, outros métodos consideram o edifício inserido no contexto urbano. O método proposto pela ISO 15927-3 (BS, 2009) é aquele que leva em conta o maior número de fatores relacionados às características do edifício, em contrapartida, é o método que resulta nos menores valores de chuva dirigida incidente na fachada. O método da ASHRAE 160 (ANSI/ASHRAE, 2009) é o método que resulta na maior quantidade de chuva incidente na superfície da fachada. Ainda, segundo a autora, nos métodos semi-empíricos, a qualidade dos dados climáticos desempenha um papel de especial importância na quantificação da chuva dirigida.

\section{3. ÍNDICE DE CHUVA DIRIGIDA (ICD)}

O conceito de chuva dirigida foi apresentado e consolidado, durante os anos 60, pelo CIB (International Council for Research and Innovation in Building and Construction). Esse conceito foi baseado nas pesquisas de Lacy $^{1}$ (1962) que fundamentou o seu trabalho no primeiro mapeamento de chuva dirigida elaborado por Hoppestad ${ }^{2}$ em 1955 para a Noruega. Baseado em uma relação entre o vento e a precipitação, o mapeamento da chuva incidente nos edifícios tinha como objetivo tipificar soluções construtivas para paredes face à severidade da zona climática em que os edifícios iam ser construídos (BAUER, 1987; PEREZ, 1988; FREITAS, 2011; KRPAN, 2013).

Lacy propôs o conceito do Índice de Chuva Dirigida (ICD ou DRI - Driving Rain Index) como sendo o produto da precipitação pela velocidade do vento incidente nas edificações, expressos por médias anuais conforme apresentado pela Equação 3.1.

$$
I C D=V \cdot \frac{P}{1000}
$$

Onde,

\footnotetext{
${ }^{1}$ LACY, R. An index of exposure to driving rain. Garston: Building Research Station, Digest No. 23, 1962. ${ }^{2}$ HOPPESTAD, S. Slagregn i Norge (in Norwegian). Norwegian Building Research Institute, rapport Nr. 13, Oslo; 1955.
} 
ICD Índice de chuva dirigida $\left(\mathrm{m}^{2} / \mathrm{s}\right)$;

$V \quad$ Velocidade média do vento (m/s, medida a $10 \mathrm{~m}$ de altura);

$P \quad$ Precipitação anual (mm).

Em relação ao nível de exposição à chuva dirigida, Lacy (1972) propôs três faixas de classificação: Protegido para ICD $\leq 3$; Moderado para $3<\mathrm{ICD} \leq 7$ e Severo para ICD > 7. A classificação dada por Lacy não considerou nenhum aspecto do entorno próximo à edificação ou da própria edificação.

Chand e Bhargava (2002) ampliaram a classificação para cinco faixas de exposição. Marsh (1977) propôs correções para os valores apresentados por Lacy ${ }^{1}$ (1972) e Chand e Bhargava ${ }^{2}$ (2002), em função da proximidade das regiões costeiras. Marsh ${ }^{3}$ (1977) propôs que as áreas distantes até $8 \mathrm{~km}$ do mar ou grandes estuários, com ICD calculado menor que $3 \mathrm{~m} / \mathrm{s}$, devem ser consideradas como exposição moderada. As áreas distantes até $8 \mathrm{~km}$ do mar ou grandes estuários, com ICD maior que $5 \mathrm{~m}^{2} / \mathrm{s}$ e menor ou igual a $7 \mathrm{~m}^{2} / \mathrm{s}$, devem ser classificadas como área de exposição uma faixa acima daquela obtida (SILVA; GIRALT, 1995; LIMA; MORELLI, 2005; GIONGO, 2007).

Quadro 3.1 - Nível de exposição à chuva dirigida.

\begin{tabular}{|c|c|c|c|}
\hline $\begin{array}{c}\text { Índice de Chuva } \\
\text { Dirigida }\left(\mathbf{m}^{2} / \mathbf{s}\right)\end{array}$ & $\begin{array}{c}\text { Chand e } \\
\text { Bhargava }^{2}\end{array}$ & $\begin{array}{c}\text { Lacy }^{1} \text { com } \\
\text { recomendação }\end{array}$ & $\begin{array}{l}\text { Chand e Bhargava } \\
\text { com recomendação }\end{array}$ \\
\hline $\mathrm{ICD} \leq 3$ & Protegido & Moderado & Moderado \\
\hline $3<\mathrm{ICD} \leq 5$ & Moderado & Moderado & Moderado \\
\hline $5<\mathrm{ICD} \leq 7$ & Moderado & Severo & Alto \\
\hline $7<\mathrm{ICD} \leq 11$ & Alto & Severo & Severo \\
\hline $\mathrm{ICD}>11$ & Severo & Severo & Severo \\
\hline
\end{tabular}

Fonte: ${ }^{1}$ Lacy (1972); ${ }^{2}$ Chand e Bhargava (2002); ${ }^{3}$ Marsh (1977) apud Giongo et al. (2007).

O ICD é um índice indicativo das condições de exposição do edifício, considerando uma situação em campo aberto, onde o vento não sofre nenhuma perturbação em sua linha de fluxo. Neste caso, para aplicar a Equação 3.1, são utilizados valores médios anuais de precipitação e de direção e velocidade do vento.

O ICD como um valor anual, calculado pelas médias anuais de precipitação e vento, pode mascarar o comportamento sazonal dos agentes climáticos envolvidos no fenômeno e o nível de exposição da envoltória da edificação de acordo com a sua orientação. Por isso, alguns autores calculam o ICD a partir de valores mensais de precipitação e vento, inclusive considerando índices para cada direção de vento (índice direcional). Como resultado, obtém-se índices de chuva dirigida direcional, para cada mês do ano (GIONGO, 2007; ESTRELA, 2010). 
Os índices mensais direcionais de chuva dirigida facilitam a análise da influência das condições de exposição à chuva dirigida, para cada orientação de fachada, além de permitir avaliar em quais períodos do ano os níveis de exposição indicam maior agressividade para a envoltória dos edifícios. Por isso, conforme propuseram Hoppestad e Lacy, o ICD pode ser utilizado como critério de avaliação do nível de exposição das edificações ao meio no qual estão inseridas, inclusive como uma forma de comparação das condições de exposição de edificações de diferentes lugares.

Segundo Krpan (2013), Lacy reconheceu que os índices de chuva dirigida (ICD) não eram uma indicação direta da quantidade de chuva que realmente era projetada na parede de um edifício, devido às perturbações no fluxo de ar influenciadas pelos edifícios. Para Lacy, as condições médias anuais assumidas no cálculo do índice de chuva dirigida não representavam efetivamente as condições mais severas das chuvas. Ele concluiu, no entanto, que a elaboração de mapas de chuva, com base nos índices eram válidos, podendo ser usado por projetistas, arquitetos e pesquisadores como uma indicação da gravidade da exposição para um determinado local de construção. O conceito do índice de chuva dirigida de Lacy tornou-se a base para os métodos analíticos (semi-empíricos) de quantificação de chuva dirigida.

\subsection{MÉTODOS DE QUANTIFICAÇÃO DE CHUVA DIRIGIDA}

A partir do Índice de Chuva Dirigida (ICD), Lacy $^{3}$ (1965) estendeu sua abordagem para estabelecer relações teóricas entre a intensidade da chuva projetada na superfície vertical $(R v)$ e a intensidade da precipitação caindo em superfície horizontal $(R h)$, assumindo gotas de diâmetro médio, distribuição uniforme e velocidade terminal de $4,5 \mathrm{~m} / \mathrm{s}$, o que corresponde a um diâmetro de gota de chuva de 1,2 $\mathrm{mm}$ (adequadas para chuvas de intensidade média) (BLOCKEN; CARMELIET, 2004). A expressão de cálculo resultante é demonstrada na Equação 3.2.

$$
R_{v}=R_{h} \cdot \frac{U}{v t}=R_{h} \cdot \frac{U}{4,505 \cdot R_{h}^{0,123}}=0,222 \cdot \mathrm{U} \cdot R_{h}^{0,88} \approx 0,222 \cdot \mathrm{U} \cdot R_{h}
$$

Onde,

$R_{v} \quad$ Intensidade de chuva dirigida $\left(\mathrm{mm} / \mathrm{h}\right.$ ou $\left.1 / \mathrm{h} . \mathrm{m}^{2}\right)$;

$R_{h} \quad$ Intensidade da precipitação em superfície horizontal (mm/h ou 1/h.m²);

$U \quad$ Velocidade do vento $(\mathrm{m} / \mathrm{s})$;

$v t \quad$ Velocidade terminal da gota de chuva $(\mathrm{m} / \mathrm{s})$.

${ }^{3}$ LACY, R. Driving-rain maps and the onslaught of rain on buildings. Building Research Station. Garston, England: Department of Scientific and Industrial Research, 1965. 
A expressão de cálculo proposta por Lacy (Equação 3.2) considera a intensidade de chuva dirigida em uma situação de campo aberto. O coeficiente de proporcionalidade de Lacy $(k=$ 0,222 s/m) é denominado por Blocken e Carmeliet (2004) como coeficiente de chuva dirigida em campo aberto (free driving rain coefficient).

A Equação 3.2 assume que a direção do vento é sempre perpendicular à superfície vertical. Observa-se que a expressão final foi simplificada, desconsiderando o expoente. Segundo, Blocken e Carmeliet (2004), o expoente 0,88, em boa aproximação, pode ser omitido.

Em geral, para a quantificação da intensidade de chuva incidente na superfície vertical, considerando a associação da chuva para cada velocidade e direção de vento passível de atingir a fachada, inclusive levando em consideração as condições locais e do próprio edifício, a expressão da intensidade de chuva dirigida (Equação 3.2) passou a ser representada pela Equação 3.3.

Segundo Blocken at al. (2011), o valor do coeficiente de chuva dirigida $\alpha$ é o que distingue os diferentes métodos de quantificação. Dependendo das condições de exposição do edifício, o coeficiente $\alpha$ da Equação 3.3 pode adquirir diferentes expressões, conforme o método adotado para o cálculo.

$$
R_{w d r}=\propto \cdot V \cdot P \cdot \cos (D-\theta)
$$

Onde,

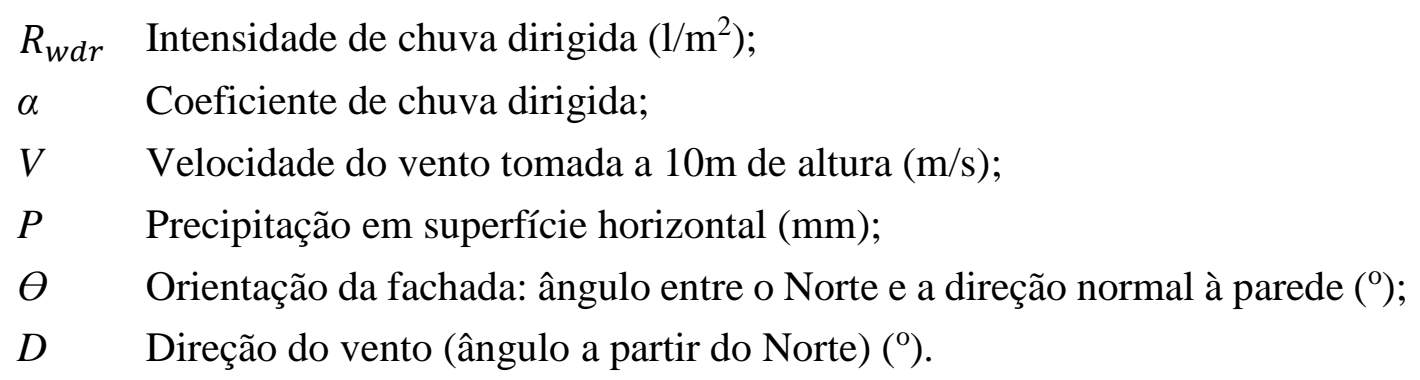

Entre os métodos semi-empíricos que levam em consideração o contexto em que o edifício está localizado, assim como suas características, destacam-se os métodos padronizados pelas normas internacionais ISO 15927-3 e ANSI/ASHRAE STANDARD 160, e o método adotado pelo programa computacional WUFI Pro 5.

O método padronizado pela ISO 15927-3 (BS, 2009) é um método originado da BS 8104:1992 - Code of practice for assessing exposure of walls to wind driven rain. Inclusive, esse método é recomendado pela ISO 15686-7 Buildings and constructed assets - Service life planning Part 7: Performance evaluation for feedback of service life data from practice (BS, 2006) para 
a avaliação das condições do clima local e do microclima, e para expressar a provável quantidade de água que impacta a parede em uma determinada orientação.

O programa de simulação higrotérmica WUFI (2013) apresenta duas opções de métodos de quantificação da chuva dirigida. São eles, o método desenvolvido e validado pelo Instituto Fraunhofer, e o método da ANSI/ASHRAE STANDARD 160:2009 - Criteria for moisturecontrol design analysis in buildings.

Pelas considerações e justificativas expostas, os três métodos semi-empíricos citados acima foram escolhidos para serem analisados e aplicados aos estudos realizados para o contexto urbano da cidade de Brasília-DF.

\subsubsection{Método da ISO 15927-3}

A ISO 15927-3 Hygrothermal performance of buildings - Calculation and presentation of climatic data - Part 3: Calculation of a driving rain index for vertical surfaces from hourly wind and rain data. (BS, 2009) permite calcular a provável quantidade de água de chuva incidente em uma fachada em uma dada orientação e considera os dados climáticos horários de precipitação e vento (velocidade e direção) de um determinado período de tempo, onde o vento sopra na direção da fachada.

A Equação 3.4 apresentada pela norma ISO 15927-3 estabelece a intensidade de chuva dirigida em um determinado período de tempo em campo aberto para uma determinada orientação de fachada $(\theta)$, considerando todos os eventos horários de precipitação e vento que sopra em direção $(D)$ à fachada. A Equação 3.5 leva em consideração a intensidade de chuva dirigida na fachada sujeita às condições de exposição da edificação (topografia, rugosidade, obstruções e tipologia da fachada).

$$
\begin{gathered}
I_{\mathrm{S}=} \frac{2}{9} \sum V P^{8 / 9} \cos (D-\theta) \\
I_{W S}=I_{S} C_{R} C_{T} O \mathrm{~W}
\end{gathered}
$$

Onde,

$I_{S} \quad$ Intensidade de chuva dirigida em uma determinada orientação de fachada $(\theta)$, em um determinado período em campo aberto $\left(1 / \mathrm{m}^{2}\right)$;

$I_{w s} \quad$ Intensidade de chuva dirigida em uma determinada orientação de fachada $(\theta)$, em um determinado período e contexto urbano $\left(1 / \mathrm{m}^{2}\right)$;

$V \quad$ Média horária da velocidade do vento $(\mathrm{m} / \mathrm{s})$, a dez metros de altura;

$P \quad$ Precipitação acumulada horária em superfície horizontal $(\mathrm{mm})$;

$\theta \quad$ Orientação da fachada: ângulo entre o Norte e a direção normal à parede;

$D \quad$ Direção do vento (ângulo a partir do Norte);

$\mathrm{Cr}$ Coeficiente de rugosidade; 
$C_{T} \quad$ Coeficiente de topografia;

$O \quad$ Fator de obstrução;

$W \quad$ Fator da fachada.

O parâmetro $C r$ considera a variação da velocidade média do vento devido à altura acima do solo e a rugosidade do terreno na direção em que sopra o vento; depende da categoria do terreno (Quadro 3.2) e é calculado a partir da Equação 3.6 ou Equação 3.7.

$$
\begin{gathered}
C_{r}(z)=K_{R} \cdot l_{n\left(\frac{z}{z_{0}}\right)}, z \geq z_{\text {min }} \\
C_{r}(z)=C_{r}\left(z_{\text {min }}\right), \quad z<z_{\text {min }}
\end{gathered}
$$

Onde,
Z Altura acima do solo (m);
$K_{R} \quad$ Fator do terreno;
$Z_{0} \quad$ Comprimento da rugosidade aerodinâmica $(\mathrm{m})$;
$Z_{\text {min }} \quad$ Altura mínima $(\mathrm{m})$.

\begin{tabular}{|c|c|c|c|c|}
\hline $\begin{array}{l}\text { Categoria do } \\
\text { terreno }\end{array}$ & Descrição & $\mathbf{K}_{\mathbf{R}}$ & $\mathbf{z}_{\mathbf{o}}$ & $\mathbf{z}_{\min }$ \\
\hline I & $\begin{array}{l}\text { Frente de mar; margens de lagos com pelo menos } 5 \mathrm{~km} \text { de água e } \\
\text { campo plano sem obstáculos }\end{array}$ & 0,17 & 0,01 & 2 \\
\hline II & $\begin{array}{l}\text { Terrenos agrícolas com sebes/vedações com estruturas agrícolas, casas } \\
\text { e árvores ocasionais }\end{array}$ & 0,19 & 0,05 & 4 \\
\hline III & Áreas suburbanas ou industriais e florestas & 0,22 & 0,3 & 8 \\
\hline IV & $\begin{array}{l}\text { Áreas urbanas em que pelo menos } 15 \% \text { da superfície tem edifícios com } \\
\text { uma altura superior a } 15 \mathrm{~m}\end{array}$ & 0,24 & 1 & 16 \\
\hline
\end{tabular}

Quadro 3.2 - Categorias do terreno e parâmetros para cálculo de $C r$.

Se existir uma variação da rugosidade do terreno a menos de $1 \mathrm{~km}$ do local em análise, deve ser considerada a categoria de terreno menos rugosa que fornece um valor de $\mathrm{Cr}$ maior.

Fonte: ISO 15927-3 (BS, 2009).

$\mathrm{O}$ fator $C_{T}$ considera o aumento da velocidade média do vento em colinas isoladas e escarpas.

Deve ser considerado para locais que estejam a mais de meia altura de uma colina ou para locais que estejam situados até 1,5 vezes a altura de uma escarpa a partir da base da mesma. $\mathrm{O}$ valor de $C_{T}$ é calculado através das Equações 3.8, 3.9 ou 3.10.

$$
\begin{array}{ll}
C_{T}=1 & \text { para } \theta<0,05 \\
C_{T}=1+2 S \theta & \text { para } 0,05 \leq \theta \leq 0,3 \\
C_{T}=1+0,6 S & \text { para } \theta>0,3
\end{array}
$$

Onde,

$S \quad$ É o fator obtido a partir dos escalonamentos das curvas de níveis (variando de 0 a 1) para o comprimento da declividade a montante, $\mathrm{L}_{\mathrm{u}}$, ou da declividade a jusante, $\mathrm{L}_{\mathrm{d}}$;

$\theta \quad$ É a declividade a montante, $\mathrm{H} / \mathrm{L}_{\mathrm{u}}$, na direção do vento, conforme Quadro 3.3 
Quadro 3.3 - Comprimento efetivo, $L_{e}$.

\begin{tabular}{|c|c|}
\hline \multicolumn{2}{|c|}{ Declive a montante do vento $\theta=\mathrm{H} / \mathrm{L}_{\mathrm{u}}$} \\
\hline \hline Raso $(0,05 \leq \theta \leq 0,3)$ & Íngreme $(\theta>0,3)$ \\
$\mathrm{L}_{\mathrm{e}}=\mathrm{L}_{\mathrm{u}}$ & $\mathrm{L}_{\mathrm{e}}=\mathrm{H} / 0,3$ \\
\hline
\end{tabular}

Fonte: ISO 15927-3 (BS, 2009).

Onde,

$\mathrm{L}_{\mathrm{u}}$ Comprimento real do declive a montante, na direção do vento;

$\mathrm{L}_{\mathrm{d}}$ Comprimento real do declive a jusante do vento;

Le Comprimento efetivo do declive a montante do vento definido no Quadro 3.4;

H Altura efetiva da elevação;

x Distância horizontal a partir do local até o topo da crista;

z Distância vertical a partir do local até o topo da crista.

O fator $W$ é uma forma de considerar o tipo de fachada (altura e características) e a variação da chuva dirigida ao longo da fachada devido ao fluxo de ar nos pontos singulares. Este fator deve ser obtido para cada posição na fachada, por meio do Quadro 3.4.

Quadro 3.4 - Fator W.

\begin{tabular}{|c|c|c|c|}
\hline DESCRIÇÃO & VALOR MÉDIO & \multicolumn{2}{|c|}{ DISTRIBUIÇÃO } \\
\hline $\begin{array}{l}2 \text { pisos } \\
\text { Fachada exposta: cobertura com inclinação } \geq 20^{0} \text {, } \\
\text { sem beiral }\end{array}$ & 0,4 & Topo & $\begin{array}{l}0,5 \\
0,4 \\
0,3 \\
0,2\end{array}$ \\
\hline $\begin{array}{l}2 \text { pisos } \\
\text { Fachada protegida: cobertura com inclinação } \geq 20^{\circ}, \\
\text { com beiral }\end{array}$ & 0,3 & Bopo & $\begin{array}{l}0,3 \\
0,3 \\
0,3\end{array}$ \\
\hline $\begin{array}{l}2 \text { pisos } \\
\text { Cobertura em terraço ou com inclinação }<20^{\circ}\end{array}$ & 0,4 & Base & $\begin{array}{l}0,5 \\
0,4 \\
0,2\end{array}$ \\
\hline $\begin{array}{l}3 \text { pisos } \\
\text { Fachada exposta: cobertura com inclinação } \geq 20^{\circ} \text {, } \\
\text { sem beiral }\end{array}$ & 0,3 & $\overbrace{\text { Base }}^{\text {Topo }}$ & $\begin{array}{l}0,5 \\
0,4 \\
0,3 \\
0,3 \\
0,2\end{array}$ \\
\hline $\begin{array}{l}3 \text { pisos } \\
\text { Fachada protegida: cobertura com inclinação } \geq 20^{\circ} \text {, } \\
\text { com beiral }\end{array}$ & 0,4 & Bopo & $\begin{array}{l}0,4 \\
0,4 \\
0,4 \\
\end{array}$ \\
\hline $\begin{array}{l}\text { Superior a } 3 \text { pisos } \\
\text { Cobertura em terraço ou com inclinação }<20^{\circ}\end{array}$ & 0,2 & $\begin{array}{r}0,5 \text { para } \\
\text { supe } \\
0,2 \text { para } \\
\text { supe }\end{array}$ & $\begin{array}{l}5 \mathrm{~m} \\
\mathrm{mais}\end{array}$ \\
\hline
\end{tabular}

Fonte: adaptada de ISO 15927-3 (BS, 2009). 
O fator $O$ considera a proteção da fachada pelo obstáculo mais próximo, que pode ser um edifício, vedações ou árvores. Seu valor é determinado pelo cálculo da distância horizontal ao obstáculo mais próximo que deve ter, no mínimo, a altura da fachada em análise (Quadro 3.5).

Quadro 3.5 - Valores do Fator de Obstrução $O$.

\begin{tabular}{|cc|}
\hline Distância da parede à obstrução $(\mathbf{m})$ & Fator de obstrução $\boldsymbol{O}(*)$ \\
\hline \hline de 4 até 8 & 0,2 \\
acima de 8 até 15 & 0,3 \\
acima de 15 até 25 & 0,4 \\
acima de 25 até 40 & 0,5 \\
acima de 40 até 60 & 0,6 \\
acima de 60 até 80 & 0,7 \\
acima de 80 até 100 & 0,8 \\
acima de 100 até 120 & 0,9 \\
acima de 120 & 1,0 \\
\hline (*) Se existir a possibilidade de ocorrência de vento convergente na direção da parede, 0 \\
fator de obstrução deve ser considerado igual a 1,0 independentemente de existirem \\
obstruções.
\end{tabular}

Fonte: ISO 15927-3 (BS, 2009).

\subsubsection{Método da ANSI/ASHRAE Standard 160}

A ANSI/ASHRAE Standard 160:2009 - Criteria for moisture-control design analysis in buildings trata dos critérios de projeto para controle da umidade em edifícios. A norma apresenta um método para determinar a intensidade de chuva dirigida incidente na fachada.

Para calcular a carga de chuva que atinge uma superfície vertical é dada a Equação 3.11.

$$
R_{b v}=F e \cdot F d \cdot F c \cdot V \cdot \cos (D-\theta) \cdot R h
$$

Onde,

$R b v$ Deposição da chuva no plano vertical da parede, $\mathrm{mm} / \mathrm{m}^{2} \cdot \mathrm{h}$;

$R h \quad$ Intensidade da precipitação, plano horizontal, $\mathrm{mm} / \mathrm{h}$;

$V \quad$ Média horária da velocidade do vento a $10 \mathrm{~m}$ de altura, $\mathrm{m} / \mathrm{s}$;

$\theta \quad$ Ângulo entre a direção do vento e a normal à parede;

Fe Fator de exposição à chuva;

Fd Fator de deposição da chuva;

Fc Constante empírica: $0,2 \mathrm{~s} / \mathrm{m}$.

$\mathrm{O}$ fator de exposição $\mathrm{Fe}$ é influenciado pela topografia, isto é, depende das características do terreno ao redor do edifício e da altura do edifício (Quadro 3.6). Para o fator de deposição $F d$ podem ser usados os valores do Quadro 3.7. 
Quadro 3.6 - Valores do fator de exposição $F e$.

\begin{tabular}{|cccc|}
\hline \multirow{2}{*}{ Altura do edifício $(\mathbf{m})$} & \multicolumn{3}{c|}{ Tipo de terreno } \\
\cline { 2 - 4 } & Exposição Severa & Exposição Média & Exposição Protegida \\
\hline \hline 10 & 1,3 & 1,0 & 0,7 \\
$10-15$ & 1,3 & 1,1 & 0,8 \\
$15-20$ & 1,4 & 1,2 & 0,9 \\
$20-30$ & 1,5 & 1,3 & 1,1 \\
$30-40$ & 1,5 & 1,4 & 1,2 \\
$40-50$ & 1,5 & 1,5 & 1,3 \\
$>50$ & 1,5 & 1,5 & 1,5 \\
\hline Terrenos classificados como exposição severa incluem topo de colinas, áreas costeiras e regiões de vento canalizado. A \\
exposição protegida inclui proteções de árvores, proximidade de edificaçôes ou regiões de vale.
\end{tabular}

Fonte: ANSI/ASHRAE 160 (2009).

Quadro 3.7 - Valores do fator de deposição $F d$.

\begin{tabular}{|cc|}
\hline Paredes sob a cobertura inclinada do edifício & 0,5 \\
Paredes em um edifício com cobertura plana & 1,0 \\
Paredes sujeitas a escorrimento & 2,0 \\
\hline
\end{tabular}

Fonte: ANSI/ASHRAE 160 (2009).

\subsubsection{Método do WUFI}

A chuva dirigida é um parâmetro de entrada do programa de simulação higrotérmica WUFI (2013). O programa obtém os dados horários de precipitação, velocidade e direção do vento do arquivo climático com 8760 horas, fornecido para alimentar as simulações computacionais. O WUFI utiliza a Equação 3.12.

$$
R_{w d r}=R_{2} \cdot R_{h} \cdot V \cdot \cos (D-\theta)
$$

Onde,

$R_{w d r} \quad$ Intensidade de chuva dirigida $(\mathrm{mm} / \mathrm{h})$;

$R_{h} \quad$ Precipitação em superfície horizontal (mm);

$R_{2} \quad$ Coeficiente dependente da localização na fachada ( $\left./ \mathrm{m}\right)$;

$V \quad$ Média horária da velocidade do vento a $10 \mathrm{~m}$ de altura, $(\mathrm{m} / \mathrm{s})$;

$D$ Direção do vento (ângulo a partir do Norte);

$\theta$ Orientação da fachada: ângulo entre o Norte e a direção normal à parede.

O WUFI utiliza a Equação 3.12 para gerar um gráfico ilustrando o montante anual de chuva dirigida incidente para cada orientação de fachada. Qualquer que seja o método escolhido, o WUFI considera um fator de redução $(F r=0,7)$ para a chuva dirigida, correspondente ao 
coeficiente de transferência à superfície, ou seja, parcela que estará disponível para ser absorvida pela superfície nas simulações higrotérmicas.

O Quadro 3.8 apresenta os valores do coeficiente $R_{2}$ relacionado à altura do edifício e à localização da área de estudo na fachada.

Quadro 3.8 - Altura do edifício e respectivo coeficiente $\boldsymbol{R}_{2}$.

\begin{tabular}{|ll|}
\hline Edifício baixo, altura até $10 \mathrm{~m}$ & 0,07 \\
Edifício alto, parte baixa até $10 \mathrm{~m}$ & 0,05 \\
Edifício alto, parte intermédia entre 10 e $20 \mathrm{~m}$ & 0,1 \\
Edifício alto, parte superior acima de $20 \mathrm{~m}$ & 0,2 \\
\hline
\end{tabular}

Fonte: WUFI (2013).

O programa WUFI permite que o utilizador selecione entre duas opções: o seu próprio método (Equação 3.12) ou o método estabelecido pela ASHRAE 160 (Equação 3.11).

Uma das condições de entrada de dados do programa WUFI são os coeficientes de transferência à superfície. No caso da chuva dirigida, o utilizador deve selecionar um fator de redução da chuva dirigida entre as seguintes opções: valor definido pelo utilizador; superfície sem absorção; valor dependente da inclinação do elemento construtivo.

Para o elemento construtivo cuja inclinação da superfície varia de $0^{\circ}$ até $90^{\circ}$, o fator de redução da chuva dirigida é 1 , ou seja, é considerada toda a carga de água que incide na superfície (por exemplo, telhado ou paredes inclinadas). Para superfícies com inclinação de $90^{\circ}$ (por exemplo, fachada vertical), o fator de redução é 0,7 , ou seja, é considerada somente $70 \%$ da chuva que incide na superfície, pois leva-se em conta que parte da chuva incidente é refutada devido aos fenômenos que ocorrem no instante de contato da gota com a superfície (respingo, ressalto, etc.). Portanto, independentemente do método de cálculo selecionado (método WUFI ou método ASHRAE), o programa considera um coeficiente de transferência à superfície de fachada de $70 \%$ para o montante de chuva dirigida calculado por meio do método selecionado.

\subsection{ESTUDOS BRASILEIROS SOBRE A CHUVA DIRIGIDA}

Entre os estudos pioneiros de chuva dirigida no Brasil, destacam-se os trabalhos de Perez (1986), Bauer (1987) e Kazmierczak (1989). Perez (1986) estudou os tipos de umidade nas edificações. Bauer (1987) analisou os fenômenos que envolvem a penetração de água de chuva em fachadas e o grau de exposição das fachadas frente à ação da chuva dirigida. Kazmierczak (1989) estudou a influência da quantidade de chuva incidente nos problemas existentes nas alvenarias de tijolos. 
Usando métodos semi-empíricos, Silva e Giralt (1995) estabeleceram o ICD anual para a cidade de Porto Alegre a partir de dados horários de precipitação, velocidade e direção do vento de cinco anos (1977- 1981).

Lima e Morelli (2005) realizaram o primeiro mapa de chuva dirigida para o Brasil, com dados do Índice de Chuva Dirigida do ano de 2004. A metodologia adotada considerou o total de chuva anual e a média anual de vento e determinou um mapa que traz informações sobre o grau de exposição, apenas para o ano de 2004, sem indicações de direção predominante da incidência de chuva dirigida.

Lima e Estrela (2010) determinaram os Índices de Chuva Dirigida para a cidade de São José dos Campos - SP, por meio da análise de dados de um ano de monitoração. Estrela (2010), também determinou o ICD para 400 localidades correspondentes às estações meteorológicas brasileiras, inclusive Brasília, considerando os dados sinóticos diários da série 1995-2010 da base de dados do CPTEC/INPE. Para o cálculo do ICD, o autor utilizou as médias mensais do vento e a precipitação acumulada mensal.

Para a classificação do nível de exposição de acordo com cada faixa de agressividade, Estrela (2010) adotou os critérios propostos por Lacy e complementados por Chand e Bhargava, e considerou a variação do ICD-mensal proporcionalmente a 1/12 da variação do ICD-anual, conforme demostrado no Quadro 3.9.

Quadro 3.9 - Faixas de agressividade propostas para o Índice de Chuva Dirigida mensal.

\begin{tabular}{|ccc|}
\hline Nível de Exposição & $\begin{array}{c}\text { ICD }- \text { anual }\left(\mathbf{m}^{2} / \mathbf{s}\right) \\
\text { Fonte: } \text { Chand e Bhargava }(2002)\end{array}$ & $\begin{array}{c}\text { ICD }- \text { mensal }\left(\mathbf{m}^{2} / \mathbf{s}\right) \\
\text { Fonte: Estrela }(2010)\end{array}$ \\
\hline \hline Protegida & ICD $\leq 3$ & ICD $\leq 0,25$ \\
Moderada & $3<$ ICD $\leq 7$ & $0,25<$ ICD $\leq 0,60$ \\
Alta & $7<$ ICD $\leq 11$ & $0,60<$ ICD $\leq 0,92$ \\
Severa & ICD $>11$ & ICD $>0,92$ \\
\hline
\end{tabular}

Os valores dos ICD-mensais obtidos por Estrela (2010), para a cidade de Brasília, estão apresentados na Tabela 3.1.

Tabela 3.1 - Índice de Chuva Dirigida $\left(\mathrm{m}^{2} / \mathrm{s}\right)$ obtidos por Estrela (2010) na localidade das estações meteorológicas 83377 e Estação 83378 - aeroporto, ambas situadas em Brasília-DF.

\begin{tabular}{lccccccccccccc}
\hline & jan & fev & mar & abr & maio & jun & jul & ago & set & out & nov & dez & ANO \\
\hline \hline Estação 83377 - Sudoeste & 0,38 & 0,37 & 0,54 & 0,35 & 0,09 & 0,02 & 0,00 & 0,07 & 0,26 & 0,50 & 0,62 & 0,68 & $\mathbf{3 , 9 8}$ \\
Estação 83378 - Aeroporto & 0,48 & 0,36 & 0,52 & 0,23 & 0,06 & 0,01 & 0,00 & 0,04 & 0,11 & 0,32 & 0,52 & 0,48 & $\mathbf{3 , 0 1}$ \\
\hline
\end{tabular}


Observa-se que os valores dos ICD mensais apresentados não são direcionais, isto é, não identificam direções de ventos predominantes ou orientações de fachadas mais impactadas. Os valores dos ICD-mensais variam diferentemente conforme a estação meteorológica. Justificavelmente, isso mostra que os resultados dependem do local e da altura da estação onde foram registrados os dados de precipitação e vento.

Melo Júnior e Carasek (2011) determinaram os Índices de Chuva Dirigida direcionais mensais para a cidade de Goiânia-GO, considerando 5 anos de dados meteorológicos, no período de 2002 a 2008

Giongo (2007) e Giongo, Padaratz e Lamberts (2011) apresentaram os Índices de Chuva Dirigida direcionais mensais para a cidade de Florianópolis-SC, com base na análise de três períodos distintos: 1961-1970, 1991/1993-1996 e setembro de 2005 a agosto de 2006.

Zanoni, Sánchez, Bauer e Amorim (2014) publicaram uma Matriz de Análise dos Índices de Chuva Dirigida direcionais mensais para a cidade de Brasília, considerando três séries históricas de dados meteorológicos consolidados (1960-1990; 1991-2000; 2001-2010).

Ainda, os autores Zanoni, Sánchez e Bauer (2014) publicaram um estudo para quantificação da intensidade de chuva dirigida para a cidade de Brasília-DF, aplicando o método semi-empírico da norma ISO 15927-3 Hygrothermal performance of buildings - Calculation and presentation of climatic data - Part 3: Calculation of a driving rain index for vertical surfaces from hourly wind and rain data (BS, 2009).

Durante a revisão bibliográfica, baseada nos autores citados, concluiu-se que não havia nenhuma pesquisa sobre medições in situ de chuva dirigida no Brasil. Os trabalhos desenvolvidos pelos pesquisadores brasileiros referem-se, principalmente, à determinação do ICD. Justifica-se assim, a necessidade do programa experimental de medição de chuva dirigida in situ, proposto por esta tese.

Para compreender melhor o ICD e os métodos semi-empíricos, inclusive para constatar as diferenças entre eles, quando aplicados ao contexto brasileiro, especificamente para a cidade de Brasília, foram desenvolvidos estudos onde foi possível aplicar e analisar os modelos citados. Esses estudos são apresentados nas seções que se seguem.

O primeiro estudo refere-se ao dimensionamento do ICD - mensal direcional para a cidade de Brasília. O segundo estudo refere-se à aplicação e comparação de três métodos semi-empíricos para quantificação de chuva dirigida. Os estudos foram realizados sempre considerando o mesmo contexto urbano e tipologia de edifício. 


\subsection{DETERMINAÇÃO DO ÍNDICE DE CHUVA DIRIGIDA PARA BRASÍLIA}

Esta seção apresenta um estudo sobre os índices de chuva dirigida direcionais mensais, para a cidade de Brasília-DF. O objetivo principal deste estudo foi determinar uma matriz de análise da chuva dirigida para a cidade de Brasília-DF, relacionando os índices de chuva dirigida, mensal e anual, e as direções dos ventos predominantes.

A motivação deste estudo foi analisar as condições de exposição dos edifícios à ação da chuva dirigida, visando aos estudos de vida útil e degradação de fachada, considerando uma condição de exposição em campo aberto (conforme proposto por Lacy).

Os índices de chuva dirigida anuais (ICD direcional-anual) e mensais (ICD direcional-mensal) para a cidade de Brasília-DF foram determinados com base em quatro séries de dados climáticos: 1961-1990, 1991-2000, 2001-2010 e 2001-2013.

O arquivo de dados da série 1961-1990 foi obtido das Normais Climatológica do Brasil 19611990, cuja série de dados sinóticos foi registra pela estação convencional 83377 - Brasília-DF. Esses dados foram consolidados e publicados em 2009 pelo INMET (INMET, 2009).

O arquivo de dados da série 2001-2013 foi fornecido pelo INMET, com dados horários registrados pela estação automática de superfície A001 - Brasília-DF.

Os arquivos de dados para os decênios 1990-2000 e 2000-2010 foram obtidos das Tabelas Climatológicas 2012 (Meteorologia TCA 105-7) publicadas pelo Ministério da Defesa, divulgando os valores decenais de parâmetros meteorológicos observados pela estação convencional 83378 - Aeroporto Presidente Juscelino Kubitschek Brasília-DF (MD, 2012).

Para a determinação do Índice de Chuva Dirigida (ICD), foi adotada a Equação 3.1, proposta por Lacy; expressão de análise simples que relaciona a velocidade do vento com a precipitação, utilizada nos estudos de Bauer (1987), Silva e Giralt (1995), Lima e Morelli (2005), Lima e Estrela (2010), Melo Júnior e Carasek (2011) e Giongo, Padaratz e Lamberts (2011).

\subsubsection{Apresentação e análise dos resultados do estudo sobre ICD para Brasília}

As Tabelas 3.2, 3.3, 3.4, 3.5, 3.6 e 3.7 apresentam os parâmetros médios mensais de precipitação, velocidade e direção dos ventos, além dos resultados obtidos para os Índices de Chuva Dirigida - mensais e anual, dimensionados pela Equação 3.1.

Observando os dados de precipitação das quatro séries analisadas (1961-1990, 1991-2000, 2001-2010 e 2001-2013), observa-se que os decênios apresentam médias de precipitação mais baixas que a série histórica 1961-1990 (Figura 3.1). 
Tabela 3.2 - Índice de Chuva Dirigida - período 1961-1990. Estação: 83377 - Brasília-DF.

\begin{tabular}{lccccccccccccc}
\hline & jan & fev & mar & abr & maio & jun & jul & ago & set & out & nov & dez & ano \\
\hline \hline Precipitação (mm) & 247,4 & 217,5 & 180,6 & 123,8 & 38,6 & 8,7 & 11,1 & 13,9 & 55,2 & 166,6 & 231,1 & 246,0 \\
Vento-intensidade (m/s) & 2,54 & 2,43 & 2,23 & 2,37 & 2,43 & 2,61 & 2,89 & 3,00 & 2,83 & 2,53 & 2,39 & 2,53 \\
Vento-direção (graus) & $\mathrm{N}$ & $\mathrm{NE}$ & $\mathrm{NE}$ & $\mathrm{L}$ & $\mathrm{L}$ & $\mathrm{L}$ & $\mathrm{L}$ & $\mathrm{L}$ & $\mathrm{L}$ & $\mathrm{NE}$ & $\mathrm{NE}$ & $\mathrm{N}$ & \\
\hline $\begin{array}{l}\text { Índice de Chuva } \\
\text { Dirigida }\left(\mathbf{m}^{\mathbf{2}} / \mathbf{s}\right)\end{array}$ & $\mathbf{0 , 6 2}$ & $\mathbf{0 , 5 2}$ & $\mathbf{0 , 4 0}$ & $\mathbf{0 , 2 9}$ & $\mathbf{0 , 0 9}$ & $\mathbf{0 , 0 2}$ & $\mathbf{0 , 0 3}$ & $\mathbf{0 , 0 4}$ & $\mathbf{0 , 1 5}$ & $\mathbf{0 , 4 2}$ & $\mathbf{0 , 5 5}$ & $\mathbf{0 , 6 2}$ & $\mathbf{3 , 7}$ \\
\hline
\end{tabular}

Tabela 3.3 - Índice de Chuva Dirigida - período 2001-2013 -

Estação automática de superfície A001- INMET - Brasília - DF.

\begin{tabular}{lccccccccccccc}
\hline & jan & fev & mar & abr & maio & jun & jul & ago & set & out & nov & dez & ano \\
\hline \hline Precipitação $(\mathrm{mm})$ & 216,0 & 164,2 & 187,9 & 132,0 & 18,5 & 2,1 & 2,4 & 15,2 & 33,8 & 138,7 & 220,8 & 242,2 \\
Vento-intensidade (m/s) & 2,42 & 2,26 & 2,23 & 2,25 & 2,34 & 2,47 & 2,66 & 2,95 & 2,82 & 2,43 & 2,3 & 2,32 & \\
Vento-direção (graus) & NO & $\mathrm{L}$ & $\mathrm{L}$ & $\mathrm{L}$ & $\mathrm{L}$ & $\mathrm{L}$ & $\mathrm{L}$ & $\mathrm{L}$ & $\mathrm{L}$ & $\mathrm{L}$ & NO & NO & \\
\hline $\begin{array}{l}\text { Índice de Chuva } \\
\text { Dirigida (m } / \mathbf{s})\end{array}$ & $\mathbf{0 , 5 2}$ & $\mathbf{0 , 3 7}$ & $\mathbf{0 , 4 2}$ & $\mathbf{0 , 3 0}$ & $\mathbf{0 , 0 4}$ & $\mathbf{0 , 0 1}$ & $\mathbf{0 , 0 1}$ & $\mathbf{0 , 0 4}$ & $\mathbf{0 , 1 0}$ & $\mathbf{0 , 3 4}$ & $\mathbf{0 , 5 1}$ & $\mathbf{0 , 5 6}$ & $\mathbf{3 , 2 1}$ \\
\hline
\end{tabular}

Tabela 3.4 - Índice de Chuva Dirigida - período 1991-2000. Vento (graus) - Primeira Predominância Aeródromo Presidente Juscelino Kubitschek - Brasília - DF.

\begin{tabular}{lccccccccccccc}
\hline & jan & fev & mar & abr & maio & jun & jul & ago & set & out & nov & dez & ano \\
\hline \hline Precipitação (mm) & 138,7 & 124,3 & 140,5 & 64,7 & 13,4 & 1,8 & 0,2 & 7,3 & 15,4 & 59,7 & 141,4 & 124,0 & \\
Vento-intensidade (m/s) & 4,11 & 3,59 & 4,11 & 3,59 & 3,59 & 3,59 & 3,59 & 4,11 & 3,59 & 3,59 & 4,11 & 3,08 & \\
Vento-direção (graus) & NO & $\mathrm{L}$ & $\mathrm{NE}$ & $\mathrm{NE}$ & $\mathrm{L}$ & $\mathrm{L}$ & $\mathrm{L}$ & $\mathrm{L}$ & $\mathrm{L}$ & $\mathrm{L}$ & $\mathrm{NE}$ & NO & \\
\hline $\begin{array}{l}\text { Índice de Chuva } \\
\text { Dirigida (m²/s) }\end{array}$ & $\mathbf{0 , 5 7}$ & $\mathbf{0 , 4 4}$ & $\mathbf{0 , 5 7}$ & $\mathbf{0 , 2 3}$ & $\mathbf{0 , 0 4}$ & - & - & $\mathbf{0 , 0 3}$ & $\mathbf{0 , 0 5}$ & $\mathbf{0 , 2 1}$ & $\mathbf{0 , 5 8}$ & $\mathbf{0 , 3 8}$ & $\mathbf{3 , 1}$ \\
\hline
\end{tabular}

Tabela 3.5 - - Índice de Chuva Dirigida -período 1991-2000. Vento (graus) - Segunda Predominância Aeródromo Presidente Juscelino Kubitschek - Brasília - DF.

\begin{tabular}{lccccccccccccc}
\hline & jan & fev & mar & abr & maio & jun & jul & ago & set & out & nov & dez & ano \\
\hline \hline Precipitação (mm) & 138,7 & 124,3 & 140,5 & 64,7 & 13,4 & 1,8 & 0,2 & 7,3 & 15,4 & 59,7 & 141,4 & 124,0 & \\
Vento-intensidade (m/s) & 3,59 & 3,59 & 3,59 & 3,08 & 3,08 & 3,08 & 4,11 & 3,59 & 4,11 & 4,11 & 3,59 & 3,08 & \\
Vento-direção (graus) & NO & NE & L & SE & SE & SE & NE & SE & NE & NE & L & NO & \\
Índice de Chuva & $\mathbf{0 , 4 9}$ & $\mathbf{0 , 4 4}$ & $\mathbf{0 , 5 0}$ & $\mathbf{0 , 1 9}$ & $\mathbf{0 , 0 4}$ & - & - & $\mathbf{0 , 0 2}$ & $\mathbf{0 , 0 6}$ & $\mathbf{0 , 2 4}$ & $\mathbf{0 , 5 0}$ & $\mathbf{0 , 3 8}$ & $\mathbf{2 , 8}$ \\
Dirigida (m²/s) & & & & & & & & & & & & &
\end{tabular}

Tabela 3.6- Índice de Chuva Dirigida - período 2001-2010. Vento (graus) - Primeira Predominância Aeródromo Presidente Juscelino Kubitschek - Brasília - DF.

\begin{tabular}{lccccccccccccc}
\hline & jan & fev & mar & abr & maio & jun & jul & ago & set & out & nov & dez & ano \\
\hline \hline Precipitação (mm) & 151,8 & 154,0 & 175,9 & 96,3 & 21,66 & 0,6 & 0,3 & 15,1 & 28,7 & 87,2 & 125,5 & 198,5 \\
Vento-intensidade (m/s) & 3,59 & 4,11 & 3,59 & 3,59 & 3,59 & 3,59 & 3,59 & 4,11 & 4,11 & 3,59 & 3,59 & 3,08 & \\
Vento-direção (graus) & $\mathrm{NE}$ & $\mathrm{L}$ & $\mathrm{NE}$ & $\mathrm{L}$ & $\mathrm{L}$ & $\mathrm{L}$ & $\mathrm{L}$ & $\mathrm{NE}$ & $\mathrm{NE}$ & $\mathrm{NE}$ & $\mathrm{NE}$ & $\mathrm{NE}$ & \\
\hline $\begin{array}{l}\text { Índice de Chuva } \\
\text { Dirigida (m } / \mathbf{s})\end{array}$ & $\mathbf{0 , 5 4}$ & $\mathbf{0 , 6 3}$ & $\mathbf{0 , 6 3}$ & $\mathbf{0 , 3 4}$ & $\mathbf{0 , 0 7}$ & - & - & $\mathbf{0 , 0 6}$ & $\mathbf{0 , 1 1}$ & $\mathbf{0 , 3 1}$ & $\mathbf{0 , 4 5}$ & $\mathbf{0 , 6 1}$ & $\mathbf{3 , 7}$ \\
\hline
\end{tabular}

Tabela 3.7 - Índice de Chuva Dirigida - período 2001-2010. Vento (graus) - Segunda Predominância Aeródromo Presidente Juscelino Kubitschek - Brasília - DF.

\begin{tabular}{|c|c|c|c|c|c|c|c|c|c|c|c|c|c|}
\hline & jan & fev & mar & abr & maio & jun & jul & ago & set & out & nov & dez & ano \\
\hline Precipitação (mm) & 151,8 & 154,0 & 175,9 & 96,3 & 21,66 & 0,6 & 0,3 & 15,1 & 28,7 & 87,2 & 125,5 & 198,5 & \\
\hline Vento-intensidade (m/s) & 3,59 & 3,59 & 3,08 & 3,59 & 3,59 & 3,59 & 3,59 & 4,11 & 4,11 & 3,59 & 3,59 & 3,08 & \\
\hline Vento-direção (graus) & $\mathrm{L}$ & $\mathrm{L}$ & $\mathrm{L}$ & $\mathrm{L}$ & $\mathrm{L}$ & $\mathrm{L}$ & $\mathrm{NE}$ & $\mathrm{L}$ & $\mathrm{L}$ & $\mathrm{L}$ & $\mathrm{L}$ & $\mathrm{L}$ & \\
\hline $\begin{array}{l}\text { Índice de Chuva } \\
\text { Dirigida }\left(\mathrm{m}^{2} / \mathrm{s}\right)\end{array}$ & 0,54 & 0,55 & 0,54 & $\mathbf{0 , 3 4}$ & $\mathbf{0 , 0 7}$ & - & - & 0,06 & $\mathbf{0 , 1 1}$ & $\mathbf{0 , 3 1}$ & $\mathbf{0 , 4 5}$ & 0,61 & 3,5 \\
\hline
\end{tabular}




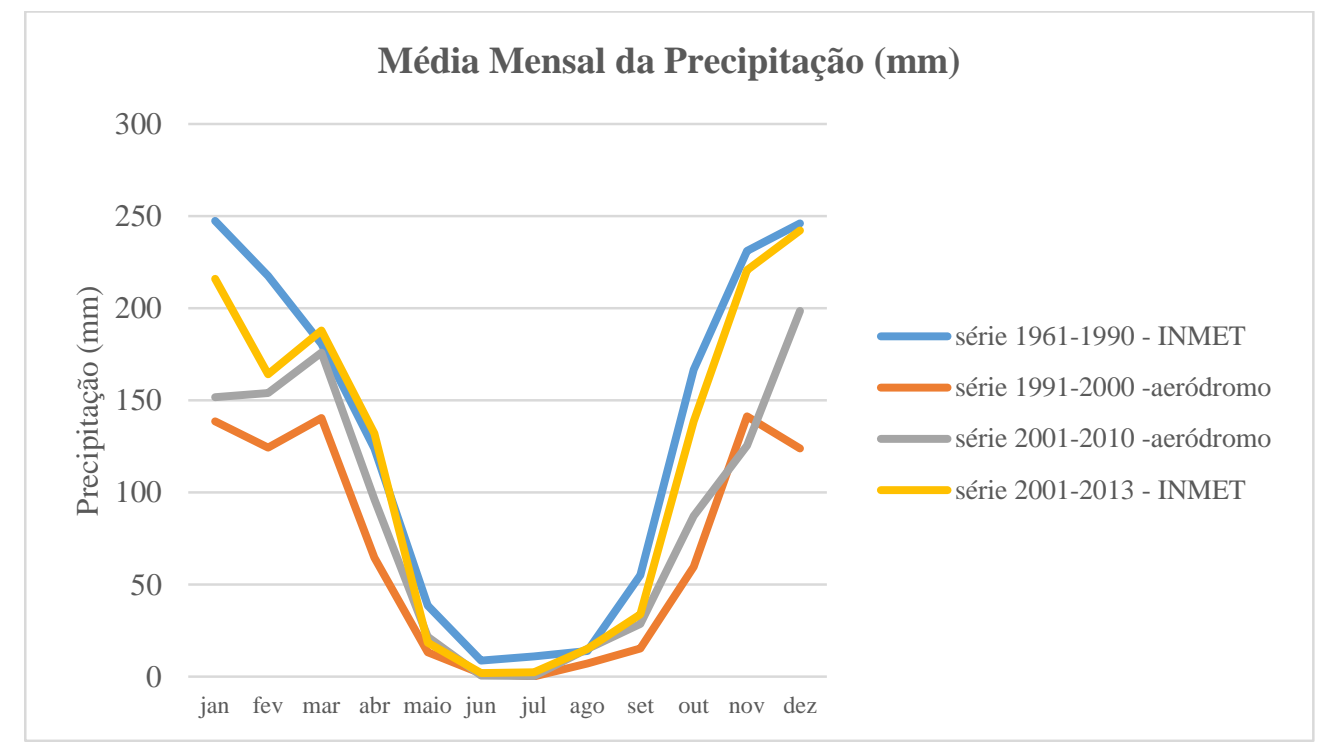

Figura 3.1 - Gráfico das médias mensais da precipitação no plano horizontal para Brasília, nos períodos 1961-1990, 1991-2000, 2001-2010 e 2001-2013.

Nas Normais Climatológica da série 1961-1990, a intensidade dos ventos varia de 2,23 a $3 \mathrm{~m} / \mathrm{s}$ (Tabela 3.2). Nos meses do período chuvoso, os ventos resultantes estão nas direções Norte e Nordeste. Nos meses do período seco, os ventos resultantes estão na direção Leste.

Na série 2001-2013, a intensidade dos ventos varia de 2,23 a 2,95 m/s (Tabela 3.3). Nos meses do período chuvoso, os ventos predominantes estão nas direções Noroeste e Leste. Nos meses do período seco, os ventos predominantes estão na direção Leste.

Nas séries decenais 1991-2000 e 2001-2010, as médias das intensidades dos ventos variam acima de $3 \mathrm{~m} / \mathrm{s}$ em todos os meses dos decênios. Nos meses do período chuvoso, os ventos predominantes estão nas direções Noroeste, Nordeste e Leste. Nos meses do período seco, os ventos predominantes estão nas direções Leste, Nordeste e Sudeste.

Observa-se que os ventos são bem distribuídos em todas as direções, por isso, dependendo da fonte do arquivo climático, podem ocorrer variações nas direções predominantes ou resultantes. Avaliando os valores anuais do ICD para Brasília verifica-se que são maiores ou iguais a 2,86 e menores ou iguais a 3,75. Com exceção do ICD-anual para a segunda predominância do decênio 1991-2000, os níveis de exposição às chuvas dirigidas correspondem ao nível de exposição Moderado com $3 \leq \mathrm{ICD}<5$, conforme classificação de Chand e Bhargava (2002) apresentada no Quadro 3.2.

As Tabelas 3.2, 3.3, 3.4, 3.5, 3.6 e 3.7 mostram os valores dos Índices de Chuva Dirigida calculados para Brasília. Esses valores foram sintetizados na Figura 3.2. 


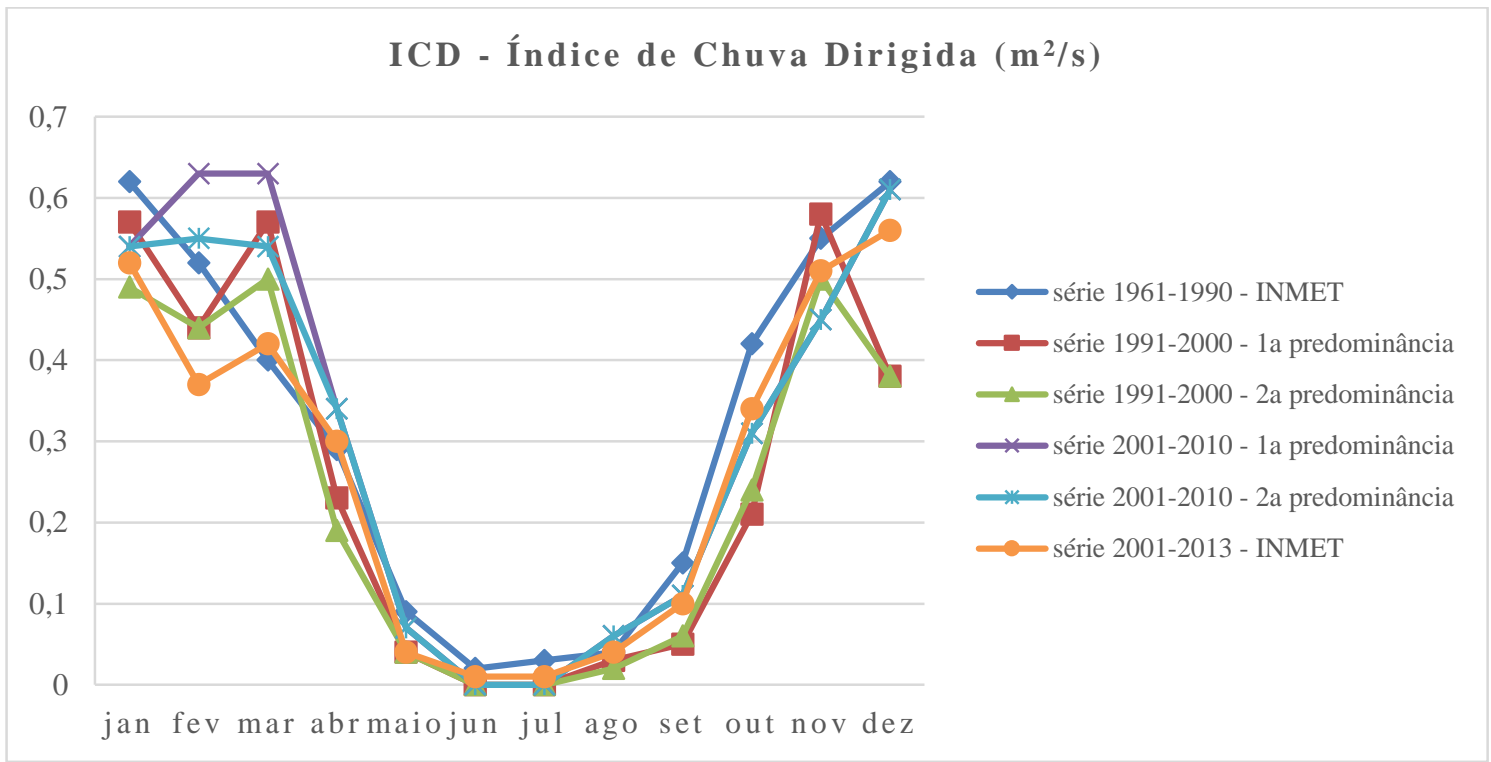

Figura 3.2 - Índice de Chuva Dirigida - mensal para Brasília, nos períodos 1961-1990, 1991-2000, 2001-2010 e 2001-2013.

Baseado em Lacy (1972) e Chand e Bhargava (2002), a classificação dos Índices de Chuva Dirigida, de acordo com os níveis de exposição para cada faixa de agressividade, considerouse que a variação do valor mensal do ICD é proporcional a 1/12 da variação do valor anual. Assim, o Quadro 3.10 apresenta as faixas de classificação dos valores mensais e anuais dos ICD, com os respectivos níveis de exposição.

Quadro 3.10 - Nível de exposição à chuva dirigida.

\begin{tabular}{|ccc|}
\hline \multirow{2}{*}{ Nível de Exposição } & \multicolumn{2}{c|}{ Índice de Chuva Dirigida $\left(\mathbf{m}^{2} / \mathbf{s}\right)$} \\
\cline { 2 - 3 } & ICD anual & ICD mensal \\
\hline \hline Protegido & $\mathrm{ICD} \leq 3$ & $\mathrm{ICD} \leq 0,3$ \\
Moderado & $3<\mathrm{ICD} \leq 7$ & $0,3<\mathrm{ICD} \leq 0,6$ \\
Alto & $7<\mathrm{ICD} \leq 11$ & $0,6<\mathrm{ICD} \leq 0,9$ \\
Severo & $\mathrm{ICD}>11$ & $\mathrm{ICD}>0,9$ \\
\hline
\end{tabular}

Fonte: baseado em Chand e Bhargava (2002) e Estrela (2010).

Os Índices de Chuva Dirigida calculados para a cidade de Brasília-DF, com base em quatro séries de dados, são apresentados em uma matriz de análise (Quadro 3.11) que relaciona os ICD-mensal com as direções predominantes ou resultantes dos ventos, facilitando a identificação das orientações de fachadas que estão mais suscetíveis à degradação pelas condições de exposição às chuvas dirigidas em campo aberto.

Com base na matriz de análise que mostra o comportamento da chuva dirigida na cidade de Brasília, ao longo dos meses do ano, pode-se avaliar que valores de ICD mensal acima de 0,30 são significativos para o estudo da agressividade das chuvas dirigidas sobre as fachadas e que ICD mensais superiores a 0,60 já indicam que as fachadas orientadas para estas direções de 
vento estão sujeitas a alto nível de exposição devido aos efeitos combinados de precipitação e vento, exigindo estratégias de projeto e manutenção para evitar a degradação precoce da fachada.

Quadro 3.11 - Matriz de análise da chuva dirigida para a cidade de Brasília-DF: Índices de Chuva Dirigida mensais (ICD) e as direções de vento mais agressivas.

\begin{tabular}{|c|c|c|c|c|c|c|c|c|c|c|c|c|c|c|}
\hline & & jan & fev & mar & abr & maio & jun & jul & ago & set & out & nov & dez & ano \\
\hline \multirow{2}{*}{$\frac{\text { Бे }}{\frac{1}{2}}$} & $\begin{array}{l}\text { Direção Resultante do } \\
\text { Vento (graus) }\end{array}$ & $\mathrm{N}$ & $\mathrm{NE}$ & $\mathrm{NE}$ & $\mathrm{L}$ & $\mathrm{L}$ & $\mathrm{L}$ & $\mathrm{L}$ & $\mathrm{L}$ & $\mathrm{L}$ & $\mathrm{NE}$ & $\mathrm{NE}$ & $\mathrm{N}$ & \\
\hline & $\begin{array}{c}\text { Índice de chuva } \\
\text { dirigida }\end{array}$ & 0,62 & 0,52 & $\mathbf{0 , 4 0}$ & 0,29 & 0,09 & $\mathbf{0 , 0 2}$ & $\mathbf{0 , 0 3}$ & 0,04 & 0,15 & 0,42 & 0,55 & 0,62 & 3,75 \\
\hline \multirow{2}{*}{ 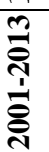 } & $\begin{array}{l}\text { Direção Predominante } \\
\text { do Vento (graus) }\end{array}$ & NO & $\mathrm{L}$ & $\mathrm{L}$ & $\mathrm{L}$ & $\mathrm{L}$ & $\mathrm{L}$ & $\mathrm{L}$ & $\mathrm{L}$ & $\mathrm{L}$ & $\mathrm{L}$ & NO & NO & \\
\hline & $\begin{array}{c}\text { Índice de chuva } \\
\text { dirigida }\end{array}$ & 0,52 & 0,37 & 0,42 & $\mathbf{0 , 3 0}$ & $\mathbf{0 , 0 4}$ & 0,01 & 0,01 & 0,04 & 0,10 & 0,34 & 0,51 & 0,56 & 3,21 \\
\hline \multirow{2}{*}{ 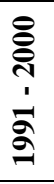 } & $\begin{array}{c}\text { Primeira } \\
\text { Predominância } \\
\text { Direção do Vento }\end{array}$ & NO & $\mathrm{L}$ & $\mathrm{NE}$ & $\mathrm{NE}$ & $\mathrm{L}$ & $\mathrm{L}$ & $\mathrm{L}$ & $\mathrm{L}$ & $\mathrm{L}$ & $\mathrm{L}$ & NE & NO & \\
\hline & $\begin{array}{c}\text { Índice de chuva } \\
\text { dirigida }\end{array}$ & 0,57 & 0,44 & $\mathbf{0 , 5 7}$ & 0,23 & 0,04 & - & - & $\mathbf{0 , 0 3}$ & 0,05 & 0,21 & $\mathbf{0 , 5 8}$ & $\mathbf{0 , 3 8}$ & 3,10 \\
\hline \multirow{2}{*}{ 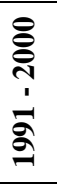 } & $\begin{array}{c}\text { Segunda } \\
\text { Predominância } \\
\text { Direção do Vento }\end{array}$ & NO & $\mathrm{NE}$ & $\mathrm{L}$ & SE & $\mathrm{SE}$ & SE & $\mathrm{NE}$ & SE & $\mathrm{NE}$ & $\mathrm{NE}$ & $\mathrm{L}$ & NO & \\
\hline & $\begin{array}{c}\text { Índice de chuva } \\
\text { dirigida }\end{array}$ & 0,49 & 0,44 & $\mathbf{0 , 5 0}$ & 0,19 & 0,04 & - & - & $\mathbf{0 , 0 2}$ & 0,06 & 0,24 & $\mathbf{0 , 5 0}$ & $\mathbf{0 , 3 8}$ & 2,86 \\
\hline \multirow{2}{*}{ 兽 } & $\begin{array}{c}\text { Primeira } \\
\text { Predominância } \\
\text { Direção do Vento }\end{array}$ & $\mathrm{NE}$ & $\mathrm{L}$ & $\mathrm{NE}$ & $\mathrm{L}$ & $\mathrm{L}$ & $\mathrm{L}$ & $\mathrm{L}$ & $\mathrm{NE}$ & $\mathrm{NE}$ & $\mathrm{NE}$ & $\mathrm{NE}$ & $\mathrm{NE}$ & \\
\hline & $\begin{array}{c}\text { Índice de chuva } \\
\text { dirigida }\end{array}$ & 0,54 & 0,63 & 0,63 & 0,34 & 0,07 & - & - & 0,06 & 0,11 & $\mathbf{0 , 3 1}$ & 0,45 & 0,61 & 3,75 \\
\hline \multirow{2}{*}{ 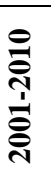 } & $\begin{array}{c}\text { Segunda } \\
\text { Predominância } \\
\text { Direção do Vento }\end{array}$ & $\mathrm{L}$ & $\mathrm{L}$ & $\mathrm{L}$ & $\mathrm{L}$ & $\mathrm{L}$ & $\mathrm{L}$ & $\mathrm{NE}$ & $\mathrm{L}$ & $\mathrm{L}$ & $\mathrm{L}$ & $\mathrm{L}$ & $\mathrm{L}$ & \\
\hline & $\begin{array}{c}\text { Índice de chuva } \\
\text { dirigida }\end{array}$ & 0,54 & $\mathbf{0 , 5 5}$ & 0,54 & 0,34 & 0,07 & - & - & 0,06 & 0,11 & $\mathbf{0 , 3 1}$ & 0,45 & 0,61 & 3,58 \\
\hline
\end{tabular}

LEGENDA:

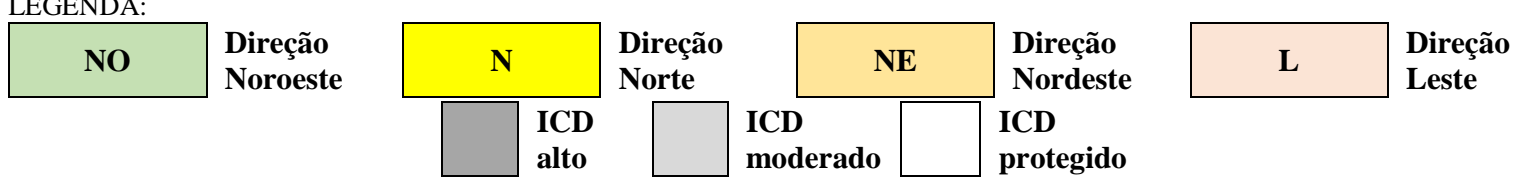

\subsubsection{Conclusões do estudo sobre ICD direcional-mensal para Brasília}

Neste estudo foram apresentados os Índices de Chuva Dirigida anual e mensais determinados para a cidade de Brasília. De acordo com a classificação proposta (Quadro 3.10), Brasília pode ser classificada com um nível de exposição moderado à chuva dirigida $(3<\mathrm{ICD} \leq 7)$, quando considerado o ICD anual, que é baseado nas médias anuais de precipitação e vento.

No entanto, quando avaliado os ICD mensais, verifica-se que alguns meses do período chuvoso apresentam alto nível de exposição à chuva dirigida (ICD mensal > 0,6). Tal constatação alerta para os erros de avaliação que podem ser cometidos quando são consideradas as médias anuais nos cálculos do ICD. Os valores dos ICD marcam fortemente a sazonalidade em dois períodos distintos (seco e chuvoso). Os meses que apresentam os maiores índices de chuva dirigida são 
os meses do período chuvoso (outubro, novembro, dezembro, janeiro, fevereiro e março). Durante o período seco (abril, maio, junho, julho, agosto e setembro) os Índices de Chuva Dirigida são muito baixos.

Analisando a matriz que relaciona os valores dos ICD-mensais com a direção dos ventos predominantes ou resultantes, conclui-se que as fachadas mais sujeitas à degradação por exposição às chuvas dirigidas são aquelas orientadas para as direções de vento Noroeste, Norte, Nordeste e Leste.

A determinação do ICD cumpre a sua função de classificar o nível de exposição do edifício ao ambiente em que está inserido, no entanto, é importante frisar que os valores obtidos para os ICD são baseados em condições de exposição a campo aberto, isto é, sem nenhuma interferência das características do edifício ou da condição urbana.

Em suma, para os estudos do comportamento higrotérmico das fachadas e das condições que apresentam maior potencial para a degradação e diminuição da vida útil, é preciso adotar modelos que quantifiquem o montante de chuva projetada na fachada, considerando a ação simultânea dos eventos de precipitação e vento, para todas as direções de vento que podem influenciar no umedecimento da superfície da fachada em determinada orientação.

Desta forma, será possível estudar a resposta da fachada decorrente do seu comportamento higrotérmico, mediante à carga de umedecimento recebida pela ação da chuva dirigida.

Para isso, é preciso adotar modelos que considerem valores horários de precipitação e vento, além de outros parâmetros que representem as características do edifício e do contexto urbano onde ele está inserido.

\subsection{COMPARAÇÃO ENTRE TRÊS MÉTODOS SEMI-EMPÍRICOS PARA QUANTIFICAÇÃO DA CHUVA DIRIGIDA NAS FACHADAS EM BRASÍLIA}

Nesta seção, são apresentados os estudos comparativos entre três métodos semi-empíricos selecionados para a quantificação da intensidade de chuva dirigida, aplicados ao contexto urbano da cidade de Brasília.

Os métodos selecionados foram ISO 15927-3, ASHRAE STANDARD 160 e WUFI, já devidamente apresentados na seção 3.4 deste capítulo. O arquivo climático adotado para este estudo refere-se à série 2001-2013, com 13 anos de dados horários registrados pela estação automática de superfície A001-Brasília do INMET. 
Para a quantificação de chuva dirigida nas fachadas, foram considerados todos os dados horários de precipitação associados simultaneamente aos dados horários de velocidade e direção dos ventos incidentes nos octantes, possibilitando assim a análise da chuva dirigida incidente em cada mês do ano, para as oito principais orientações de fachada correspondente aos pontos cardeais (Norte, Leste, Sul, Oeste) e aos pontos colaterais (Nordeste, Sudeste, Sudoeste e Noroeste), a saber:

$\rightarrow$ orientação Norte: compreendida no octante definido pelos azimutes 337,5 e 22,5;

$\rightarrow$ orientação Nordeste: compreendida no octante definido pelos azimutes 22,5 e 67,5;

$\rightarrow$ orientação Leste: compreendida no octante definido pelos azimutes 67,5 e 112,5;

$\rightarrow$ orientação Sudeste: compreendida no octante definido pelos azimutes 112,5 e 157,5;

$\rightarrow$ orientação Sul: compreendida no octante definido pelos azimutes 157,5 e 202,5;

$\rightarrow$ orientação Sudoeste: compreendida no octante definido pelos azimutes 202,5 e 247,5;

$\rightarrow$ orientação Oeste: compreendida no octante definido pelos azimutes 247,5 e 292,5;

$\rightarrow$ orientação Noroeste: compreendida no octante definido pelos azimutes 292,5 e 337,5.

Para contextualizar o estudo, foi considerado um edifício residencial com seis pavimentos $(\mathrm{h}=18 \mathrm{~m})$, localizado em uma superquadra no Plano Piloto, ao longo do Eixo Rodoviário Residencial de Brasília. A Figura 3.3 ilustra o contexto urbano analisado.

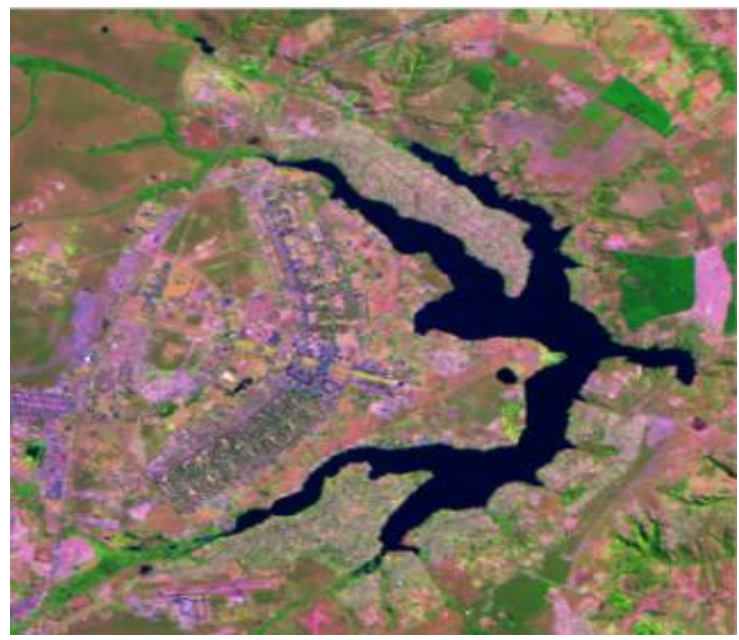

Fonte: http://pessoal.utfpr.edu.br/ligia/material/ cartografia/tutorial_hipsometria_srtm.pdf

a)

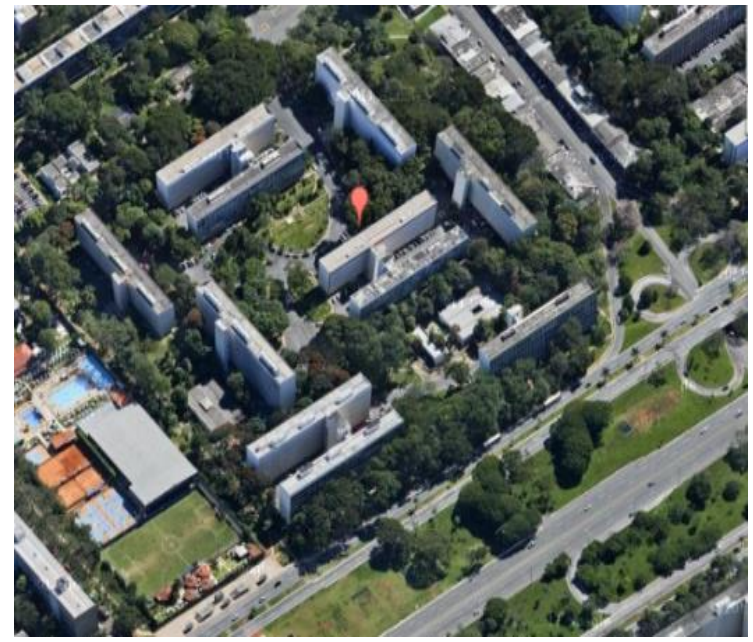

Fonte: http://maps.google.com.br/maps

b)

Figura 3.3 - Situação geográfica do edifício na superquadra do Plano Piloto de Brasília: a) Plano Piloto; b) Superquadra.

Os parâmetros utilizados em cada método de quantificação estão sintetizados nos Quadros 3.12, 3.13 e 3.14. As Tabelas 3.8, 3.9 e 3.10 mostram os resultados das quantificações efetuadas e as Figuras 3.4, 3.5, 3.6 e 3.7 ilustram as quantificações apresentadas nas tabelas. 
Quadro 3.12 - Apresentação dos resultados da quantificação de chuva dirigida pelo método ASHRAE 160, no contexto de Brasília - DF.

\begin{tabular}{|c|c|c|}
\hline \multicolumn{2}{|c|}{ MÉTODO DE QUANTIFICAÇÃO DE CHUVA DIRIGIDA } & EXPRESSÃO DE CÁLCULO \\
\hline \multicolumn{2}{|c|}{$\begin{array}{l}\text { ASHRAE Standard 160- Criteria for moisture-control design analysis in } \\
\text { buildings (ANSI/ASHRAE, 2009). }\end{array}$} & $R b v=F e \cdot F d \cdot F c \cdot V \cdot \cos (D-\theta) \cdot R h$ \\
\hline COEFICIENTES & \multicolumn{2}{|c|}{\begin{tabular}{|l} 
JUSTIFICATIVAS \\
\end{tabular}} \\
\hline $\mathrm{Fe}=1,2$ & \multicolumn{2}{|c|}{$\begin{array}{l}\text { Para a definição do Fator de Exposição à chuva }(\mathrm{Fe})=1,2 \text {, foram considerados: } \\
\text { - característica do edifício: altura do edifício na categoria } 15-20(\mathrm{~m}) ; \\
\text { - topografia: tipo de terreno com exposição média. }\end{array}$} \\
\hline$F d=1,0$ & \multicolumn{2}{|c|}{$\begin{array}{l}\text { Para a definição do Fator de Deposição da chuva }(\mathrm{Fd})=1,0 \text {, foi considerado: } \\
\text { - paredes em um edifício com cobertura plana. }\end{array}$} \\
\hline$F c=0,2$ & \multicolumn{2}{|c|}{ Constante empírica $(\mathrm{s} / \mathrm{m})$} \\
\hline
\end{tabular}

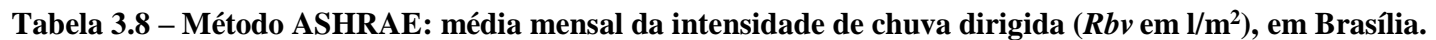

\begin{tabular}{rcccccccc}
\hline & $\mathbf{N}$ & $\mathbf{N E}$ & $\mathbf{E}$ & $\mathbf{S E}$ & $\mathbf{S}$ & $\mathbf{S O}$ & $\mathbf{O}$ & NO \\
\hline \hline Janeiro & 83,97 & 57,71 & 29,17 & 18,64 & 15,35 & 23,18 & 48,95 & 81,15 \\
Fevereiro & 60,70 & 48,02 & 29,40 & 18,32 & 16,06 & 18,63 & 32,48 & 52,06 \\
Março & 49,19 & 39,21 & 32,33 & 27,60 & 21,41 & 20,69 & 33,92 & 48,38 \\
Abril & 24,54 & 30,81 & 30,08 & 27,78 & 20,71 & 14,64 & 11,03 & 17,02 \\
Maio & 2,31 & 3,55 & 6,10 & 7,98 & 6,73 & 3,60 & 1,76 & 1,78 \\
Junho & 0,29 & 0,23 & 0,30 & 0,50 & 0,63 & 0,50 & 0,35 & 0,29 \\
Julho & 0,10 & 0,13 & 0,97 & 1,35 & 1,03 & 0,29 & 0,27 & 0,20 \\
Agosto & 5,26 & 5,14 & 4,51 & 4,48 & 3,35 & 1,83 & 1,74 & 3,87 \\
Setembro & 7,72 & 7,50 & 8,17 & 11,81 & 12,54 & 8,77 & 5,15 & 6,27 \\
Outubro & 25,23 & 29,41 & 37,61 & 40,80 & 34,20 & 24,18 & 21,24 & 22,89 \\
Novembro & 70,29 & 53,51 & 38,12 & 35,98 & 32,35 & 29,28 & 41,80 & 65,41 \\
Dezembro & 96,45 & $\mathbf{6 5 , 2 3}$ & 34,38 & 25,84 & 24,96 & 29,38 & 55,17 & 91,09 \\
\hline ANUAL & $\mathbf{4 2 6 , 0 6}$ & $\mathbf{3 4 0 , 4 5}$ & $\mathbf{2 5 1 , 1 5}$ & $\mathbf{2 2 1 , 0 8}$ & $\mathbf{1 8 9 , 3 2}$ & $\mathbf{1 7 4 , 9 6}$ & $\mathbf{2 5 3 , 8 6}$ & $\mathbf{3 9 0 , 4 0}$ \\
\hline
\end{tabular}

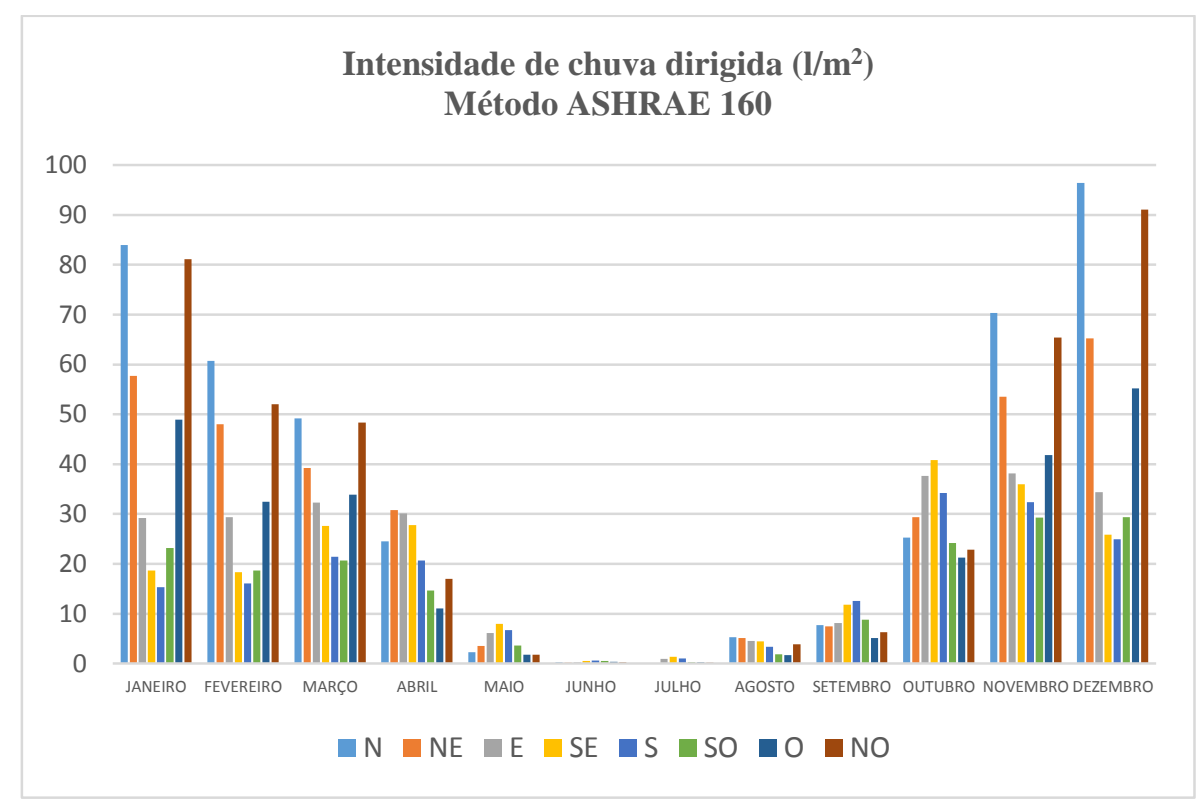

Figura 3.4 -Intensidade de chuva dirigida $\left(1 / \mathrm{m}^{2}\right)$ em Brasília: método ASHRAE. 
Quadro 3.13 - Apresentação dos resultados da quantificação de chuva dirigida pelo método WUFI, no contexto de Brasília - DF.

\begin{tabular}{|c|c|c|}
\hline \multicolumn{2}{|c|}{ MÉTODO DE QUANTIFICAÇÃO DE CHUVA DIRIGIDA } & EXPRESSÃO DE CÁLCULO \\
\hline \multicolumn{2}{|c|}{ Programa de simulação higrotérmica WUFI PRO 5 (2013) } & $R_{w d r}=R_{2} \cdot R_{h} \cdot V \cdot \cos (D-\theta)$ \\
\hline COEFICIENTES & \multicolumn{2}{|c|}{ JUSTIFICATIVAS } \\
\hline$R_{2}=0,2$ & \multicolumn{2}{|c|}{$\begin{array}{l}\text { Para a definição do coeficiente de localização relacionado com a altura do edifício }\left(R_{2}\right)=0,2 \text {, foi } \\
\text { considerado: } \\
\text { - categoria Edifício Alto, cuja parte superior está a } 20 \mathrm{~m} \text {. }\end{array}$} \\
\hline$F r=0,7$ & \multicolumn{2}{|c|}{$\begin{array}{l}\text { Para a definição do coeficiente de transferência à superfície da chuva dirigida, foi considerado: } \\
\text { - fator de redução }(F r)=0,7 \text { correspondente a } 70 \% \text { da água incidente no elemento construtivo } \\
\text { (fachada) cuja inclinação é igual a } 90^{\circ} \text {. }\end{array}$} \\
\hline
\end{tabular}

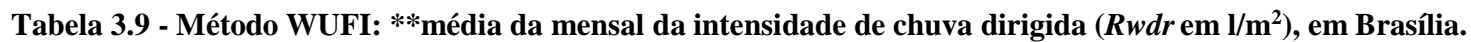

\begin{tabular}{|c|c|c|c|c|c|c|c|c|}
\hline & $\mathbf{N}$ & NE & $\mathbf{E}$ & SE & $\mathbf{S}$ & SO & $\mathbf{O}$ & NO \\
\hline Janeiro & 48,98 & 33,67 & 17,02 & 10,87 & 8,96 & 13,52 & 28,56 & 47,33 \\
\hline Fevereiro & 35,41 & 28,01 & 17,15 & 10,69 & 9,37 & 10,87 & 18,95 & 30,37 \\
\hline Março & 28,69 & 22,87 & 18,86 & 16,10 & 12,49 & 12,07 & 19,79 & 28,22 \\
\hline Abril & 14,32 & 17,97 & 17,55 & 16,21 & 12,08 & 8,54 & 6,44 & 9,93 \\
\hline Maio & 1,35 & 2,07 & 3,56 & 4,65 & 3,93 & 2,10 & 1,02 & 1,04 \\
\hline Junho & 0,17 & 0,13 & 0,17 & 0,29 & 0,37 & 0,29 & 0,20 & 0,17 \\
\hline Julho & 0,06 & 0,07 & 0,57 & 0,79 & 0,60 & 0,17 & 0,16 & 0,12 \\
\hline Agosto & 3,07 & 3,00 & 2,63 & 2,61 & 1,95 & 1,07 & 1,01 & 2,26 \\
\hline Setembro & 4,50 & 4,38 & 4,77 & 6,89 & 7,31 & 5,12 & 3,00 & 3,66 \\
\hline Outubro & 14,72 & 17,15 & 21,94 & 23,80 & 19,95 & 14,10 & 12,39 & 13,35 \\
\hline Novembro & 41,00 & 31,22 & 22,24 & 20,99 & 18,87 & 17,08 & 24,38 & 38,16 \\
\hline Dezembro & 56,26 & 38,05 & 20,05 & 15,07 & 14,56 & 17,14 & 32,18 & 53,14 \\
\hline \multicolumn{9}{|c|}{ ** Valores mensais foram calculados com o Fator de Redução $F r=0,7$} \\
\hline $\begin{array}{r}\text { Anual: com fator } \\
\text { de redução } 0,7\end{array}$ & 248,54 & 198,59 & 146,50 & 128,96 & 110,44 & 102,06 & 148,08 & 227,73 \\
\hline $\begin{array}{l}\text { Anual: sem fator } \\
\text { de redução }\end{array}$ & 355,05 & 283,70 & 209,29 & 184,23 & 157,76 & 145,79 & 211,54 & 325,33 \\
\hline
\end{tabular}

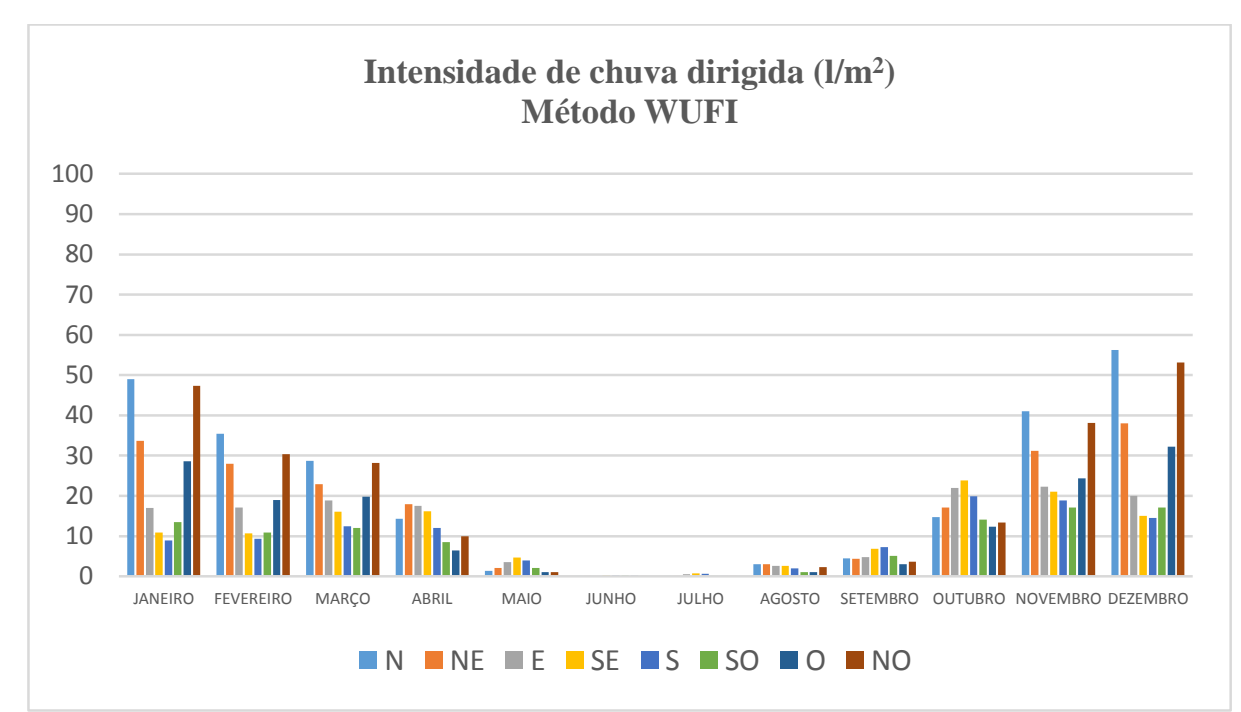

Figura 3.5 -Intensidade de chuva dirigida $\left(1 / \mathrm{m}^{2}\right)$ em Brasília: método WUFI com fator de redução de 0,7 . 
Quadro 3.14 - Apresentação dos resultados da quantificação de chuva dirigida pelo método ISO 15927-3, no contexto de Brasília - DF.

\begin{tabular}{|c|c|c|}
\hline \multicolumn{2}{|c|}{ MÉTODO DE QUANTIFICAÇÃO DE CHUVA DIRIGIDA } & EXPRESSÃO DE CÁLCULO \\
\hline \multicolumn{2}{|c|}{$\begin{array}{l}\text { ISO 15927-3 Hygrothermal performance of buildings - Calculation and } \\
\text { presentation of climatic data - Part 3: Calculation of a driving rain index for } \\
\text { vertical surfaces from hourly wind and rain data (BS, 2009). }\end{array}$} & $\begin{aligned} \mathbf{I}_{\mathbf{S}}= & \frac{2}{9} \sum V P^{8 / 9} \cos (D-\theta) \\
& \mathbf{I}_{\boldsymbol{W S}}=I_{S} C_{R} C_{T} O W\end{aligned}$ \\
\hline COEFICIENTES & \multicolumn{2}{|c|}{ JUSTIFICATIVAS } \\
\hline & \multicolumn{2}{|c|}{$\begin{array}{l}\text { Para a definição do Fator de Rugosidade }\left(C_{R}\right)=0,90 \text {, foi considerada a situação mais crítica entre } \\
\text { as categorias } 3 \text { e } 4 \text {, ou seja: }\end{array}$} \\
\hline$C r=0,9$ & \multicolumn{2}{|c|}{$\begin{array}{l}\text { - categoria de terreno igual a } 4 \text { - área urbana em que pelo menos } 15 \% \text { da superfície tem edifícios } \\
\text { com uma altura superior a } 15 \mathrm{~m} \text {; }\end{array}$} \\
\hline & \multicolumn{2}{|c|}{ - altura $Z$ igual a $20 \mathrm{~m}$ - parte superior da cobertura da edificação de 6 pavimentos. } \\
\hline$C t=1$ & \multicolumn{2}{|c|}{$\begin{array}{l}\text { Para a definição do Fator de Topografia } C_{T}=1 \text {, foram considerados: } \\
\text { - situação topográfica da região analisada com declividade menor que } 0,05 \text {. }\end{array}$} \\
\hline$O=1$ & \multicolumn{2}{|c|}{$\begin{array}{l}\text { Para a definição do Fator de Obstrução } O=1 \text {, foi considerado: } \\
\text { - existência da possibilidade de ocorrência de vento convergente na direção da parede. }\end{array}$} \\
\hline$W=0,5$ & \multicolumn{2}{|c|}{$\begin{array}{l}\text { Para a definição do Fator de Parede } W=0,5 \text {, foram considerados: } \\
\text { - parte do edifício em análise correspondente à } 2,5 \mathrm{~m} \text { da parte superior da edificação, com mais de } \\
3 \text { pisos e cobertura em terraço. }\end{array}$} \\
\hline
\end{tabular}

Tabela 3.10 - Método ISO 15927-3: média da mensal da intensidade de chuva dirigida ( $I w s$ em 1/m²), em Brasília.

\begin{tabular}{|c|c|c|c|c|c|c|c|c|}
\hline & $\mathbf{N}$ & NE & $\mathbf{E}$ & SE & $\mathbf{S}$ & SO & $\mathbf{O}$ & NO \\
\hline Janeiro & 29,93 & 20,64 & 10,47 & 6,55 & 5,19 & 7,81 & 17,07 & 28,72 \\
\hline Fevereiro & 20,69 & 16,19 & 9,96 & 6,28 & 5,47 & 6,43 & 11,37 & 18,05 \\
\hline Março & 16,94 & 13,56 & 11,08 & 9,37 & 7,30 & 7,15 & 11,64 & 16,58 \\
\hline Abril & 7,98 & 9,95 & 9,82 & 9,13 & 6,86 & 4,92 & 3,83 & 5,69 \\
\hline Maio & 0,83 & 1,28 & 2,15 & 2,75 & 2,33 & 1,29 & 0,66 & 0,64 \\
\hline Junho & 0,12 & 0,10 & 0,13 & 0,21 & 0,25 & 0,20 & 0,14 & 0,12 \\
\hline Julho & 0,04 & 0,05 & 0,32 & 0,44 & 0,34 & 0,10 & 0,10 & 0,07 \\
\hline Agosto & 1,72 & 1,73 & 1,57 & 1,56 & 1,18 & 0,67 & 0,62 & 1,27 \\
\hline Setembro & 2,64 & 2,65 & 2,97 & 4,22 & 4,40 & 3,04 & 1,77 & 2,12 \\
\hline Outubro & 8,70 & 10,06 & 12,64 & 13,55 & 11,43 & 8,35 & 7,50 & 7,99 \\
\hline Novembro & 24,40 & 18,36 & 12,98 & 12,08 & 10,75 & 9,96 & 14,75 & 22,98 \\
\hline Dezembro & 33,41 & 22,15 & 11,56 & 8,74 & 8,36 & 9,98 & 19,41 & 32,00 \\
\hline ANUAL & 147,40 & 116,72 & 85,65 & 74,88 & 63,85 & 59,90 & 88,85 & 136,22 \\
\hline
\end{tabular}

\section{Intensidade de chuva dirigida $\left(1 / \mathrm{m}^{2}\right)$}

Método ISO 15927-3

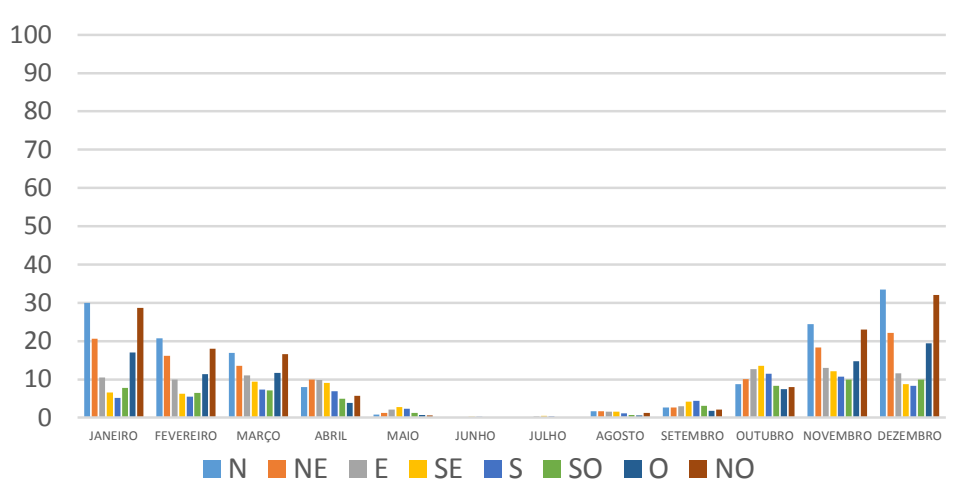

Figura 3.6 - Intensidade de chuva dirigida $\left(1 / \mathrm{m}^{2}\right)$ em Brasília: método ISO 15927-3. 


\subsubsection{Conclusões do estudo comparativo entre os métodos de quantificação}

Os resultados mensais representados nas Figuras 3.4, 3.5, 3.6 e 3.7 mostram que a maior intensidade de chuva dirigida ocorre no mês de dezembro, seguido pelos meses de janeiro, novembro, fevereiro, março e outubro (meses do período chuvoso). No período seco (abril a setembro), a intensidade de chuva dirigida é bastante baixa, principalmente nos meses de maio, junho, julho e agosto.

Quanto à orientação mais exposta à chuva dirigida, a fachada Norte é aquela que recebe a maior quantidade de chuva, ao longo do ano, seguida pela fachada Noroeste. Isso é explicado, considerando que as direções Noroeste e Norte estão entre aquelas onde ocorrem os ventos predominantes associados aos eventos de precipitação (ver Figura 2.24).

As orientações de fachada mais atingidas pela chuva dirigida independem do método (são as mesmas em todos os métodos), pois são resultado da ação combinada da precipitação e vento (direção e velocidade), conforme ilustra a Figura 3.7 que representa as rosas dos ventos resultantes dos três métodos aplicados.

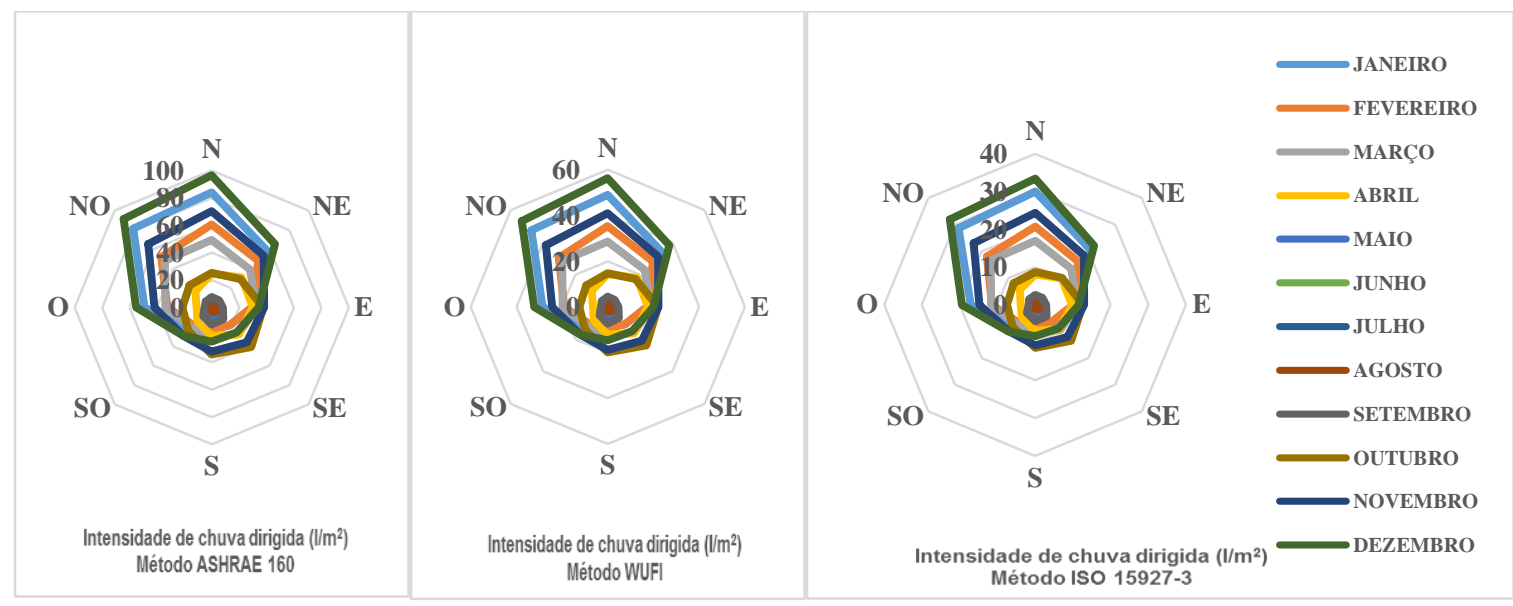

Figura 3.7 - Intensidade de chuva dirigida em Brasília, conforme três métodos de dimensionamento.

Analisando a intensidade da chuva dirigida obtida por meio dos três diferentes métodos de quantificação, observa-se diferenças bastantes significativas nos resultados.

Ao selecionar os parâmetros de cada método, para os estudos realizados, teve-se o cuidado de adotar valores representativos das mesmas condições urbanas e da arquitetura do edifício, para que os resultados pudessem ser comparados.

Essa discrepância entre os valores ocorre porque cada um dos métodos considera diferentes coeficientes de representação das características arquitetônicas e das condições de exposição 
do edifício em relação ao lugar (topografia, rugosidade, altura e geometria do edifício, tipo de cobertura, proteções, etc.).

Essas diferenças já tinham sido analisadas por Freitas (2011) quando comparou diversos métodos de quantificação da intensidade da chuva dirigida para Portugal. Na sua pesquisa, a autora não selecionou o melhor método, pois não conseguiu estabelecer correlação com os valores de medições in situ.

A aplicação dos três principais métodos semi-empíricos (ISO 15927-3, ASHRAE 160 e WUFI) permitiu quantificar a intensidade de água de chuva que é projetada na fachada em cada mês do ano, identificando qual orientação de fachada é mais exposta à umidificação pela ação da chuva dirigida.

Comparando os resultados, constata-se que os montantes calculados pelo método WUFI correspondem a $83 \%$ daqueles obtidos pelo método recomendado pela ASHRAE, enquanto que os valores calculados pelo método da ISO 15927-3 correspondem a cerca de $35 \%$ daqueles obtidos pelo método da ASHRAE.

Importante esclarecer que, nesta análise de comparação entre os três métodos, os montantes pelo método WUFI foram calculados sem considerar o fator de redução de 0,7.

Se a comparação for feita em relação aos montantes calculados pelo método do WUFI, verificase que o método da ASHRAE é cerca de 20\% maior que do WUFI e da ISO 15927-3 é cerca de $40 \%$ do montante dimensionado pelo WUFI.

A Figura 3.8 mostra os gráficos dos montantes calculados por meio dos métodos citados, onde é possível observar as diferenças entre os métodos.

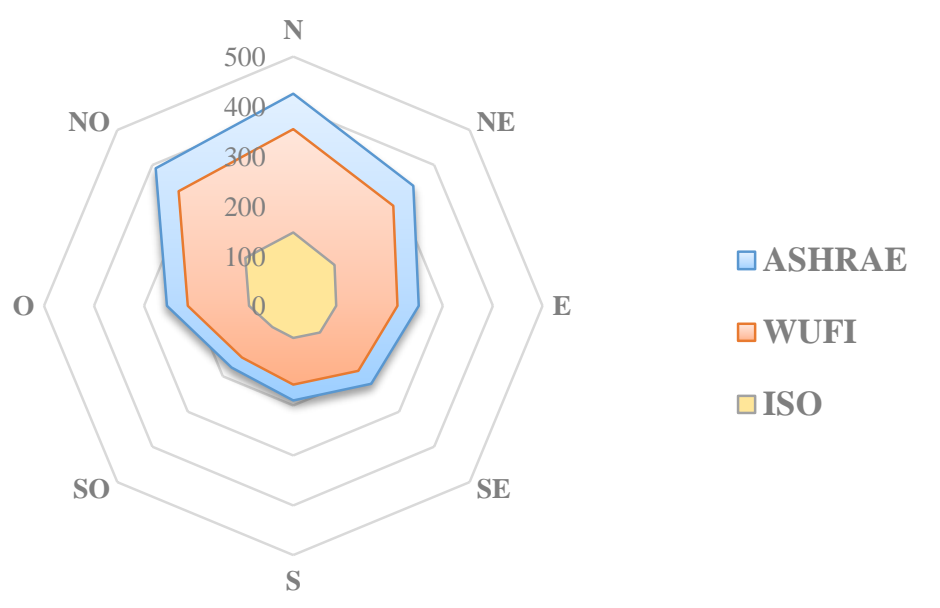

Figura 3.8 - Comparação entre três métodos de quantificação de chuva dirigida para a cidade de Brasília. 
Importante salientar que a diferença entre os métodos resulta em quantidades diferentes de chuva dirigida porque cada método adota diferentes coeficientes de chuva dirigida, cabendo ao usuário decidir qual dos métodos melhor representará a condição urbana e as variáveis relacionadas ao edifício em estudo.

O método do WUFI considera uma única condição, que está relacionada ao fator de parede, isto é, a altura da região da parede onde se está estudando a incidência da chuva dirigida. Para a pior condição, ou seja, para região do edifício acima de 20 metros o WUFI considera um valor igual a 0,2 enquanto o método da ASHRAE considera o valor 1,0 e o método da ISO considera o valor 0,5 . Portanto, constata-se que o parâmetro mencionado é bastante variável entre os métodos.

Quanto às condições urbanas locais onde o edifício está inserido, o WUFI não estabelece nenhum fator, enquanto a ISO estabelece 4 fatores e a ASHRAE considera 2 fatores. Tanto o método da ISO como o método da ASHRAE consideram a constante de proporcionalidade que relaciona a chuva dirigida em uma situação de campo aberto.

A ASHRAE considera, em um único fator, o ajuste necessário para as condições de topografia, rugosidade e exposição do edifício, relacionando os valores com a altura do edifício e com três categorias de exposição. Por outro lado, a ISO adota quatro fatores de ajustes, pois considera separadamente os valores para cada um dos fatores mencionados, resultando em menores montantes calculados.

Para balizar a seleção de qual método é mais representativo para as condições brasileiras, em especial, para o contexto de Brasília, foi necessário a realização de um programa experimental (ver seção 3.12) que permitiu averiguar qual dos métodos representa melhor correlação com os valores de medições feitas in situ.

\subsection{MÉTODOS EXPERIMENTAIS PARA MEDIÇÃO DE CHUVA DIRIGIDA}

Registros sobre medições de chuva em campo aberto constam desde o ano de 1816 , sendo que o primeiro registro sobre medição de chuva incidente em edifícios data de 1937 (BLOCKEN; CARMELIET, 2004). Ao longo dos tempos, os experimentos in situ foram realizados em diversos tipos de estudo com variados dispositivos de medição, visando diferentes objetivos: montantes de chuva projetada sobre as paredes; percurso das gotas de chuva; distribuição da chuva entre as várias orientações; distribuição espacial da chuva na fachada; estanqueidade de 
juntas, de janelas; padrão de manchamento da fachada; formação e escoamento da lâmina; impacto da gota sobre a superfície; absorção da superfície; entre outros.

Segundo Blocken e Carmeliet (2006), as medições in situ tem sido a principal ferramenta nas pesquisas de chuva dirigida, embora os métodos semi-empíricos e os modelos numéricos de simulação computacional sejam cada vez mais utilizados para as quantificações. No entanto, as medições in situ continuam a ser importantes pois são a base essencial para o desenvolvimento e validação dos modelos analíticos e numéricos. Inclusive, os autores citados sinalizam que, para validar o avanço dos modelos numéricos baseados na Dinâmica dos Fluídos Computacionais (Computational Fluid Dynamics - FD) será necessária muita pesquisa futura.

\subsubsection{Dispositivos para medição in situ}

Os dispositivos de medição in situ são projetados para colher a chuva trazida pelo vento e são, basicamente, constituídos por uma placa coletora ligada por um tubo condutor à um reservatório. A chuva coletada pode ser medida em volume ou pesada.

A Figura 3.9 mostra um dos primeiros dispositivos usados para medições em campo aberto, com abertura na horizontal para captar a precipitação (superfície vertical) e aberturas verticais para captar a chuva projetada pela ação do vento, para quatro direções.

As Figuras 3.9, 3.10, 3.11, 3.12, 3.13 e 3.15 mostram diferentes dispositivos para a medição na superfície da fachada de edifícios. A Figura 3.14 mostra um pluviômetro de báscula com mecanismo de gravação.

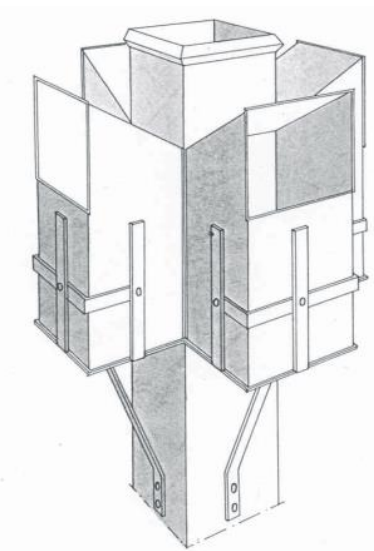

Fonte: Blocken; Carmeliet (2004).

Figura 3.9 -

Dispositivo para medição de chuva em campo aberto, projetado em 1937 por Norwegian Building Research Institute.

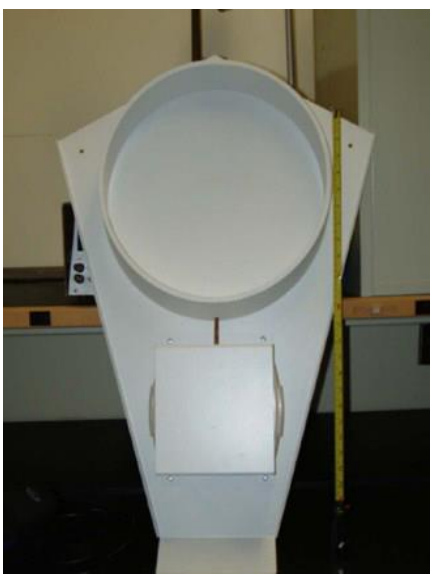

Fonte: Krpan (2013)

Figura 3.10 - Dispositivo para medição de chuva dirigida, projetado por National Research Council Canada.

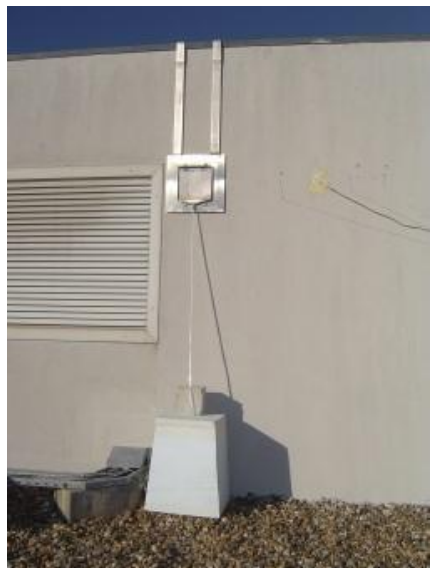

Fonte: Barreira (2010).

Figura 3.11 - Dispositivo para medição de chuva dirigida projetado pelos pesquisadores da Universidade do Porto (FEUP). 
As medidas em volume podem ser feitas de forma manual ou, automaticamente, por meio de pluviômetros (KRPAN, 2013; BLOCKEN; CARMELIET, 2005, 2006). Preferencialmente, os dados de precipitação, velocidade e direção do vento podem ser fornecidos pelas estações meteorológicas.

Nos experimentos para medição de chuva dirigida, não existe nenhum padrão normatizado para os coletores, tampouco procedimentos para estimar erros de medida. Cada pesquisador desenvolve o seu dispositivo de medição. Existe uma predominância do tipo "coletores de placa”, mas há uma grande variação de forma, tamanho e materiais usados pelos diversos pesquisadores (van MOOK, 1999; GE; KRPAN, 2007; KUBILAY, et al., 2014).

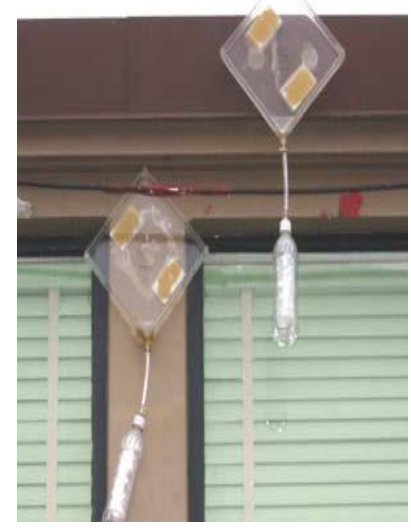

Fonte: Ge; Krpan (2007)

Figura 3.12 - Dispositivo para medição de chuva dirigida.

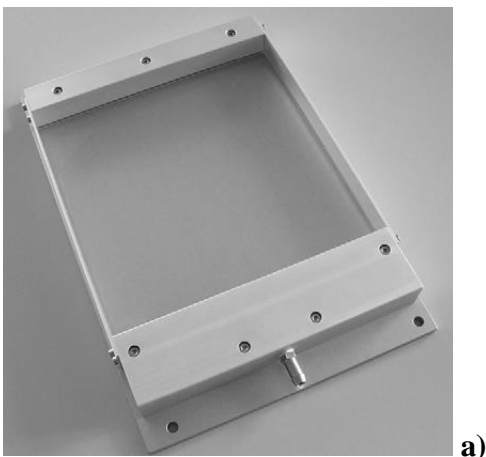

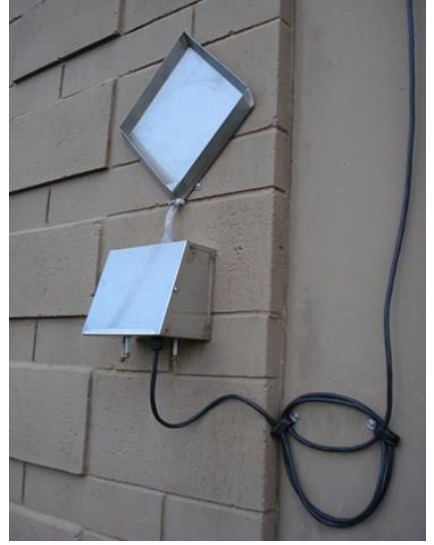

Fonte: Ge; Krpan (2009)

Figura 3.13 - Dispositivo para medição de chuva dirigida.
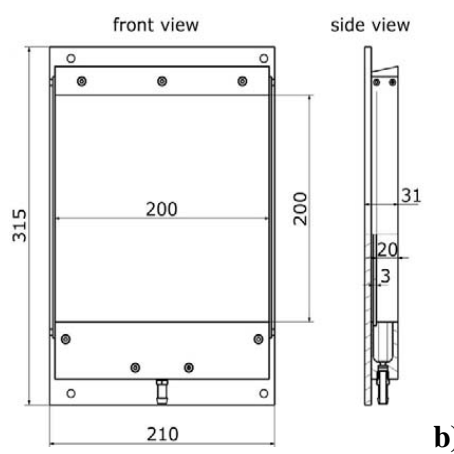

b)

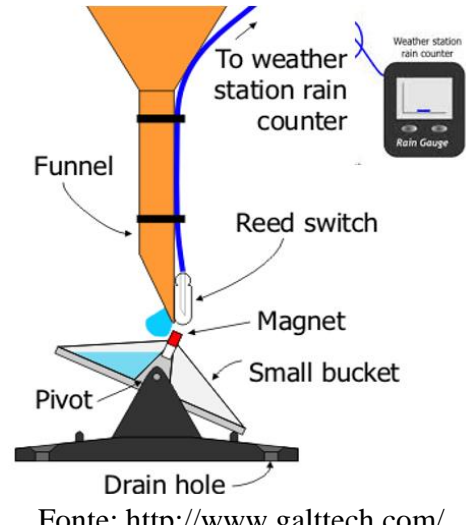

Fonte: http://www.galttech.com/

Figura 3.14 - Pluviômetro de báscula com contador de pulso.

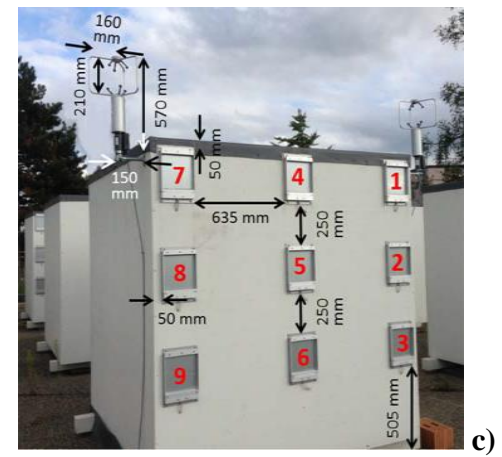

Fonte: Kubilay; Derome; Blocken; Carmeliet (2014).

Figura 3.15 - a) Dispositivo de medição de chuva dirigida; b)dimensionamento do coletor; c) aparato no Campus da Swiss Federal Laboratories de Ciência dos Materiaise Tecnologia (APEM) em Dübendorf, Suiça.

\subsubsection{Precisão e erro nas medições}

Blocken e Carmeliet (2006) desenvolveram uma pesquisa para investigar a precisão nas medições de chuva dirigida em edifícios. Os autores citam que o principal erro associado às 
medições é a água não medida, aquela que fica aderida na superfície coletora na forma de gotas ou de filme. Entre as principais razões, são destacadas:

- evaporação da água aderida à área de coleta;

- evaporação da água aderida no lado interior do tubo de drenagem;

- perdas por evaporação da água no reservatório;

- respingamento (salpicos) de gotas a partir da área de coleta;

- condensação em alguma parte do dispositivo de coleta;

- erros por perturbação no fluxo dos ventos.

Nos estudos comparativos conduzidos pelos autores citados foram utilizados 6 diferentes tipos de coletores com diferentes materiais: PVC (policloreto de vinil); PMMA (polimetilmetacrilato -acrílico); PTFE (politetrafluoroetileno); vidro comum; vidro com um revestimento hidrófilo; vidro com um revestimento hidrofóbico.

Entre as principais conclusões relatadas pelos pesquisadores, destaca-se que a evaporação da água de adesão na superfície coletora é a principal fonte de erro. Para diminuir os erros por evaporação da água aderida na superfície, recomendam-se coletores com pequena área de superfície de coleta.

Os estudos do ângulo de contato das gotas na superfície dos diferentes materiais não forneceu nenhuma indicação direta a respeito da quantidade de água aderida no coletor relacionada a materiais mais ou menos hidrofóbicos, provavelmente, porque nem sempre a aderência da água se dá na forma de gota, mas sim na forma de filme.

Nas superfícies verticais, segundo Blocken e Carmeliet (2006), era de se esperar que os materiais hidrofóbicos promovessem um maior escoamento da água. No entanto, os autores relatam que isso nem sempre ocorreu nos estudos realizados, portanto, não recomendam materiais hidrofóbicos, como o PTFE e o vidro com revestimento hidrofóbico, pois aumentam os erros de medição devido à maior adesão de água que os materiais PMMA e PVC. Os coletores de vidro são preferíveis que coletores de PMMA e PVC. Apesar das placas de vidro serem hidrofílicas, foi pequena a quantidade de água aderida.

A condensação é um tipo de erro que, ao contrário dos outros, contribui com o volume de água colhida. Mas, segundo os autores, a contribuição é muito pequena.

A evaporação da água colhida no reservatório pode ser minimizada, desde que sejam reduzidas a área de exposição à radiação solar e a taxa de ventilação no reservatório. 
A estimativa de cada um dos erros associada com as medições de chuva dirigida mostrou-se de difícil obtenção, especialmente os erros associados ao vento e ao impacto das gotas na superfície coletora. Em especial, os autores consideram que a melhor opção para estimar estes dois tipos de erros são os estudos por simulação numérica com CFD.

A perturbação do vento na proximidade do coletor ocorre pela presença do próprio coletor, por isso a recomendação é adotar uma pequena altura de borda (os autores sugerem $10 \mathrm{~mm}$ ). Outra forma de diminuir os erros causados pela perturbação dos ventos é selecionar os eventos de chuva associados à ventos com direção aproximadamente perpendicular à fachada em estudo.

Os erros de medição por respingamento das gotas de chuva (colisão da gota na superfície sólida) são menores em eventos de chuva que se caracterizam por velocidade de vento inferior a 10 $\mathrm{m} / \mathrm{s}$ e com precipitação com intensidades menor que $20 \mathrm{~mm} / \mathrm{h}$, o que possibilita tamanho de gotas com diâmetros entre 1,0 e $3,0 \mathrm{~mm}$.

O erro relativo pode ser reduzido para sequência de eventos de chuva dirigida com volumes maiores de água coletada. Segundo Blocken e Carmeliet (2004), coletas de pequenas quantidades de chuva dirigida (cerca de $0,08 \mathrm{~mm}$ ) podem conter erro de medição de $100 \%$, isto é, toda a água colhida fica aderida na superfície do dispositivo; para valores acima desse limite, pode-se considerar erros absolutos de medição constante, ou seja, o erro de medição relativa diminui à medida que o valor colhido de chuva dirigida aumenta.

Krpan (2013) também testou cinco materiais para coletores de chuva dirigida: vidro, polimetilmetacrilato (PMMA, acrílico), alumínio, aço inoxidável eletro-banhado e aço inoxidável polido. De acordo com as conclusões de pesquisa do autor, entre os materiais testados, o vidro foi o material que apresentou a menor quantidade de água aderida, no entanto, o coletor é relativamente pesado, difícil de fabricar e instalar. O desempenho dos materiais aço inoxidável polido e PMMA (acrílico) foram semelhantes. O pesquisador utilizou o coletor projetado por Ge e Krpan (2009).

Para as suas pesquisas, Krpan (2013) utilizou um coletor em forma de diamante com as dimensões de 228,6 $\mathrm{mm}$ por 228,6 mm. A borda do coletor, com 25,4 mm, é projetada a um ângulo de $45^{\circ}$. Nas duas bordas superiores a projeção é para fora e nas duas bordas inferiores é para dentro, permitindo assim a captura da água e a sua condução pelo tubo de escoamento, direto para o reservatório. A projeção da borda do coletor foi escolhida para minimizar a perturbação do campo de vento e desviar a lâmina da água ao redor do coletor. A Figura 3.13 mostra um protótipo do coletor utilizado por Krpan (2013). 
Todas as recomendações sugeridas pelos autores, citadas nesta seção, serviram de diretrizes para a concepção dos aparatos utilizados nas medições in situ realizadas no programa experimental desta tese.

\subsubsection{Referenciais metodológicos para quantificação da chuva dirigida a partir das medições in situ}

Os experimentos para medição da intensidade da chuva dirigida buscam, em geral, determinar a taxa de captura (catch ratio) que é obtida pela relação entre a quantidade de água recolhida pelo dispositivo na posição vertical (chuva dirigida) e a precipitação (água coletada na posição horizontal).

Blocken e Carmeliet (2004) denominam a taxa de captura como coeficiente de chuva dirigida (driving rain coefficient) que se refere à razão entre a intensidade da chuva dirigida e a intensidade de precipitação horizontal.

$$
\eta=\frac{R_{w d r}}{R_{h}}
$$

Onde,

$\eta \quad$ Taxa de captura (catch ratio) ou coeficiente de chuva dirigida (driving rain coefficient);

$R_{w d r}$ Intensidade de chuva dirigida (quantidade projetada na superfície vertical);

$R_{h} \quad$ Precipitação (quantidade coletada na superfície horizontal).

Blocken e Carmeliet (2004) relatam que Hoppestad (1955) conduziu quatro experimentos em campo aberto para a determinação da relação entre a chuva dirigida e a precipitação $\left(R_{h}\right)$ e vento (U).

A Equação 3.11 foi a expressão utilizada por Hoppestad que chamou o $R w d r$ de relação de chuva dirigida e o fator $k$ de coeficiente de chuva dirigida. Os valores obtidos foram os seguintes: Oslo- $k=0,130$, Bergen $k=0,188$, Trondheim $-k=0,221$ e Tromso- $k=0,148$, produzindo um valor médio de 0,180 .

$$
R_{w d r}=k . U . R_{h}
$$

Foi baseado nos valores experimentais de Hoppestad e nas relações empíricas relacionadas à precipitação e ao tamanho médio e velocidade terminal das gotas de chuva que Lacy propôs $k=0,222 \mathrm{~s} / \mathrm{m}$ para o coeficiente de chuva dirigida (ver Equação 3.2). 
Observa-se que os valores mencionados consideram uma condição de vento sem perturbação; não é levado em consideração o padrão de fluxo de vento em torno do edifício, tampouco os fenômenos locais induzidos pela topografia e pelo próprio edifício.

Blocken e Carmeliet (2004) enfatizam que o valor $k=0,222 \mathrm{~s} / \mathrm{m}$ é um valor teórico (free driving rain coefficient), válido para condições de campo aberto apenas (sem prédios).

Straube e Burnett (1997) encontraram em seus experimentos valores para o coeficiente de chuva dirigida variando entre $0,20 \mathrm{~s} / \mathrm{m}$ e $0,25 \mathrm{~s} / \mathrm{m}$ para condições médias, mas podendo sofrer grande variação para diferentes intensidades de precipitação. O coeficiente pode variar de mais de 0,5 $\mathrm{s} / \mathrm{m}$ para garoa e $0,1 \mathrm{~s} / \mathrm{m}$ para aguaceiros intensos.

Baseado nas pesquisas de diversos autores, Blocken e Carmeliet (2004) citam valores para os coeficientes de chuva dirigida variando entre $0,02 \mathrm{~s} / \mathrm{m}$ e $0,26 \mathrm{~s} / \mathrm{m}$, dependendo do tamanho do edifício ou da posição na fachada. Por isso, Künzel (1994) recomenda que o coeficiente de chuva dirigida deve refletir um valor médio, considerando vários eventos de chuva.

Enfim, para avaliar a quantidade de chuva dirigida em edifícios, inseridos em uma condição urbana, a expressão $R_{w d r}=\propto \cdot U \cdot R_{v} \cdot \cos (D-\theta)$ deve ser usada com um valor médio apropriado para $\alpha$ (ver Equação 3.3 e os métodos semi-empíricos abordados neste capítulo).

\subsection{PROGRAMA EXPERIMENTAL PARA MEDIÇÃO IN SITU DE CHUVA DIRIGIDA NA CIDADE DE BRASÍLIA-DF}

Este programa experimental teve caráter exploratório, considerando que não existe relato de medição de chuva dirigida em fachadas no Brasil, assim como nenhuma metodologia proposta para a sua coleta in situ, em território nacional.

As medições foram realizadas durante os meses de fevereiro e março de 2015, em duas diferentes localidades. Na sede do INMET foram fixados quatro aparatos, orientados para Noroeste, Norte, Nordeste e Leste. Na cobertura do bloco H na SQN 214 foram fixados três aparatos, dois deles orientados para Norte e um deles orientado para Leste.

As medições das coletas de chuva dirigida foram feitas diariamente, conforme as ocorrências diárias dos eventos de precipitação.

A coleta, em curtos intervalos de tempo, logo após a sequência de eventos horários de chuva, evitou períodos prolongados de insolação, diminuindo a probabilidade de evaporação da água colhida. As medições foram feitas usando provetas como medidores de volume. 
Os resultados obtidos in situ foram correlacionados com os dados da estação meteorológica, por meio dos métodos de cálculo semi-empírico, obtendo assim coeficientes de chuva dirigida para a cidade de Brasília.

\subsubsection{Objetivos do programa experimental}

\section{a) Objetivo geral:}

- Estimar um coeficiente de chuva dirigida representativo do contexto urbano em estudo, para a quantificação da intensidade de chuva dirigida, em fachadas de edifícios na cidade de Brasília-DF.

\section{b) Objetivos específicos:}

- Propor e testar um método de coleta de chuva dirigida, de baixo custo e simples aplicação, para todo o território nacional.

- Determinar os coeficientes de chuva dirigida, considerando as fachadas em duas situações de densidade urbana.

- Comparar os resultados das medições in situ com os resultados de três métodos semiempíricos de referência.

- Selecionar um método semi-empírico de quantificação de chuva dirigida mais representativo para os estudos higrotérmicos por meio de simulação computacional.

\subsubsection{Descrição do aparato de coleta de chuva dirigida}

Cada aparato de medição de chuva dirigida consiste em um coletor interligado por um tubo condutor a um reservatório (Figura 3.16).

O coletor constitui-se de uma bandeja de alumínio compósito com pintura eletrostática na cor branca. A bandeja diamantada de forma quadrada, com $25 \mathrm{~cm}$ de lado, possui área de $625 \mathrm{~cm}^{2}$ corresponde à $1 / 16$ de $1 \mathrm{~m}^{2}$. As bordas de $25 \mathrm{~mm}$ são dobradas a $45^{\circ}$ em relação à vertical, sendo que as bordas inferiores são projetadas para dentro e as bordas superiores para fora.

A bandeja coletora, confeccionada em alumínio compósito com pintura eletrostática de fábrica, possui superfície lisa e brilhante, de baixa absorção de umidade, baixa emissividade, baixo condutividade térmica e facilidade no escoamento das gotas de água. O vértice inferior da bandeja coletora é chanfrado e inclinado, dificultando a perda da água enquanto ela é recolhida pelo tubo condutor. Neste vértice inferior da bandeja existe um tubo liso de alumínio de $20 \mathrm{~mm}$ de diâmetro, conectado à uma mangueira de polietileno de $3 / 4$ " de parede grossa que capta a água e a conduz para um reservatório que é protegido do vento e isolado termicamente por um recipiente de isopor. 


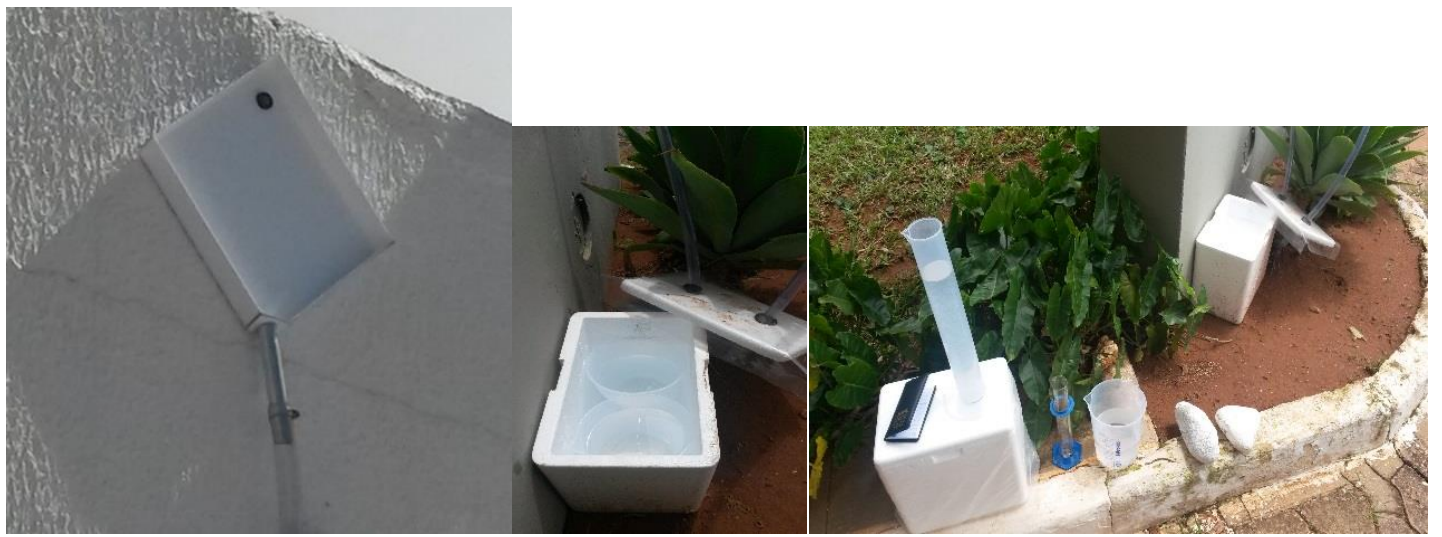

Figura 3.16 - Aparato de coleta de chuva dirigida em Brasília: a) bandeja coletora; b) recipiente coletor protegido pelo recipiente protetor (caixa térmica de isopor com tampa); c) provetas para medição.

Cada recipiente de coleta foi dimensionado para suportar um volume de chuva incidente correspondente a 2 litros de água, equivalente a $32 \mathrm{~mm}$ de precipitação acumulada no plano horizontal. Para esse dimensionamento foi considerada uma situação extrema onde o valor precipitado no plano horizontal, sob a ação do vento atuando diretamente na direção do coletor, é totalmente projetado para o plano vertical. No caso da cidade de Brasília, foi possível adotar tal procedimento considerando que a chuva nessa intensidade não acontece frequentemente (durante 13 anos de dados horários da série 2001-2013 ocorreram somente 20 eventos com precipitação horária maior que $32 \mathrm{~mm}$ ).

\subsubsection{Localização dos aparatos de coleta de chuva dirigida}

Os aparatos foram fixados em duas localizações urbanas:

a) Sede do INMET (Figuras 3.17, 3.18 e 3.19);

b) SQN 214 - cobertura do Bloco H (Figuras 3.17, 3.20, 3.21, 3.22 e 3.23).

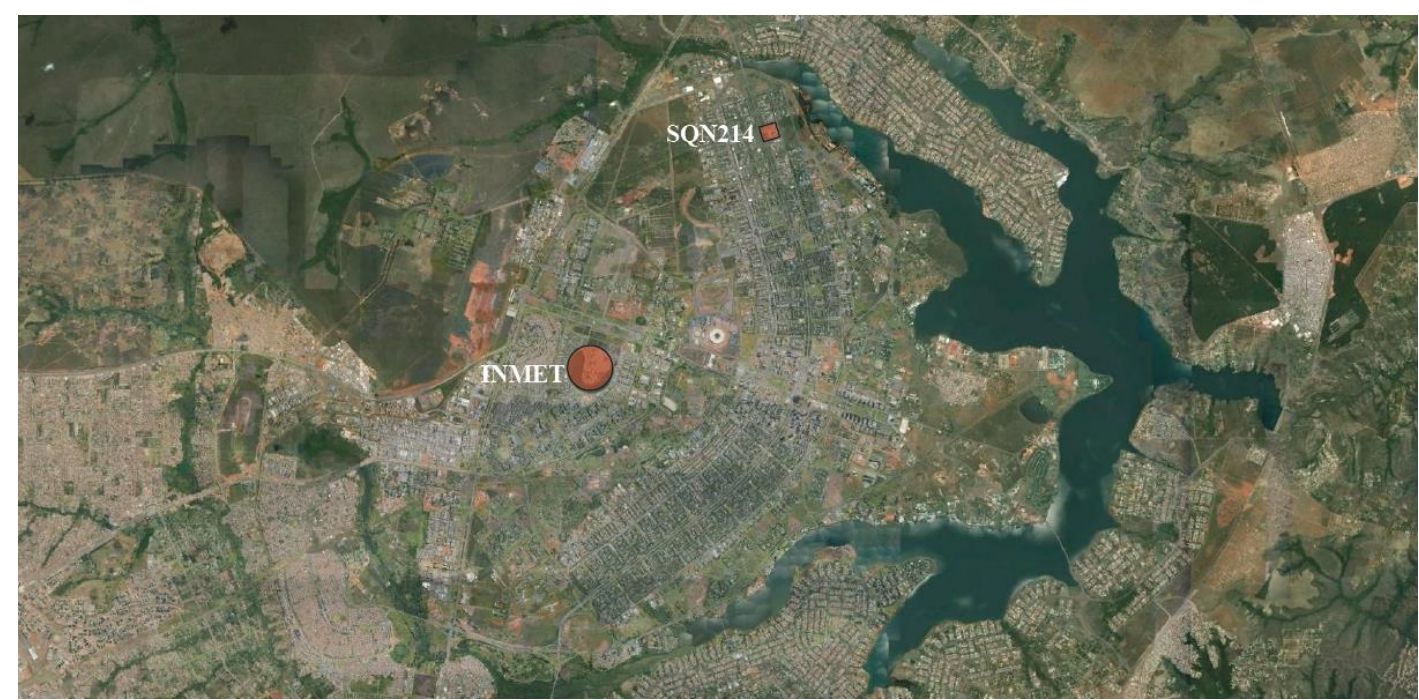

Figura 3.17 - Plano Piloto de Brasília: localização do Instituto de Meteorologia-INMET no Sudoeste e da SQN 214 na Asa Norte. 

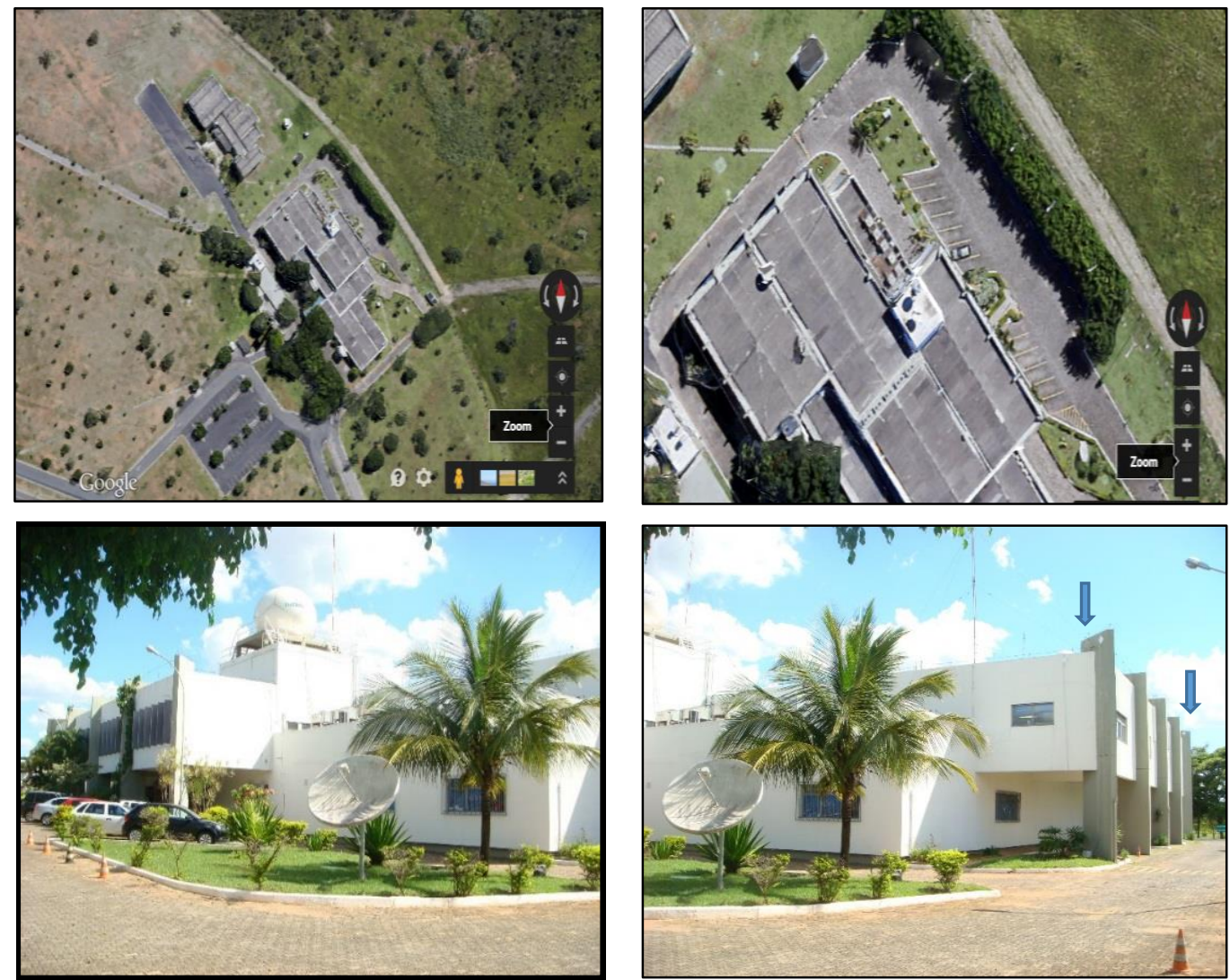

Figura 3.18 - Sede do INMET em Brasília: localização dos aparatos de mediação de chuva dirigida.
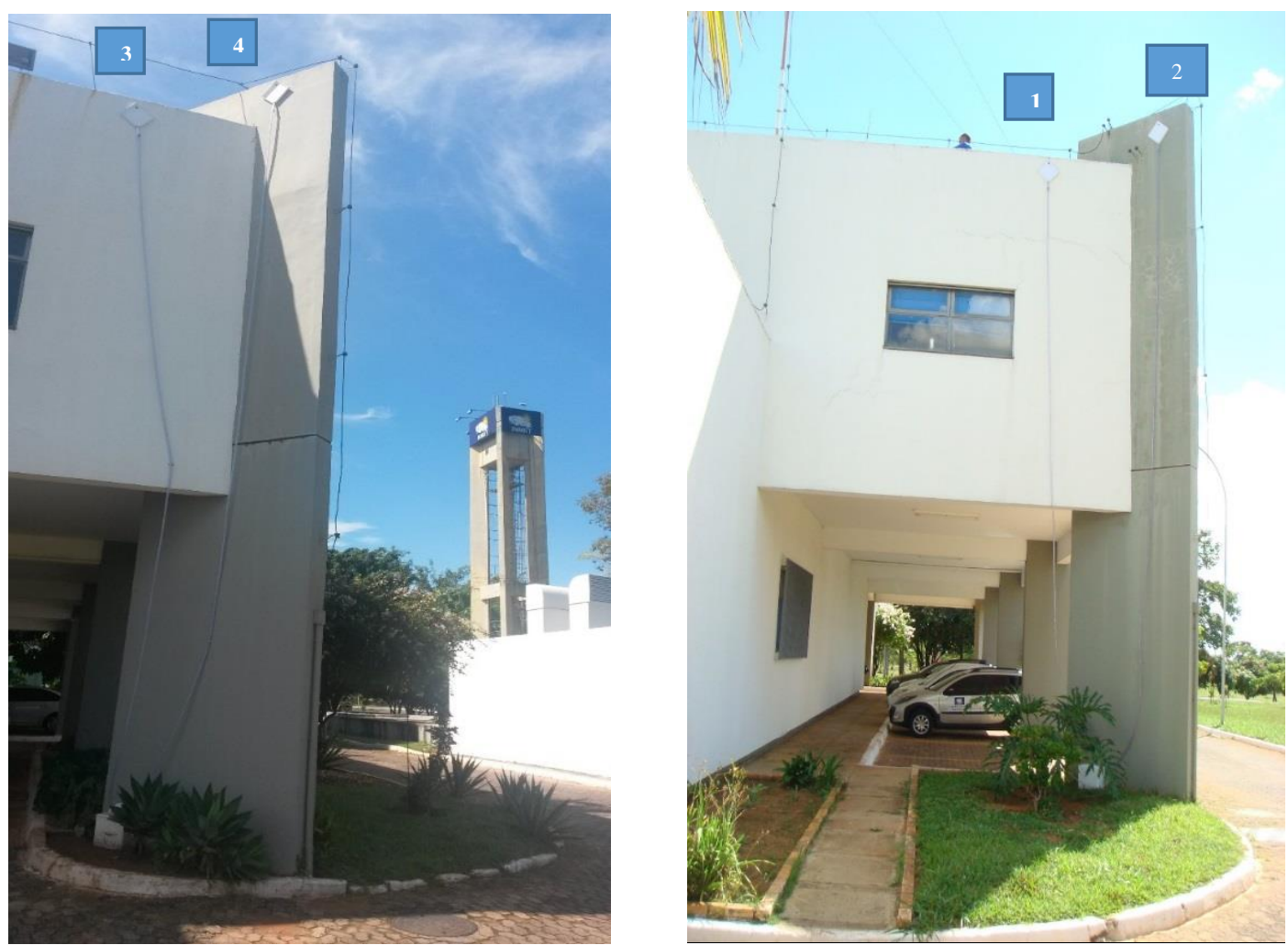

Figura 3.19 - Aparatos de coleta de chuva dirigida na sede do INMET em Brasília: 1-Fachada Noroeste; 2-Fachada Norte; 3- Fachada Nordeste; 4- Fachada Leste. 
A sede do Instituto de Meteorologia-INMET está localizada na cidade de Brasília-DF no setor Sudoeste. Nesta área está situada a estação automática A001 do INMET. A sede do INMET é um edifício com cerca de 10 metros de altura, cuja fachada principal é orientada para Nordeste. $\mathrm{Na}$ fachada lateral, orientada para Noroeste, existe uma sequência de pilares externos. Os pilares posicionados nos vértices dessa fachada são inclinados a $45^{\circ}$ em relação às faces Noroeste e Nordeste, permitindo assim obter superfícies com orientação Norte e Leste.

A geometria do edifício, sua altura e orientação favoreceram o posicionamento de 4 aparatos em 4 diferentes orientações de fachada: Noroeste, Norte, Nordeste e Leste. A altura do edifício também foi um fator importante, pois permitiu posicionar as bandejas de coleta a cerca de 10 metros de altura, similar à altura padronizada da estação automática para os medidores de vento.
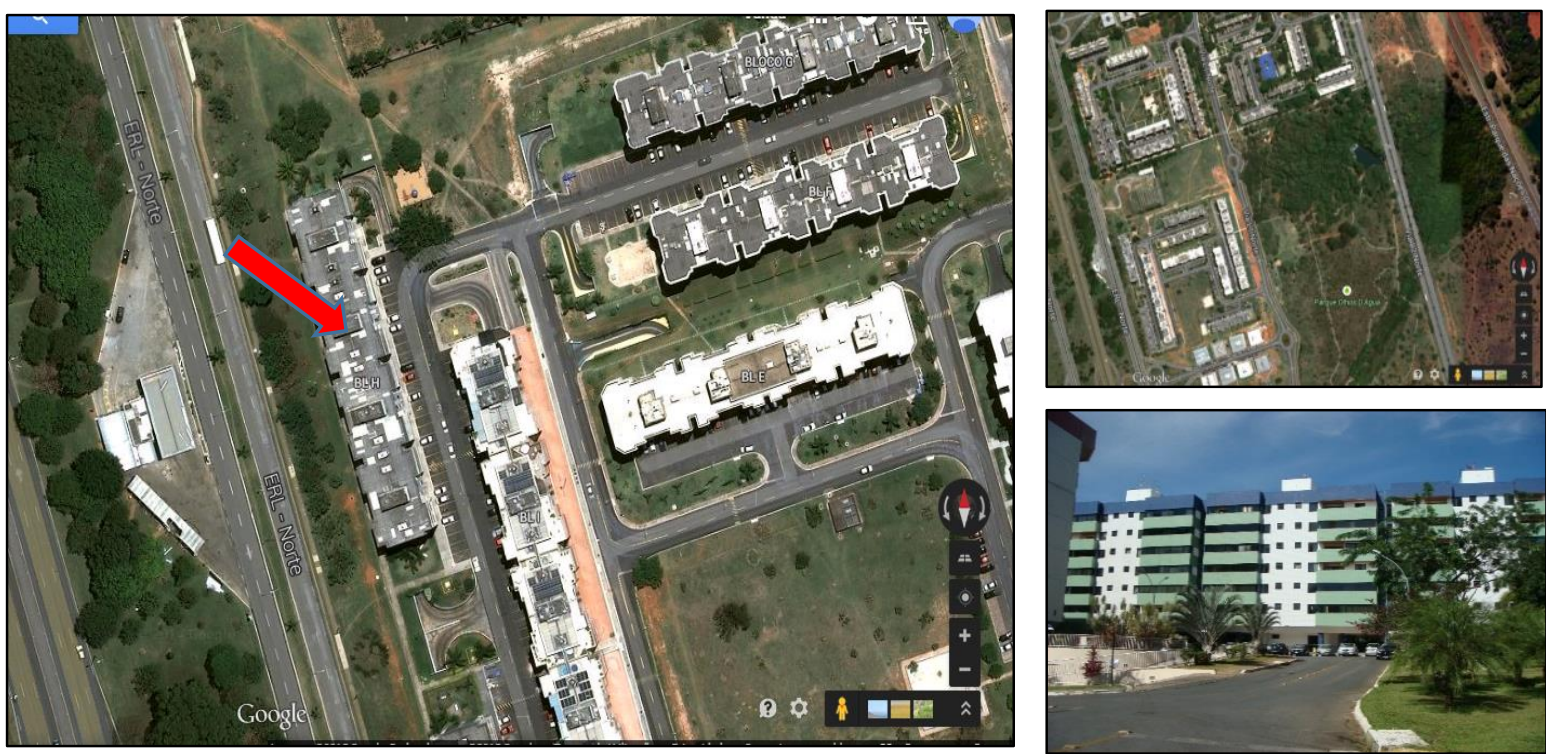

Figura 3.20 - Bloco H - SQN 214 - Asa Norte - Brasília.
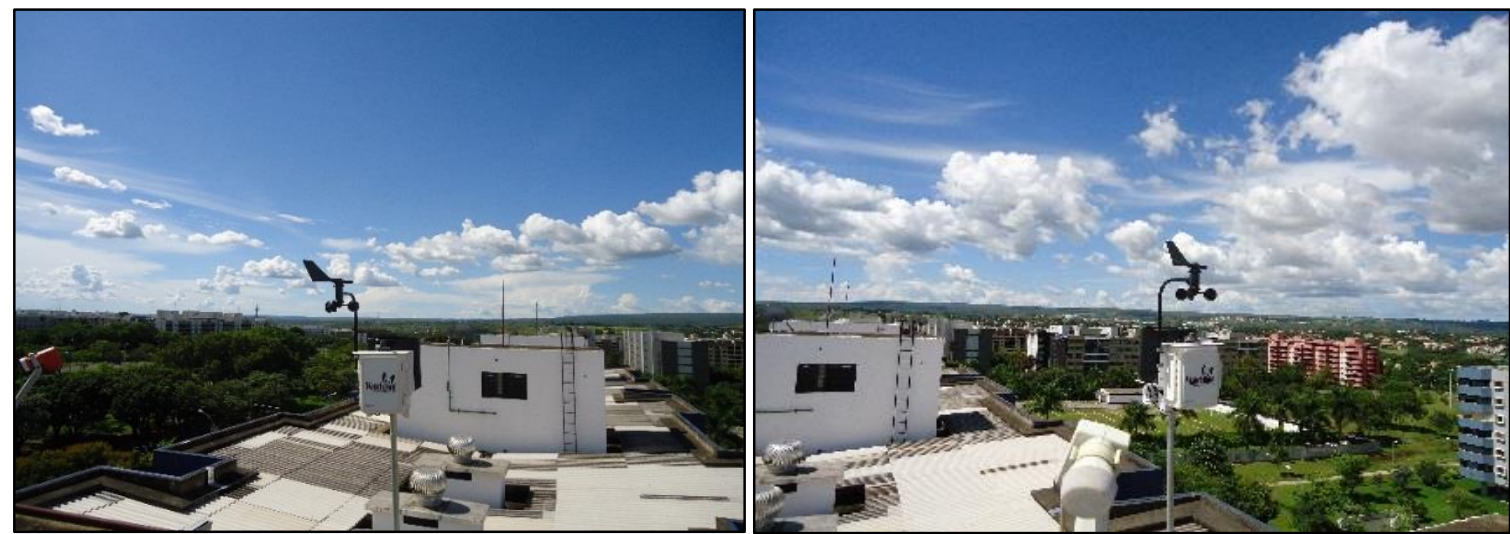

Figura 3.21 - Posicionamento da estação meteorológica portátil na cobertura do Bloco H - SQN 214 em Brasília. 
O Bloco H na SQN 214 é um edifício com 6 pavimentos e pilotis, localizado na Asa Norte do Plano Piloto, na cidade de Brasília -DF. Na torre da caixa d'água da cobertura do edifício foi instalada uma estação meteorológica portátil da marca WatchDog - model 900ET da Spectrum Technologies Inc., com coleta de dados horários registrados em um datalogger. Os aparatos de medição foram fixados na parede Norte e na parede Leste da torre da caixa d'água.

As bandejas foram fixadas próximas à estação portátil, portanto mantendo altura similar.

$\mathrm{Na}$ parede Norte foram fixados dois aparatos, com 2,00m de distância entre eles e $0,50 \mathrm{~m}$ do vértice da parede. $\mathrm{O}$ aparato da parede Leste também distou $0,50 \mathrm{~m}$ do vértice vertical da parede.
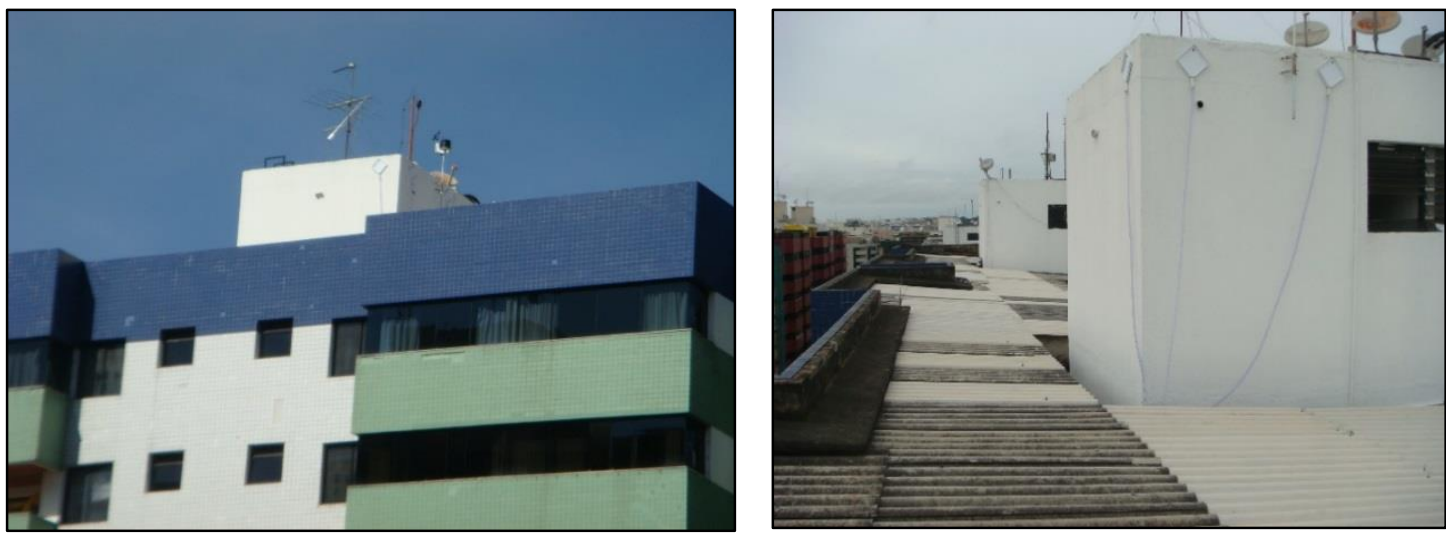

Figura 3.22 - Cobertura do bloco H na SQN 214 em Brasília: a) torre da caixa d'água; b) posicionamento dos aparatos.
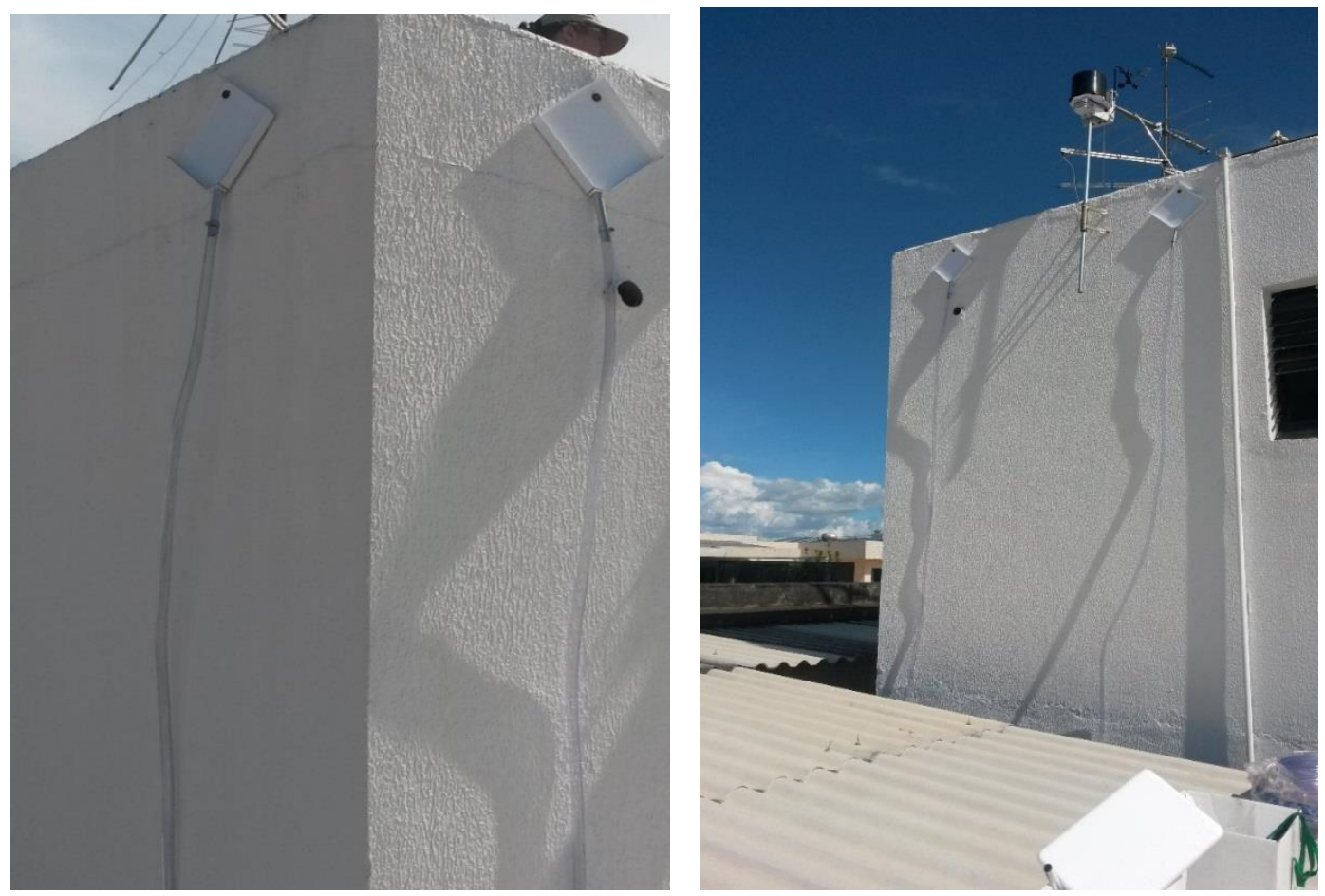

Figura 3.23 - Bloco H - SQN 214 em Brasília: a) posicionamento nas paredes Leste e Norte em relação ao vértice; b) posicionamento da estação meteorológica portátil e dos dois aparatos na parede Norte. 


\subsubsection{Apresentação e discussão dos resultados do programa experimental de chuva dirigida}

Durante os meses de fevereiro e março de 2015 foram colhidos os montantes de chuva dirigida projetados nos 4 aparatos fixados na sede do INMET, orientados para Noroeste, Norte, Nordeste e Leste, e três aparatos fixados na cobertura do bloco H na SQN 214, dois deles orientados para Norte e um deles orientado para Leste.

Para validar o programa experimental realizado, foi necessário avaliar se as amostras colhidas in situ durante dois meses eram representativas de uma série de maior duração. Para isso, foram comparados os números de eventos horários de precipitação e as correspondentes precipitações acumuladas no período, tanto dos locais dos experimentos como da série 2001-2013.

Nos dois meses de medições de chuva dirigida foram registrados 106 eventos horários de precipitação com 284,0 mm acumulado, na SQN 214 pela estação meteorológica portátil. No mesmo período, na estação automática de superfície A001 do INMET, foram computados 178 eventos horários de precipitação com 418,6 mm acumulados.

Considerando a precipitação acumulada de todos os meses de fevereiro e março, em 13 anos de dados da série 2001-2013, foram encontrados 1939 eventos horários de precipitação que acumularam 4.578,8 mm. Considerando a média nos dois meses da série 2001-2013, esses valores correspondem a 149 eventos horários de precipitação com 352,2 mm acumulado.

A Tabela 3.11 mostra os números dos eventos horários de precipitação e a precipitação acumulada para as três situações analisadas.

Tabela 3.11 - Relação de eventos horários de precipitação horizontal nos meses de fevereiro e março, em Brasília.

\begin{tabular}{cccc}
\hline Fonte & Período & $\begin{array}{c}\text { Número de eventos horários de } \\
\text { precipitação }\end{array}$ & $\begin{array}{c}\text { Precipitação acumulada no } \\
\text { período em mm }\end{array}$ \\
\hline \hline $\begin{array}{c}\text { Amostra } \\
\text { coletada na } \\
\text { SQN214 }\end{array}$ & $28 / 01 / 2015$ a 28/03/2015 & 106 registros horários & $284,0 \mathrm{~mm}$ \\
\hline $\begin{array}{c}\text { Amostra } \\
\text { coletada na } \\
\text { Sede do } \\
\text { INMET }\end{array}$ & $28 / 01 / 2015$ a 28/03/2015 & 178 registros horários & $418,6 \mathrm{~mm}$ \\
\hline $\begin{array}{c}\text { Série histórica } \\
\mathbf{2 0 0 1 - 2 0 1 3} \\
\text { (INMET) }\end{array}$ & $\begin{array}{c}\text { Todos os meses de fevereiro e } \\
\text { março da série 2001-2013 }\end{array}$ & $\begin{array}{c}1939 \text { registros horários (13 anos) } \\
149 \text { registros (média do período) }\end{array}$ & 352,2 mm (média do período) \\
\hline
\end{tabular}

As amostras foram submetidas a testes estatístico para avaliar a hipótese de normalidade dos dados. Quando os dados não apresentam distribuição normal, os testes não paramétricos são os mais recomendados. Neste caso, como as amostras não atenderam aos critérios de normalidade, 
foi realizado um teste de comparação denominado Kruskal-Wallis que é uma extensão do teste de Wilcoxon-Mann-Whitney.

O teste de Kruskal-Wallis (KW) é um teste não paramétrico utilizado para comparar três ou mais populações. Ele é usado para testar a hipótese nula de que todas as populações possuem funções de distribuição iguais contra a hipótese alternativa de que ao menos duas das populações possuem funções de distribuição diferentes.

A Figura 3.24 mostra o resultado do teste Kruskal-Wallis aplicado às amostras, sendo que o valor encontrado igual a 0,4085 é maior que o nível de significância estabelecido de 0,05, ou seja, não se comprovou diferença entre as amostras testadas.

Portanto, os testes de hipótese permitiram comprovar que não há diferença estatisticamente significativa entre as amostras de precipitação registradas na sede do INMET e na SQN214, quando comparadas entre si e com os dados da série histórica 2001-2013.

Conclui-se que, sendo as amostras de precipitação correspondentes entre si, as chuvas dirigidas coletadas nas localidades INMET e SQN são representativas da série história 2001-2013, nos meses analisados.

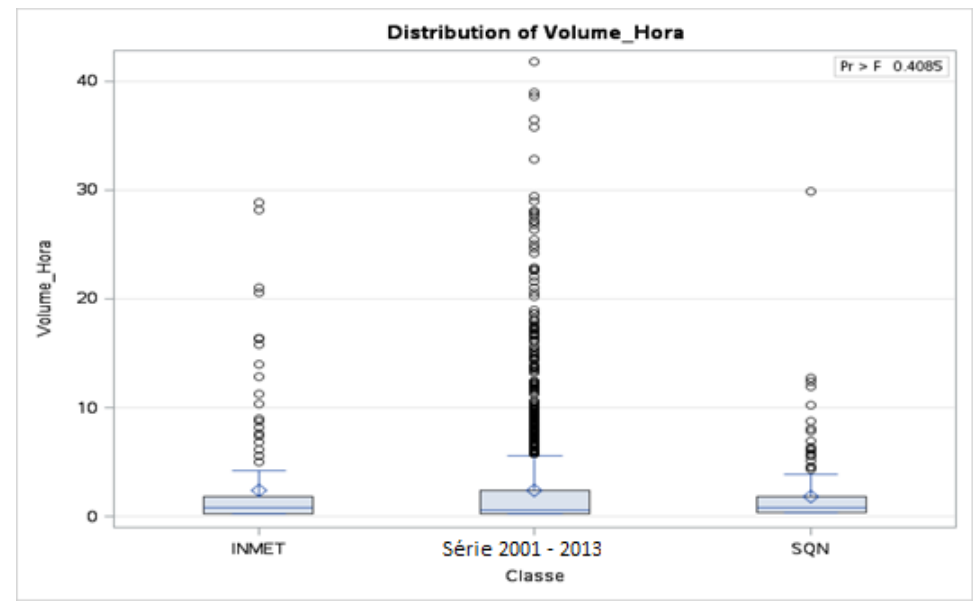

Figura 3.24 - Análise comparativa entre as medianas das amostras coletadas na Sede de do INMET, na SQN e os dados da série 2001-2013 da estação automática de superfície A001 em Brasília.

Todas as chuvas precipitadas no período de estudo foram medidas, no entanto, após um controle de qualidade dos dados registrados, verificando as falhas de registro na ocorrência simultânea entre vento e precipitação, foram descartadas as medições que não tiveram registros completos de dados na estação. Assim, para o INMET, a amostra foi composta pelas medições que tiveram dados de precipitação e vento registrados pela estação, nas horas correspondentes ao período de chuva dirigida coletada (Tabela 3.12). O Quadro 3.15 apresenta os resultados referentes à 
determinação do coeficiente de chuva dirigida $(\alpha)$. A Figura 3.25 ilustra a regressão linear entre as variáveis.

Tabela 3.12 - Apresentação da amostra coletada na Sede de do INMET e na estação automática de superfície A001 em Brasília.

\begin{tabular}{|c|c|c|c|c|c|}
\hline Eventos & $V \cdot P \cdot \cos (D-\theta)$ & Medição in situ & Eventos & $V \cdot P \cdot \cos (D-\theta)$ & Medição in situ \\
\hline 1 & 32,55 & 4,80 & 29 & 8,36 & 1,44 \\
\hline 2 & 128,87 & 19,20 & 30 & 34,35 & 4,80 \\
\hline 3 & 39,56 & 9,92 & 31 & 7,31 & 0,32 \\
\hline 4 & 29,54 & 8,32 & 32 & 62,91 & 5,44 \\
\hline 5 & 0,43 & 0,03 & 33 & 2,58 & 0,02 \\
\hline 6 & 22,50 & 4,03 & 34 & 0,97 & 0,05 \\
\hline 7 & 16,00 & 1,18 & 35 & 7,68 & 0,78 \\
\hline 8 & 77,47 & 25,28 & 36 & 9,75 & 4,88 \\
\hline 9 & 6,51 & 3,55 & 37 & 106,87 & 21,28 \\
\hline 10 & 1,50 & 0,38 & 38 & 16,35 & 10,00 \\
\hline 11 & 28,65 & 4,96 & 39 & 7,59 & 1,25 \\
\hline 12 & 56,07 & 13,92 & 40 & 31,30 & 6,85 \\
\hline 13 & 11,72 & 2,37 & 41 & 57,06 & 32,58 \\
\hline 14 & 63,21 & 3,81 & 42 & 7,88 & 1,66 \\
\hline 15 & 28,77 & 3,36 & 43 & 18,10 & 0,77 \\
\hline 16 & 114,98 & 15,68 & 44 & 0,00 & 0,00 \\
\hline 17 & 32,92 & 16,24 & 45 & 0,58 & 0,16 \\
\hline 18 & 58,55 & 13,92 & 46 & 37,55 & 7,52 \\
\hline 19 & 1,55 & 0,03 & 47 & 2,27 & 0,00 \\
\hline 20 & 4,17 & 0,61 & 48 & 2,18 & 0,00 \\
\hline 21 & 16,01 & 1,42 & 49 & 4,85 & 0,64 \\
\hline 22 & 127,47 & 22,56 & 50 & 16,48 & 3,42 \\
\hline 23 & 13,20 & 6,02 & 51 & 76,65 & 31,36 \\
\hline 24 & 2,65 & 0,62 & 52 & 14,54 & 1,38 \\
\hline 25 & 37,82 & 6,80 & 53 & 18,89 & 4,08 \\
\hline 26 & 77,39 & 15,01 & 54 & 16,71 & 5,89 \\
\hline 27 & 13,41 & 1,89 & 55 & 1,97 & 0,29 \\
\hline 28 & 56,94 & 0,70 & 56 & 2,88 & 0,38 \\
\hline
\end{tabular}

Quadro 3.15 - Determinação do coeficiente de chuva dirigida ( $\alpha$ ) para a amostra da Sede do INMET em Brasília.

\begin{tabular}{|rc|}
\hline Método semi-empírico (generalização) & $I=\propto . V \cdot P \cdot \cos (D-\theta)$ \\
\hline$V \cdot P \cdot \cos (D-\theta)$ & $1675,02 \mathrm{~mm}$ \\
\hline Montante de chuva dirigida colhida in situ $(I)$ & $353,86 \mathrm{~mm}$ \\
\hline Coeficiente de chuva dirigida $(\propto)$ & $\mathbf{0 , 2 0 0 5} \mathbf{~} / \mathbf{m}$ \\
\hline Reta de regressão linear & $y=0,2005 x$ \\
\hline Coeficiente de determinação & $\mathrm{R}^{2}=0,6195$ \\
\hline Coeficiente de correlação & $\mathrm{R}=0,78889$ \\
\hline
\end{tabular}




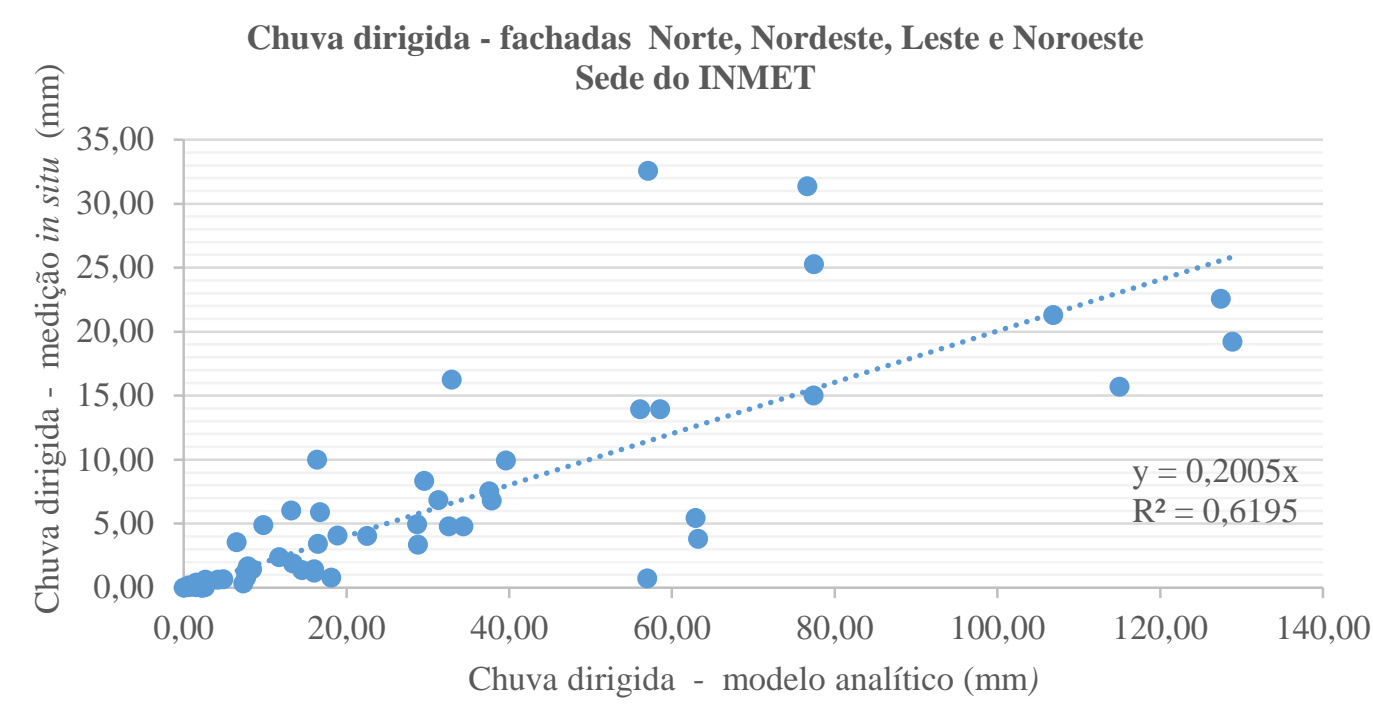

Figura 3.25 - Coeficiente de chuva dirigida: amostra coletada na sede do INMET em Brasília, nas fachadas Norte, Nordeste, Leste e Noroeste.

Os dados da Tabela 3.12 foram utilizados para estimar o coeficiente de chuva dirigida $(\alpha)$ por meio da regressão linear, ou seja, se a regressão da chuva dirigida (modelo analítico) contra os dados observados (medição in situ) for significativa, quer dizer que o coeficiente de chuva dirigida determinado está adequado aos dados observados.

Para verificar a existência e a intensidade da relação linear entre as variáveis foi realizado um teste de correlação. Como podemos observar a correlação entre as variáveis é de 0,7888 que é uma correlação significativa. O intervalo de confiança observado para a correlação está entre $(0,6636 ; 0,8711)$. Observamos que o $\mathrm{R}^{2}$ da regressão é de 0,6195 , o que é um bom valor de explicação, considerando as características do fenômeno estudado. O que corrobora com o resultado que o coeficiente $\alpha$ utilizado é adequado aos dados obtidos no INMET.

A equação de regressão final é significativa mesmo a $1 \%$ de significância e pode ser representada pela seguinte equação:

Chuva Dirigida coletada in situ INMET $=0,2005 *$ Chuva Dirigida do Modelo Analítico

No experimento da cobertura do Bloco H na SQN 214 foram montados dois aparatos na parede Norte. O objetivo foi investigar o comportamento da chuva dirigida mediante a situação de vértices e bordas. Também, foi uma forma de verificar o desempenho das bandejas coletoras, aferindo a capacidade dos dispositivos de recolher a água da chuva de forma homogênea.

Pelo gráfico da Figura 3.26 é possível verificar que o aparato Norte 2, em todas as medições, recolheu menor quantidade de chuva dirigida. 


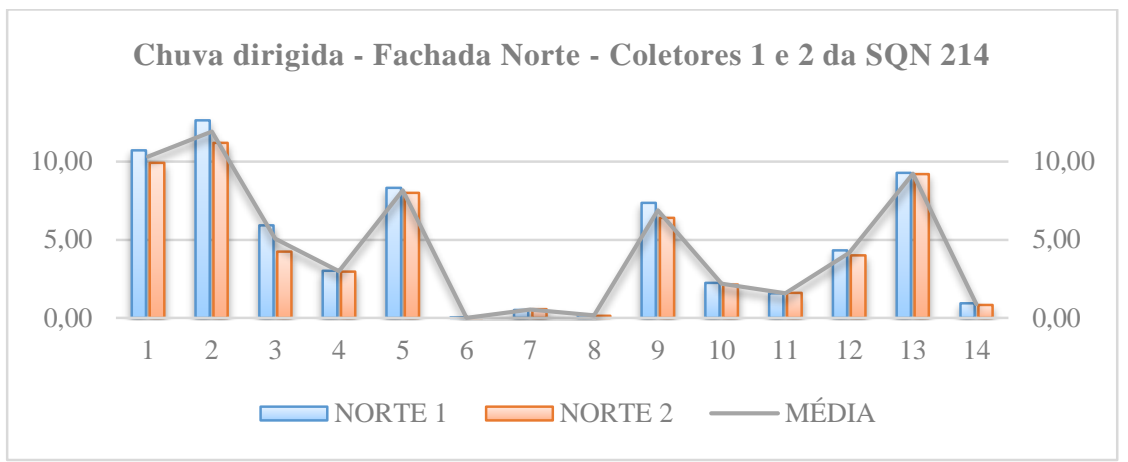

Figura 3.26 - Coeficiente de chuva dirigida: amostras coletadas nas fachadas Norte e Leste, na SQN 214 em Brasília.

A amostra Norte 2 refere-se ao aparato que está posicionado mais próximo ao vértice da parede da caixa d'água (cerca de $50 \mathrm{~cm}$ ). A menor coleta de água pelo aparato Norte 2 do que pelo aparato Norte 1 pode ser explicada pela maior turbulência que ocorre nos vértices das edificações. Nesta localização atuam, com maior intensidade, os ventos turbulentos que dificultam a colisão das gotas de chuva com a superfície e intensificam os respingos e ressaltos. No entanto, pela parábola de molhagem, que é um padrão característico do comportamento da chuva quando projetada sobre a fachada, essa região no topo da edificação está sujeita, em média, às mesmas intensidades de chuva dirigida.

Para verificar as diferenças entre as duas amostras Norte na SQN 214, foi realizada análise estatística. Os dados das duas amostras não apresentaram distribuição normal, por isso foi aplicado um teste Wilcoxon não paramétrico para comparação de duas amostras pareadas. Para comprovar os resultados, foi aplicado, também, o teste Kruskal-Wallis para dados não paramétricos, adequado para a condição de normalidade não atendida. A Figura 3.27 mostra no gráfico Box-plot, o resultado de um dos testes aplicados.

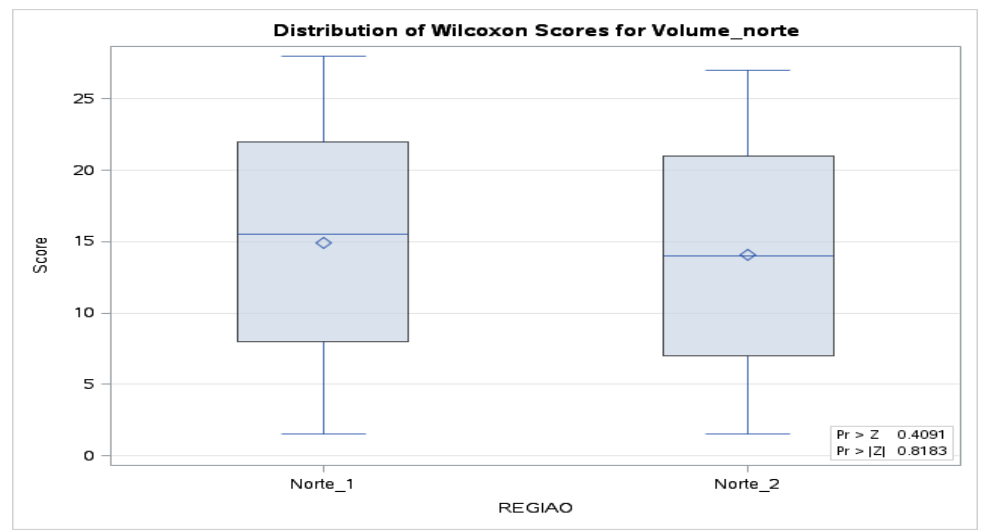

Figura 3.27 - Resultado do teste não paramétrico Wilcoxon para as duas amostras da fachada Norte na SQN 214. 
Os resultados obtidos pelos testes mostraram que não há diferença estatisticamente significativa entre as medianas das amostras coletadas pelos dois aparatos na fachada Norte, visto que pvalor $>0,8005$, muito superior ao nível de significância utilizado que foi de 0,05 . Desse modo, conclui-se que independente do teste utilizado, não há diferença entre as amostras Norte da SQN 214. Desta forma, para se obter os valores das medições in situ na fachada Norte, foi possível fazer a média entre as duas amostras pareadas.

Para a SQN 214, a amostra foi composta pelas medições que tiveram dados de precipitação e vento registrados pela estação, nas horas correspondentes ao período de chuva dirigida coletada, conforme apresentado na Tabela 3.13.

O Quadro 3.16 apresenta os resultados referentes à determinação do coeficiente de chuva dirigida $(\alpha)$ na condição urbana da SQN 214. A Figura 3.28 ilustra a regressão linear entre as variáveis.

Tabela 3.13 - Apresentação da amostra coletada na estação portátil e na cobertura do Bloco H, SQN 214 - Brasília.

\begin{tabular}{cccccc}
\hline Eventos & $\boldsymbol{V} . \boldsymbol{P}$. cos $(\boldsymbol{D}-\boldsymbol{\theta})$ & Medição in situ & Eventos & $\boldsymbol{V} . \boldsymbol{P}$. cos $(\boldsymbol{D}-\boldsymbol{\theta})$ & Medição in situ \\
\hline \hline 1 & 44,07 & 10,32 & 12 & 12,72 & 4,16 \\
2 & 48,19 & 11,92 & 13 & 26,33 & 9,24 \\
3 & 16,23 & 5,08 & 14 & 1,52 & 0,88 \\
4 & 14,36 & 2,99 & 15 & 4,51 & 0,80 \\
5 & 20,82 & 8,16 & 16 & 8,29 & 3,20 \\
6 & 1,08 & 0,02 & 17 & 3,77 & 0,00 \\
7 & 5,16 & 0,54 & 18 & 0,68 & 0,06 \\
8 & 0,17 & 0,16 & 19 & 0,05 & 0,03 \\
9 & 13,81 & 6,88 & 20 & 5,27 & 3,01 \\
10 & 4,02 & 2,19 & 21 & 2,63 & 1,44 \\
11 & 2,90 & 1,59 & 22 & 1,28 & 0,51 \\
\hline
\end{tabular}

Quadro 3.16- Determinação do coeficiente de chuva dirigida ( $\alpha$ ) para a amostra do Bloco H, SQN 214 - Brasília.

\begin{tabular}{|rc|}
\hline Método semi-empírico (generalização) & $I=\propto . V \cdot P \cdot \cos (D-\theta)$ \\
\hline$V \cdot P \cdot \cos (D-\theta)$ & $237,85 \mathrm{~mm}$ \\
\hline Montante de chuva dirigida colhida in situ $(I)$ & $73,19 \mathrm{~mm}$ \\
\hline Coeficiente de chuva dirigida $(\propto)$ & $\mathbf{0 , 2 7 8 4}$ \\
\hline Reta de regressão linear & $y=0,2784 x$ \\
\hline Coeficiente de determinação & $\mathrm{R}^{2}=0,8813$ \\
\hline Coeficiente de correlação & $\mathrm{R}=0,945622$ \\
\hline
\end{tabular}




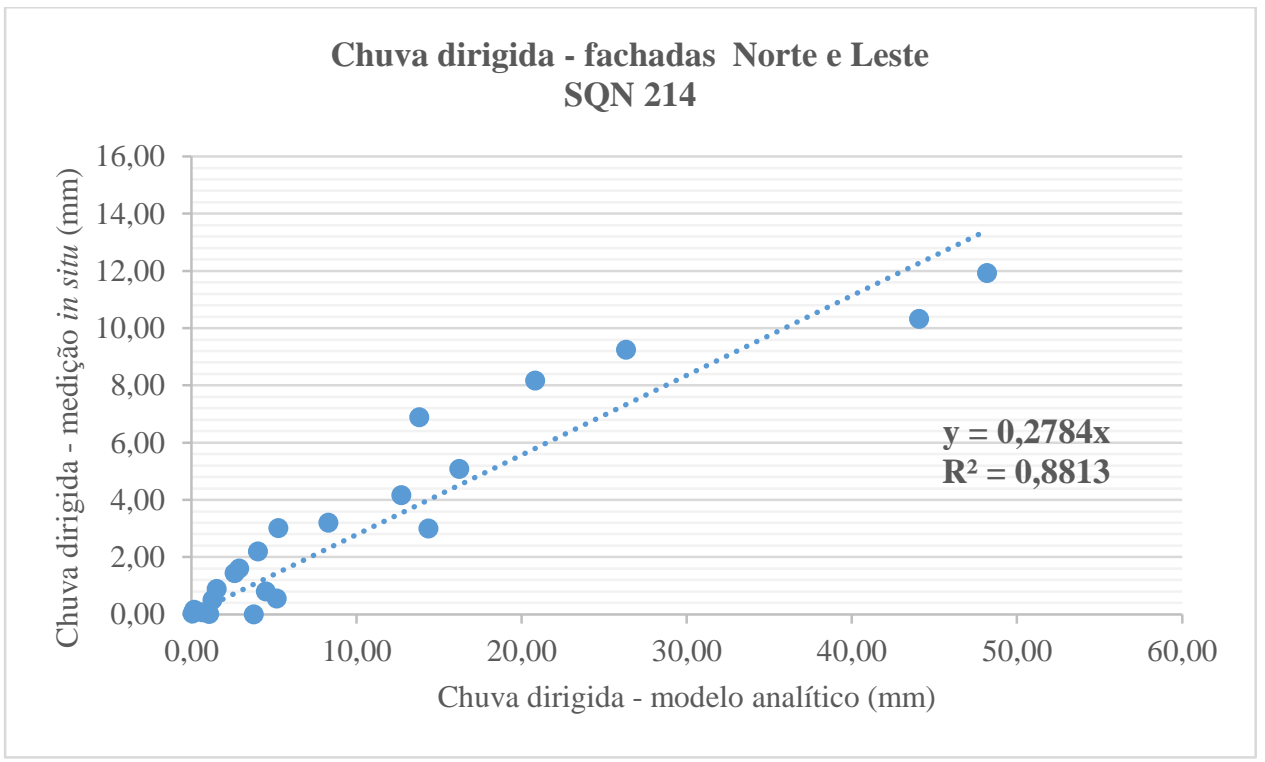

Figura 3.28 - Coeficiente de chuva dirigida: amostra coletada no Bloco H-SQN 214, fachadas Norte e Leste, em Brasília.

Os dados da Tabela 3.13 foram utilizados para estimar o coeficiente de chuva dirigida $(\alpha)$ por meio da regressão linear, ou seja, se a regressão do modTabelaelo de chuva dirigida (modelo analítico) contra os dados observados (medição in situ) for significativa, quer dizer que o coeficiente de chuva dirigida determinado está adequado aos dados observados.

Para verificar a existência e a intensidade da relação linear entre as variáveis foi realizado um teste de correlação. Como podemos observar a correlação entre as variáveis é de 0,945622 que é uma correlação muito significativa.

O intervalo de confiança observado para a correlação está entre $(0,8714 ; 0,9775)$. Observamos que o $\mathrm{R}^{2}$ da regressão é de 0,8941 , o que é um bom valor de explicação, corroborando com o resultado que o coeficiente $\alpha$ utilizado é adequado aos dados obtidos na SQN 214.

A equação de regressão final é significativa mesmo a $1 \%$ de significância e pode ser representada pela seguinte equação:

Chuva Dirigida coletada in situ SQN $214=0,2784 *$ Chuva Dirigida do Modelo Analítico

\subsubsection{Conclusões do programa experimental}

O programa experimental alcançou êxito na obtenção de dados suficientemente representativos para os estudos comparativos entre os métodos semi-empíricos de referência (modelo analítico) 
e a intensidade de chuva dirigida medida experimentalmente (in situ) em contexto brasileiro, especificamente na cidade de Brasília-DF.

A Tabela 3.14 sintetiza os resultados obtidos pelo modelo analítico de referência e as medições in situ. O coeficiente de chuva dirigida expresso na regressão linear é o que melhor ajusta o montante estimado pelo modelo analítico (x) contra os montantes obtidos por medição in situ (y).

Tabela 3.14 - Montantes de chuva dirigida obtidos em Brasília.

\begin{tabular}{|c|c|c|c|c|c|}
\hline Amostra & $\begin{array}{c}\text { Modelo } \\
\text { V. P. Cos (D - A) } \\
\text { N, NE, L e NO } \\
(\mathbf{m m})\end{array}$ & $\begin{array}{c}\text { Modelo } \\
\text { V.P. Cos }(D-\theta) \\
\text { N e L } \\
(\mathbf{m m})\end{array}$ & $\begin{array}{l}\text { Coleta in situ } \\
\text { N, NE, L e NO } \\
(\text { (mm) }\end{array}$ & $\begin{array}{l}\text { Coleta in situ } \\
\qquad \begin{array}{l}\text { N e L } \\
(\mathbf{m m})\end{array}\end{array}$ & Regressão Linear \\
\hline Sede INMET & 1675,02 & & 353,85 & - & $y=0,2005 x$ \\
\hline Sede INMET & & 781,39 & - & 159,98 & $y=0,1954 x$ \\
\hline SQN 214 & & 237,85 & - & 73,192 & $y=0,2784 x$ \\
\hline
\end{tabular}

A Tabela 3.15 apresenta os modelos analíticos, seus fatores de ajustes e as respectivas expressões de regressão linear que representam o resultado dos parâmetros adotados para adequar a condição de campo aberto à condição urbana dos aparatos do experimento in situ.

Tabela 3.15 - Coeficientes e fatores de ajustes aplicados aos modelos analíticos de referência para quantificação da chuva dirigida em Brasília.

\begin{tabular}{|c|c|c|c|c|c|c|c|c|}
\hline \multicolumn{8}{|c|}{ Modelo analítico e seus fatores de ajustes } & \multirow{2}{*}{$\begin{array}{l}\text { Modelo de } \\
\text { regressão } \\
\text { linear }\end{array}$} \\
\hline Métodos & $\begin{array}{c}\text { Altura do } \\
\text { edifício } \\
\text { (m) }\end{array}$ & Constante & $\begin{array}{c}\text { Fator de } \\
\text { parede }\end{array}$ & $\begin{array}{c}\text { Fator de } \\
\text { topografia }\end{array}$ & $\begin{array}{c}\text { Fator de } \\
\text { obstrução }\end{array}$ & $\begin{array}{c}\text { Fator de } \\
\text { rugosidade }\end{array}$ & $\mathbf{X}$ & \\
\hline ASHRAE & $<10$ & 0,2 & 1,0 & \multicolumn{2}{|c|}{1,0} & - & V.P. $\operatorname{Cos}(\mathrm{D}-\theta)$ & $y=0,20 x$ \\
\hline ASHRAE & $15-20$ & 0,2 & 1,0 & \multicolumn{2}{|c|}{1,2} & - & V.P. Cos $(D-\theta)$ & $y=0,24 x$ \\
\hline WUFI* & $>20$ & - & 0,2 & - & - & - & V.P. $\operatorname{Cos}(\mathrm{D}-\theta)$ & $y=0,20 x$ \\
\hline ISO & $10-20$ & $2 / 9$ & 0,5 & 1,0 & 1,0 & 0,9 & V.P. $\operatorname{Cos}(D-\Theta)$ & $y=0,10 x$ \\
\hline
\end{tabular}

*O WUFI considera um coeficiente de transferência a superfície (fator de redução $=0,7$ ) aplicado a qualquer um dos métodos selecionado para a simulação computacional, portanto não deve ser considerado na formulação e análise do coeficiente de chuva dirigida.

Analisando os parâmetros adotados pelos modelos analíticos e os critérios estabelecidos para cada um deles (Tabela 3.15), observa-se que a grande diferença entre os métodos, além da quantidade de fatores considerados, é o fator de ajuste relacionado à altura da região da parede do edifício, onde está sendo analisada a incidência de chuva dirigida.

Comparando os resultados dos três métodos semi-empíricos de referência (Tabela 3.15) com os resultados das medições in situ, pode-se considerar que o método da ISO 15927-3 (com coeficiente $\alpha=0,10 \mathrm{~s} / \mathrm{m}$ ) subestima os valores de chuva dirigida quando comparado com as medições in situ, nas condições analisadas (Tabela 3.14). 
O método do WUFI apresenta para as situações mais críticas (parte superior acima de $20 \mathrm{~m}$ em edifícios altos) os mesmos resultados que o método ASHRAE para situações mais brandas (edifícios com altura de $10 \mathrm{~m}$ em terrenos de exposição média).

O método proposto pela ASHRAE é o método semi-empírico que apresentou melhor correlação com as medidas in situ, em ambas situações urbanas propostas, inclusive com a vantagem de apresentar fatores de ajuste que facilitam a adequação do modelo a uma maior diversidade de contexto urbano em análise.

Assim, atendendo aos objetivos propostos para o programa experimental, conclui-se que:

- A intensidade de chuva dirigida em fachadas de edifícios na cidade de Brasília-DF pode ser estimada para um coeficiente de chuva dirigida $\alpha=0,20 \mathrm{~s} / \mathrm{m}$, para um contexto urbano com exposição média, em fachadas de edifícios com altura em torno de $10 \mathrm{~m}$.

- Para um contexto urbano em exposição média, em fachadas de edifícios com altura em torno de 20 metros, a intensidade de chuva dirigida em fachadas de edifícios na cidade de Brasília-DF pode ser estimada para um coeficiente de chuva dirigida $\alpha=0,27 \mathrm{~s} / \mathrm{m}$.

- O método da ASHRAE representa melhor os achados experimentais desta pesquisa, considerando que para edifícios com altura de $10 \mathrm{~m}$, em terrenos de exposição média, o coeficiente de chuva dirigida é $\alpha=0,20 \mathrm{~s} / \mathrm{m}$ e, para edifícios com altura de $15 \mathrm{~m}$ a 20 $\mathrm{m}$, em terrenos de exposição média, o coeficiente de chuva dirigida é $\alpha=0,24 \mathrm{~s} / \mathrm{m}$.

O método de coleta de chuva dirigida, incluído o aparato utilizado, mostrou-se viável economicamente e de fácil aplicação e operação, podendo ser replicada para todo o território nacional.

\subsection{CONSIDERAÇÕES FINAIS DO CAPÍTULO}

Neste capítulo foram apresentados os estudos sobre chuva dirigida realizados a partir dos métodos analíticos e do programa experimental in situ.

Um dos estudos apresentados neste capítulo foi a determinação do Índice de Chuva Dirigida ICD direcional mensal para a cidade de Brasília. O ICD é um bom balizador das condições de exposição do edifício ao lugar onde será inserido, inclusive indicando quais as orientações que estão sujeitas a um maior nível de agressividade. No entanto, não quantifica o montante de água que é projetada na fachada em determinado contexto urbano. 
Os métodos semi-empíricos quantificam a intensidade de chuva dirigida a partir de coeficientes destinados a ajustar as condições em campo aberto para as condições locais das fachadas, de acordo com o contexto urbano onde o edifício está inserido, inclusive levando em consideração as características do edifício.

Nos estudos realizados foi possível constatar que métodos semi-empíricos de quantificação apresentam resultados bastante discrepantes entre si. Os resultados obtidos por meio desses métodos variam decorrentes do coeficiente de chuva dirigida $\alpha$ que corresponde ao conjunto de parâmetros e constantes adotados para ajustar as condições urbanas e as características da edificação. O coeficiente de chuva dirigida é determinado a partir de experimentos de medições in situ, que precisam ser validadas para as condições locais de interesse do estudo.

Por esta razão, o programa experimental realizado neste trabalho de tese alcançou os objetivos, ao determinar os coeficientes de chuva dirigida para a cidade de Brasília, embasando assim a seleção de um métodos semi-empíricos para uso em simulações computacionais higrotérmicas e análise de sensibilidade de resultados relacionados à intensidade de chuva dirigida.

A chuva dirigida é uma das principais fontes de umidade das edificações. Existem várias normas internacionais que apresentam critérios, métodos e procedimentos para determinar os montantes de chuva dirigida em fachada. No entanto, não foi encontrada nenhuma referência sobre chuva dirigida nas normas brasileiras. Não foi encontrada, também, nenhuma referência sobre medições realizadas em fachada. Por isso, o programa experimental desenvolvido nesta tese tem um caráter pioneiro na realização de medições in situ no Brasil. 


\section{CAPÍtULO IV}

\section{COMPORTAMENTO HIGROTÉRMICO E DEGRAÇÃO DE FACHADA}

\subsection{CONSIDERAÇÕES INICIAIS}

Neste capítulo são abordados os conceitos e propriedades que envolvem o comportamento higrotérmico dos sistemas porosos de fachada. São apresentados, também, os fenômenos relacionados aos transportes de calor e massa, às cargas e variações higrotérmicas, que aceleram a degradação da fachada e o envelhecimento natural das edificações.

As propriedades relacionadas com o transporte de calor e massa, apresentadas neste capítulo, são aquelas que embasaram as análises dos resultados desta tese, além de servirem como eixo orientador na seleção da revisão bibliográfica e fundamentação teórica para um melhor entendimento do programa de simulação higrotérmica WUFI (2013).

Finalizando o capítulo, são apresentados os agentes e os mecanismos de degradação de origem climática que atuam nos sistemas de revestimento de fachada, assim como as principais manifestações patológicas relacionadas às variações higrotérmicas.

\subsection{PROPRIEDADES HIGROTÉRMICAS RELACIONADAS AO TRANSPORTE DE CALOR E MASSA}

A transferência de calor e massa na superfície porosa da envoltória da edificação ocorre sempre que houver diferenças de temperatura e conteúdo de umidade. Os fenômenos ocorrem simultaneamente e são altamente interdependentes, o que exige o entendimento de ambos os fenômenos. Por isso, nesta seção, são apresentadas as propriedades relacionadas tanto ao transporte de massa como ao transporte de calor.

\subsubsection{Teor de umidade $-W$}

O teor de umidade representa a quantidade de água presente nos poros (nas fases líquida, sólida ou vapor) em relação ao seu volume ou massa e pode ser expresso pelas seguintes relações:

- Teor de umidade massivo: relação entre a massa de água e a massa de material seco $(\mathrm{kg} / \mathrm{kg})$. 
- Teor de umidade volumétrico: relação entre o volume de água e o volume aparente do material seco $\left(\mathrm{m}^{3} / \mathrm{m}^{3}\right)$.

- Teor de umidade em massa por unidade de volume: relação entre a massa de água e o volume aparente do material seco $\left(\mathrm{kg} / \mathrm{m}^{3}\right)$.

Os materiais de construção, em geral, são higroscópicos, isto é, possuem uma estrutura porosa capaz de absorver a umidade do ar, na forma de vapor.

Variando a umidade do meio, varia o seu teor de umidade (FREITAS et al., 2008). A Figura 4.1 apresenta os estágios de umidificação.

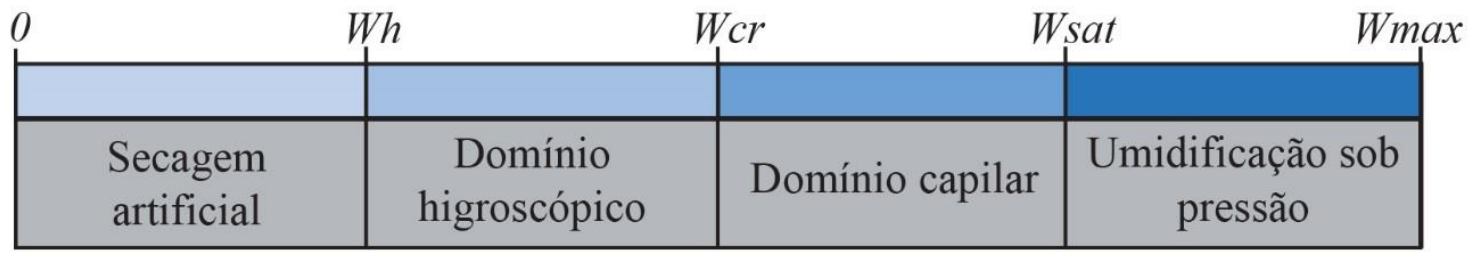

Fonte: baseado em Freitas (1992).

Figura 4.1- Estágios de umidificação e teor de umidade de um material.

De acordo com os estágios de umidificação, segundo Freitas et al., (2008) e ASHRAE (2009), o teor de umidade pode ser classificado como:

- Teor de umidade higroscópico $\left(W_{h}\right)$ : corresponde ao teor de água que um material contém quando em equilíbrio com a umidade relativa do meio em que está inserido.

- Teor de umidade crítico $\left(W_{c r}\right)$ : corresponde ao máximo teor de água que um material contém quando em contato com um meio saturado, representando o valor limite entre o domínio higroscópico e o domínio capilar.

- Teor de umidade capilar ou de saturação capilar $\left(W_{s a t}\right)$ : corresponde ao máximo teor de água que um material contém quando em contato com água líquida, durante um certo período de tempo.

- Teor de umidade máximo $\left(W_{\max }\right)$ : representa o máximo teor de umidade que um material pode atingir quando todo o volume da estrutura porosa está ocupado por água (líquida e vapor). Acima do teor de umidade capilar $\left(W_{s a t}\right)$, o aumento no teor de umidade do material só ocorre quando se aplicam técnicas de umidificação sob pressão, necessária para expulsar o ar que ficou retido no interior da estrutura porosa. Na prática, o valor $W_{\max }$ é dificilmente alcançado, considerando que é impossível preencher todos os poros de um material. 


\subsubsection{Isotermas de Equilíbrio (Curvas Higroscópicas)}

Isotermas de Equilíbrio são curvas higroscópicas que, a uma determinada temperatura, mostram a relação entre a umidade relativa e o teor de umidade. As isotermas de sorção representam as curvas de adsorção e dessorção do material. A diferença entre elas é chamada de histerese, que mostra o comportamento diferenciado entre os fenômenos de adsorção (umedecimento) e dessorção (secagem). Quando a umidade relativa sobe, os materiais higroscópicos ganham umidade (adsorção) e quando umidade relativa cai, eles perdem a umidade (dessorção). O processo de dessorção é mais lento que o processo de adsorção.

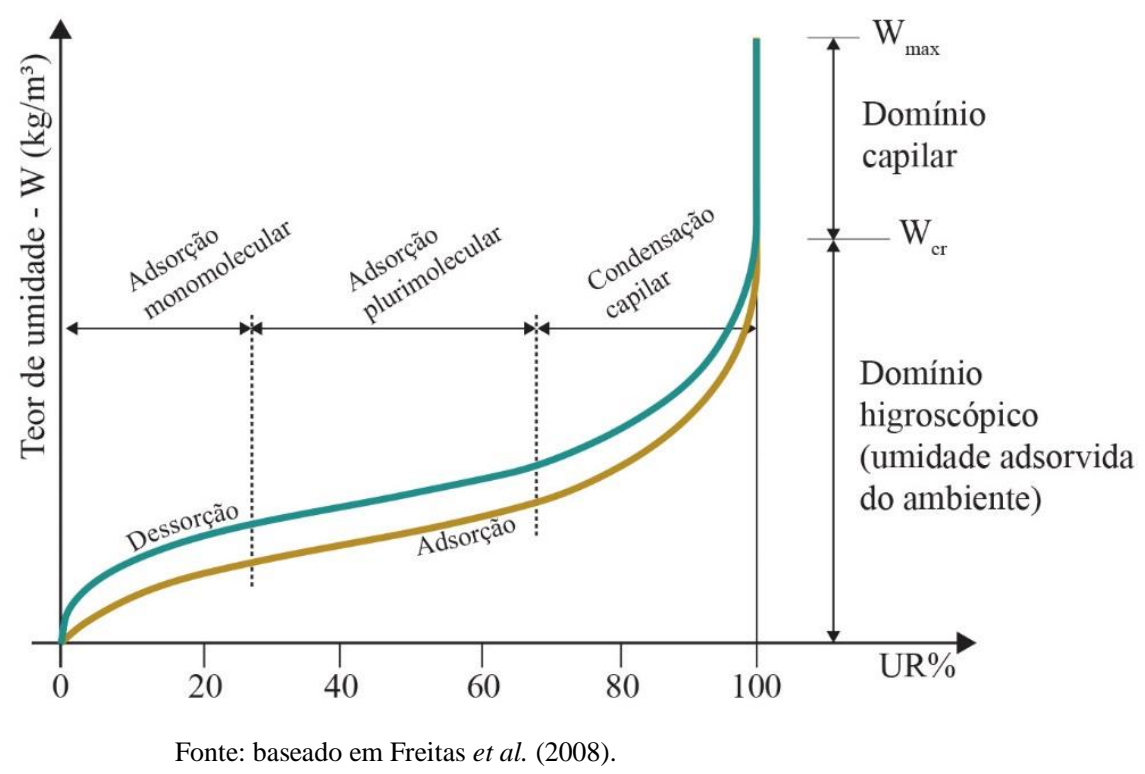

Figura 4.2 - Isotermas de Equilíbrio.

O teor de umidade aumenta com a umidade relativa do ar, especialmente acima de $80 \%$ de umidade relativa. Os teores de umidade acima de W95 (teor de umidade de equilíbrio a 95\% de umidade relativa) não podem ser alcançados unicamente por adsorção de vapor, porque esta região é caracterizada pela capilaridade. Em condição de alta umidade relativa do ar, pequenos poros tornam-se inteiramente preenchidos com água por condensação capilar. Teoricamente, o teor máximo de umidade deveria ser alcançado em $100 \%$ de umidade relativa, quando todos os poros estão cheios de água, mas experimentalmente, isto só pode ser conseguido com técnicas utilizando pressurização, banho em ebulição ou mantendo o material em contato com a água por um tempo extremamente longo. Na prática, o teor máximo de umidade de um material poroso em condições normais de uso é o valor chamado de teor de umidade capilar ou de saturação $\left(W_{f}=W_{\text {sat }}\right)(\mathrm{ASHRAE}, 2009)$. 
As isotermas de sorção são obtidas através de ensaios onde amostras são submetidas em um ambiente de temperatura e umidade relativa controladas. Esse método de ensaio obtém pontos mensuráveis abaixo de 96\% de umidade relativa (MENDES, 1997). Acima desse valor, limitado pelo tipo de ensaio, a extrapolação pode ser obtida, entre outras técnicas, por meio da curva de pressão de intrusão realizada através da porosimetria a mercúrio (SANTOS, 2009).

\subsubsection{Coeficiente de transferência de água líquida - DW $\left[\mathrm{m}^{2} / \mathrm{s}\right]$}

O coeficiente de transferência de água líquida é um coeficiente de difusividade hídrica. O WUFI determina o coeficiente de transferência de água líquida por sucção $\left(\mathrm{DW}_{\mathrm{S}}\right)$ para descrever a fase de absorção capilar da água, quando a superfície absorvente está totalmente úmida. Quando a fonte externa já umedeceu a superfície o suficiente, inicia-se a fase de propagação da água absorvida. O coeficiente de transferência de água líquida por redistribuição ( $\left.\mathrm{DW}_{\mathrm{W}}\right)$ descreve a fase de secagem da água presente no material (WUFI, 2014).

No âmbito da física das construções, estes dois coeficientes traduzem, respectivamente, o efeito da chuva sobre uma fachada umedecendo os materiais e, após a chuva cessar, a fase de secagem da água absorvida com a migração de umidade para o exterior (JORNE, 2010).

A Figura 4.3 exemplifica a variação do coeficiente de transporte de água líquida em função do teor de umidade para um determinado material, considerando a faixa de variação entre o teor de umidade de referência (w80 - teor de umidade para $80 \%$ de umidade relativa) e o teor de umidade de saturação capilar ( $\left.\mathrm{W}_{\text {sat }}\right)$.

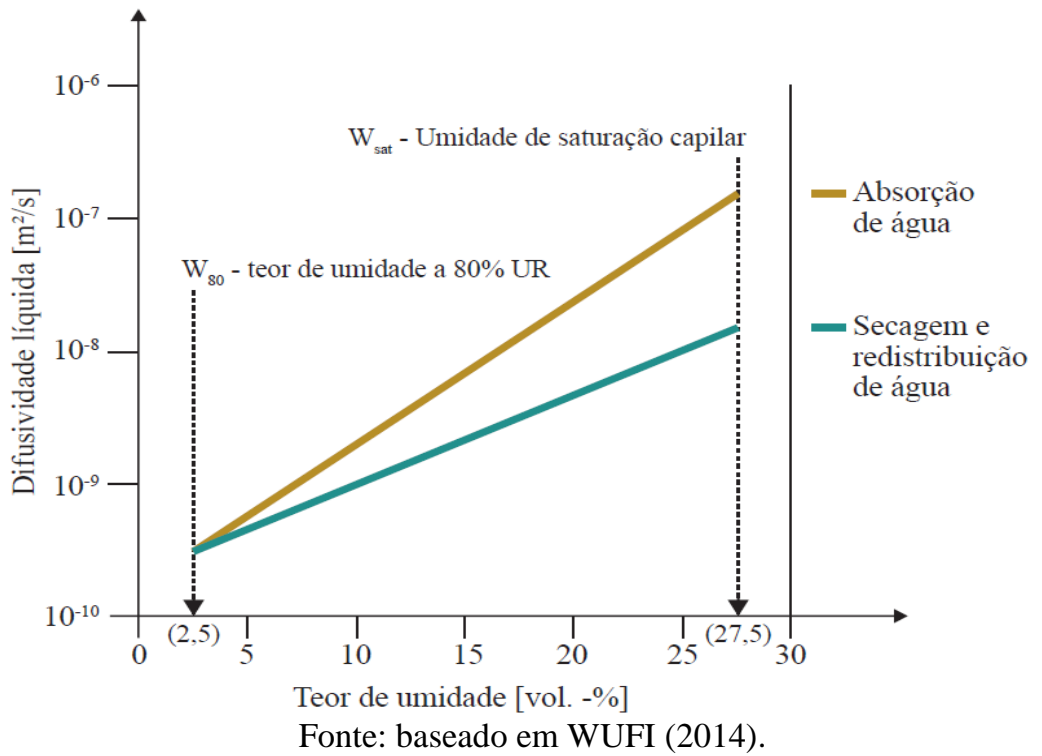

Figura 4.3 - Exemplo de curvas de transferência da água na fase líquida: absorção e redistribuição. 
O WUFI, por meio de métodos de cálculo amplamente validados (Equação 4.1), obtém o coeficiente de transporte de água líquida a partir das curvas higroscópicas e do coeficiente de capilaridade. Uma vez que a redistribuição tem lugar nos capilares menores, que apresentam uma alta resistência ao fluxo, o $\mathrm{DW}_{\mathrm{W}}$ é geralmente bastante menor que o $\mathrm{DW}_{\mathrm{S}}$, dado ser um processo mais lento. $\mathrm{O} \mathrm{DW}$ cresce exponencialmente com o teor de água do material e expressa bem o comportamento do material quando úmido (WUFI online help, 2014).

$$
\mathrm{D}_{\mathrm{Ws}}(\mathrm{W})=3,8 \cdot\left(\frac{\mathrm{A}}{\mathrm{W}_{\mathrm{f}}}\right)^{2} \cdot 1000^{(\mathrm{w} / \mathrm{wf})-1}
$$

Onde,

DWs Coeficiente de transferência de água líquida por sução $\left(\mathrm{m}^{2} / \mathrm{s}\right)$;

A Coeficiente de capilaridade $\left(\mathrm{kg} / \mathrm{m}^{2} . \mathrm{s}^{1 / 2}\right)$;

$W \quad$ Teor de umidade $\left(\mathrm{kg} / \mathrm{m}^{3}\right)$;

Wf Teor de umidade de saturação livre $\left(\mathrm{kg} / \mathrm{m}^{3}\right)$.

Alguns parâmetros adicionais para a análise do comportamento higrotérmico não estão disponíveis para muitos materiais de construção. O coeficiente de transporte de água líquida é um destes parâmetros usualmente não obtidos em laboratório, pois envolve custo e tempo que nem sempre estão disponíveis. Em alguns casos, é possível estimar com segurança as propriedades dos materiais a partir dos dados conhecidos (WUFI, 2014; KRUS, 1996).

4.2.4. Coeficiente de absorção de água líquida (coeficiente de capilaridade) - Avalor $\left[\mathrm{g} / \mathrm{dm}^{2} \cdot \mathrm{min}^{1 / 2}\right.$ ou $\left.\mathrm{kg} / \mathrm{m}^{2} \cdot \mathrm{h}^{1 / 2}\right]$

O coeficiente de capilaridade caracteriza a capilaridade do material quando em contato com a água na fase líquida; é a propriedade de um material em absorver água líquida por sucção em função do tempo. De acordo com a NBR 15259 (ABNT, 2005a), o coeficiente de capilaridade é o coeficiente angular da reta determinada pelo incremento de peso $\left(\mathrm{g} / \mathrm{dm}^{2}\right)$ pela raiz do tempo $(\min )$.

\subsubsection{Coeficiente de Permeabilidade $-\delta[\mathrm{kg} / \mathrm{m} . s . P a]$}

A permeabilidade refere-se à aptidão dos materiais de serem atravessados por um fluído (líquido, ar ou vapor), quando submetidos a um gradiente de pressão (FREITAS; PINTO, 2000). A permeabilidade aumenta com o aumento da porosidade; materiais mais porosos facilitam a permeação do fluído através do sólido (CARDOSO, 2009). 
a) Coeficiente de permeabilidade à água líquida $(\boldsymbol{\delta} \boldsymbol{a})$ : é a velocidade de um fluxo laminar de água através de uma seção transversal unitária de material, submetida a um gradiente hidráulico unitário sob condições padrão de temperatura (GTA, 2009; ABNT, 2013).

b) Coeficiente de permeabilidade ao vapor de água ( $\delta v)$ : é uma propriedade do material que expressa a quantidade de vapor de água que atravessa uma unidade de superfície com espessura unitária na unidade de tempo e sob uma diferença de pressão de vapor unitária entre as duas faces (LANZINHA; FREITAS, 1998; FAUSTINO, 1997).

\subsubsection{Permeância ao vapor de água $-w\left[\mathrm{~kg} / \mathrm{m}^{2} . \mathrm{s.Pa}\right]$}

Segundo Carbone et al. (2013), a permeância (w) é definida como a quantidade de vapor que se difunde por unidade de superfície de um material com uma espessura determinada, por unidade de tempo, e quando entre suas faces se estabelece uma diferença de pressão unitária. Conforme a ISO 12.572, a permeabilidade ao vapor é calculada pelo produto da permeância pela espessura do material $(\delta=w . e)$. A permeância é inversamente proporcional à resistência ao vapor de difusão de água e é utilizada no cálculo do coeficiente de resistência à difusão do vapor de água $(\mu)(B S$ EN, 2001).

\subsubsection{Fator de resistência à difusão do vapor de água - $\boldsymbol{\mu}[-]$}

A difusão do vapor d'água origina-se da diferença de concentração. Sempre que existir diferenças de pressão de vapor de água ocorrerão, inevitavelmente, fenômenos de difusão de vapor através do elemento.

Para caracterizar a permeabilidade ao vapor de água é usado o fator de resistência à difusão do vapor de água $\mu$. Este fator é um valor característico dos materiais, obtido pela razão (adimensional) entre o coeficiente de permeabilidade ao vapor de água do ar ( $\delta$ ar) e o coeficiente de permeabilidade ao vapor de água do próprio material $(\delta p)$, e indica quantas vezes a resistência à difusão ao vapor de água do material é maior do que a resistência à difusão ao vapor de água de uma camada de ar em repouso, de igual espessura e sujeita às mesmas condições ambientais que a camada de material (BS EN, 2001; FAUSTINO, 1997).

Assim, quanto maior for o valor do fator $\mu$, menor será a permeabilidade do material e viceversa. Valores baixos de $\mu$ significam alta difusão de vapor. Quando comparado dois materiais, quanto menor for o $\mu$ maior deve ser a espessura da camada para permitir a mesma difusão de vapor de água. Este valor é independente do substrato onde o material é aplicado, pois é uma propriedade inerente ao material. 
A quantidade de umidade que pode penetrar em uma camada como resultado da difusão do vapor, depende da resistência à difusão do vapor de água (fator $\mu$ ) do material. Quanto mais baixo for o fator $\mu$ de um material, maior será o conteúdo de umidade, consequentemente, as perdas energéticas aumentarão com os anos.

Por outro lado, os valores do fator $\mu$ são dependentes da umidade. Hipoteticamente, em condição de máxima saturação, o valor de $\mu$ tende ao infinito, ou seja, em teores muito elevados de umidade até os capilares maiores tornam-se obstruídos com água e não podem mais contribuir para o transporte de vapor (WUFI online help, 2014; JORNE, 2010).

\subsubsection{Espessura da camada de ar de difusão equivalente - $S d[\mathrm{~m}]$}

A espessura da camada de ar de difusão equivalente $\left(S_{d}=\mu . e\right)$, obtido do produto do fator $\mu$ pela espessura $e$ do material, corresponde a uma grandeza de caráter prático, destinada a substituir uma camada do material com uma dada espessura por uma camada de ar de espessura tal que tenham a mesma permeância (FAUSTINO, 1997).

Em suma, $S_{d}$ significa uma altura de coluna de ar (em metros) que possui a mesma resistência de difusão de vapor que a camada de material. Assim, valores baixos de $S_{d}$ significam facilidade de difusão de vapor.

\subsubsection{Porosidade aberta $-\varepsilon\left[\mathrm{m}^{3} / \mathrm{m}^{3}\right]$}

A porosidade de um material é dada pela razão entre o volume de poros abertos e o volume total da amostra (incluído os vazios). A porosidade aberta caracteriza-se pelos vazios intercomunicados presentes na microestrutura, por onde pode ocorrer a passagem de fluídos, seja por percolação ou por capilaridade (GTA, 2009).

A porosidade é uma propriedade necessária à caracterização do material quanto à capacidade de absorção de vapor de água ou água líquida, sendo que a dimensão e a geometria dos poros são fatores que influenciam a permeabilidade do material.

\subsubsection{Densidade de massa $-\rho\left[\mathrm{kg} / \mathrm{m}^{3}\right]$}

A densidade de massa é dada pela relação entre a massa completamente seca e o seu volume, excluindo o volume dos vazios em seu interior. O termo densidade de massa aparente é a denominação dada quando a relação entre a massa completamente seca e o seu volume inclui o volume dos vazios em seu interior (GTA, 2009). 


\subsubsection{Condutividade térmica $-\lambda[\mathrm{W} / \mathrm{m} . \mathrm{K}]$}

A condutividade térmica é uma propriedade física que expressa a capacidade de um material homogêneo e isótropo em conduzir maior ou menor quantidade de calor por unidade de tempo. Verifica-se um fluxo constante de calor que atravessa perpendicularmente uma superfície de área unitária na unidade de tempo, quando submetido a um gradiente unitário uniforme de temperatura por metro (ABNT, 2005a).

$\mathrm{O}$ aumento do teor de umidade do material aumenta a condutividade térmica, facilitando a transmissão de calor. Por outro lado, quanto menor a densidade de massa aparente do material menor a sua condutividade térmica, que tende a diminuir com o aumento da quantidade de ar presente no material (ALVES; PIETROBON; PIETROBON, 1999).

Isso se explica devido à condutividade térmica da água ser aproximadamente 25 vezes maior do que a do ar (SANTOS, 2009).

Segundo Ordenes et al. (2008, p.5), a condutividade térmica nos metais é da ordem de $20-700$ W/m.K, podendo ser considerada alta, devido à livre movimentação dos elétrons. Os materiais sólidos não metálicos não permitem o movimento livre de elétrons, somente a vibração molecular, isto faz com que sua condutividade térmica esteja entre 0,5 e $30 \mathrm{~W} / \mathrm{m} . \mathrm{K}$.

\subsubsection{Calor específico - c [J/kg.K]}

O calor específico é a quantidade de energia necessária para fazer variar em uma unidade $\left({ }^{\circ} \mathrm{C}\right.$ ou ${ }^{\circ} \mathrm{K}$ ) a temperatura de uma unidade de massa de uma determinada substância (ABNT, 2005a).

\subsubsection{Capacidade térmica - $\mathrm{C}\left[\mathrm{kJ} / \mathrm{m}^{2} . \mathrm{K}\right]$}

Quando se deseja avaliar a capacidade de um sistema em reter mais ou menos calor, ou avaliar a sua contribuição em termos de inércia térmica, utiliza-se a propriedade capacidade térmica, que consiste na quantidade de calor necessária para variar em uma unidade a temperatura de um sistema por unidade de área (LAMBERTS et al., 2013).

\subsubsection{Coeficiente de absorção (absortância) - $\alpha[-]$}

O coeficiente de absorção é uma propriedade da superfície do material e expressa a fração da energia radiante que é absorvida (CIB W040, 2012). A parcela absorvida da radiação incidente depende, principalmente da cor da superfície exposta. Segundo Lamberts et al. (2013), os materiais de construção são seletivos à radiação de onda curta (radiação solar) e a cor superficial é a característica determinante para esse comportamento. 
O Quadro 4.1 apresenta alguns valores para absortância e emissividade estabelecidos pela NBR 15220-2 (ABNT, 2005b).

\section{Quadro 4.1 - Absortância ( $\alpha$ ) para radiação solar (ondas curtas) e emissividade ( $(\varepsilon)$ para radiações à temperaturas comuns (onda longas).}

\begin{tabular}{|c|c|c|c|}
\hline \multicolumn{2}{|c|}{ Tipo de superfície } & $\begin{array}{l}\text { Absortância } \\
(\alpha)\end{array}$ & $\begin{array}{c}\text { Emissividade } \\
(\varepsilon)\end{array}$ \\
\hline \multicolumn{2}{|c|}{ "Chapa de alumínio (nova e brilhante) } & 0,05 & 0,05 \\
\hline \multicolumn{2}{|c|}{ Chapa de alumínio (oxidada) } & 0,15 & 0,12 \\
\hline \multicolumn{2}{|c|}{ Chapa de aço galvanizada (nova e brilhante) } & 0,25 & 0,25 \\
\hline \multicolumn{2}{|c|}{ Caiação nova } & $0,12 / 0,15$ & 0,90 \\
\hline \multicolumn{2}{|c|}{ Concreto aparente } & $0,65 / 0,80$ & $0,85 / 0,95$ \\
\hline \multicolumn{2}{|c|}{ Telha de barro } & $0,75 / 0,80$ & $0,85 / 0,95$ \\
\hline \multicolumn{2}{|c|}{ Tijolo aparente } & $0,65 / 0,80$ & $0,85 / 0,95$ \\
\hline \multicolumn{2}{|c|}{ Reboco claro } & $0,30 / 0,50$ & $0,85 / 0,95$ \\
\hline \multicolumn{2}{|c|}{ Revestimento asfáltico } & $0,85 / 0,98$ & $0,90 / 0,98$ \\
\hline \multirow{7}{*}{ Pintura } & Branca & 0,20 & 0,90 \\
\hline & Amarela & 0,30 & 0,90 \\
\hline & Verde clara & 0,40 & 0,90 \\
\hline & “Alumínio" & 0,40 & 0,50 \\
\hline & Verde escura & 0,70 & 0,90 \\
\hline & Vermelha & 0,74 & 0,90 \\
\hline & Preta & 0,97 & 0,90 \\
\hline
\end{tabular}

Fonte: baseada na NBR 15220-2 (ABNT, 2005b).

A NBR 15575-1 (ABNT, 2013a) orienta o uso dos seguintes valores para a absortância, quando da indisponibilidade de um valor próprio do material da superfície:

- cor clara $\propto=0,3$;

- cor média $\propto=0,5$

- cor escura $\propto=0,7$.

\subsubsection{Emissividade - $\varepsilon[-]$}

A emissividade é uma propriedade da superfície do material e expressa a razão entre a energia emitida por uma superfície e a energia emitida por um corpo negro, em uma unidade de tempo, quando expostos a uma mesma condição de temperatura (CIB W040, 2012).

Lamberts et al. (2013) classifica os materiais de construções em metálicos, quando possuem baixa emissividade, compreendidas entre 0,05 e 0,30, e não metálicos como aqueles que possuem alta emissividade, variando de 0,85 a 0,90 . O Quadro 4.1 apresenta alguns valores para emissividade estabelecidos pela NBR 15220-2 (ABNT, 2005b). 


\subsubsection{Coeficiente superficial de transmissão de calor $-h\left[\mathrm{~W} / \mathrm{m}^{2} . \mathrm{K}\right]$}

O coeficiente superficial de transmissão de calor constitui-se em duas parcelas: coeficiente superficial de troca por radiação $(h r)$ e coeficiente superficial de troca por convecção $(h c)$. O coeficiente total é a soma das contribuições convectivas e radiativas $(h=h r+h c)$.

O coeficiente de convecção $(h c)$ é uma constante de proporcionalidade que resume as condições nas camadas mais próximas à superfície, considerando a geometria da superfície, a natureza do escoamento (laminar ou turbulento) e as propriedades do fluído (densidade, viscosidade, condutividade térmica e calor específico) (ORDENES et al., 2008).

O valor do coeficiente de transmissão por convecção entre o ar e as superfícies de uma edificação pode ser expresso pelos valores apresentados no Quadro 4.2. Observa-se que os valores e expressões variam entre diversos autores.

Segundo Barreira (2010), a determinação do valor do coeficiente de transmissão de calor por convecção não é consensual e a diversidade resulta da complexidade do próprio fenômeno que depende não só das propriedades do ar, mas também da geometria e rugosidade da superfície, da diferença de temperatura entre a superfície e o ar, da velocidade e movimentação do ar à superfície e da direção e sentido do fluxo de calor (HENS, 2007; BATISTA et al., 2011).

Quadro 4.2 - Expressões e valores para o coeficiente superficial de transmissão por convecção (hc).

\begin{tabular}{|c|c|c|}
\hline Expressão & Condições & Fonte \\
\hline$h c=3,0$ & Para superfícies verticais & \multirow{4}{*}{ Lamberts, et al., 2013} \\
\hline$h c=4,3$ & $\begin{array}{l}\text { Para fluxo de baixo para cima: ar para o forro } \\
\text { em superfícies interiores }\end{array}$ & \\
\hline$h c=1,5$ & $\begin{array}{l}\text { Para fluxo de cima para baixo: ar para o piso em } \\
\text { superfícies interiores }\end{array}$ & \\
\hline$h c=5,8+4,1 . v$ & $\begin{array}{l}\text { Para superfícies expostas ao vento (velocidade } \\
\text { do vento em } \mathrm{m} / \mathrm{s} \text { ) }\end{array}$ & \\
\hline$h c=4,5+1,6 . v$ & Para superfícies expostas ao vento & \multirow{2}{*}{ WUFI, 2014} \\
\hline$h c=4,5+0,33 . v$ & Para superfícies protegidas do vento & \\
\hline$h c=5+4,5 \cdot v-0,14 \cdot v^{2}$ & Superfície voltada ao vento; $\mathrm{v} \leq 10 \mathrm{~m} / \mathrm{s}$ & \multirow{4}{*}{$\begin{array}{l}\text { Hagentoft (2001) apud } \\
\text { Barreira, } 2010\end{array}$} \\
\hline$h c=5+1,5 . v$ & Superfícies protegidas do vento; $\mathrm{V} \leq 8 \mathrm{~m} / \mathrm{s}$ & \\
\hline$h c=5,6+3,9 \cdot v$ & $\mathrm{~V} \leq 5 \mathrm{~m} / \mathrm{s}$ & \\
\hline$h c=7,2 \cdot v^{0,78}$ & $\mathrm{~V}>5 \mathrm{~m} / \mathrm{s}$ & \\
\hline$h c=4+4 . v$ & Superfície exterior & DIN EN 15026:2007 \\
\hline Legenda: & $\begin{array}{l}\text { hc em } \mathrm{W} / \mathrm{m}^{2} . \mathrm{K} \\
\text { velocidade do vento }(\mathrm{v}) \mathrm{em} \mathrm{m} / \mathrm{s}\end{array}$ & \\
\hline
\end{tabular}

O coeficiente superficial de transmissão por radiação $(h r)$ é um coeficiente de proporcionalidade que relaciona todos os fatores que interferem na troca de calor por radiação 
entre o ar e as superfícies de uma edificação, tais como, temperatura superficial, aspectos geométricos e físicos das superfícies, principalmente a emissividade $(\varepsilon)$ e a absortância $(\alpha)$ (FROTA; SCHIFFER, 2001). O $h r$ pode ser expresso pelas expressões do Quadro 4.3.

Quadro 4.3 - Expressões para o coeficiente superficial de transmissão por radiação $(h r)$.

\begin{tabular}{|cc|cc|}
\hline Expressão & Condições & Emissividade efetiva $\left(\varepsilon_{\mathrm{e}}\right)$ & \\
\hline \hline$h r=5,7 . \varepsilon_{e}$ & Para superfície a $20^{\circ} \mathrm{C}$ & $\varepsilon_{\mathrm{e}}=\frac{1}{\frac{1}{\varepsilon_{1}}+\frac{1}{\varepsilon_{2}}}$ & Fonte: \\
$h r=4,6 . \varepsilon_{e}$ & Para superfície a $10^{\circ} \mathrm{C}$ & Lamberts et al., 2013 \\
\hline
\end{tabular}

\subsubsection{Resistência térmica superficial $-R s\left[\mathrm{~m}^{2} . \mathrm{K} / \mathrm{W}\right]$}

Os efeitos das trocas de calor por radiação e convecção entre a superfície do componente e o ambiente que o circunda dependem da resistência térmica superficial.

A resistência térmica superficial externa $\left(R_{s e}\right)$ é um coeficiente que representa as trocas de calor por convecção e radiação entre a superfície exterior e o meio exterior. $O$ incremento da temperatura da superfície externa depende da sua resistência superficial externa $\left(R_{s e}\right)$, cujo valor é em função da velocidade do vento.

Para as superfícies internas, as trocas térmicas entre a superfície interior e o ambiente interno acontecem, também, por radiação e por convecção. O coeficiente que representa as trocas de calor entre a superfície interna e o ambiente interior é a resistência térmica superficial interna $\left(R_{s i}\right)$.

O Quadro 4.4 apresenta os valores médios recomendados pela NBR 15220-2 (ABNT, 2005b) para as resistências térmicas superficiais externa e interna, considerando a direção do fluxo de calor.

Quadro 4.4 - Resistência térmica superficial interna e externa.

\begin{tabular}{|c|c|c|c|c|c|}
\hline \multicolumn{3}{|c|}{$\mathrm{R}_{\mathrm{si}}\left(\mathrm{m}^{2} \cdot \mathrm{K}\right) / \mathrm{W}$} & \multicolumn{3}{|c|}{$\mathrm{R}_{\mathrm{se}}\left(\mathrm{m}^{2} . \mathrm{K}\right) \mathrm{W}$} \\
\hline \multicolumn{3}{|c|}{ Direção do fluxo de calor } & \multicolumn{3}{|c|}{ Direção do fluxo de calor } \\
\hline Horizontal & Ascendente & Descendente & Horizontal & Ascendente & Descendente \\
\hline$\Rightarrow 1$ & $\hat{\imath}$ & תู & $\Rightarrow$ | & $\hat{\imath}$ & 纟ु \\
\hline 0,13 & 0,10 & 0,17 & 0,04 & 0,04 & 0,04 \\
\hline
\end{tabular}

Fonte: NBR 15220-2 (ABNT, 2005b). 


\subsubsection{Resistência térmica total $-R_{T}\left[\mathrm{~m}^{2} . \mathrm{K} / \mathrm{W}\right]$}

A resistência térmica de um material é uma propriedade que expressa a sua resistência à passagem do calor e está relacionada com a espessura do material $(e)$ e o seu coeficiente de condutividade térmica $(\lambda)$.

A resistência térmica de um material homogêneo é diretamente proporcional à sua espessura $\mathrm{e}$ inversamente proporcional ao seu coeficiente de condutividade térmica. $(R=e / \lambda)$.

A Figura 4.4 apresenta as expressões 4.2 e 4.3 para o cálculo das resistências superficiais, respectivamente, do componente e do sistema como um todo, incluído as interações entre a superfície e o meio.

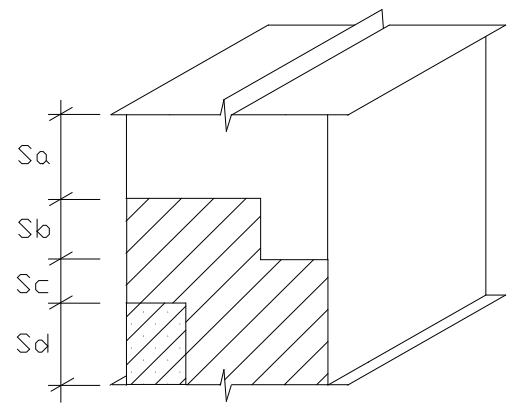

$$
\begin{aligned}
& \mathrm{R}_{\mathrm{t}}=\frac{\mathrm{A}_{\mathrm{a}}+\mathrm{A}_{\mathrm{b}}+\ldots+\mathrm{An}_{\mathrm{n}}}{\frac{\mathrm{A} \mathrm{a}}{\mathrm{Ra}}+\frac{\mathrm{Ab}_{\mathrm{b}}}{\mathrm{Rb}}+\ldots+\frac{\mathrm{An}_{\mathrm{n}}}{\mathrm{Rn}}} \\
& R_{T}=R_{s e}+R_{t}+R_{s i} \\
& \text { Fonte: ABNT (2005b). }
\end{aligned}
$$

Figura 4.4 - Expressões para resistência térmica do componente $\left(R_{t}\right)$ e do sistema como um todo $\left(R_{T}\right)$.

Para um componente composto por várias camadas homogêneas, a resistência térmica é dada pela associação em série das resistências de cada camada. Mas, se o componente é composto por alguma camada heterogênea (por exemplo, uma parede de tijolo furado com revestimento em argamassa) a resistência de superfície a superfície é dada pela associação em paralelo das resistências de cada seção do componente, conforme estabelecido pela NBR 15220-2 e apresentado na Figura 4.4. Para determinar a resistência total do componente, considerando de ambiente a ambiente, devem ser incluídas as resistências superficiais externa e interna.

\subsubsection{Transmitância térmica $-U\left[W / m^{2} . K\right]$}

Transmitância térmica (ou coeficiente global de transferência de calor) é o inverso da resistência térmica total $\left(U=1 / R_{T}\right)(\mathrm{ABNT}, 2005 \mathrm{~b})$.

A transmitância térmica é uma propriedade importante, pois permite avaliar o desempenho do sistema por meio da avaliação global da transferência de calor de ambiência a ambiência, inclusive comparando os diversos sistemas entre si. 


\subsection{MECANISMOS DE TRANSPORTE DE MASSA (UMIDADE)}

A umidade pode estar presente nos materiais porosos tanto na forma de vapor quanto na forma líquida ou sólida (gelo).

A higroscopicidade é a propriedade que descreve a capacidade do material poroso em adsorver vapor d'água presente no ar e dessorver de volta para a atmosfera, quando varia a umidade relativa do meio. Quanto mais higroscópico é um material, maior sua capacidade de umedecer (CIB W040, 2012; FREITAS,1992).

A capilaridade descreve a capacidade de um material poroso, quando em contato com a água em fase líquida, absorver e transportar a água no estado líquido, em função da hidrofilia das superfícies e dos vazios contínuos existentes na sua microestrutura, mesmo sem a existência de um gradiente hidráulico (GTA, 2009).

Segundo Freitas (1992), em condições isotérmicas, o fluxo de umidade no interior do material poroso pode ocorrer na fase de vapor por difusão, por meio do gradiente de pressão parcial de vapor ou pelos fluxos convectivos de ar, e na fase líquida devido à capilaridade, sob os efeitos das forças capilares, dos gradientes de pressão externa ou da gravidade.

Portanto, o transporte de umidade ocorre, simultaneamente, na fase líquida e fase vapor. Ramos (2007) explica que raramente a transferência de umidade em um meio poroso pode ser definida de forma isolada como pura difusão de vapor ou pura sucção capilar. Para existir somente o fenômeno da difusão, seria necessário um ambiente com muito baixa umidade relativa e, no caso de pura sucção, o meio poroso teria que estar totalmente saturado.

Segundo a ASHRAE (2009), é difícil distinguir experimentalmente entre o fluxo líquido de sucção e o fluxo de vapor de água por difusão, na estrutura porosa dos materiais higroscópicos. Como os sistemas porosos desses materiais são muito complexos, parte dos poros pode estar preenchida por líquido e parte por vapor. Então, frequentemente, os fluxos de líquido e vapor são tratados como processos paralelos.

\subsubsection{Transporte de umidade por difusão de vapor de água}

A difusão do vapor d'água origina-se da diferença de concentração entre dois componentes da mistura gasosa: ar seco e vapor d'água. De acordo com os princípios da física e da Lei de Fick, dois meios gasosos com diferentes concentrações tendem ao equilíbrio por meio do transporte de moléculas do meio mais concentrado para o meio menos concentrado. Sempre que houver diferenças de pressão de vapor de água devido às diferenças de concentração das moléculas 
entre dois ambientes, inevitavelmente ocorrerá um fluxo difusivo de vapor através do elemento poroso que os separa (MENDES, 1997; SANTOS, 2009; ASHRAE, 2009).

O comportamento higroscópico do material em função da umidade relativa caracteriza-se em uma primeira fase de adsorção em mono-camada, onde ocorre a fixação de moléculas de água na parede do poro, seguida por uma segunda fase de adsorção plurimolecular, correspondente à sobreposição das várias camadas de moléculas que, reduzindo o diâmetro do poro, leva à condensação capilar, conforme mostra a Figura 4.5 (FREITAS et al., 2008).

No domínio higroscópico, a fixação de vapor por adsorção é atribuída às forças intermoleculares, ou de Van Der Waals que atuam na interface sólido-fluido no interior dos poros (FREITAS, 1992).
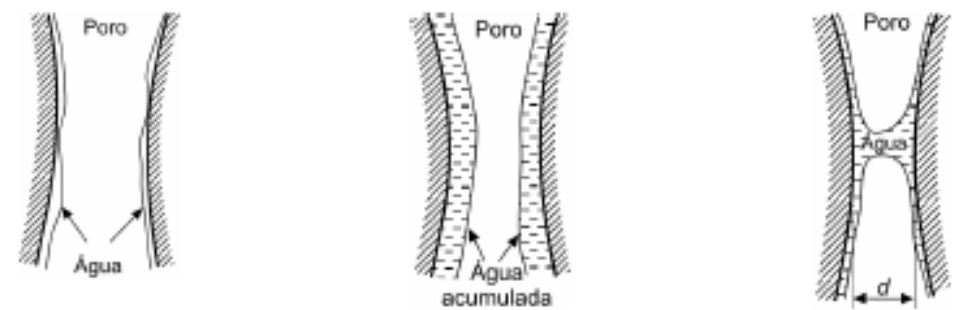

Fonte: Couasnet (1989) apud Ramos (2007).

Figura 4.5 -Etapas da fixação das moléculas de vapor de água nos poros.

Enquanto a umidade relativa for menor que a umidade crítica, existe vapor de água em equilíbrio com a camada adsorvida. Nesta condição, o transporte de umidade é caracterizado pelo mecanismo de difusão do vapor de água. Quando a camada plurimolecular adsorvida na parede do poro se junta, formando um menisco cujo raio atinge o valor correspondente à do raio crítico, a umidade é condensada no interior do poro, preenchendo-o e formando, inicialmente, uma porção de água oriunda da condensação capilar (FREITAS et al., 2008).

Segundo Sato (1998), a água na forma de vapor é fixada nos poros superficiais devido aos processos de adsorção física e depois é transferida para as regiões mais internas à superfície pelos mecanismos de condensação e de difusão de vapor. Quanto menores forem os poros do material, mais alta será a quantidade de umidade produzida por condensação capilar.

Caso haja a formação de água condensada em quantidade suficiente para preencher todo o poro, o transporte de água para o interior do material se processa por capilaridade. Enquanto não existir um meio líquido contínuo, o transporte se dá basicamente por difusão; à medida em que se estabelece uma continuidade de massa, passa a predominar o mecanismo de transporte de umidade na forma líquida, por capilaridade (SATO, 1998). 


\subsubsection{Transporte de umidade por capilaridade}

O fenômeno da capilaridade ocorre em meios porosos não saturados e é constituído pelas forças externas criadas por contato superficial, gradiente de pressão capilar e peso de coluna de líquido. A Lei de Darcy foi aplicada, inicialmente, para os fenômenos de transporte de água líquida em meios porosos saturados. Posteriormente, foi estendida para as situações de transporte em meios não saturados (INCROPERA; DEWITT, 2003).

Para que haja invasão de água por capilaridade é necessário que a interação entre as moléculas do líquido seja mais importante que a interação delas com a superfície sólida, possibilitando a formação de pontes de líquido entre superfícies opostas. Isto é, o mecanismo de fixação por capilaridade tem início quando a espessura da camada d'água adsorvida for suficientemente grande para que a força intermolecular seja mais importante que a força entre a fase líquida e a superfície sólida (HALL, 1977; MENDES, 1997; SATO,1998).

O ângulo de contato de molhagem é o ângulo entre o menisco de água e a superfície capilar. Quanto menor for este ângulo, maior será a sucção capilar. Para os materiais hidrofílicos (que atrai água) o ângulo é inferior a $90^{\circ}$ e para os materiais hidrofóbicos (repelente à água) o ângulo está entre $90^{\circ}$ e $180^{\circ}$ (ASHRAE, 2009).

$\mathrm{O}$ transporte da água para o interior do material ocorre devido às forças capilares que atuam em função do contanto entre o poro e a fase líquida. Segundo Sato (1998), o mecanismo de transporte de água por capilaridade prevalece apenas nas camadas superficiais, que apresentam poros abertos e conectados.

"Mesmo estando estes poros conectados até as camadas mais internas, o transporte não ocorre indefinidamente por capilaridade pois os poros opõem uma resistência ao escoamento de fluídos, determinada fundamentalmente pelas suas dimensões, sendo que poros menores apresentam maiores resistências hidráulicas que os maiores. Além disso, os poros podem assumir diferentes formas, e assim, à medida em que a interface água/ar se movimenta através do poro, pode ter o seu movimento interrompido ao atingir uma situação de menisco estável, resultante de um aumento no diâmetro e consequente redução da força capilar. A partir da interrupção no escoamento do líquido, o transporte ocorre somente por difusão até que, por adsorção e condensação de vapor difundido, seja formada nova continuidade de líquido. ” (SATO, 1998) 
Quanto maior o teor de umidade do material menor é a sucção, que se anula para um teor de umidade igual ao teor de umidade máximo (FREITAS et al., 2008).

A sucção capilar é maior em poros menores, então a água se move a partir dos poros menores para os poros maiores. Os poros maiores têm uma capacidade muito maior de transporte de líquido do que os poros menores, mas os poros maiores só podem ser preenchidos com água quando os poros menores já estão saturados. Quando os poros possuem raios equivalentes e constantes, a água se move em direção às zonas com menor ângulo de contato de molhagem. Embora a tensão superficial seja uma função decrescente da temperatura (quanto maior a temperatura, menor é a tensão superficial) a água se move em direção às zonas com temperatura mais baixa (ASHRAE, 2009, p. 25-11).

\subsubsection{Transporte convectivo de ar no meio poroso}

O transporte convectivo de ar em meio poroso ocorre como um fluxo; neste caso, na medida em que o poro é preenchido com água, a permeabilidade ao ar decresce substancialmente.

Nos processos convectivos em paredes com múltiplas camadas, o potencial de transporte ocorre pela diferença de pressão entre as superfícies externa e interna da parede; deste modo, para cada material deve-se considerar um valor de permeabilidade ao ar.

Santos (2009), em sua tese de doutorado, estudou os fenômenos de transporte de calor e massa em blocos vazados. Perante as lacunas encontradas na literatura, a respeito do transporte convectivo de ar em meio poroso, o autor concluiu que:

“... embora o acoplamento dos fenômenos tenha recebido grande atenção atualmente, a literatura disponível, no que diz respeito à transferência de calor e umidade em blocos vazados, é ainda limitada. Esta limitação deve-se tanto à complexidade de se incluir em um modelo todos os fenômenos físicos presentes como ao alto tempo computacional necessário nas simulações, mesmo nas dimensões padrão dos blocos estruturais. ” (SANTOS, 2009)

Esse mecanismo de transporte não será contemplado nos estudos do comportamento higrotérmico em meio poroso dos materiais de fachada, considerando que o modelo do WUFI não acopla o fenômeno de transporte convectivo em meios porosos em suas equações governantes. 


\subsection{UMIDIFICAÇÃO E SECAGEM}

Os materiais porosos apresentam certa quantidade de umidade mesmo quando expostos à ambientes relativamente secos, em decorrência da umidade adsorvida e condensada nos menores vazios (espaços interlamelares) e da umidade apenas adsorvida nos poros maiores. Materiais com grande fração de poros menores são mais higroscópicos, ou seja, quando em contato com o ar úmido, retêm uma quantidade maior de água que os materiais de poros maiores (SATO, 1998).

Os materiais porosos também absorvem água em estado líquido quando em contato com vazamentos, água de chuva, inundações ou resultante de condensações superficiais. O processo de molhagem pode levar o material a atingir o teor de umidade capilar (de saturação) quando os poros maiores são preenchidos com água. Materiais porosos com diferentes teores de umidade, quando em contato direto uns com os outros, também podem umedecer pelo fluxo capilar de um material para o outro até que todos os poros de um certo tamanho são enchidos com água em ambos os materiais; todos os poros com tamanhos acima deste limite permanecem vazios porque os capilares menores têm uma força de sucção maior do que os maiores (ASHRAE, 2009).

O processo de secagem de um material envolve vários mecanismos de transporte e passa por diferentes fases. A evaporação é um desses mecanismos de secagem.

A condensação e a evaporação ocorrem em interface líquido-ar . Inicialmente, em ambas as extremidades do poro, a massa de água está em contato com as fases gasosas e, então, passa a sofrer condensação na extremidade mais interior do poro e evaporação na extremidade mais exterior da superfície. No extremo mais seco ocorre uma redução no transporte de vapor em razão da diminuição das pontes de líquido disponíveis. No outro extremo, quando a quantidade de água se aproxima da saturação, o vapor encontra dificuldades para se locomover, diminuindo também a sua taxa de transferência (SANTOS, 2009).

A evaporação começa na superfície de um material saturado, onde o mecanismo de transporte que conduz a água até a superfície são as forças capilares. Com o processo de evaporação, ocorre um recuo da frente úmida, então se instala o processo de difusão do vapor de água desde a frente úmida até à superfície exterior. Quando deixar de existir frente úmida, termina o processo no domínio capilar iniciando-se a difusão de vapor no domínio higroscópico. Quando o teor de água de equilíbrio higroscópico for atingido o processo de secagem terminou (PÁSCOA, 2012). 


\subsection{MECANISMOS DE TRANSPORTE DE CALOR}

A transferência de calor ocorre sempre devido à uma diferença de temperatura que faz a energia térmica (calor) se mover a partir de uma região de temperatura mais alta para uma região de temperatura mais baixa (ASHRAE, 2009).

Os mecanismos de transporte de calor referem-se à energia térmica transferida por condução, radiação, convecção e entalpia, ou a combinação delas (CIB W040, 2012).

\subsubsection{Fluxo de calor por condução - $q c d\left[\mathrm{~W} / \mathrm{m}^{2}\right]$}

A transferência de calor por condução é um fenômeno relacionado com o transporte de energia térmica (calor) em um meio sólido devido ao gradiente de temperatura. O processo de transferência de calor pode ser expresso pela Lei de Fourier, conforme representado na Figura 4.6 (INCROPERA; DEWITT, 2003). A Equação 4.4 expressa o fluxo de calor por condução em uma superfície.

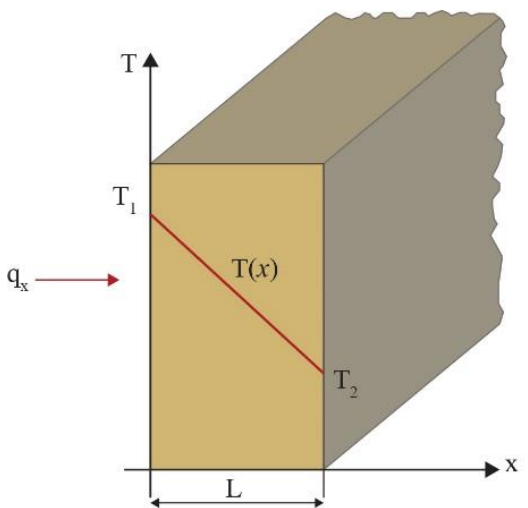

Fonte: Bergman et al. (2011).

$$
q_{c d}=\lambda \cdot A \cdot \frac{T_{2}-T_{1}}{L} \quad\left[\mathrm{~W} / \mathrm{m}^{2}\right]
$$

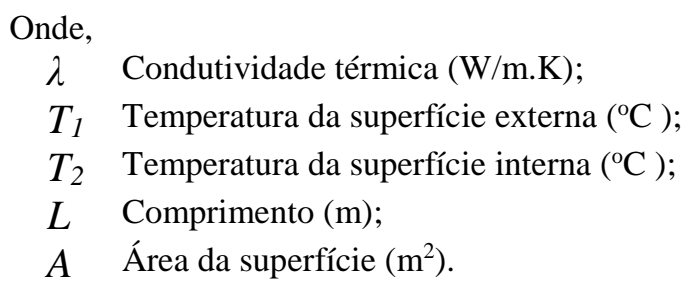

Figura 4.6 - Fluxo de calor por condução.

\subsubsection{Fluxo de calor por convecção - $q c v\left[\mathrm{~W} / \mathrm{m}^{2}\right]$}

A transferência de calor por convecção ocorre entre um fluído em movimento (devido às diferenças de pressão) e uma superfície, quando os dois se encontram em diferentes temperaturas (Figura 4.7). O fluxo de calor por convecção pode ser expresso pela Lei de Newton (Equação 4.5) que é proporcional à diferença entre as temperaturas da superfície e do ar (fluido). A seleção do coeficiente de transferência de calor por convecção $(h c)$ é determinante nos estudos de convecção (INCROPERA; DEWITT, 2003). 


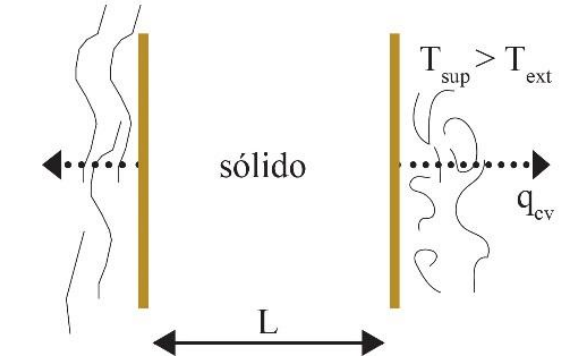

Fonte: baseado em Incropera; Dewitt (2003).

$$
q_{c v}=h c . A \cdot\left(T_{\text {sup }}-T_{\text {ext }}\right) \quad\left[\mathrm{W} / \mathrm{m}^{2}\right]
$$

Onde,

hc Coeficiente de convecção $\left(\mathrm{W} / \mathrm{m}^{2} . \mathrm{K}\right)$;

$T_{\text {ext }} \quad$ Temperatura externa $\left({ }^{\circ} \mathrm{C}\right)$;

$T_{\text {sup }} \quad$ Temperatura da superfície $\left({ }^{\circ} \mathrm{C}\right)$;

$A$ Área da superfície $\left(\mathrm{m}^{2}\right)$.

Figura 4.7 - Fluxo de calor por convecção.

\subsubsection{Fluxo de calor por radiação - $q r a d\left[\mathrm{~W} / \mathrm{m}^{2}\right]$}

O processo de transferência de calor por radiação é causado pela absorção e emissão de ondas eletromagnéticas que ocorrem, inclusive, no vácuo, pois não necessitam de um meio material para a sua propagação. A Figura 4.8 mostra a radiação térmica pertinente à transferência de calor, que é a fração do espectro eletromagnético da radiação que se estende, aproximadamente, de 0,1 micra até 100 micras, incluindo parcela da região ultravioleta (UV) e toda a região de luz visível e infravermelho (IV) (BERGMAN et al., 2011).

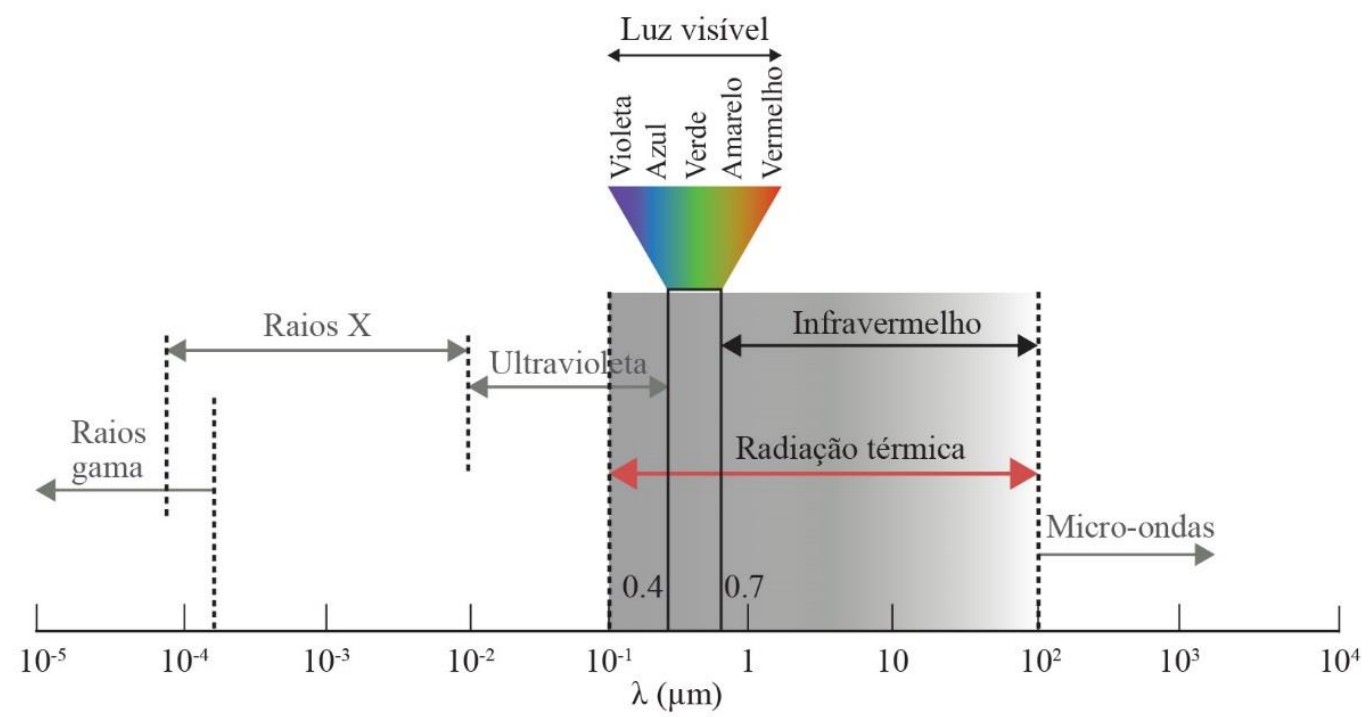

Fonte: baseado em Bergman et al. (2011).

Figura 4.8 - Espectro eletromagnético da radiação solar.

A troca de calor por radiação ocorre mediante uma dupla transformação da energia: uma parte do calor do corpo com maior temperatura se converte em energia radiante que chega até o corpo com menor temperatura, onde é absorvida numa proporção que depende das propriedades da superfície receptora, sendo novamente transformada em calor. As propriedades da superfície receptora são representadas pela emissividade (ou poder emissivo) do corpo. A emissividade está relacionada às fontes de baixa temperatura (ondas longas). Quando a superfície está exposta 
à radiação solar (fonte de alta temperatura - onda curta) as propriedades desta superfície são representadas pela absortância $\alpha$ (LAMBERTS et al., 2011).

O fluxo de calor por radiação, resultante da parcela da irradiação incidente na fachada [I] que é absorvida pela superfície opaca, pode ser expresso por $q_{\text {rad }}=\propto . I$.

Toda a superfície com temperatura não nula tem poder emissivo, liberando uma taxa de energia por unidade de área $\left(\mathrm{W} / \mathrm{m}^{2}\right)$ que pode ser expressa pela Lei de Steffan-Boltzmann onde a temperatura da superfície (Tsup) deve ser considerada em unidade absoluta $\left({ }^{\circ} \mathrm{K}\right)$ e $\sigma$ é a constante de Steffan-Boltzmann $\left(\sigma=5,67 \times 10^{-8} \mathrm{~W} / \mathrm{m}^{2} \mathrm{~K}^{4}\right)$ (BERGMAN, et al., 2011), conforme apresentado na Figura 4.9. A Equação 4.6 expressa o fluxo de calor por radiação entre a superfície do componente e a superfície do entorno.

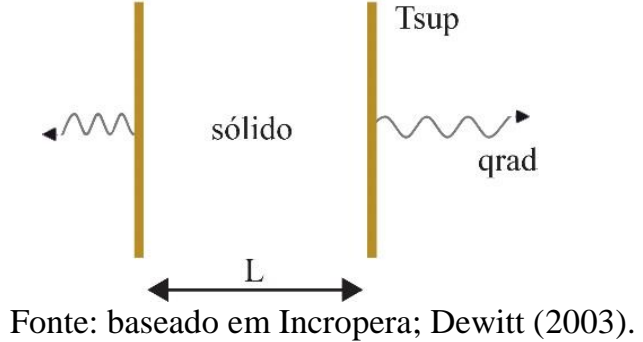

Figura 4.9 - Fluxo de radiação emitido pela superfície.

$$
q_{\text {rad }}=\varepsilon \cdot \sigma \cdot T_{\text {sup }}^{4}
$$

Onde,

$\varepsilon \quad$ Emissividade [-];

$\sigma \quad$ Constante de Steffan-Boltzmann

$T_{\text {sup }} \quad$ Temperatura da superfície $\left({ }^{\circ} \mathrm{K}\right)$;

$L \quad$ Comprimento (m).

Analogamente ao fluxo de calor por convecção, a Equação 4.7 expressa o fluxo de calor por radiação absorvido pela superfície do componente (INCROPERA; DEWITT, 2003).

$$
q_{\text {rad }}=h r \cdot A \cdot\left(T_{\text {sup }}-T_{\text {ext }}\right) \quad\left[\mathrm{W} / \mathrm{m}^{2}\right]
$$

Onde,

$h r \quad$ Coeficiente de radiação $\left(\mathrm{W} / \mathrm{m}^{2} . \mathrm{K}\right)$;

$T_{\text {ext }} \quad$ Temperatura externa $\left({ }^{\circ} \mathrm{C}\right)$;

$T_{\text {sup }} \quad$ Temperatura da superfície $\left({ }^{\circ} \mathrm{C}\right)$;

A Área da superfície $\left(\mathrm{m}^{2}\right)$.

\subsubsection{Balanço energético na superfície da fachada}

De acordo com a Lei de Conservação de Energia ( $1^{\mathrm{a}}$ lei da termodinâmica), a energia armazenada em um sistema é o resultado da diferença entre a energia que entra e a energia que sai do sistema.

Atendendo ao Princípio de Conservação de Energia, a energia incidente é igual à soma das energias absorvida, refletida e transmitida. A Equação 4.8 representa o balanço térmico de uma superfície. 


$$
\propto . I+\rho . I+\zeta . I=I \quad \rightarrow \propto+\rho+\zeta=1
$$

Onde,

$\propto \quad$ Coeficiente de absorção (absortância);

$\rho \quad$ Coeficiente de reflexão;

$\zeta \quad$ Coeficiente de transmissão;

I Radiação solar incidente na superfície.

A parcela referente à transmissão de radiação $(\tau)$ somente é considerada em superfícies transparentes (por exemplo, vidro); nas superfícies opacas não há transmissão. Se o elemento da fachada for uma superfície opaca (por exemplo, sistema de revestimento com material poroso) o balanço térmico da energia radiante é a somatória das frações absorvida $(\alpha)$ e refletida $(\rho)$, cujo valor numérico é igual a 1.

O balanço térmico em uma fachada é o resultado das trocas de calor por condução, convecção e radiação entre a superfície e o meio, e estão envolvidos os ganhos e as perdas de energia através dos fluxos de calor. Havendo uma diferença de temperatura, o fluxo de calor será sempre da superfície mais quente para a superfície mais fria.

A Figura 4.10 mostra o balanço energético da superfície de uma fachada.
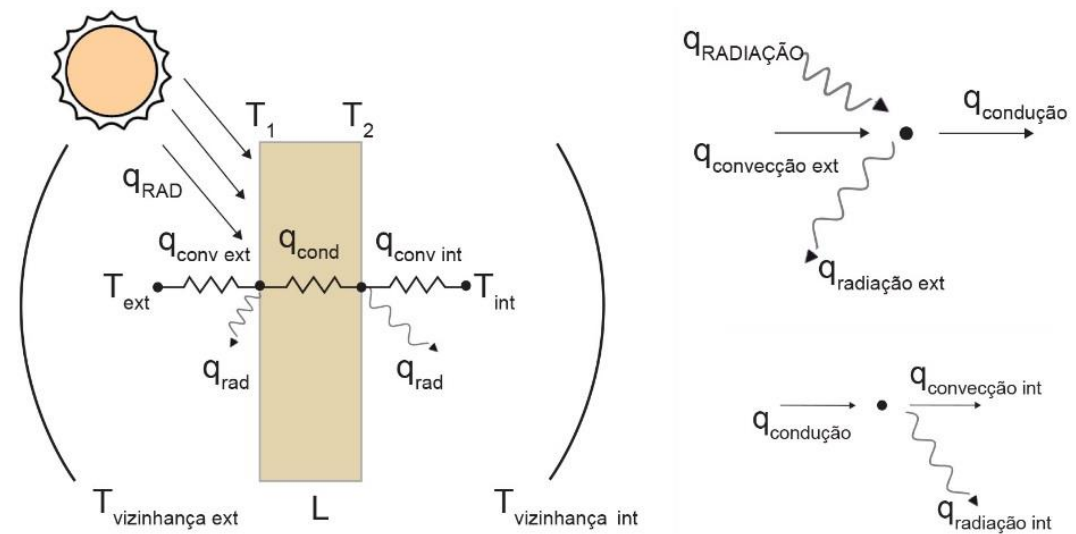

Fonte: baseado em Ordenes et al. (2008).

Figura 4.10 - Balanço energético na fachada.

O fluxo total de calor $\varnothing$ que atravessa uma superfície opaca (por exemplo, a fachada) é expresso pela Equação 4.9.

$$
\emptyset=U \cdot \Delta T \cdot A=U \cdot A \cdot\left(T_{\text {ext }}-T_{i n t}\right)
$$

Onde,

$U \quad$ Transmitância térmica $\left(\mathrm{W} / \mathrm{m}^{2} \cdot \mathrm{K}\right)$;

$T_{\text {ext }} \quad$ Temperatura externa $\left({ }^{\circ} \mathrm{C}\right)$;

$T_{\text {int }} \quad$ Temperatura interna $\left({ }^{\circ} \mathrm{C}\right)$;

$A \quad$ Área da superfície $\left(\mathrm{m}^{2}\right)$. 


\subsection{RADIAÇÃO SOLAR INCIDENTE NA FACHADA}

A radiação solar incidente na envoltória da edificação é um fenômeno que ocorre na superfície dos elementos de fachada, visto que, para os materiais sólidos, a emissão de calor por radiação acontece nas moléculas que se encontram a uma distância não superior a $1 \mu \mathrm{m}$ da superfície (ORDENES et al., 2008).

A radiação solar incidente na fachada é uma parcela da radiação solar global horizontal e é constituída pelas componentes direta, difusa e refletida (ver Figura 2.17).

A componente direta da radiação que atinge a fachada é aquela proveniente diretamente do Sol sem ocorrência alguma de mudança de direção dos raios solares que não seja a ocasionada pela refração atmosférica. A componente difusa (considerada isotrópica) é aquela recebida pela fachada após as reflexões e espalhamento dos raios solares pelas nuvens, partículas da atmosfera e abóbada celeste. Por sua vez, a radiação refletida é aquela recebida pela fachada após reflexão dos raios solares em superfícies adjacentes de prédios, árvores ou solos, sendo bastante dependente das características das superfícies refletoras, ou seja, do albedo (SEVERINO, 2008; SILVA, 2010; VIANA, 2011).

Enquanto que os picos diários da irradiância solar global horizontal ocorrem próximo ao meio dia do horário solar local, os picos diários da irradiância solar na superfície das fachadas variam conforme o dia do ano e a orientação de fachada. Considerando a geometria da insolação, as irradiâncias incidentes nas fachadas são simétricas em relação ao eixo N-S. No entanto, as variações da condição de céu, ao longo do dia, podem afetar os resultados nas diferentes superfícies de fachadas (em termos aproximados, a radiação recebida em um dia nublado é de cerca de um terço do que receberia se tivesse sido sem nuvens).

Considerando que a irradiância solar incidente na fachada é dificilmente medida por instrumentos, métodos semi-empíricos de cálculo são utilizados para a sua determinação (DUFFIE; BECKMAN, 1980).

\subsection{TEMPERATURA NA SUPERFÍCIE DA FACHADA}

A temperatura da superfície exterior é uma variável fundamental nos estudos do comportamento higrotérmico e do processo de degradação dos sistemas de fachada. Considerando que a temperatura do ar interior, a transmitância térmica do sistema, a cor da superfície e a resistência superficial externa são valores constantes em um regime estacionário, ou que apresentam pouca 
variação nos regimes transientes, verifica-se que a temperatura superficial exterior depende fortemente da radiação solar incidente e da temperatura do ar exterior, visto que são os parâmetros que variam ao longo do dia.

\subsubsection{Temperatura Equivalente (Temperatura Sol-Ar)}

A radiação solar age sobre a fachada por meio de uma temperatura equivalente (temperatura sol-ar). Segundo a definição da EN 15026 (DIN, 2007), estando a superfície da fachada exposta à radiação, as trocas de calor por radiação e por convecção com o meio são representadas por uma temperatura equivalente.

Expressa pela Equação 4.10, a temperatura equivalente $\left(T_{e q}\right)$ ou temperatura sol-ar $\left(T_{\text {sol-ar }}\right)$ é uma temperatura fictícia que representa o efeito combinado da temperatura do ar com a radiação solar incidente na envolvente do edifício, as trocas de energia radiante com o céu e outras superfícies exteriores e as trocas de calor por convecção com ar exterior; nestes processos intervêm o coeficiente de absorção $(\alpha)$ e a emissividade $(\varepsilon)$ da superfície (ASHRAE, 2009; LAMBERTS et al., 2011).

$$
T_{e q}=T_{a r}+\propto \cdot I \cdot R_{s e}-\varepsilon \cdot \Delta R_{L} \cdot R_{s e}
$$

Onde,
$\alpha \quad$ Coeficiente de absorção [-];
I Radiação solar total incidente na superfície $\left(\mathrm{W} / \mathrm{m}^{2}\right)$;
$R_{s e} \quad$ Resistência superficial externa $\left(\mathrm{m}^{2} \mathrm{~K} / \mathrm{W}\right)$;
$\Delta R_{L} \quad$ Diferença entre a radiação de onda longa emitida e recebida pela superfície;
$\varepsilon \quad$ Emissividade [-].

O processo de interação entre a radiação solar e os elementos da fachada depende da absortância solar (relacionada com a cor e a superfície) e do meio envolvente (representado pela resistência superficial externa $\left.-R_{s e}\right)$. A fração da radiação total absorvida pela superfície opaca da fachada é $\boldsymbol{\alpha} \cdot \boldsymbol{I} \cdot \boldsymbol{R}_{\boldsymbol{s} \boldsymbol{e}}$. A resistência térmica da superfície externa $\left(R_{s e}\right)$ é um coeficiente que representa as trocas de calor por convecção e radiação entre a superfície externa e o meio $\left(\mathrm{m}^{2} . \mathrm{K} / \mathrm{W}\right)$ e varia de acordo com diversos fatores, tais como, emissividade, velocidade do ar sobre a superfície e temperaturas da superfície, do ar e superfícies próximas.

Para planos verticais, a diferença entre a radiação de onda longa emitida e recebida pela superfície $\left(\Delta R_{L}\right)$ é nula, pois as perdas ficam compensadas pela radiação de onda longa recebida do solo e das superfícies do meio (LAMBERTS et al., 2011). Assim, a Equação 4.9 passa a ser expressa pela Equação 4.11.

$$
T_{e q}=T_{a r}+\propto . I \cdot R_{s e}
$$


Barreira (2010), estudando a envoltória de edifícios com revestimento de argamassa, esclarece que as fachadas se comportam como um corpo cinzento, absorvendo uma parte da radiação de onda longa emitida pelos objetos do entorno (radiação terrestre) e pelo céu (radiação atmosférica). Por outro lado, a fachada também emite radiação com uma intensidade calculada a partir da Lei de Stefan-Boltzmann, considerando a emissividade do reboco exterior. A radiação terrestre resultante é o somatório da radiação de onda longa emitida pelas diferentes superfícies terrestres, que também se comportavam como corpos cinzentos, obedecendo, por isso, à Lei de Stefan-Boltzmann. Sendo as temperaturas de todas as superfícies terrestres semelhantes, o balanço das trocas de radiação de onda longa que ocorrem entre a fachada do edifício e as superfícies restantes torna-se equilibrado e praticamente nulo (BARREIRA, 2010).

\subsubsection{Cálculo da temperatura superficial na fachada}

A temperatura superficial externa na fachada da edificação pode ser obtida pela Equação 4.12, que considera o balanço térmico e o princípio de conservação de energia.

$$
\frac{T_{\text {ext }}-T_{\text {int }}}{R_{T}}=\frac{T_{\text {ext }}-T_{\text {sup.ext }}}{R_{\text {se }}}
$$

No caso das fachadas das edificações, a temperatura externa a ser considerada é a temperatura equivalente ou temperatura sol-ar dada pela Equação 4.10, que representa o efeito combinado da temperatura do ar com a radiação solar incidente na superfície e as trocas de calor por radiação e convecção da superfície com o ar exterior e o meio.

A resistência total da superfície $\left(R_{T}\right)$ a ser considerada é aquela expressa pela Equação 4.2, sendo que a transmitância é inversamente proporcional à resistência total da superfície.

Dessa forma, a Equação 4.12 passa a ser expressa pela Equação 4.13.

$$
T_{\text {sup.ext }}=T_{e q}-U \cdot R_{\text {se }} \cdot\left(T_{e q}-T_{\text {int }}\right)
$$

Considerando o fluxo total de calor $\emptyset$ na fachada, a Equação 4.9 passa a ser expressa pela Equação 4.14.

$$
\emptyset=U \cdot A \cdot\left(T_{\text {ext }}-T_{\text {int }}\right)=\text { U.A. }\left(\mathrm{T}_{\mathrm{ar}}+\propto . \mathrm{I} \cdot \mathrm{R}_{\mathrm{se}}-\mathrm{T}_{\text {int }}\right)
$$

\footnotetext{
Onde,

$T_{\text {sup.ext }} \quad$ Temperatura da superfície exterior da fachada $\left({ }^{\circ} \mathrm{C}\right)$;

$T_{e q} \quad$ Temperatura equivalente ou Temperatura sol-ar $\left({ }^{\circ} \mathrm{C}\right)$;

$U$ Transmitância térmica do sistema $\left(\mathrm{W} / \mathrm{m}^{2} . \mathrm{K}\right)$;

$R_{\text {se }} \quad$ Resistência superficial externa $\left(\mathrm{m}^{2} \mathrm{~K} / \mathrm{W}\right)$;

$\mathrm{T}_{\text {int }} \quad$ Temperatura do ambiente interno $\left({ }^{\circ} \mathrm{C}\right)$;

A Área da superfície de fachada $\left(\mathrm{m}^{2}\right)$;

$\mathrm{T}_{\mathrm{ar}} \quad$ Temperatura do ar $\left({ }^{\circ} \mathrm{C}\right)$;

I Radiação solar total incidente na superfície $\left(\mathrm{W} / \mathrm{m}^{2}\right)$;

$\propto \quad$ Coeficiente de absorção [-].
} 


\subsection{AGENTES E MECANISMOS DE DEGRADAÇÃO DE FACHADA}

A degradação é um processo pelo qual uma ou mais propriedades do material são afetadas pela ação dos agentes de degradação (BS ISO 15686-8: 2008b). Os agentes de degradação são todos aqueles que, agindo sobre a edificação ou suas partes, afetam negativamente o seu desempenho (BS ISO 15686-2: 2012).

Vários autores apresentam, de diferentes formas, a classificação dos agentes e mecanismos de degradação. Adaptado da ISO 6241: 1984, a norma ISO 15686-2: 2012 apresenta o Quadro 4.5 que classifica os agentes de degradação de acordo com a sua própria natureza e não com a natureza da ação que promovem.

Quadro 4.5 - Natureza dos agentes de degradação.

\begin{tabular}{|c|l|}
\hline \multicolumn{1}{|c|}{ Natureza } & Classe \\
\hline \multirow{3}{*}{ Agentes mecânicos } & Gravidade \\
& Cargas e deformações impostas ou restringidas \\
& Energia cinética \\
& Vibrações e ruídos \\
\hline \multirow{4}{*}{ Agentes Eletromagnéticos } & Radiação \\
& Eletricidade \\
& Magnetismo \\
\hline Agentes térmicos & Níveis extremos ou alterações bruscas de temperatura \\
\hline \multirow{3}{*}{ Agentes químicos } & Água e solventes \\
& Agentes oxidantes \\
& Agentes redutores \\
& Ácidos \\
& Bases \\
& Sais \\
& Agentes quimicamente neutros (poeira, gordura, sílica) \\
\hline Agentes biológicos & Vegetais (plantas, raízes) \\
& Microbianos (bactérias, fungos e bolor) \\
& Animal (insetos, aves, roedores, cupim) \\
\hline
\end{tabular}

Fonte: ISO 15686-2 (2012) adaptado de ISO 6241 (1984).

Os mecanismos de degradação explicam a forma como um elemento de construção reage sobre a aplicação de uma ação, isto é, referem-se às alterações químicas, biológicas, físicas ou mecânicas que conduzem às mudanças de uma propriedade ou característica crítica de um edifício ou de uma parte da construção quando exposta aos agentes de degradação. Observa-se que um mecanismo de degradação pode envolver uma ou mais alterações, mudanças de propriedade ou agentes de degradação (JERNBERG et al., 2004).

Os agentes de degradação podem agir isoladamente ou em sinergia, atuando de diferentes formas, associadas ou não, simultâneas ou sequenciais, levando a edificação às diferentes 
condições de exposição. Segundo a NBR 15.575-1, as condições de exposição são as ações ou um conjunto de ações atuantes na edificação (ABNT, 2013a).

\subsubsection{Movimentações térmicas nas fachadas}

O edifício e suas partes estão sujeitos às movimentações de origem térmica que provocam dilatação ou contração nos materiais. Essas variações dimensionais dependem das características e propriedades dos materiais, do grau de restrição imposto pelos vínculos à livre movimentação de cada componente e da intensidade da ação dos agentes climáticos envolvidos no mecanismo. As movimentações térmicas restringidas pelos vínculos causam tensões térmicas de tração, compressão ou cisalhamento nos constituintes da edificação, que podem levar às fissuras ou deformações.

Segundo Thomaz (1989), é importante considerar tanto a amplitude das movimentações térmicas diferenciadas como a rapidez com que elas ocorrem. Se as variações dimensionais forem lentas e graduais, os diferentes materiais ou componentes que trabalham justapostos podem responder melhor, ajustando-se às tensões impostas, do que se as variações térmicas forem bruscas.

Fiorito (1994) alerta que as movimentações térmicas que atuam nos sistemas de revestimento são um termo somatório às outras diversas causas de manifestações patológicas. Um revestimento já sujeito às tensões de compressão (por exemplo, retração da alvenaria), ao sofrer uma variação de temperatura poderá diminuir ou aumentar esta compressão. Uma sequência de variações térmicas, para mais e para menos, poderá romper gradativamente por fadiga a ligação entre as camadas.

Para Flores-Colen (2009), o que interessa para os estudos de degradação dos sistemas de revestimento são os valores máximos e mínimos das temperaturas e o choque térmico (variação brusca de temperatura). São as variações de temperatura que resultam em expansões ou contrações nos materiais. As alterações das dimensões em condições restringidas aumentam as tensões. Os fenômenos cíclicos de dilatação e contração, decorrentes das variações de temperatura, podem conduzir à fadiga do material, levando à perda de aderência entre as camadas de revestimento ou entre o revestimento e o suporte.

Esquivel (2009) considera que, além do estado de tensão provocado pelo gradual aumento ou diminuição da temperatura, existe ainda uma situação crítica que depende da velocidade (taxa) com que ocorre esta variação. As variações cíclicas de temperatura associadas às tensões e deformações produzidas em cada ciclo pode desencadear um processo de fadiga do sistema de 
revestimento, mas se a temperatura superficial do material variar rapidamente, será produzido um gradiente térmico entre a superfície do corpo e seu interior, o que pode provocar tensões de elevada magnitude, fenômeno denominado de choque térmico.

O que determina a intensidade das tensões térmicas é o gradiente térmico, originado pela diferença de temperatura entre a face externa e a face interna da fachada, ou entre a face externa e a camada ligeiramente abaixo da superfície exposta à temperatura externa.

O gradiente térmico provoca um momento fletor no plano vertical, em relação à um eixo horizontal na parede, isto é, enquanto uma das superfícies está sujeita à compressão, a outra superfície está sujeita a tração. Segundo Esquivel (2009), na escala microscópica, os gradientes térmicos são originados pela heterogeneidade dos materiais devido às suas diferentes propriedades higrotérmicas.

\subsubsection{Fadiga térmica}

A temperatura superficial da fachada é resultado da interação entre temperatura do ar, radiação solar, nebulosidade, ventos, precipitação e as características higrotérmicas e mecânicas dos constituintes da fachada, conforme a sua orientação e localização geográfica. As variações das temperaturas superficiais da fachada possuem comportamento sazonal (verão e inverno) e cíclico (dia e noite, por exemplo).

As variações térmicas cíclicas causam variações de repetição que podem levar à fadiga. Além da amplitude das variações térmicas e da rapidez com que elas ocorrem, deve-se considerar com que frequência acontecem os ciclos de carregamento-descarregamento ou as solicitações alternadas de tração-compressão. Ainda, a estabilidade do sistema de fachada implica que cada uma de suas camadas sobrepostas deve suportar as tensões atuantes no sistema (ESQUIVEL, 2009; THOMAZ; 1989; JUNGINGER; 2003).

No fenômeno da fadiga, após certo número de ciclos, as tensões térmicas atuantes podem produzir perda de desempenho, mesmo com valores de tensão inferiores ao limite de resistência do material constituinte. Um exemplo deste fenômeno é o descolamento entre as camadas sobrepostas de um sistema de fachada com revestimento cerâmico que ocorre por fadiga (SARAIVA, 1998; SARAIVA; BAUER; BEZERRA, 2002; PAES; CARASEK, 2002; UCHÔA et al., 2008; DAS CHAGAS, 2009; BARBOSA, 2013).

O processo de ruptura por fadiga é caracterizado por três fases distintas: 1) microfissuras já existentes ou iniciação de pequenas fissuras; 2) propagação gradual das fissuras; 3 ) ruptura final (etapa mais rápida). Este fenômeno ocorre mesmo que as deformações impostas apresentem 
magnitudes inferiores à deformação de ruptura, ou seja, em condições de solicitações de magnitude inferior à capacidade resistente do material. Geralmente, a superfície de fratura é perpendicular ao carregamento aplicado. Portanto, a falha começa na forma de pequenas fissuras, que vão crescendo e reduzindo a seção resistente, até que uma sobrecarga provoque a ruptura final, por uma propagação brusca da fissura (CERVO, 2004; UCHÔA, 2007; DAS CHAGAS, 2009).

\subsubsection{Choque térmico}

Choque térmico é o fenômeno produzido quando a temperatura superficial externa cai rapidamente em relação ao restante do sistema. Thomaz (1989) refere-se ao choque térmico como uma mudança brusca de temperatura.

Segundo Esquivel (2009), exceto em situação de incêndio ou em ambientes industriais, fornos, etc., a produção de choque térmico nas edificações ocorre em condições de exposição da fachada ao meio ambiente, onde as temperaturas superficiais das fachadas podem chegar a $70^{\circ} \mathrm{C}$ ou $80^{\circ} \mathrm{C}$. Oliveira et al. (2014) supõem que, no Brasil, as temperaturas superficiais de uma fachada com cor escura (absortância $\geq 0,7$ ) podem chegar até a $80{ }^{\circ} \mathrm{C}$, dependendo da localização geográfica e orientação. Guimarães et al. (2002), em medições de campo durante 3 dias de outono na cidade de Goiânia, obtiveram valores máximos na ordem de $55^{\circ} \mathrm{C}$ para superfície com pintura em esmalte sintético preto.

Segundo Goldberg (1998) apud Temoche e Barros (2010), os valores da rápida queda de temperatura, geralmente, não ultrapassam os $50^{\circ} \mathrm{C}$.

Como requisito de resistência à ação do calor e choque térmico, a NBR 15575-4 (ABNT, 2013b) estabelece um método de ensaio de desempenho onde um corpo de prova representativo do sistema construtivo a ser avaliado é exposto a 10 ciclos de aquecimento (por painel radiante) e resfriamento (por aspersão de água), não devendo apresentar fissuras, falhas ou deslocamentos que comprometam o desempenho previsto. $\mathrm{O}$ método de ensaio prescreve como temperatura máxima de aquecimento $(80 \pm 3){ }^{\circ} \mathrm{C}$ e temperatura após resfriamento do corpo de prova de $(20 \pm 5){ }^{\circ}$ C. A NBR 15575-4 (ABNT, 2013b) não define o tempo de aquecimento ou de resfriamento para cada fase do ensaio, mas, segundo Oliveira et al. (2014), o tempo médio de ciclo varia em torno de $6 \mathrm{~h}$.

A variação de temperatura causa tensões térmicas geradas pela restrição à livre deformação. A resistência ao choque térmico refere-se à maior capacidade de o revestimento resistir a uma 
grande variação de temperatura, com ciclos de frio - quente - frio, sem sofrer perda de sua integridade e mantendo suas propriedades.

Segundo Kingery (1995) apud Esquivel (2009), choque térmico não é uma propriedade intrínseca do material e sim uma interação entre determinadas propriedades térmicas e mecânicas do material e as condições de contorno em que ocorre o choque térmico.

O choque térmico está associado ao rápido aquecimento ou resfriamento da superfície da fachada. Para as edificações constituídas de materiais porosos, esse processo não é instantâneo e depende das características higrotérmicas da fachada, da inércia térmica e das condições de exposição da fachada ao meio ambiente.

Os fenômenos meteorológicos que propiciam o choque térmico são:

- Tempestades de verão, após um período de forte insolação, provocando uma queda de temperatura superficial em pouco tempo, acelerada pelo aumento da nebulosidade e pela ação convectiva do vento sobre a superfície da fachada.

- Resfriamento brusco da fachada devido à rápida queda da temperatura do ar ou ação das rajadas de vento frio, no final de um dia ensolarado e de altas temperaturas.

- Resfriamento brusco da fachada devido à rápida mudança na nebulosidade no período mais quente do dia, associado a uma entrada de frente fria.

- Aquecimento brusco da superfície devido à incidência de alta irradiação na fachada nas primeiras horas de uma manhã em condição de céu claro, quando a superfície da fachada se encontra com baixa temperatura superficial, após uma noite de inverno e de forte arrefecimento das superfícies.

- Rápida mudança na nebulosidade nos períodos mais quentes ou mais frios do dia, alterando as condições de céu e, portanto, a radiação solar incidente na fachada.

\subsubsection{Umidade nas construções}

A presença de umidade nas construções constitui-se em uma das principais causas de degradação das edificações. Os materiais a serem usados nos sistemas de fachada devem ser estanques à água líquida e, ao mesmo tempo, permitir as trocas de vapor para que os teores de umidade dos materiais não favoreçam a ocorrência de movimentações dimensionais, condensações, bolor, manchas, alterações físicas e química nos materiais, entre outros tipos de manifestações patológicas oriundas da presença de umidade. 
A forma de classificação da umidade a partir da origem da água é tradicionalmente agrupada em cinco tipos (GRATWICK, 1971; PEREZ, 1988; VALLEJO, 1990; CARRIO, 1994; MORALES, 1995):

a) Umidade da obra: originada da água utilizada nos processos de fabricação e construção; é um tipo de umidade própria de obras com materiais porosos. Mesmo os componentes industrializados ou processos construtivos mais racionalizados resultam em elevado teor de umidade de obra que, gradualmente, vai diminuindo após o término da obra. A água presente, ao se evaporar, aumenta a estrutura porosa do material.

b) Umidade ascendente ou de capilaridade: originada da absorção da água presente no solo. Toda superfície porosa em contato com o solo tende a umedecer-se pela atuação das forças capilares, mesmo não atuando uma pressão externa, bastando as forças de sucção resultante da atração superficial entre sólido e líquido. Vários são os fatores que intervém no fenômeno de umidade ascendente: grau de saturação do solo, presença de sais nos materiais de construção, velocidade de evaporação desde a superfície, configuração da estrutura porosa e da permeabilidade dos materiais (diâmetro, tortuosidade, conectividade etc.). A altura alcançada pela água em um capilar é inversamente proporcional ao seu diâmetro. Quanto menor o tamanho dos poros, maior será a altura que a água pode atingir. A umidade ascendente afeta, principalmente, os materiais da base das paredes, provocando manchas, bolor, eflorescência, etc., além de comprometer a qualidade do ambiente interior.

c) Umidade de infiltração: proveniente da água de chuva que se projeta sobre a envoltória edificada e penetra através de seus elementos constituintes. A chuva é uma das principais fontes de umidificação da construção. Segundo Perez (1988), a água de chuva só pode penetrar em uma edificação se forem reunidas três condições: água sobre a superfície, aberturas permitindo a penetração da água e forças empurrando a água. As forças que atuam sobre a fachada impelindo a penetração da água de chuva pelas aberturas são resultantes da energia cinética das gotas, das forças capilares de sucção, das forças de gravidade e da pressão do vento.

d) Umidade de condensação: proveniente da condensação do vapor de água, quando atinge a temperatura do ponto de orvalho. A condensação pode ser superficial ou intersticial, respectivamente, quando o fenômeno ocorre na superfície ou em algum ponto interno da parede. A condensação pode, também, ser higroscópica, quando causada pela presença de sais higroscópicos no interior dos poros. 
e) Umidade acidental: originada de vazamentos ou rompimento de instalações de água ou outros dispositivos ou componentes da edificação.

Ainda, incluindo a esta classificação mais uma categoria importante para entender as origens e formas de umidade, cita-se aquela originada do uso e manutenção da edificação, por exemplo, as águas de limpeza e lavagem.

\subsubsection{Movimentações higroscópicas}

Entre os principais mecanismos de degradação associados aos agentes climáticos estão as movimentações higroscópicas, especialmente aquelas causadas pelos processos de umidificação e secagem. $\mathrm{O}$ aumento do teor de umidade em materiais porosos produz uma dilatação higroscópica (expansão por umidade) enquanto que a diminuição da umidade provoca uma contração.

Caso existam vínculos que impeçam ou restrinjam as movimentações higroscópicas, as tensões de compressão, tração ou cisalhamento geradas implicam em movimentações diferenciadas entre os componentes, causando danos aos sistemas ou suas partes (FIORITO, 1994; THOMAZ, 1989).

A umidificação e a secagem dos materiais dependem de suas propriedades higrotérmicas, mas depende também das condições de exposição aos agentes climáticos (radiação solar, temperatura do ar, umidade relativa, vento, precipitação).

Segundo Freitas (1992), quanto maior a temperatura, mais rápida é a secagem. O aumento da umidade relativa do ambiente dificulta a secagem. Pelo diagrama psicométrico, é possível verificar a conjunção entre a umidade relativa e a temperatura, definindo a concentração de vapor. O que realmente influencia o fluxo de secagem é a diferença entre a concentração de vapor à superfície e a umidade relativa do ar do ambiente. Os fluxos de secagem são mais elevados nas orientações onde as temperaturas superficiais são mais elevadas, ou seja, onde a radiação é maior. Mas, quando os teores de umidade à superfície são reduzidos, a radiação já não tem praticamente influência na secagem. O processo de secagem é mais lento que o processo de umedecimento (histerese) o que provoca a acumulação de umidade quando a duração das fases molhagem e secagem são iguais.

Normalmente, vários ciclos de carga de molhagem e secagem se sobrepõem (por exemplo, verão / inverno, dia / noite, chuva / sol). No entanto, as magnitudes das cargas dependem da propriedade dos componentes, das condições de exposição e da geometria da construção (orientação, altura, proteções, etc.) (ASHRAE, 2009, cap.25). 


\subsubsection{Condensações superficiais ou intersticiais}

A umidificação das fachadas pode ter origem nas condensações intersticiais ou nas condensações superficiais.

A temperatura de ponto de orvalho é a temperatura a partir da qual o vapor de água condensa. O vapor de água que condensa é aquele que excede a capacidade do ar de conter vapor, naquela pressão e temperatura. Se o ar úmido é arrefecido e a quantidade de água presente no vapor continua a ser a mesmo, a umidade relativa aumenta. Quando o ponto de saturação correspondente a $100 \%$ de umidade relativa é alcançado, a condensação irá ocorrer (BS 6150:1991).

As condensações intersticiais ocorrem dentro da estrutura porosa do componente de fachada. Durante o processo de difusão de vapor de água, caso seja atingida a temperatura na qual uma dada mistura de ar-vapor de água atinge o ponto de saturação, ocorre a condensação intersticial. Para uma determinada temperatura e umidade relativa do ar, corresponde uma certa pressão parcial de vapor do ar. Caso ocorra uma queda de temperatura, igualando-se à temperatura do ponto de orvalho, sem que haja alteração na pressão de vapor do ar, a curva de saturação para 100\%UR é atingida, ou seja, se a temperatura cair abaixo desse ponto a massa de ar úmido atinge o limite da saturação, ocorrendo a condensação do vapor excedente (mudança de estado do tipo isobárica).

Durante o dia, a radiação solar aquece a superfície da fachada, o que eleva a evaporação da umidade a partir da camada da superfície exterior. Durante a noite, pode ocorrer um arrefecimento excessivo da fachada, principalmente em noites de céu claro, onde a ausência de nuvens facilita a perda de calor das superfícies para a atmosfera. Neste caso, estando a superfície com uma temperatura igual ou inferior à temperatura do ponto de orvalho, ocorrem as condensações superficiais.

Se a temperatura for mantida constante, mas houver um aumento do vapor de água do ar até atingir a curva de saturação para $100 \%$ UR, ocorre a condensação do restante do vapor de água que ultrapassar o limite de saturação (mudança de estado do tipo isotérmica).

A condensação é um indicador de excesso de umidade que, por sua vez, favorece a proliferação de bolor. A ISO 13788 considera que a umidade crítica para crescimento de bolor corresponde ao valor médio mensal de $80 \%$ UR (DIN, 2012). 
A ISO13788 Hygrothermal performance of building components and building elementsInternal surface temperature to avoid critical surface humidity and interstitial condensation é uma norma internacional que trata dos critérios, das condições críticas e do método de cálculo em regime permanente, relacionados às condensações intersticiais e temperaturas superficiais internas (DIN, 2012).

\subsubsection{A ação do vento como agente de degradação da fachada}

$\mathrm{O}$ vento age na fachada da edificação sob a forma de pressão estática ou dinâmica. $\mathrm{Na}$ engenharia estrutural, a intensidade do vento é um fator determinante das soluções estruturais, sendo que negligenciar os parâmetros normativos pode levar às catástrofes. Nos estudos de energia, eficiência energética e conforto ambiental, o vento é elemento chave para obtenção de soluções passivas ou aplicação sustentável dos recursos naturais. No entanto, em relação ao envelhecimento natural das edificações, o vento entra como um importante elemento coadjuvante, e seu potencial de degradação está relacionado com a interação entre os agentes climáticos atuantes e os condicionantes ambientais e arquitetônicos.

Baseado nos trabalhos de Perez (1988), Carrio (2000), Flores-Colen (2009), Bittencourt e Candido (2010), são apresentados os principais fenômenos em que o vento participa como agente de degradação da edificação:

- Chuva dirigida: o vento age sobre a precipitação, criando as pressões necessárias para que a chuva projetada na fachada penetre na edificação.

- Erosão mecânica: o vento atua como meio de transporte de partículas erosivas que desgastam os revestimentos mais porosos, tornando-os mais permeáveis à água e mais rugosos, favorecendo a fixação de microrganismos e sujidades.

- Ataque químico e biológico: o vento age no transporte de sais, micro-organismos e agentes poluentes.

- Secagem: os movimentos convectivos do vento aumentam a velocidade de evaporação da água capilar superficial, podendo causar a desidratação excessiva, por exemplo, durante a fase de cura das argamassas.

- Deformações: atuando como carga estática ou dinâmica (vibrações), o vento pode provocar deformações nos elementos ou componentes de fachada.

- Resfriamento: causado pelo movimento convectivo do ar sobre a superfície da fachada, o resfriamento da superfície pode apresentar aspectos positivos, mas também alguns aspectos negativos. As trocas térmicas por convecção favorecem a remoção do excesso de umidade 
por evaporação, reduzem a temperatura devido ao consumo de calor pela mudança de fase. Por outro lado, pode intensificar as quedas bruscas de temperatura que produzem os choques térmicos. A intensidade do resfriamento da superfície depende da velocidade e da temperatura do ar; mas também depende da turbulência do fluxo de ar e da umidade relativa do meio.

\subsection{MANIFESTAÇÕES PATOLÓGICAS NAS FACHADAS DECORRENTES DOS AGENTES CLIMÁTICOS DE DEGRADAÇÃO}

Os agentes climáticos agem sobre a fachada, produzindo movimentações higrotérmicas que causam dilatações ou contrações no plano da superfície. Dependendo das restrições impostas, as variações dimensionais geram tensões de tração ou de compressão que podem provocar fissuras, destacamentos, descolamentos, deformações, entre outras manifestações patológicas que atuam nos sistemas de fachada ao longo da sua vida útil.

As juntas são componentes importantes na durabilidade dos sistemas de revestimento de fachadas, pois garantem as folgas necessárias para o alívio das tensões provocadas pelas movimentações higrotérmicas. As interfaces entre os componentes da fachada (por exemplo, encontro entre esquadrias e revestimento) também se configuram como juntas, pois são junções responsáveis por absorver as movimentações diferenciadas entre os diferentes componentes.

As tensões térmicas causadas pela insolação danificam ou causam completa remoção (expulsão) do rejunte das juntas de movimento, podendo agravar as situações de infiltração de água na fachada, e, principalmente, permitindo que se incremente um processo de descolamento e destacamento dos sistemas de revestimento cerâmico (BAUER et al., 2015e).

O envelhecimento das juntas caracteriza-se pela perda da estanqueidade, podendo iniciar logo após a sua execução através de procedimentos inadequados de limpeza, ataques de agentes atmosféricos agressivos e solicitações mecânicas. O envelhecimento das juntas agrava-se com a presença de chuvas ácidas, micro-organismos ou aparecimento de fissuras (CAMPANTE; BAÍA, 2003; BAUER et al., 2005).

A combinação de agentes e mecanismos de degradação provoca importantes alterações nas características químicas e físicas dos materiais, levando à perda de desempenho (JONH; SATO, 2006). Dentre as principais manifestações patológicas estão: degradação dos sistemas de pintura; eflorescências; manchas; perda da cor; erosão; deterioração dos materiais de base orgânica; entre outros. 
As manifestações patológicas em sistemas de revestimento de fachada são importantes indicadores de degradação, principalmente porque podem ser visualmente detectadas ou identificadas pelos métodos de inspeção não destrutivos, permitindo gerenciar o desempenho ao longo da vida útil da edificação, por meio das curvas de degradação (SILVA, 2014; BAUER et al., 2015c).

As curvas de degradação mostram a evolução dos danos da edificação. A taxa da velocidade da degradação, ao longo do tempo de vida útil, caso não haja intervenções de manutenção, sinaliza o comportamento da fachada ou seus elementos mediante as condições de exposição aos agentes agressivos (SILVA, 2014; SILVA et al., 2014; BAUER et.al, 2015e).

Neste contexto e de forma sucinta, são apresentadas as principais manifestações patológicas que surgem nas fachadas com sistemas de revestimento poroso, decorrentes da ação dos agentes e mecanismos de degradação de origem climática.

\subsubsection{Fissuras}

Fissura é a abertura que ocorre no componente por ruptura do material constituinte, decorrente de esforços mecânicos. Em fachadas ou sistemas de vedação vertical externo (SVVE), a NBR 15575-4 estabelece os seguintes critérios quanto à tolerância de ocorrências de fissuras:

- As fissuras no corpo das fachadas e outros seccionamentos do gênero são toleráveis desde que não sejam detectáveis a olho nu por um observador posicionado a 1,00 m da superfície do elemento em análise, em um cone visual com ângulo igual ou inferior a $60^{\circ}$, sob iluminamento natural em dia sem nebulosidade.

Nas fachadas, os pontos preferenciais de penetração da água em baixa pressão são as fissuras e as interfaces entre materiais. Em relação à porosidade do material, depende do diâmetro dos capilares; quanto maior os poros, maior a velocidade de absorção da água.

Uma das formas mais comum de monitorar a degradação de argamassa é observando a fissuração. A partir do padrão de fissuração, sua distribuição, densidade e abertura, a intensidade da degradação pode ser julgada e a estimativa da vida útil e métodos de reparação podem ser planejados.

\subsubsection{Descolamento}

Os descolamentos caracterizam-se pela perda de aderência entre os componentes e sua respectiva base (ANBT NBR 15575-4: 2013b). 
Inicialmente, a frágil aderência entre as camadas que constituem o sistema de revestimento evolui para a ruptura das ligações na interface entre as camadas. $\mathrm{O}$ descolamento entre as camadas é percebido pelo som cavo quando a superfície é percutida ou pela deformação geométrica (estufamento) do componente que se projeta do plano da fachada. Inicialmente, o descolamento não significa desprendimento de partes do componente, mas a sua propagação pode levar ao destacamento (CAMPANTE; BAÍA; 2003).

As causas do descolamento estão relacionadas a diversos fatores. Os principais fatores de origem climática são as deformações oriundas das variações higrotérmicas na camada do revestimento ou as deformações higrotérmicas diferenciadas entre as camadas. As variações higroscópicas causam expansão por umidade nos componentes (CASAREK, 1996; BAUER, 2005).

As variações térmicas causam tensões nas camadas de revestimento. $\mathrm{Na}$ fase de aquecimento, as camadas de revestimento dilatam causando tração, que por sua vez, ocasiona o surgimento de tensões de cisalhamento entre as diferentes camadas. O descolamento ocorrerá na interface que não suportar os esforços oriundos das deformações ocasionadas pelas tensões atuantes. DAS CHAGAS (2009) apresenta um estudo do processo de descolamento de placas cerâmicas, considerando que o fenômeno é causado pelas tensões cíclicas decorrentes da variação de temperatura. Ou seja, o descolamento nada mais é do que a perda de aderência no sistema de revestimento decorrente do fenômeno da fadiga, em virtude de as solicitações impostas ultrapassarem a resistência de aderência entre essas camadas.

Sabbatini e Barros (2001) explicam que, dentre outros fatores, o descolamento é provocado basicamente pelas tensões decorrentes da instabilidade do suporte (acomodação do edifício e deformação lenta da estrutura de concreto) e das variações higroscópicas e de temperatura.

A NBR 15575-4 (ANBT, 2013b) estabelece os seguintes critérios quanto à tolerância de ocorrências de descolamentos em fachadas ou sistemas de vedação vertical externo (SVVE):

- Os descolamentos entre placas de revestimento e outros seccionamentos do gênero são toleráveis desde que não sejam detectáveis a olho nu por um observador posicionado a 1,00 $m$ da superfície do elemento em análise, em um cone visual com ângulo igual ou inferior a $60^{\circ}$, sob iluminamento natural em dia sem nebulosidade.

- Os descolamentos de revestimentos localizados, detectáveis visualmente ou por exame de percussão (som cavo), são toleráveis desde que não impliquem descontinuidades ou risco 
de projeção do material, não ultrapassando área individual de $0,10 \mathrm{~m}^{2}$ ou área total correspondente a $5 \%$ do pano de fachada em análise.

\subsubsection{Destacamento}

O destacamento é uma consequência do descolamento, quando ocorre a queda de partes do sistema de revestimento. As causas do destacamento são as mesmas do descolamento, uma vez que este fenômeno o precede. A queda de parte do componente representa risco para a segurança dos usuários, portanto é considerado um dano grave.

\subsubsection{Eflorescência}

As eflorescências são depósitos salinos esbranquiçados que ocorrem na superfície dos elementos da fachada, decorrente da lixiviação causada pela infiltração ou presença de água (localmente) nos materiais componentes da fachada (argamassas, blocos cerâmicos) sendo que essa água, oriunda da chuva ou da conformação dos materiais, dissolve os componentes solúveis dos materiais. A água, ao chegar à superfície externa, evapora e deposita os componentes na superfície, provocando manchas (BAUER et al., 2010; UEMOTO, 1988).

Segundo Falcão Bauer (2008), para que ocorra eflorescência é necessária a presença de água, sais solúveis e pressão hidrostática para a percolação da água e migração da solução para a superfície.

Portanto, a eflorescência é uma manifestação patológica que sinaliza a presença de água na fachada, tornando-se um indicador importante para detectar umidade. Mesmo que as eflorescências não sejam, em geral, suficientes para desencadear um processo de deterioração do material, as manchas afetam a percepção do usuário e a estética do edifício, desvalorizando o bem imóvel.

\subsubsection{Manchas}

As manchas podem ser causadas por eflorescência, pela deposição de poluentes ou pela presença da ação diferenciada da água sobre a fachada.

A água da chuva, ao ser projetada sobre a superfície da fachada interage de acordo com as seguintes fases, conforme descreve Carrio (2000):

- Fase de molhagem: as primeiras gotas molham a superfície e, por simples absorção, penetram nos poros da superfície com uma intensidade que depende do coeficiente de capilaridade do material. 
- Fase de saturação: de acordo com o coeficiente de capilaridade, o material é saturado superficialmente quando então não é mais capaz de absorver mais água em seus poros.

- Fase de lamina d'água: uma vez saturados os materiais da superfície, a água começa a escorrer pela superfície formando uma lâmina d'água que, em função da sua espessura, adquire maior ou menor velocidade.

A partir de uma determinada velocidade, e em função da porosidade superficial, esta lamina de água começa a succionar, por efeito Venturi, a água que penetrou nos poros, arrastando para o exterior as partículas de sujidade depositadas. A água de chuva pela ação do vento, e dependendo do efeito combinado, pode modificar o processo de sujidade, intensificando o efeito do lavado. As fases molhagem e saturação são muito rápidas, passando para a fase de lâmina d'água que é mais intensa, passando em seguida para a fase em que a lâmina adquire grande velocidade, o que explica os lavados diferenciados (CARRIO, 2000).

A ação da chuva com o vento pode variar desde a concentração pontual da água até o seu espalhamento uniforme, limpando toda a fachada ou deixando as marcas dos escorrimentos.

O principal problema relacionado com a umidade de obra é quando a edificação não está suficientemente seca para receber os acabamentos finais mais impermeáveis. Neste caso, a água retida tende a evaporar-se, mas tendo a sua saída dificultada, ocasiona manchas, eflorescências, empolamentos, entre outras manifestações patológicas.

\subsubsection{Perda da cor (desbotamento)}

A perda ou mudança de cor do componente superficial da fachada ocorre pela ação degradante da luz solar. O desbotamento é um fenômeno natural que ocorre em todos os materiais. De acordo com a resistência física e química de alguns pigmentos utilizados para a obtenção das cores, estas podem apresentar um desbotamento mais acelerado.

\subsubsection{Deterioração de componentes de base orgânica}

A fração ultravioleta do espectro eletromagnético da radiação solar é a principal responsável pela deterioração dos componentes de base orgânica. No entanto, a radiação age na superfície, atingindo principalmente os rejuntes e selantes, os sistemas de pintura e a coloração dos componentes.

Os rejuntes a base de cimento que preenchem as juntas de assentamento das placas cerâmicas, normalmente, recebem adição de resina orgânica, e os selantes que preenchem as juntas de 
movimento são de base orgânica, o que aumenta a suscetibilidade destes componentes ao envelhecimento causado pela radiação solar (CAMPANTE; BAÍA, 2003).

\subsubsection{Degradação biológica}

O bolor é o resultado da proliferação intensa de fungos. Para o desenvolvimento desses agentes microbianos são necessários, além da presença de esporos na superfície, umidade e temperatura adequadas ao tipo de organismo, nutrientes e tempo de exposição. Pedra, concreto e tijolos são mais tolerantes ao crescimento dos fungos, mas a poeira ou outras substâncias orgânicas acumuladas nas superfícies vão mudar as suas propriedades e torná-las mais apropriadas ao emboloramento. Os fungos e bactérias são capazes de deteriorar diferentes tipos de materiais (VIITANEN, 1996; ALUCCI et al., 1988).

Para que se instale um processo de degradação biológica é necessária certa duração das condições de exposição propícias para o crescimento microbiano. Na prática, altos teores de umidade em curto espaço de tempo não são suficientes para o crescimento do bolor, se a umidade não perdurar por mais tempo. Por exemplo, 95\% UR durante 2 horas em cada dia não causa nenhum dano, se as condições gerais do microclima apresentam taxas de umidade relativa abaixo de 75\% (VIITANEN, et al., 2008).

Segundo ASHRAE (2011), o crescimento de mofo em menos de uma semana exige mais de $85 \%$ UR e, em menos do que uma estação, requer mais de $70 \%$ UR.

As situações ambientais propícias para o desenvolvimento de bolor (mofo) dependem da espécie do microrganismo. Segundo Alucci et al. (1988), muitos desses organismos desenvolvem-se relativamente bem em temperaturas entre $10^{\circ} \mathrm{C}$ e $35^{\circ} \mathrm{C}$ e umidades relativas do ar acima de $75 \%$.

A ISO 13788 considera a umidade crítica para crescimento de bolor o valor médio mensal de 80\%UR (DIN EN, 2012).

\subsection{CONSIDERAÇÕES FINAIS DO CAPÍTULO}

Este capítulo apresentou uma revisão bibliográfica dos principais conceitos, propriedades, agentes e mecanismos relacionados com o comportamento higrotérmico dos componentes e a degradação dos sistemas porosos de fachada. 
Conclui-se que as variações de umidade e temperatura, ao longo da vida útil da edificação, aceleram a degradação dos sistemas porosos de fachada, pois provocam variação dimensional dos materiais, gerando tensões.

Os materiais do sistema de fachada são heterogêneos entre si; as diferentes propriedades higrotérmicas, geram diferentes gradientes térmicos e variações higroscópicas.

Nas edificações, as fachadas constituídas de materiais porosos sempre estarão sujeitas a um certo teor de umidade, decorrente das diferentes concentrações de vapor entre os ambientes internos e externos. Por isso, é necessário que as fachadas sejam permeáveis ao vapor, isto é, não devem impedir as trocas gasosas. No entanto, as fachadas devem ser estanques, ou seja, devem constituir-se como uma barreira à entrada de água líquida.

Neste capítulo foi possível compreender que a determinação das condições locais atuantes na superfície da fachada e da sinergia entre os agentes de degradação é bastante complexa. Os estudos e medições dos fluxos higrotérmicos e os potenciais de transporte de umidade e calor são difíceis de serem medidos até em condições de laboratório. Em alguns casos, simulações em computador são necessárias para avaliar o microclima agindo de acordo com as diferentes orientações ou tipo de superfície. Devido à complexidade dos mecanismos de transporte de umidade em meios porosos, é necessário simplificar os modelos, para que seja possível, com as técnicas atuais, representar as situações reais. Simplificações são necessárias e dependem dos objetivos de cada autor na busca das soluções para os problemas (RAMOS, 2007; FREITAS, 1992; MENDES, 1997; SANTOS, 2009; KÜNZEL, 1994; ASHRAE, 2009, cap.25). A investigação do comportamento higrotérmico do sistema poroso da envoltória do edifício como uma resposta aos impactos ambientais representa um dos primeiros passos para uma melhor compreensão dos processos de degradação (KÜNZEL, 2015). 


\section{CAPÍtULO V}

\section{PROCEDIMENTOS METODOLÓGICOS: ETAPA SIMULAÇÃO HIGROTÉRMICA COMPUTACIONAL}

\subsection{CONSIDERAÇÕES INICIAIS}

Neste capítulo são apresentados os procedimentos metodológicos adotados para os estudos do comportamento higrotérmico do sistema poroso de fachada, por meio de simulação computacional.

É apresentado o programa WUFI PRO 5.3, selecionado para as simulações higrotérmicas, assim como os esquemas da metodologia empregada, a estrutura de análise das variáveis e os critérios para a seleção dos componentes do sistema poroso de fachada e suas variações.

\subsection{WUFI PRO 5.3 - PROGRAMA DE SIMULAÇÃO COMPUTACIONAL DO COMPORTAMENTO HIGROTÉRMICO}

O WUFI PRO 5.3 (Wärme- Und Feuchtetransport Instationär - Transient Heat and Moisture Transport) é uma ferramenta de cálculo computacional para simulação do comportamento higrotérmico da envoltória da edificação, desenvolvido pela Fraunhofer Institute for Building Physics (WUFI, 2013).

O programa WUFI PRO 5.3 adota um modelo unidirecional de transporte de calor e umidade não estacionário (transiente), governado pelas Equações Diferenciais 5.1 e 5.2, respectivamente, equação de equilíbrio de calor e equação de equilíbrio de umidade.

O modelo usado pelo WUFI atende todos os requisitos e critérios estabelecidos pela EN 15026 Hygrothermal performance of building components and building elements - Assessment of moisture transfer by numerical simulation (DIN, 2007).

As equações diferenciais discretizadas por meio do método dos volumes finitos implícito são resolvidas de forma iterativa (WUFI, 2013). Os termos dos lados esquerdos das duas equações são referentes ao armazenamento e os dos lados direitos referem-se ao transporte. 


$$
\begin{aligned}
& \frac{\partial H}{\partial T} \frac{\partial T}{\partial t}=\nabla(\lambda \nabla T)+h_{\mathrm{v}} \nabla\left(\delta_{\mathrm{p}} \nabla\left(\varphi p_{\text {sat }}\right)\right) \\
& \frac{\partial w}{\partial \varphi} \frac{\partial \varphi}{\partial t}=\nabla\left(D_{\varphi} \nabla \varphi+\delta_{\mathrm{p}} \nabla\left(\varphi p_{\text {sat }}\right)\right)
\end{aligned}
$$

Onde,

$\begin{array}{ccl}H & \mathrm{~J} / \mathrm{m}^{3} & \text { Entalpia; } \\ h v & \mathrm{~J} / \mathrm{kg} & \text { Calor latente com mudança de estado (evaporação); } \\ \text { psat } & \mathrm{Pa} & \text { Pressão de vapor de saturação; } \\ w & \mathrm{~kg} / \mathrm{m}^{3} & \text { Teor de água; } \\ \delta_{p} & \mathrm{~kg} / \mathrm{m} . \mathrm{s.Pa} & \text { Permeabilidade ao vapor; } \\ T & { }^{\circ} \mathrm{Kelvin} & \text { Temperatura; } \\ \lambda & \mathrm{W} / \mathrm{m} . \mathrm{K} & \text { Condutibilidade térmica; } \\ \varphi & \% & \text { Umidade relativa; } \\ t & \mathrm{~s} & \text { Tempo; } \\ D \varphi & \mathrm{kg} / \mathrm{m} . \mathrm{s} & \text { Coeficiente de transferência de água líquida. }\end{array}$

A equação de equilíbrio de umidade é descrita pela derivada da função curva de armazenamento de umidade $(\partial \mathrm{w} / \partial \varphi)$ e o lado direito traduz as condições de transporte descritas pela divergência de fluxo líquido e de vapor de água. A equação de equilíbrio de calor é descrita pela derivada da entalpia em função da temperatura no tempo e o termo do lado direito da equação de energia contém a capacidade calorífica do material seco e a entalpia da água absorvida pelo material (JORNE, 2010; WUFI, 2014).

As variáveis envolvidas no modelo de cálculo do WUFI atendem as exigências da EN 15026 (DIN, 2007). Entre elas, estão:

- densidade de massa aparente;

- condutividade térmica da matéria seca e dependência com a umidade;

- calor específico;

- porosidade;

- coeficiente de absorção de água;

- permeabilidade ao vapor de água e dependência com a umidade;

- fator de resistência à difusão do vapor de água;

- teor de umidade de referência;

- teor de umidade de saturação livre;

- condutividade térmica complementar dependente da umidade; 
- condutividade térmica complementar dependente da temperatura;

- curva de armazenamento de umidade: isotermas de adsorção e dessorção;

- coeficiente de transferência de água líquida - sucção (fase de umedecimento por absorção) e redistribuição (fase de secagem).

\subsubsection{Considerações sobre o programa WUFI}

Entre os programas de simulação higrotérmica, o WUFI se destaque por ser um dos que mais utilizam propriedades de materiais no seu modelo de cálculo. Delgado et al. (2010) apresenta um levantamento dos programas de simulação higrotérmica de uso público em geral, relacionando as propriedades contempladas pelos diferentes programas (Quadro 5.1).

Dentre os programas listados por Delgado et al. (2010), encontra-se o UMIDUS que é um programa freeware desenvolvido pelo pesquisador brasileiro Nathan Mendes da Universidade Federal do Paraná. Esse programa é um modelo unidimensional para transporte de calor e umidade em meio poroso (poros médios). Os fenômenos modelados pelo programa são a difusão e a capilaridade, sendo que o transporte de umidade ocorre nas fases de vapor e líquido (MENDES, 1997; MENDES et al., 1999).

Segundo Mendes, o método desenvolvido para o UMIDUS precisa de um conjunto de dados mínimos necessários para simular transferência de calor e umidade em paredes porosas. Basicamente, as propriedades necessárias são: curva isotérmica de adsorção e de intrusão de mercúrio, além de dados básicos como densidade, calor específico e condutividade térmica para material seco. O objetivo do pesquisador, ao construir um programa com poucas variáveis de entrada, foi suprir a falta de propriedades higrotérmicas dos materiais de construção e pelo fato de que um determinado material nunca possuir a mesma distribuição de poros, o que modifica suas propriedades de transporte. Além disso, buscou-se estabelecer um algoritmo matemático apropriado à incorporação em pacotes computacionais de simulação rápida sem limitações no passo de tempo e em qualquer tipo de configuração de parede (MENDES, 1997; MENDES et al., 1999).

O programa WUFI desenvolvido pelo Fraunhofer Institute foi amplamente validado por meio de experimentos realizados pelas equipes de desenvolvedores e, também, por pesquisadores de vários países que, por meio de análise de sensibilidade, demonstraram a viabilidade da adoção do WUFI como uma ferramenta de estudos higrotérmicos. 
Quadro 5.1 - Modelos higrotérmicos e abrangência das propriedades dos materiais.

\begin{tabular}{|c|c|c|c|c|c|c|c|c|c|c|c|c|c|c|c|}
\hline \multirow{2}{*}{\multicolumn{2}{|c|}{$\begin{array}{c}\text { Programas } \\
\text { Higrotérmicos }\end{array}$}} & \multicolumn{14}{|c|}{ Propriedade dos materiais } \\
\hline & & 1 & 2 & 3 & 4 & 5 & 6 & 7 & 8 & 9 & 10 & 11 & 12 & 13 & 14 \\
\hline \multicolumn{2}{|c|}{ ID-HAM } & $\mathrm{X}$ & & $\mathrm{X}$ & $\mathrm{X}$ & $\mathrm{X}$ & $X$ & & & & & & & $\mathrm{X}$ & \\
\hline \multicolumn{2}{|c|}{ BSim2000 } & $\mathrm{X}$ & $\mathrm{X}$ & $\mathrm{X}$ & $\mathrm{X}$ & $\mathrm{X}$ & $\mathrm{X}$ & & & & & & $\mathrm{X}$ & & $\mathrm{X}$ \\
\hline \multicolumn{2}{|c|}{ DELPHIN 5} & $\mathrm{X}$ & $\mathrm{X}$ & $\mathrm{X}$ & $\mathrm{X}$ & $\mathrm{X}$ & & $\mathrm{X}$ & $\mathrm{X}$ & $\mathrm{X}$ & & $\mathrm{X}$ & & $\mathrm{X}$ & \\
\hline \multicolumn{2}{|c|}{ EMPTIED } & $\mathrm{X}$ & & $\mathrm{X}$ & $X$ & & $\mathrm{X}$ & & $\mathrm{X}$ & & & & & $X$ & \\
\hline \multicolumn{2}{|c|}{ GLASTA } & $\mathrm{X}$ & & $\mathrm{X}$ & $\mathrm{X}$ & & $\mathrm{X}$ & $\mathrm{X}$ & & & & & & & \\
\hline \multicolumn{2}{|c|}{ hygIRC-ID } & $\mathrm{X}$ & & $\mathrm{X}$ & $\mathrm{X}$ & $\mathrm{X}$ & $\mathrm{X}$ & & $\mathrm{X}$ & $\mathrm{X}$ & & & & $\mathrm{X}$ & \\
\hline \multicolumn{2}{|c|}{ HAMLab } & $X$ & & $\mathrm{X}$ & $\mathrm{X}$ & & & $\mathrm{X}$ & & & $X$ & & $\mathrm{X}$ & & \\
\hline \multicolumn{2}{|c|}{ HAM-Tools } & $X$ & $X$ & $X$ & $\mathrm{X}$ & $\mathrm{X}$ & $X$ & & $X$ & & & $X$ & & $X$ & \\
\hline \multicolumn{2}{|c|}{ IDA-ICE } & $\mathrm{X}$ & & $\mathrm{X}$ & $\mathrm{X}$ & $\mathrm{X}$ & $\mathrm{X}$ & & & & & & $\mathrm{X}$ & $\mathrm{X}$ & \\
\hline \multicolumn{2}{|c|}{ MATCH } & $X$ & $X$ & $X$ & $X$ & $X$ & $X$ & & $X$ & & & $X$ & $X$ & & $\mathrm{X}$ \\
\hline \multicolumn{2}{|c|}{ MOIST } & $X$ & & $\mathrm{X}$ & $X$ & $X$ & $X$ & & $\mathrm{X}$ & $X$ & & & & $\mathrm{X}$ & \\
\hline \multicolumn{2}{|c|}{ MOIST-EXP. } & $X$ & $X$ & $X$ & $X$ & $\mathrm{X}$ & $X$ & & $X$ & $\mathrm{X}$ & & $X$ & $\mathrm{X}$ & $\mathrm{X}$ & \\
\hline \multicolumn{2}{|c|}{ UMIDUS } & $X$ & $\mathrm{X}$ & $\mathrm{X}$ & $\mathrm{X}$ & $X$ & & $\mathrm{X}$ & & & & & & & \\
\hline \multicolumn{2}{|c|}{ WUFI } & $X$ & $\mathrm{X}$ & $\mathrm{X}$ & $\mathrm{X}$ & $\mathrm{X}$ & $\mathrm{X}$ & & & $X$ & $\mathrm{X}$ & $\mathrm{X}$ & $X$ & & \\
\hline \multirow{3}{*}{\multicolumn{2}{|c|}{$\begin{array}{l}\text { Programas } \\
\text { Higrotérmicos }\end{array}$}} & & & & & & içõe & con & no & sup & & & & & \\
\hline & & & & & & & rna & & & & & & & & \\
\hline & & $\mathbf{A}$ & B & $\mathbf{C}$ & D & $\mathbf{E}$ & $\mathbf{F}$ & $\mathbf{G}$ & H & $\mathbf{I}$ & $\mathbf{J}$ & I & II & III & IV \\
\hline ID-1 & & $X$ & $X$ & $X$ & $X$ & & & & $X$ & & & $X$ & $X$ & & \\
\hline $\mathrm{BSi}$ & 000 & $X$ & $X$ & $X$ & $X$ & $\mathrm{X}$ & $X$ & & $X$ & $X$ & & $X$ & $X$ & $\mathrm{X}$ & \\
\hline$\overline{\mathrm{DEI}}$ & IIN 5 & $X$ & $X$ & $X$ & $X$ & $X$ & $X$ & $\mathrm{X}$ & $\mathrm{X}$ & & & $X$ & $X$ & $X$ & \\
\hline$\overline{\mathrm{EM}}$ & IED & $X$ & $X$ & $X$ & & & & & & & & $X$ & $X$ & $X$ & \\
\hline GL & & $X$ & $X$ & & $X$ & & & & $X$ & & & $X$ & & & \\
\hline hyg & C-ID & $X$ & $X$ & & $X$ & $X$ & $X$ & $X$ & & $X$ & $X$ & $X$ & X & & $X$ \\
\hline $\mathrm{HA}$ & & $X$ & $X$ & & & $X$ & $X$ & & $X$ & $X$ & & $X$ & $X$ & & \\
\hline $\mathrm{HA}$ & Tools & $X$ & $X$ & $X$ & $\mathrm{X}$ & $X$ & $X$ & $X$ & $X$ & $X$ & & $X$ & $X$ & $X$ & \\
\hline IDA & & $\mathrm{X}$ & $X$ & $X$ & $X$ & $X$ & $X$ & & $X$ & & & $X$ & $X$ & & \\
\hline$\overline{\mathrm{MA}}$ & & $X$ & $X$ & & $X$ & $X$ & & $X$ & $X$ & $X$ & & $X$ & $\mathrm{X}$ & & \\
\hline $\mathrm{MO}$ & & $X$ & $X$ & & $X$ & $X$ & $X$ & & & $X$ & & $X$ & $X$ & & \\
\hline $\mathrm{MO}$ & Г-EXP. & $X$ & $X$ & $X$ & $X$ & $X$ & $X$ & $X$ & $X$ & $X$ & $X$ & $X$ & $X$ & $X$ & $X$ \\
\hline$\overline{\mathrm{UM}}$ & & $X$ & $X$ & & $X$ & $X$ & $X$ & & & & & $X$ & $X$ & & \\
\hline WU & & $X$ & $X$ & & $X$ & $X$ & $X$ & $X$ & $X$ & $X$ & & $X$ & $X$ & & \\
\hline & & & & & Lege & da: I & ta de & prie & & & & & & & \\
\hline 1 & Densidade d & assa & & & $\mathrm{A}$ & Ten & ratur & & & & & & & & \\
\hline 2 & Porosidade & & & & $\mathrm{B}$ & $\mathrm{Um}$ & de re & $\mathrm{va} / \mathrm{po}$ & de o & lho/p & ão d & por/c & centr & & \\
\hline 3 & Calor especi & & & & $\mathrm{C}$ & Pre & o do & & & & & & & & \\
\hline 4 & Condutivida & érmic & & & $\mathrm{D}$ & $\mathrm{Rad}$ & ão sc & & & & & & & & \\
\hline 5 & Curva higro & & & & $\mathrm{E}$ & Vel & dade & vento & & & & & & & \\
\hline 6 & Permeabilid & ao va & de ág & & $\mathrm{F}$ & Dir & o do & & & & & & & & \\
\hline 7 & Difusão de & & & & $\mathrm{G}$ & Pre & itaçãa & & & & & & & & \\
\hline 8 & Pressão de s & & & & $\mathrm{H}$ & Tro & por & a lon & & & & & & & \\
\hline 9 & Difusão líqu & & & & I & Índi & de $n$ & osida & & & & & & & \\
\hline 10 & Fator de res & icia à & usão & & $\mathrm{J}$ & Cap & idade & evap & & & & & & & \\
\hline 11 & Condutivida & la águ & & & I & Ten & ratur & & & & & & & & \\
\hline 12 & Capacidade & oscóp & espe & & II & $\mathrm{Um}$ & de re & $\mathrm{va} / \mathrm{po}$ & de o & lho/p & ão d & apor/c & centr: & & \\
\hline 13 & Permeabilid & ao ar & & & III & Pre & o do & & & & & & & & \\
\hline 14 & Histerese da & va hiq & cópic & & IV & Efe & chan & do in & & & & & & & \\
\hline
\end{tabular}

Fonte: Delgado et al. (2010). 
Segundo Westphal e Lamberts (2004), a validação de um programa pode ser feita de três maneiras: verificação analítica, a partir de uma solução numérica conhecida; verificação empírica, a partir de resultados de medição em um caso real; e teste comparativo, ou seja, entre diferentes programas ou versões de um mesmo programa.

Segundo a definição de termo apresentada pela ISO 15686-5 - Buildings and constructed assets - Sevice-life planning. Part 5 - Life-cycle costing, a análise de sensibilidade refere-se aos testes de resultado de uma análise, alterando um ou mais parâmetros do valor inicial (test of the outcome of an analysis by altering one or more parameters from initial value) (BS, 2008).

Nesta tese, entende-se por análise de sensibilidade as verificações analíticas (modelos teóricos ou métodos semi-empíricos), verificações empíricas (a partir de resultados de medição em um caso real) ou verificações por meio de simulação computacional, como formas de possibilitar as comparações entre respostas e referências conhecidas, a partir da variação de determinados parâmetros.

\subsubsection{Dados de entrada do programa WUFI}

Os dados de entrada necessários para alimentar o programa WUFI são fundamentados na EN 15026 - Hygrothermal performance of building components and building elements Assessment of moisture transfer by numerical simulation (DIN, 2007).

Os fatores mais relevantes para a simulação higrotérmica são:

- Configuração dos componentes do sistema de fachada, orientação e inclinação da fachada;

- Propriedades higrotérmicas dos componentes.

- Condições de fronteira, coeficientes de transferência à superfície do clima interior e exterior.

- Condições iniciais, período de simulação e parâmetros numéricos de controle.

O arquivo climático utilizado deve fornecer um ano típico ou de referência, com 8760 horas de dados de precipitação, radiação solar (global e difusa), temperatura do ar, umidade relativa, nebulosidade, pressão atmosférica, velocidade e direção do vento.

Conforme apresentado e justificado no Capítulo II, o ano climático selecionado para as simulações computacionais para a cidade de Brasília foi o TMY-EPW/ANTAC (RORIZ, 2012).

Para melhor compreensão, o Quadro 5.2 apresenta os parâmetros utilizados na tese como dados de entrada, isto é, a configuração do sistema, os coeficientes e as condições de fronteira. 
Quadro 5.2 - Dados de entrada para o programa computacional higrotérmico WUFI.

\begin{tabular}{|c|c|c|c|c|}
\hline \multicolumn{2}{|c|}{ Parâmetro } & Símbolo & Unidade & Valor \\
\hline \multicolumn{5}{|c|}{ Configuração dos componentes do elemento construtivo } \\
\hline \multicolumn{2}{|c|}{ Camada exterior: argamassa de revestimento ${ }^{1}$} & $e_{e x t}$ & $\mathrm{~m}$ & 0,025 \\
\hline \multicolumn{2}{|c|}{ Camada intermediária: bloco cerâmico } & $e_{b}$ & $\mathrm{~m}$ & 0,12 \\
\hline \multicolumn{2}{|c|}{ Camada interior: argamassa de revestimento } & $e_{i n t}$ & $\mathrm{~m}$ & 0,025 \\
\hline \multicolumn{2}{|c|}{ Espessura total do elemento construtivo } & $e_{t}$ & $\mathrm{~m}$ & 0,17 \\
\hline \multicolumn{5}{|c|}{ Coeficientes de transferência à superfície exterior } \\
\hline \multicolumn{2}{|c|}{ Resistência térmica da superfície exterior } & Rse & $\mathrm{m}^{2} \mathrm{~K} / \mathrm{W}$ & $0,0588(1 / 17)$ \\
\hline \multicolumn{2}{|c|}{ Valor de $\mathrm{Sd}^{2}$} & $S d$ & {$[\mathrm{~m}]$} & - \\
\hline \multicolumn{2}{|c|}{ Coeficiente de absorção solar ${ }^{3}$} & $\alpha$ & {$[-]$} & 0,7 \\
\hline \multicolumn{2}{|c|}{ Refletividade do solo (onda curta) - albedo } & $r$ & {$[-]$} & 0,20 \\
\hline \multicolumn{2}{|c|}{ Fator de redução da chuva dirigida } & $F r$ & {$[-]$} & 0,7 \\
\hline \multicolumn{5}{|c|}{ Coeficientes de transferência à superfície interior } \\
\hline \multirow{2}{*}{\multicolumn{2}{|c|}{$\begin{array}{l}\text { Resistência térmica da superfície interior } \\
\text { Valor de Sd }\end{array}$}} & $R s i$ & $\mathrm{~m}^{2} \mathrm{~K} / \mathrm{W}$ & $0,125(1 / 8)$ \\
\hline & & $S d$ & $\mathrm{~m}$ & - \\
\hline \multicolumn{5}{|c|}{ Condições de fronteira } \\
\hline \multirow{2}{*}{ Condições iniciais } & Umidade relativa & $80 \%$ & \multirow{2}{*}{\multicolumn{2}{|c|}{ Modelo ASHRAE 160 (ANSI/ASHRAE, 2009) }} \\
\hline & Temperatura inicial & $20^{\circ} \mathrm{C}$ & & \\
\hline \multirow{3}{*}{ Período de cálculo } & Início & 2014 & & \\
\hline & Fim & 2016 & & \\
\hline & Ano utilizado & 2016 & & \\
\hline \multirow{5}{*}{$\begin{array}{c}\text { Exterior } \\
\text { (lado esquerdo) }\end{array}$} & Localização & Brasília-DF & & \\
\hline & Inclinação da superfície & Fachada $(90$ & & \\
\hline & Orientação da fachada & $\mathrm{N}, \mathrm{NE}, \mathrm{L}, \mathrm{S}$ & $, \mathrm{SO}, \mathrm{O}, \mathrm{N}$ & \\
\hline & Chuva dirigida & Modelo AS & $\mathrm{AE} 160(\mathrm{~A}$ & HRAE, 2009) \\
\hline & Clima exterior & Arquivo cli & ico TMY - & NTAC (RORIZ, 2012) \\
\hline $\begin{array}{c}\text { Interior } \\
\text { (lado direito) }\end{array}$ & Clima interior & $\begin{array}{l}\text { EN } 15026( \\
\text { normal }\end{array}$ & J, 2007) - F & de umidificação \\
\hline \multicolumn{5}{|c|}{$\begin{array}{l}{ }^{1} \text { As camadas exterior e interior caracterizam-se como argamassa de revestimento, ou seja, não foi considerada } \\
\text { camada de pintura ou, se existir, encontra-se degradada ou com perda de desempenho pelo envelhecimento. } \\
{ }^{2} \text { Considerando a ausência de camada de pintura de proteção, não se atribui valor ao Sd. } \\
{ }^{3} \text { O coeficiente de absorção solar para cores escuras } \alpha=0,7 \text { foi adotado para todos os casos simulados. }\end{array}$} \\
\hline
\end{tabular}

Para as simulações efetuadas, os únicos dados de entrada que foram mudados entre os casos estudados foram as orientações e as propriedades higrotérmicas dos componentes. Assim, foi possível realizar as múltiplas comparações e as análises de interação entre as sete variações de sistema construtivo utilizadas nas simulações.

\subsubsection{Dados de saída do programa WUFI}

Os dados de saída fornecidos pelo programa WUFI também são fundamentados na EN 15026 - Hygrothermal performance of building components and building elements - Assessment of moisture transfer by numerical simulation (DIN, 2007), a saber: 
- Distribuição dos fluxos de temperatura e calor e variações temporais.

- Conteúdo de umidade, umidade relativa e distribuição dos fluxos de umidade e variações temporais.

O Quadro 5.3 apresenta os parâmetros de saída, possíveis de serem extraídos do WUFI.

Quadro 5.3 - Dados de saída fornecidos pelo programa higrotérmico WUFI.

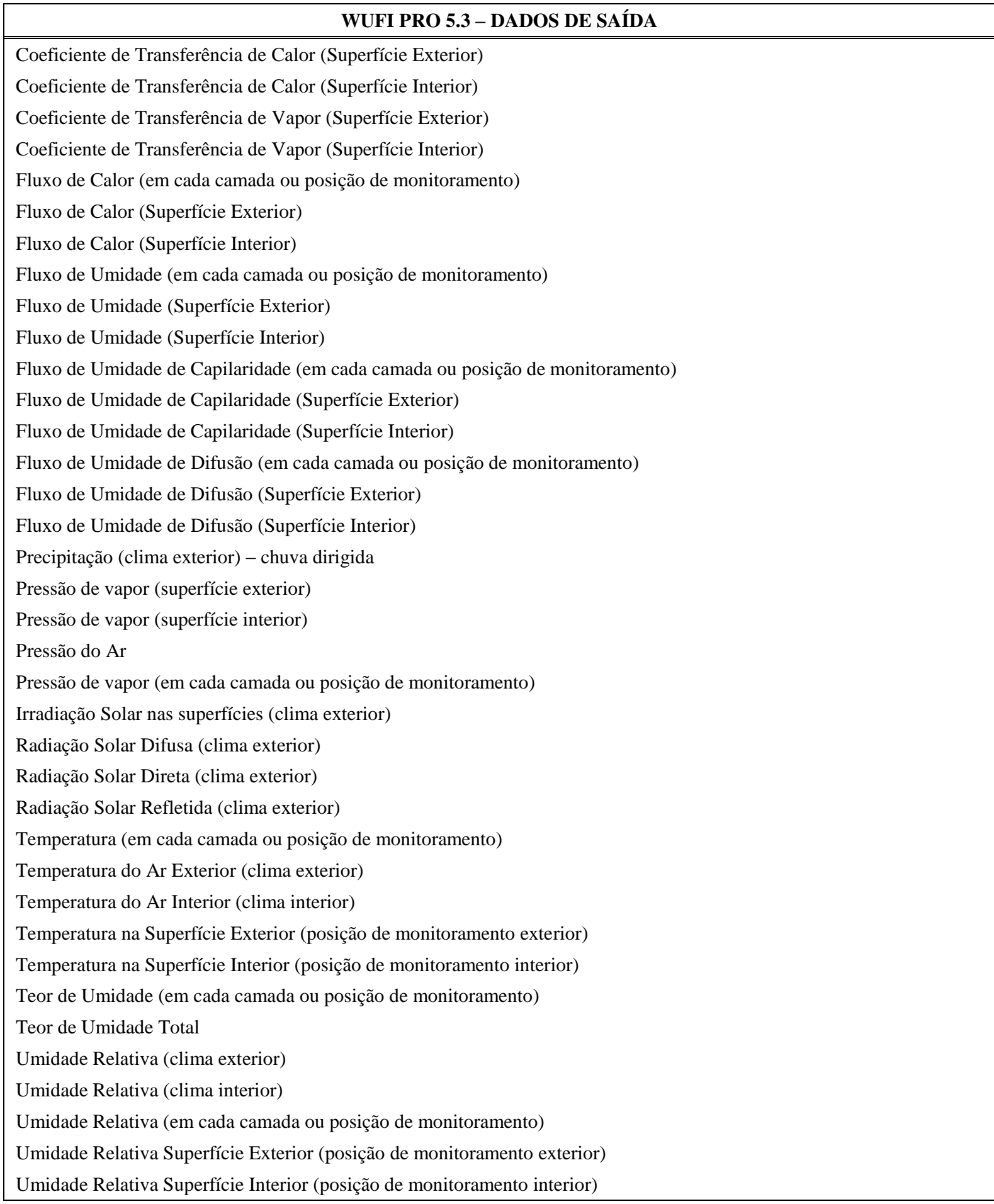


Para este estudo de tese, os dados de saída utilizados no pós-processamento foram:

- chuva dirigida;

- irradiação solar incidente na superfície da fachada;

- temperatura da superfície exterior;

- teor de umidade em cada camada do sistema construtivo;

- teor de umidade total do sistema construtivo.

Os dados de saída são apresentados na forma de relatório de dados de resultados das simulações (Quadro 5.3), conforme passo de tempo selecionado pelo usuário (horário, diário) e no período de tempo desejado (mês, ano).

\subsubsection{Pós-processamento}

A fase de pós-processamento, segundo a EN 15026: 2007, está relacionada com a aplicação dos resultados das simulações nos estudos, por exemplo, de energia, de degradação, crescimento biológico, corrosão, entre outros riscos decorrentes dos vários mecanismos de danos na envoltória da edificação, relacionados ao transporte de calor e umidade, em regime transiente.

Nesta tese, os estudos pós-processamento foram centrados na degradação de fachada, especificamente, nas condições de exposição das fachadas aos agentes climáticos de degradação e a resposta higrotérmica do elemento construtivo, delimitando assim a temática e seu enquadramento.

\subsection{PROCEDIMENTOS PARA A SELEÇÃO DOS MATERIAIS PARA AS SIMULAÇÕES}

Os procedimentos adotados para a seleção dos materiais aplicados nas simulações computacionais basearam-se em uma pesquisa de referência de propriedades higrotérmicas de componentes disponibilizados na literatura nacional e internacional.

Ao pesquisar dados brasileiros disponibilizados em publicações, verificou-se que as informações encontradas eram escassas, incompletas e que havia muitas lacunas quanto às propriedades higrotérmicas necessárias para alimentar o programa de simulação adotado.

Algumas das poucas informações obtidas nas bases brasileiras e outras informações referenciais de bases estrangeiras são apresentadas no Quadro 5.4 que serviu para subsidiar a seleção dos materiais utilizados nos estudos desta tese. 
Quadro 5.4 - Base de referência: propriedades higrotérmicas de argamassas e tijolos.

\begin{tabular}{|c|c|c|c|c|c|c|c|c|}
\hline \multirow[b]{2}{*}{ ARGAMASSA } & 1 & 2 & 3 & 4 & 5 & 6 & 7 & \multirow[b]{2}{*}{ Base de dados } \\
\hline & $\begin{array}{c}\rho \\
\mathrm{kg} / \mathrm{m}^{3}\end{array}$ & $\begin{array}{c}\lambda \\
W / m . K\end{array}$ & $\begin{array}{c}c \\
\mathrm{~kJ} / \mathrm{kg} . \mathrm{K}\end{array}$ & $\begin{array}{l}\varepsilon \\
\%\end{array}$ & $\begin{array}{c}A_{\text {valor }} \\
\mathrm{kg} / \mathrm{m}^{2} \cdot \sqrt{h}\end{array}$ & $\begin{array}{c}\delta \\
\mathrm{kg} / \mathrm{m} . \mathrm{s} . P a\end{array}$ & $\begin{array}{c}\mu \\
{[-]}\end{array}$ & \\
\hline $\begin{array}{l}\text { Argamassa de } \\
\text { assentamento }\end{array}$ & 2.000 & 1,15 & 1,00 & - & - & - & - & $\begin{array}{l}\text { ABNT 15220: } \\
2005\end{array}$ \\
\hline Reboco & 2.000 & 1,15 & 1,00 & - & - & - & - & $\begin{array}{l}\text { ABNT 15220: } \\
2005\end{array}$ \\
\hline $\begin{array}{c}\text { Argamassa } \\
\text { (comum) para } \\
\text { reboco e } \\
\text { assentamento de } \\
\text { tijolos e blocos }\end{array}$ & $\begin{array}{l}1.400-1.800 \\
1.800-2.100\end{array}$ & $\begin{array}{l}0,65 \\
1,15\end{array}$ & $\begin{array}{l}0,84 \\
1,00\end{array}$ & - & - & - & - & $\begin{array}{l}\text { Lamberts et al., } \\
\quad 2013\end{array}$ \\
\hline Argamassa de cal & 1.600 & $0,8-1,5$ & 0,92 & 26 & $0,6-15$ & 4,5 a $13 \times 10-12$ & 15 & Freitas, 2008 \\
\hline $\begin{array}{l}\text { Argamassa a base } \\
\text { de cal }\end{array}$ & 1.400 a 1.800 & & & & & $\frac{4,5 \text { a } 29 \text { x } 10-12}{13 \times 10-12}$ & $\begin{array}{c}6,4 \text { a } 41 \\
----- \\
15\end{array}$ & $\begin{array}{l}\text { Freitas; Pinto, } \\
\quad 2000\end{array}$ \\
\hline $\begin{array}{l}\text { Argamassa a base } \\
\text { de cimento }\end{array}$ & 1.900 a 2.100 & & & & & 4,5 a $12 \times 10-12$ & 15 a 41 & $\begin{array}{l}\text { Freitas; Pinto, } \\
\quad 2000\end{array}$ \\
\hline $\begin{array}{l}\text { Argamassa de cal e } \\
\text { cimento }\end{array}$ & 1.800 a 1.900 & & & & & 5,3 a $12 \times 10-12$ & 15 a 35 & $\begin{array}{l}\text { Freitas; Pinto, } \\
2000\end{array}$ \\
\hline $\begin{array}{l}\text { Argamassa 1:1:6 } \\
\text { (ref:Cica6) }\end{array}$ & 1.886 & & & 28 & 9,8 & $1,19 \times 10-11$ & & $\begin{array}{l}\text { Faria et al., } \\
\quad 2007\end{array}$ \\
\hline $\begin{array}{l}\text { Argamassa 1:2:9 } \\
\text { (ref: Cica9) }\end{array}$ & 1.825 & & & 29 & 12,3 & $1,49 \times 10-11$ & & $\begin{array}{l}\text { Faria et al., } \\
\quad 2007\end{array}$ \\
\hline \multirow[b]{2}{*}{ TIJOLO } & 1 & 2 & 3 & 4 & 5 & 6 & 7 & \multirow[b]{2}{*}{ Base de dados } \\
\hline & $\begin{array}{c}\rho \\
\mathbf{k g} / \mathrm{m}^{3}\end{array}$ & $\begin{array}{c}\lambda \\
W / m . K\end{array}$ & $\begin{array}{c}c \\
\mathrm{~kJ} / \mathrm{kg} \cdot \mathrm{K}\end{array}$ & $\begin{array}{l}\varepsilon \\
\%\end{array}$ & $\begin{array}{c}A_{\text {valor }} \\
\mathrm{kg} / \mathrm{m}^{2} \cdot \sqrt{\mathrm{h}}\end{array}$ & $\begin{array}{c}\delta \\
\mathrm{kg} / \mathrm{m} . \mathrm{s} . P a\end{array}$ & $\begin{array}{c}\mu \\
{[-]}\end{array}$ & \\
\hline Tijolo cerâmico & 1.600 & 0,9 & 0,92 & - & - & - & - & $\begin{array}{l}\text { ABNT 15220: } \\
2005\end{array}$ \\
\hline $\begin{array}{l}\text { Material cerâmico - } \\
\text { tijolos e telhas de } \\
\quad \text { barro }\end{array}$ & $\begin{array}{l}1.000-1.300 \\
1.300-1.600 \\
1.600-1.800 \\
1.800-2.000\end{array}$ & $\begin{array}{l}0,70 \\
0,90 \\
1,00 \\
1,05\end{array}$ & $\begin{array}{l}0,92 \\
0,92 \\
0,92 \\
0,92\end{array}$ & - & - & - & - & $\begin{array}{l}\text { Lamberts et al, } \\
\quad 2013\end{array}$ \\
\hline Tijolo cerâmico & $\begin{array}{c}1.360 \\
1.530-1.860\end{array}$ & - & - & - & - & - & $\begin{array}{c}6,8 \\
9,3-10\end{array}$ & Polisseni, 1986 \\
\hline Tijolo cerâmico & $1.000-2.400$ & $0,34-1,04$ & 1,00 & 28 & 3,0 & $2,4 \times 10-12$ & - & Freitas, 2008 \\
\hline Tijolo genérico* & $1.803,9$ & 0,672 & 0,886 & 32,4 & 10,14 & - & 24,95 & $\begin{array}{l}\text { Zhao et al., } \\
2015\end{array}$ \\
\hline $\begin{array}{l}\text { Alvenaria de tijolo } \\
\text { furado }(0,20 \mathrm{~m})(* *)\end{array}$ & - & - & - & - & - & $1,04 \times 10-11$ & 18 & Faustino, 1997 \\
\hline $\begin{array}{l}\text { Alvenaria de tijolo } \\
\text { furado }(0,15 \mathrm{~m})(* *)\end{array}$ & - & - & - & - & - & $9,36 \times 10-12$ & 20 & Faustino, 1997 \\
\hline $\begin{array}{c}\text { Alvenaria de blocos } \\
\text { furados } \\
(0,20 \mathrm{~m})(* *)\end{array}$ & - & - & - & - & - & $1,35 \times 10-11$ & 14 & Faustino, 1997 \\
\hline \multicolumn{9}{|c|}{$\begin{array}{l}\text { *Tijolo genérico resultante das propriedades de } 23 \text { tijolos específicos, por } \mathrm{m} \\
\text { ** A permeabilidade equivalente apresentada tem em consideração os alvéo } \\
\text { Legenda }\end{array}$} \\
\hline \multicolumn{9}{|c|}{$\begin{array}{rr}\text { Legenda } \\
\end{array}$} \\
\hline \begin{tabular}{|l|l|}
1 & \\
\end{tabular} & $\rho\left(\mathrm{kg} / \mathrm{m}^{3}\right)$ & \multicolumn{7}{|c|}{ Densidade de massa aparente } \\
\hline 2 & $(\mathrm{~W} / \mathrm{m} . \mathrm{K})$ & \multicolumn{7}{|c|}{ Condutividade térmica } \\
\hline 3 & $(\mathrm{~kJ} / \mathrm{kg} . \mathrm{K})$ & \multicolumn{7}{|c|}{ Calor específico } \\
\hline 4 & $\varepsilon(\%)$ & \multicolumn{7}{|c|}{ Porosidade } \\
\hline $\mathrm{A}_{\mathrm{v}}$ & $\operatorname{lor}\left(\mathrm{kg} / \mathrm{m}^{2} \cdot \sqrt{s}\right)$ & \multicolumn{7}{|c|}{ Coeficiente de absorção de água } \\
\hline 6 & $(\mathrm{~kg} / \mathrm{m} . \mathrm{s} . \mathrm{Pa})$ & \multicolumn{7}{|c|}{ Permeabilidade ao vapor de água } \\
\hline 7 & $\mu(-)$ & & & tor de & resistência & difusão do vapor & água & \\
\hline
\end{tabular}

Para obter dados dos materiais para os estudos propostos neste trabalho de tese, algumas possibilidades foram analisadas, entre elas: realizar ensaios laboratoriais para obtenção dos 
dados necessários para alimentar o programa de simulação higrotérmica; obter dados de ensaios já realizados e disponibilizados na bibliografia ou em relatórios técnicos de ensaios laboratoriais; ou utilizar a base de dados dos materiais disponibilizada pelo programa de simulação adotado.

Mendes (1997) considera que uma das grandes dificuldades para o uso das simulações higrotérmicas por meio de programas computacionais é a falta de propriedades higrotérmicas dos materiais de construção e pelo fato de que um determinado material nunca possuir a mesma distribuição de poros, o que modifica suas propriedades de transporte.

Para uso em programas de simulação, Freitas et al. (2008) sugere a seleção de materiais com uma caracterização genérica, correspondente às propriedades médias dos componentes. $\mathrm{O}$ autor justifica, explicando que a determinação de valores em ensaios experimentais mostra uma dispersão considerável quando se comparam resultados referentes a um mesmo material específico. Essa variabilidade decorre de diferentes fatores, entre eles, alterações na estrutura porosa e diferentes técnicas de ensaio (FREITAS, 1992).

Um material específico é um material de características próprias, geralmente associado à um determinado fabricante ou produtor, cujas propriedades foram obtidas por medições de amostras representativas da linha de produção. Um material genérico é um material que representa um aglomerado de materiais (clusters). Por meio de um processo de síntese, as técnicas estatísticas aplicadas permitem derivar de um conjunto de materiais específicos, um material genérico de cada cluster identificado. Um material genérico representa um grupo de materiais específicos que tenham características semelhantes (ZHAO et al., 2013; ZHAO et. al., 2015).

Cardoso (2009), em ampla pesquisa sobre argamassas nacionais de revestimento para estudo do comportamento reológico, concluiu que os produtos nacionais apresentam uma grande variedade de características de formulação. Comparando a formulação das argamassas brasileiras com as europeias, o pesquisador concluiu que as características médias são bastante similares.

As propriedades térmicas dos materiais porosos são relativamente homogêneas, enquanto o fluxo de massa (umidade) tem grandes discrepâncias, devido ao complexo mecanismo de transporte no meio poroso, dependendo principalmente da forma e teor de umidade dos poros (HENS, 2009). Isto é, em comparação com as outras propriedades, as propriedades dos 
materiais relacionadas ao transporte de umidade costumam mostrar uma grande variabilidade (ZHAO et. al., 2015).

Para realizar os ensaios laboratoriais necessários para as simulações desta tese, seria necessário despender muitos recursos, inclusive de tempo, inviabilizando a pesquisa. Os dados de ensaios encontrados em publicações e relatórios técnicos forneceram parâmetros muito específicos e não suficientemente completos para as simulações desejadas.

Por essas razões, optou-se, então, por selecionar materiais genéricos disponibilizados na base do programa WUFI, representativos dos componentes aplicados na construção civil brasileira, estabelecendo uma base de referência para as análises do sistema poroso de fachada adotado nesta tese.

Neste contexto e analisando o consistente banco de dados de materiais disponibilizado pelo WUFI, verificou-se a viabilidade de selecionar os componentes necessários para atender, genericamente, as características dos materiais brasileiros, considerando que o principal eixo metodológico desta tese é a análise comparativa entre os comportamentos higrotérmicos dos componentes, conforme as oito orientações de fachada. Para tal, foi necessário selecionar materiais de acordo com faixas referenciais de propriedades higrotérmicas para o estudo do comportamento do sistema analisado.

No Brasil, as exigências normativas são mínimas, quanto aos requisitos e critérios para os estudos do comportamento higrotérmico dos sistemas construtivos de vedação vertical, quando consideradas as condições de exposição aos agentes climáticos.

A NBR 13281 (ABNT, 2005d) classifica as argamassas em seis classes conforme a variação do coeficiente capilaridade, apresentadas no Quadro 5.5.

Quadro 5.5 - Classificação do coeficiente de capilaridade dados pela ABNT NBR 13281.

\begin{tabular}{|c|c|c|}
\hline $\begin{array}{c}\text { Classe } \\
\text { ABNT NBR 13281 } \\
\end{array}$ & $\begin{array}{c}\text { Coeficiente de capilaridade } \\
\mathrm{g} / \mathrm{dm}^{2} \cdot \mathrm{min}^{1 / 2}\end{array}$ & $\begin{array}{c}\text { Coeficiente de capilaridade } \\
\mathrm{kg} / \mathrm{m}^{2} \cdot \mathrm{h}^{1 / 2}\end{array}$ \\
\hline $\mathrm{C} 1$ & $\leq 1,5$ & $\leq 1,16$ \\
\hline $\mathrm{C} 2$ & 1,0 a 2,5 & 0,77 a 1,93 \\
\hline $\mathrm{C} 3$ & 2,0 a 4,0 & 1,55 a 3,10 \\
\hline $\mathrm{C} 4$ & 3,0 a 7,0 & 2,32 a 5,24 \\
\hline $\mathrm{C} 5$ & 5,0 a 12,0 & 3,87 a 9,30 \\
\hline C6 & $>10,0$ & $>7,75$ \\
\hline
\end{tabular}

Fonte: NBR 13281 (ABNT, 2005d).

Para a NBR 13281 Argamassa para revestimento de paredes e tetos - Requisitos (ABNT, 2005d), as argamassas destinadas ao assentamento e revestimento de paredes e tetos são classificadas conforme as seguintes características e propriedades: resistência à compressão, 
densidade de massa no estado fresco e no estado endurecido, resistência à tração na flexão, coeficiente de capilaridade, retenção de água (estado fresco) e resistência potencial de aderência à tração.

Portanto, observa-se que o coeficiente de capilaridade e a densidade de massa são as únicas propriedades exigidas que estão relacionadas ao comportamento higrotérmico do material no estado endurecido. Ainda, a norma não estabelece nenhuma relação entre classificação, desempenho e especificação de uso das argamassas para revestimento.

Künzel et al. (2004), em um estudo experimental em campo aberto, avaliando o coeficiente de absorção de água em amostras expostas às chuvas e amostras protegidas, verificaram que o coeficiente de absorção dos materiais deve ser limitado, mesmo que as condições de secagem sejam satisfatórias, pois afeta o desempenho térmico. A recomendação dos pesquisadores é que, em sistemas de revestimento com argamassa, Avalor não pode exceder $0,5 \mathrm{~kg} / \mathrm{m}^{2} \mathrm{~h}^{1 / 2}$ $\left(0,0083 \mathrm{~kg} / \mathrm{m}^{2} \mathrm{~s}^{1 / 2}\right.$ ou $0,0645 \mathrm{~kg} / \mathrm{m}^{2} \mathrm{~min}^{1 / 2}$ ou $\left.0,645 \mathrm{~g} / \mathrm{dm}^{2} \min ^{1 / 2}\right)$.

No entanto, Flores-Colen (2009, p.86) sugere que o coeficiente de capilaridade deve apresentar um limite superior de $0,4 \mathrm{~kg} / \mathrm{m}^{2} \cdot \mathrm{min}^{1 / 2}\left(3 \mathrm{~kg} / \mathrm{m}^{2} \cdot \mathrm{h}^{1 / 2}\right)$, mas que pode ser excedido nas argamassas de uso geral (produtos que possuem normalmente uma camada de acabamento de outro material que confere também uma proteção adicional à sucção capilar).

Segundo Bauer et al. (2013), para as argamassas de revestimento, são críticos os valores do coeficiente de capilaridade superiores a $4,0 \mathrm{~g} / \mathrm{dm}^{2} \cdot \min ^{1 / 2}\left(3,1 \mathrm{~kg} / \mathrm{m}^{2} \cdot \mathrm{h}^{1 / 2}\right)$.

Baseado em CSTB $^{1}$ (1982), Flores-Colen (2009) cita que as argamassas podem ser classificadas em três categorias: forte capilaridade $\mathrm{C}>3,1 \mathrm{~kg} / \mathrm{m}^{2} \cdot \mathrm{h}^{1 / 2}$; fraca capilaridade $1,16<\mathrm{C}<3,1$ $\mathrm{kg} / \mathrm{m}^{2} \cdot \mathrm{h}^{1 / 2}$; muito fraca capilaridade $\mathrm{C}<1,16 \mathrm{~kg} / \mathrm{m}^{2} \cdot \mathrm{h}^{1 / 2}$.

A DIN 4108-3:2011 considera a seguinte classificação: $A_{\text {valor }} \geq 2 \mathrm{~kg} / \mathrm{m}^{2} \mathrm{~h}^{1 / 2}$ para camada superficial absorvedora de água; $0,5 \mathrm{~kg} / \mathrm{m}^{2} \mathrm{~h}^{1 / 2}<\mathrm{A}_{\text {valor }}<2 \mathrm{~kg} / \mathrm{m}^{2} \mathrm{~h}^{1 / 2}$ para camada superficial resistente à água; $A_{\text {valor }} \leq 0,5 \mathrm{~kg} / \mathrm{m}^{2} \mathrm{~h}^{1 / 2}$ para camada superfícial repelente à água.

Künzel et al. (2004) estabeleceram relações entre a espessura da camada de ar equivalente (que é diretamente proporcional ao fator de resistencia à difusão do vapor de água) com o coeficiente de absorção de água líquida. A teoria de Künzel et al. (2004) permitiu mostrar que, se um material absorve maior quantidade de água $\left(\mathrm{A}_{\text {valor }}\right.$ alto) sua permeabilidade ao vapor de água

${ }^{1}$ CSTB (1982) - "Note d'information sur les caractéristiques et le comportement des enduits extérieurs d'imperméabilisation de murs à base de liants hidraulyques". Cahier 1778. Paris: Centre Scientifique et Technique du Bâtiment, (230): Juin. 
deve aumentar ( $\mu$ mais baixo, ou seja, Sd mais baixo), para eliminar por difusão o excesso de umidade (BECERE, 2007; FLORES_COLEN, 2009), conforme ilustrado pela Figura 5.1.

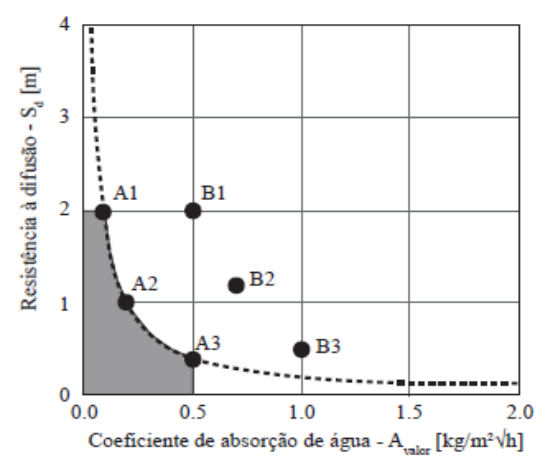

$$
\begin{gathered}
A_{\text {valor }} * S_{d} \leq 0,2 \\
A_{\text {valor }} \quad \text { Coeficiente de absorção de água }\left(\mathrm{kg} / \mathrm{m} \cdot \mathrm{h}^{1 / 2}\right) \\
S_{d} \quad \text { Espessura da camada de ar equivalente }(\mathrm{m})
\end{gathered}
$$

Fonte: Künzel et al. (2004).

Figura 5.1 - Limites toleráveis de resistência à difusão do vapor de água e do coeficiente de absorção de água.

Segundo Flores-Colen (2009), a EN 998-1 (CEN, 2003) recomenda valores para o fator de resistência à difusão do vapor de água $\mu \leq 15$ para argamassas mais permeáveis ao vapor de água (maior permeabilidade), ou seja, quando a base requer materiais com menor resistência à difusão do vapor de água.

Conforme foi amplamente explanado, os componentes de construção possuem um leque muito grande de possibilidades e propriedades (BAUER et al., 2013; BAUER et al.,2015d; IPT, 2008; MORISHITA et al., 2011), por isso a adoção de valores de referência justifica-se para alcançar os objetivos propostos por este trabalho de tese. Além das pesquisas de referência de propriedades higrotérmicas de materiais, foram feitas simulações computacionais exploratórias testando vários componentes para argamassas de revestimento e blocos cerâmicos obtidos do banco de dados do WUFI.

Após as pesquisas preliminares das características e propriedades dos materiais brasileiros (ver Tabela 5.4), genéricos e específicos, e algumas simulações exploratórias com a base de dados do WUFI, foi possível selecionar os componentes necessários para os estudos desta tese, baseado em faixas de referência para as análises de comportamento e sistematização dos resultados, conforme mostra o Quadro 5.6.

\begin{tabular}{|c|c|c|c|c|c|c|}
\hline $\begin{array}{l}\text { Faixa de } \\
\text { referência }\end{array}$ & $\begin{array}{c}\text { Calor específico - } \\
\text { c (J/kg.K) }\end{array}$ & $\begin{array}{c}\text { Condutividade } \\
\text { térmica - } \lambda \\
(\mathbf{W} / \mathbf{m} . \mathbf{K})\end{array}$ & $\begin{array}{c}\text { Porosidade } \\
\text { aberta - } \varepsilon \\
\left(\mathbf{m}^{3} / \mathbf{m}^{3}\right)\end{array}$ & $\begin{array}{c}\text { Coeficiente de } \\
\text { capilaridade - } \\
\mathbf{A}_{\text {valor }} \\
\left(\mathbf{k g} / \mathbf{m}^{2} \cdot \mathbf{h}^{1 / 2}\right)\end{array}$ & $\begin{array}{c}\text { Densidade de } \\
\text { massa aparente } \\
\rho(\mathrm{kg} / \mathrm{m} 3)\end{array}$ & $\begin{array}{c}\text { Resistência à } \\
\text { difusão do } \\
\text { vapor de } \\
\text { água - } \boldsymbol{\mu}[-]\end{array}$ \\
\hline 1 & $\leq 800$ & $\leq 0,5$ & $\leq 0,20$ & $\leq 0,5$ & $\leq 1000$ & $\leq 10$ \\
\hline 2 & $800<\mathbf{C} \leq 900$ & $0,5<\lambda \leq 1,0$ & $0,20<\boldsymbol{\varepsilon} \leq 0,30$ & $0,5<\mathbf{A}_{\text {valor }} \leq 1,5$ & $1000<\boldsymbol{\rho} \leq 1400$ & $10<\boldsymbol{\mu} \leq 15$ \\
\hline 3 & $900<\mathbf{C} \leq 1000$ & $1,0<\lambda \leq 1,5$ & $0,30<\varepsilon \leq 0,40$ & $1,5<\mathbf{A}_{\text {valor }} \leq 3$ & $1400<\boldsymbol{\rho} \leq 1800$ & $15<\boldsymbol{\mu} \leq 20$ \\
\hline 4 & $1000<\mathbf{C} \leq 2000$ & $1,5<\lambda \leq 2,0$ & $0,40<\boldsymbol{\varepsilon} \leq 0,50$ & $3<\mathbf{A}_{\text {valor }} \leq 7$ & $1800<\boldsymbol{\rho} \leq 2000$ & $20<\boldsymbol{\mu} \leq 25$ \\
\hline 5 & $>2000$ & $>2,0$ & $>0,50$ & $>7$ & $>2000$ & $>25$ \\
\hline
\end{tabular}

Quadro 5.6 -Proposta de faixas de referência** das propriedades higrotérmicas dos materiais selecionados para simulação computacional, nos estudos da tese.

** As faixas de referência definem as variações dos valores das propriedades higrotérmicas, mas não estabelece correlação entre as variáveis apresentadas nas colunas. 
Portanto, os sete casos analisados nesta tese constituem-se em um conjunto de casos de simulação de referência (suíte of benchmark simulation), conforme sugerem Daniotti et al., (2014) e Janssen (2013), estabelecendo assim, um referencial de base para análise do comportamento higrotérmico dos sistemas porosos ou suas variações.

\subsection{APRESENTAÇÃO DOS COMPONENTES E SISTEMA CONSTRUTIVO SELECIONADOS E SUAS PROPRIEDADES HIGROTÉRMICAS}

O sistema construtivo de fachada selecionado para os estudos desta tese constitui-se em uma parede de alvenaria de bloco cerâmico com $12 \mathrm{~cm}$, revestida em ambas as faces (interna e externa) com uma camada de argamassa de revestimento com $2,5 \mathrm{~cm}$ de espessura.

Para os estudos do comportamento higrotérmico do sistema de fachada, por meio da simulação computacional, foram selecionadas sete variações do sistema construtivo especificado, identificadas como SC1, SC2, SC3, SC4, SC5, SC6 e SC7.

Para compor os sete casos de estudo, foram selecionados 4 tipos de argamassa mista (cimento, cal e areia) de revestimento e 3 tipos de bloco cerâmico. As argamassas foram identificas por A1, A2, A3 e A4, e os blocos cerâmicos por B1, B2 e B3. Todas as propriedades higrotérmicas desses componentes são apresentadas no Quadro 5.7.

Os blocos cerâmicos são exemplos de material pouco higroscópico, mas bastante permeável, enquanto que as argamassas mistas são mais higroscópicas, mas menos permeáveis. Desta forma, foi possível representar uma grande variedade de materiais (JANSSEN, 2013).

As sete variações adotadas para os casos estudados foram constituídas pela combinação de três variações de base e 4 variações de revestimento com argamassa, a saber:

- Caso 1 - variação SC1 do sistema construtivo composto pelo bloco cerâmico B1 e a argamassa de revestimento A1.

- Caso 2 - variação SC2 do sistema construtivo composto pelo bloco cerâmico B3 e a argamassa de revestimento A3.

- Caso 3 - variação SC3 do sistema construtivo composto pelo bloco cerâmico B1 e a argamassa de revestimento A2.

- Caso 4 - variação SC4 do sistema construtivo composto pelo bloco cerâmico B2 e a argamassa de revestimento A1. 
- Caso 5 - variação SC5 do sistema construtivo composto pelo bloco cerâmico B2 e a argamassa de revestimento A2.

- Caso 6 - variação SC6 do sistema construtivo composto pelo bloco cerâmico B1 e a argamassa de revestimento A4.

- Caso 7 - variação SC7 do sistema construtivo composto pelo bloco cerâmico B2 e a argamassa de revestimento A4.

Quadro 5.7 - Componentes selecionados para as simulações higrotérmicas computacionais.

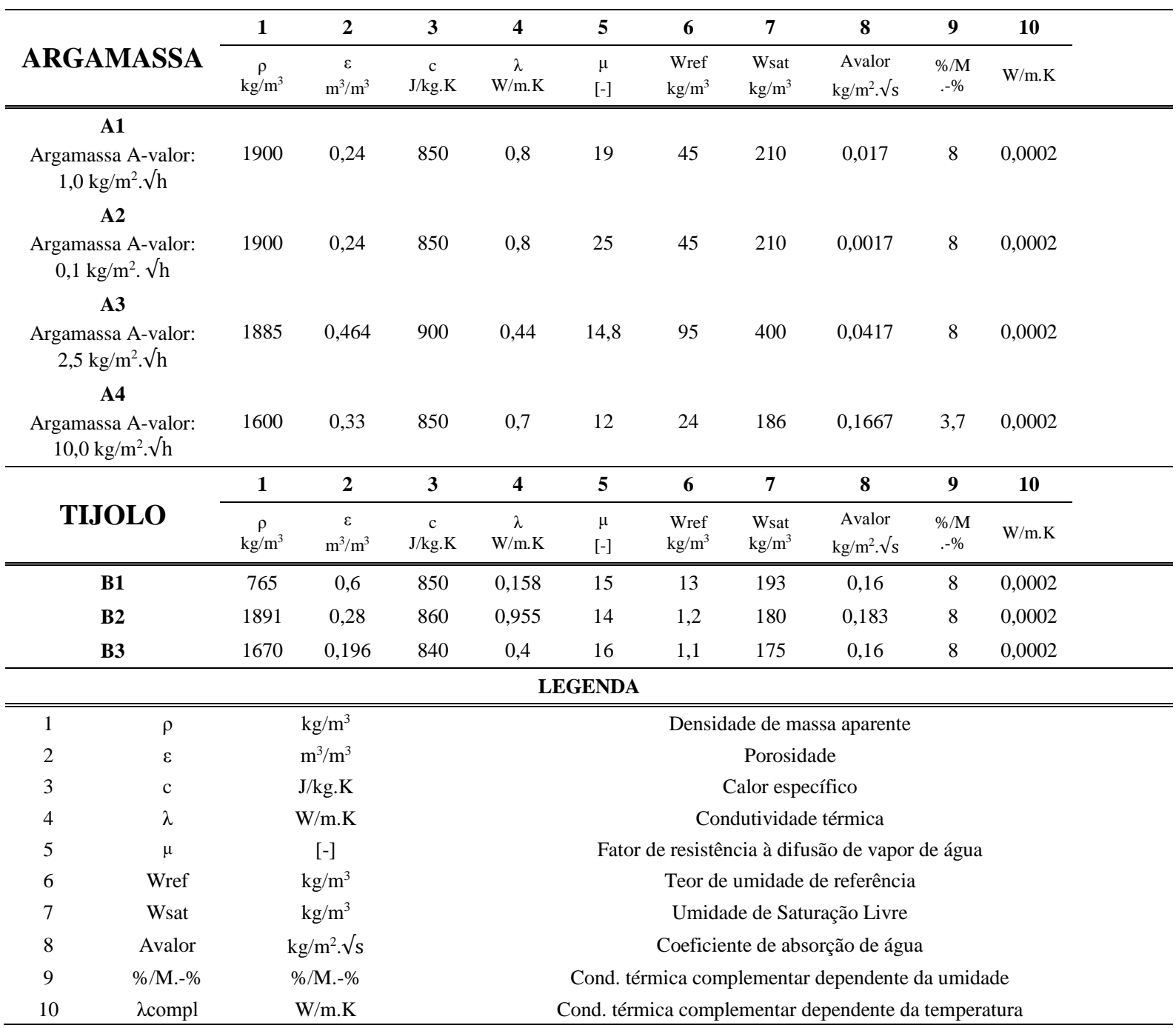

Fonte: WUFI PRO 5.3 (2013).

\subsubsection{Caracterização das argamassas}

As argamassas de revestimento selecionadas para os estudos foram denominadas A1, A2, A3 e A4, cujas propriedades higrotérmicas são apresentadas no Quadro 5.8.

As argamassas A1 e A2 possuem a mesma densidade de massa aparente e porosidade, enquanto que a argamassa A3 é muito mais porosa que as argamassas A1 e A2, mesmo apresentando 
densidade de massa aparente semelhante. A argamassa A4 é menos porosa que a argamassa A3, mas é mais porosa que as argamassas A1 e A2, embora seja a argamassa de menor densidade aparente entre todas.

Quadro 5.8 - Propriedades higrotérmicas das argamassas selecionadas.

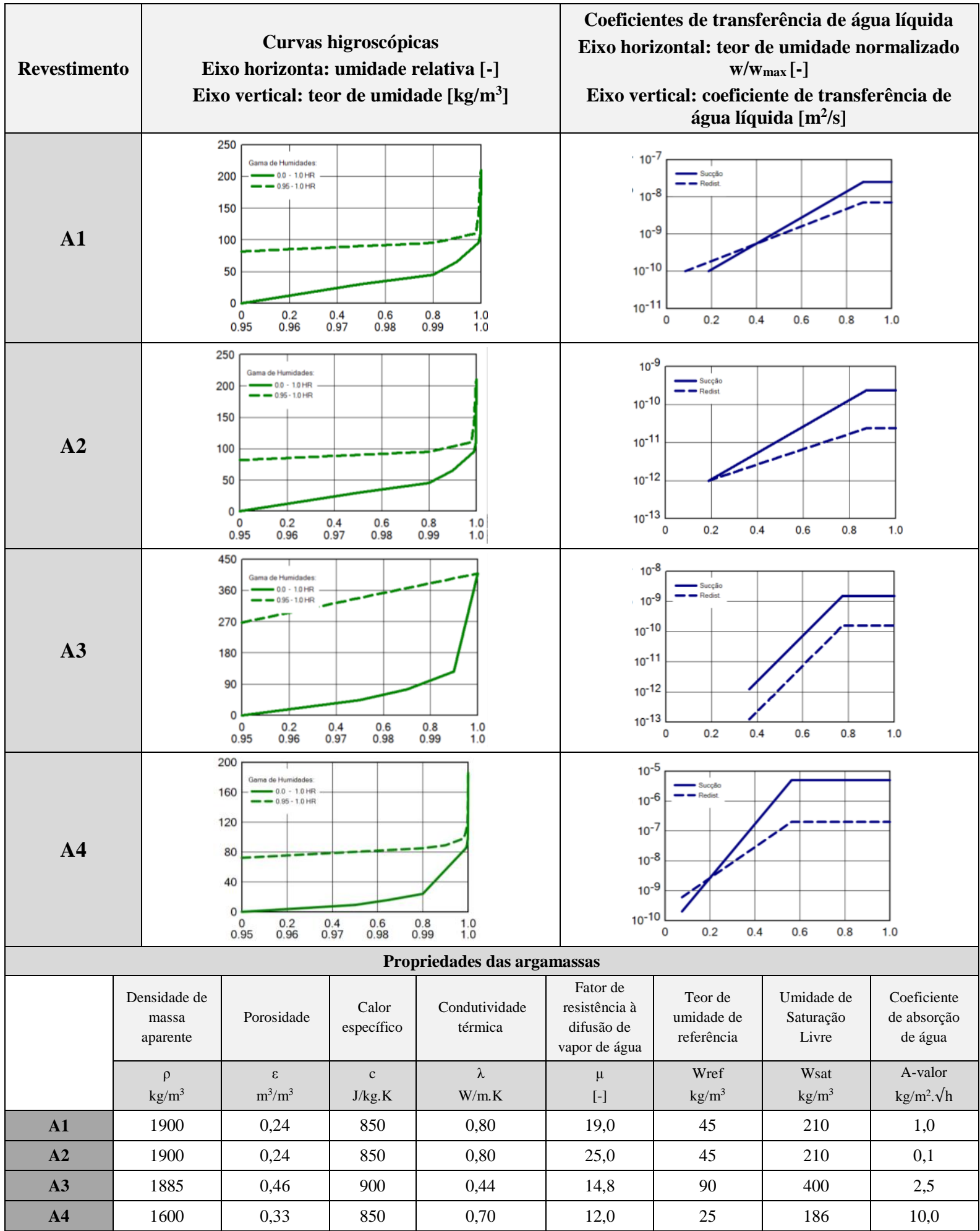

Fonte: WUFI (2013). 
As argamassas A1 e A2 possuem a mesma condutividade térmica, que é um pouco maior que a condutividade térmica da argamassa A4. A argamassa A3 é a de menor condutividade térmica entre todas. As argamassas A1, A2 e A4 possuem a mesma capacidade calorífica, e menor que aquela apresentada pela argamassa A3.

Comparando as curvas higroscópicas, verifica-se que as argamassas A1 e A2 possuem as mesmas isotermas de sorção, ou seja, apresentam o mesmo teor de umidade quando expostas à variação de umidade relativa, tanto para a adsorção (umedecimento) como para a dessorção (secagem). A argamassa A4 é um pouco menos higroscópica, isto é, adsorve um pouco menos umidade de vapor de água que as argamassas A1 e A2. A argamassa A3 é aquela que apresenta uma isoterma de equilíbrio com maior armazenamento de umidade entre todas as argamassas analisadas, ou seja, é a argamassa mais higroscópica.

Para teor de umidade de equilíbrio a 90\% de umidade relativa, as argamassas A1 e A2 possuem $65 \mathrm{~kg} / \mathrm{m}^{3}$, enquanto que para essa mesma condição, a argamassa A3 apresenta $\mathrm{w} 90=126,3$ $\mathrm{kg} / \mathrm{m}^{3}$ e a argamassa A4 apresenta $\mathrm{w} 90=56 \mathrm{~kg} / \mathrm{m}^{3}$. Ou seja, A3 é a argamassa que tem maior capacidade de adsorção da água na forma de vapor do que A1, A2 e A4. Observa-se que as argamassas A3 e A4 são aquelas que oferecem menor resistencia à difusão ao vapor de água do que as argamassas A1 e A2.

Os materiais mais porosos são mais permeáveis. A permeabilidade aumenta com a porosidade que facilita a permeação dos fluidos (líquido ou vapor).

A permeabilidade ao vapor de água é expressa por meio do fator de resistência à difusão de vapor de água $(\mu)$. Os valores usuais de $\mu$ para argamassas de revestimento de cimento e cal variam de 15 a 35, para densidade de massa compreendida entre 1800 a $1900 \mathrm{~kg} / \mathrm{m}^{3}$ (ver Quadro 5.4 para características genéricas, cuja referência é Freitas e Pinto, 2000). Para as argamassas de maior capilaridade, recomenda-se menor fator $\mu$ (FLORES-COLEN, 2009). As argamassas A1 e A2 são pouco permeáveis, baixa capilaridade e $\mu$ alto. A argamassa A3 possui maior capilaridade que A1 e A2 mas possui menor $\mu$, enquanto a argamassa A4 é aquela, entre todas, que possui a maior capilaridade e o menor fator $\mu$.

A capilaridade é representada pelo coeficiente de absorção de água ( $\mathrm{A}_{\text {valor }}$ ) e demonstra a capacidade da argamassa de absorver água líquida, quando em contato com ela, devido às forças capilares e sem que haja outro tipo de gradiente de pressão imposto.

A argamassa A4 é aquela que apresenta a maior capilaridade $(A=10,0)$, com valor bastante representativo das argamassas que são muito absorvedoras, produzidas em canteiro de obra 
pelos métodos tradicionais. A argamassa $\mathrm{A} 3(\mathrm{~A}=2,5)$ também é uma argamassa absorvedora, mas representa menor capilaridade que a argamassa A4, ou seja, desejável para as argamassas industrializadas ou argamassas dosadas em obra com rigoroso controle da qualidade. Já a argamassa $\mathrm{A} 1(\mathrm{~A}=1,0)$ representa revestimentos cuja camada superficial é resistente à água, e a argamassa $\mathrm{A} 2(\mathrm{~A}=0,1)$ representa aquelas cuja camada superfícial de revestimento é repelente à água.

Em síntese, pode-se dizer que a argamassa A4 é um material de forte capilaridade, altamente absorvedor e com rápida sucção. Já a argamassa A3 possui rápida sucção, mas fraca capilaridade, bem menor que A4. As argamassas A1 e A2 possuem muito fraca capilaridade e podem ser consideradas como material resistente à água, sendo que a argamassa A2 é um material repelente à água (quase impermeável).

Averiguando o coeficiente de transferência de água líquida, observa-se que a argamassa A4 apresenta um DWs maior que a argamassa A1 e A3, que por sua vez apresenta um DWs maior que a argamassa A2. Como DWs cresce exponencialmente com $A_{v a l o r}$, era de se esperar essa relação. Mas, importante observar que a velocidade da frente úmida para as argamassas A4 e A3 é bem maior do que para as argamassas A1 e A2, pois A4 e A3 possuem maior capilaridade que A1 e A2, além de serem mais porosas.

As curvas de trasferencia de água líquida mostram que o processo de secagem (redistribuição capilar da umidade) é mais lento que o processo de absorção (sucção).

A argamassa que tem um coeficiente de absorção maior, responde mais rapidamente aos processos de secagem, ou seja, a argamassa mais absorvente, também é a argamassa que perde mais rapidamente o seu teor de umidade. Inclusive, sendo mais porosas, são mais permeáveis.

\subsubsection{Caracterização dos blocos cerâmicos}

Os blocos cerâmicos selecionados para os estudos foram denominados B1, B2 e B3, e suas propriedades higrotérmicas são apresentadas no Quadro 5.9.

Os blocos B1, B2 e B3 apresentam densidades de massa aparente, porosidades e condutividades térmicas diferentes entre si. O bloco B1 é bastante poroso, apresentando baixa densidade de massa e muito baixa condutividade térmica. O bloco B2 e o Bloco B3 possuem propriedades muito semelhantes aos blocos usualmente utilizados nas construções de fachadas convencionais brasileiras. O bloco B3 possui capilaridade similar aos outros blocos, mas em relação ao bloco B2, é menos denso, menos poroso e apresenta menor coeficiente de condutividade térmica. 
Quadro 5.9 - Propriedades higrotérmicas dos blocos cerâmicos selecionados.

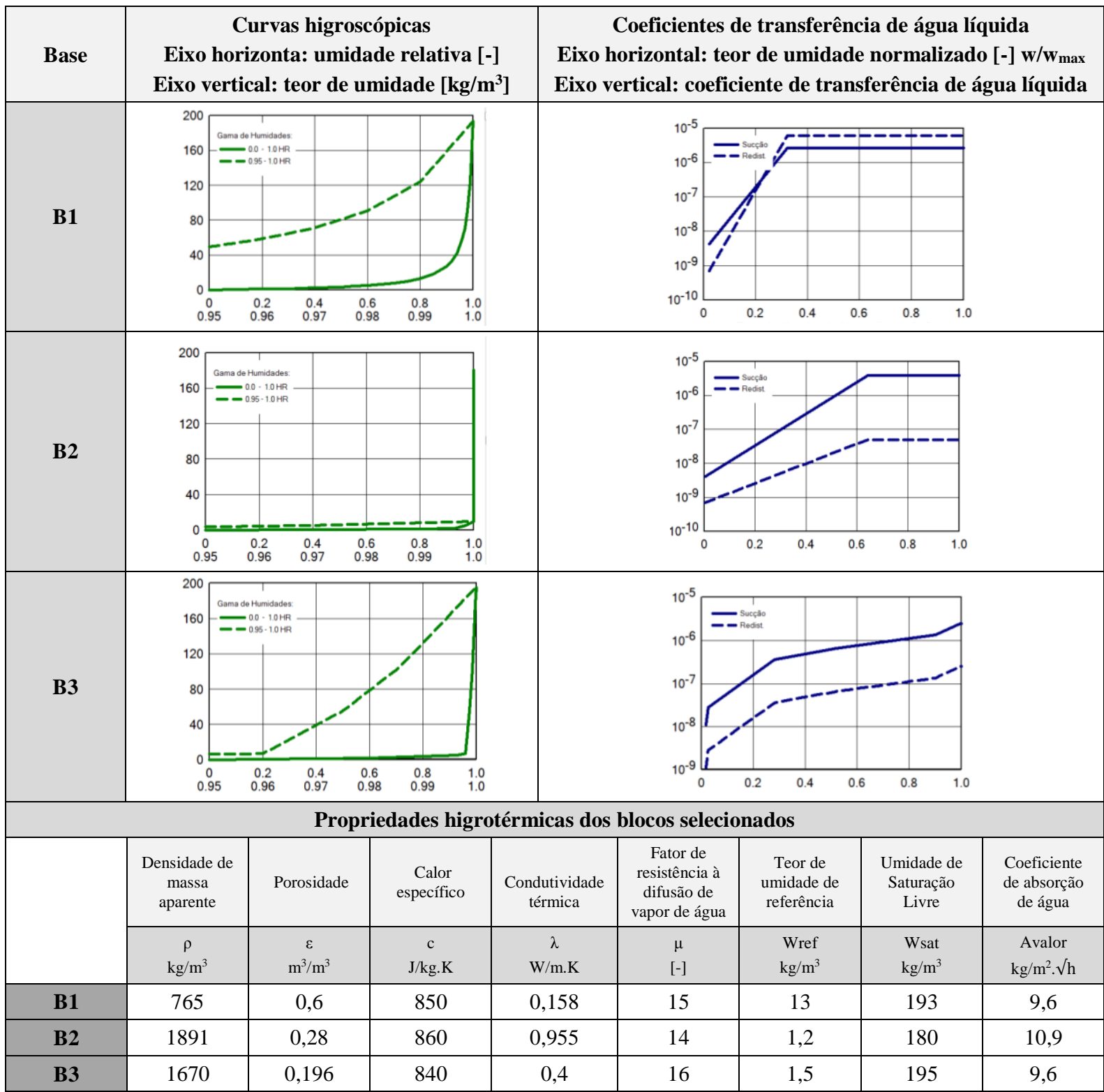

Fonte: WUFI (2013).

Os 3 tipos de blocos apresentam coeficientes de absorção de água similares, apesar de o B1 apresentar maior velocidade de sucção. Também, apresentam fator de resistência à difusão de vapor de água similar, que expressa a permeabilidade ao vapor de água. Os blocos possuem $\mu$ similares à argamassa A3 e A4, mas menores que as argamassas A1 e A2.

Nas isotermas de adsorção dos blocos B1, B2 e B3, verifica-se que o teor de água no domínio higroscópico é muito baixo para os três blocos. Os blocos apresentam baixa capacidade de adsorção, isto é, são materiais pouco higroscópicos (característica dos blocos cerâmicos). O bloco B1 é o que tem maior capacidade de adsorver água na forma de vapor do meio ambiente. 
Ou seja, observando o teor de umidade no domínio higroscópico, para w95 o B2 é o que tem menor capacidade de umedecimento, seguido pelos blocos B3 e B1.

Apesar de os blocos apresentarem coeficientes de absorção de água similares e lembrando que o coeficiente de transferência de água líquida na sucção (DWs) cresce exponencialmente com $\mathrm{A}_{\text {valor }}$, observa-se que o avanço da frente úmida a partir da superfície acontece com velocidades diferentes nos blocos. A absorção do bloco B1 é mais rápida.

\subsection{ESTRUTURA DE ANÁliSE E ESQUEMA DA METODOLOGIA EMPREGADA}

A norma EN 15026 - Hygrothermal performance of building components and building elements - Assessment of moisture transfer by numerical simulation (DIN, 2007) define a aplicação prática dos procedimentos e critérios para simulações higrotérmicas em regime transiente em uma direção, para transporte de calor e umidade na envoltória da edificação.

Baseado nas fases citadas, a saber, dados de entrada, processamento, dados de saída e pósprocessamento, conforme prescreva a EN 15026 (DIN, 2007), é apresentado um esquema dos procedimentos metodológicos empregados para os estudos desta tese (Figura 5.2).

As variáveis selecionadas para as análises foram o teor de umidade e a temperatura superficial externa da fachada, resultantes da interação entre calor e umidade em regime transiente.

Derivada da temperatura superficial externa, mais duas variáveis de análise foram contempladas: amplitude térmica na superfície da fachada (diferença diária entre as temperaturas máxima e mínima na fachada) e choque térmico (mudança brusca de temperatura para intervalo de tempo de 1 hora e de 2 horas).

A estrutura de análise compreendeu:

- Comparações do teor de umidade total entre fachadas, e em cada camada, para os períodos seco e chuvoso, para sete diferentes variações do sistema de fachada selecionado.

- Comparações da amplitude térmica na superfície externa da fachada para os períodos seco e chuvoso, para sete diferentes variações de sistema de fachada selecionado.

- Caracterização e quantificação do comportamento das variáveis de análise, por meio da análise das médias, máximas e mínimas, além das frequências de ocorrência. 


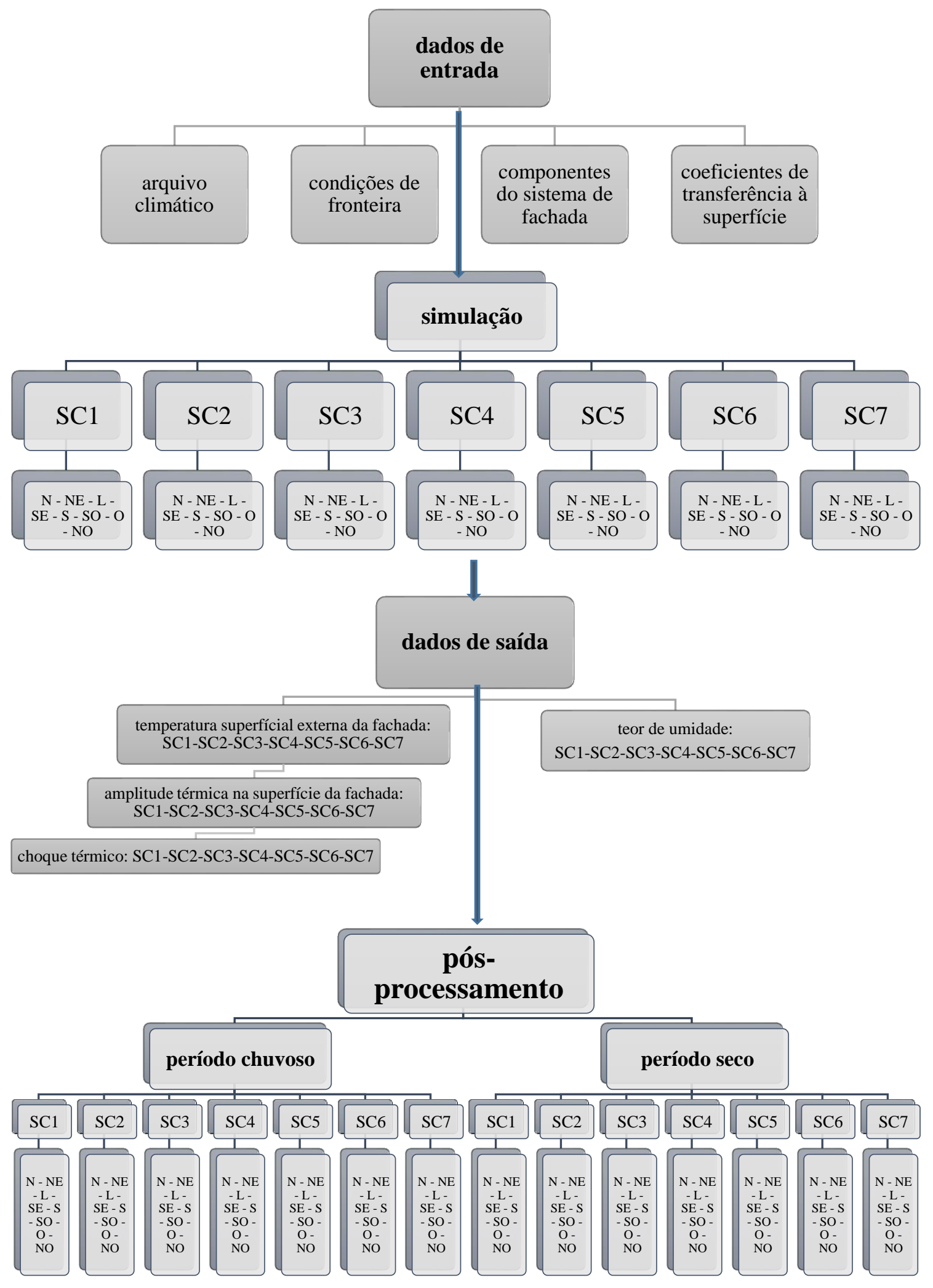

Figura 5.2 - Esquema da metodologia empregada para a etapa simulação higrotérmica. 
O Quadro 5.10 sintetiza a estrutura analítica que foi aplicada na fase de pós-processamento.

Quadro 5.10 - Estrutura analítica para a fase de pó-processamento.

\begin{tabular}{|c|c|c|}
\hline $\begin{array}{l}\text { Dados de saída } \\
\text { (Relatórios) }\end{array}$ & Variável de análise & Critérios de análise \\
\hline \multirow{2}{*}{$\begin{array}{l}\text { Temperatura } \\
\text { superficial externa da } \\
\text { fachada }\end{array}$} & $\begin{array}{l}\text { Amplitude térmica na superfície } \\
\text { da fachada }\end{array}$ & \multirow{4}{*}{$\begin{array}{l}\text { - Comportamento dos valores médios, } \\
\text { máximos e mínimos, ao longo do mês e do } \\
\text { ano } \\
\text { - }\end{array}$} \\
\hline & $\begin{array}{l}\text { Choque térmico: mudança brusca } \\
\text { de temperatura (para intervalo de } \\
\text { tempo de } 1 \text { hora e de } 2 \text { horas) }\end{array}$ & \\
\hline \multirow{2}{*}{ Teor de umidade } & Teor de umidade em cada camada & \\
\hline & $\begin{array}{l}\text { Teor de umidade total do sistema } \\
\text { poroso de fachada }\end{array}$ & \\
\hline
\end{tabular}

\subsection{PROCEDIMENTOS PARA ANÁliSe ESTATÍSTICA, APRESENTAÇÃo E DISCUSSÃO DOS RESULTADOS}

Após as simulações, os resultados foram organizados em gráficos e tabelas. Os resultados referem-se ao comportamento das variáveis "temperatura superficial externa da fachada", "amplitude térmica da superfície da fachada" e "teor de umidade total do elemento construtivo".

As amplitudes térmicas diárias na superfície da fachada foram obtidas por meio da diferença entre as temperaturas superficiais máximas e mínimas, ocorridas durante o dia, para cada uma das oito principais orientações de fachada. $\mathrm{O}$ teor de umidade considerado nas análises referese ao teor de umidade total do elemento construtivo em cada uma das fachadas.

As interações entre as variáveis permitiram gerar resultados para as sete variações do sistema poroso de fachada, constituídas por 4 tipos de revestimento e três tipos de base, oito orientações de fachada e dois períodos (seco e chuvoso).

As análises foram efetuadas com base na fundamentação conceitual sobre os agentes e mecanismos de degradação, e no comportamento higrotérmico dos sistemas porosos como resposta aos agentes climáticos atuantes sobre as fachadas. Os testes estatísticos aplicados permitiram efetuar as múltiplas comparações, considerando a sinergia e a ação simultânea entre os agentes climáticos de degradação e as fachadas.

Foi aplicada a técnica estatística Análise de Variância de três vias (ANOVA three way) para as análises das interações entre as variáveis dependentes ("teor de umidade total do elemento construtivo" e "amplitude térmica na superfície da fachada") e as variáveis independentes ("período", “ orientação de fachada" e "variações do sistema construtivo"). 
Para tal análise, foi composta uma matriz de 20440 dados (cuja estrutura pode ser visualizada no Apêndice B), sendo 10192 dados para os 182 dias do período chuvoso e 10248 para os 183 dias do período seco, considerando cada uma das sete variações do sistema construtivo (SC1, SC2, SC3, SC4, SC5, SC6 e SC7), para cada orientação de fachada (1-N, 2-NE, 3-L, 4-SE, 5$\mathrm{S}, 6-\mathrm{SO}, 7-\mathrm{O}$ e 8-NO).

Por meio da técnica de análise estatística ANOVA three way foi possível efetuar as múltiplas comparações entre as variáveis dependentes (teor de umidade do elemento e amplitude térmica da superfície) relacionadas às sete variações do sistema de fachada, e cada orientação de fachada, para cada período do ano (seco e chuvoso).

Após os testes de confirmação de distribuição normal das amostras, foi verificado por meio do pós-teste de Tukey quais interações apresentavam diferenças estatísticas significativas $(\mathrm{p}<0,05)$. Foram obtidos 112 resultados de interação para cada variável dependente (2 períodos versus 7 variações de sistema construtivo versus 8 orientações). Para obtenção das análises estatísticas foram utilizados dois pacotes estatísticos que se complementaram:

- SIGMA PLOT (Systat Software, 2015)

- IBM*SPSS STATISTIC - version 20 (IBM, 2011)

Os resultados permitiram mostrar a influência das variáveis independentes no comportamento das variáveis dependentes, quando consideradas as ações e interações entre os agentes climáticos de degradação e o comportamento higrotérmico dos sistemas porosos de vedação vertical (alvenaria de bloco cerâmico e revestimento com argamassa).

\subsection{CONSIDERAÇÕES FINAIS DO CAPÍTULO}

A seleção dos componentes para os estudos higrotérmicos por meio de simulação mostrou-se suficientemente representativa dos sistemas porosos de vedação vertical encontrados na construção civil brasileira.

Foram realizadas sete simulações de referência que representaram a base para a análise do comportamento higrotérmico do sistema de fachada selecionado, em resposta à ação e interação dos agentes climáticos de degradação.

Estes casos constituíram-se em patamares de referência, visando à análise de sensibilidade de soluções a serem especificadas em situação de projeto ou retrofit (reforma). Além disso, como uma ferramenta de suporte para a fase de diagnóstico de degradação, podem servir para 
referenciar o comportamento higrotérmico de componentes genéricos para a construção, visto que representam uma ampla gama de ocorrências de transferência de calor e umidade em sistemas de vedação vertical porosos de fachada.

Em síntese, a partir dos resultados das simulações e dos estudos desenvolvidos ao longo da tese, as análises e as conclusões resultantes dos sete estudos são apresentadas em cenários representativos das condições de exposição de cada uma das oito principais orientações de fachada, nos períodos seco e chuvoso.

Os encartes fixados no final do Capítulo VI mostram os cenários que se constituem em uma referência para a caracterização de fachada nas fases de projeto e diagnóstico para manutenção, baseada na interação entre os agentes climáticos de degradação e o comportamento higrotérmico de fachada. 


\section{CAPÍTULO VI}

\section{RESULTADOS DOS ESTUDOS HIGROTÉRMICOS}

\subsection{CONSIDERAÇÕES INICIAIS}

Neste capítulo são apresentados e discutidos os resultados dos sete estudos de simulação higrotérmica efetuados para a cidade de Brasília, por meio do programa computacional WUFI PRO 5.3 (2013).

O Quadro 6.1 sintetiza as sete variações simuladas do sistema de vedação vertical de alvenaria de bloco cerâmico revestido com argamassa.

Quadro 6.1- Variações do sistema construtivo de fachada para os estudos higrotérmicos.

\begin{tabular}{|c|c|c|c|c|c|c|c|}
\hline \multicolumn{3}{|r|}{ Caso simulado 1} & \multirow{2}{*}{ Propriedades } & $\rho$ & $\varepsilon$ & $\mu$ & Avalor $_{\text {va }}$ \\
\hline A1 & \multirow{3}{*}{$\mathrm{SC} 1$} & \multirow{3}{*}{$\begin{array}{l}\text { Espessura total da parede: } 0,17 \mathrm{~m} \\
\text { Transmitância térmica U: } 1,105 \mathrm{~W} / \mathrm{m}^{2} \mathrm{~K}\end{array}$} & & $\mathrm{~kg} / \mathrm{m}^{3}$ & $\mathbf{m}^{3} / \mathbf{m}^{3}$ & {$[-]$} & $\mathrm{kg} / \mathrm{m}^{2} \cdot \sqrt{\mathrm{h}}$ \\
\hline B1 & & & Argamassa A1 & 1900 & 0,24 & 19 & 1,0 \\
\hline A1 & & & Bloco cerâmico B1 & 765 & 0,60 & 15 & 9,6 \\
\hline \multicolumn{3}{|r|}{ Caso simulado 2} & \multirow{2}{*}{ Propriedades } & $\rho$ & $\varepsilon$ & $\mu$ & $\mathbf{A}_{\text {valor }}$ \\
\hline A3 & \multirow{3}{*}{$\mathrm{SC} 2$} & \multirow{3}{*}{$\begin{array}{l}\text { Espessura total da parede: } 0,17 \mathrm{~m} \\
\text { Transmitância térmica } \mathrm{U}: 1,687 \mathrm{~W} / \mathrm{m}^{2} \mathrm{~K}\end{array}$} & & $\mathrm{~kg} / \mathrm{m}^{3}$ & $\mathbf{m}^{3} / \mathbf{m}^{3}$ & {$[-]$} & $\mathrm{kg} / \mathrm{m}^{2} \cdot \sqrt{\mathrm{h}}$ \\
\hline B3 & & & Argamassa A3 & 1885 & 0,46 & 15 & 2,5 \\
\hline A3 & & & Bloco cerâmico B3 & 1670 & 0,19 & 16 & 10,0 \\
\hline \multicolumn{3}{|r|}{ Caso simulado 3} & \multirow{2}{*}{ Propriedades } & $\rho$ & $\varepsilon$ & $\mu$ & $\mathbf{A}_{\text {valor }}$ \\
\hline A2 & \multirow{3}{*}{$\mathrm{SC} 3$} & \multirow{3}{*}{$\begin{array}{l}\text { Espessura total da parede: } 0,17 \mathrm{~m} \\
\text { Transmitância térmica } \mathrm{U}: 1,105 \mathrm{~W} / \mathrm{m}^{2} \mathrm{~K}\end{array}$} & & $\mathrm{~kg} / \mathrm{m}^{3}$ & $\mathbf{m}^{3} / \mathbf{m}^{3}$ & {$[-]$} & $\mathrm{kg} / \mathrm{m}^{2} \cdot \sqrt{\mathrm{h}}$ \\
\hline B1 & & & Argamassa A2 & 1900 & 0,24 & 25 & 0,1 \\
\hline A2 & & & Bloco cerâmico B1 & 765 & 0,60 & 15 & 9,6 \\
\hline \multicolumn{3}{|r|}{ Caso simulado 4} & \multirow{2}{*}{ Propriedades } & $\rho$ & $\varepsilon$ & $\mu$ & Avalor \\
\hline A1 & \multirow{3}{*}{$\mathrm{SC} 4$} & \multirow{3}{*}{$\begin{array}{l}\text { Espessura total da parede: } 0,17 \mathrm{~m} \\
\text { Transmitância térmica U: } 2,766 \mathrm{~W} / \mathrm{m}^{2} \mathrm{~K}\end{array}$} & & $\mathrm{~kg} / \mathrm{m}^{3}$ & $\mathbf{m}^{3} / \mathbf{m}^{3}$ & {$[-]$} & $\mathrm{kg} / \mathrm{m}^{2} \cdot \sqrt{\mathrm{h}}$ \\
\hline B2 & & & Argamassa A1 & 1900 & 0,24 & 19 & 1,0 \\
\hline A1 & & & Bloco cerâmico B2 & 1891 & 0,28 & 14 & 10,9 \\
\hline \multicolumn{3}{|r|}{ Caso simulado 5} & \multirow{2}{*}{ Propriedades } & $\rho$ & $\varepsilon$ & $\mu$ & Avalor $_{\text {var }}$ \\
\hline A2 & \multirow{3}{*}{ SC5 } & \multirow{3}{*}{$\begin{array}{l}\text { Espessura total da parede: } 0,17 \mathrm{~m} \\
\text { Transmitância térmica U: } 2,766 \mathrm{~W} / \mathrm{m}^{2} \mathrm{~K}\end{array}$} & & $\mathrm{~kg} / \mathrm{m}^{3}$ & $\mathbf{m}^{3} / \mathbf{m}^{3}$ & {$[-]$} & $\mathrm{kg} / \mathrm{m}^{2} \cdot \sqrt{\mathrm{h}}$ \\
\hline$\overline{\text { B2 }}$ & & & Argamassa A2 & 1900 & 0,24 & 25 & 0,1 \\
\hline A2 & & & Bloco cerâmico B2 & 1891 & 0,28 & 14 & 10,9 \\
\hline \multicolumn{3}{|r|}{ Caso simulado 6} & \multirow{2}{*}{ Propriedades } & $\rho$ & $\varepsilon$ & $\mu$ & Avalor $_{\text {val }}$ \\
\hline A4 & \multirow{3}{*}{ SC6 } & \multirow{3}{*}{$\begin{array}{l}\text { Espessura total da parede: } 0,17 \mathrm{~m} \\
\text { Transmitância térmica U: } 1,087 \mathrm{~W} / \mathrm{m}^{2} \mathrm{~K}\end{array}$} & & $\mathrm{~kg} / \mathrm{m}^{3}$ & $\mathrm{~m}^{3} / \mathrm{m}^{3}$ & {$[-]$} & $\mathrm{kg} / \mathrm{m}^{2} \cdot \sqrt{\mathrm{h}}$ \\
\hline$\overline{B 1}$ & & & Argamassa A4 & 1600 & 0,33 & 12 & 10,0 \\
\hline A4 & & & Bloco cerâmico B1 & 765 & 0,60 & 15 & 9,6 \\
\hline \multicolumn{3}{|r|}{ Caso simulado 7} & \multirow{2}{*}{ Propriedades } & $\rho$ & $\varepsilon$ & $\mu$ & $\mathbf{A}_{\text {valor }}$ \\
\hline A4 & \multirow{3}{*}{ SC7 } & \multirow{3}{*}{$\begin{array}{l}\text { Espessura total da parede: } 0,17 \mathrm{~m} \\
\text { Transmitância térmica U: } 2,655 \mathrm{~W} / \mathrm{m}^{2} \mathrm{~K}\end{array}$} & & $\mathrm{~kg} / \mathrm{m}^{3}$ & $\mathrm{~m}^{3} / \mathrm{m}^{3}$ & {$[-]$} & $\mathrm{kg} / \mathrm{m}^{2} \cdot \sqrt{\mathrm{h}}$ \\
\hline B2 & & & Argamassa A4 & 1600 & 0,33 & 12 & 10,0 \\
\hline A4 & & & Bloco cerâmico B2 & 1891 & 0,28 & 14 & 10,9 \\
\hline
\end{tabular}




\subsection{ANÁLISE DO COMPORTAMENTO DO TEOR DE UMIDADE INFLUENCIADO PELAS PROPRIEDADES DO SISTEMA DE FACHADA}

Com os resultados das simulações higrotérmicas computacionais, foram gerados relatórios referentes aos dados relacionados às fontes de umedecimento, ao teor de umidade de cada camada (base em alvenaria e revestimento com argamassa) e ao teor de umidade total presente no elemento de fachada.

O teor de umidade é resultante da ação da água na forma líquida e vapor. As fontes dessa umidade são, respectivamente, a chuva dirigida e a umidade relativa do ar. Tanto o montante de chuva dirigida que incide sobre a fachada como a umidade relativa do ar são ações de origem externa, portanto, são variáveis independentes do sistema construtivo.

A Figura 6.1 mostra o montante de chuva dirigida incidente em cada orientação de fachada, correspondente ao total acumulado mensal, com base no arquivo climático TMY da base EPW/ANTAC que alimentou o programa WUFI nas simulações higrotérmicas.

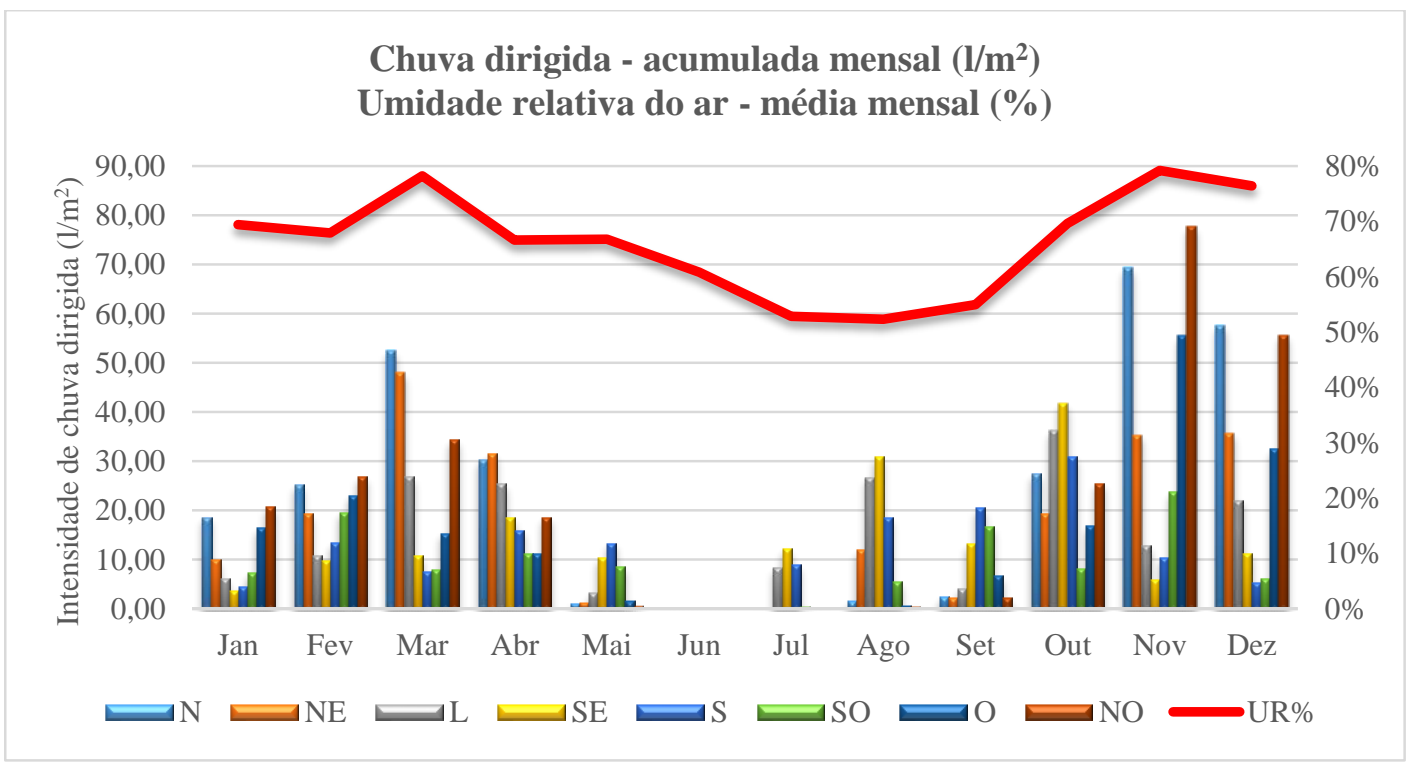

Figura 6.1 - Média mensal da umidade relativa do ar e montante mensal de chuva dirigida incidente em cada orientação de fachada, com base no TMY da base EPW/ANTAC para a cidade de Brasília.

O teor de umidade na fachada é uma variável dependente, ou seja, é resultado da ação da chuva dirigida, da umidade relativa do ar, das temperaturas superficiais e das características higrotérmicas dos componentes, em cada orientação de fachada. Para a análise do comportamento do teor de umidade foram feitas as médias mensais com os resultados horários das 8760 horas de simulação.

O Quadro 6.2 apresenta o comportamento médio mensal do teor de umidade total de cada caso estudado, para cada orientação de fachada, ao longo dos meses do ano. 
Quadro 6.2 - Comportamento do teor de umidade total: média mensal $\left(\mathrm{kg} / \mathrm{m}^{2}\right)$.

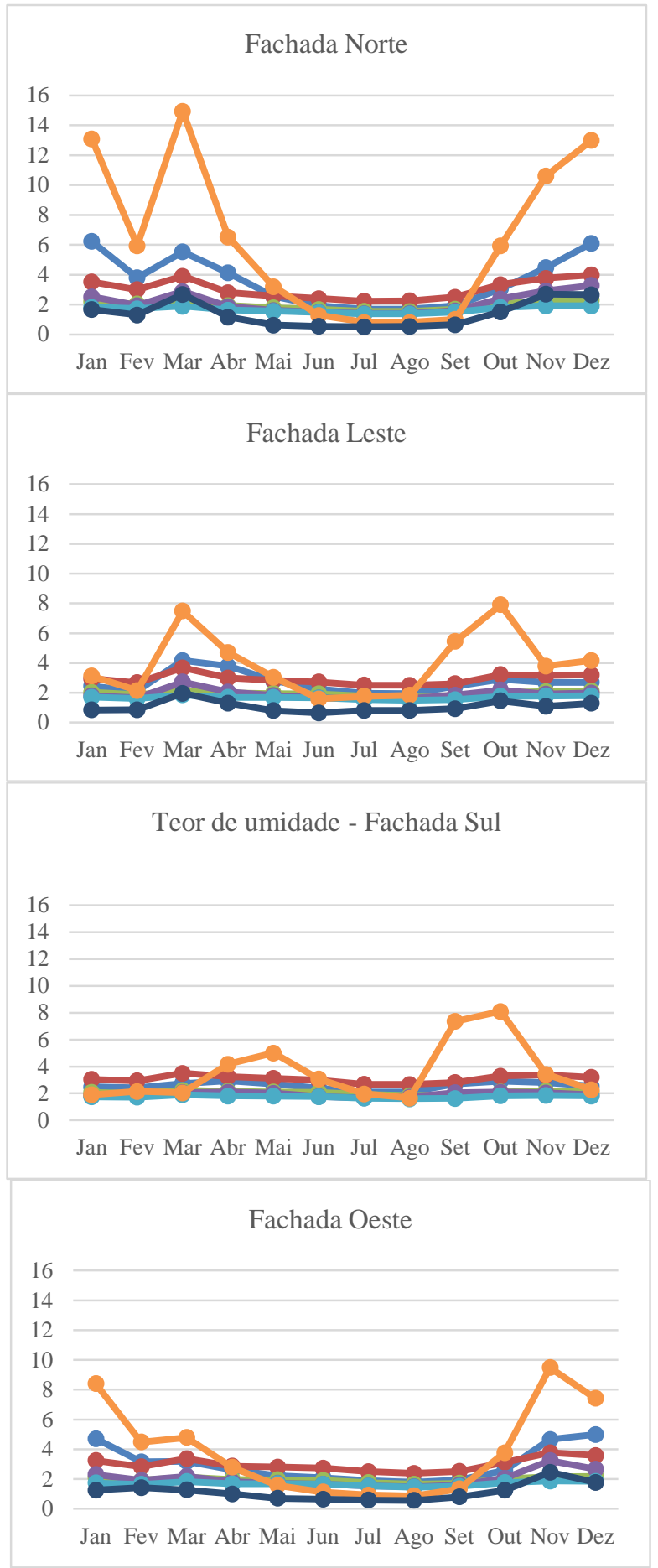

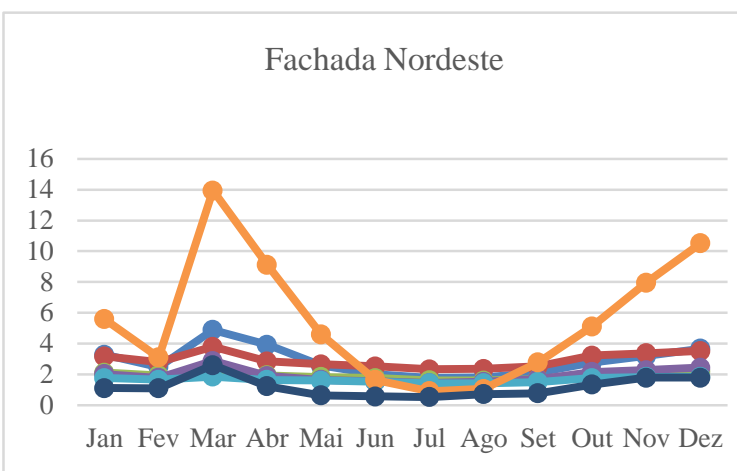

Fachada Sudeste

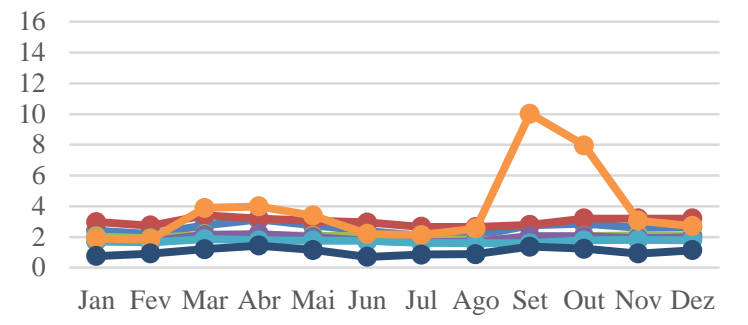

Fachada Sudoeste

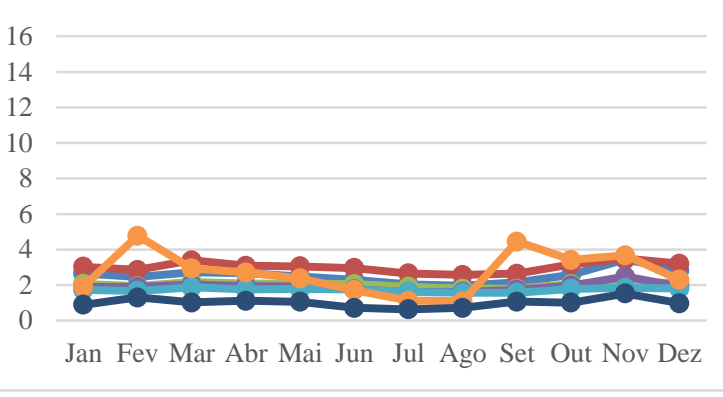

Fachada Noroeste

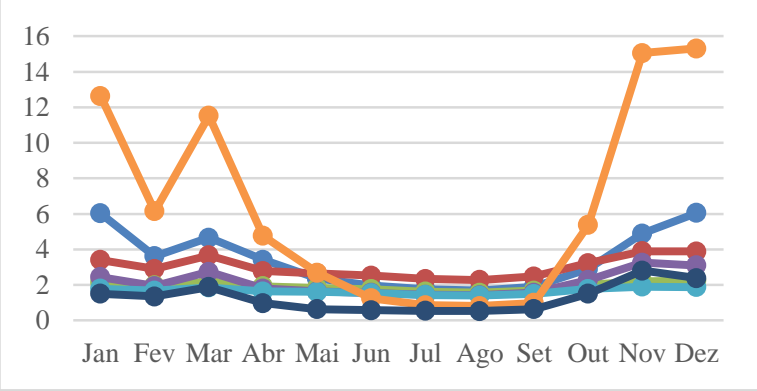

Legenda:

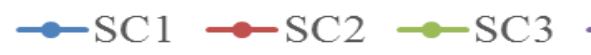

$\longrightarrow \mathrm{SC} 4$

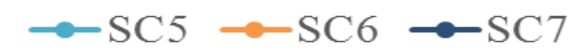

Observa-se que, com exceção do sistema SC6, todos os outros apresentaram média mensal do teor de umidade em uma faixa variando até $9 \mathrm{~kg} / \mathrm{m}^{2}$. Para melhorar a visualização gráfica, o Quadro 6.3 mostra o comportamento dos casos estudados, suprimindo o sistema SC6, o que permitiu a representação gráfica em uma escala maior. 
Para melhor compreender o comportamento mensal dos casos que estão em uma faixa mais delimitada de teor de umidade, o Quadro 6.3 mostra, para cada mês, a máxima média diária do teor de umidade total para os casos SC1, SC2, SC3, SC4, SC5 e SC7.

Quadro 6.3 - Comportamento do teor de umidade total: máxima média diária do mês $\left(\mathrm{kg} / \mathrm{m}^{2}\right)$.
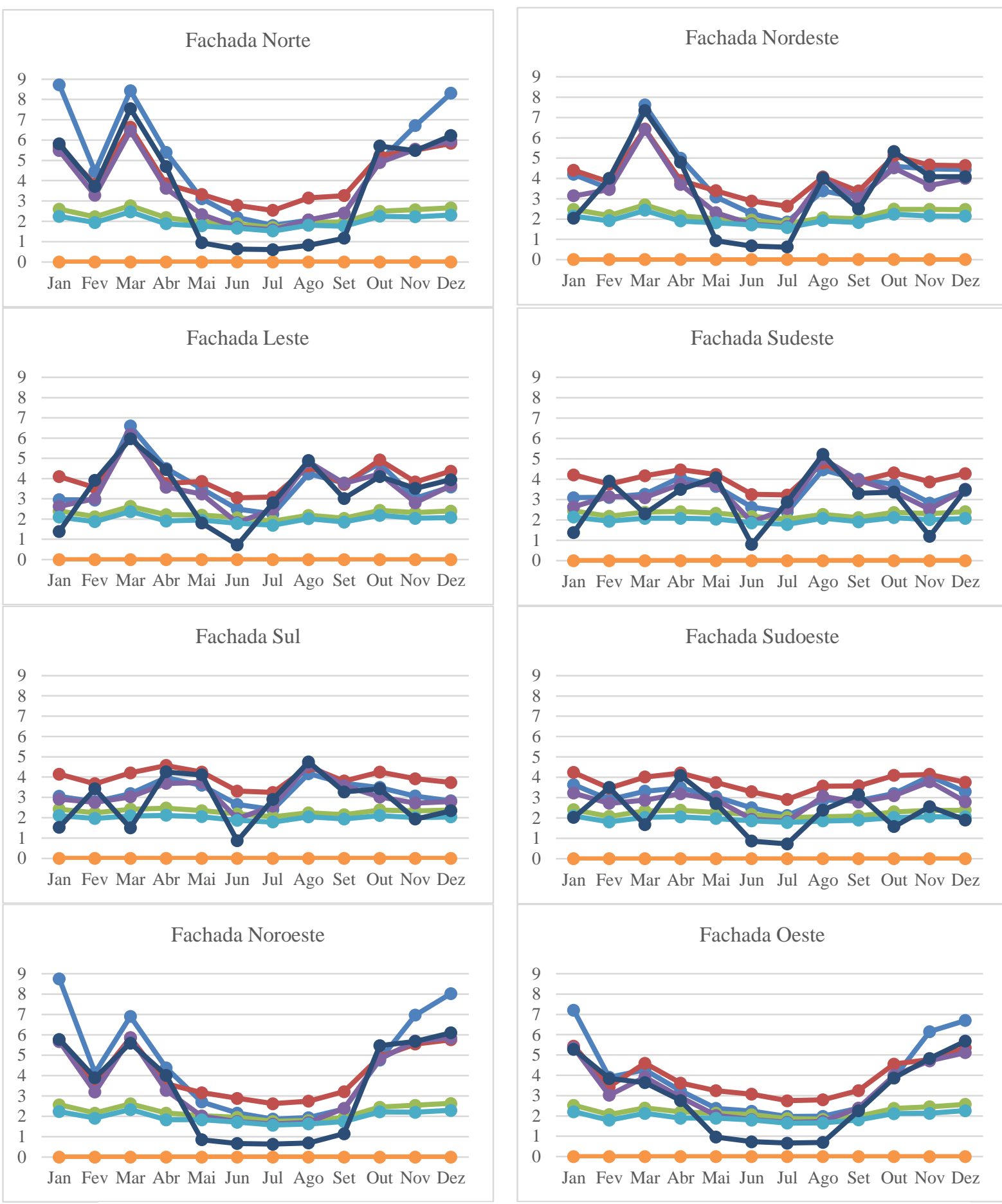

Fachada Sudoeste

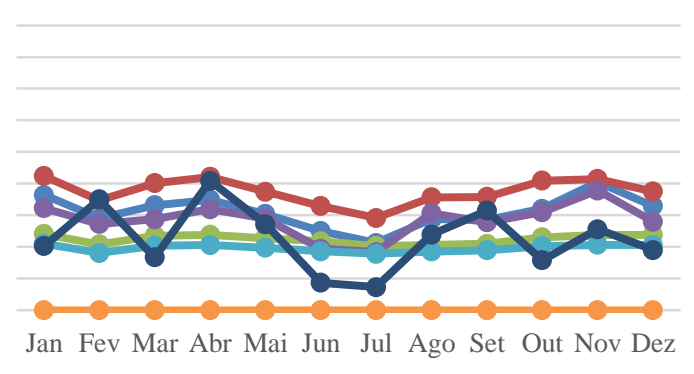

Jan Fev Mar Abr Mai Jun Jul Ago Set Out Nov Dez

Fachada Oeste

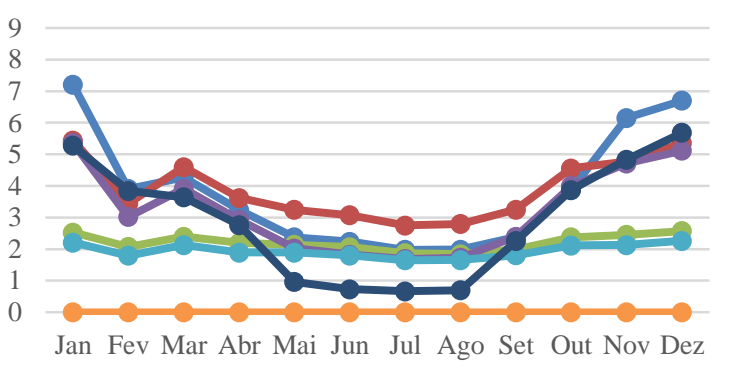

Legenda:

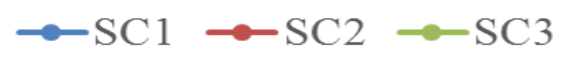

$\longrightarrow \mathrm{SC}$

C4 $\multimap$ SC5 $\multimap$ SC6 $\rightarrow$ SC7

Com base no gráfico da Figura 6.1 e analisando os gráficos dos Quadros 6.2 e 6.3, observa-se que os meses de maior teor de umidade correspondem aos meses mais chuvosos, quando a 
umidade relativa do ar também é maior. A variação do teor de umidade observada em cada orientação de fachada e para cada um dos sete casos estudados é resultante da resposta do sistema construtivo mediante a incidência da chuva dirigida que varia de acordo com a direção dos ventos predominantes.

Nas fachadas Noroeste e Norte concentram-se os maiores teores de umidade, visto que estas fachadas são aquelas mais expostas à chuva dirigida, nos meses mais chuvosos. Observa-se que nas outras orientações de fachadas, em menor intensidade, os picos do teor de umidade ocorrem, também, nos meses em que a chuva dirigida é mais incidente.

As Figuras 6.2, 6.3, 6.4, 6.5, 6.6, 6.7 e 6.8 apresentam o teor de umidade em cada camada dos casos analisados, referentes à fachada Noroeste, considerando o comportamento da umidade ao longo de 8760 horas do ano climático.

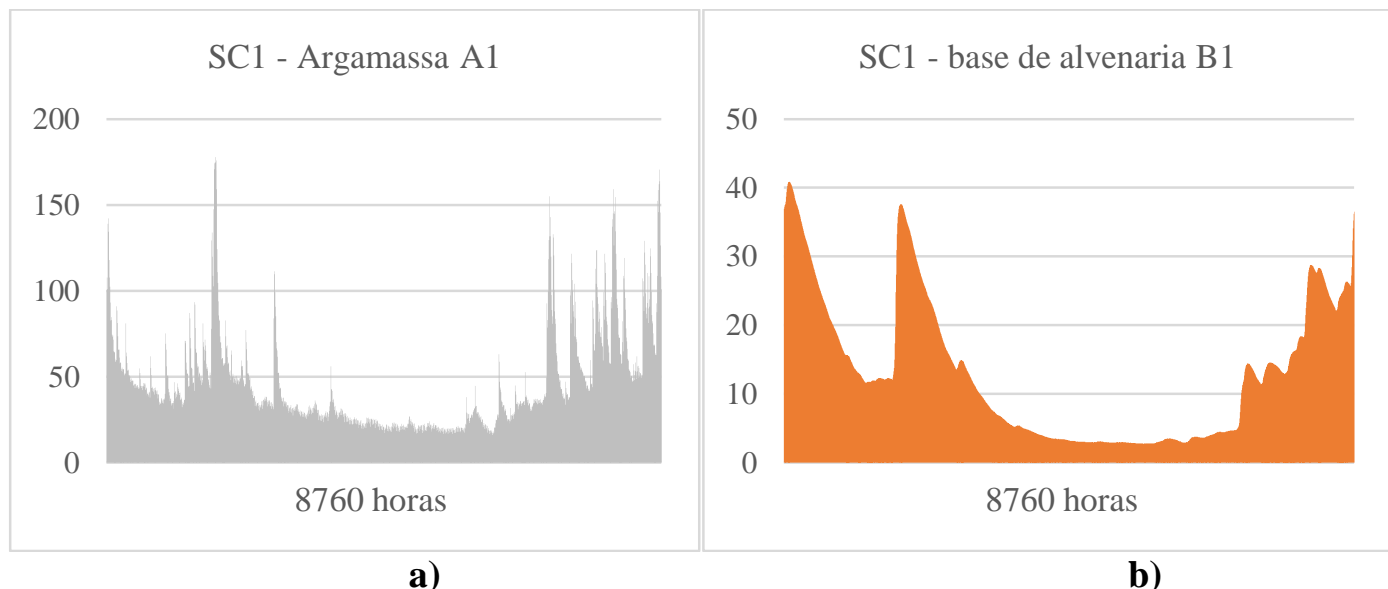

Figura 6.2 - Representação gráfica do teor de umidade $\left(\mathrm{em} \mathrm{kg} / \mathrm{m}^{3}\right)$ das camadas do sistema SC1: a) revestimento com argamassa A1 com capilaridade $A_{\text {valor }}=1,0 \mathrm{~kg} / \mathrm{m}^{2} \sqrt{\mathrm{h}}$;

b) base de alvenaria $B 1$ (porosidade alta e densidade de massa aparente baixa).

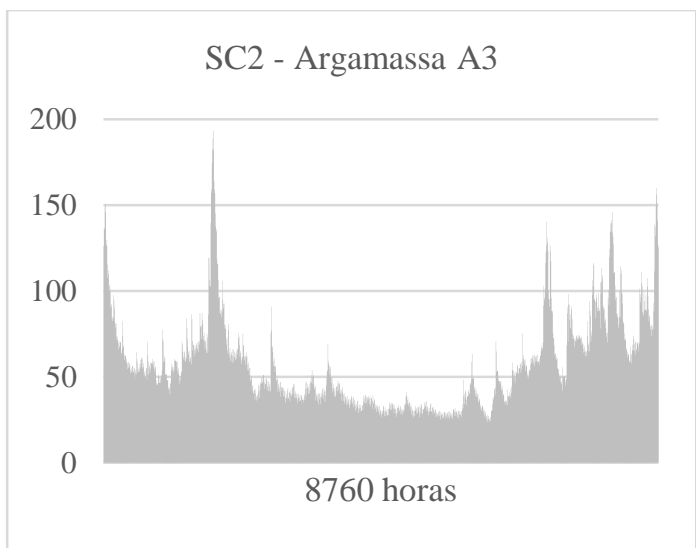

a)

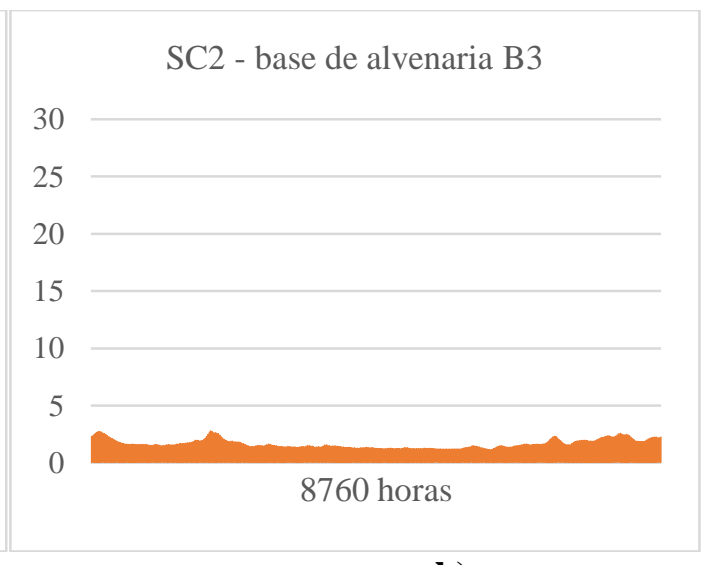

b)

Figura 6.3 - Representação gráfica do teor de umidade $\left(\mathrm{em} \mathrm{kg} / \mathrm{m}^{3}\right)$ das camadas do sistema SC2: a) revestimento com argamassa $A 3$ com capilaridade $A_{\text {valor }}=2,5 \mathrm{~kg} / \mathrm{m}^{2} \sqrt{\mathrm{h}}$;

b) base de alvenaria B3 (porosidade baixa e densidade de massa aparente média). 


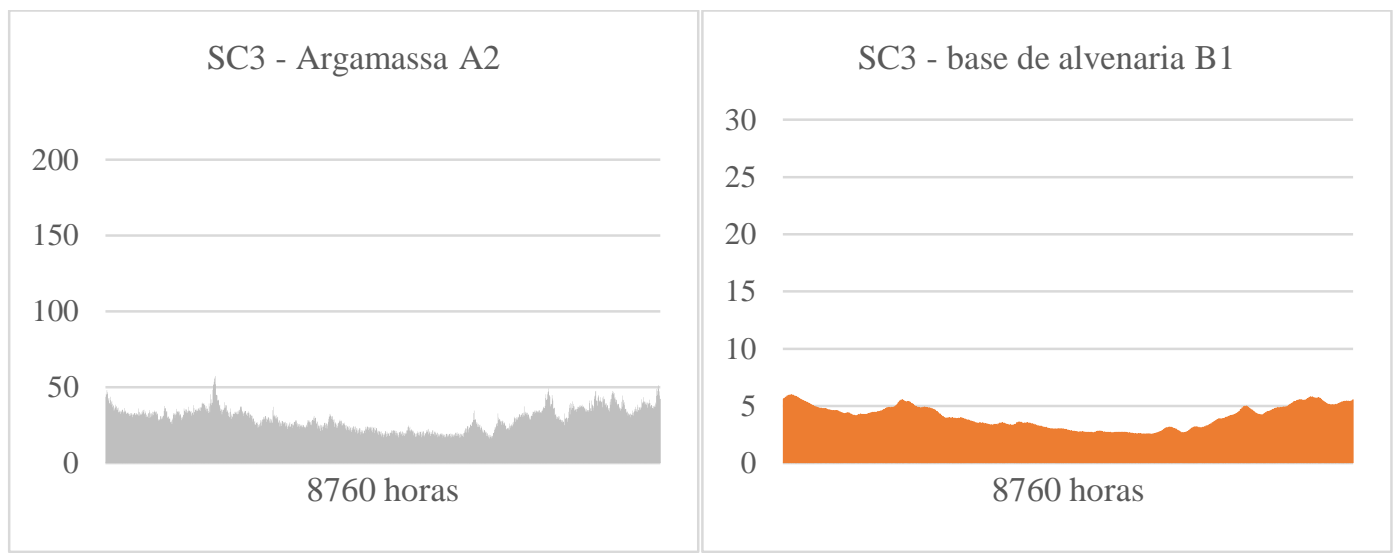

a)

b)

Figura 6.4 - Representação gráfica do teor de umidade $\left(\mathrm{em} \mathrm{kg} / \mathrm{m}^{3}\right)$ das camadas do sistema SC3:

a) revestimento com argamassa A2 com capilaridade $A_{\text {valor }}=0,1 \mathrm{~kg} / \mathrm{m}^{2} \sqrt{\mathrm{h}}$;

b) base de alvenaria $B 1$ (porosidade alta e densidade de massa aparente baixa).

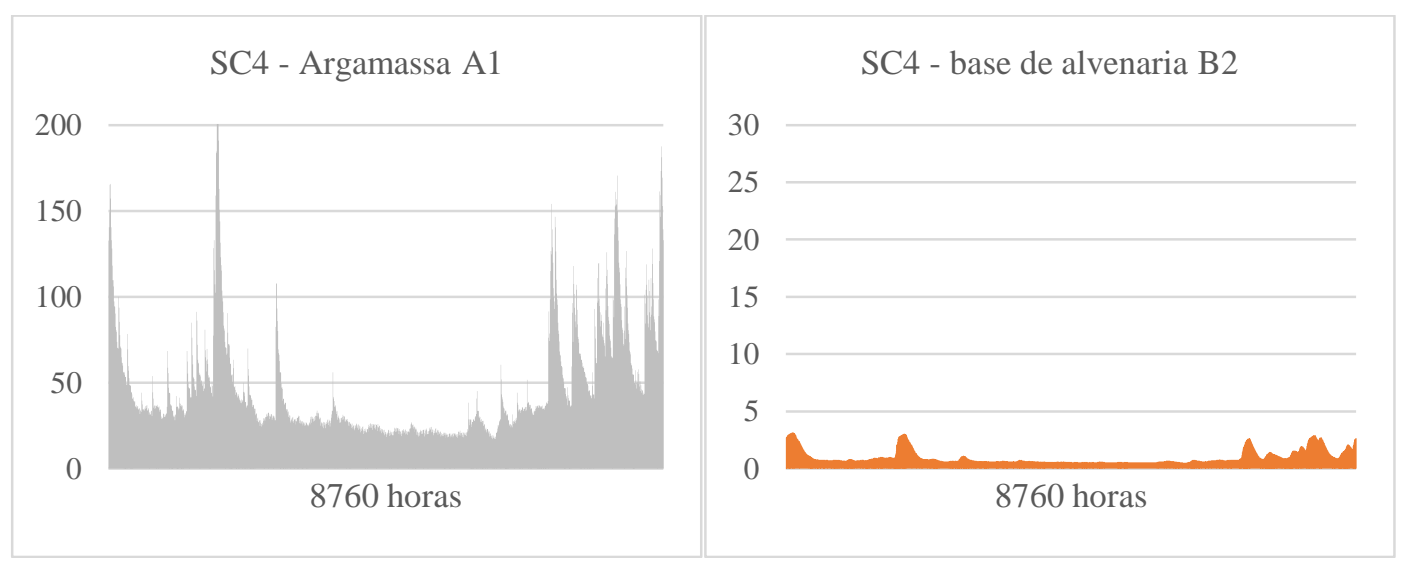

a)

b)

Figura 6.5 - Representação gráfica do teor de umidade $\left(\mathrm{em} \mathrm{kg} / \mathrm{m}^{3}\right)$ das camadas do sistema SC4:

a) revestimento com argamassa A1 com capilaridade $A_{\text {valor }}=1,0 \mathrm{~kg} / \mathrm{m}^{2} \sqrt{\mathrm{h}}$;

b) base de alvenaria $\mathrm{B} 2$ (porosidade baixa e densidade de massa aparente alta).

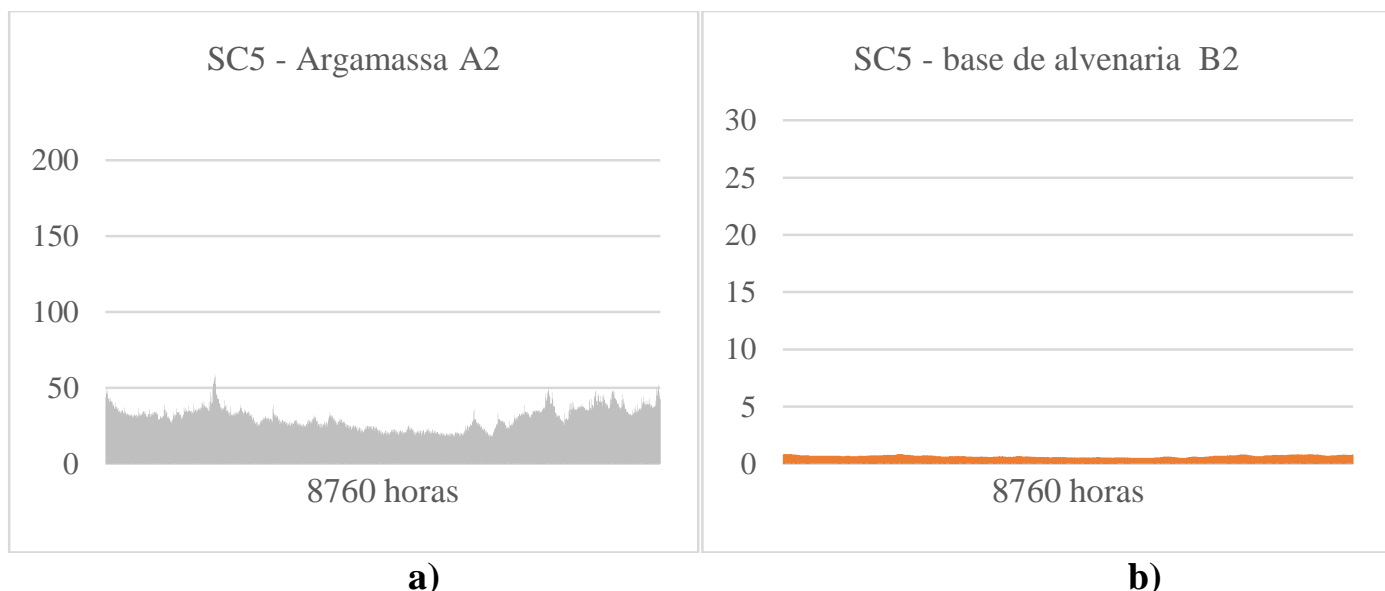

Figura 6.6 - Representação gráfica do teor de umidade $\left(\mathrm{em} \mathrm{kg} / \mathrm{m}^{3}\right)$ das camadas do sistema SC5:

a) revestimento com argamassa A2 com capilaridade $A_{\text {valor }}=0,1 \mathrm{~kg} / \mathrm{m}^{2} \sqrt{\mathrm{h}}$

b) base de alvenaria $\mathrm{B} 2$ (porosidade baixa e densidade de massa aparente alta). 


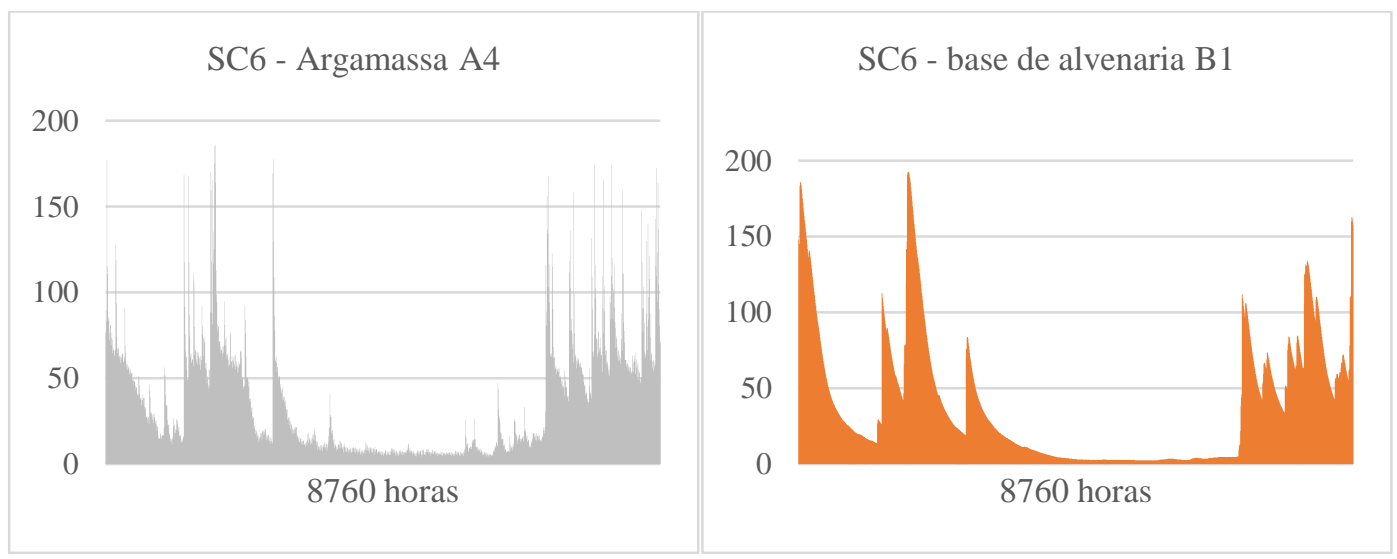

a)

b)

Figura 6.7 - Representação gráfica do teor de umidade $\left(\mathrm{em} \mathrm{kg} / \mathrm{m}^{3}\right)$ das camadas do sistema SC6:

a) revestimento com argamassa $A 4$ com capilaridade $A_{\text {valor }}=10,0 \mathrm{~kg} / \mathrm{m}^{2} \sqrt{\mathrm{h}}$;

b) base de alvenaria $\mathrm{B} 1$ (porosidade alta e densidade de massa aparente baixa).

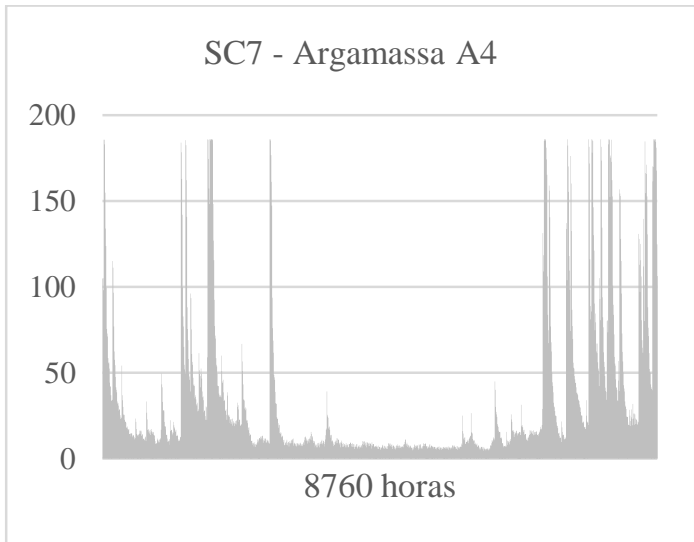

a)

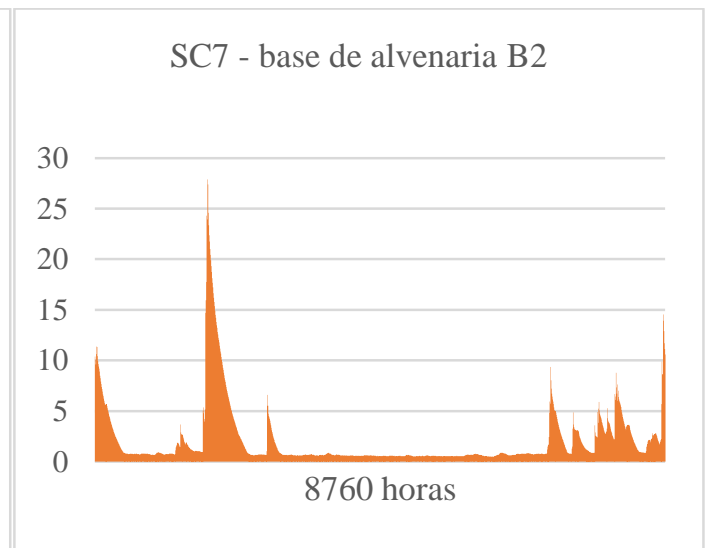

b)

Figura 6.8 - Representação gráfica do teor de umidade $\left(\mathrm{em} \mathrm{kg} / \mathrm{m}^{3}\right)$ das camadas do sistema SC7:

a) revestimento com argamassa A4 com capilaridade $A_{\text {valor }}=10,0 \mathrm{~kg} / \mathrm{m}^{2} \sqrt{\mathrm{h}}$;

b) base de alvenaria $\mathrm{B} 2$ (porosidade baixa e densidade de massa aparente alta).

Quando analisados os sete casos, observa-se que o SC6 é aquele com maior teor de umidade nos meses chuvosos, pois a alvenaria é a mais porosa $(\varepsilon=0,60)$ entre todas as estudadas. Seu revestimento, cuja porosidade é $\varepsilon=0,33 \mathrm{~m}^{3} / \mathrm{m}^{3}$, é aquele com a maior capilaridade $(A=10,0)$ entre os casos simulados. Além do mais, é o sistema que tem baixo fator de resistência à difusão do vapor de água. Então, no período chuvoso, o SC6 armazena o maior teor de umidade entre os sistemas estudados, mas mantém alta capacidade de secagem pela rapidez e facilidade de evaporação da água, mantendo-se com baixo teor de umidade nos meses mais secos.

O sistema SC7 possui o mesmo revestimento que o sistema SC6, ambos sujeitos à elevada absorção de água líquida devido à alta capilaridade $(A=10,0)$. No entanto, no período chuvoso, influenciado pela alvenaria $(\mathcal{E}=0,28)$ que é muito menos porosa, o sistema SC7 retém menos umidade do que o sistema SC6, inclusive na camada de revestimento. Nos meses 
secos, o sistema SC7 é aquele, entre todos, que apresentou os menores teores de umidade, devido à menor absorção de água líquida pela alvenaria nos meses chuvosos, e à baixa resistência à difusão do vapor de água, associado ao grau de porosidade do revestimento, que permitem boa evaporação da possível umidade retida no período chuvoso.

Portanto, SC6 e SC7, ambos os sistemas com o mesmo tipo de revestimento, possuem comportamentos diferenciados, como consequência das diferentes porosidades da alvenaria da base. Enquanto no período chuvoso, os revestimentos com alta capilaridade e a base mais porosa favorecem o armazenamento de umidade, no período seco a evaporação é facilitada, tanto na camada de revestimento como na base de alvenaria. Isso resulta em sistemas com as menores retenções de umidade no período seco entre todos os sistemas estudados.

Os sistemas SC3 e SC5 possuem o mesmo revestimento pouco poroso $(\varepsilon=0,24)$, com capilaridade muito baixa $(\mathrm{A}=0,1)$ e com alto fator de resistência à difusão do vapor de água $(\mu=25)$. Mesmo com a alvenaria de diferentes porosidades $(0,60$ e 0,28 , respectivamente), o revestimento garante baixa absorção e adsorção de umidade ao longo de todo o ano. O SC3 armazena um pouco mais de umidade que o SC5, mas ambos mostram um comportamento bastante similar e uniforme, entre eles e ao longo dos meses do ano.

Nos meses mais secos, os sistemas SC6 e SC7 conseguem armazenam menores teores de umidade que os sistemas SC3 e SC5. Enquanto a evaporação da umidade retida nos sistemas SC6 e SC7 é favorecida pelo revestimento com alta capilaridade e porosidade e menor fator de resistência à difusão de vapor, os revestimentos com baixíssima capilaridade e menor porosidade dos sistemas SC3 e SC5 protegem bem a base contra a penetração de água líquida e, praticamente, não ocorre alteração do teor de umidade entre os meses chuvosos e os meses secos. A boa resistência à difusão do vapor de água também colabora para que os sistemas SC3 e SC5 mantenham-se sem grandes alterações do teor de umidade, ao longo do ano.

Os sistemas SC1 e SC4 possuem o mesmo revestimento pouco poroso $(\varepsilon=0,24)$ e com capilaridade baixa $(A=1,0)$, sendo as alvenarias de diferentes porosidades $(0,60$ e 0,28 , respectivamente). Nestes casos, observa-se que os sistemas absorvem umidade conforme varia a intensidade de chuva dirigida e nas fachadas onde a incidência da chuva dirigida é predominante. Analisando SC1 e SC4, a umidade armazenada é muito maior na alvenaria que possui maior porosidade $(\varepsilon=0,60)$; não há grandes variações entre o teor de umidade das camadas de revestimentos. Nos meses mais secos e nas fachadas com baixa incidência de chuva dirigida, os dois sistemas comportam-se similarmente. Ou seja, o revestimento com $\mathrm{A}=1,0$ de capilaridade não impede que, nos meses mais chuvosos, a umidade penetre na base 
de alvenaria do sistema SC1 que é mais porosa, mas não dificulta a secagem, nos meses mais secos.

Interessante observar que o sistema SC7 $(\mathrm{A}=10,0)$ possui um revestimento com capilaridade muito maior que o sistema SC4 $(\mathrm{A}=1,0)$ e ambos com a mesma alvenaria de baixa porosidade $(0,28)$. O revestimento com maior capilaridade permite uma maior absorção de água pela base, no entanto permite uma maior e mais rápida secagem de todo o sistema. No sistema SC4 o maior teor de umidade fica concentrado no revestimento, enquanto a base fica mais protegida das variações de umidade. Isso é possível identificar observando que a média do teor de umidade do sistema SC7 ao longo dos meses mantém-se uniforme, mesmo verificando que os valores máximos mensais do teor de umidade nos meses chuvosos são maiores, na sua maioria, que os do sistema SC4.

Os sistemas SC4, SC5 e SC7 possuem a mesma base de alvenaria com a maior densidade de massa e a mais baixa capacidade de armazenamento de umidade entre os sistemas analisados. No entanto, devido à maior capilaridade da argamassa, absorve água nos picos de chuva dirigida mas apresenta boa capacidade de secagem. Quanto mais baixa é a capilaridade da camada de revestimento, maior é a proteção da base de alvenaria.

O sistema SC2 possui uma base de alvenaria com baixa porosidade $(\varepsilon=0,19)$ e baixa capacidade de adsorção e dessorção, ou seja, é uma alvenaria pouco higroscópica. A alvenaria apresenta um processo mais lento de umidificação e secagem. Por outro lado, o sistema SC2 possui o revestimento com a maior porosidade $(\mathcal{E}=0,46)$ entre os sistemas analisados e, em condições de saturação, ocorre uma perda da capacidade resistente à difusão do vapor de água. Por ser mais poroso e com capilaridade $A=2,5$, o revestimento facilita a penetração de água de chuva e é rapidamente saturado. Portanto, nos meses mais chuvosos, o sistema SC2 mantém um comportamento semelhante ao sistema SC1 e SC4, mas nos meses mais secos retém os maiores picos de umidade entre todos os sistemas analisados, devido à sua baixa capacidade de secagem.

\subsection{TEOR DE UMIDADE: ANÁLISE DAS INTERAÇÕES ENTRE SISTEMAS CONSTRUTIVOS, ORIENTAÇÕES DE FACHADA E PERÍODOS DO ANO}

$\mathrm{Na}$ seção anterior foi analisado o comportamento do teor de umidade, com base nas propriedades das camadas do sistema de fachada, ao longo dos meses do ano, caracterizando 
assim, cada uma das sete variações do sistema construtivo estudado, como resposta à influência dos agentes climáticos de degradação.

Nesta seção, são apresentadas as análises para verificar a influência dos agentes climáticos de degradação no comportamento higrotérmico das fachadas, considerando o efeito da sazonalidade do clima no envelhecimento natural da edificação. Por isso, são estudados dois ciclos de tempo: período seco e período chuvoso. Desta forma, busca-se caracterizar a ação e a interação entre os agentes climáticos de degradação e o comportamento higrotérmico das fachadas, na cidade de Brasília. Neste caso, considerando os efeitos e danos a longo prazo, as médias dos períodos são os indicadores mais representativos dos fenômenos em estudo.

Este estudo foi baseado em uma análise estatística sobre a interação entre as variáveis, por meio da técnica estatística Análise de Variância de três vias (ANOVA - three way), após verificação da distribuição normal da amostra.

Por meio do pós-teste de Tukey da ANOVA de três vias, foram efetuadas as múltiplas comparações entre as sete variações do sistema construtivo, as oito orientações de fachadas e os dois períodos do ano, que estabeleceram 112 diferentes comparações, indicando quais delas apresentaram diferenças estatísticas significativas $(\mathrm{p}<0,05)$.

Na Tabela 6.1 são apresentados os resultados das interações entre as sete variações do sistema construtivo selecionado (SC1, SC2, SC3, SC4, SC5, SC6 e SC7) e as oito orientações de fachadas (Norte, Nordeste, Leste, Sul, Sudoeste, Oeste e Noroeste), nos períodos seco e chuvoso do ano. Os valores apresentados são os resultados das médias \pm desvios padrão das médias. As primeiras letras maiúsculas na coluna indicam se existem diferenças estatisticamente significativas no teor de umidade entre os períodos. As letras maiúsculas em negrito na linha indicam se existem diferenças no teor de umidade entre os sistemas construtivos. As letras minúsculas na coluna indicam se as orientações de fachada influenciam o teor de umidade, para cada sistema construtivo e período do ano.

Tabela 6.1 - Teor de umidade $\left(\mathrm{kg} / \mathrm{m}^{2}\right)$ : resultados da ANOVA de três vias para as interações entre orientações de fachada, períodos do ano e sistemas construtivos.

\begin{tabular}{|c|c|c|c|c|c|c|c|c|}
\hline Fachada & Estação & \multicolumn{7}{|c|}{ Sistema construtivo (SC) } \\
\hline \multirow{6}{*}{ Norte } & \multirow{3}{*}{ Seco } & B & B & A & B & A & B & B \\
\hline & & $\mathrm{a}$ & $\mathrm{a}$ & $\mathrm{a}$ & a & $\mathrm{a}$ & $\mathrm{c}$ & $\mathrm{a}$ \\
\hline & & BC & $\mathbf{A}$ & CD & D & D & $\mathbf{A B}$ & $\mathbf{E}$ \\
\hline & \multirow{3}{*}{ Chuvoso } & A & A & A & A & A & A & A \\
\hline & & $\mathrm{a}$ & $\mathrm{a}$ & $\mathrm{a}$ & $\mathrm{a}$ & $\mathrm{a}$ & $\mathrm{a}$ & $\mathrm{a}$ \\
\hline & & B & $\mathbf{C}$ & $\mathbf{E}$ & D & $\mathbf{E}$ & $\mathbf{A}$ & $\mathbf{E}$ \\
\hline
\end{tabular}


Continuação

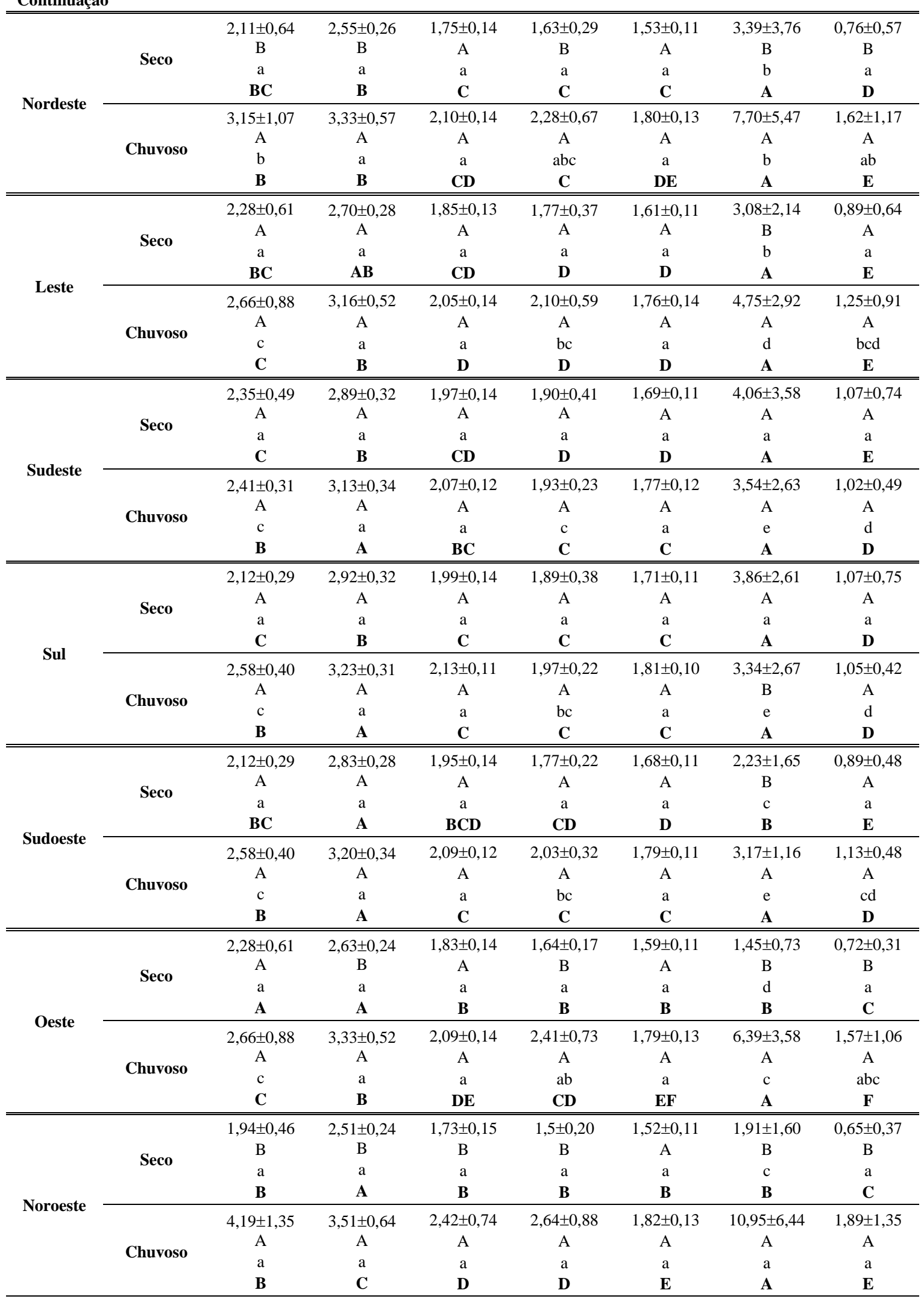

Os resultados estão apresentados em média \pm desvio padrão da média. Letras maiúsculas na coluna indicam diferença entre os períodos. Letras minúsculas na coluna indicam diferença entre as orientações de fachada. Letras maiúsculas em negrito na linha indicam diferença entre os sistemas construtivos. As múltiplas comparações foram realizadas por meio do pós-teste de Tukey $(\mathrm{p}<0,05)$. 
O Quadro 6.4 mostra as diferenças entre as médias do teor de umidade nos períodos seco e chuvoso para cada variação do sistema construtivo estudado, em cada orientação de fachada.

Quadro 6.4 - Comparação entre as médias do teor de umidade nos períodos seco e chuvoso.
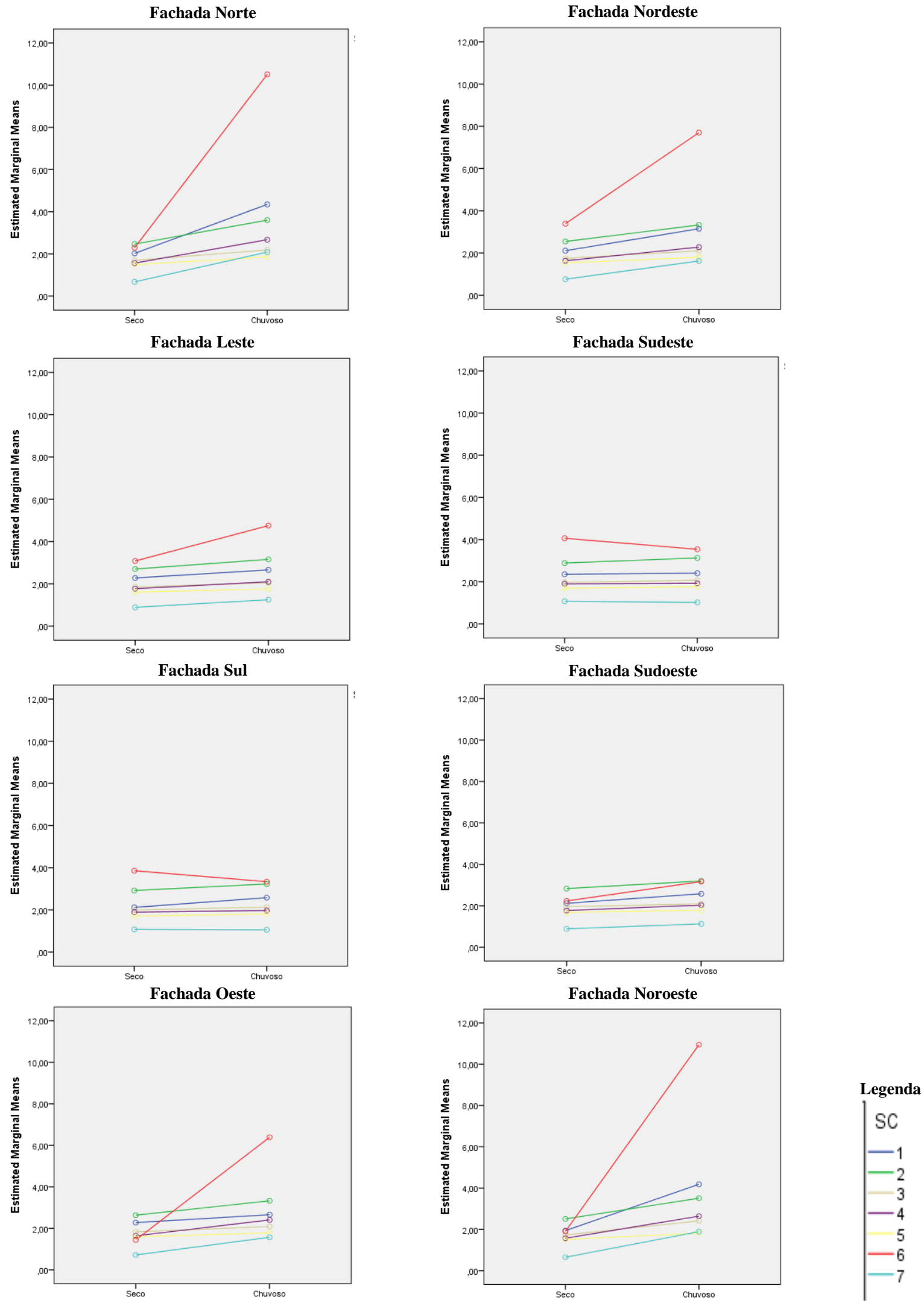
Comparando as diferenças estatisticamente significativas entre as médias do teor de umidade, nos períodos seco e chuvoso, observou-se que:

a) Na fachada Norte e Nordeste, somente os sistemas SC3 e SC5 não mostraram diferenças significativas entre os períodos; nos demais sistemas as médias do teor de umidade do período chuvoso foram maiores que no período seco.

b) Na fachada Leste, não existiram diferenças significativas entre as médias dos períodos, com exceção do sistema SC6 que apresentou maior teor de umidade no período chuvoso que no período seco.

c) Na fachada Sudeste, nenhum dos sistemas mostrou diferença significativa entre as médias do teor de umidade dos períodos.

d) Na fachada Sul, com exceção do sistema SC6 que apresentou maior teor de umidade no período seco, nenhum dos demais sistemas mostrou diferença significativa entre as médias do teor de umidade dos períodos.

e) $\mathrm{Na}$ fachada Oeste, os sistemas SC1, SC3 e SC5 não apresentaram diferenças significativas entre as médias do teor de umidade dos períodos, mas os sistemas SC2, SC4, SC6 e SC7 mostraram que no período chuvoso as médias foram maiores que no período seco.

f) Na fachada Noroeste, somente o sistema SC5 não mostrou diferença significativa entre os períodos; em todos os outros sistemas as médias do teor de umidade do período chuvoso foram maiores que no período seco.

Como resultados gráficos dos dados da Tabela 6.1, a Figura 6.9 e a Figura 6.10 mostram, respectivamente, as diferenças entre os teores de umidade de cada caso estudado, conforme a orientação de fachada, nos períodos chuvoso e seco.

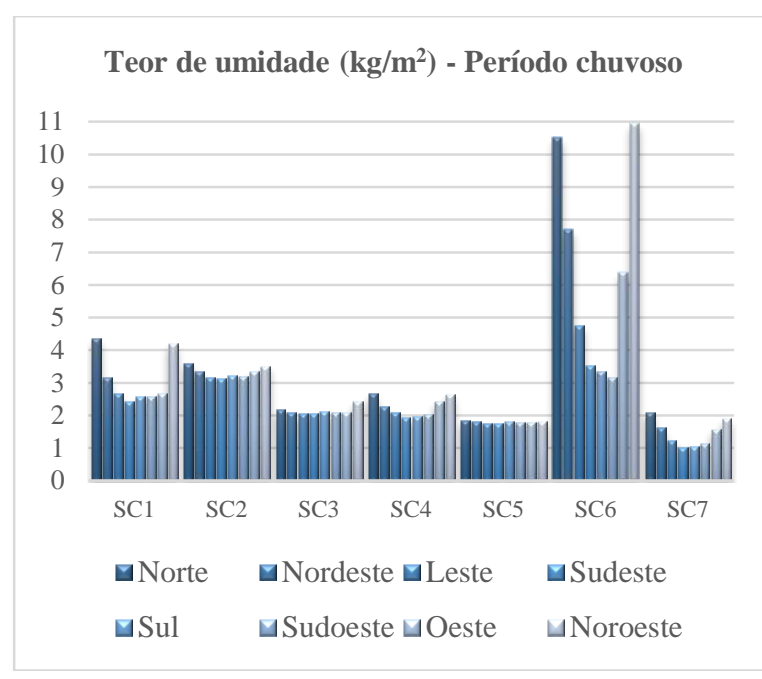

Figura 6.9 - Comparação entre as médias do teor de umidade nas fachadas - período chuvoso.

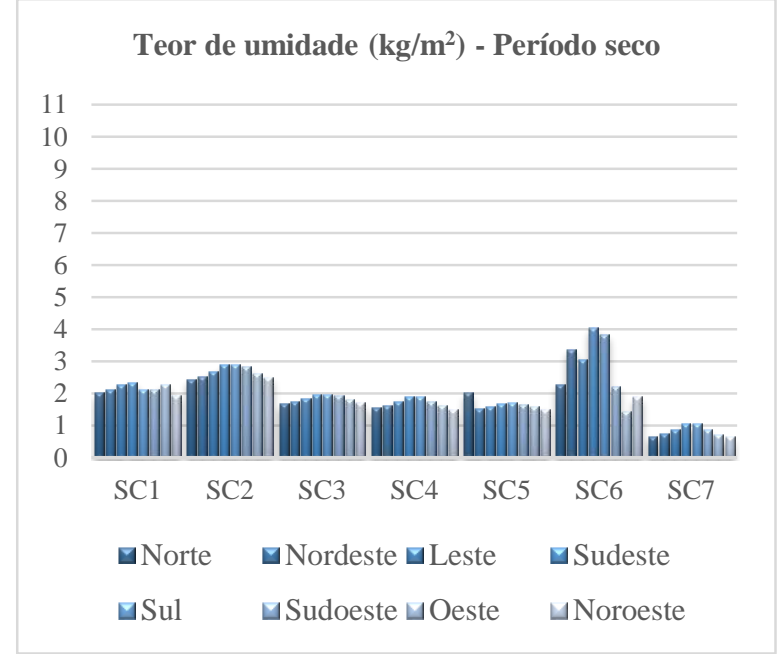

Figura 6.10 - Comparação entre as médias do teor de umidade nas fachadas - período seco. 
No período seco (Figura 6.9), comparando as médias do teor de umidade do sistema construtivo em cada fachada, observou-se que os casos estudados não apresentaram diferenças estatisticamente significativas no teor de umidade entre as fachadas, com exceção do sistema SC6 que armazenou maior teor de umidade nas fachadas Sul e Sudeste, seguidas pelas fachadas Leste e Nordeste. As fachadas Norte, Sudoeste e Noroeste não apresentaram diferenças significativas nos teores de umidade retidos, que foram menores que nas fachadas anteriormente citadas. O menor teor de umidade para o sistema SC6 neste período foi encontrado na fachada Oeste.

No período chuvoso (Figura 6.10), comparando as diferenças estatisticamente significativas entre as médias do teor de umidade dos casos estudados, em cada fachada, observou-se que:

a) Os sistemas SC2, SC3 e SC5 não apresentaram diferenças entre as fachadas, no teor de umidade armazenado.

b) Os sistemas SC1, SC4, SC6 e SC7 apresentaram os maiores teores de umidade nas fachadas Norte e Noroeste. Nestas fachadas ocorreram as maiores incidências de chuva dirigida.

c) Os teores de umidade armazenados pelo sistema SC1 nas fachadas Norte e Noroeste são similares. Com menor teor de umidade, está a fachada Nordeste, seguida pelas fachadas Leste, Sudeste, Sul, Sudoeste e Oeste, que não mostraram diferenças entre si.

d) No sistema SC4, os maiores teores de umidade foram armazenados pelas fachadas Norte e Noroeste, seguidas pelas fachadas Nordeste e Oeste. As outras fachadas, com menor teor de umidade, não mostraram diferenças significativas entre si.

e) O sistema SC6 apresentou diferentes teores de umidade nas diversas orientações de fachada. A resposta do sistema SC6 à incidência da chuva dirigida foi mais intensa, principalmente nas fachadas Norte e Noroeste, decrescendo nas fachadas Nordeste, Oeste e Leste. Com menor teor de umidade estão as fachadas Sudeste, Sul e Sudoeste, que não mostraram diferenças significativas entre si.

f) As fachadas Norte e Noroeste são aquelas que apresentaram os maiores teores de umidade para o sistema SC7, seguidas das fachadas Nordeste e Oeste. Para as outras fachadas, este sistema não apresentou muita diferença entre os teores de umidade.

Como resultados gráficos dos dados da tabela 6.1, a Figura 6.11 e a Figura 6.12 mostram, respectivamente, a comparação do teor de umidade entre os sistemas e a resposta de cada orientação de fachada quanto ao teor de umidade de cada caso estudado, nos períodos seco e chuvoso. 


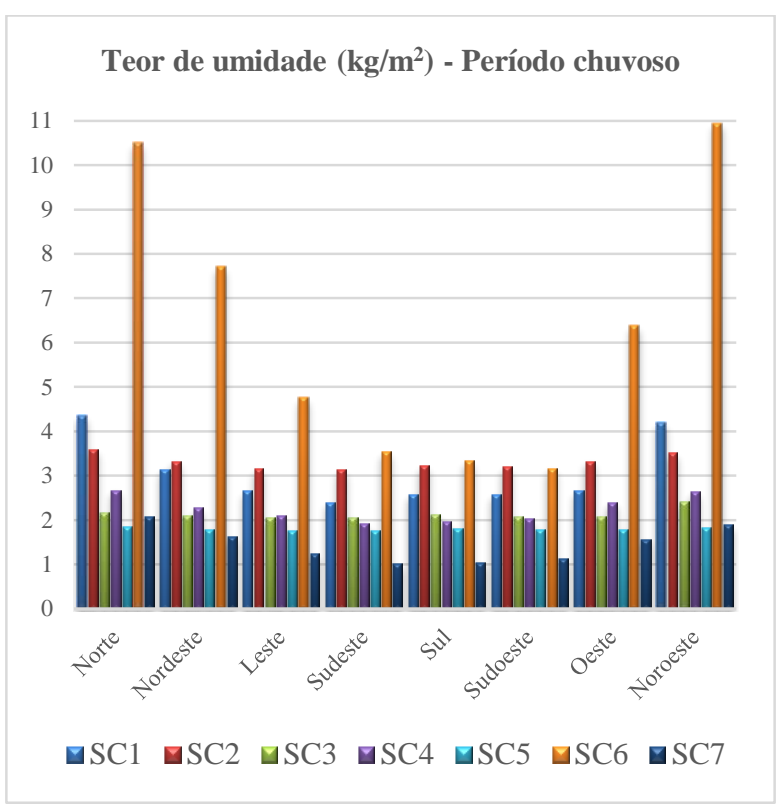

Figura 6.11 - Comparação entre as médias do teor de umidade dos sistemas construtivos - período chuvoso.

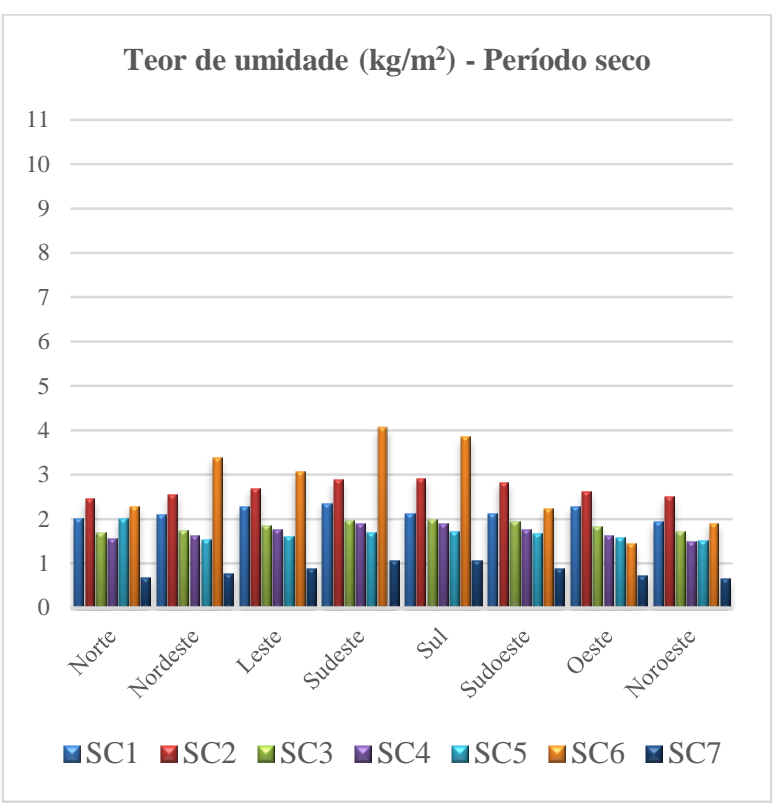

Figura 6.12 - Comparação entre as médias do teor de umidade dos sistemas construtivos - período seco.

No período chuvoso (Figura 6.11), comparando o teor de umidade entre os casos estudados, para cada fachada, observou-se que:

a) O sistema SC6 apresentou o maior teor de umidade entre todos os sistemas analisados, em todas as orientações de fachada, sendo que nas fachadas Sudeste, Sul e Sudoeste, o teor de umidade do sistema SC2 não apresentou diferença significativa do sistema SC6.

b) Abaixo do teor de umidade do sistema SC6, encontra-se o sistema SC1 nas fachadas Norte, Nordeste, Sudeste, Sul, Sudoeste e Noroeste, e o sistema SC2 nas fachadas Nordeste, Leste e Oeste.

c) O sistema SC7 é aquele que apresentou o menor teor de umidade entre todos os sistemas analisados, em todas as orientações de fachada.

d) Os sistemas SC3, SC4 e SC5 não apresentaram diferença significativa do teor de umidade nas fachadas Sudeste, Sul e Sudoeste.

No período seco (Figura 6.12), comparando o teor de umidade entre os sistemas construtivos, para cada fachada, observou-se que:

a) Os sistemas SC2 e SC6 são aqueles com maior teor de umidade. Nas fachadas Norte, Sudoeste, Oeste e Noroeste o sistema SC2 apresentou maior umidade que o sistema SC6. No entanto, nas fachadas Nordeste, Leste, Sudeste e Sul foi o sistema SC6 que predominou sobre o sistema SC2. 
b) O sistema SC7 é aquele que armazenou o menor teor de umidade entre todos os sistemas analisados, em todas as orientações de fachada.

c) Na fachada Oeste, os sistemas SC1 e SC2 são aqueles que armazenaram os maiores teores de umidade, seguidos pelos sistemas SC3, SC4, SC5 e SC6, que não mostraram diferenças significativas nos teores armazenados.

d) $\mathrm{Na}$ fachada Noroeste, o sistema SC2 armazenou o maior teor de umidade, seguido pelos sistemas SC1, SC3, SC4, SC5 e SC6 que não mostraram diferenças significativas nos teores de umidade retidos.

e) Nas fachadas Nordeste e Sul, é o sistema SC6 que armazenou a maior umidade, seguido pelo sistema SC2. Os sistemas SC1, SC3, SC4 e SC5 não apresentaram diferenças significativas entre eles, no teor de umidade armazenado.

f) Nas fachadas Leste, Sudeste e Sudoeste, o sistema SC6 reteve o maior teor de umidade, seguido pelo sistema SC2. Os sistemas SC1, SC3, SC4 e SC5 não apresentaram diferenças significativas entre eles, na umidade armazenada.

\subsection{ANÁLISE DO COMPORTAMENTO DA TEMPERATURA SUPERFICIAL EXTERNA INFLUENCIADO PELAS PROPRIEDADES DO SISTEMA DE FACHADA}

Com os resultados das simulações higrotérmicas computacionais, com base no arquivo climático TMY da base EPW/ANTAC que alimentou o programa WUFI nas simulações higrotérmicas, foram gerados relatórios referentes aos dados relacionados à temperatura superficial exterior.

O comportamento da temperatura superficial exterior ao longo dos meses do ano depende da orientação solar e está fortemente relacionada com a irradiância solar incidente na superfície da fachada.

A Figura 6.13 mostra o valor acumulado mensal da irradiação solar que varia, principalmente, conforme a geometria da insolação. Mostra, também, um perfil dos valores da máxima média diária da temperatura do ar exterior, em cada mês do ano.

Os meses de fevereiro, setembro e outubro são aqueles que apresentam os maiores valores de temperatura do ar exterior. 


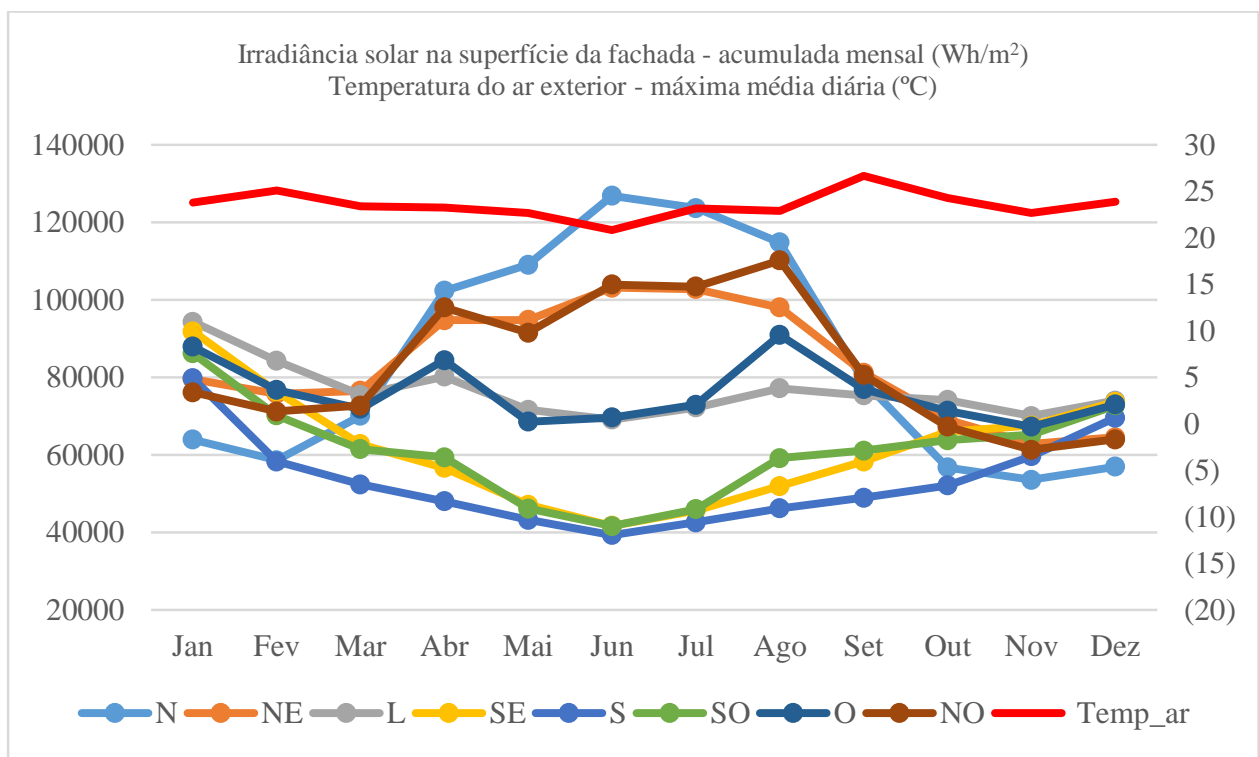

Figura 6.13 - Irradiância solar na superfície da fachada e temperatura do ar exterior, com base no TMY da base EPW/ANTAC para a cidade de Brasília.

Para obter os gráficos das temperaturas superficiais externas, foi selecionada a máxima temperatura horária que ocorreu ao longo de cada mês na superfície externa da fachada, para cada caso estudado, conforme apresentado nos gráficos do Quadro 6.5.

O comportamento da temperatura superficial exterior depende da irradiância solar total, mas depende, também, da variação da temperatura do ar exterior, dos movimentos convectivos do ar e das características higrotérmicas do sistema construtivo, entre outros.

Analisando o comportamento dos valores da temperatura superficial externa, apresentados no Quadro 6.5, observa-se que variaram ao longo do ano em torno de $32^{\circ} \mathrm{C}$ a $52^{\circ} \mathrm{C}$ para o caso $\mathrm{SC} 1$; de $31^{\circ} \mathrm{C}$ a $50^{\circ} \mathrm{C}$ para o caso $\mathrm{SC} 2$; de $32^{\circ} \mathrm{C}$ a $53^{\circ} \mathrm{C}$ para o caso $\mathrm{SC} 3$; de $30^{\circ} \mathrm{C}$ a $47^{\circ} \mathrm{C}$ para o caso SC4; de $30^{\circ} \mathrm{C}$ a $48^{\circ} \mathrm{C}$ para o caso SC5; de $32^{\circ} \mathrm{C}$ a $52^{\circ} \mathrm{C}$ para o caso SC6; e de $31^{\circ} \mathrm{C}$ a $48^{\circ} \mathrm{C}$ para o caso SC7.

Observa-se que as menores temperaturas atingidas pelos sistemas em análise são em torno de $30^{\circ} \mathrm{C}$ a $32^{\circ} \mathrm{C}$ e as maiores de $50^{\circ} \mathrm{C}$ a $53^{\circ} \mathrm{C}$.

Os sistemas SC1, SC3 e SC6 são aqueles que atingiram as maiores temperaturas superficiais, em todas as orientações de fachada. Esses sistemas têm em comum o mesmo tipo de alvenaria, sendo que os revestimentos possuem diferentes capilaridades (respectivamente, 1,0; 0,1 e 10,0). Além do mesmo tipo de alvenaria, os três sistemas apresentam baixos valores para transmitância térmica $\left(1,1 \mathrm{~W} / \mathrm{m}^{2} \cdot \mathrm{K}\right)$. Nestes casos, a densidade e a condutividade térmica da alvenaria é muito baixa $(\lambda=0,158)$ e a sua porosidade é muito alta $(\varepsilon=0,60)$.

Entre os três sistemas, SC1, SC3 e SC6, a maior temperatura superficial foi atingida pelo sistema SC3 que é aquele com a camada de revestimento de menor capilaridade. 
Quadro 6.5 - Comportamento da máxima temperatura superficial exterior mensal $\left({ }^{\circ} \mathrm{C}\right)$.
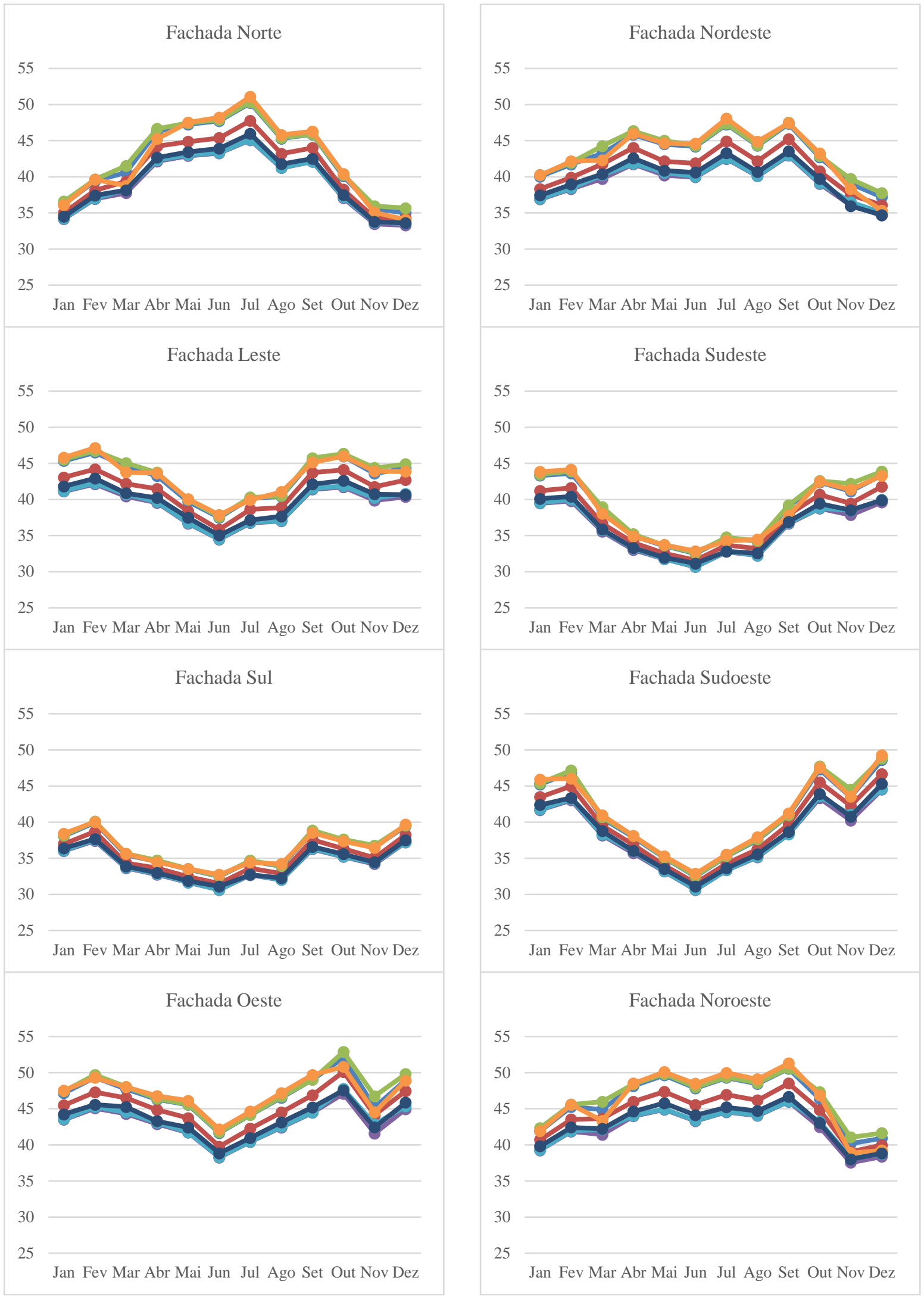

Legenda:

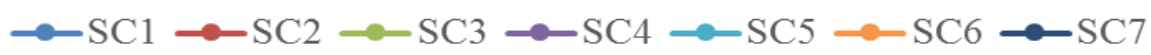


Os sistemas SC4, SC5 e SC7 são aqueles que apresentaram os menores valores de temperatura superficial externa. Estes sistemas possuem o mesmo tipo de alvenaria, com condutividade térmica em torno de $\lambda=0,955$ e porosidade $\varepsilon=0,28$, mas diferentes revestimentos cujas capilaridades são, respectivamente, 1,0; 0,1 e 10,0. Entre todos, são aqueles que possuem os maiores valores para transmitância térmica (em torno de 2,7 $\left.\mathrm{W} / \mathrm{m}^{2} . \mathrm{K}\right)$.

O sistema SC2 apresenta-se em uma faixa intermediária entre os casos estudados, com transmitância térmica de $1,68 \mathrm{~W} / \mathrm{m}^{2} . \mathrm{K}$ e alvenaria com condutividade térmica $\lambda=0,4$.

A fachada que apresentou os valores de pico para a máxima temperatura superficial exterior é a fachada Oeste $\left(52,87^{\circ} \mathrm{C}\right)$, seguida pelas fachadas Noroeste $\left(51,28^{\circ} \mathrm{C}\right)$ e Norte $\left(51,09^{\circ} \mathrm{C}\right)$.

Todos os sistemas apresentaram os maiores valores de temperatura superficial máxima na fachada Oeste, com exceção do SC6 que apresentou as maiores temperaturas superficiais máximas nas fachadas Noroeste e Norte.

\subsection{ANÁLISE DO COMPORTAMENTO DA AMPLITUDE TÉRMICA NA SUPERFÍCIE DA FACHADA INFLUENCIADO PELAS PROPRIEDADES DO SISTEMA DE FACHADA}

A amplitude térmica na superfície da fachada foi obtida pela diferença entre as temperaturas superficiais máxima e mínima que ocorrem ao longo das 24 horas do dia.

Portanto, a amplitude térmica da superfície da fachada corresponde a um Delta-T $(\Delta \mathrm{T})$ que ocorre na superfície da camada mais exterior do sistema de fachada, resultado das movimentações cíclicas diárias da radiação solar e da temperatura do ar exterior.

O Quadro 6.6 mostra os gráficos das máximas amplitudes térmicas na superfície exterior da fachada para cada orientação, em cada mês do ano.

Observa-se que, em todos os casos e orientações estudados, as amplitudes térmicas variaram entre valores maiores que $12,9^{\circ} \mathrm{C}$ e menores que $35,0^{\circ} \mathrm{C}$.

Analisando o comportamento dos valores máximos mensais da amplitude térmica na superfície da fachada apresentados no Quadro 6.6, observa-se que os valores variaram ao longo do ano em torno de $15^{\circ} \mathrm{C}$ a $34^{\circ} \mathrm{C}$ para o caso $\mathrm{SC} 1$; de $14^{\circ} \mathrm{C}$ a $31^{\circ} \mathrm{C}$ para o caso $\mathrm{SC} 2$; de $16^{\circ} \mathrm{C}$ a $35^{\circ} \mathrm{C}$ para o caso $\mathrm{SC} 3$; de $13^{\circ} \mathrm{C}$ a $28^{\circ} \mathrm{C}$ para o caso $\mathrm{SC} 4$; de $13^{\circ} \mathrm{C}$ a $28^{\circ} \mathrm{C}$ para o caso SC5; de $14^{\circ} \mathrm{C}$ a $34^{\circ} \mathrm{C}$ para o caso SC6; e de $13^{\circ} \mathrm{C}$ a $29^{\circ} \mathrm{C}$ para o caso SC7. 
Quadro 6.6 - Comportamento da máxima amplitude térmica mensal na superfície exterior $\left(\Delta \mathrm{T}\right.$ em $\left.{ }^{\circ} \mathrm{C}\right)$.

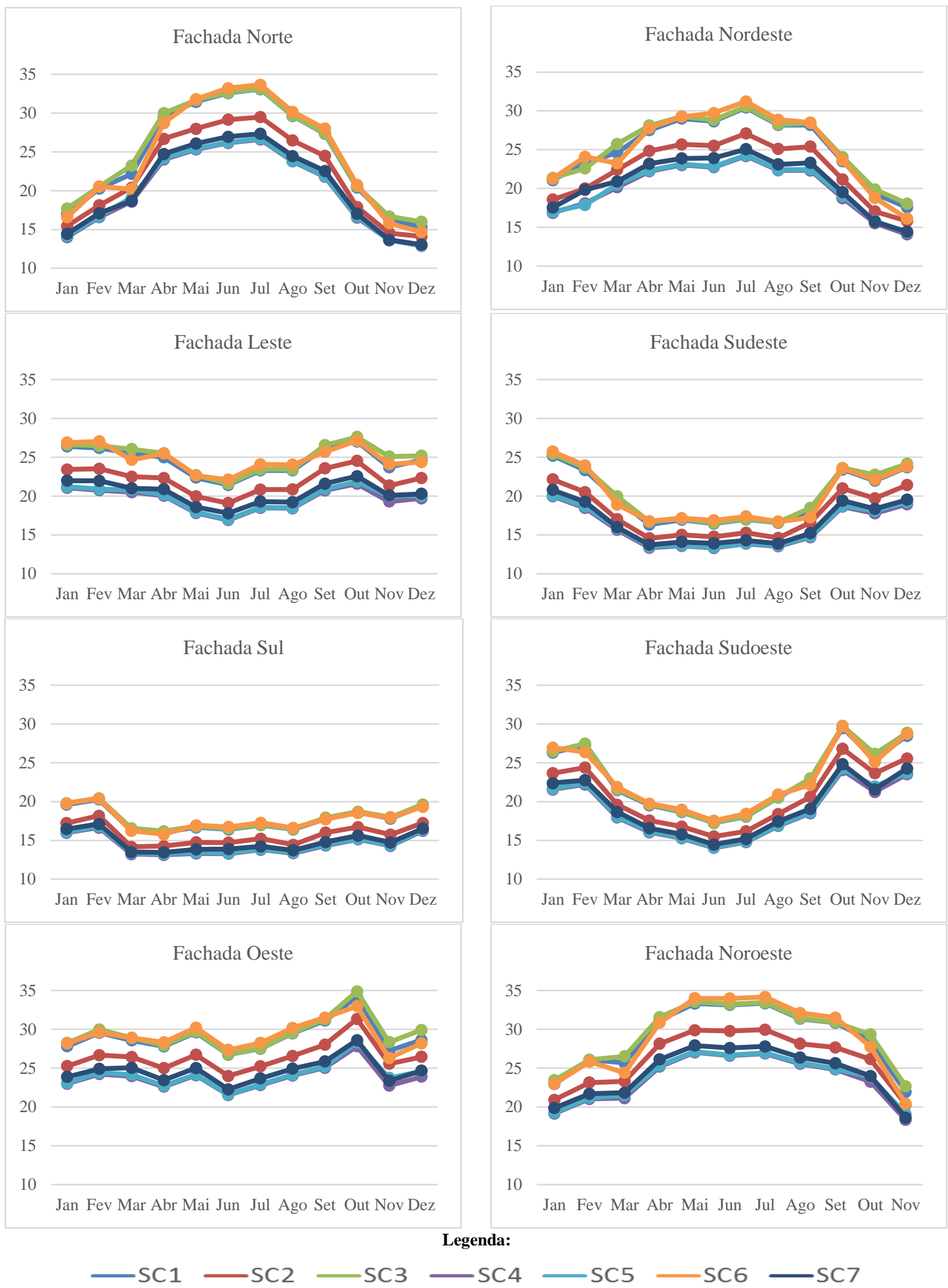


A fachada que apresentou os valores de pico para as amplitudes térmicas ao longo do ano é a fachada Oeste $\left(34,88^{\circ} \mathrm{C}\right)$, seguida pelas fachadas Noroeste $\left(34,16^{\circ} \mathrm{C}\right)$ e Norte $\left(33,65^{\circ} \mathrm{C}\right)$. Acompanhando o mesmo comportamento das temperaturas superficiais externas, as amplitudes térmicas na superfície das fachadas também apresentaram os valores máximos na fachada Oeste, para todos os sistemas, com exceção do SC6 que apresentou as máximas nas fachadas Noroeste e Norte.

Os sistemas que apresentaram as maiores amplitudes térmicas ao longo do ano são os SC1, SC3 e SC6, pelos mesmos motivos já justificados para as temperaturas superficiais externas. Isto é, apesar de possuírem revestimentos com diferentes capilaridades, os três sistemas possuem o mesmo tipo de alvenaria, com os mais baixos valores para transmitância térmica (cerca de $1,1 \mathrm{~W} / \mathrm{m}^{2} . \mathrm{K}$ ).

Compreende-se que o comportamento, tanto da temperatura superficial como da amplitude térmica na superfície da fachada, é decorrente da geometria da insolação, influenciado pelo teor de umidade nos meses mais secos ou mais chuvosos, dependendo das características higrotérmicas do sistema.

O envelhecimento natural é consequência da atuação dos mecanismos de degradação ao longo do tempo, decorrente não só da intensidade, mas também da frequência de ocorrência da ação dos agentes de degradação.

Por isso, foram analisados os percentuais das frequências de ocorrência das amplitudes térmicas classificadas em faixas de variação de temperatura $\left(\mathrm{em}{ }^{\circ} \mathrm{C}\right)$, a saber: $0 \leq \Delta \mathrm{T} \leq 10$, $10<\Delta \mathrm{T} \leq 15,15<\Delta \mathrm{T} \leq 20,20<\Delta \mathrm{T} \leq 25,25<\Delta \mathrm{T} \leq 30$ e $30<\Delta \mathrm{T} \leq 35$.

O Quadro 6.7 representa, para cada caso estudado, os percentuais da amplitude térmica na superfície da fachada, por faixa de frequência de ocorrência, para cada orientação. No Apêndice C, são apresentados os histogramas com os respectivos valores que permitiram gerar os gráficos do Quadro 6.7.

As fachadas Oeste $(53 \%)$ e Noroeste (51\%) são aquelas que apresentaram maior probabilidade de ocorrência da amplitude térmica na superfície para valores de $\Delta \mathrm{T}>20^{\circ} \mathrm{C}$, seguidas pelas fachadas Nordeste (42\%), Norte (40\%), Leste (29\%), Sudoeste (15\%), Sudeste $(7 \%)$ e $\operatorname{Sul}(3 \%)$

Em todas as fachadas, os sistemas SC1, CS3 e SC6 são aqueles que apresentaram maior frequência de ocorrência da amplitude térmica na fachada para $\Delta \mathrm{T}>20^{\circ} \mathrm{C}$, com exceção da fachada Sul. Nesta fachada, somente o sistema SC2 apresentou frequência de ocorrência para $\Delta \mathrm{T}>20^{\circ} \mathrm{C}$. 
Quadro 6.7 - Frequência de ocorrência da máxima amplitude térmica mensal na superfície exterior.

Fachada Norte

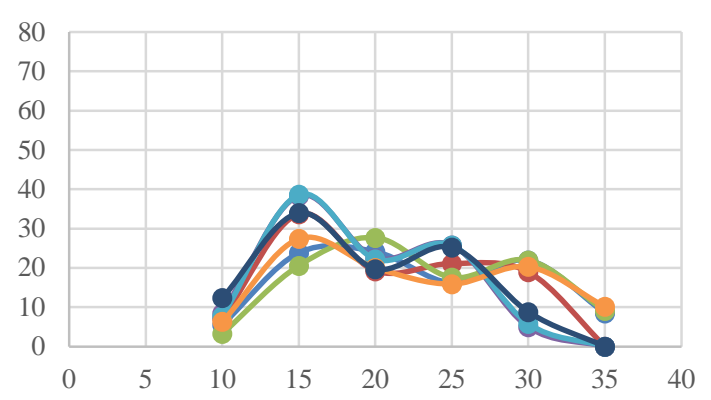

Fachada Leste

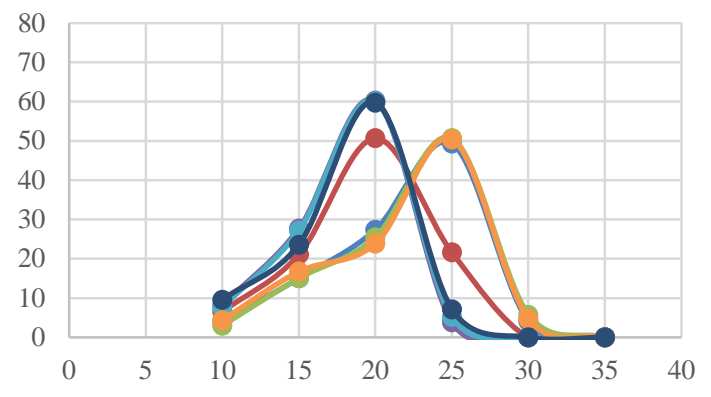

Fachada Sul

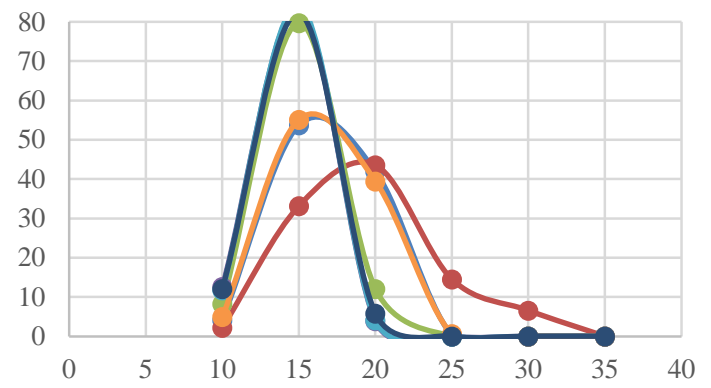

Fachada Oeste

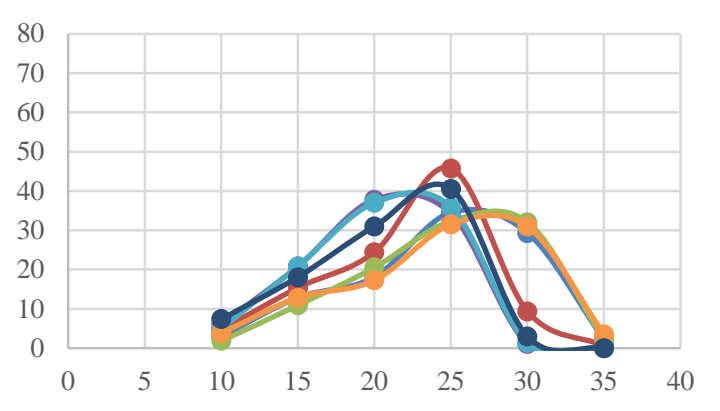

Fachada Nordeste

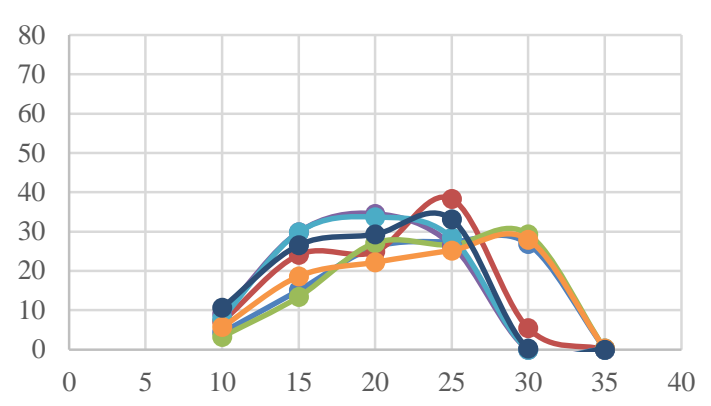

Fachada Sudeste

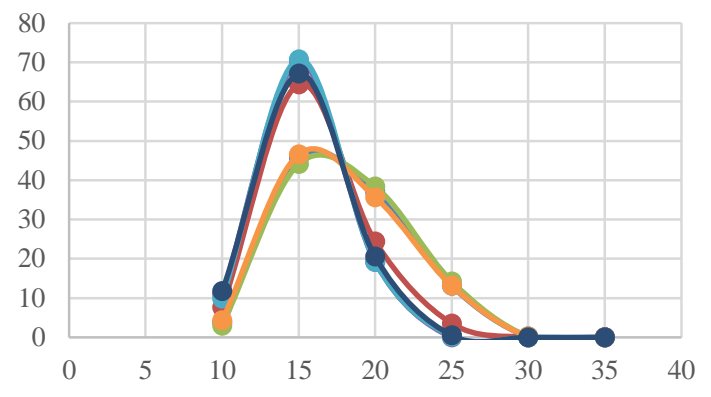

Fachada Sudoeste

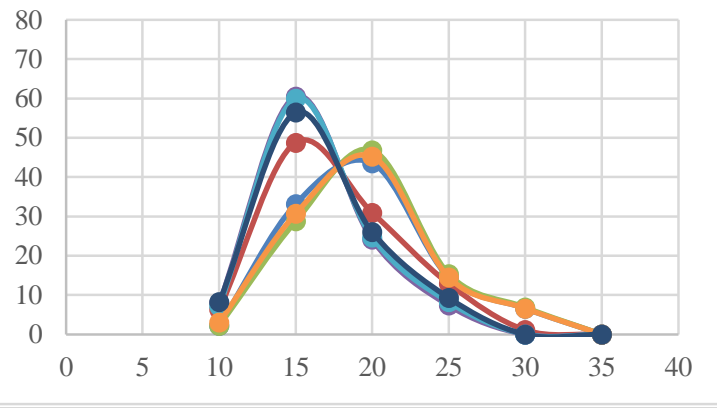

Fachada Noroeste

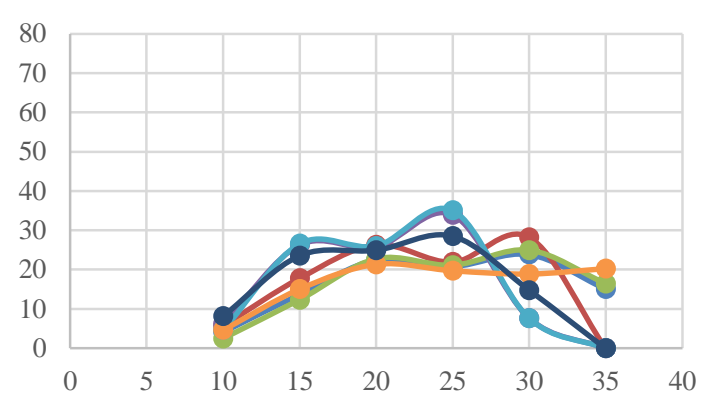

Legenda:

$\multimap \mathrm{SC} 1 \multimap \mathrm{SC} 2 \multimap \mathrm{SC} 3 \multimap \mathrm{SC} 4 \multimap \mathrm{SC} 5 \multimap \mathrm{SC} 6 \multimap \mathrm{SC} 7$ 
Conforme já analisado e justificado, os sistemas SC1, CS3 e SC6 são aqueles que apresentaram, também, os maiores valores de temperatura superficial e amplitude térmica na fachada.

$\mathrm{Na}$ faixa $25<\Delta \mathrm{T} \leq 30$, as maiores frequências da amplitude térmica na superfície da fachada ocorreram, predominantemente, para os sistemas SC1, CS3, SC6 e, também, o sistema SC2. Os maiores percentuais de frequência de ocorrência nesta faixa aconteceram na fachada Noroeste, seguida pelas fachadas Oeste, Norte e Nordeste.

Amplitudes térmicas na superfície da fachada na faixa $30<\Delta \mathrm{T} \leq 35$ ocorreram somente para os sistemas SC1, CS3 e SC6. Os maiores percentuais da frequência de ocorrência aconteceram na fachada Noroeste, cujos valores são, respectivamente, $15 \%, 16 \%$ e $20 \%$.

Na fachada Norte, seguida pela fachada Oeste, também ocorreram valores de amplitude térmica na superfície na faixa $30<\Delta \mathrm{T} \leq 35$, mas com frequência de ocorrência igual ou abaixo de $10 \%$. Nas outras fachadas, não foram verificados eventos nesta faixa de valor.

\subsection{CHOQUE TÉRMICO}

Investigando os fenômenos de variações térmicas que ocorreram nas fachadas, foi explorada a possibilidade de ocorrência de choque térmico, isto é, abrupta variação térmica medida pela diferença de temperatura na superfície da fachada.

Para o levantamento dos dados, foram consideradas duas situações de intervalo de tempo: um intervalo de uma hora (60 minutos) e um intervalo de duas horas (120 minutos).

Ou seja, foi obtida a amplitude térmica na superfície da fachada pela diferença entre as temperaturas superficiais máxima e mínima que ocorreram entre dois passos de tempo (1 hora) e entre três passos de tempo (2 horas).

Mediante a diferença de temperatura em intervalos de tempo de 1 hora $\left(\Delta \mathrm{T}_{\mathrm{ch}}=\mathrm{h}_{\mathrm{n}}-\mathrm{h}_{\mathrm{n}-1}\right)$, foi quantificado o número de eventos $\Delta \mathrm{T}_{\mathrm{ch}}>|8|$ que ocorrem na superfície da camada mais exterior do sistema de fachada para os sete casos estudados, em cada orientação de fachada.

Buscando compreender melhor a possibilidade de ocorrência do fenômeno choque térmico, foi verificada, também, a frequência de eventos com variação térmica em intervalos de tempo de 2 horas $\left(\Delta \mathrm{T}_{\mathrm{ch}}=\mathrm{h}_{\mathrm{n}}-\mathrm{h}_{\mathrm{n}-2}\right)$.

Mediante essa diferença de temperatura, foi quantificada a frequência de ocorrência nas seguintes faixas de variação térmica: $\Delta \mathrm{T}_{\mathrm{ch}}>|8| ; \Delta \mathrm{T}_{\mathrm{ch}}>|15| \mathrm{e} \Delta \mathrm{T}_{\mathrm{ch}}>|20|$. 


\subsubsection{Análise das frequências de ocorrência dos eventos de variação térmica com intervalos de tempo de 1 hora e 2 horas}

A Figura 6.14 mostra as frequências dos eventos horários, quando ocorre aquecimento ou arrefecimento da temperatura superficial maior ou igual a $8^{\circ} \mathrm{C}$ para cada orientação de fachada ao longo de um ano climático típico, considerando o intervalo de tempo de 1 hora.

As Figuras 6.15, 6.16 e 6.17 representam as variações da temperatura superficial para cada orientação de fachada, ao longo de um ano climático típico, considerando o intervalo de tempo de 2 horas em situação de aquecimento ou arrefecimento da temperatura superficial, para valores $\Delta \mathrm{T}_{\mathrm{ch}}>|8| ; \Delta \mathrm{T}_{\mathrm{ch}}>|15|$ e $\Delta \mathrm{T}_{\mathrm{ch}}>|20|$, respectivamente.

Em síntese, as figuras mostram os sete sistemas estudados, representando no eixo vertical as frequências (\%) por faixas de variações térmicas, e no eixo horizontal as orientações de fachada, assim identificadas: $\mathrm{N}=1 ; \mathrm{NE}=2 ; \mathrm{L}=3 ; \mathrm{SE}=4 ; \mathrm{S}=5 ; \mathrm{SO}=6 ; \mathrm{O}=7$ e $\mathrm{NO}=8$.

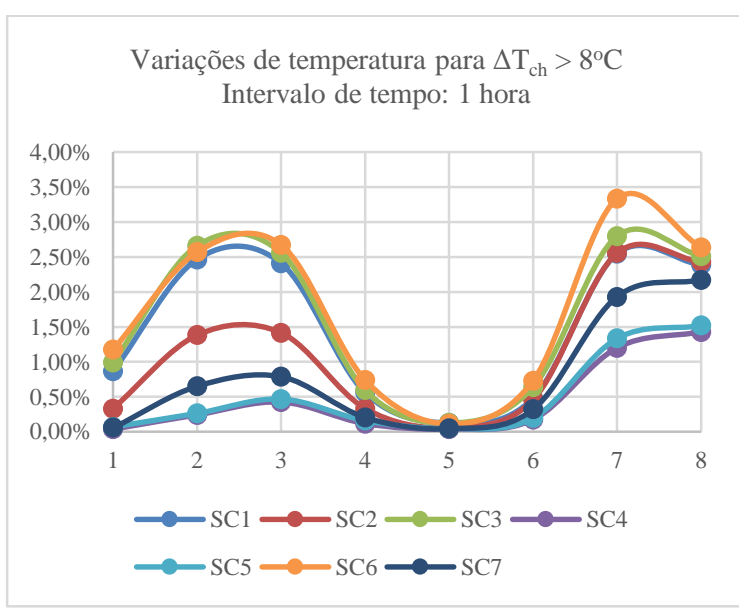

Figura 6.14 - Variações de temperatura para $\Delta \mathrm{T}_{\mathrm{ch}}>8^{\circ} \mathrm{C}$, para intervalo de tempo de 1 hora.

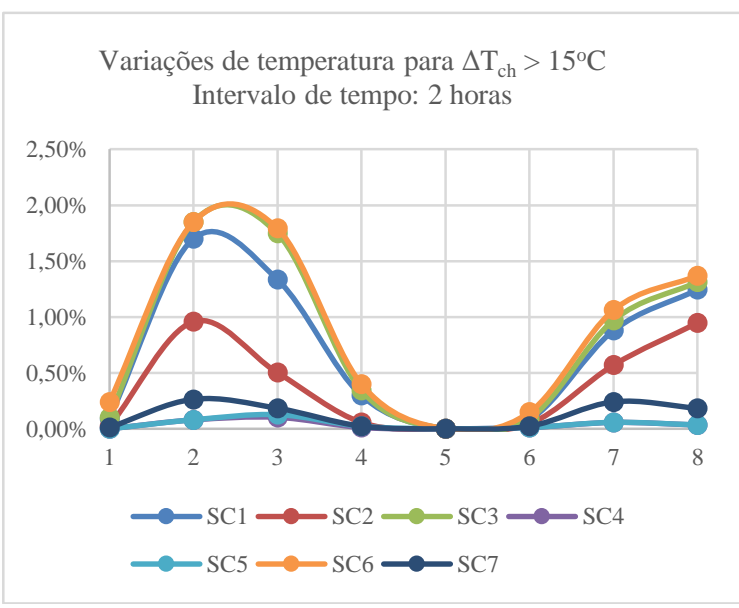

Figura 6.16 - Variações de temperatura para $\Delta \mathrm{T}_{\mathrm{ch}}>1^{\circ} \mathrm{C}$, para intervalo de tempo de 2 horas.

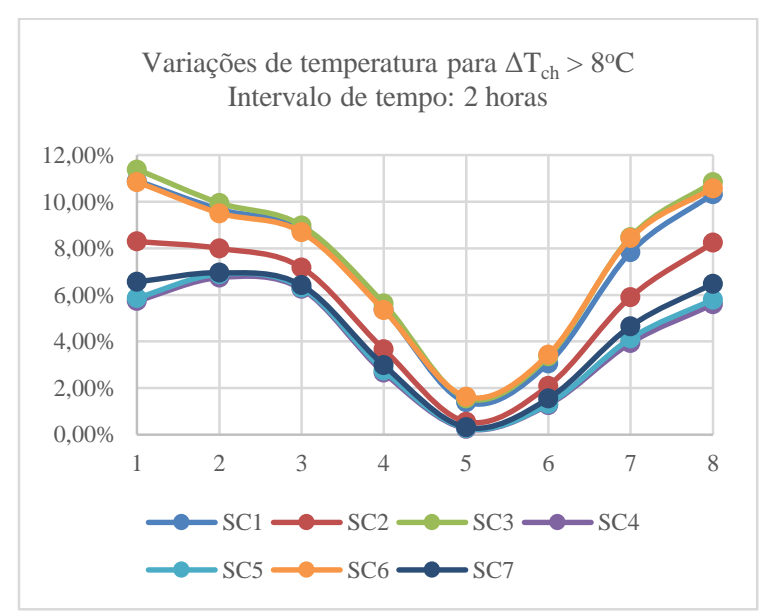

Figura 6.15 - Variações de temperatura para $\Delta \mathrm{T}_{\mathrm{ch}}>8^{\circ} \mathrm{C}$, para intervalo de tempo de 2 horas.

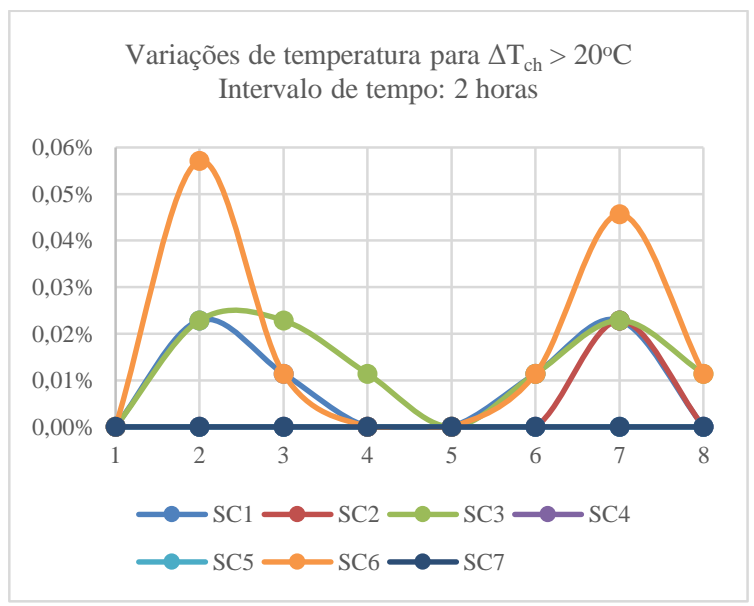

Figura 6.17 - Variações de temperatura para $\Delta \mathrm{T}_{\mathrm{ch}}>20^{\circ} \mathrm{C}$, para intervalo de tempo de 2 horas. 
Analisando o percentual de eventos com variações de temperatura acima de $8^{\circ} \mathrm{C}$, em intervalo de tempo de 1 hora, verificam-se frequências de ocorrência menores que 3,5\%, conforme mostra a Figura 6.7. Nesta faixa de variação térmica, o sistema SC6 é aquele que apresentou o maior percentual de eventos (cerca de 3,5\%), na fachada Oeste. Em segunda predominância de ocorrência, surgem nas fachadas Noroeste, Nordeste e Leste, os sistemas SC6, SC3 e SC1 para frequências de ocorrência em torno de $2,5 \%$.

Em suma, os sistemas SC6, SC3 e SC1 são aqueles que apresentaram as maiores frequências de ocorrência, nas fachadas Oeste, Noroeste, Nordeste e Leste, considerando variações de temperatura acima de $8^{\circ} \mathrm{C}$, em intervalo de tempo de 1 hora.

Para variações de temperatura acima de $8^{\circ} \mathrm{C}$, em intervalos de tempo de 2 hora, as frequências ocorrem em até $12 \%$. Os sistemas SC6, SC3 e SC1 são aqueles que apresentaram as maiores frequências nesta faixa de variação térmica, principalmente nas fachadas Norte e Noroeste, seguidas pelas fachadas Nordeste, Leste e Oeste.

Considerando as variações térmicas para diferenças de temperatura maior do que $15^{\circ} \mathrm{C}$, observa-se que menos de $2,0 \%$ dos eventos ocorrem com essa variação térmica ao longo de um ano climático típico, em intervalos de tempo de 2 horas. Os sistemas SC6, SC3 e SC1 continuaram apresentando as maiores frequências, principalmente nas fachadas Nordeste e Leste, para esta faixa de variação térmica.

Analisando as 8760 horas do ano típico e considerando intervalo de tempo de 2 horas, para eventos com variações térmicas maiores do que $20^{\circ} \mathrm{C}$, a máxima ocorrência identificada foram 12 eventos no sistema SC6, o que significa menos de $0,1 \%$ de frequência, sendo que nenhum deles foi maior que $23^{\circ} \mathrm{C}$.

Considerando todos os eventos com $\Delta \mathrm{Tch}>|8|{ }^{\circ} \mathrm{C}$ (ver Tabela C. 2 no Apêndice C), observa-se que cerca de $18,5 \%$ desses eventos acontecem na fachada Norte, $18 \%$ na fachada Noroeste e $18 \%$ na fachada Nordeste. A ocorrência na fachada Leste é de cerca de $16 \%$ e na fachada Oeste é de 13,5\%. As menores ocorrências acontecem nas fachadas Sudeste (9\%), Sudoeste $(5 \%)$ e na $\operatorname{Sul}(2 \%)$

\subsubsection{Análise do comportamento da variação térmica considerando resfriamento ou aquecimento da superfície da fachada durante os períodos do ano}

Nas frequências de ocorrência estudadas na seção anterior, os valores apresentados para $\Delta \mathrm{T}_{\mathrm{ch}}$ referem-se a valores absolutos, sem distinguir se as variações térmicas foram referentes à aquecimento ou arrefecimento da superfície da fachada. 
No entanto, ao quantificar as diferenças das temperaturas superficiais no intervalo de tempo de 1 hora e de 2 horas, observou-se que a variação térmica pode ocorrer com resfriamento da superfície (diminuição da temperatura) ou com aquecimento (elevação da temperatura).

Para demonstrar o comportamento das variações térmicas ao longo de um ano climático típico, o Quadro 6.8 apresenta os gráficos de todas as variações térmicas que ocorrem nas fachadas em 8760 horas, para os sistemas SC3 e SC6, considerando o intervalo de tempo de 2 horas.

No caso do resfriamento, $\Delta \mathrm{T}_{\mathrm{ch}}=\mathrm{h}_{\mathrm{n}}-\mathrm{h}_{\mathrm{n}-2}$ resulta em um valor negativo e no caso do aquecimento o resultado é positivo. Observa-se que que os valores de $\Delta \mathrm{T}_{\mathrm{ch}}$ abaixo do eixo (valores negativos) representam variações térmicas com diminuição da temperatura superficial e os valores acima do eixo, variações térmicas com aumento da temperatura superficial.

O comportamento (desenho cíclico) das variações térmicas sofre fortemente a influência da radiação solar, pois acompanha a geometria da insolação como foi visto nos estudos das temperaturas superficiais e nas amplitudes térmicas nas superfícies das fachadas. No entanto, a intensidade depende de outros fatores, assim como a distribuição das frequências de ocorrência.

Observando os gráficos do Quadro 6.8 que mostram o comportamento das variações térmicas para todos os eventos, durante um ano climático típico, verifica-se que na fachada Sul, a proporção entre evento de arrefecimento e de aquecimento é bastante uniforme.

Nas fachadas Norte, Nordeste, Leste e Sudeste, os eventos predominantes são aqueles relacionados ao aquecimento da fachada. Nas fachadas Noroeste, Oeste e Sudoeste, a maioria dos eventos está relacionada com o arrefecimento da fachada (queda de temperatura superficial).

Considerando todos os eventos com $\Delta \mathrm{T}_{\mathrm{ch}}>8^{\circ} \mathrm{C}$ e $\Delta \mathrm{T}_{\mathrm{ch}}<-8^{\circ} \mathrm{C}$, foi avaliada a proporção entre eventos de arrefecimento e de aquecimento. Constatou-se que cerca de $65 \%$ das variações térmicas ocorreram com aumento da temperatura superficial. Somente cerca de 35\% acontecem com queda de temperatura.

Verificando os eventos com $\Delta \mathrm{T}_{\mathrm{ch}}>15^{\circ} \mathrm{C}$ e $\Delta \mathrm{T}_{\mathrm{ch}}<-15^{\circ} \mathrm{C}$, observou-se que as variações térmicas com elevação de temperatura superficial ocorreram em cerca de $60 \%$ dos eventos, e cerca de $40 \%$ referem-se à queda brusca de temperatura. 
Quadro 6.8 - Comportamento das variações térmicas na superfície da fachada para intervalo de tempo de 2 horas, considerando todos os eventos de um ano climático típico.
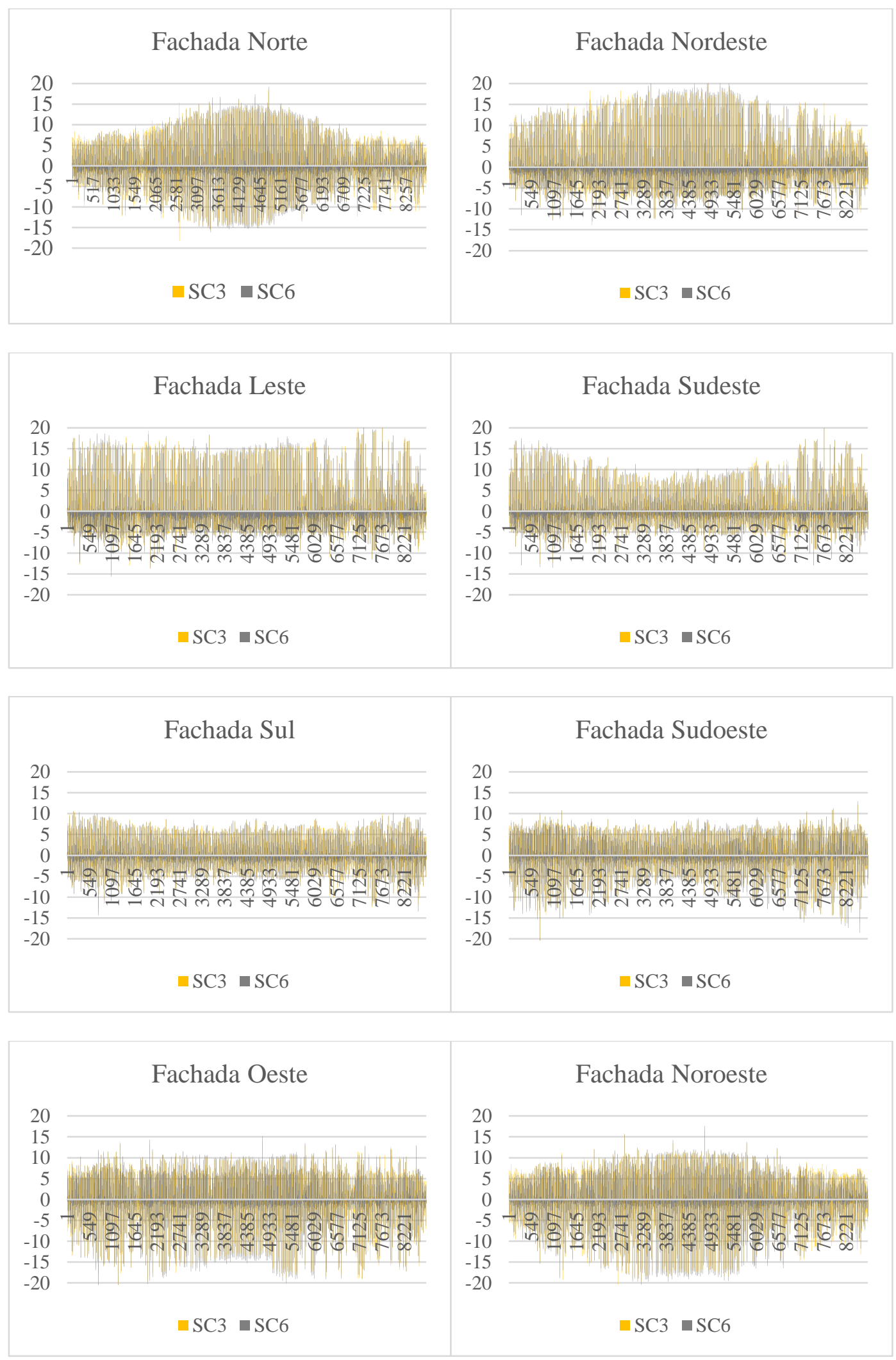
Para verificar se as variações térmicas em intervalos de tempo de 2 horas são predominantes nos meses mais frios, que correspondem aos meses mais secos na cidade de Brasília, foi realizado um levantamento da frequência de ocorrência dos eventos de variação térmica que ocorrem em um ano climático. Para isso, foram considerados os sistemas SC3 e SC6, que foram aqueles que apresentaram os maiores valores de temperatura superficial e amplitude térmica diária na superfície da fachada.

A Figura 6.18 demonstra as frequências para o período seco e período chuvoso, considerando o total acumulado dos eventos de variação térmica que ocorreram a cada 2 horas, em cada orientação de fachada, para os sistemas SC3 e SC6.

Constata-se que as orientações Nordeste e Noroeste são aquelas onde ocorreram com maior frequência as variações térmicas, quando considerados os sistemas SC3 e SC6. No entanto, na fachada Norte, as ocorrências no período seco aconteceram, praticamente, com a mesma frequência das ocorrências nas fachadas Nordeste e Noroeste, para o mesmo período.

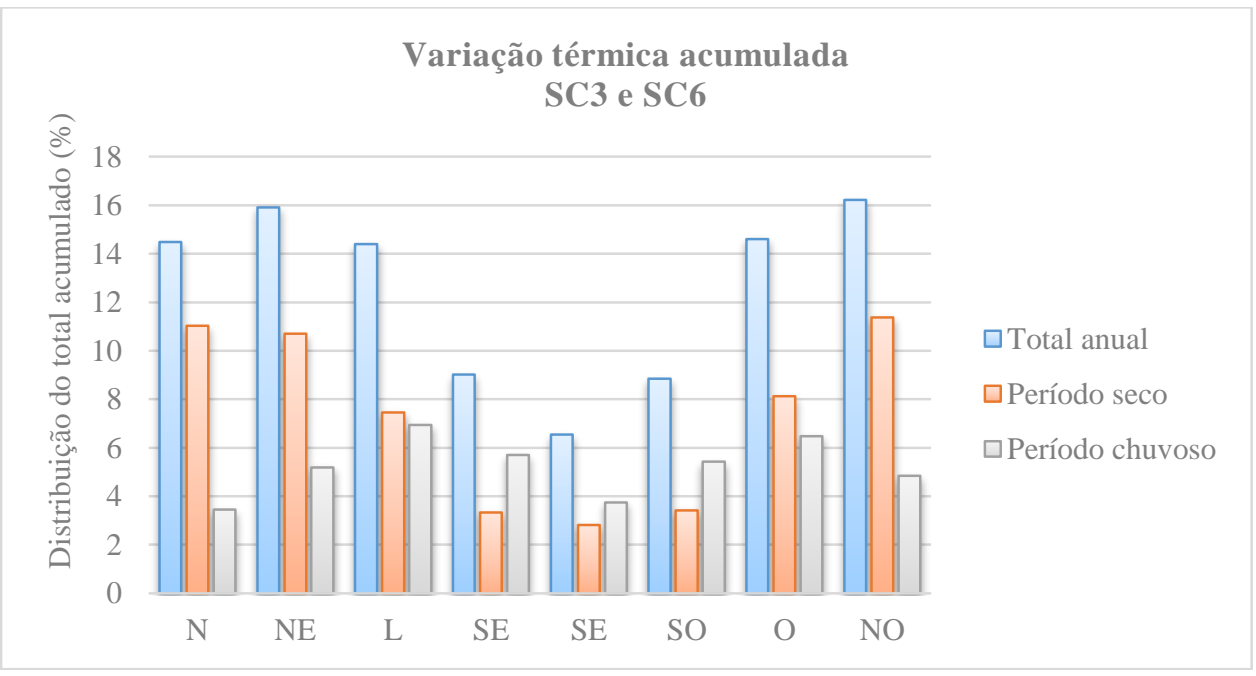

Figura 6.18 - Comportamento das variações térmicas nos períodos seco e chuvoso.

Assim, enquanto as maiores variações térmicas na fachada Norte ocorreram de forma mais concentrada nos meses mais frios do ano (que compreendem o período seco), nas fachadas Nordeste e Noroeste, as maiores variações térmicas aconteceram de forma mais distribuída ao longo do ano e com valores maiores que aqueles apresentados pela fachada Norte.

As fachadas Leste e Oeste apresentaram comportamentos muito similares, ambas com os maiores valores de variação térmica distribuídos ao longo de todo o ano. Apesar de as maiores variações acontecerem no período seco, não há grande diferença entre os períodos.

As fachadas Sudeste, Sul e Sudoeste são aquelas que apresentaram as variações térmicas mais concentradas no período chuvoso. 


\subsection{AMPLITUDE TÉRMICA NA SUPERFÍCIE EXTERIOR: ANÁLISE DAS INTERAÇÕES ENTRE SISTEMAS CONSTRUTIVOS, ORIENTAÇÕES DE FACHADA E PERÍODOS DO ANO}

Na seção anterior foi analisado o comportamento da temperatura superficial e da amplitude térmica na superfície exterior, com base nas propriedades das camadas do sistema de fachada, ao longo dos meses do ano, caracterizando assim cada uma das sete variações do sistema construtivo estudado, além da intensidade e frequência de ocorrência dos eventos, como resposta à influência dos agentes climáticos de degradação.

Nesta seção, são apresentadas as análises para verificar a influência dos agentes climáticos de degradação no comportamento higrotérmico das fachadas, considerando o efeito da sazonalidade do clima no envelhecimento natural da edificação. Por isso, são estudados dois ciclos de tempo: período seco e período chuvoso. Desta forma, busca-se caracterizar a ação e a interação entre os agentes climáticos de degradação e o comportamento higrotérmico das fachadas, na cidade de Brasília. Neste caso, considerando os efeitos e danos a longo prazo, as médias são os indicadores mais representativos dos fenômenos em estudo.

Este estudo foi baseado em uma análise estatística sobre a interação entre as variáveis, por meio da técnica estatística Análise de Variância de três vias (ANOVA - three way), após verificação da distribuição normal da amostra.

Por meio do pós-teste de Tukey da ANOVA de três vias, foram efetuadas as múltiplas comparações entre as sete variações do sistema construtivo, as oito orientações de fachadas e os dois períodos do ano, que estabeleceram 112 diferentes interações, inclusive quais delas apresentaram diferenças estatísticas significativas $(\mathrm{p}<0,05)$.

$\mathrm{Na}$ Tabela 6.2 são apresentados os resultados das interações entre os sete sistemas construtivos estudados (SC1, SC2, SC3, SC4, SC5, SC6 e SC7) e as oito orientações de fachadas (Norte, Nordeste, Leste, Sul, Sudoeste, Oeste e Noroeste), nos períodos seco e chuvoso do ano. Os valores apresentados são os resultados das médias \pm desvios padrão das médias. As primeiras letras maiúsculas nas colunas indicam se existem diferenças estatisticamente significativas no teor de umidade entre os períodos. As letras maiúsculas em negrito na linha indicam se existem diferenças no teor de umidade entre sistemas construtivos. As letras minúsculas na coluna indicam se as orientações de fachada influenciam o teor de umidade, para cada sistema construtivo e período do ano. 
Tabela 6.2 - Amplitude térmica na superfície exterior $\left({ }^{\circ} \mathrm{C}\right)$ : resultados da ANOVA de três vias para as interações entre orientações de fachada, períodos do ano e sistemas construtivos.

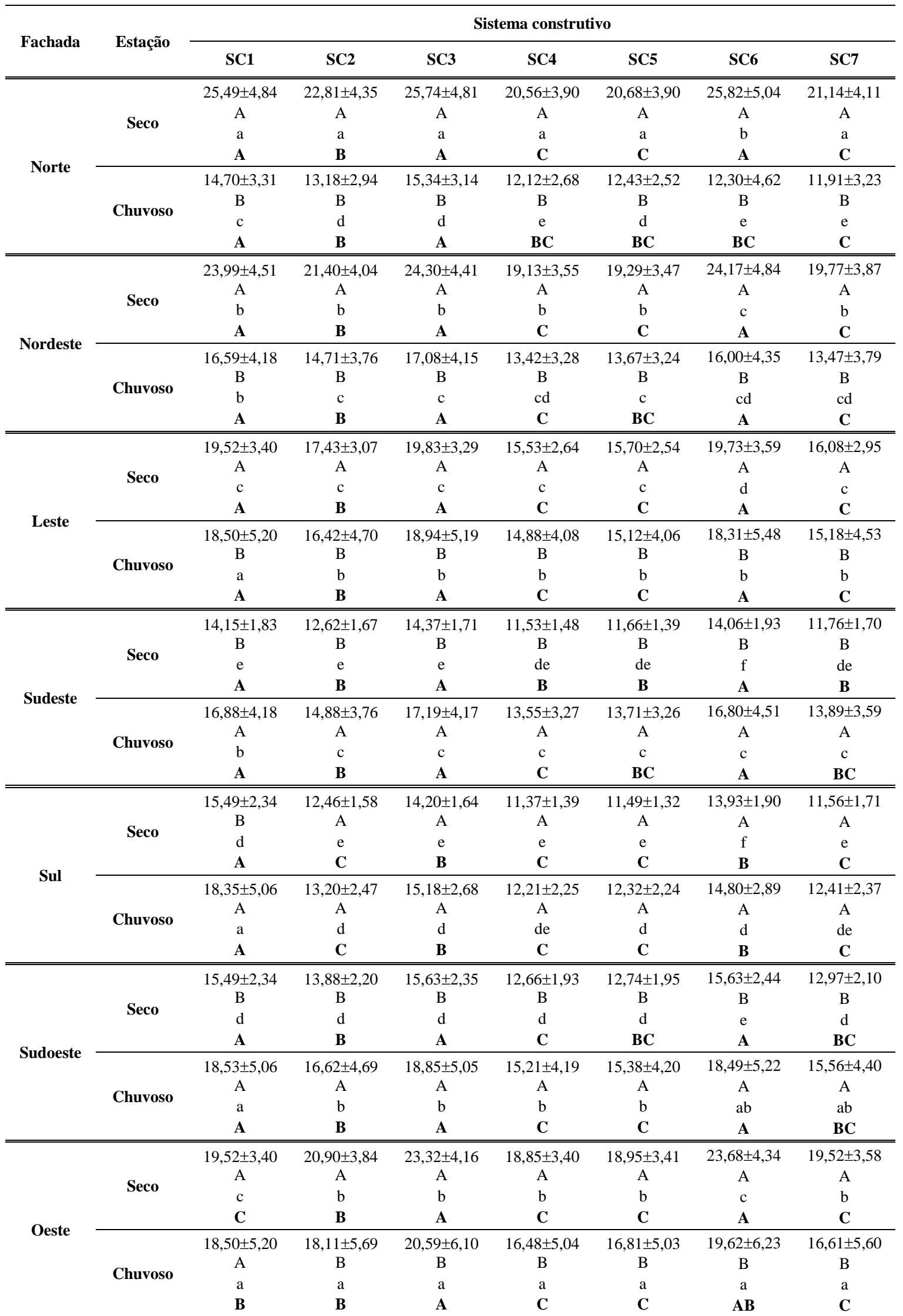


Continuação

\begin{tabular}{|c|c|c|c|c|c|c|c|c|}
\hline \multirow{2}{*}{ Noroeste } & Seco & $\begin{array}{c}26,58 \pm 5,17 \\
\mathrm{~A} \\
\mathrm{a} \\
\mathrm{A}\end{array}$ & $\begin{array}{c}23,90 \pm 4,67 \\
\text { A } \\
\text { a } \\
\text { B }\end{array}$ & $\begin{array}{c}26,82 \pm 5,17 \\
\text { A } \\
\text { a } \\
\text { A }\end{array}$ & $\begin{array}{c}21,48 \pm 4,16 \\
\mathrm{~A} \\
\mathrm{a} \\
\mathrm{C}\end{array}$ & $\begin{array}{c}21,60 \pm 4,17 \\
\mathrm{~A} \\
\mathrm{a} \\
\mathrm{C}\end{array}$ & $\begin{array}{c}27,10 \pm 5,35 \\
\mathrm{~A} \\
\mathrm{a} \\
\mathbf{A}\end{array}$ & $\begin{array}{c}22,18 \pm 4,38 \\
\text { A } \\
\text { a } \\
\text { C }\end{array}$ \\
\hline & Chuvoso & $\begin{array}{c}17,52 \pm 4,90 \\
\text { B } \\
\text { ab } \\
\text { AB }\end{array}$ & $\begin{array}{c}15,90 \pm 4,48 \\
\text { B } \\
\text { bc } \\
\text { CD }\end{array}$ & $\begin{array}{c}18,21 \pm 4,77 \\
\text { B } \\
\text { bc } \\
\text { A }\end{array}$ & $\begin{array}{c}14,52 \pm 4,02 \\
\text { B } \\
\text { bc } \\
\text { E }\end{array}$ & $\begin{array}{c}14,88 \pm 3,92 \\
\text { B } \\
\text { bc } \\
\text { DE }\end{array}$ & $\begin{array}{c}16,77 \pm 5,01 \\
\text { B } \\
\text { c } \\
\text { BC }\end{array}$ & $\begin{array}{c}14,43 \pm 4,62 \\
\text { B } \\
\text { bc } \\
\text { E }\end{array}$ \\
\hline
\end{tabular}

Os resultados estão apresentados em média \pm desvio padrão da média. Letras maiúsculas na coluna indicam diferença entre os períodos. Letras minúsculas na coluna indicam diferença entre as orientações de fachada. Letras maiúsculas em negrito na linha indicam diferença entre os sistemas construtivos. As múltiplas comparações foram realizadas por meio do pós-teste de Tukey $(\mathrm{p}<0,05)$.

O Quadro 6.9 mostra as diferenças entre as médias da amplitude térmica na superfície da fachada, nos períodos seco e chuvoso.

\section{Quadro 6.9 - Amplitude térmica $\left({ }^{\circ} \mathrm{C}\right)$ na superfície da fachada do sistema construtivo nos períodos seco e chuvoso.}
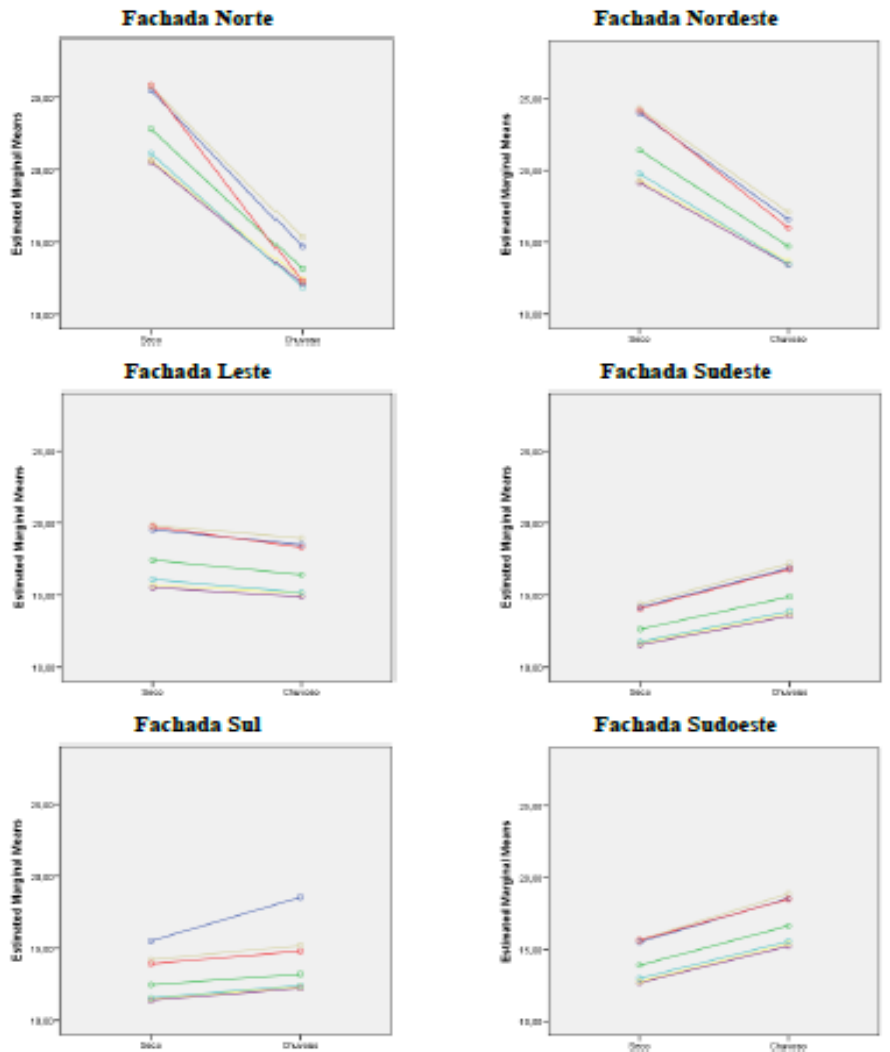

Fachada Oeste
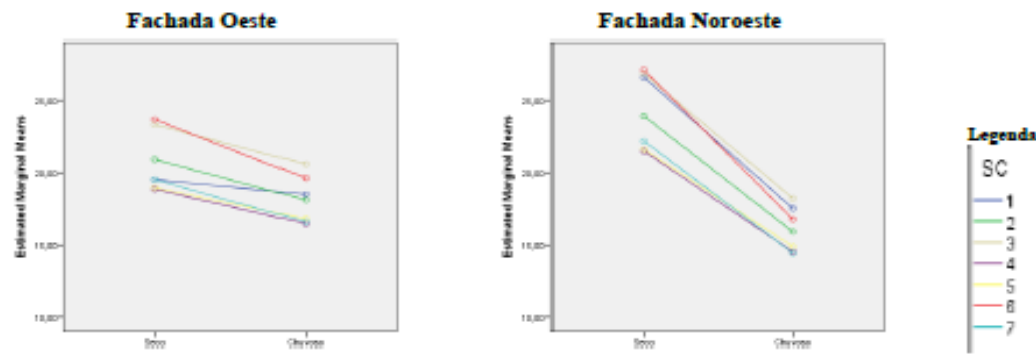
Comparando as diferenças estatisticamente significativas entre as médias da amplitude térmica na superfície das fachadas, nos períodos seco e chuvoso, observou-se que:

a) Nas fachadas Norte, Nordeste, Leste e Noroeste foram constatadas diferenças estatisticamente significativas entre as médias da amplitude térmica na superfície de cada sistema estudado, sendo que no período seco as médias são maiores que no período chuvoso.

b) Nas fachadas Sudeste e Sudoeste, as médias da amplitude térmica na superfície, no período chuvoso, são maiores que no período seco.

c) $\mathrm{Na}$ fachada Sul, somente o sistema $\mathrm{SC} 1$ apresentou médias maiores no período chuvoso que no seco; todos os demais sistemas não mostraram diferenças significativas entre os períodos.

d) Na fachada Oeste, somente o sistema SC1 não mostrou diferença significativa entre os períodos; todos os demais sistemas apresentaram médias maiores no período seco que no chuvoso.

A Figura 6.19 e a Figura 6.20 mostram os resultados gráficos dos dados da Tabela 6.2, respectivamente, nos períodos chuvoso e seco, para as diferenças da amplitude térmica na superfície de cada sistema estudado, em cada orientação de fachada.

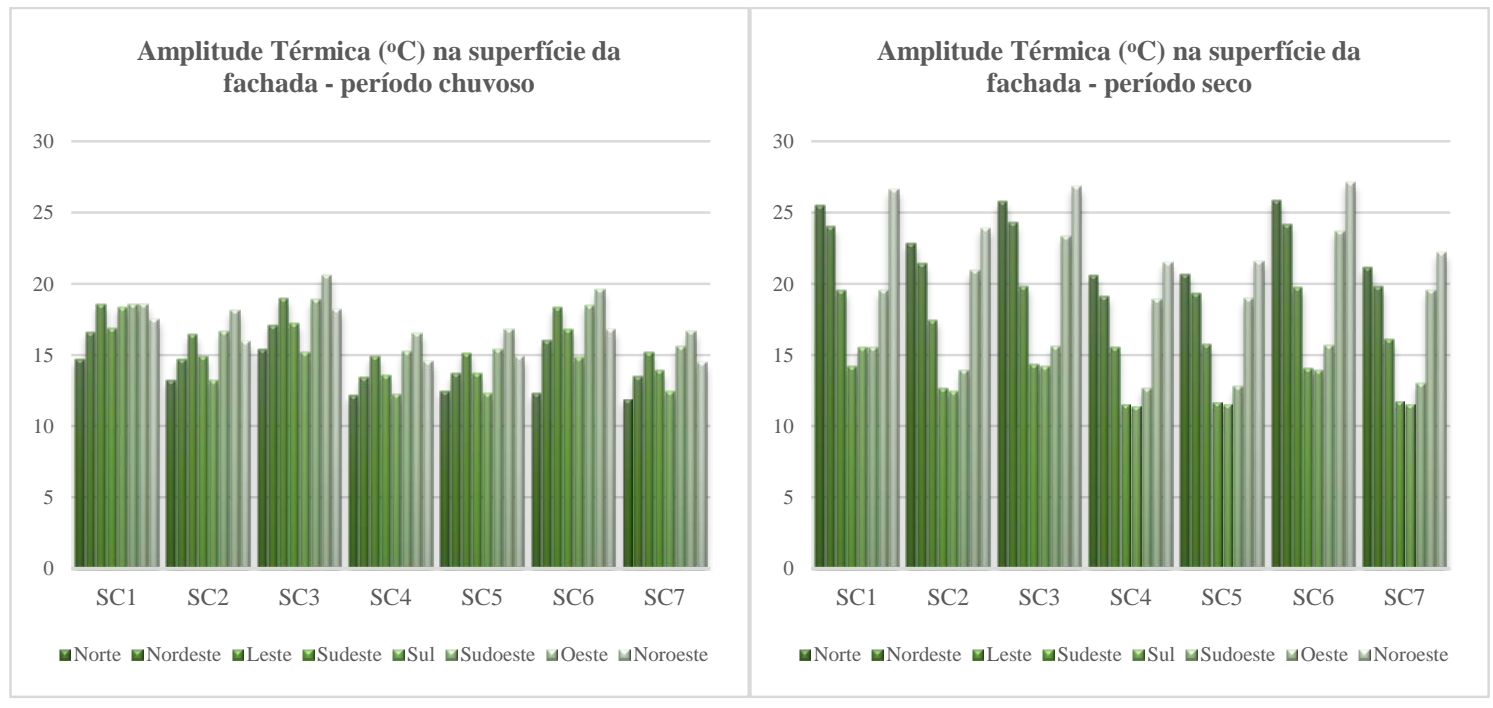

Figura 6.19 - Média da amplitude térmica na superfície da fachada no período chuvoso.
Figura 6.20 - Média da amplitude térmica na superfície da fachada no período seco.

Comparando a amplitude térmica na superfície de cada sistema conforme a orientação de fachada, no período chuvoso, observou-se que: 
a) O sistema $\mathrm{SC} 1$ é aquele que apresentou menos variação de amplitude térmica entre as fachadas. As fachadas Leste, Sul, Sudoeste e Oeste não foram diferentes entre si, e apresentaram os maiores valores. Com menores médias de amplitude térmica estão as fachadas Noroeste, Sudeste e Nordeste, seguidas pela Norte.

b) Os sistemas SC2, SC3 e SC5 apresentaram as maiores médias de amplitude térmica na fachada Oeste, seguida pelas fachadas Leste e Sudoeste. Com médias menores, em valores decrescentes, estão as fachadas Noroeste, Nordeste e Sudeste, Norte e Sul.

c) Os sistemas SC4, SC6 e SC7 apresentaram as maiores médias de amplitude térmica na fachada Oeste seguida pelas fachadas Sudoeste e Leste, que não mostraram diferença entre si. Na sequência, com valores decrescentes, encontram-se as fachadas Noroeste, Sudeste e Nordeste, seguidas pelas Sul e Norte.

Comparando a amplitude térmica na superfície de cada sistema conforme a orientação de fachada, no período seco, observou-se que:

a) No sistema $\mathrm{SC} 1$, as maiores médias de amplitude térmica estão nas fachadas Norte e Noroeste, que não mostraram diferenças significativas entre si. Em sequência decrescente estão as fachadas Nordeste, Leste e Oeste, Sul e Sudoeste, seguidas pela Sudeste.

b) Os sistemas SC2, SC3, SC4, SC5 e SC7 apresentaram as maiores médias de amplitude térmica nas fachadas Norte e Noroeste, que não mostraram diferenças significativas entre si. Em sequência decrescente estão as fachadas Nordeste e Oeste, Leste, Sudoeste e, finalmente as fachadas Sul e Sudeste.

c) No sistema SC6, surgiram as maiores variações entre as médias de amplitude térmica nas fachadas. A maior média ocorreu na fachada Noroeste, seguida pela fachada Norte. Com médias menores estão as fachadas Nordeste e Oeste, que não apresentaram diferença significativa entre si, seguidas pelas fachadas Leste e Sudoeste. Com os menores valores encontram-se as fachadas Sudeste e Sul.

A Figura 6.21 e a Figura 6.22 mostram os resultados gráficos dos dados da Tabela 6.2, respectivamente, nos períodos seco e chuvoso, para as diferenças entre as médias da amplitude térmica na superfície entre sistema construtivo conforme a orientação de fachada. 


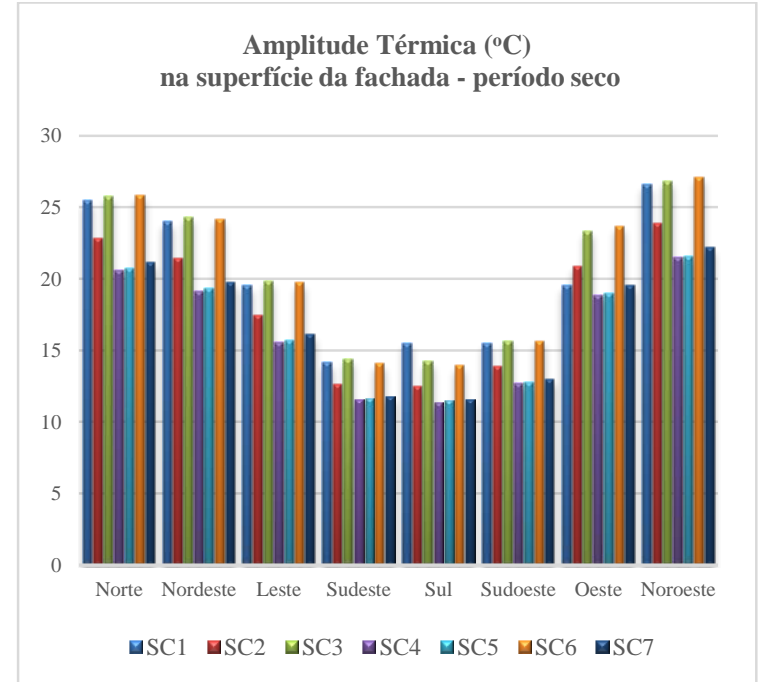

Figura 6.21 - Média da amplitude térmica na superfície da fachada no período seco.

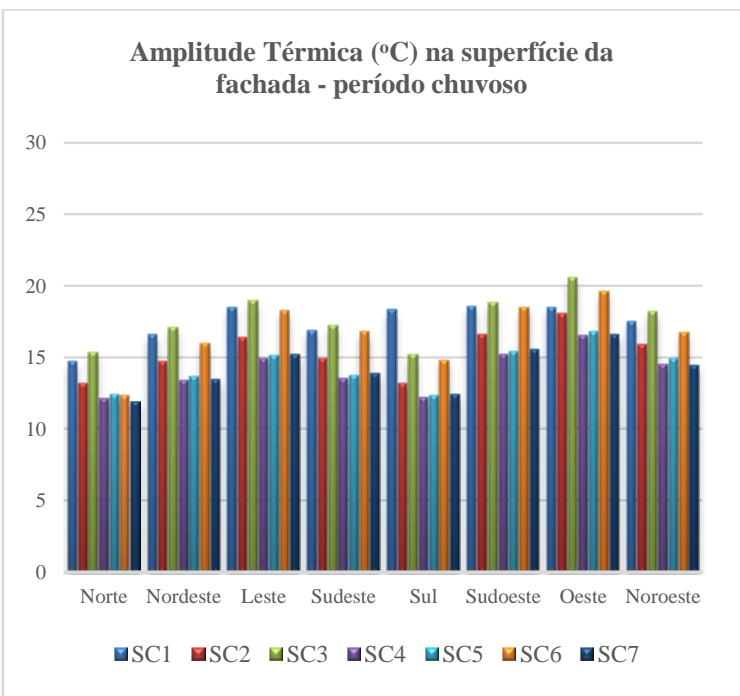

Figura 6.22 - Média da amplitude térmica na superfície da fachada no período chuvoso.

Comparando a amplitude térmica na superfície de cada sistema conforme a orientação de fachada, no período seco observou-se que:

a) Nas fachadas Norte, Nordeste, Leste, Sudeste, Sudoeste e Noroeste, os sistemas SC1, SC3 e SC6 apresentaram as maiores médias de amplitude térmica da superfície. Com valores decrescentes das médias, segue o sistema SC2, e depois, os sistemas SC4, SC5 e SC7, que não mostraram diferenças significativas entre si.

b) Na fachada Sul, o sistema SC1 apresentou o maior valor de média, seguido pelos sistemas SC3 e SC6. Nesta fachada, os sistemas SC2, SC4, SC5 e SC7 apresentaram as menores médias que não mostraram diferenças significativas entre si.

c) Na fachada Oeste, são os sistemas SC3 e SC6 aqueles que apresentaram as maiores médias de amplitude térmica, seguidos pelo sistema SC2. Os sistemas SC1, SC4, SC5 e SC7 apresentaram as menores médias, que não mostraram diferenças significativas entre si.

Comparando a amplitude térmica na superfície de cada sistema conforme a orientação de fachada, no período chuvoso, observou-se que:

a) Nas fachadas Nordeste, Leste, Sudeste e Sudoeste os sistemas SC1, SC3 e SC6 apresentaram as maiores médias de amplitude térmica da superfície. Com valores decrescentes das médias, segue o sistema SC2, e depois, os sistemas SC4, SC5 e SC7, que não mostraram diferenças significativas entre si. 
b) Na fachada Norte, os sistemas SC1 e SC3 apresentaram as maiores médias, seguidos do sistema SC2. Os sistemas SC4, SC5, SC6 e SC7 não mostraram diferenças significativas entre si.

c) Na fachada Sul, o sistema SC1 apresentou a maior média, seguido pelos sistemas SC3 e SC6. Os sistemas SC2, SC4, SC5 e SC7 apresentaram as menores médias, que não mostraram diferenças significativas entre si.

d) Na fachada Oeste, o sistema SC3 apresentou a maior média, seguido pelos sistemas SC1, SC2 e SC6. As menores médias foram apresentadas pelos sistemas SC4, SC5 e SC7, que não mostraram diferenças significativas entre si.

e) Na fachada Noroeste, em ordem decrescente da média das amplitudes térmicas foram encontrados os sistemas SC3, SC1, SC6, SC2 e SC5. Os menores valores foram para SC4 e SC7.

\subsection{CONSIDERAÇÕES FINAIS DO CAPÍTULO}

Neste capítulo foram apresentados os resultados dos sete estudos realizados por meio de simulação higrotérmica computacional que possibilitaram quantificar e analisar as variáveis teor de umidade, temperatura superficial externa e amplitude térmica nas superfícies da fachadas, além das múltiplas comparações das interações entre as sete variações de sistema construtivo, as oito orientações de fachada, em dois períodos do ano, permitindo assim discutir a influência dos agentes climáticos de degradação no comportamento higrotérmico das fachadas na cidade de Brasília.

As variações do teor de umidade do elemento mostram a sua capacidade de umidificação e secagem, que dependem das condições de exposição aos agentes externos de origem climática, mas também das características higrotérmica dos componentes da fachada.

Os principais resultados obtidos com base nos estudos do teor de umidade mostram que os picos de umidade armazenada no elemento construtivo ocorrem nas fachadas onde a chuva dirigida é mais intensa. As fachadas mais expostas à degradação por ação da chuva dirigida, pela ordem decrescente de condições de exposição, são as fachadas Noroeste, Norte, Nordeste, Oeste, Leste, Sudoeste, Sul e Sudeste.

No entanto, não existem diferenças estatisticamente significativas no teor de umidade entre as orientações de fachada, quando ocorrem as seguintes condições: 
$\left.1^{\circ}\right)$ No período chuvoso:

a) elementos construtivos com camada de revestimento com muito baixa capilaridade (SC3 e SC5);

b) elementos construtivos com a base em alvenaria muito pouco higroscópica e baixa porosidade (SC2).

$2^{\circ}$ ) No período seco:

a) elementos construtivos que não tenham associados camada de revestimento e base em alvenaria com alta porosidade e capilaridade (todos os sistemas, exceto SC6).

Em outras palavras, o comportamento do teor de umidade é influenciado pelas diversas orientações de fachada quando os elementos construtivos possuem revestimento com média e alta capilaridade e base de alvenaria bastante porosa.

A capilaridade da camada de revestimento é fator preponderante no teor de umidade armazenado pelo elemento construtivo da fachada, quando exposta à chuva dirigida. A alta capilaridade da camada de revestimento facilita a umidificação no período chuvoso, mas favorece a secagem, por redistribuição e evaporação da água líquida.

Em sistemas com alta capilaridade na camada de revestimento, a base de alvenaria influencia na maior ou menor retenção de umidade no sistema. Em elementos construtivos com o mesmo tipo de revestimento, a base de alvenaria menos porosa resulta em um menor armazenamento de umidade, inclusive na camada de revestimento.

Por outro lado, somente camada de revestimento com capilaridade muito baixa protege a base de alvenaria das variações no teor de umidade, independente da porosidade da base, mantendo os teores de umidade sem alterações significativas entre meses secos ou chuvosos. É possível inferir que estes elementos mantem somente a umidade higroscópica.

Analisando o comportamento da temperatura superficial exterior ao longo dos meses e em cada orientação de fachada, observa-se menor variação nos meses mais chuvosos e nas fachadas com maior incidência de chuva dirigida. Investigando a relação entre as variações das temperaturas superficiais externas e o teor de umidade, observa-se que os sistemas mais porosos, que absorvem maior umidade nos meses mais chuvosos, alteram para menor os valores das temperaturas superficiais.

As condições de exposição das fachadas à degradação por ação das amplitudes de temperatura na superfície são fortemente influenciadas pelas variações do teor de umidade. No período 
chuvoso, as fachadas mais expostas às chuvas dirigidas amenizam as amplitudes térmicas. No período seco, as variações térmicas ocorrem fortemente influenciadas pelas condições de exposição aos agentes externos que determinam a temperatura superficial na fachada.

Os sistemas que apresentaram as maiores temperaturas superficiais são aqueles que possuem baixa transmitância térmica, com a mesma alvenaria bastante porosa, apesar dos revestimentos terem diferentes capilaridades. Isso afeta o armazenamento de umidade, justificando as diferenças nas variações térmicas em decorrência das orientações de fachada e incidência de chuva dirigida.

A fachada Noroeste apresenta os maiores valores acumulados de amplitude térmica na superfície, ao longo de todas as 8760 horas do ano. Em seguida estão as fachadas Nordeste, Norte e Oeste. Essas fachadas estão entre aquelas que atingem os maiores valores de temperatura na sua superfície.

No período seco, que compreende os meses de inverno, a radiação é mais intensa na fachada Norte, no entanto, ao longo do período, foi a fachada Noroeste que apresentou os maiores valores de temperatura superficial e de amplitude térmica na superfície, quando as temperaturas noturnas são mais baixas e a temperaturas ao longo do dia se elevam, afetando a temperatura superficial da fachada.

A seguir, pela ordem decrescente, são listadas as fachadas mais expostas às variações térmicas diárias.

$1^{\circ}$ ) No período seco:

- Fachada Noroeste

- Fachada Norte

- Fachada Nordeste

- Fachada Oeste

- Fachada Leste

- Fachada Sudoeste

- Fachada Sudeste

- Fachada Sul $2^{\circ}$ ) No período chuvoso:

- Fachadas Oeste

- Fachada Leste

- Fachada Sudoeste

- Fachada Noroeste

- Fachada Nordeste

- Fachada Sudeste

- Fachada Sul

- Fachada Norte

A umidade afeta a condutividade térmica dos materiais, diminuindo a sua resistência à transferência do calor, ou seja, aumentando a transmitância térmica e, portanto, arrefecendo as temperaturas superficiais pela maior transferência de calor. 
Em sistemas com baixa transmitância térmica, são encontradas as maiores temperaturas superficiais, que são menos acentuadas quanto maior o teor de umidade do sistema. Os sistemas mais suscetíveis às altas amplitudes térmicas na superfície da fachada são aqueles com a menor transmitância térmica.

Assim, conclui-se que os sistemas de menor transmitância apresentam os maiores valores para a temperatura superficial exterior, pois transferem menos calor para o interior da edificação, ou seja, apresentam maior resistência térmica total à passagem do calor absorvido na camada superficial externa.

Na cidade de Brasília, a fachada mais afetada pelos picos de amplitudes térmicas na sua superfície é a fachada Noroeste, pois considerando todos os sistemas estudados, é a que apresentou a maior probabilidade de ocorrência de amplitudes térmicas $\Delta \mathrm{T}>20$, além de ser aquela que apresentou a maior frequência de ocorrência para a faixa $30<\Delta \mathrm{T} \leq 35$.

Os eventos em que há uma queda brusca de temperatura da superfície da fachada são menos frequentes do que aqueles em que as variações térmicas ocorrem com aquecimento da superfície.

A frequência de ocorrência das variações térmicas e sua intensidade variam de fachada para fachada e ao logo de todo o ano, sendo que as fachadas Noroeste e Nordeste são aquelas onde os fenômenos de variação térmica, em intervalos de 2 horas, são mais frequentes para os casos analisados.

Como síntese da caracterização de cada uma das oito orientações de fachada na cidade de Brasília, são apresentados os cenários das condições de exposição resultantes das interações entre períodos, fachadas e variações do sistema construtivo, nos encartes desta seção. 


\begin{tabular}{|c|c|c|}
\hline \multicolumn{3}{|c|}{ 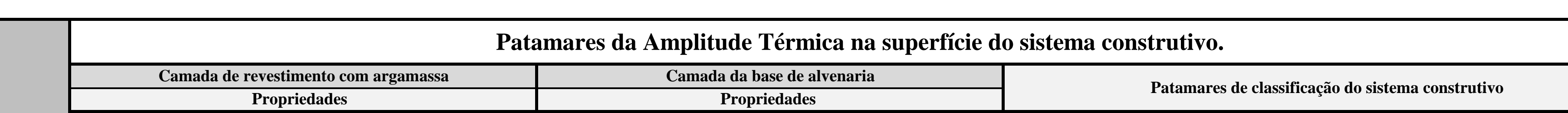 } \\
\hline 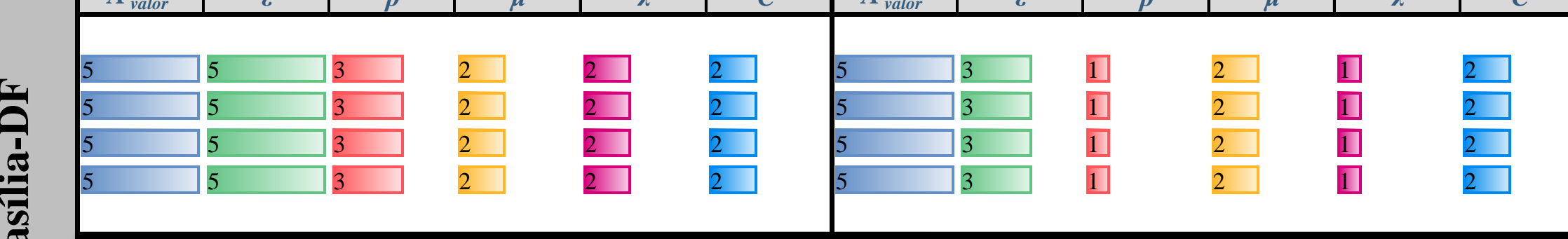 & mimixix & 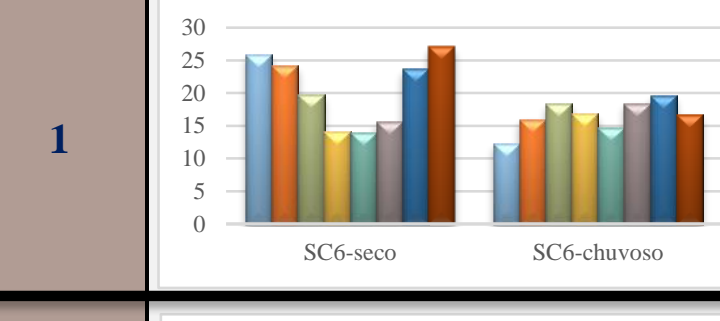 \\
\hline 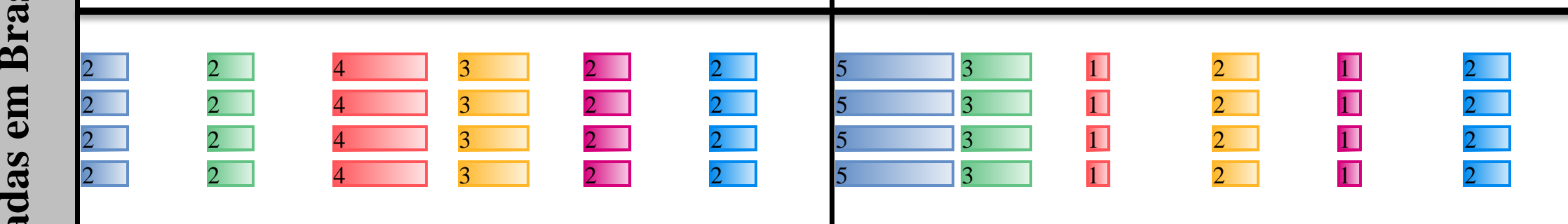 & inmowix & 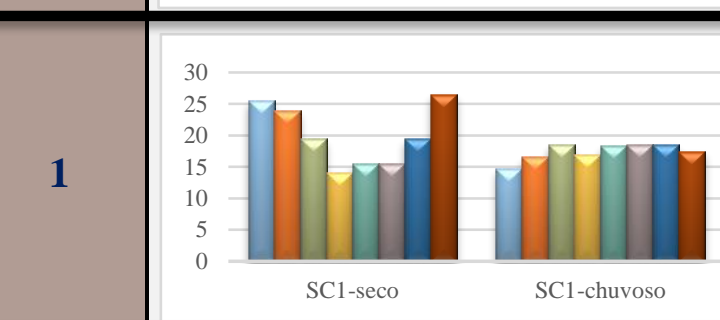 \\
\hline 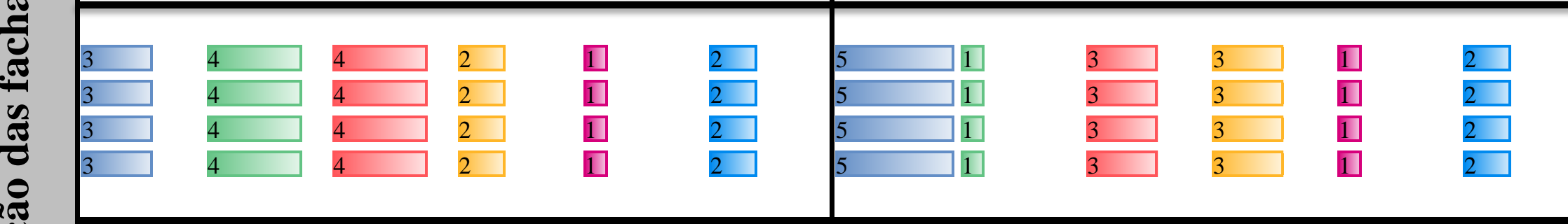 & , memixix & 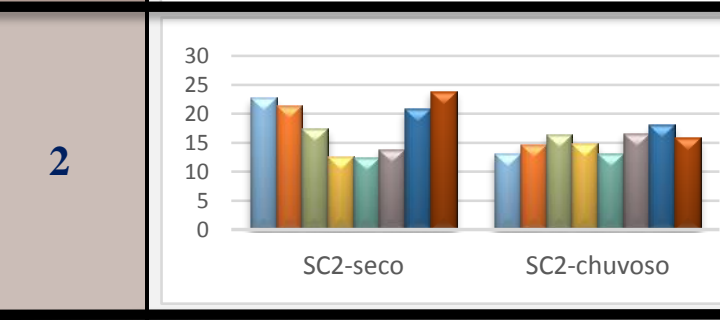 \\
\hline 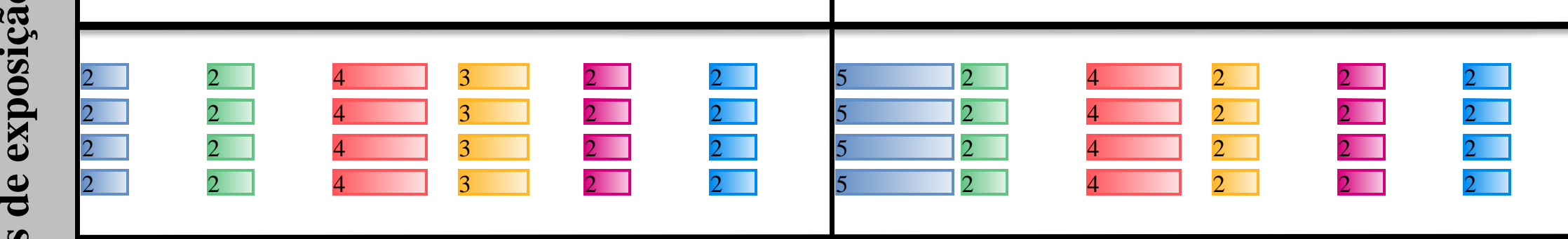 & smomers & 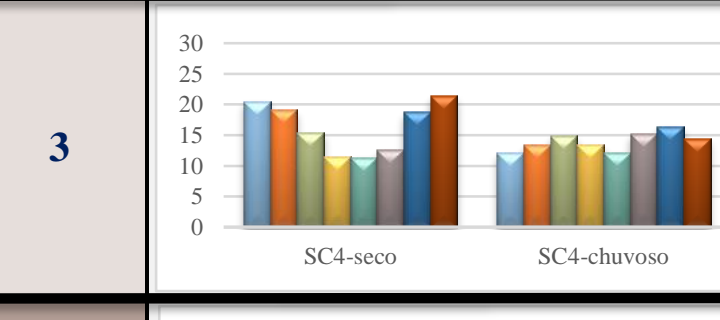 \\
\hline 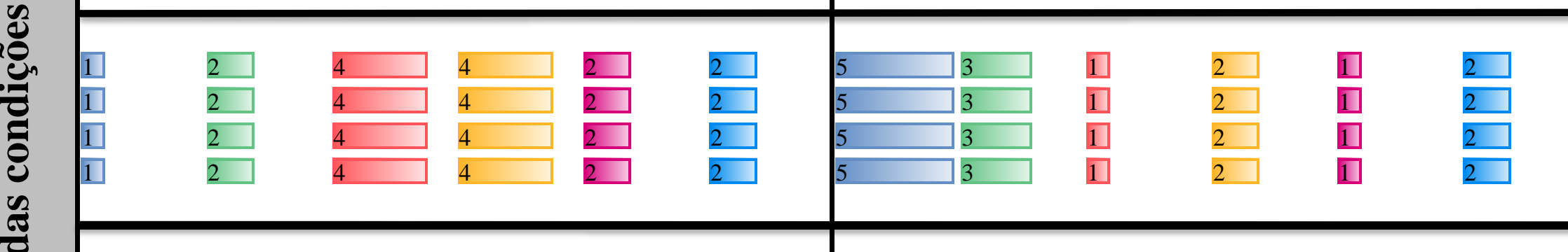 & numberix & 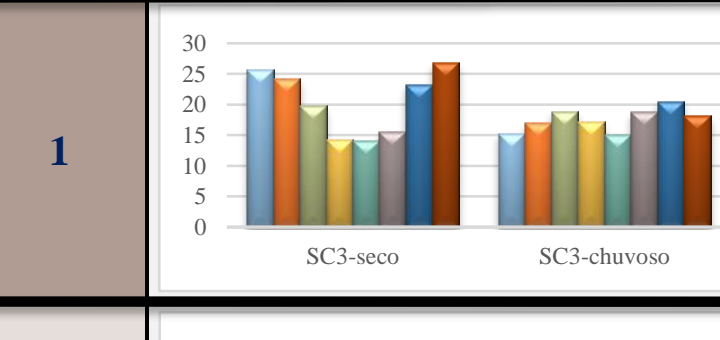 \\
\hline 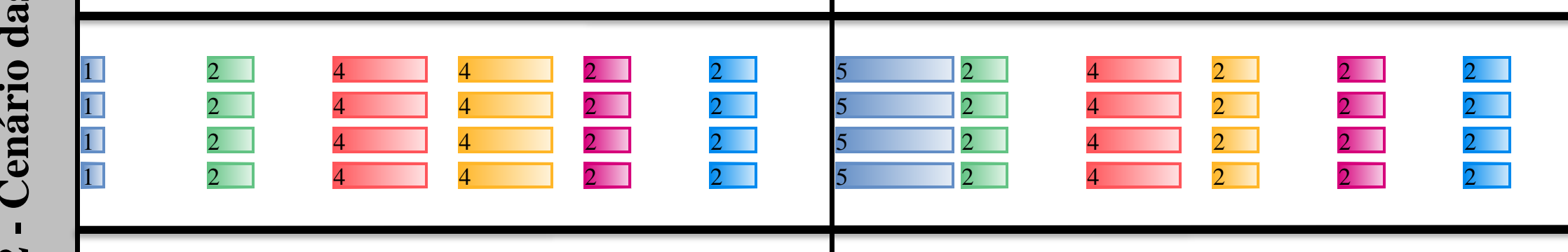 & smawaix & 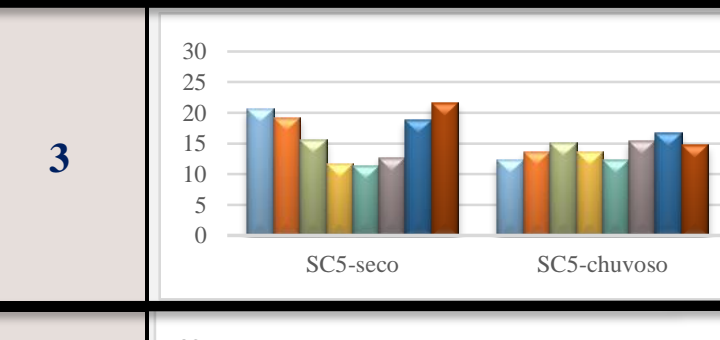 \\
\hline 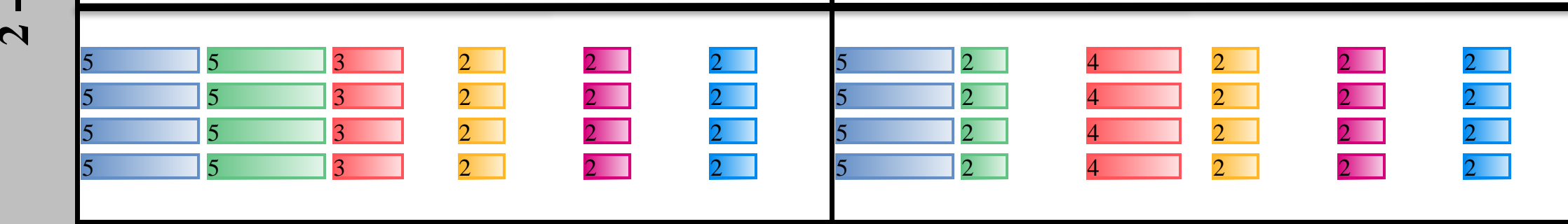 & 2asmonx & 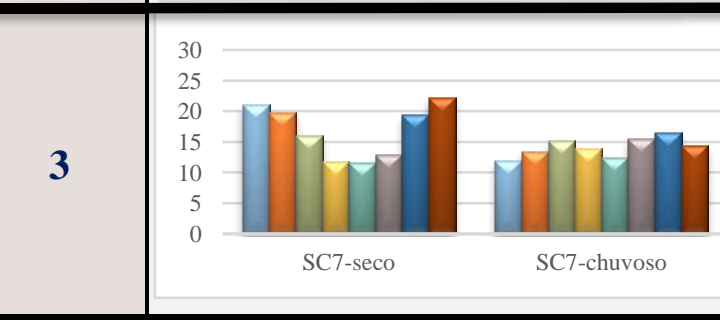 \\
\hline
\end{tabular}




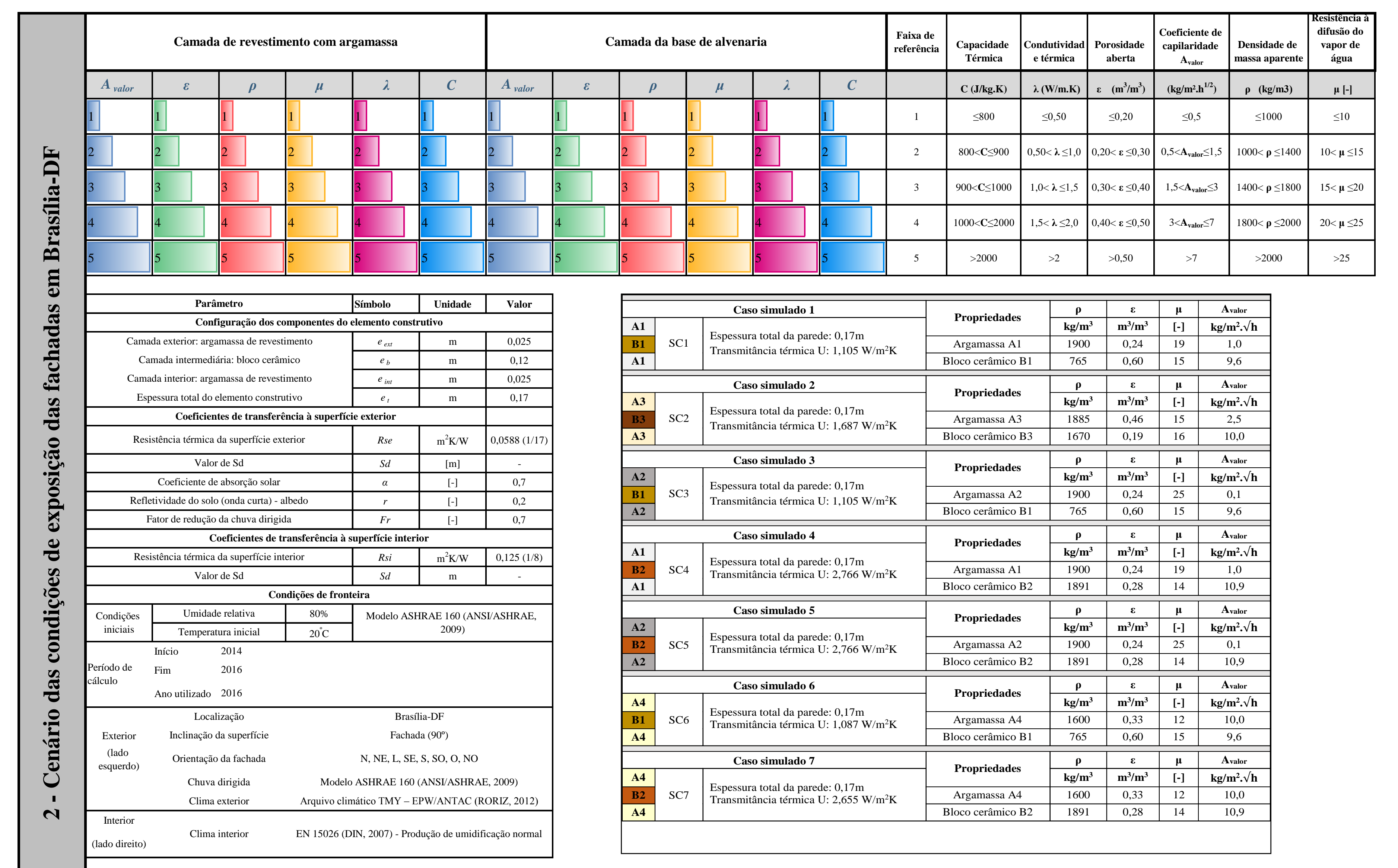




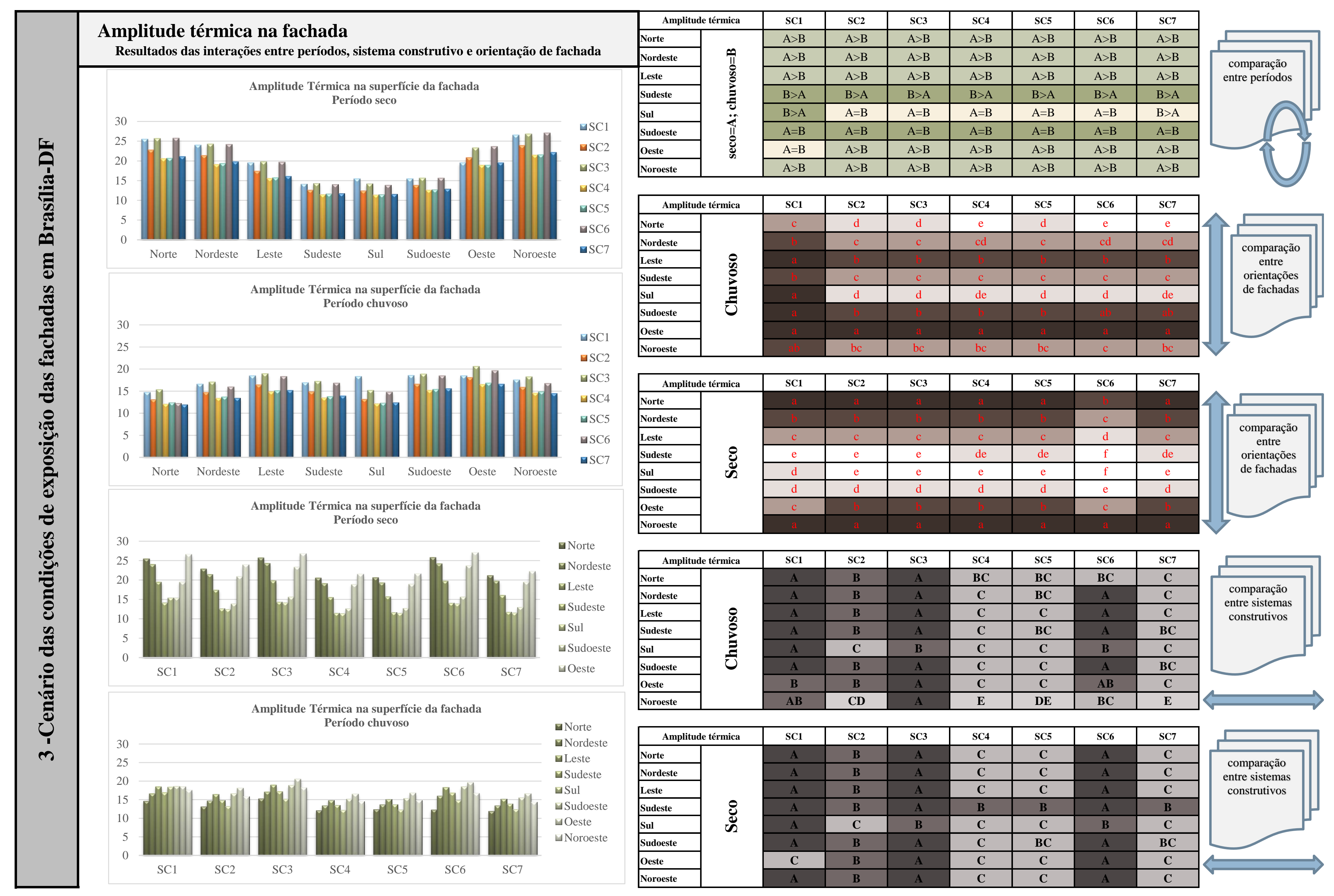




\section{Amplitude térmica na fachada}

Resultados das interaç̃os entre períodos, sistema construtivo e orientação de fachada

Estudo baseado em uma análise estatística sobre a interação entre as variáveis, por meio da técnica estatística Análise de Variância de três vias (ANOVA - three way), após verificação da distribuição normal da amostra. Por meio do pós-teste de Tukey da ANOVA de três vias, foram efetuadas as múltiplas comparações entre as sete variações do sistema construtivo, as oito orientações de fachadas e os dois períodos do ano, que estabeleceram 112 diferentes comparações, indicando quais delas apresentaram diferenças estatísticamente significativas $(\mathrm{p}<0,05)$.

Os valores apresentados são resultados das médias \pm desvios padrão das médias.

As letras maiúsculas nas colunas indicam se existem diferenças estatisticamente significativas no teor de umidade entre os períodos: A-seco e B-chuvoso.

As letras minúsculas nas colunas indicam se as orientações de fachada influenciam o teor de umidade, para cada sistema construtivo e período do ano, sendo: $\mathrm{a}>\mathrm{b}>\mathrm{c}>\mathrm{d}>\mathrm{e}$

As letras maiúsculas nas linhas indicam se existem diferenças no teor de umidade entre os sistemas construtivos, sendo: $\mathbf{A}>\mathbf{B}>\mathbf{C}>\mathbf{D}>\mathbf{E}$.

- Nas fachadas Norte, Nordeste, Leste e Noroeste foram constatadas diferenças estatisticamente significativas entre as médias da amplitude térmica na superfície de cada sistema estudado, sendo que no período seco as médias são maiores que no período chuvoso. - Nas fachadas Sudeste e Sudoeste, as médias da amplitude térmica na superfície, no período chuvoso, são maiores que no período seco - Na fachada Sul, somente o sistema SC1 apresentou médias maiores no período chuvoso que no seco; todos os demais sistemas não mostraram diferenças significativas entre os períodos.

- Na fachada Oeste, somente o sistema SC1 não mostrou diferença significativa entre os períodos; todos os demais sistemas apresentaram médias maiores no período seco que no chuvoso.

mparando a amplitude térmica na superfície de cada sistema conforme a orientação de fachada, no período chuvoso, observou-se que:

- O sistema SC1 é aquele que apresentou menos variação de amplitude térmica entre as fachadas. As fachadas Leste, Sul, Sudoeste e Oeste não foram diferentes entre si, e apresentaram os maiores valores. Com menores médias de amplitude térmica estão as fachadas Noroeste, Sudeste e Nordeste, seguidas pela Norte.

- Os sistemas SC2, SC3 e SC5 apresentaram as mesmas médias de amplitude térmica nas diversas fachadas. Os sistemas SC4, SC6 SC7 também apresentaram as mesmas médias de amplitude térmica nas diversas fachadas. Para esses sistemas, a fachada Oeste é aquela que apresentou os maiores valores de amplitude térmica na superfície, seguida pelas fachadas Sudoeste e Leste, que não mostraram diferença entre si. Na sequência, com valores decrescentes, encontram-se as fachadas Noroeste, Sudeste e Nordeste, seguidas pelas Sul e Norte.

Comparando a amplitude térmica na superfície de cada sistema conforme a orientação de fachada, no período seco, observou-se que - No sistema SC1, as maiores médias de amplitude térmica estão nas fachadas Norte e Noroeste, que não mostraram diferenças significativas entre si. Em sequência decrescente estão as fachadas Nordeste, Leste e Oeste, Sul e Sudoeste, seguidas pela Sudeste. - Os sistemas SC2, SC3, SC4, SC5 e SC7 apresentaram as mesmas médias de amplitude térmica entre as diversas fachadas. - No sistema SC6, surgiram as maiores variações entre as médias de amplitude térmica nas fachadas. A maior média ocorreu na diferença significativa entre si, seguidas pelas fachadas Leste e Sudoeste. Com os menores valores encontram-se as fachadas Sudeste Sul.

Comparando a amplitude termica na superfície de cada sistema conforme a orientação de fachada, no período seco observou-se que: - Nas fachadas Norte, Nordeste, Leste, Sudeste, Sudoeste e Noroeste, os sistemas SC1, SC3 e SC6 apresentaram as maiores médias de amplitude térmica da superfície. Com valores decrescentes das médias, segue o sistema SC2, e depois, os sistemas SC4, SC5 e SC7, que não mostraram diferenças significativas entre si.

- Na fachada Sul, o sistema SC1 apresentou o maior valor de média, seguido pelos sistemas SC3 e SC6. Nesta fachada, os sistemas SC2, SC4, SC5 e SC7 apresentaram as menores médias que não mostraram diferenças significativas entre sì.

- Na fachada Oeste, são os sistemas SC3 e SC6 aqueles que apresentaram as maiores médias de amplitude térmica, seguidos pelo sistema SC2. Os sistemas SC1, SC4, SC5 e SC7 apresentaram as menores médias, que não mostraram diferenç̧as significativas entre

Comparando a amplitude termica na superfície de cada sistema conforme a orientação de fachada, no período chuvoso, observou-se

- Nas fachadas Nordeste, Leste, Sudeste e Sudoeste os sistemas SC1, SC3 e SC6 apresentaram as maiores médias de amplitude térmica da superfície. Com valores decrescentes das médias, segue o sistema SC2, e depois, os sistemas SC4, SC5 e SC7, que não mostraram diferenças significativas entre si.

- Na fachada Norte, os sistemas SC1 e SC3 apresentaram as maiores médias, seguidos do sistema SC2. Os sistemas SC4, SC5, SC6 e SC7 não mostraram diferenças significativas entre sì.

- Na fachada Sul, o sistema SC1 apresentou a maior média, seguido pelos sistemas SC3 e SC6. Os sistemas SC2, SC4, SC5 e SC7 apresentaram as menores médias, que não mostraram diferenças significativas entre si.

- Na fachada Oeste, o sistema SC3 apresentou a maior média, seguido pelos sistemas SC1, SC2 e SC6. As menores médias foran apresentadas pelos sistemas SC4, SC5 e SC7, que não mostraram diferenças significativas entre si.

- Na fachada Noroeste, em ordem decrescente da média das amplitudes térmicas foram encontrados os sistemas SC3, SC1, SC6, SC2 e SC5. Os menores valores foram para SC4 e SC7. 


\begin{tabular}{|c|c|c|c|c|c|c|c|c|c|c|c|c|c|c|}
\hline \multirow{11}{*}{ 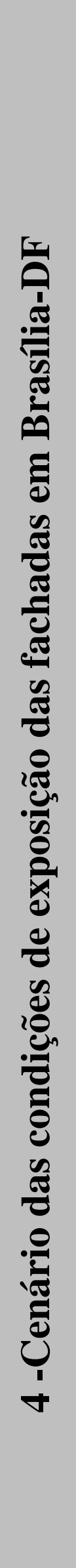 } & \multicolumn{14}{|c|}{ Patamares do Teor de Umidade Total e Teor de Umidade em cada camada do sistema construtivo. } \\
\hline & \multicolumn{7}{|c|}{ Camada de Revestimento com argamassa } & sc & \multicolumn{6}{|c|}{ Camada de base de alvenaria } \\
\hline & \multicolumn{5}{|c|}{ Propriedades } & \multirow{2}{*}{\multicolumn{5}{|c|}{\begin{tabular}{l}
\multicolumn{3}{|c|}{ Patamares de classificação } \\
Wtotal
\end{tabular}}} & \multicolumn{4}{|c|}{$\begin{array}{r}\text { Propriedades } \\
\end{array}$} \\
\hline & $A_{\text {valor }}$ & $\varepsilon$ & I $\rho$ & $\mu$ & 2 & & & & & & \begin{tabular}{l|l}
$A_{\text {valor }}$ & \\
\end{tabular} & $\rho \rho$ & $\mu$ & 2 \\
\hline & $\begin{array}{l}5 \\
5 \\
5 \\
5 \\
5 \\
5\end{array}$ & $\begin{array}{l}5 \\
5 \\
5 \\
5\end{array}$ & $\begin{array}{l}3 \\
3 \\
3\end{array}$ & $\begin{array}{l}2 \\
2 \\
2 \\
2 \\
2\end{array}$ & $\begin{array}{l}2 \\
2 \\
2 \\
2 \\
2 \\
\end{array}$ & 4 & 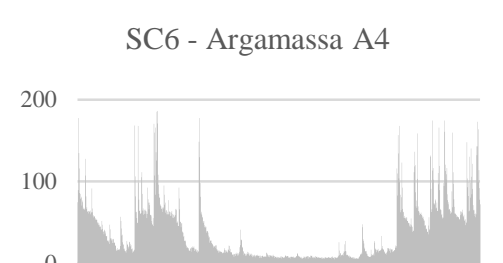 & & 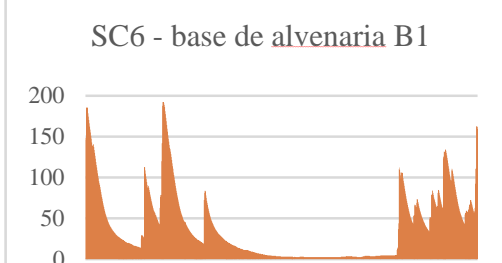 & 1 & \begin{tabular}{|l|l|}
5 & 3 \\
5 & 3 \\
5 & 3 \\
5 & 3 \\
\end{tabular} & $\begin{array}{l}1 \\
1 \\
1 \\
1\end{array}$ & $\begin{array}{l}2 \\
2 \\
2 \\
2 \\
\end{array}$ & $\begin{array}{l}1 \\
0 \\
0 \\
0 \\
1\end{array}$ \\
\hline & \begin{tabular}{|l}
2 \\
2 \\
2 \\
2 \\
\end{tabular} & $\begin{array}{l}2 \\
2 \\
2 \\
2 \\
2\end{array}$ & \begin{tabular}{l|}
4 \\
4 \\
4 \\
4 \\
\end{tabular} & $\begin{array}{l}\frac{3}{3} \\
\frac{3}{3} \\
3 \\
\end{array}$ & $\begin{array}{l}2 \\
2 \\
2 \\
2 \\
2\end{array}$ & 3 & ${ }_{200} \frac{\text { SC1 - Argamassa A1 }}{{ }_{100}}$ & 2 & $\begin{array}{l}200 \\
150 \\
100 \\
50 \\
0\end{array}$ & 2 & \begin{tabular}{l|l}
5 & 3 \\
5 & 3 \\
5 & 3 \\
5 & 3 \\
\end{tabular} & $\begin{array}{l}1 \\
1 \\
1 \\
1 \\
1\end{array}$ & $\begin{array}{l}2 \\
2 \\
2 \\
2 \\
\end{array}$ & $\begin{array}{l}1 \\
1 \\
1 \\
1 \\
1\end{array}$ \\
\hline & \begin{tabular}{|l|}
3 \\
3 \\
3 \\
3 \\
\end{tabular} & \begin{tabular}{l|}
4 \\
4 \\
4 \\
4 \\
\end{tabular} & \begin{tabular}{l|}
4 \\
4 \\
4 \\
4 \\
\end{tabular} & $\begin{array}{l}2 \\
2 \\
2 \\
2 \\
\end{array}$ & $\begin{array}{l}1 \\
0 \\
0 \\
0 \\
0\end{array}$ & & $\begin{array}{l}200 \\
\text { SC2 - Argamassa A3 } \\
150 \\
100 \\
50 \\
0\end{array}$ & 3 & $\begin{array}{l}\text { SC2 - base de alvenaria B3 } \\
200 \\
150 \\
150 \\
50 \\
0\end{array}$ & 5 & \begin{tabular}{|l|l|}
5 & 1 \\
5 & 1 \\
5 & 1 \\
5 & 1
\end{tabular} & $\begin{array}{l}3 \\
3 \\
3 \\
3\end{array}$ & $\begin{array}{l}\frac{3}{3} \\
3 \\
3 \\
\end{array}$ & $\begin{array}{l}1 \\
1 \\
1 \\
1 \\
1\end{array}$ \\
\hline & \begin{tabular}{|l}
2 \\
2 \\
2 \\
2 \\
\end{tabular} & $\begin{array}{l}2 \\
2 \\
2 \\
2 \\
\end{array}$ & \begin{tabular}{l|}
4 \\
4 \\
4 \\
4 \\
\end{tabular} & $\begin{array}{l}\frac{3}{3} \\
\frac{3}{3} \\
3\end{array}$ & $\begin{array}{l}2 \\
2 \\
2 \\
2 \\
2 \\
\end{array}$ & 2 & \begin{tabular}{r|r|r|} 
& SC4 - Argamassa A1 \\
200 & \\
150 & & \\
100 & & \\
50 & & \\
0 & &
\end{tabular} & 4 & $\begin{array}{l}\text { SC4 - base de alvenaria B2 } \\
200 \\
150 \\
100 \\
50 \\
0\end{array}$ & 6 & \begin{tabular}{|l|l|}
5 & 2 \\
5 & 2 \\
5 & 2 \\
5 & 2 \\
\end{tabular} & \begin{tabular}{l|}
4 \\
4 \\
4 \\
4
\end{tabular} & $\begin{array}{l}2 \\
2 \\
2 \\
2 \\
2\end{array}$ & $\begin{array}{l}2 \\
2 \\
2 \\
2 \\
\end{array}$ \\
\hline & $\begin{array}{l}1 \\
1 \\
1 \\
1 \\
1\end{array}$ & $\begin{array}{l}2 \\
2 \\
2 \\
2 \\
2\end{array}$ & \begin{tabular}{l|}
4 \\
4 \\
4 \\
4 \\
\end{tabular} & \begin{tabular}{l|}
4 \\
4 \\
4 \\
4 \\
\end{tabular} & $\begin{array}{l}2 \\
2 \\
2 \\
2 \\
2 \\
\end{array}$ & 7 & 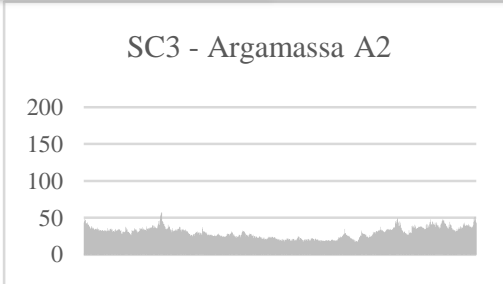 & 5 & $\begin{array}{l}\text { SC3 - base de alvenaria B1 } \\
200 \\
150 \\
100 \\
50 \\
0\end{array}$ & 3 & \begin{tabular}{l|l|}
5 & 3 \\
5 & 3 \\
5 & 3 \\
5 & 3 \\
\end{tabular} & $\begin{array}{l}1 \\
1 \\
1 \\
1 \\
1\end{array}$ & $\begin{array}{l}2 \\
2 \\
2 \\
2 \\
\end{array}$ & $\begin{array}{l}1 \\
1 \\
1 \\
1 \\
1\end{array}$ \\
\hline & $\begin{array}{l}1 \\
1 \\
1 \\
1 \\
1 \\
1\end{array}$ & $\begin{array}{l}2 \\
2 \\
2 \\
2 \\
\end{array}$ & \begin{tabular}{l|}
4 \\
4 \\
4 \\
4 \\
\end{tabular} & \begin{tabular}{l|}
4 \\
4 \\
4 \\
4 \\
\end{tabular} & $\begin{array}{l}2 \\
2 \\
2 \\
2 \\
2 \\
\end{array}$ & 6 & 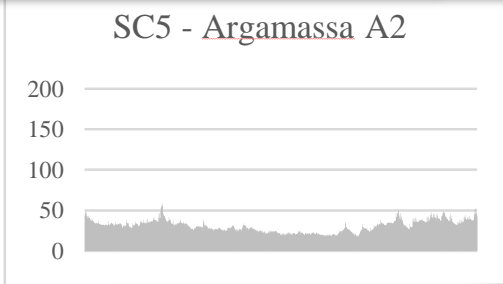 & 6 & $\begin{array}{l}\text { SC5 - base de alvenaria B2 } \\
200 \\
150 \\
100 \\
50 \\
0\end{array}$ & 7 & \begin{tabular}{|l|l|}
5 & 2 \\
5 & 2 \\
5 & 2 \\
5 & 2 \\
\end{tabular} & \begin{tabular}{l|}
4 \\
4 \\
4 \\
4
\end{tabular} & $\begin{array}{l}2 \\
2 \\
2 \\
2 \\
2\end{array}$ & $\begin{array}{l}2 \\
2 \\
2 \\
2 \\
2\end{array}$ \\
\hline & $\begin{array}{l}5 \\
5 \\
5 \\
5 \\
5 \\
5\end{array}$ & $\begin{array}{l}5 \\
5 \\
5 \\
5\end{array}$ & $\begin{array}{l}3 \\
3 \\
3\end{array}$ & $\begin{array}{l}2 \\
2 \\
2 \\
2 \\
\end{array}$ & $\begin{array}{l}2 \\
2 \\
2 \\
2 \\
2 \\
\end{array}$ & 5 & \begin{tabular}{rl|l||} 
& \multicolumn{2}{c}{ SC7 - Argamassa A4 } \\
200 & \\
150 \\
100 \\
50 \\
0 \\
0
\end{tabular} & 7 & $\begin{array}{l}\text { SC7 - base de alvenaria B2 } \\
200 \\
150 \\
100 \\
50 \\
0\end{array}$ & 4 & \begin{tabular}{|l|l|}
5 & 2 \\
5 & 2 \\
5 & 2 \\
5 & 2 \\
\end{tabular} & \begin{tabular}{l|}
4 \\
4 \\
4 \\
4
\end{tabular} & $\begin{array}{l}2 \\
2 \\
2 \\
2 \\
\end{array}$ & $\begin{array}{l}2 \\
2 \\
2 \\
2 \\
2\end{array}$ \\
\hline
\end{tabular}




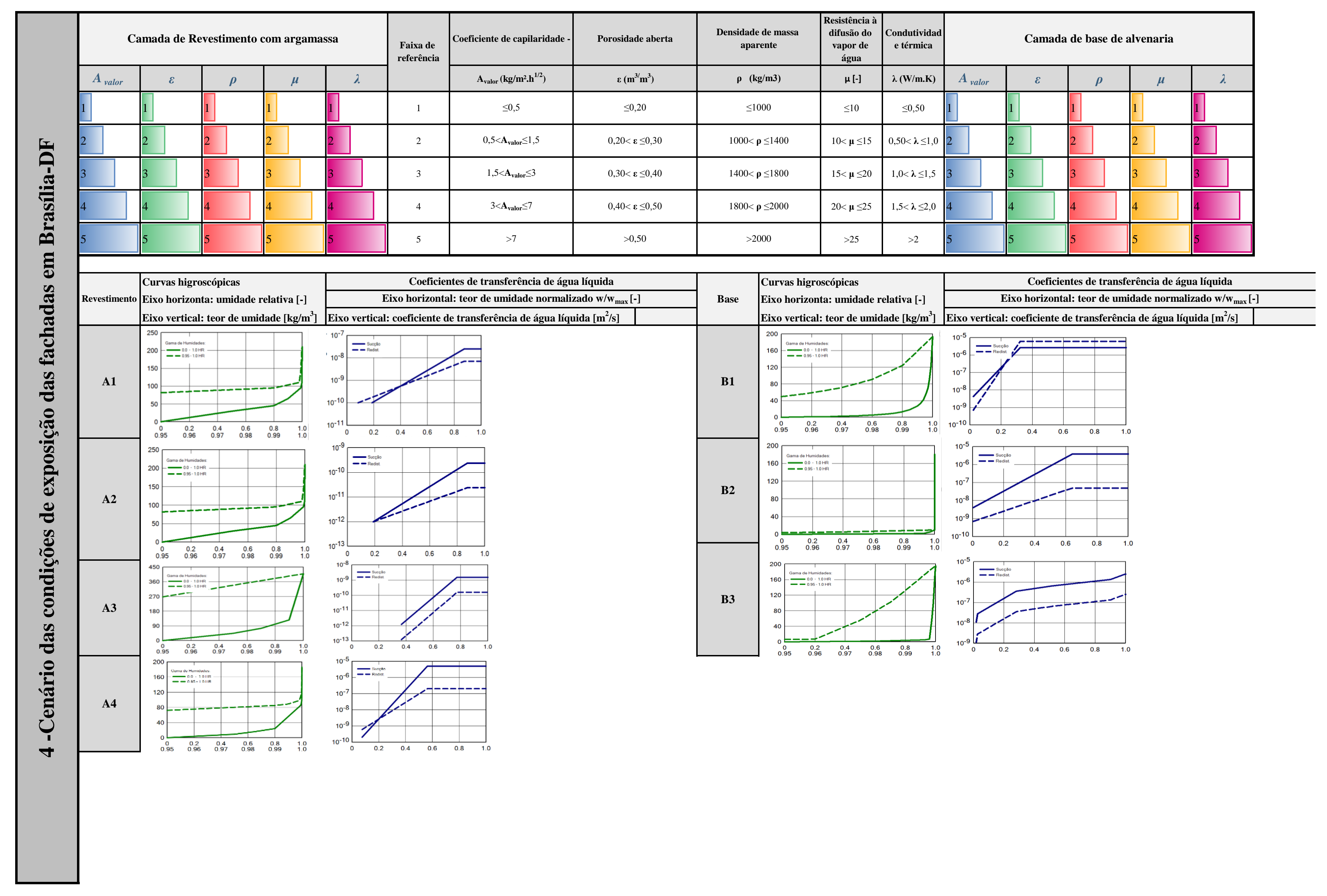




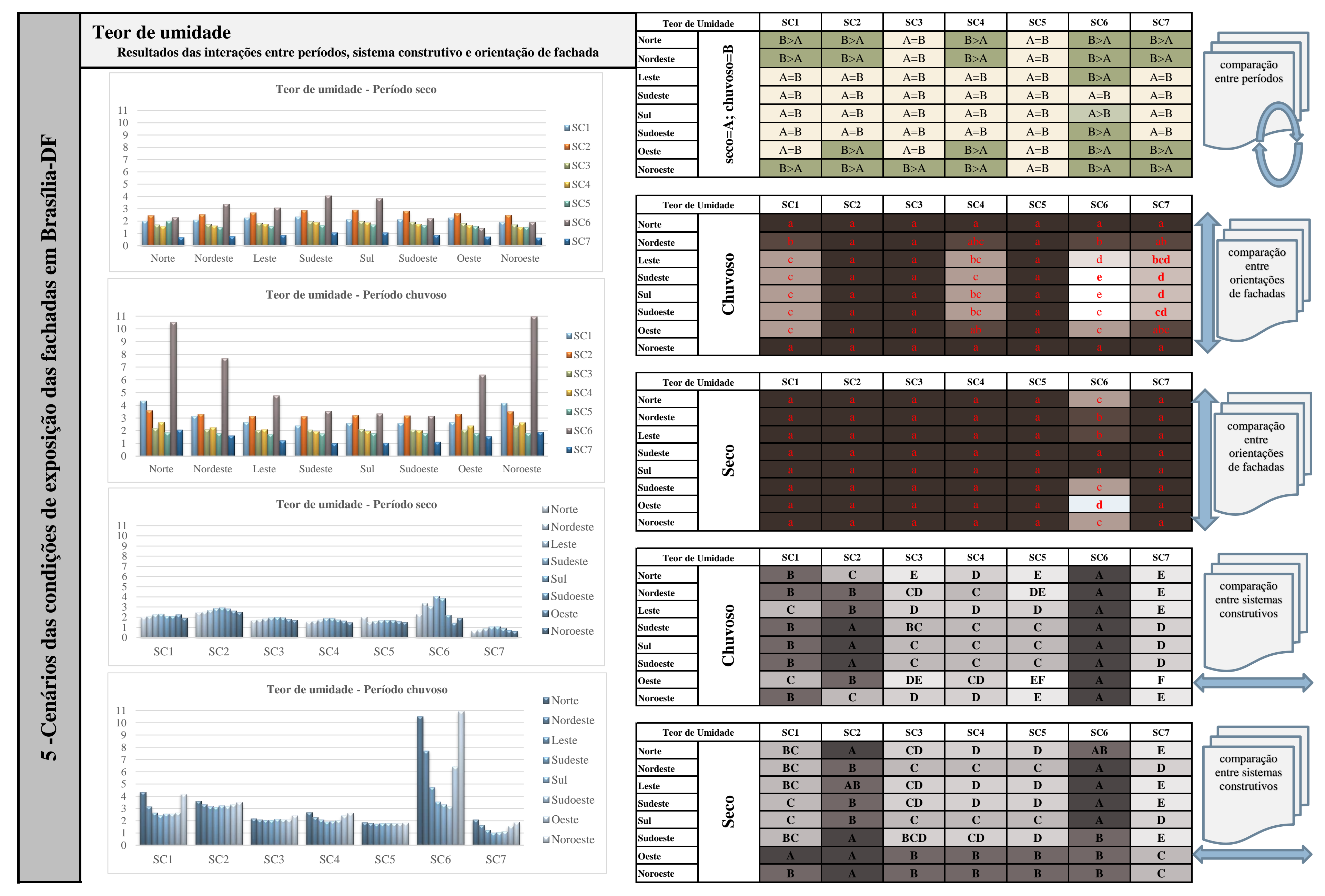




\section{Teor de umidade}

\section{Resultados das interações entre períodos, sistema construtivo e orientação de fachada}

Estudo baseado em uma análise estatística sobre a interação entre as variáveis, por meio da técnica estatística Análise de Variância de três vias (ANOVA - three way), após verificação da distribuição normal da amostra. Por meio do pós-teste de Tukey da ANOVA de três vias, foram efetuadas as múltiplas comparações entre as sete variações do sistema construtivo, as oito orientações de fachadas e os dois períodos do ano, que estabeleceram 112 diferentes comparações, indicando quais delas apresentaram diferenças estatísticamente significativas $(\mathrm{p}<0,05)$

Os valores apresentados são resultados das médias \pm desvios padrão das médias.

As letras maiúsculas nas colunas indicam se existem diferenças estatisticamente significativas no teor de umidade entre os períodos: A-seco e B-chuvoso.

As letras minúsculas nas colunas indicam se as orientações de fachada influenciam o teor de umidade, para cada sistema construtivo e período do ano, sendo: $\mathrm{a}>\mathrm{b}>\mathrm{c}>\mathrm{d}>\mathrm{e}$

As letras maiúsculas nas linhas indicam se existem diferenças no teor de umidade entre os sistemas construtivos, sendo: $\mathbf{A}>\mathbf{B}>\mathbf{C}>\mathbf{D}>\mathbf{E}$.
Resultados das interaç̃es entre as sete variaç̃es do sistema construtivo (SC1, SC2, SC3, SC4, SC5, SC6 e SC7) e as oito orientações de fachadas (Norte, Nordeste, Leste, Sudeste, Sul, Sudoeste, Oeste e Noroeste), nos períodos seco e chuvoso do aco:

- Na fachada Norte e Nordeste, somente os sistemas SC3 e SC5 não mostraaram diferenças significativas entre os períodos; nos demais sistemas as nédias do teor de umidade do período chuvoso foram maiores que no período seco.

- Nas fachadas Leste e Sudoeste, não existiram diferenças significativas entre as médias dos períodos, com exceção do sistema SC6 que apresentou

gnificativa entre as médias do teor de umidade nos períodos.

- Na fachada Sul, com exceção do sistema SC6 que apresentou maior teor de umidade no período seco, nenhum dos demais sistemas mostrou

diferença significativa entre as médias do teor de umidade nos períodos.

- Na fachada Oeste, os sistemas SC1, SC3 e SC5 não apresentaram diferenças significativas entre as médias do teor de umidade nos períodos, mas o de umidade do período chuvoso foram maiores que no período seco.

No período seco:

- Os casos estudados não apresentaram diferenças estatisticamente significativas no teor de umidade entre as fachadas, com exceção do sistema SC6 que armazenou maior teor de umidade nas fachadas Sul e Sudeste, seguidas pelas fachadas Leste e Norleste. As fachadas Norte, Sudoeste e Noroeste de umidade para o sistema SC6 neste período foi encontrado na fachada Oeste.

No período chuvoso:

- Os sistemas SC2, SC3 e SC5 não apresentaram diferenças entre as fachadas, quanto ao teor de umidade armazenado.

- Os sistemas SCl, SC4, SC6 e SC7 apresentaram os maiores teores de umidade nas fachadas Norte e Noroeste. Nestas fachadas ocorrem as maiores incidências de chuva dirigida.

ados pelo sistema SC1 nas fachadas Norte e Noroeste são similares. Com menor teor de umidade, está a fachada Nordeste, seguida pelas fachadas Leste, Sudeste, Sul, Sudoeste e Oeste, que não mostraram diferenças entre si.

gelaidas pelas fachadas Nordeste e Oeste. As - O sistema SC6 apresentou os maiores teores de umidade nas fachadas Norte e Noroeste, em resposta à incidência da chuva dirigida. Em quantidade decrescente do teor de umidade estão as fachadas Nordeste, Oeste e Leste. Os menores teores são encontrados nas fachadas Sudeste, Sul e Sudoeste,

- Para o sistema SC7, as fachadas Norte e Noroeste são aquelas que apresentaram os maiores teores de umidade, seguidas das fachadas Nordeste e Oeste. Com os menores teores de umidade estão as fachada Sudeste, Sul e Sudoeste que não apresentaram muita diferença entre si.

No período chuvoso observou-se que

- O sistema SC6 apresentou o maior teor de umidade entre todos os sistemas analisados, em todas as orientações de fachada, sendo que nas fachadas Sudeste, Sul e Sudoeste, o teor de umidade do sistema SC2 não apresentou diferennça significativa do sistema SC6.

- Abaixo do teor de umidade do sistema SC6, encontra-se o sistema SC1 nas fachadas Norte, Nordeste, Sudeste, Sul, Sudoeste e Noroeste, e o

sistema SC2 nas fachadas Nordeste, Leste e Oeste.
- Os sistemas SC3, SC4, SC5 e SC7 apresentaram os menores teores de umidade, sendo que o sistema SC7 é aquele que apresentou o menor teor de

No período seco observou-se que:

- Os sistemas SC2 e SC6 são aqueles com maior teor de umidade. Nas fachadas Norte, Sudoeste, Oeste e Noroeste o sistema SC2 apresentou maio umidade que o sistema SC6. No entanto, nas fachadas Nordeste, Leste, Sudeste e Sul foi o sistema SC6 que predominou sobre o sistema SC

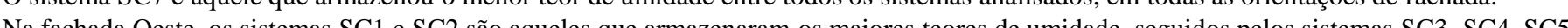
SC6, que ñ O mostras diferençs significativas nos teores a - Na fachada Noroeste, o sistema SC2 armazenou on diferenç̧as significativas nos teores de umidade retidos. (a) - Nas fachadas Leste, Sudeste e Sudoeste, o e sistema SC6 reteve o maior teor de un. SC5 não apresentaram diferenças significativas entre eles, na umidade armazenada. 


\section{CAPÍtULO VII}

\section{CONCLUSÕES DA TESE}

\subsection{CONSIDERAÇÕES INICIAIS}

O envelhecimento natural das edificações é consequência da atuação de mecanismos de degradação ao longo do tempo, decorrente não só da intensidade, mas também da frequência de ocorrência das ações dos agentes de degradação.

Como os processos que envolvem a degradação de fachadas são complexos devido à sinergia entre os agentes de degradação, nem sempre é possível estudá-los somente no ambiente controlado do laboratório de ensaios. Por isso, as simulações computacionais, assim como as medições em campo e as experimentações laboratoriais, devem ser complementares, tornandose um conjunto de recursos necessários para que se amplie a compreensão dos fenômenos de degradação e as variáveis envolvidas.

O conhecimento das condições de exposição das fachadas aos agentes externos de origem climática permite compreender melhor as interações entre os agentes e os processos de degradação ao longo da vida útil da edificação.

A ação e interação entre os agentes climáticos de degradação e o comportamento higrotérmico do sistema construtivo, em relação às orientações de fachada ao longo dos períodos do ano, são informações necessárias para balizar os procedimentos de especificação em projeto ou planejamento de manutenções de sistemas de fachadas.

No entanto, esta tese revela a ausência de requisitos e critérios para os estudos sistematizados de degradação de fachadas quando envolvem as condições de exposição aos agentes externos de origem climática.

Não havendo uma abordagem metodológica estabelecida, esta tese torna-se um estudo prospectivo/propositivo das sistematizações e referências necessárias para avançar na consolidação do conhecimento relacionado à degradação e aos fenômenos envolvidos, delineando uma base técnica de referência para a análise de sensibilidade no uso de ferramentas higrotérmicas computacionais. 


\subsection{OBJETIVOS ALCANÇADOS E CONTRIBUIÇÕES DA TESE}

\section{$\rightarrow \quad$ Relacionados aos estudos dos arquivos e agentes climáticos}

Os estudos exploratórios e comparativos sobre as variáveis climáticas e os arquivos de dados climáticos apresentados no Capítulo II permitiram caracterizar as variáveis climáticas, com base em 13 anos de dados horários.

Entre as ausências reveladas por esta tese, uma das principais dificuldades e limitações encontradas nos estudos realizados foi a falta de referências brasileiras para a seleção, apresentação e aplicação em projeto de dados climáticos, por exemplo, como aquelas apresentadas pelas normas BS EN ISO 15927-4: 2005, DIN EN 15026: 2007, entre outras.

Apesar de os importantes avanços da NBR15575, esse conjunto de normas brasileiras de desempenho enfatiza os estudos de desempenho térmico, prescrevendo dados climáticos somente para os dias típicos, sem considerar aspectos relacionados às interações entre o clima e a durabilidade das fachadas. Ou seja, a análise pontual das condições de exposição em um dia típico não é uma abordagem que atende às necessidades dos estudos de degradação por envelhecimento natural, que necessitam de longos períodos de tempo, mais representativos das condições de exposição durante a vida útil do sistema construtivo.

Os anos climáticos, típico ou de referência, disponíveis para a cidade de Brasília, são aqueles construídos por meio de metodologias consagradas para os estudos de eficiência energética e conforto ambiental. Para os estudos de degradação no Brasil, não existe uma avaliação sobre qual a melhor metodologia para compor um ano climático de referência que contemple a natureza dos problemas específicos a serem tratados.

Os estudos exploratórios e comparativos, realizados entre alguns arquivos climáticos existentes para a cidade de Brasília, permitiram compreender que é necessário desenvolver um ano climático de referência para os estudos de degradação que tenha uma metodologia mais adequada aos fenômenos estudados, tal como proposto pela norma BS EN ISO 15927-4: 2005, que parte da premissa que a correta simulação do desempenho do edifício depende não apenas dos valores médios das variáveis meteorológicas, mas também das distribuições de frequência desses e da correlação entre eles. Além dos valores de temperatura e umidade relativa, a metodologia da norma citada contempla as variáveis radiação solar e vento.

A oportunidade pioneira de trabalhar com a caracterização da série 2001-2013 do INMET, que compõe a primeira base de dados climáticos horários para Brasília, registrados pela estação automática de superfície A001-Brasília-DF, foi uma importante contribuição para melhor 
compreender a qualidade dos arquivos climáticos e outras fontes de informações que são disponibilizados ao público, assim como caracterizar quantitativamente as variáveis climáticas em seu comportamento cíclico e sazonal ao longo do ano, com base nos estudos dos valores médios, mínimos, máximos e frequências de ocorrência.

A quantificação dos valores médios, máximos e mínimos, assim como a frequência de ocorrência das principais variáveis climáticas para os estudos de degradação, permitiram mostrar que os comportamentos dos agentes climáticos em Brasília, ao longo dos meses do ano, caracterizam dois períodos bem distintos, identificados como seco e chuvoso, com periodicidade semestral para os estudos de degradação de fachada nesta cidade.

Os estudos comparativos entre os arquivos climáticos disponíveis para a cidade de Brasília permitiram selecionar o arquivo TMY-EPW/ANTAC (RORIZ, 2012) como o mais representativo para os estudos higrotérmicos por meio de simulação computacional, visando à avaliação das condições de exposição das edificações à degradação por envelhecimento natural. Os resultados alcançados foram sintetizados em um cenário de representação das condições de exposição das fachadas aos agentes externos de origem climática, atendendo aos objetivos propostos nesta tese.

A representação síntese dos dados climáticos da série 2001-2013 em cenários das condições de exposição aos agentes climáticos de degradação, consolida uma base referencial para a análise de sensibilidade, nos estudos sobre os agentes externos de origem climática.

\section{$\rightarrow$ Relacionados aos estudos sobre chuva dirigida}

A umidade é considerada uma das principais causas de degradação das edificações. A variação do teor de umidade presente no sistema de fachadas é um indicador das condições de exposição da edificação e representa a capacidade de armazenamento, redistribuição e secagem do sistema de vedação vertical como resposta às variações de umidade ao longo da sua vida útil.

A principal fonte de umidade das edificações é a chuva dirigida, no entanto, os estudos sobre chuva dirigida apresentados no Capítulo III permitiram identificar a ausência de dados sobre medições in situ de chuva dirigida no Brasil.

Observou-se, também, que o conceito de chuva dirigida não é citado em nenhuma norma brasileira, diferentemente do que acontece no âmbito internacional, onde várias normas e documentos de referência técnica abordam modelos, métodos, critérios e requisitos associados à chuva dirigida, a exemplo da norma ISO 15927-4 (BS, 2005) e da ANSI/ASHRAE 160:2009. 
A necessidade de selecionar um método de quantificação de chuva dirigida, para ser utilizado nos estudos higrotérmicos por meio de simulação computacional, levou ao desenvolvimento do programa experimental de medição in situ realizado para esta tese.

O programa experimental com medições in situ da chuva dirigida, realizado em Brasília, é uma contribuição inédita desta tese e atingiu plenamente os objetivos propostos.

Foram determinados os coeficientes de chuva dirigida e inferido qual o método semi-empírico para quantificação de chuva dirigida que melhor representa as condições urbanas da cidade de Brasília.

Os resultados do programa experimental para medição de chuva dirigida in situ permitiram determinar os seguintes coeficientes de chuva dirigida $(\alpha)$ para Brasília:

- $\alpha=0,20$ para um contexto urbano com exposição média, em região de fachada com cerca de $10 \mathrm{~m}$ de altura;

- $\alpha=0,27$ para um contexto urbano com exposição média, em região de fachada com cerca de $20 \mathrm{~m}$ de altura.

Por inferência, o método proposto pela ASHRAE 160:2009 para quantificação de chuva dirigida é aquele que apresenta o coeficiente $\alpha$ com a maior correlação em relação ao coeficiente de chuva dirigida obtido por meio das medições in situ, podendo ser indicado como um método representativo das condições urbanas estudadas na cidade de Brasília, visando ao uso de ferramentas de simulação higrotérmica computacional.

Os estudos trouxeram uma abordagem metodológica que integra os métodos analíticos com o método experimental de medição in situ, procedimento importante para consolidar os modelos semi-empíricos que são acessíveis e de baixo custo.

O método adotado para medição de chuva dirigida in situ mostrou-se eficiente, pouco oneroso e de simples aplicação, podendo ser replicado para qualquer cidade brasileira, desde que se tenha, concomitantemente com as medições in situ da chuva dirigida, os dados de uma estação meteorológica representativa do contexto urbano em análise.

$\rightarrow$ Relacionados aos estudos sobre comportamento higrotérmico de sistemas de fachadas porosas e simulação higrotérmica computacional

Os estudos das variações higrotérmicas dos sistemas porosos de vedação vertical (alvenaria revestida com argamassa) foram fundamentados por uma base teórica referente aos fenômenos de transporte de calor e massa, aos agentes e mecanismos de degradação e às propriedades 
higrotérmicas dos materiais e componentes de construção, tratados no Capítulo IV. Esse capítulo preparou a base conceitual para os estudos por meio de simulações higrotérmicas computacionais, embasando a seleções dos componentes construtivos e as análises dos resultados.

A máxima temperatura superficial da fachada apresenta comportamento similar ao comportamento da máxima amplitude térmica. No entanto, as condições de exposição do sistema construtivo às variações térmicas, em determinada orientação de fachada, são melhor representadas pelas máximas amplitudes térmicas mensais na superfície da fachada, visto que sintetizam melhor os fenômenos de aquecimento e arrefecimento cíclico diário, decorrentes das variações horárias da geometria da insolação e da temperatura do ar, além das características e propriedades higrotérmicas do elemento construtivo em análise.

Devido à simetria da trajetória solar em relação ao eixo Norte-Sul, a radiação solar incidente na fachada Oeste é similar à fachada Leste, assim como a radiação solar incidente na Fachada Noroeste e Sudoeste são, respectivamente, similares às fachadas Nordeste e Sudeste. A temperatura superficial, assim como a amplitude térmica na superfície, são melhores indicadores das variações higrotérmicas que atuam nas fachadas do que o total da irradiação solar incidente, pois são resultados da interação entre a radiação solar e a elevação da temperatura do ar, ao longo do dia.

O ano climático típico TMY, conforme sua metodologia de obtenção, é um ano resultante de meses com dados médios de temperatura e umidade relativa. Por isso, conclui-se que as máximas mensais para a amplitude térmica na superfície da fachada são indicadores mais representativos das condições de exposição ao envelhecimento natural das edificações.

Por outro lado, o ano climático típico pode não ser representativo do regime de chuvas ou de ventos. Portanto, para não incorrer no risco de estar selecionando valores extremos ou valores máximos, que representam precipitações ou ventos cuja frequência de ocorrência pode ser muito baixa, considera-se a média mensal do teor de umidade o indicador mais representativo. O teor de umidade do sistema construtivo é uma resposta às condições de exposição à chuva dirigida e à umidade relativa do ar. Os picos de umidade coincidem com os picos de chuva dirigida, nos meses em que a fachada em análise é mais afetada pela incidência da chuva. No entanto, o teor de umidade médio mensal representa melhor as condições de exposição do sistema construtivo às variações de umidade, pois equaliza melhor o comportamento dos 
processos de molhagem, redistribuição e secagem nas diferentes camadas do sistema de fachada, ao longo dos dias do mês.

A seleção das variáveis de estudo, a saber, teor de umidade e amplitude térmica da fachada, mostraram-se capazes de representar a influência dos agentes externos de degradação de origem climática, nos períodos seco e chuvoso, permitindo avaliar as condições de exposição das principais orientações de fachada.

A partir das quantificações das variações higrotérmicas por meio das simulações realizadas e da técnica estatística Análise de Variância (ANOVA de três vias) foi possível aferir as interações por meio de múltiplas comparações.

Constatou-se, como principal limitação no uso do programa de simulação higrotérmica, a ausência de uma base de dados brasileira de propriedades higrotérmicas de materiais e componentes de construção. Usualmente, parte das propriedades não são determinadas pelos laboratórios brasileiros de ensaio, visto que as normas nacionais trazem exigências ou critérios mínimos quanto à seleção de materiais e especificações baseados nas propriedades e desempenho higrotérmicos. Além disso, em geral, as normas brasileiras não exigem dos fabricantes, tampouco dos projetistas e construtores, caracterização das propriedades higrotérmicas, com base nos mecanismos de transporte de calor e umidade, ou visando os agentes e mecanismos de degradação aos quais estão sujeitos os sistemas de fachada porosa, durante a sua vida útil.

Já existe no Brasil um conjunto de informações sobre propriedades térmicas genéricas destinado aos estudos voltados para desempenho térmico, eficiência energética e conforto ambiental (conforme apresentado pela ABNT NBR 15220-3: 2005c). No entanto, falta uma base referencial brasileira de dados genéricos resultantes de ensaios laboratoriais para as propriedades higrotérmicas dos componentes e sistemas construtivos mais utilizados.

O programa computacional de simulação higrotérmica WUFI Pro 5.3 Fraunhofer - IBP (2013) mostrou-se uma ferramenta computacional para simulação higrotérmica com potencial para os estudos de degradação.

$\mathrm{Na}$ fase de pós-processamento, os resultados das análises das simulações computacionais apresentados no Capítulo VI atenderam aos objetivos propostos e responderam às questões de pesquisa. Foi possível estabelecer uma relação entre dose e resposta, com base nos agentes e mecanismos de degradação relacionados às variações higrotérmicas do sistema construtivo estudado. 
Os programas computacionais usados no Brasil, tanto para os estudos energéticos como das estruturas, geralmente avaliam as condições de transporte de calor, mas não avaliam o transporte de massa.

Por isso, o uso do WUFI, de forma pioneira no Brasil, mostrou-se capaz de atender aos objetivos desta pesquisa, cumprindo a função de fornecer dados de transporte de calor e massa no regime transiente, permitindo associar o comportamento higrotérmico das fachadas com os fenômenos de degradação relacionados às condições de exposição aos agentes externos de origem climática.

\subsection{RESPONDENDO ÀS QUESTÕES DE PESQUISA}

Durante todas as etapas desta tese, as questões que nortearam a pesquisa foram: "Qual é a influência dos agentes climáticos no comportamento higrotérmico dos sistemas de fachada, considerando as principais orientações de fachada, ao longo dos períodos do ano? " e "Qual é a resposta higrotérmica do sistema poroso de fachada mediante a ação e interação entre os agentes climáticos de degradação e a fachada, considerando as intensidades, as frequências de ocorrência e o comportamento cíclico e sazonal dos fenômenos climáticos?”.

Baseado nos resultados obtidos por meio das simulações computacionais e análises estatísticas, além dos outros estudos desenvolvidos ao longo do trabalho de tese, os objetivos específicos foram alcançados e, ao responder às questões de pesquisa, busca-se atingir o objetivo geral, permitindo concluir que:

- Os agentes climáticos influenciam de forma diferenciada o comportamento higrotérmico dos sistemas de fachada, conforme as oito principais orientações de fachada e os períodos seco e chuvoso do ano. A resposta higrotérmica das fachadas mediante a ação e interação dos agentes climáticos de degradação varia em intensidade e frequência de ocorrência, de acordo com as diferentes orientações de fachada e as propriedades higrotérmicas dos materiais.

- A fachada mais exposta à ação da chuva dirigida, nas condições dos estudos realizados, é a fachada Norte, seguida pela fachada Noroeste. Quando avaliado o teor de umidade total do sistema construtivo, ambas as fachadas, Noroeste e Norte são as mais afetadas pela umidade. No entanto, quando a capilaridade do componente da camada de revestimento é muito baixa ou quando a base de alvenaria apresenta baixa porosidade e higroscopicidade, o teor de umidade total presente nas setes variações do sistema de fachada analisadas não apresentam diferenças estatisticamente significativas entre as 8 principais orientações de 
fachadas, no período chuvoso. Em outras palavras, os elementos construtivos cujo revestimento possui média ou alta capilaridade associado à base de alvenaria bastante porosa apresentam diferentes teores de umidade conforme cada orientação de fachada.

- As fachadas com maior incidência de chuva dirigida são aquelas que sofrem as menores variações de temperatura superficial entre os períodos seco e chuvoso, ou seja, as amplitudes térmicas são amenizadas pelo aumento no teor de umidade. Por isso, nos meses mais chuvosos as variações térmicas nas fachadas são menores que nos meses mais secos. A umidade afeta a condutividade térmica dos materiais, diminuindo a sua resistência térmica, justificando assim, o arrefecimento das temperaturas superficiais pela menor resistência à transferência de calor.

- Nos elementos de fachada com menor transmitância térmica são encontradas as maiores temperaturas superficiais externas, que são menos acentuadas quanto maior o teor de umidade do sistema. Os elementos de fachada mais suscetíveis às altas amplitudes térmicas na superfície são aqueles com a menor transmitância térmica.

- As fachadas Oeste (53\%) e Noroeste (51\%) são aquelas que apresentaram maior probabilidade de ocorrência de amplitude térmica na superfície para valores de $\Delta \mathrm{T}>20^{\circ} \mathrm{C}$, no entanto, para as faixas mais elevadas de amplitude térmica na superfície $(30<\Delta \mathrm{T} \leq 35)$, a fachada Noroeste é aquela onde a frequência de ocorrência é maior (de 15\% a 20\%).

- A maioria dos eventos relacionados às variações térmicas por elevação de temperatura, ocorre nas fachadas Norte, Nordeste, Leste e Sudeste. Nas fachadas Noroeste, Oeste e Sudoeste, a maioria dos eventos está relacionada com o arrefecimento da fachada (queda de temperatura superficial).

- A fachada Noroeste é aquela que apresenta o maior somatório de intensidades de variações térmicas diárias, ao longo de 8760 horas do ano climático.

- Para variações térmicas abruptas $\Delta \mathrm{T}>|8|^{\circ} \mathrm{C}$, em intervalos de tempo de 2 horas, são mais frequentes as situações de aumento da temperatura superficial do que os eventos com arrefecimento da superfície.

- Os estudos dos eventos relacionados às variações térmicas abruptas, visando identificar a probabilidade de ocorrência de choque térmico, mostraram que as frequências de ocorrência são muito baixas: cerca de 3,5\% ou menos para variações de temperatura superficial acima de $8^{\circ} \mathrm{C}$, em intervalo de tempo de 1 hora; cerca de $12 \%$ ou menos para variações de temperatura acima de $8^{\circ} \mathrm{C}$, em intervalos de tempo de 2 hora; e cerca de $2,0 \%$ ou menos 
para variações de temperatura superficial acima de $15^{\circ} \mathrm{C}$, em intervalos de tempo de 2 horas (nenhum deles atingindo valores máximos acima de $23^{\circ} \mathrm{C}$ ).

- Portanto, quanto aos fenômenos relacionados com as variações térmicas, considerando os estudos realizados cuja absortância adotada foi $\alpha=0,7$ (ver p.180), as variações cíclicas que causam variações de repetição que podem levar à fadiga são mais significativas que os fenômenos relacionados ao choque térmico que se mostraram inexpressivos quanto à intensidade e frequência de ocorrência.

Os indicadores amplitude térmica na superfície da fachada e teor de umidade total são suficientemente representativos para retratar os eventos que induzem às variações higrotérmicas, resultantes da ação simultânea dos agentes climáticos de degradação, das características do edifício e do ambiente que mais afetam o comportamento higrotérmico diferenciado dos sistemas de fachada em Brasília, em cada uma das oito principais orientações. Considerando as solicitações impostas às oito principais orientações de fachada e a resposta higrotérmica dada pelo sistema construtivo, conclui-se que a fachada Noroeste é aquela que apresenta as condições de exposição mais suscetíveis à degradação por agentes externos de origem climática, tanto para os fenômenos relacionados à umidade como à temperatura.

Ao avaliar a influência entre os agentes climáticos de degradação e o comportamento higrotérmico do sistema poroso de fachada, foi possível sintetizar os resultados alcançados por meio das simulações higrotérmicas computacionais, em cenários de representação das condições de exposição de cada orientação de fachadas, representativos das interações entre agentes externos de origem climática e comportamento higrotérmico do sistema construtivo estudado, nos períodos seco e chuvoso.

Enfim, os resultados desta tese mostraram a relevância de tratar, separadamente, cada uma das orientações de fachada que podem ser avaliadas conforme seu enquadramento em um dos oitos principais octantes, a saber, N, NE, L, SE, S, SO, O e NO, que representam diferentes cenários das condições de exposição aos agentes climáticos de degradação.

\subsection{SUGESTÕES PARA TRABALHOS FUTUROS}

As sugestões para os trabalhos futuros são baseadas em lacunas percebidas ao logo dos estudos da tese e nos avanços necessários para a continuidade das pesquisas desenvolvidas: 
- Aplicar a metodologia utilizada nesta tese para caracterizar fachadas em outras cidades brasileiras, assim como para outros sistemas construtivos.

- Avançar nos estudos de quantificação de degradação das fachadas (fator de danos), por meio de levantamento de campo, e simulações higrotérmicas computacionais para correlacionar as manifestações patológicas com o comportamento higrotérmico dos sistemas de fachada, conforme as oito orientações de fachada.

- Aprofundar a utilização da ferramenta WUFI para os estudos de degradação, utilizando outras variáveis geradas como dado de saída pelas simulações higrotérmicas.

- Explorar outras possibilidades de ferramentas computacionais (por exemplo, o software UMIDUS) para estudo do comportamento higrotérmico, permitindo análises comparativas e avanços na compreensão dos conceitos e resultados relacionados aos mecanismos e agentes de degradação de fachadas.

- Expandir o programa experimental de medição in situ de chuva dirigida.

- Desenvolver um ano climático de referência para Brasília, utilizando a base de dados climáticos horários da série 2001-2013 do INMET, aplicando a metodologia da ISO15927-4 (BS, 2005).

- Construir um banco de dados (catálogo) de propriedades higrotérmicas para os componentes construtivos mais usuais no Brasil, criando uma base de dados para materiais e componentes genéricos a serem usados em simulações computacionais.

- Com base nos estudos desta tese, avançar nas pesquisas para estabelecer critérios, requisitos e indicadores do comportamento higrotérmico, para serem inseridos nas normas brasileiras relacionadas aos sistemas de vedação vertical. 


\section{REFERÊNCIAS}

AKUTSU, M. Métodos para avaliação do desempenho térmico de edificações no Brasil. Tese (Doutorado). Faculdade de Arquitetura e Urbanismo da Universidade de São Paulo. São Paulo, 1998.

AKUTSU, M., VITTORINO, F. Tratamento de dados climáticos para a avaliação do desempenho térmico de edificações - Manual de Procedimentos (Aplicação à Cidade de São Paulo) - Anexo I. Publicação IPT 1732. São Paulo, 1998.

ALMEIDA, R.M.S.F.; FREITAS, V.P.; DELGADO, J.M.P.Q.; PAULA, P. Hygrothermal performance of a naturally ventilated gypsum house - the Brazilian climate influence. In: XIII International Conference on Durability of Building Materials and Components. Proceedings ... São Paulo: CIB/USP, setembro de 2014. p.220-227.

ALUCCI, M. P.; FLAUZINO, W. D.; MILANO, S. Bolor em edifícios: causa e recomendações. Tecnologia de edificações. Projeto de Divulgação Tecnológica Lix da Cunha. São Paulo: PINI: Instituto de Pesquisa Tecnológica - Divisão de Edificações do IPT, 1988. p.565-570.

ALVARES, C. A.; STAPE, J. L.; SENTELHAS, P. C.; GONCALVES, J. L. M; SPAROVEK, G. Köppen's climate classification map for Brazil. Meteorologische Zeitschrift, v. 22, n. 6. p.711-728. Gebrüder Borntraeger, Stuttgart, 2013.

ALVES, S.M.; PIETROBON, C.L.R.; PIETROBON, C. E. Determinação da condutividade térmica de materiais da construção civil e sua variação com umidade e densidade. In: Encontro Latino Americano de Conforto no Ambiente Construído, 2, Encontro Nacional de Conforto no Ambiente Construído, 5, Fortaleza, CE, 1999. Anais... Fortaleza, CE, 1999.

AMORIM, C. N.; BRAGA, D. K. Conforto térmico em edifícios residenciais do Plano Piloto de Brasília. In: X Encontro Nacional de Tecnologia do Ambiente Construído, São Paulo, 2004. Conferência Latino-Americana de Construção Sustentável, 1. Anais ... ANTAC, 2004.

ANSI/ASHRAE - American National Standards Institute \& American Society of Heating, Refrigerating and AirConditioning Engineers. ANSI/ASHRAE 160 - Criteria for Moisture-Control Design Analysis in Buildings. Atlanta, 2009.

ANTUNES, G. R. Estudo de manifestações patológicas em revestimento de fachada em Brasília: sistematização da incidência de casos. Dissertação (Mestrado). Universidade de Brasília, 2010.

ASHRAE - American Society of Heating, Refrigerating and Air-Conditioning Engineers, Inc. Handbook 2009 Fundamentals. Atlanta, 2009.

ASHRAE - American Society of Heating, Refrigerating and Air-Conditioning Engineers, Inc. HANDBOOK 2011 - HVAC Applications, 2011.

ASSOCIAÇÃO BRASILEIRA DE NORMAS TÉCNICAS. ABNT NBR 13281 Argamassa para assentamento e revestimento de paredes e tetos - Requisitos. Rio de Janeiro, 2005 (d).

ASSOCIAÇÃO BRASILEIRA DE NORMAS TÉCNICAS. ABNT NBR 15220-2 Desempenho Térmico de Edificações - parte 2: Métodos de cálculo da transmitância térmica, da capacidade térmica, do atraso térmico e do fator solar de elementos e componentes de edificações. Rio de Janeiro, 2005 (b).

ASSOCIAÇÃO BRASILEIRA DE NORMAS TÉCNICAS. ABNT NBR 15220-3 Desempenho Térmico de Edificações - Parte 3: Zoneamento Bioclimático Brasileiro e Diretrizes Construtivas para Habitações Unifamiliares de Interesse Social. Rio de Janeiro, 2005 (c). 
ASSOCIAÇÃO BRASILEIRA DE NORMAS TÉCNICAS. ABNT NBR 15259 Argamassa para assentamento e revestimento de paredes e tetos - Determinação da absorção de água por capilaridade e do coeficiente de capilaridade. Rio de Janeiro, 2005 (a).

ASSOCIAÇÃO BRASILEIRA DE NORMAS TÉCNICAS. ABNT NBR 15575-1 Edificações habitacionais Desempenho - Parte 1: Requisitos gerais. Rio de Janeiro, 2013 (a).

ASSOCIAÇÃO BRASILEIRA DE NORMAS TÉCNICAS. ABNT NBR 15575-4 Edificações habitacionais Desempenho. Parte 4: Sistemas de vedações verticais internas e externas - SVVIE. Rio de Janeiro, 2013 (b).

ASSOCIAÇÃO BRASILEIRA DE NORMAS TÉCNICAS. ABNT NBR 6118 Projeto de Estrutura de Concreto - Procedimento. Rio de Janeiro, 2014.

BARBOSA, A. S. Estudo Numérico-Computacional e Analítico do Choque Térmico em Fachadas de Edificações. Dissertação (Mestrado). Programa de Pós-Graduação em Estruturas e Construção Civil, Universidade de Brasília, Brasília-DF, 2013.

BARREIRA, E. S. B. M. Degradação biológica de fachadas com sistemas de isolamento térmico pelo exterior devida ao desempenho higrotérmico. Tese (Doutorado). Faculdade de Engenharia da Universidade do Porto. Portugal, 2010.

BATISTA, J. O.; LAMBERTS, R.; GÜTHS, S. Influências dos algoritmos de condução e convecção sobre os resultados de simulações do comportamento térmico de edificações. Ambiente Construído, v. 11, n. 4, p. 79-97, out./dez. 2011. Porto Alegre, ANTAC - Associação Nacional de Tecnologia do Ambiente Construído, 2011.

BAUER, E.; CASTRO, E. K.; LEAL, F. E.; ALIVERT, M. Relatório Técnico no. 10090300-c. LEM/EM/UNB, 2010.

BAUER, E (Coord.). Revestimentos de argamassa: características e peculiaridades. Brasília-DF: Sinduscon, 2005.

BAUER, E. Resistência a penetração da chuva em fachadas de alvenaria de materiais cerâmicos: uma análise de desempenho. Dissertação (Mestrado). Programa de Pós-Graduação em Engenharia Civil / UFRGS, Porto Alegre, 1987.

BAUER, E.; CASTRO, E. K.; SILVA, M.N.B. Estimativa da degradação de fachadas com revestimento cerâmico: estudo de caso de edifícios de Brasília. Cerâmica 6: 151-159, 2015 (e).

BAUER, E.; FEITOSA, C. P.; RODRIGUES FILHO, H.; ALMEIDA, P. O. Análise comparativa dos requisitos e do desempenho de argamassas de revestimento empregadas em obras do Distrito Federal. In: X SBTA Simpósio Brasileiro de Tecnologia das Argamassas. Anais ... Fortaleza, 2013.

BAUER, E.; KRAUS, E.; ANTUNES, G.R.; LEAL, F.E. Identification and Quantification of Failure Modes of New Buildings Façades in Brasília. In: XII DBMC, Anais ... Porto, Portugal, 2011.

BAUER, E.; SALOMÃO, M. C.; RODRIGUES FILHO, H. Avaliação de argamassas industrializadas quanto à capilaridade e retração de acordo com os critérios da NBR 13281 e do Método MERUC/CSTB. In: XI SBTA Simpósio Brasileiro de Tecnologia das Argamassas. Anais ... Porto Alegre, 2015 (d).

BAUER, E.; SILVA, M. N. B.; ZANONI, V. A. G.; CASTRO, E. K.; FRANCINETE JR, P. Quantificação da Gravidade de Anomalias em Fachadas de Brasília - Estudo de Caso. In: PATORREB 2015 - $5^{\text {a }}$ Conferência sobre Patologia e Reabilitação de edifícios. Anais ... Faculdade de Engenharia da Universidade do Porto, Portugal, 2015 (c).

BAUER, E; CASTRO, E. K.; SILVA, M.N.B.; ZANONI, V.A.G. Evaluation of damage of building facades in Brasília. In: International Conference on Durability of Building Materials and Components, XIII DBMC 2014 Proceedings ... Universidade de São Paulo, São Paulo, 2014. p. 535-542.

BAUER, E; SILVA, M.N.B.; ZANONI, V.A.G. Mensuração da degradação e vida útil em fachadas. In: XI SBTA - Simpósio Brasileiro de Tecnologia das Argamassas. Anais ... ANTAC: Porto Alegre, 2015 (a) 
BAUER, E; SILVA, M.N.B.; ZANONI, V.A.G.; CASTRO, E. K. Perfis de degradação de fachadas de edifícios em Brasília-Brasil. In: CONPAT2015 - XIII Congresso Latino-Americano de Patologia da Construção. XV Congresso de Controlo da Qualidade na Construção. Congresso Luso-Africano da Construção. Anais ... Lisboa - Portugal, Universidade de Lisboa, 2015 (b).

BECERE, O. H. Revestimentos de ligantes sintéticos: proposta de métodos de ensaios para avaliação de desempenho. Dissertação (Mestrado). IPT-Instituto de Pesquisas Tecnológicas do Estado de São Paulo. São Paulo, 2007.

BERGMAN, T. L.; LAVINE, A. S.; INCROPERA, F. P.; DEWITT, D. P. Fundamentals of Heat and Mass Transfer. 7. ed. United States of America: JOHN WILEY \& SONS, 2011.

BITTENCOURT, L.; CANDIDO, C. Ventilação Natural em Edificações. PROCEL EDIFICA - Eficiência Energética em Edificações. Eletrobras. Rio de Janeiro, 2010.

BLOCKEN, B.; ABUKU, M.; NORE, K.; BRIGGEN, P.M.; SCHELLEN, H.L.; THUE, J.V.; ROEL, S. S.; CARMELIET, J. Intercomparison of wind-driven rain deposition models based on two case studies with fullscale measurements. Journal of Wind Engineering and Industrial Aerodynamics 99(4): 448-459, 2011.

BLOCKEN, B.; CARMELIET, J. A review of wind-driven rain research in building science. Journal of Wind Engineering and Industrial Aerodynamics, 92: 1079-1130, 2004.

BLOCKEN, B.; CARMELIET, J. High-resolution wind-driven rain measurements on a low-rise building experimental data for model development and model validation. Journal of Wind Engineering and Industrial Aerodynamics 93(12): 905-928, 2005.

BLOCKEN, B.; CARMELIET, J. On the accuracy of wind-driven rain measurements on buildings. Building and Environment 41(12): 1798-1810, 2006.

BLOCKEN, B.; CARMELIET, J. Overview of three state-of-the-art wind-driven rain assessment models and comparison based on model theory. Building and Environment 45 (3): 691-703, 2010.

BLOCKEN, B.; DEROME, J.; CARMELIET, J. Rainwater runoff from building facades: a review. Building and Environment 60: 339-361, 2013.

BRITISH STANDARD INSTITUTION. BS 6150 Code of practice for Painting of buildings. London, 1991.

BRITISH STANDARD INSTITUTION. BS 8104 Code of practice for assessing exposure of walls to wind driven rain. London, 1992.

BRITISH STANDARD INSTITUTION. BS EN ISO 12572 Hygrothermal performance of building materials and products - Determination of water vapour transmission propertie. BS EN, 2001.

BRITISH STANDARD INSTITUTION. BS EN ISO 15927-3 Hygrothermal performance of buildings Calculation and presentation of climatic data. Part 3: Calculation of a driving rain index for vertical surfaces from hourly wind and rain data. BS EN ISO, 2009.

BRITISH STANDARD INSTITUTION. BS EN ISO15927-4 Hygrothermal performance of buildings Calculation and presentation of climatic data. Part 4: Hourly data for assessing the annual energy use for heating and cooling. BS EN ISO, 2005.

BRITISH STANDARD INSTITUTION. BS ISO 15686-2 Buildings and constructed assets - Service life planning. Part 2: Service life prediction procedures. London, 2012.

BRITISH STANDARD INSTITUTION. BS ISO 15686-5 Buildings and constructed assets - Sevice-life planning. Parte 5: Life-cycle costing. London, 2008 (a).

BRITISH STANDARD INSTITUTION. BS ISO 15686-7 Buildings and constructed assets - Service life planning — Part 7: Performance evaluation for feedback of service life data from practice. London, 2006. 
BRITISH STANDARD INSTITUTION. BS ISO 15686-8 Buildings and constructed assets — Service life planning — Part 8: Reference service life and service-life estimation. London, 2008.

CAMPANTE, E.F.; BAÍA, L.L.M. Projeto e execução de revestimento cerâmico. São Paulo: O Nome da Rosa, 2003.

CARASEK, H. Aderência de argamassa à base de cimento Portlant a substratos porosos: avaliação dos fatores intervenientes e contribuição ao estudo do mecanismo da ligação. Tese (Doutorado). Escola Politécnica da Universidade de São Paulo. São Paulo, 1996.

CARBONE, C. E.; SANTOS, H.; ROMANO, R. C. O.; PILEGGI, R. G. Efeito da adição de látex nas pastas de cimento branco no estado endurecido. Ambiente Construído, v. 13, n. 3, p. 317-330, jul./set. 2013. Porto Alegre: ANTAC, 2013.

CARDOSO, F. A. Método de formulação de argamassas de revestimento baseado em distribuição granulométrica e comportamento reológico. Tese (Doutorado). Escola Politécnica da Universidade de São Paulo. São Paulo, 2009.

CARLO, J. C.; LAMBERTS, R. Processamento de arquivos climáticos para simulação do desempenho energético de edificações. Convênio ECV-007/2004 Eletrobrás/UFSC. Relatório LabEEE-200504.

Florianópolis, 2005.

CARRIO, J. M. Patologia de cerramientos y acabados arquitectonicos. 3.ed. Madrid:Editorial Munilla-Leria, 2000 .

CAVALCANTI, E. P.; GOMES FILHO, M. F.; BEZERRA, W. A. Fluxo de vapor de água atmosférico na obtenção do resíduo ET-P em três macrorregiões brasileiras. Revista Brasileira de Engenharia Agrícola e Ambiental v.12, n.5, p.471-479, Campina Grande, PB, 2008.

CEPAGRI - Centro de Pesquisas Meteorológicas e Climáticas Aplicadas à Agricultura. Artigos especiais: vendavais - Relação entre velocidade do vento e danos. Disponível em http://www.cpa.unicamp.br/artigosespeciais/vendavais.html. Acesso em janeiro de 2015.

CERVO, T. C. Estudo da resistência à fadiga de concretos de cimento Portland para pavimentação. Tese (Doutorado). Orientador: José Tadeu Balbo. Escola Politécnica da Universidade de São Paulo - USP. São Paulo, 2004.

CHAND, I.; BHARGAVA, P.K. Estimation of driving rain index for India. Building and Environment 37: 549-554, 2002

CIB W040 - HEAT AND MOISTURE TRANSFER IN BUILDINGS. Heat, air and moisture transfer terminology - parameters and concepts. Publication 369. Edited by Vasco Peixoto de Freitas (coord) e Eva Barreira. CIB - International Council for Research and Innovation in Building and Construction; FEUP - Porto University, Faculty of Engineering; LFC - Building Physics Laboratory. Porto: FEUP Edições, 2012.

DANIOTTI, B., LUPICA, S., PAGNOLO, S.; PAOLINI, R. Climatic data analysis to define accelerated ageing for reference service life evaluation. In: 11th International Conference on Durability of Building Materials and Components. Proceedings of ... 11-14, v. 3: 1343 - 1350. Istanbul, Turkey, may 2008.

DANIOTTI, B.; RE CECCONI, F. Prediction of service life of building component and materials. Accelerated laboratory test procedures and correlation between laboratory tests and service life data. CIB W080, Milão, Itália, 2010 (a).

DANIOTTI, B.; RE CECCONI, F. State of the art report on accelerated laboratory test procedures and correlation between laboratory tests and service life data. CIB Report: Publication 331. CIB W080: WG3 Test Methods for Service Life Prediction, 2010 (b).

DANIOTTI, B.; RE CECCONI, F.; PAOLINI, R.; COCCHETTI, G.; GALLIANO, R.; CORNAGGIA, A. Multi-physics modelling for durability evaluation of ETICS. In: XIII International Conference on Durability of Building Materials and Components. Proceedings... São Paulo, 2014. 
DANIOTTI, B.; RE CECCONI, F.; PAOLINI, R.; GALLIANO, R. Durability evaluation of external thermal insulation composite systems: frequency assessment of thermal shocks. In: 19th CIB World Building Congress the Brisbane 2013 Construction and Society. Proceedings ... Queensland University of Technology, Brisbane, 2013.

DANIOTTI, B.; RE CECCONI, F.; PAOLINI, R.; GALLIANO, R.; FERRER, J.; BATTAGLIA; L. Durability evaluation of ETICS: analysis of failures case studies and heat and moisture transfer simulations to assess the frequency of critical events. In: 4th Portuguese Conference on Mortars \& ETICS. Proceedings of... Coimbra, Portugal, 2012.

DAS CHAGAS, S. V. M. Estudo e Proposta de um Modelo de Resistência à Fadiga de Argamassas de Revestimento em Estado Plano e Tridimensional de Tensões. Dissertação (Mestrado). Departamento de Engenharia Civil e Ambiental. Faculdade de Tecnologia da Universidade de Brasília. Brasília, 2009.

DELGADO, J.M.P.Q., RAMOS, N.M.M., BARREIRA, E., FREITAS, V.P. A critical review of hygrothermal models used in porous building materials. Journal of Porous Media, v. 13, v. 3, pp. 221-230, Begell House. Inc., New York, 2010.

DEUTSCHES INSTITUT FÜR NORMUNG. DIN 4108-3 Wärmeschutz und Energie-Einsparung in Gebäuden Teil 3: Klimabedingter Feuchteschutz, Anforderungen, Berechnungsverfahren und Hinweise für Planun und Ausführung. Berlin, 2011.

DEUTSCHES INSTITUT FÜR NORMUNG. DIN EN 15026 Hygrothermal performance of building components and building elements - Assessment of moisture transfer by numerical simulation. CEN, Brussels, Belgium, 2007.

DEUTSCHES INSTITUT FÜR NORMUNG. DIN EN ISO 13788 Hygrothermal performance of building components and building elements - Internal surface temperature to avoid critical surface humidity and interstitial condensation - Calculation methods. Comité Européen de Normalisation-CEN, 2012.

DOMUS - PROCEL EDIFICA. Software de simulação higrotérmica e energética de edificações. Manual do usuário. Versão 1.9.8, 19 de março de 2013. Disponível em: http://domus.pucpr.br. Acesso em maio de 2013.

DUFFIE, J. A.; BECKMAN, W. A. Solar engineering of thermal processes. USA: Wiley, 1980.

DURACRETE. Models for environmental actions on concrete structures. Projeto - União Europeia Project BE 95-1347. Netherlands, 1999.

ESQUIVEL, J. F. T. Avaliação da influência do choque térmico na aderência dos revestimentos de argamassa. Tese (Doutorado). Escola Politécnica, Universidade de São Paulo, São Paulo, 2009.

ESTRELA, P. H. T. Determinação e Análise de Índices de Exposição à Chuva Dirigida para 400 Estações Brasileiras - Dados de 1995 a 2010. Trabalho de Conclusão de Curso (Graduação). Instituto Tecnológico de Aeronáutica - ITA, São José dos Campos, 2010.

FALCÃO BAUER, R.J. Falhas em Revestimentos. Capítulo 30. p. 903-945. In: L.A. Falcão Bauer (coord.). Materiais de construção. v. 2. 5.ed. Rio de Janeiro: LTC, 2008.

FARIA, P.; HENRIQUES, F. M. A.; RATO, V. M. Argamassas Correntes: Influência do Tipo de Ligante e do Agregado. In: $2^{\circ}$ Congresso Nacional de Argamassas de Construção. Anais... Lisboa, APFAC, 2007.

FAUSTINO, J. J. P. Análise de soluções construtivas face à difusão de vapor - Importância da composição e do clima. Dissertação (Mestrado). Orientador: Vasco Peixoto de Freitas. Faculdade de Engenharia da Universidade do Porto. Porto, 1997.

FIORITO, A. J. S. L. Manual de argamassa e revestimentos: estudos e procedimentos de execução. São Paulo: PINI, 1994.

FLORES-COLEN, I. Estratégias de manutenção - elementos da envolvente de edifícios correntes. Dissertação (Mestrado). Instituto Superior Técnico, Universidade Técnica de Lisboa, Lisboa, 2002. 
FLORES-COLEN, I. Metodologia de avaliação do desempenho em serviço de fachadas rebocadas na óptica da manutenção predictiva. Tese (Doutorado). Engenharia Civil do Instituto Superior Técnico. Universidade Técnica de Lisboa, Lisboa, 2009.

FRANCINETE JR, P.; SOUZA, J. S.; ZANONI, V. A. G.; SILVA, M. N. B.; BAUER, E. Relação entre a degradação de fachadas e a incidência de chuva dirigida e temperatura - estudo de caso para os edifícios de Brasília-Brasil. In: CONPAT2015 - XIII Congresso Latino-Americano de Patologia da Construção. XV Congresso de Controlo da Qualidade na Construção. Congresso Luso-Africano da Construção. Anais... Lisboa Portugal, Universidade de Lisboa, 2015.

FREITAS, A. S. S. L. A. Avaliação do Comportamento Higrotérmico de Revestimentos Exteriores de Fachadas devido à Acção da Chuva Incidente. Dissertação (Mestrado). Faculdade de Engenharia da Universidade do Porto. Porto, 2011.

FREITAS, V. P.; PINTO, P. S. Permeabilidade ao vapor de materiais de construção - condensações internas. 2.ed. Nota de informação técnica - NIT - 002 do Laboratório de Física das Construções - LFC da Faculdade de Engenharia da Universidade do Porto. Porto, 2000.

FREITAS, V.P. Transferência de humidade em paredes de edifícios- análise do fenómeno de interface. Tese (Doutorado). Faculdade de Engenharia da Universidade do Porto, 1992.

FREITAS, V.P.; TORRES, M.I.T.; Guimarães, A.S. Humidade ascencional. Faculdade de Engenharia da Universidade do Porto. Porto: Feup-edições, 2008.

FROTA, A. B; SCHIFFER, S. R. Manual de Conforto Térmico: arquitetura e urbanismo. 5. ed. São Paulo: Studio Nobel, 2001.

FU, P; RICH, P.M. A geometric solar radiation model and its applications in agriculture and forestry. In: Second International Conference on Geospatial Information in Agriculture and Forestry. Proceedings of... 2000. p.357364.

GASPAR, P.; BRITO, J. de. Quantifying environment effects on cement-rendered facades: a comparison between different degradation indicators. Building and Environment 43 (11): 1818-1828, 2008.

GE, H., KRPAN, R. Field measurement of wind-driven rain on a low-rise building in the coastal climate of British Columbia. In:11th Canadian Conference on Building Science and Technology. Proceedings of... Banff, Alberta, 2007.

GE, H., KRPAN, R., FAZIO, P. Field measurements of wind-driven rain: A study of seven buildings in Metro Vancouver. In: Canadian Conference on Building Science and Technology $12^{\text {th }}$, p. 37-48. Proceedings of... Montreal: National Building Envelope Council, 2009.

GIONGO, M. Análise do Nível de Exposição das Edificações à Chuva Dirigida para Florianópolis. Dissertação (Mestrado). Programa de Pós-Graduação em Engenharia Civil, Universidade Federal de Santa Catarina, Florianópolis, 2007.

GIONGO, M.; PADARATZ, I. J.; LAMBERTS, R. Determinação da exposição à chuva dirigida em Florianópolis, SC: índices de chuva dirigida e métodos semi-empíricos. Ambiente Construído, v. 11, n. 1, p. 7 23, Porto Alegre, 2011.

GOLDBERG, R. P. Revestimientos exteriores con adherencia directa de azulejos cerámicos, piedra y ladrillos caravista. Manual de diseno tecnico. Bethany, Laticrete International, CT 1998.

GOULART, S. V. G. Dados climáticos para avaliação de desempenho térmico em edificações em Florianópolis. Dissertação (Mestrado). Universidade Federal de Santa Catarina, 1993.

GOULART, S. V. G; LAMBERTS, R.; FIRMINO, S. Dados climáticos para projeto e avaliação energética de edificações para 14 cidades brasileiras. 2. ed. Florianópolis: Núcleo de Pesquisa em Construção / UFSC, 1998. 
GRATWICK, R. T. La humedad en la construcción: sus causas y remedies. Barcelona, Editores Técnicos Associados, 1971.

GTA - GRUPO DE TRABALHO EM ARGAMASSA. Terminologia de Argamassas. Luís Carlos Bonin (org.). In: VIII SBTA, Curitiba - PR. Anais... UFRGS: GT-Argamassas / ANTAC, maio de 2009.

GUIMARÃES, L. E. et al. Acompanhamento das Variações das Temperaturas Superficiais dos Principais Materiais Utilizados em Fachadas. In: Encontro sobre Pesquisas de Materiais de Construção, 2. Anais... Goiás, 2002.

HAAG, R. Estimativa da distribuição espectral da radiação solar sobre o território brasileiro através de análise multiinstrumental. Tese (Doutorado). Programa de Pós-Graduação em Engenharia Mecânica. Universidade Federal do Rio Grande do Sul, 2012.

HAAGENRUD, S. Factors Causing Degradation: Part II. In: Guide and Bibliography to Service Life and Durability Research for Buildings and Components. CIB Publication 295, p.1.2-104. CIB, Rotterdam, March 2004.

HAGENTOFT, C. E. Introduction to Building Physics. Studentlitteratur. Lund, Sweden. 2001.

HALL, C. Water movement in porous building materials - I. Unsaturated flow theory and its applications. Building and Environment 12: 117-125, 1977.

HANS, J.; CHEVALIER, JL. Sustainable tools and methods for estimating building materials and components service life. In: 10DBMC International Conference on Durability of Building Materials and Components. Proceedings... LYON (France), 17-20, 2005.

HELENE, P. A Nova NBR 6118 e a Vida Útil das Estruturas de Concreto In: II Seminário de Patologia das Construções, Porto Alegre. Novos Materiais e Tecnologias Emergentes. Anais... v.1. p.1/30 - 30/30, Porto Alegre: LEME. UFRGS, 2004.

HENRIQUES, F. M. A. Quantification of wind driven rain. An experimental approach. Building Research and Information; 20: 295-297, 1992.

HENS, H. Building Physics - Heat, air and moisture. Fundamentals and engineering methods with examples and exercises. Leuven, Belgium: Ernst \& Sohn - Wiley, 2007.

HENS, H. Vapor permeability measurements: impact of cup sealing, edge correction, flow direction, and mean relative humidity. Journal ASTM Int 6(9): 2009.

HOPPESTAD, S. Slagregn i Norge (in Norwegian). Norwegian Building Research Institute, rapport Nr. 13, Oslo; 1955.

HOVDE, P. J.; MOSER, K. State of the Art Reports (Part A: Factor Methods for Service Life Prediction. Part B: Engineering design methods for service life prediction. CIB Report: Publication 294. CIB Rotterdam: W080/ RILEM 175 SLM, 2004.

IBGE - Instituto Brasileiro de Geografia e Estatística. Mapas Brasil Climas. Rio de Janeiro, 1978. Versão disponível on line com adaptações em: ftp://geoftp.ibge.gov.br/mapas_tematicos/mapas_murais/clima. pdf. Acesso em: maio de 2015.

INCROPERA, F. P.; DEWITT, D. P. Fundamentos de transferência de calor e massa. 5.ed. LTC - Livros Técnicos e Científicos Editora S.A. Rio de Janeiro, 2003.

INMET - Instituto Nacional de Meteorologia. Normais Climatológicas do Brasil 1961-1990. Ed. rev. e ampliada. Organizadores: Andrea Malheiros Ramos, Luiz André Rodrigues dos Santos, Lauro Tadeu Guimarães Fortes. Brasília, DF: INMET, 2009.

INMET - Instituto Nacional de Meteorologia. Manual de observações meteorológicas. 3.ed. Ministério da Agricultura e do Abastecimento, Brasília, 1999. 
INMET - Instituto Nacional de Meteorologia. Normais Climatológicas do Brasil (1961-1990). Disponível em: http://www.inmet.gov.br/portal/index.php?r=clima/graficosClimaticos. Acesso em fevereiro de 2013.

INMET - Instituto Nacional de Meteorologia. Tempo e Clima. Disponível em: http://www.inmet.gov.br/html/ informacoes/curiosidade/ tempo_clima.html. Acesso em fevereiro de 2014.

INSTITUTO DE PESQUISA TECNOLÓGICA (IPT). Relatório Técnico No 99 922-205, p. 1-9. Ensaios de caracterização de argamassa para revestimento (Cliente: Usina Fortaleza ICMF Ltda.). Centro de Tecnologia de Obras de Infraestrutura do Laboratório de Materiais de Construção Civil do IPT, Julho/2008.

Instituto Nacional de Pesquisas Espaciais. Portal do Monitoramento de Queimadas e Incêndios. INPE, 2012. Disponível em http://www.inpe.br/queimadas. Acesso em: abril de 2015.

JANSSEN, Hans. Efficiency and accuracy of different potentials for the simulation of moisture transfer in building materials. In: BS2013: Conference of International Building Performance Simulation Association, $13^{\text {th }}$. Proceedings of... Chambéry, France, 2013. p.3570-3577.

JERNBERG, P.; LACASSE, M. A.; HAAGENRUD, S.E.; SJÖSTRÖM, C. Guide and Bibliography to Service Life and Durability Research for Building Materials and Components. Joint CIB W80 / RILEM TC 140 TSL Committee on Service Life of Building Materials and Components, CIB Report, Publication 295, 2004 (b).

JERNBERG, P.; SJÖSTRÖM, C.; LACASSE, M. A.; BRANDT, E.; SIEMES, T. Service life and durability research. In: Guide and Bibliography to Service Life and Durability Research for Buildings and Components. CIB Publication 295, p.11-59. CIB, Rotterdam, 2004 (a).

JOHN, V.M.; SATO, N.M.N. Durabilidade de componentes da construção. In: SATTLER, Miguel Aloysio; PEREIRA Fernando Oscar Ruttkay (Ed.). Coletânia Habitare: Construção e Meio Ambiente, v.7. p. 21-57. Porto Alegre: ANTAC, 2006.

JOHN, V.M.; SATO, N.M.N.; AGOPYAN, V.; SJOSTROM, C. Durabilidade e Sustentabilidade: Desafios para a Construção Civil Brasileira. In: II Workdur - Workshop sobre Durabilidade das Construções. Anais...ITA Instituto Tecnológico de Aeronáutica, São José dos Campos, ITA/CTA, 2001.

JORNE, F.J.F. Análise do comportamento higrotérmico de soluções construtivas de paredes em regime variável. Dissertação (Mestrado). Faculdade de Ciências Tecnologia da Universidade Nova de Lisboa. Orientador: Professor Doutor Fernando Henriques. Lisboa, 2010.

JUNGINGER, M. Rejuntamento de revestimentos cerâmicos: influência das juntas de assentamento na estabilidade de painéis. Dissertação (Mestrado). Programa de Pós-graduação em Construção Civil, Escola Politécnica, Universidade de São Paulo, 2003.

KAZMIERCZAK, C. S. Desempenho de Alvenarias de Materiais Cerâmicos à Penetração de Água da Chuva: Uma Análise de Fatores Condicionantes. Dissertação (Mestrado). Curso de Pós-Graduação em Engenharia Civil, UFRGS, Porto Alegre, 1989.

KRENZINGER, A.; BUGS R. C. RADIASOL2 - Software para sintetizar dados de radiação solar. Laboratório de Energia Solar/PROMEC da UFRGS. In: IV Conferência Latino Americana de Energía Solar (IV ISES CLA) y XVII Simpósio Peruano de Energía Solar (XVII - SPES). Anais... Cuzco, 2010.

KRPAN, R. Wind-driven Rain on Buildings in Metro Vancouver: Parameters for Rain Penetration Testing of Window Assemblies. (Thesis). Department of Building, Civil and Environmental Engineering, Concordia University, Montreal, Quebec, Canada, 2013.

KRUS, M. Moisture Transport and Storage Coefficients of Porous Mineral Building Materials. Theoretical Principles and New Test Methods. Fraunhofer IRB Verlag, 1996.

KUBILAY, A.; DEROME, D.; BLOCKEN, B.; CARMELIET, J. High-resolution field measurements of winddriven rain on an array of low-rise cubic buildings. Building and Environment 78:1-13, 2014. 
KÜNZEL, H. M.; KÜNZEL, H.; HOLM, A. Rain Protection of Stucco Facades. ASHRAE, 2004. Disponível em: http://www.hoki.ibp.fraunhofer.de/ibp/publikationen/ konferenzbeitraege/ Rain_Protection_of_Stucco_ Facades.pdf. Acesso em janeiro de 2015.

KÜNZEL, H.M. Identifying the causes of building degradation and finding appropriate solutions through hygrothermal analysis. Key-Note Lecture. In:1st International Symposium on Building Pathology (ISBP-2015). Anais... Porto, Portugal, 2015.

KÜNZEL, H.M. Simultaneous Heat and Moisture Transport in Building Components. One and twodimensional calculation using simple parameters. Thesis (PHD). Fraunhofer Institute for Building Physics, Stuttgart, 1994.

LACASSE, M. A.; SJÖSTRÖM, C. Methods for service life prediction of building materials and components - recent activities of the CIB W80/RILEM 175-SLM, pp 1-11. Milan, Italy, 2003.

LACY, R. An index of exposure to driving rain. Garston: Building Research Station, Digest n. $23,1962$.

LACY, R. Driving-rain maps and the onslaught of rain on buildings. Building Research Station. Garston, England: Department of Scientific and Industrial Research, 1965.

LACY, R. E. Survey of Meteorological Information for Architecture and Building. (S.1): Building Research Station, Department of the Environment, 1972.

LAMBERTS, R. et al. Desempenho térmico de edificações. Apostila da disciplina ECV 5161 do LABEEELaboratório de Eficiência Energética em Edificações. Universidade Federal de Santa Catarina, Florianópolis, 2011.

LAMBERTS, R.; DUTRA, L.; PEREIRA, F.O.R. Eficiência Energética na Arquitetura. 3.ed. Rio de Janeiro: Eletrobras Procel Edifica, 2013.

LEIVAS, J.; FONTANA, D.; BERLATO, M. CARDOSO, L. Variação diária do albedo sobre uma superfície vegetada e sobre um lago na estação experimental da UFRGS-RS. In: XV Congresso Brasileiro de Agrometeorologia. Anais... Aracaju - SE, 2007.

LENCIONI, J. W.; LIMA, M. G.; MORELLI, F. Uma discussão sobre o conhecimento dos fatores ambientais nos estudos sobre degradação do ambiente construído. In: Encontro Nacional de Tecnologia do Ambiente Construído, XI. Anais... p.2990-2998. Florianópolis, 2006.

LICHTENSTEIN, N. B. Patologia das construções: procedimentos para diagnóstico e recuperação. Boletim Técnico da Escola Politécnica da USP, São Paulo, 1986. Disponível em: 〈http:www.infohab.org.br〉. Acesso em: novembro de 2005 .

LIMA, M. G. Ação do Meio Ambiente sobre as Estruturas de Concreto. In: Geraldo Cechella Isaia. (Org.). Concreto: Ensino, Pesquisa e Realizações. 1 ed. 2v. p. 713-751. São Paulo: IBRACON, 2005.

LIMA, M. G., MORELLI, F. Mapa Brasileiro de Chuva Dirigida - Algumas Considerações. In: Simpósio Brasileiro Tecnologia de Argamassas, Florianópolis, 2005. Anais... ANTAC, 2005, 16p. 58.

LIMA, M. G.; ESTRELA, P.H.T. Determinação e análise de índices de exposição à chuva dirigida para São José dos Campos - SP com base em dados dos anos de 2008 e 2009. In: XIII Encontro Nacional de Tecnologia do Ambiente Construído, Canela - RS, 2010. Anais ... ANTAC, 2010. p. 1-9.

LIMA, M. G.; MORELLI F.; LENCIONI, J. W. Discussão sobre os parâmetros ambientais fatores de degradação do ambiente construído - Estudos relativos a materiais e sistemas para fachadas. In: Encontro Nacional de Tecnologia do Ambiente Construído, XI, Florianópolis, 2006. Anais... Florianópolis, 2006. p.635649.

LOURENÇO, P.B.; LUSO, E.; ALMEIDA, M.G. Defects and moisture problems in buildings from historical city centres: a case study in Portugal. Building and Environment 41(2): 223-234, 2006. 
MARSH, P. Air \& Rain Penetration of Buildings. New York: The Construction Press, 1977.

MELO JÚNIOR, C. M.; CARASEK, H. Índices de chuva dirigida direcional e análise do nível de umedecimento em fachadas de edifício em multipavimentos em Goiânia, GO. Ambiente Construído, v. 11, n. 3, p. 23-37. Associação Nacional de Tecnologia do Ambiente Construído- ANTAC, Porto Alegre, jul./set. 2011.

MENDES, N. Modelos para Previsão da Transferência de Calor e de Umidade em Elementos Porosos de Edificações. Tese (Doutorado). Universidade Federal de Santa Catarina. Florianópolis, 1997.

MENDES, N.; RIDLEY, I.; LAMBERTS, R.; PHILIP, P.C.; BUDAG, K. UMIDUS-A PC Program for the Prediction of Heat and Moisture Transfer in Porous Building Elements. Building Energy Simulation, v.20 (4): 2-8, Berkeley, CA, 1999.

MENDONÇA, F. A.; DANNI-OLIVEIRA, I. M. Climatologia: noções básicas e climas do Brasil. São Paulo: Oficina de Textos, 2007.

MINISTÉRIO DA DEFESA - MD. Comando da Aeronáutica. Meteorologia TCA 105-7: Tabelas Climatológicas 2012. Departamento de Controle do Espaço aéreo, publicada no $B C A n^{\circ} 001$, de 2 de janeiro de 2012. Disponível em: http://www.redemet.aer.mil.br/publicacoes.php. Acesso em fevereiro de 2013.

MOOJEN, T. M. B.; CAVALCANTE, R. B. L.; MENDES, C. A. B. Avaliação da radiação solar com base em dados de nebulosidade. Geografia. v. 21, n. 3.p.41-55, set/dez,2012. Londrina, 2012.

MORALES, S.G. Metodologia de diagnóstico de humedades de capilaridad ascendente y condensación higroscópica, en edifícios históricos. Tesis. Escuela Técnica Superior de Arquitectura da Universidad Politécnica de Madrid, 1995.

MORELLI, F. Aplicações de sistemas de informações geográficas ao ambiente construído: mapeamento dos agentes de degradação dos materiais e sistemas de construção. Tese (Doutorado). Orientadora: Maryangela Geimba de Lima. ITA - Instituto Tecnológico de Aeronáutica, São José dos Campos, 2008.

MORETTIN, P. A.; TOLOI, C. M. C. Análise de Séries Temporais. 2. ed. São Paulo: Blusher, 2006.

MORISHITA, C.; SORGATO, M. J.; VERSAGE, R.; TRIANA, M. A.; MARINOSKI, D. L.; LAMBERTS, R. Catálogo de propriedades térmicas de paredes e coberturas. (v.5). Laboratório de Eficiência Energética em Edificações do Centro Tecnológico da Universidade Federal de Santa Catarina. Florianópolis, outubro de 2011.

MUNHOZ, F. C.; GARCIA, A. Caracterização da velocidade e direção predominante dos ventos para a localidade de Ituverava-SP. Revista Brasileira de Meteorologia v.23, n.1: 30-34, 2008.

NICOLELLA, M.; DE PASCALE, A. A model for determining accelerated ageing cycles in durability research: a case study on continuous roofing. In: 11 DBMC Conference on Durability of Building Materials and Components. Proceedings of... Istanbul, Turkey, 2008.

OLIVEIRA, L. A. Metodologia para desenvolvimento de projeto de fachadas leves. Tese (Doutorado). Escola Politécnica da Universidade de São Paulo. São Paulo, 2009.

OLIVEIRA, L. A.; FONTENELLE, J.H.; MITIDIERI FILHO, C. V. Durabilidade de fachadas: método de ensaio para verificação da resistência à ação de calor e choque térmico. Ambiente Construído v. 14, n. 4, p. 5367, Associação Nacional de Tecnologia do Ambiente Construído-ANTAC, Porto Alegre, out. /dez. 2014.

ORDENES, M.; LAMBERTS, R.; GÜTHS, S. Transferência de calor na envolvente da edificação. Centro Tecnológico do Departamento de Engenharia Civil. Programa de Pós-Graduação em Engenharia Civil da Universidade Federal de Santa Catarina. Florianópolis, 2008.

PAES, I.N.L.; CARASEK, H. Desempenho das argamassas de rejuntamento no sistema de revestimento cerâmico. Ambiente Construído, v. 2, n. 2, p. 93-103, Associação Nacional de Tecnologia do Ambiente Construído-ANTAC, Porto Alegre, abr.jun. 2002. 
PÁSCOA, L.S. N. Índice de secagem como parâmetro em serviço dos rebocos aplicados em paredes exteriores. Dissertação. Engenharia Civil. Orientadora: Inês dos Santos Flores Barbosa Colen. UTI- Técnico de Lisboa, 2012.

PBMC-2014. Base científica das mudanças climáticas. Contribuição do Grupo de Trabalho 1 do Painel Brasileiro de Mudanças Climáticas ao Primeiro Relatório da Avaliação Nacional sobre Mudanças Climáticas [Ambrizzi, T., Araujo, M. (eds.) ]. COPPE. Universidade Federal do Rio de Janeiro, Rio de Janeiro, RJ, Brasil, 2014.

PEREIRA, B. B.; PAIS, M. B. Z.; SALES, P. R. H. Análise espectral de séries temporais: uma introdução para Engenharia, Economia e Estatística. Rio de Janeiro: Arte Final Leasing Editorial; Eletrobrás S.A., 1986.

PEREIRA, E. B.; MARTINS, F. R.; ABREU, S. L., RÜTHER, R. Atlas brasileiro de energia solar (SWERA). São José dos Campos: INPE, 2006.

PEREIRA, R. S.; NUNES, A. B. Influência da nebulosidade na atenuação atmosférica na cidade de Pelotas-RS. Estudo de caso. Revista Ciência e Natura (Edição Especial). Revista do Centro do Ciências Naturais e Exatas - UFSM. Santa Maria, dez. 2013. p. 487 - 489.

PEREZ, A. R. Umidade nas Edificações: Recomendações para a Prevenção da Penetração de Água pelas Fachadas. Tecnologia de Edificações (1 $1^{\mathrm{a}}$ e $2^{\mathrm{a}}$ partes). São Paulo, PINI, IPT-Divisão de Edificações, 1988. p. $571-578$

PEREZ, Ary Rodrigo. Umidade nas edificações. Dissertação (Mestrado). Engenharia Civil. Escola Politécnica da Universidade de São Paulo, São Paulo, Brasil,1986.

PITTIGLIANI, M. Controle de Qualidade de Dados Hidrometeorológicos do Simepar. In: XI CBMET Congresso Brasileiros de Meteorologia. Anais ... Rio de Janeiro, 2000.

QUERINO, C. A. S.; MOURA, M. A. L.; QUERINO, J.K. A.S.; RADOW, C. V.; MARQUES FILHO, A. O. Estudo da radiação solar global e do índice de transmissividade (kt), externo e interno, em uma floresta de mangue em Alagoas - Brasil. Revista Brasileira de Meteorologia, v.26, n.2, 204 - 294, 2011.

QUERINO, C.A.S. Avaliação e comparação de radiação solar global e albedo com o ângulo Zenital na Floresta Amazônica. Monografia (Bacharel em Meteorologia). Departamento de Meteorologia, Universidade Federal de Alagoas, Maceió, 2004.

RAMOS, A. M. et al. Revisão das Normais Climatológicas do Brasil para o Período 1961-1990: Procedimentos de Cálculo e Produto Final. In: XVI Congresso Brasileiro de Meteorologia. Anais ... Belém, PA, setembro de 2010. Disponível em: http://www.cbmet2010.com/anais/artigos/652_91895.pdf. Acesso em 2013.

RAMOS, N. M. M. A importância da inercia higroscópica no comportamento higrotérmico dos edifícios. Tese (Doutorado). Orientador: Vasco M. A. P. Freitas. Faculdade de Engenharia da Universidade do Porto, 2007.

REBOITA, M. S.; KRUSCHE, N.; AMBRIZZI, T.; ROCHA, R.P. Entendendo o tempo e o clima na América do Sul. TERR/E DIDATICA 8(1):34-50, 2012.

ROMERO, M.A.B. Arquitetura do Lugar. Uma Visão Bioclimática da Sustentabilidade em Brasília. Editora Nova Técnica: São Paulo, 2011.

ROMERO, M.A.B. Princípios Bioclimáticos para o Desenho Urbano. ProEditores, São Paulo, 2000.

RORIZ, M. Correções nas Irradiâncias e Iluminâncias dos arquivos EPW da Base ANTAC. Grupo de Trabalho sobre Conforto e Eficiência Energética de Edificações. ANTAC - Associação Nacional de Tecnologia do Ambiente Construído. São Carlos - SP, 2012. Disponível em: http://www.labeee.ufsc.br/downloads/arquivosclimaticos/formato-epw. Acesso em: setembro de 2013.

SABBATINI, F.H.; BARROS, M.M.S.B. Produção de revestimentos cerâmicos para paredes de vedação de alvenaria: Diretrizes Básicas. EPUSP-PCC, São Paulo, 2001. 
SALES, N. D.; REBELLO, E.; SILVA, J.F. Chuvas Intensas em Brasília nos últimos cinco anos. In: XVI Congresso Brasileiro de Meteorologia - CBMET2010. Anais... Belém, setembro de 2010.

SANTOS, A.; DELGADO, J.M.P.Q.; RAMOS, N.M.M. Degradation of brazilian gypsum exterior walls due to hygrothermal action. In: XIII International Conference on Durability of Building Materials and Components. Proceedings ... São Paulo: CIB/USP, setembro de 2014. p.220-227.

SANTOS, G. H. Transferência de calor, ar e umidade através de elementos porosos de edificações. Tese (Doutorado). Orientador Paulo C. Philippi; Co-Orientador Nathan Mendes. Universidade Federal de Santa Catarina, Florianópolis, 2009.

SARAIVA, A. G. Contribuição ao estudo de tensões de natureza térmica em sistema de revestimento cerâmico de fachadas. Dissertação (Mestrado). Universidade de Brasília-UnB, Brasília, 1998.

SARAIVA, A. G.; BAUER, E.; BEZERRA, L. M. Análise das tensões entre argamassa colante e placas cerâmicas submetidas a esforços de natureza térmica. Ambiente Construído, v. 2, n. 2, p. 47-56, Porto Alegre, abr./jun. 2002.

SATO, N. M. N. Análise da porosidade e das propriedades de transporte de massa de concretos com vistas à avaliação de suas durabilidades. Tese (Doutorado). Orientador: Vahan Agopyan. Escola Politécnica da Universidade de São Paulo. São Paulo, 1998.

SCHELLER, C.; MELO, A. P.; SORGATO, M. J.; LAMBERTS, R. Análise de arquivos climáticos para a simulação do desempenho energético de edificações. Centro Brasileiro de eficiência energética em edificações-CB3E. Universidade de Santa Catarina-UFSC. Florianópolis, 2015.

SENTELHAS, P. C.; ANGELOCCI, L. R. Radiação solar: balanço de Energia. Notas de aulas. ESALQ/USP. Piracicaba, 2009. Disponível em: http://www.lce.esalq.usp.br/aulas/lce306/Aula5.pdf . Acesso: abril/2013.

SEVERINO, M. M. Avaliação Técnico-Econômica de um Sistema Híbrido de Geração Distribuída para Atendimento a Comunidades Isoladas da Amazônia. Tese (Doutorado). Engenharia Elétrica, Faculdade de Tecnologia, UnB, Brasília. 2008.

SHOHET, I. M.; ROSENFELD, Y.; PUTERMAN, M.; GILBOA, E. Deterioration patterns for maintenance management - a methodological approach. Durability of Building Materials and Components, p. 1666-1678. Institute for Research in Construction, Ottawa, Canada, 1999.

SIGMA PLOT. Systat Software Inc, 2015.

SILVA, A.; DIAS, J.L.; GASPAR, P.L.; BRITO, J. Service life prediction models for exterior stone cladding. Building Research and Information, 39(6): 637-653, 2011.

SILVA, A.; DIAS, J.L.; GASPAR, P.L.; BRITO, J. Statistical models applied to service life prediction of rendered façades. Automation in Construction, 30: 151-160, 2013.

SILVA, A.C.S.B.; GIRALT, R.P. Estabelecimento de um índice de chuva dirigida para Porto Alegre. In: Encontro Nacional de Tecnologia do Ambiente Construído, VI. Anais... p.605-610. Rio de Janeiro, 1995.

SILVA, C. F. O conforto térmico de cavidades urbanas: contexto climático do Distrito Federal. Tese (Doutorado). Programa de Pós-Graduação em Arquitetura e Urbanismo. Universidade de Brasília-UnB, 2013.

SILVA, M.N.B.; BAUER, E; CASTRO, E. K.; ZANONI, V.A.G. Distribuição de ocorrência de danos e patologias em fachadas de Brasília - estudo de caso. In: ARGAMASSAS 2014 - I Simpósio de Argamassas e Soluções Térmicas de Revestimento. ITECons/ APFAC. Anais...Universidade de Coimbra, Portugal, 2014.

SILVA, M. N. B. Avaliação Quantitativa da Degradação e Vida Útil de Revestimentos de Fachada Aplicação ao Caso de Brasília/DF. Tese (Doutorado). Orientador: Elton Bauer. Programa de Pós-Graduação em Estruturas e Construção Civil. Universidade de Brasília-UnB, 2014. 
SILVA, P. C. Sistema para tratamento, armazenamento e disseminação de dados de vento. Tese (Doutorado). Engenharia Mecânica, COPPE, Universidade Federal do Rio de Janeiro, 1999.

SILVA, S. B. Dimensionamento Ótimo de Sistemas Híbridos, com Geração Fotovoltaica e Célula a Combustível, para Atendimento a Comunidades Isoladas na Amazônia. Tese (Doutorado). Departamento de Engenharia Elétrica, Universidade de Brasília, Brasília, DF, 2010.

SIQUEIRA, T.C. P.A.; AKUTSU, M.; LOPES, J. I. E.; SOUZA, H. A. Dados climáticos para avaliação de desempenho térmico de edificações. REM: R. Esc. Minas, Ouro Preto, 58(2): 133-138, abr. jun. 2005.

SORGATO, M. J.; MARINOSKI, D. L. Comentários e sugestões quanto à formatação e nomenclatura presentes na norma NBR 15575. Laboratório de Eficiência Energética em Edificações. Florianópolis, 2012.

SPSS STATISTIC - version 20. IBM SPSS Software, 2011.

STRAUBE, J. F. Simplified Prediction of Driving Rain on Buildings: ASHRAE 160P and WUFI 4.0. Building Science Digest 148, 2010.

STRAUBE, J.F.; BURNETT, E.F.P. Field testing of filled-cavity wall systems. In: Conference Building Envelope Science and Tech. '97. Proceedings ... Bath, UK, 1997.

TEMOCHE, J.F.; BARROS, M. Estudo do comportamento mecânico de argamassas de revestimento devido ao choque térmico. In: Congresso Nacional de Argamassas de Construção. Anais... Lisboa, APFAC, 2010.

THOMAZ, E. Trincas em Edifícios: causas, prevenção e recuperação. São Paulo: PINI, EPUSP, IPT, 1989.

THOMAZ, E.; DEL MAR, C. P. Desempenho de edificações habitacionais: guia orientativo para atendimento à norma ABNT NBR 15575/2013. Câmara Brasileira da Indústria da Construção. Fortaleza: Gadioli Cipolla Comunicação, 2013.

TIBA, C. et al. Software contendo a base de dados solarimétricos e aplicativos de análise do Atlas Solarimétrico do Brasil: banco de dados solarimétricos. Recife: Ed. Universitária da UFPE, 2001. Disponível em: http://www.cresesb.cepel.br/publicacoes/index.php?task=livro\&cid=2. Acesso em 2013.

TUBELIS, A.; NASCIMENTO, F. J. L. Meteorologia descritiva: fundamentos e aplicações brasileiras. São Paulo, Nobel, 1980.

UCHÔA, J.C.B. Procedimento Numérico e Experimental para a Avaliação da Resistência à Fadiga em Sistema de Revestimento. Dissertação (Mestrado). Departamento de Engenharia Civil e Ambiental, Universidade de Brasília, Brasília, 2007.

UCHÔA, J.C.B.; BEZERRA, L.M.; BAUER, E.; DAS CHAGAS, S. V. M.; ARAÚJO, J. Análise experimental da resistência à fadiga de sistemas de revestimentos. In: $50^{\circ}$ Congresso Brasileiro do Concreto. Anais ... Salvador: IBRACON, 2008.

UEMOTO, K. L. Patologia: danos causados por eflorescência. Tecnologia de Edificações ( $1^{\mathbf{a}}$ e $2^{\mathbf{a}}$ partes). p. 561-564. São Paulo, PINI, IPT-Divisão de Edificações, 1988.

VALLEJO, F.J.L. Ensuciamiento de fachadas pétreas por la contaminación atmosférica. El caso de la ciudad de Valladolid, España (Contamination of stone façades by atmospheric pollution. The case of Valladolid, Spain). Consejo Superior de Investigaciones Científicas: Informes de la Construcción, Vol. $41 \mathrm{n}{ }^{\circ}$ 405, enero/febrero, 1990

VAN MOOK, F. J. Full-scale measurements and numeric simulations of driving rain on a building. In: International Conference on Wind Engineering $10^{\text {th }}$. Anais...Copenhagen, Denmark, 1999. p. $1145-1152$.

VIANA, T. Energia Solar Fotovoltaica- geração de energia elétrica a partir do sol. Notas de aula. Labeee.UFSC, 2011. 
VIITANEN, H. Factors affecting the development of mould and brown rot decay in wooden material and wooden structures. Effect of humidity, temperature and exposure time. Thesis (Doctoral). The Swedish University of Agricultural Sciences, Department of Forest Products, Uppsala, 1996.

WESTPHAL, F. S.; LAMBERTS, R. Simulação térmica e energética de edificações a partir de dados climáticos simplificados: validação através do método BESTEST. Ambiente Construído, v. 4, n. 3, p. 37-49. Porto Alegre, jul. / set. 2004.

WMO - WORLD METEOROLOGICAL ORGANIZATION. Guide to the Global Observing System: WMONo. 488. 3. ed. Geneva, 2007.

WOLLMANN, C. A.; SARTORI, M. G. B. A nebulosidade como fator condicionante à percepção da pluviometria anual pela população urbana e rural de São Sebastião do Caí/RS. Revista Brasileira de Geografia Física v.3, n.1, 2010, p. 01-06.

WOLLMANN, C. A.; SARTORI, M. G. B.; RUOSO, D.; COSTA, E. R. A influência da nebulosidade na percepção da pluviometria anual no Rio Grande do Sul: Uma relação bioclimática. In: Simpósio Brasileiro de Climatologia Geográfica, 7. Anais... Rondonópolis: UFMT, 2006a.

WOLLMANN, C. A.; SARTORI, M. G. B.; RUOSO, D.; COSTA, E. R.; KLEINPAUL, J. J. A nebulosidade como fator condicionante à percepção da pluviometria anual pela população rural e urbana de São Sebastião do Caí/RS. In: Seminário Latinoamericano de Geografia Física, 4. Anais... Maringá: UEM, $2006 b$.

WUFI online help. Forum Software $@$ phpBB. Disponível em http://wufi-forum.com/index.php. Acesso em 2014.

WUFI Pro 5.3. IBP - Fraunhofer Institute for Building Physics. Holzkirchen, Germany, 2013.

ZAHUMENSKÝ, I. Guidelines on Quality Control Procedures for data from Automatic Weather Stations. Slovak Hydrometeorological Institute - SHMI. Slovakia, 2004.

ZANONI, V. A. G.; SÁNCHEZ, J.M. M.; BAUER, E. Chuva dirigida: um estudo da ISO 15927-3 no contexto brasileiro. In: XV ENTAC - Encontro Nacional de Tecnologia do Ambiente Construído, 2014. Anais ... Porto Alegre: ANTAC, 2014. p. 1645-1654.

ZANONI, V. A. G.; SÁNCHEZ, J.M. M.; BAUER, E.; AMORIM, C.N.D. Matriz de análise do índice de chuva dirigida (ICD) para a cidade de Brasília-DF. REVISTA PARANOÁ (cadernos de arquitetura e urbanismo) Conforto e Projeto: Cidades 11: 67-76. Brasília, 2014.

ZANONI, V.; SÁNCHEZ, J. M.; BAUER. E.; AMORIM, C. Comparação entre arquivos climáticos de irradiância para estudos de degradação de fachada em Brasília-DF. In: XIII ENCAC - Encontro Nacional e IX Encontro Latino-americano de Conforto no Ambiente Construído, 2015. Anais.... Campinas,2015.

ZANONI, V.; SÁNCHEZ, J. M.; BAUER. E.; AMORIM, C. Arquivos climáticos com dados horários de irradiância para estudos de degradação de fachada. In: I Euro-ELECS 2015 -first Latin-American and European Conference on Sustainable Buildings and Communities. Anais... Guimarães, Portugal. Universidade do Minho, 2015.

ZHAO, J.; PLAGGE, R.; RAMOS, N. M.M.; SIMÕES, M. L.; GRUNEWALD, J. Concept for development of stochastic databases for building performance simulation - A material database pilot project. Building and Environment 84: 189-203; 2015.

ZHAO, J; GRUNEWALD, J; PLAGGE, R. Definition of generic materials by using a cluster analysis method. In: 2nd Central European Symposium on Building Physics. Proceedings of... Vienna, Austria; 2013. p. 875 81. 
APÊNDICE A

\section{TABELAS E QUADROS COMPLEMENTARES DO CAPÍTULO 2}

\section{Tabela A.1 - Precipitação (mm/hora) da série 2001-2013: Estatística Descritiva.}

Precipitação (mm)

Dados horários com velocidade zero: incluídos

$\begin{array}{cc}\text { Média } & 0,16307549 \\ \text { Erro padrão } & 0,003913831 \\ \text { Mediana } & 0 \\ \text { Modo } & 0\end{array}$

Desvio padrão

Variância da amostra

Curtose

1,295336316

1,677896172

379,0737721

Assimetria

Intervalo

Mínimo

Máximo

Soma

Contagem
16,22074067

60,8

0

60,8

17862,8

109537
Precipitação (mm)

Dados horários com velocidade zero: excluídos

$\begin{array}{cc}\text { Média } & 2,294809866 \\ \text { Erro padrão } & 0,049042395 \\ \text { Mediana } & 0,8 \\ \text { Modo } & 0,2\end{array}$

Desvio padrão

4,326862425

Variância da amostra

18,72173845

Curtose

29,77426219

Assimetria

4,529166787

Intervalo

60,6

Mínimo

0,2

Máximo

60,8

Soma

17862,8

Contagem

7784

Tabela A.2 - Umidade relativa do ar (\%) da série 2001-2013: Estatística Descritiva.

\begin{tabular}{ll}
\hline \multicolumn{2}{c}{ Umidade relativa (\%) } \\
\hline \hline Média & 66,44714283 \\
Erro padrão & 0,061167971 \\
Mediana & 68 \\
Modo & 94 \\
Desvio padrão & 20,25528187 \\
Variância da amostra & 410,2764435 \\
Curtose & $-0,86791611$ \\
Assimetria & $-0,36553418$ \\
Intervalo & 89 \\
Mínimo & 10 \\
Máximo & 99 \\
Soma & 7286195 \\
Contagem & 109654 \\
Nível de confiança & 0,119888343 \\
(95,0\%)
\end{tabular}


Tabela A.3 - Umidade relativa (\%): frequência de ocorrência da série 2001-2013.

\begin{tabular}{ccc|ccc|ccc}
\hline \multicolumn{3}{c}{ Período Total } & \multicolumn{3}{c}{ Período chuvoso } & \multicolumn{3}{c}{ Período seco } \\
\hline \hline UR\% & Frequência & Cumulativo & UR\% & Frequência & Cumulativo & UR\% & Frequência & Cumulativo \\
\hline \hline 10 & 1 & $0,00 \%$ & 10 & 0 & $0,00 \%$ & 10 & 1 & $0,00 \%$ \\
15 & 169 & $0,16 \%$ & 15 & 19 & $0,03 \%$ & 15 & 140 & $0,25 \%$ \\
20 & 651 & $0,75 \%$ & 20 & 108 & $0,23 \%$ & 20 & 543 & $1,23 \%$ \\
25 & 1623 & $2,23 \%$ & 25 & 322 & $0,83 \%$ & 25 & 1301 & $3,59 \%$ \\
30 & 2965 & $4,93 \%$ & 30 & 591 & $1,91 \%$ & 30 & 2374 & $7,88 \%$ \\
35 & 4155 & $8,72 \%$ & 35 & 849 & $3,48 \%$ & 35 & 3306 & $13,85 \%$ \\
40 & 4698 & $13,01 \%$ & 40 & 1122 & $5,54 \%$ & 40 & 3576 & $20,32 \%$ \\
45 & 5694 & $18,20 \%$ & 45 & 1557 & $8,41 \%$ & 45 & 4137 & $27,80 \%$ \\
50 & 6534 & $24,16 \%$ & 50 & 1955 & $12,01 \%$ & 50 & 4579 & $36,08 \%$ \\
55 & 7259 & $30,78 \%$ & 55 & 2568 & $16,73 \%$ & 55 & 4691 & $44,56 \%$ \\
60 & 7932 & $38,01 \%$ & 60 & 3161 & $22,55 \%$ & 60 & 4771 & $53,18 \%$ \\
65 & 8328 & $45,61 \%$ & 65 & 3742 & $29,44 \%$ & 65 & 4586 & $61,47 \%$ \\
70 & 8522 & $53,38 \%$ & 70 & 4019 & $36,84 \%$ & 70 & 4503 & $69,61 \%$ \\
75 & 8422 & $61,06 \%$ & 75 & 4237 & $44,64 \%$ & 75 & 4185 & $77,18 \%$ \\
80 & 8650 & $68,95 \%$ & 80 & 4813 & $53,50 \%$ & 80 & 3837 & $84,11 \%$ \\
85 & 8812 & $76,98 \%$ & 85 & 5566 & $63,74 \%$ & 85 & 3246 & $89,98 \%$ \\
90 & 10153 & $86,24 \%$ & 90 & 7443 & $77,44 \%$ & 90 & 2710 & $94,88 \%$ \\
95 & 13050 & $98,14 \%$ & 95 & 10589 & $96,93 \%$ & 95 & 2461 & $99,33 \%$ \\
100 & 2036 & $100,00 \%$ & 100 & 1666 & $100,00 \%$ & 100 & 370 & $100,00 \%$ \\
\hline
\end{tabular}

Tabela A.4 - Pressão atmosférica do ar (hPa) da série 2001-2013: Estatística Descritiva

\begin{tabular}{lr}
\hline \multicolumn{2}{c}{ Pressão atmosférica do ar } \\
\hline Média & 887,155213 \\
Erro padrão & 0,011673789 \\
Mediana & 887,1 \\
Modo & 887,2 \\
Desvio padrão & 3,864729436 \\
Variância da amostra & 14,93613361 \\
Curtose & 193,7319615 \\
Assimetria & 6,53256606 \\
Intervalo & 160,1 \\
Mínimo & 863,4 \\
Máximo & 1023,5 \\
Soma & 97233098,5 \\
Contagem & 109601 \\
Nível de confiança $(95,0 \%)$ & 0,022880459 \\
\hline
\end{tabular}


Tabela A.5 - Temperaturas do ar, máxima e mínima $\left({ }^{\circ} \mathrm{C}\right)$ : frequência de ocorrência da série 2001-2013.

\begin{tabular}{|c|c|c|c|c|c|c|c|c|}
\hline $\mathbf{T}_{\mathrm{ar}}$ & Frequência & Cumulativo & $\mathbf{T}_{\max }$ & Frequência & Cumulativo & $\mathbf{T}_{\min }$ & Frequência & Cumulativo \\
\hline 9,0 & 1 & $0,00 \%$ & 9,0 & 0 & $0,00 \%$ & 9,0 & 3 & $0,00 \%$ \\
\hline 10,0 & 15 & $0,01 \%$ & 10,0 & 7 & $0,01 \%$ & 10,0 & 30 & $0,03 \%$ \\
\hline 11,0 & 52 & $0,06 \%$ & 11,0 & 21 & $0,03 \%$ & 11,0 & 96 & $0,12 \%$ \\
\hline 12,0 & 151 & $0,20 \%$ & 12,0 & 71 & $0,09 \%$ & 12,0 & 289 & $0,38 \%$ \\
\hline 13,0 & 417 & $0,58 \%$ & 13,0 & 171 & $0,25 \%$ & 13,0 & 763 & $1,08 \%$ \\
\hline 14,0 & 937 & $1,43 \%$ & 14,0 & 528 & $0,73 \%$ & 14,0 & 1392 & $2,35 \%$ \\
\hline 15,0 & 1823 & $3,10 \%$ & 15,0 & 1272 & $1,89 \%$ & 15,0 & 2429 & $4,57 \%$ \\
\hline 16,0 & 2876 & $5,72 \%$ & 16,0 & 2231 & $3,93 \%$ & 16,0 & 3511 & $7,78 \%$ \\
\hline 17,0 & 4426 & $9,76 \%$ & 17,0 & 3652 & $7,27 \%$ & 17,0 & 5405 & $12,72 \%$ \\
\hline 18,0 & 7760 & $16,83 \%$ & 18,0 & 6183 & $12,92 \%$ & 18,0 & 9509 & $21,41 \%$ \\
\hline 19,0 & 13467 & $29,11 \%$ & 19,0 & 11470 & $23,40 \%$ & 19,0 & 15282 & $35,38 \%$ \\
\hline 20,0 & 14644 & $42,47 \%$ & 20,0 & 14022 & $36,22 \%$ & 20,0 & 14835 & $48,94 \%$ \\
\hline 21,0 & 11541 & $52,99 \%$ & 21,0 & 11788 & $46,99 \%$ & 21,0 & 11157 & $59,13 \%$ \\
\hline 22,0 & 9437 & $61,60 \%$ & 22,0 & 9593 & $55,76 \%$ & 22,0 & 9047 & $67,40 \%$ \\
\hline 23,0 & 8139 & $69,02 \%$ & 23,0 & 8214 & $63,27 \%$ & 23,0 & 7980 & $74,70 \%$ \\
\hline 24,0 & 7784 & $76,12 \%$ & 24,0 & 7710 & $70,31 \%$ & 24,0 & 7429 & $81,49 \%$ \\
\hline 25,0 & 7342 & $82,81 \%$ & 25,0 & 7705 & $77,36 \%$ & 25,0 & 6681 & $87,59 \%$ \\
\hline 26,0 & 6537 & $88,77 \%$ & 26,0 & 7308 & $84,03 \%$ & 26,0 & 5300 & $92,44 \%$ \\
\hline 27,0 & 4911 & $93,25 \%$ & 27,0 & 6285 & $89,78 \%$ & 27,0 & 3634 & $95,76 \%$ \\
\hline 28,0 & 3348 & $96,31 \%$ & 28,0 & 4695 & $94,07 \%$ & 28,0 & 2326 & $97,88 \%$ \\
\hline 29,0 & 2046 & $98,17 \%$ & 29,0 & 3096 & $96,90 \%$ & 29,0 & 1210 & $98,99 \%$ \\
\hline 30,0 & 1126 & $99,20 \%$ & 30,0 & 1747 & $98,50 \%$ & 30,0 & 680 & $99,61 \%$ \\
\hline 31,0 & 529 & $99,68 \%$ & 31,0 & 915 & $99,33 \%$ & 31,0 & 283 & $99,87 \%$ \\
\hline 32,0 & 243 & $99,90 \%$ & 32,0 & 456 & $99,75 \%$ & 32,0 & 117 & $99,98 \%$ \\
\hline 33,0 & 91 & $99,99 \%$ & 33,0 & 214 & $99,94 \%$ & 33,0 & 22 & $100,00 \%$ \\
\hline 34,0 & 12 & $100,00 \%$ & 34,0 & 54 & $99,99 \%$ & 34,0 & 2 & $100,00 \%$ \\
\hline 35,0 & 4 & $100,00 \%$ & 35,0 & 5 & $100,00 \%$ & 35,0 & 3 & $100,00 \%$ \\
\hline 36,0 & 0 & $100,00 \%$ & 36,0 & 2 & $100,00 \%$ & 36,0 & 0 & $100,00 \%$ \\
\hline
\end{tabular}


Tabela A.6 - Temperaturas do ar da série 2001-2013: Estatística Descritiva.

\begin{tabular}{|c|c|c|c|c|c|}
\hline \multicolumn{2}{|c|}{$\begin{array}{l}\text { TEMPERATURA DO AR } \\
\left({ }^{\circ} \mathbf{C}\right)\end{array}$} & \multicolumn{2}{|c|}{$\begin{array}{l}\text { TEMPERATURA MAXIMA } \\
\left({ }^{\circ} \mathbf{C}\right)\end{array}$} & \multicolumn{2}{|c|}{$\begin{array}{l}\text { TEMPERATURA MINIMA } \\
\left({ }^{\circ} \mathbf{C}\right)\end{array}$} \\
\hline Média & 21,27784 & Média & 21,92303 & Média & 20,65558 \\
\hline Erro padrão & 0,011061 & Erro padrão & 0,011219 & Erro padrão & 0,010574 \\
\hline Mediana & 20,7 & Mediana & 21,4 & Mediana & 20,1 \\
\hline Modo & 19,1 & Modo & 19,4 & Modo & 19,1 \\
\hline Desvio padrão & 3,591803 & Desvio padrão & 3,710935 & Desvio padrão & 3,497584 \\
\hline $\begin{array}{l}\text { Variância da } \\
\text { amostra }\end{array}$ & 12,90105 & $\begin{array}{l}\text { Variância da } \\
\text { amostra }\end{array}$ & 13,77104 & $\begin{array}{l}\text { Variância da } \\
\text { amostra }\end{array}$ & 12,2331 \\
\hline Curtose & $-0,27631$ & Curtose & $-0,43467$ & Curtose & $-0,13158$ \\
\hline Assimetria & 0,281104 & Assimetria & 0,285747 & Assimetria & 0,25803 \\
\hline Intervalo & 25,8 & Intervalo & 25,9 & Intervalo & 25,6 \\
\hline Mínimo & 9,1 & Mínimo & 9,4 & Mínimo & 8,8 \\
\hline Máximo & 34,9 & Máximo & 35,3 & Máximo & 34,4 \\
\hline Soma & 2243493 & Soma & 2398708 & Soma & 2260010 \\
\hline Contagem & 105438 & Contagem & 109415 & Contagem & 109414 \\
\hline $\begin{array}{l}\text { Nível de confiança } \\
(95,0 \%)\end{array}$ & 0,02168 & $\begin{array}{l}\text { Nível de confiança } \\
(95,0 \%)\end{array}$ & 0,021989 & $\begin{array}{l}\text { Nível de confiança } \\
(95,0 \%)\end{array}$ & 0,020725 \\
\hline
\end{tabular}

Tabela A.7 - Amplitude térmica (AT) da série 2001-2013: Estatística Descritiva.

\begin{tabular}{lr}
\hline \multicolumn{2}{c}{ Amplitude Térmica } \\
\hline \hline Média & 10,1176772 \\
Erro padrão & 0,03833013 \\
Mediana & 10,1 \\
Modo & 10 \\
Desvio padrão & 2,62330495 \\
Variância da amostra & 6,88172888 \\
Curtose & 0,45120106 \\
Assimetria & $-0,2720155$ \\
Intervalo & 18,2 \\
Mínimo & 0,1 \\
Máximo & 18,3 \\
Soma & 47391,2 \\
Contagem & 4684 \\
\hline
\end{tabular}


Tabela A.8 - Nebulosidade da série 2001-2013: Estatística Descritiva.

\begin{tabular}{cc}
\hline Nebulosidade & \\
\hline \hline Média & 5,824801 \\
Erro padrão & 0,029933 \\
Mediana & 7 \\
Modo & 10 \\
Desvio padrão & 3,570861 \\
Variância da amostra & 12,75105 \\
Curtose & $-1,30845$ \\
Assimetria & $-0,41823$ \\
Intervalo & 10 \\
Mínimo & 0 \\
Máximo & 10 \\
Soma & 82892,75 \\
Contagem & 14231 \\
Nível de confiança $(95,0 \%)$ & 0,058673 \\
\hline
\end{tabular}

Tabela A.9 - Velocidade dos ventos da série 2001-2013: Estatística Descritiva.

\begin{tabular}{lr}
\hline \multicolumn{2}{c}{ Velocidade dos ventos } \\
\hline \hline Média & 2,458170642 \\
Erro padrão & 0,003888249 \\
Mediana & 2,4 \\
Modo & 1,8 \\
Desvio padrão & 1,283711188 \\
Variância da & \\
amostra & 1,647914414 \\
Curtose & $-0,072780809$ \\
Assimetria & 0,392352435 \\
Intervalo & 10,4 \\
Mínimo & 0 \\
Máximo & 10,4 \\
Soma & 267940,6 \\
Contagem & 109000 \\
\hline
\end{tabular}


Quadro A.1 - Regime de vento: frequência de ocorrência da velocidade dos ventos diurnos e ventos noturnos.

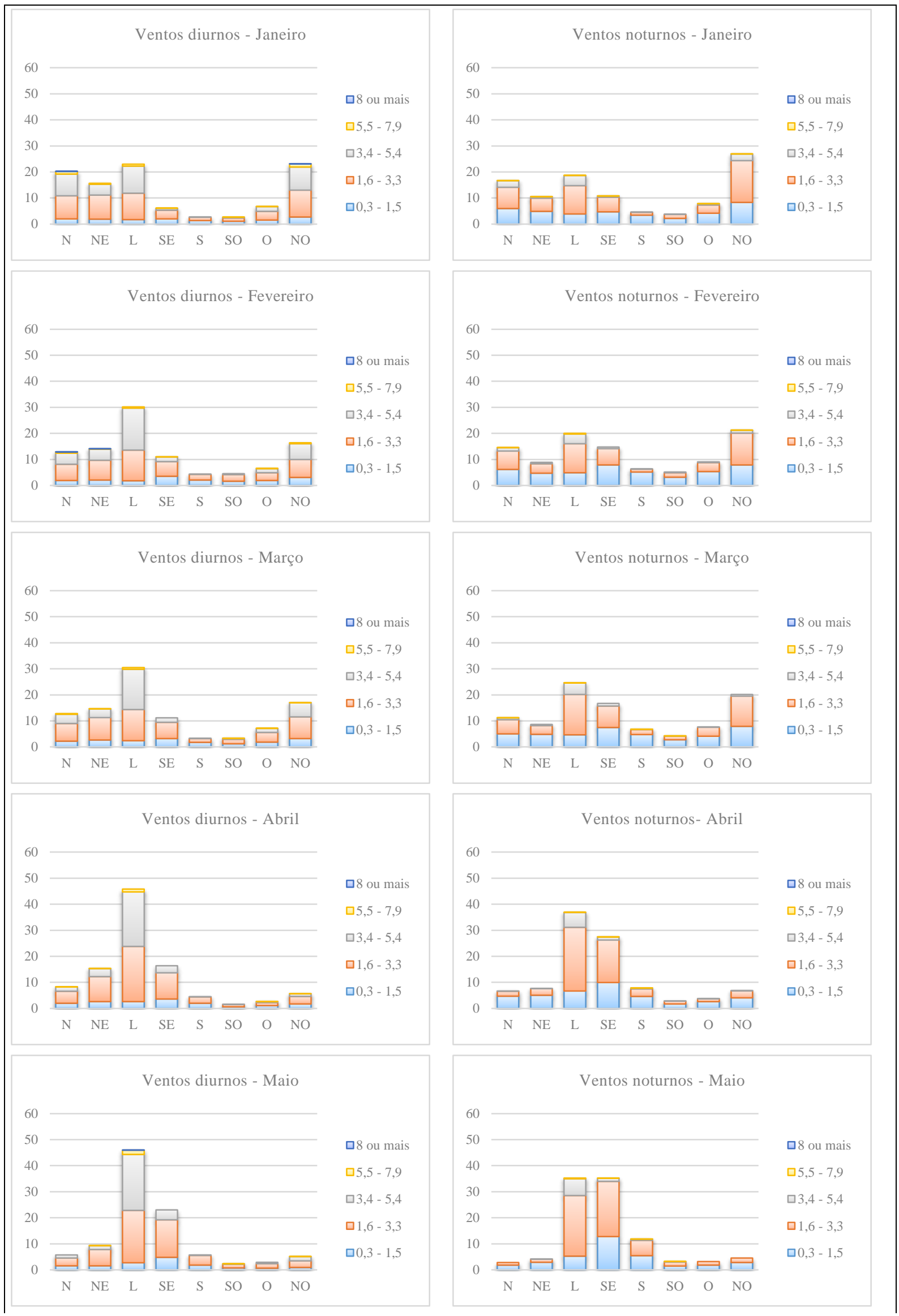



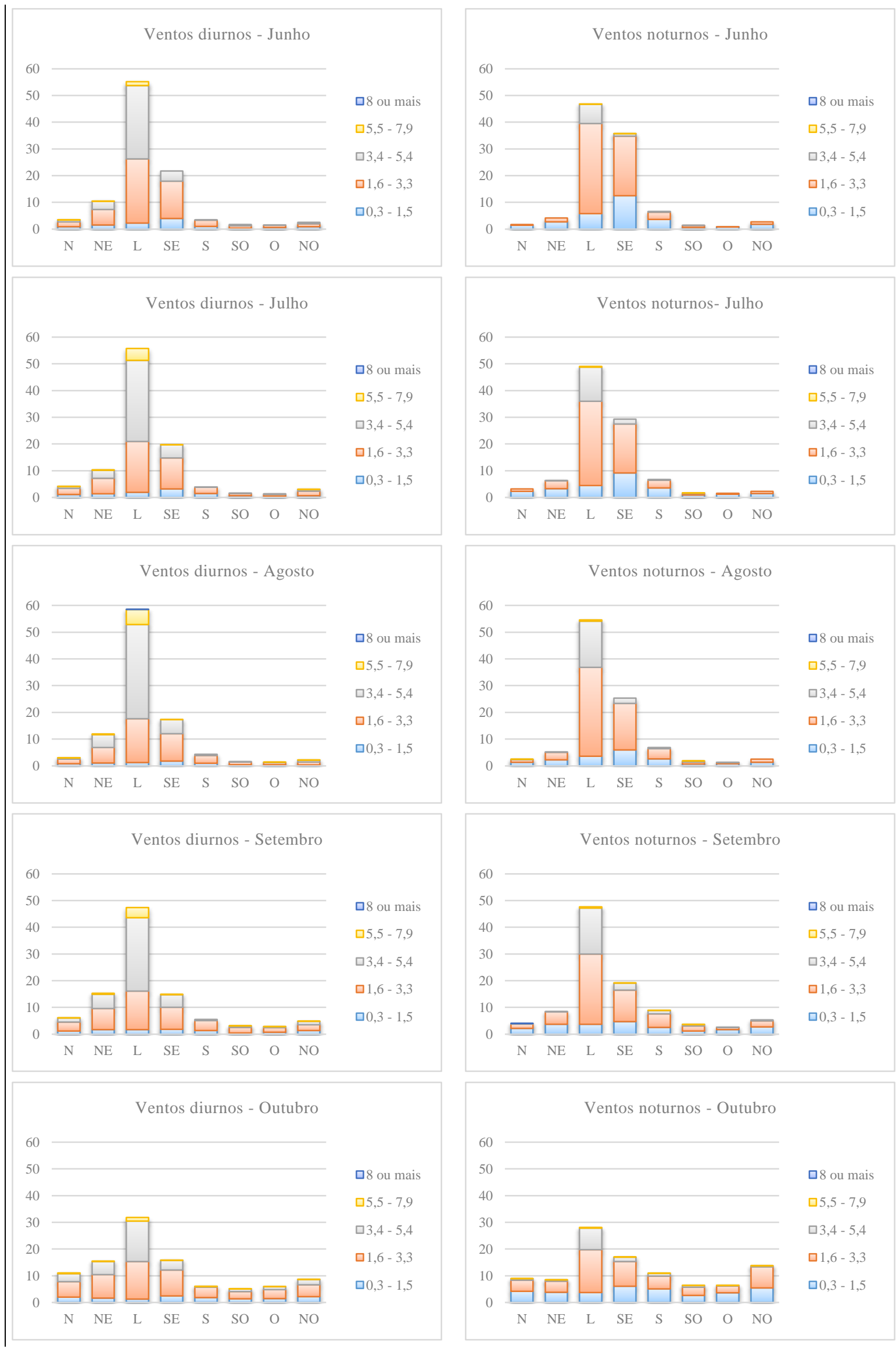


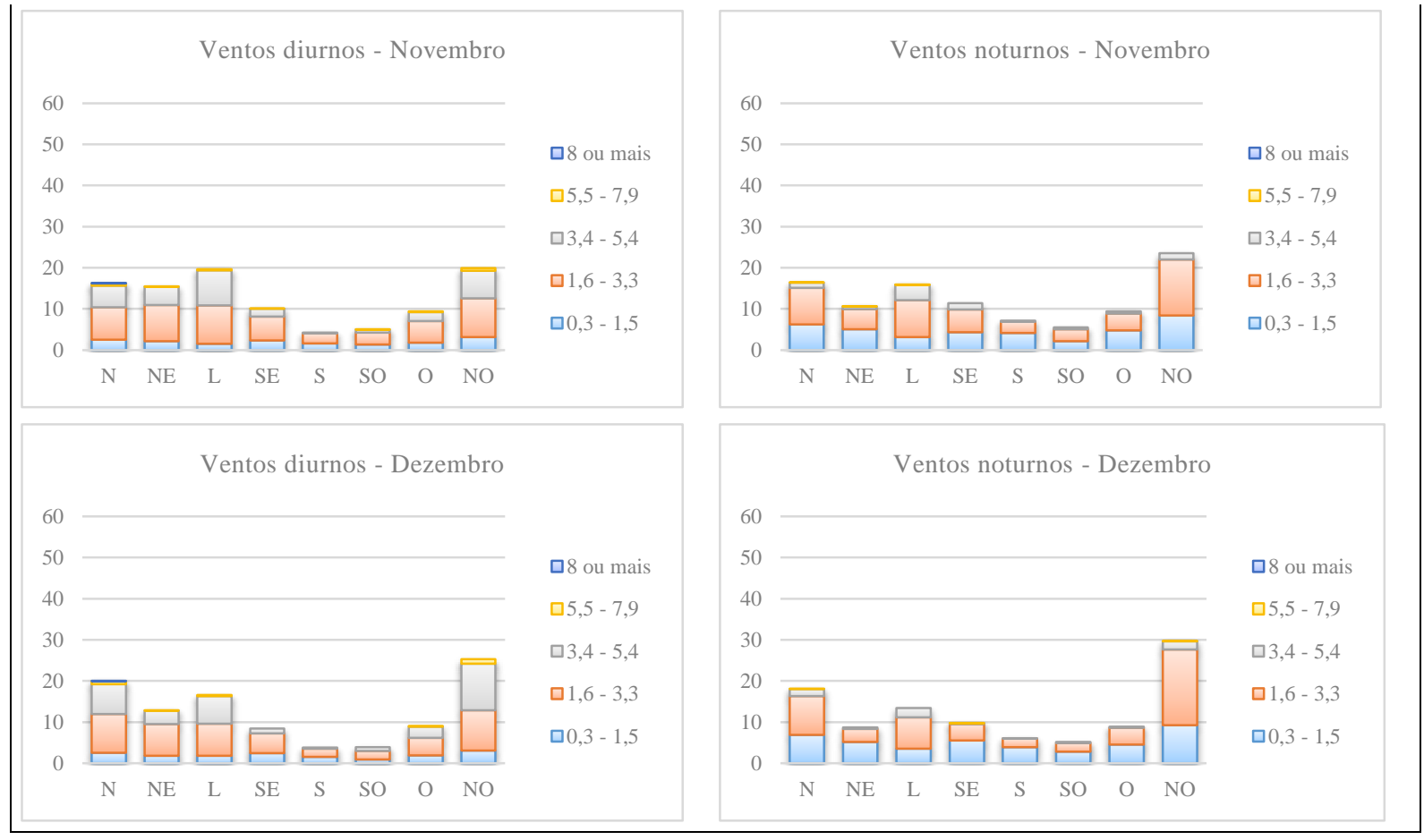


APÊNDICE B

TABELAS E QUADROS COMPLEMENTARES DO CAPÍTULO V

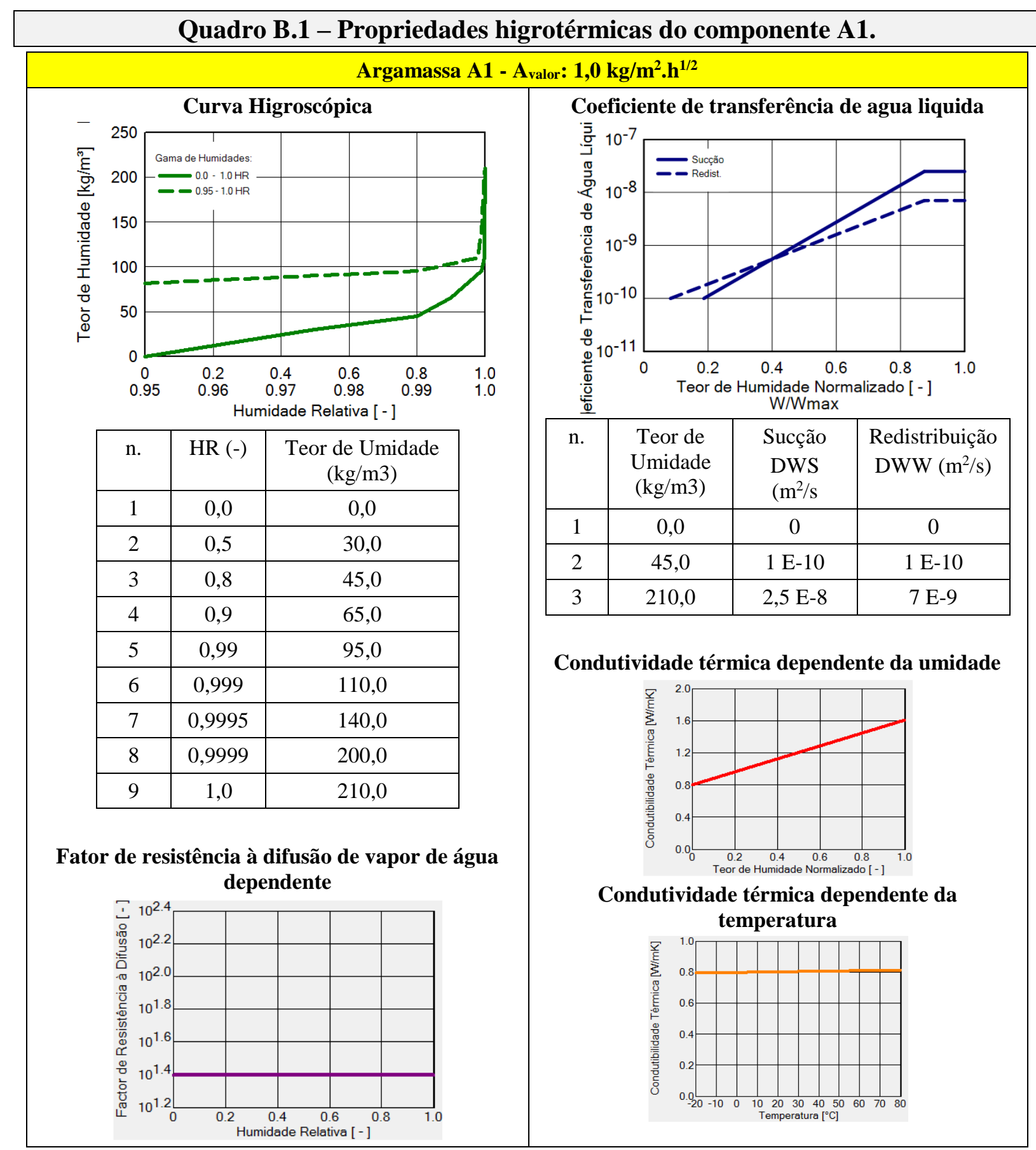

Fonte: WUFI PRO 5.3 (2013). 


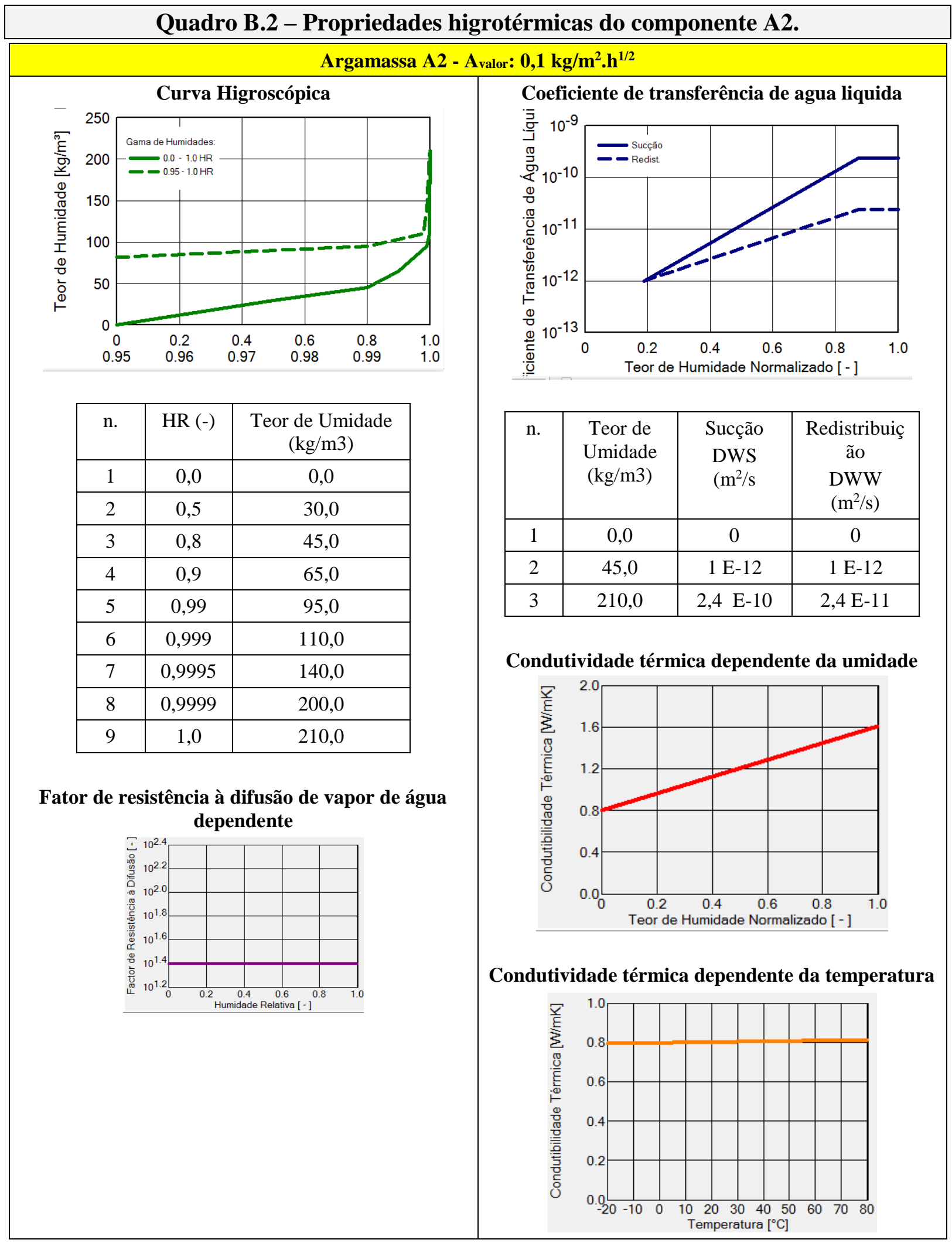

Fonte: WUFI PRO 5.3 (2013). 


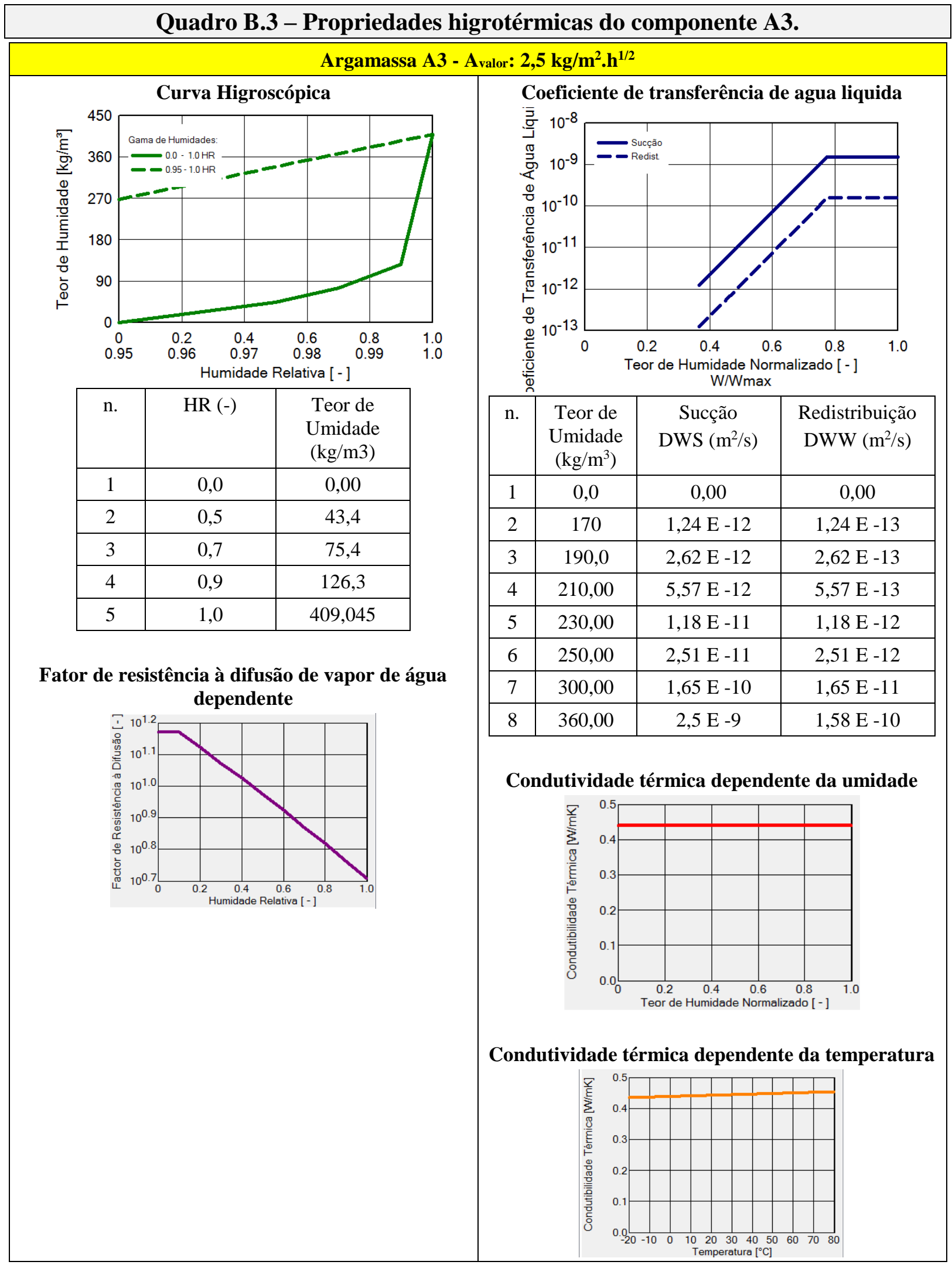

Fonte: WUFI PRO 5.3 (2013). 


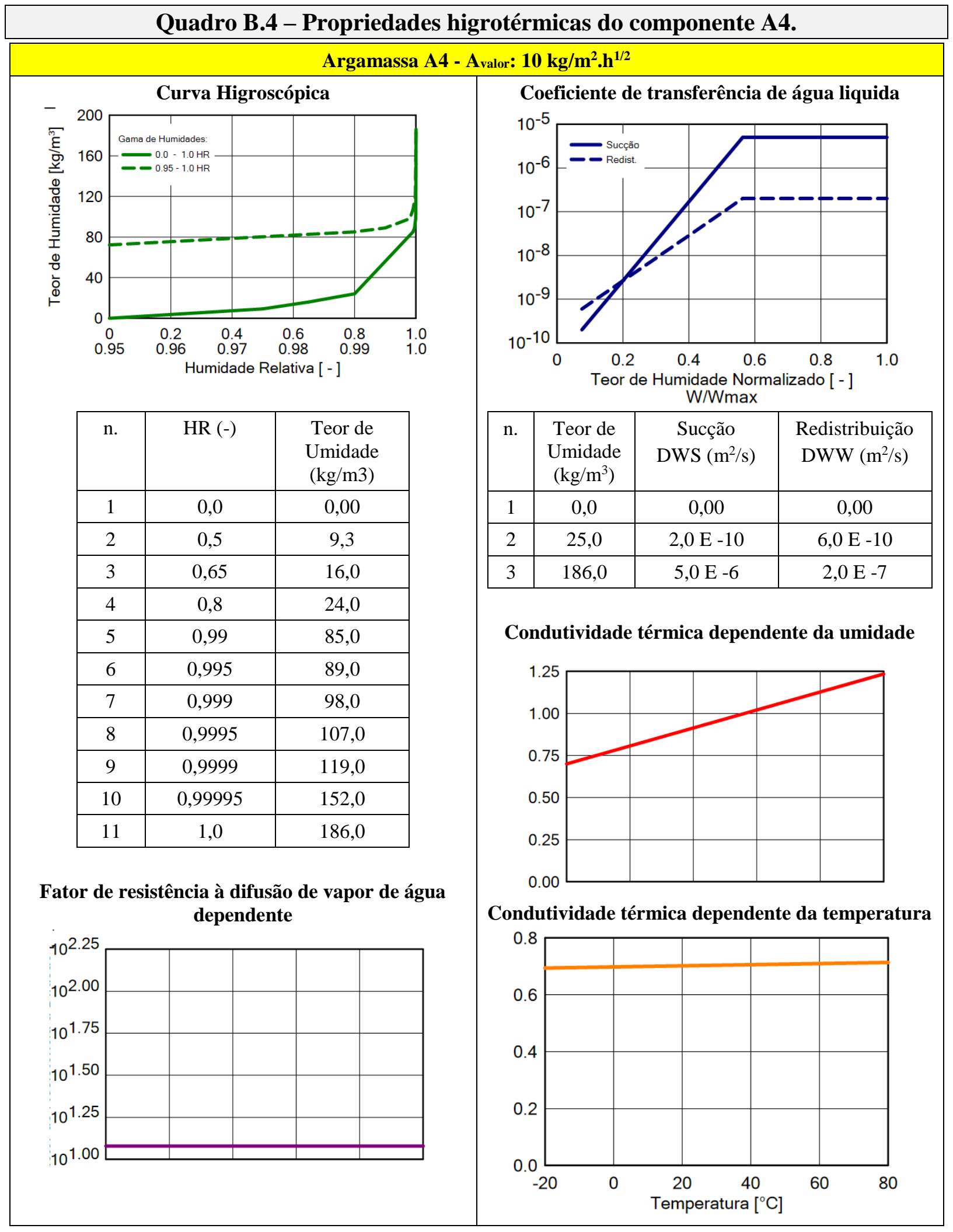

Fonte: WUFI PRO 5.3 (2013). 


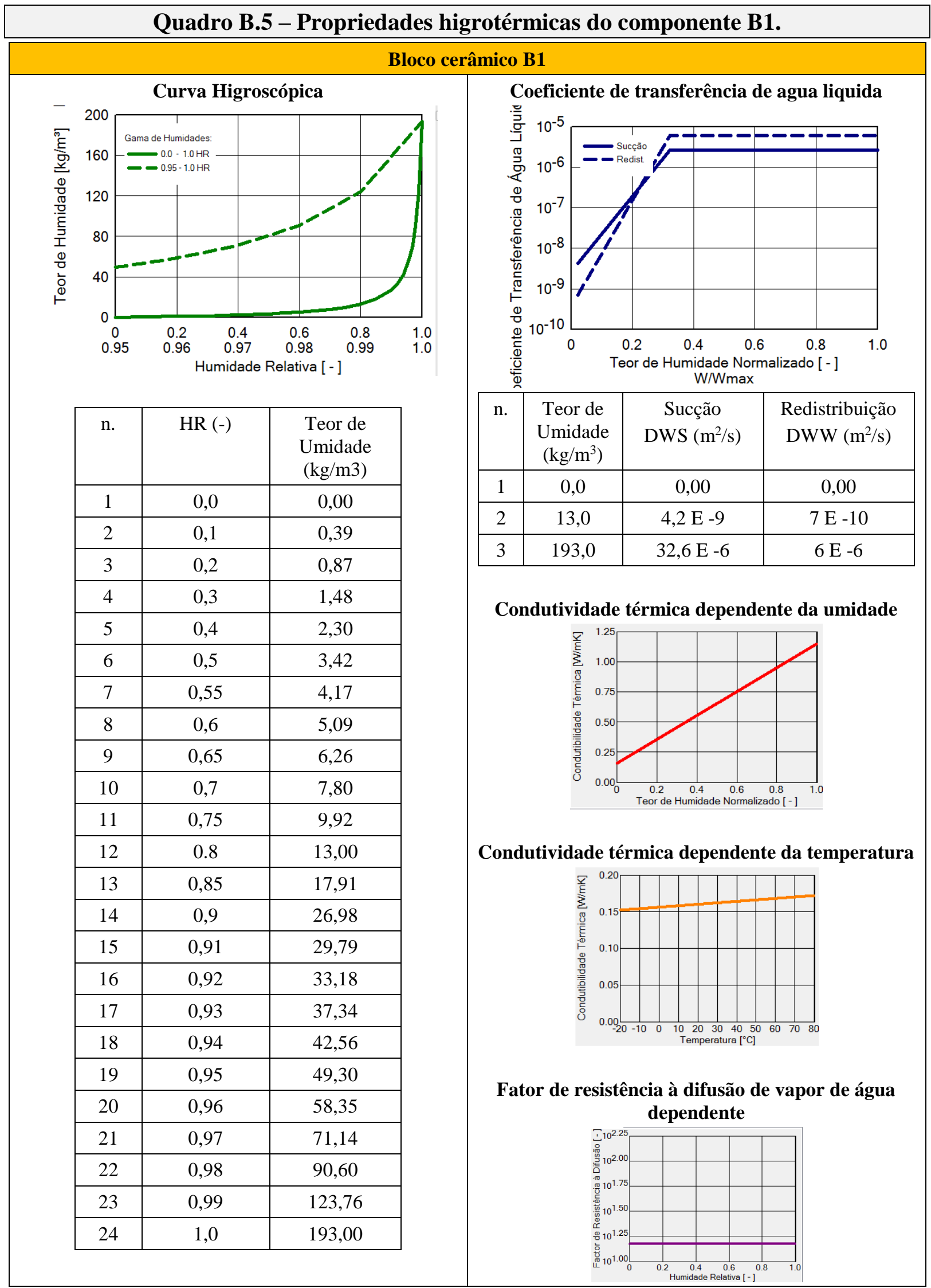

Fonte: WUFI PRO 5.3 (2013). 


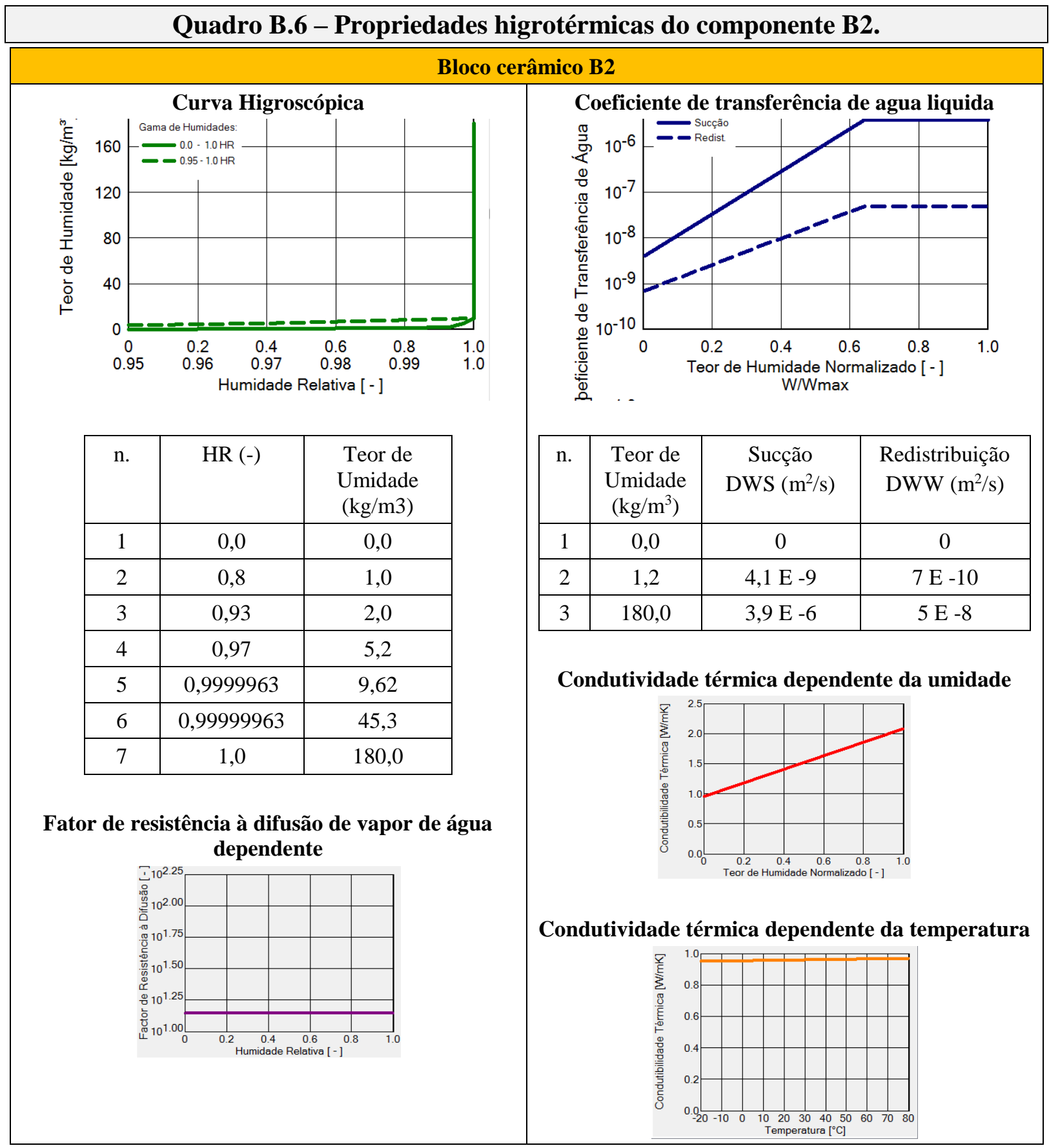

Fonte: WUFI PRO 5.3 (2013). 
Quadro B.7 - Propriedades higrotérmicas do componente B3.

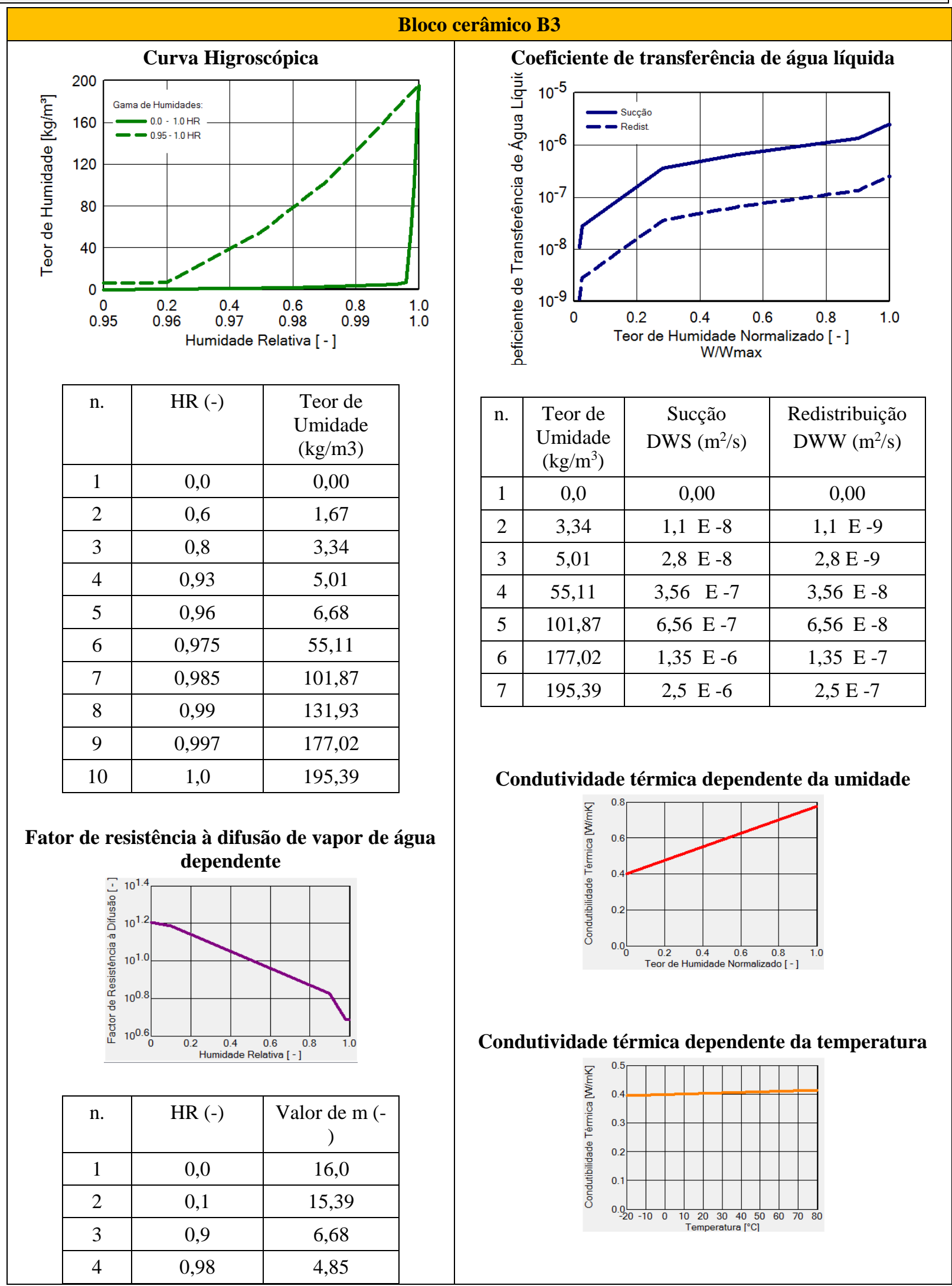

Fonte: WUFI PRO 5.3 (2013). 
Quadro B.8 - Estrutura da matriz de análise estatística utilizada para a ANOVA three way.

\begin{tabular}{|c|c|c|c|c|c|}
\hline Período & $\begin{array}{c}\text { BOrientação da } \\
\text { fachada }\end{array}$ & $\begin{array}{c}\text { Sistema de fachada } \\
\text { SC } \\
\end{array}$ & Dia & $\begin{array}{l}\text { Teor de umidade do } \\
\text { elemento construtivo }\end{array}$ & $\begin{array}{l}\text { Amplitude térmica diária na } \\
\text { superfície da fachada }\end{array}$ \\
\hline \multirow{53}{*}{ Chuvoso } & \multirow[t]{6}{*}{ 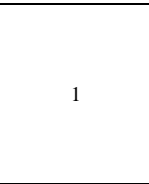 } & SC1 & & & \\
\hline & & $\begin{array}{l}\mathrm{SC} 2 \\
\mathrm{SC3}\end{array}$ & & & \\
\hline & & $\begin{array}{l}\mathrm{SC} 3 \\
\mathrm{SC} 4\end{array}$ & & & \\
\hline & & SC5 & & & \\
\hline & & SC6 & & & \\
\hline & & SC7 & & & \\
\hline & \multirow{7}{*}{2} & SC1 & & & \\
\hline & & $\mathrm{SC} 2$ & & & \\
\hline & & $\mathrm{SC} 3$ & & & \\
\hline & & SC4 & & & \\
\hline & & SC5 & & & \\
\hline & & SC6 & & & \\
\hline & & $\begin{array}{lll}\text { SC7 } \\
\text { S7 }\end{array}$ & & & \\
\hline & & $\begin{array}{ll}\mathrm{SC1} \\
\mathrm{S} 21\end{array}$ & & & \\
\hline & & $\frac{\mathrm{SC}_{2}}{\mathrm{~S} \mathrm{C}_{3}}-1-10$ & & & \\
\hline & 3 & $\frac{\mathrm{SC} 3}{\mathrm{SC} 4}$ & & & \\
\hline & & SC5 & & & \\
\hline & & SC6 & & & \\
\hline & & SC7 & & & \\
\hline & & $\mathrm{SC} 1$ & & & \\
\hline & & $\mathrm{SC} 2$ & & & \\
\hline & & SC3 & & & \\
\hline & 4 & SC4 & & & \\
\hline & & SC5 & & & \\
\hline & & SC6 & & & \\
\hline & & SC7 & 182 dias correspondentes & 182 dados de média diária & 182 dados de amplitude \\
\hline & & $\begin{array}{l}\mathrm{SC1} \\
\mathrm{S} 21\end{array}$ & aos meses chuvosos & de teor de umidade & $\begin{array}{l}\text { termica duarla na superficle } \\
\text { da fachada }\end{array}$ \\
\hline & & $\begin{array}{l}\mathrm{SC} 2 \\
\mathrm{SC} 3\end{array}$ & & & \\
\hline & 5 & SC4 & & & \\
\hline & & SC5 & & & \\
\hline & & SC6 & & & \\
\hline & & SC7 & & & \\
\hline & & SC1 & & & \\
\hline & & $\mathrm{SC} 2$ & & & \\
\hline & & SC3 & & & \\
\hline & 6 & SC4 & & & \\
\hline & & SC5 & & & \\
\hline & & SC6 & & & \\
\hline & & SC7 & & & \\
\hline & & SC1 & & & \\
\hline & & $\mathrm{SC} 2$ & & & \\
\hline & & $\mathrm{SC} 3$ & & & \\
\hline & 7 & SC4 & & & \\
\hline & & SC5 & & & \\
\hline & & SC6 & & & \\
\hline & & SC7 & & & \\
\hline & & $\mathrm{SC1}$ & & & \\
\hline & & $\mathrm{SC2}$ & & & \\
\hline & & $\mathrm{SC} 3$ & & & \\
\hline & 8 & SC4 & & & \\
\hline & & SC5 & & & \\
\hline & & SC6 & & & \\
\hline & & $\mathrm{SC} 7$ & & & \\
\hline Período & $\begin{array}{l}\text { Orientação da } \\
\text { fachada }\end{array}$ & $\begin{array}{l}\text { Sistema de fachada } \\
\text { SC }\end{array}$ & Dia & $\begin{array}{l}\text { Teor de umidade do } \\
\text { elemento construtivo }\end{array}$ & $\begin{array}{l}\text { Amplitude térmica diária na } \\
\text { superfície da fachada }\end{array}$ \\
\hline & & SC1 & & & \\
\hline & & $\mathrm{SC} 2$ & & & \\
\hline & & $\mathrm{SC} 3$ & & & \\
\hline & 1 & SC4 & & & \\
\hline & & SC5 & & & \\
\hline & & SC6 & & & \\
\hline & & SC7 & & & \\
\hline & & $\mathrm{SC} 1$ & & & \\
\hline & & $\mathrm{SC2}$ & & & \\
\hline & & $\mathrm{SC} 3$ & & & \\
\hline & 2 & SC4 & & & \\
\hline & & SC5 & & & \\
\hline & & SC6 & & & \\
\hline & & SC7 & & & \\
\hline & & $\mathrm{SC} 1$ & & & 183 dados de amplitude \\
\hline Seco & & $\mathrm{SC} 2$ & 183 dias correspondentes & 183 dados de média diária & 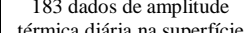 \\
\hline & & SC3 & aos meses secos & de teor de umidade & termica diaria na supericie \\
\hline & 3 & SC4 & & & \\
\hline & & SC5 & & & \\
\hline & & SC6 & & & \\
\hline & & SC7 & & & \\
\hline & & $\mathrm{SC} 1$ & & & \\
\hline & & $\mathrm{SC} 2$ & & & \\
\hline & & SC3 & & & \\
\hline & 4 & SC4 & & & \\
\hline & & SC5 & & & \\
\hline & & SC6 & & & \\
\hline & & SC7 & & & \\
\hline & & $\mathrm{SC1}$ & & & \\
\hline & 5 & $\mathrm{SC} 2$ & & & \\
\hline & 3 & $\begin{array}{lll}\mathrm{SC} 3 \\
\mathrm{SC} 4\end{array}$ & & & \\
\hline & & $\mathrm{SC} 4$ & & & \\
\hline
\end{tabular}




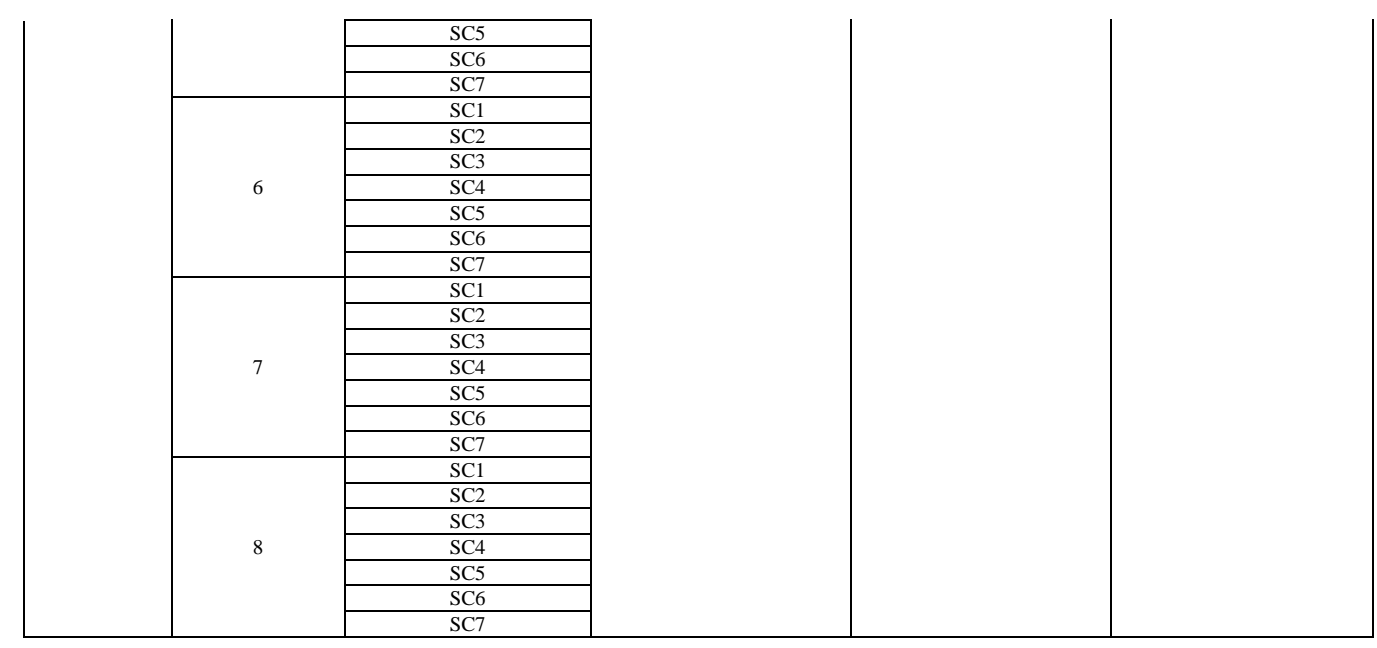


APÊNDICE C

FIGURAS, TABELAS E QUADROS COMPLEMENTARES DO CAPÍTULO VI

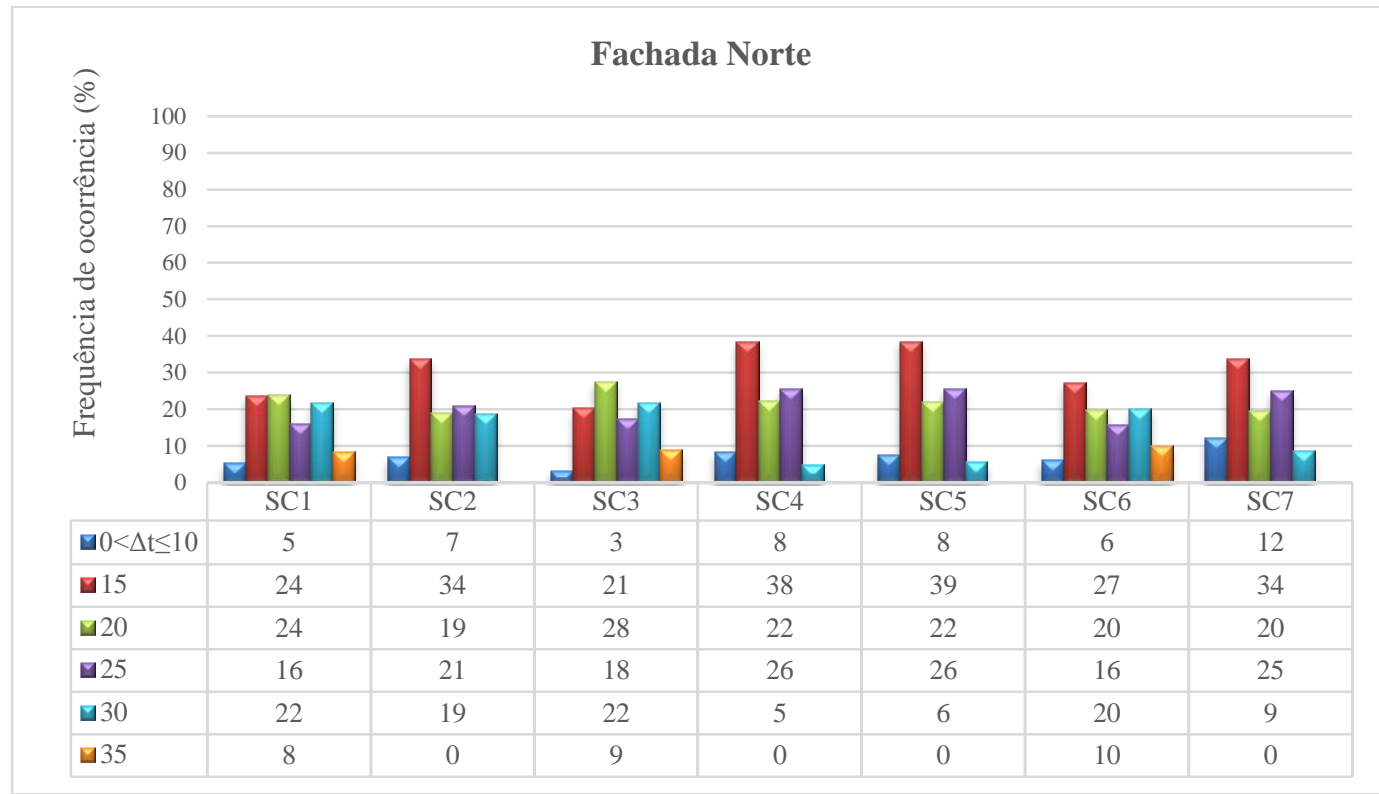

Figura C.1 - Frequência de ocorrência (\%) da amplitude térmica na superfície do sistema construtivo da fachada Norte.

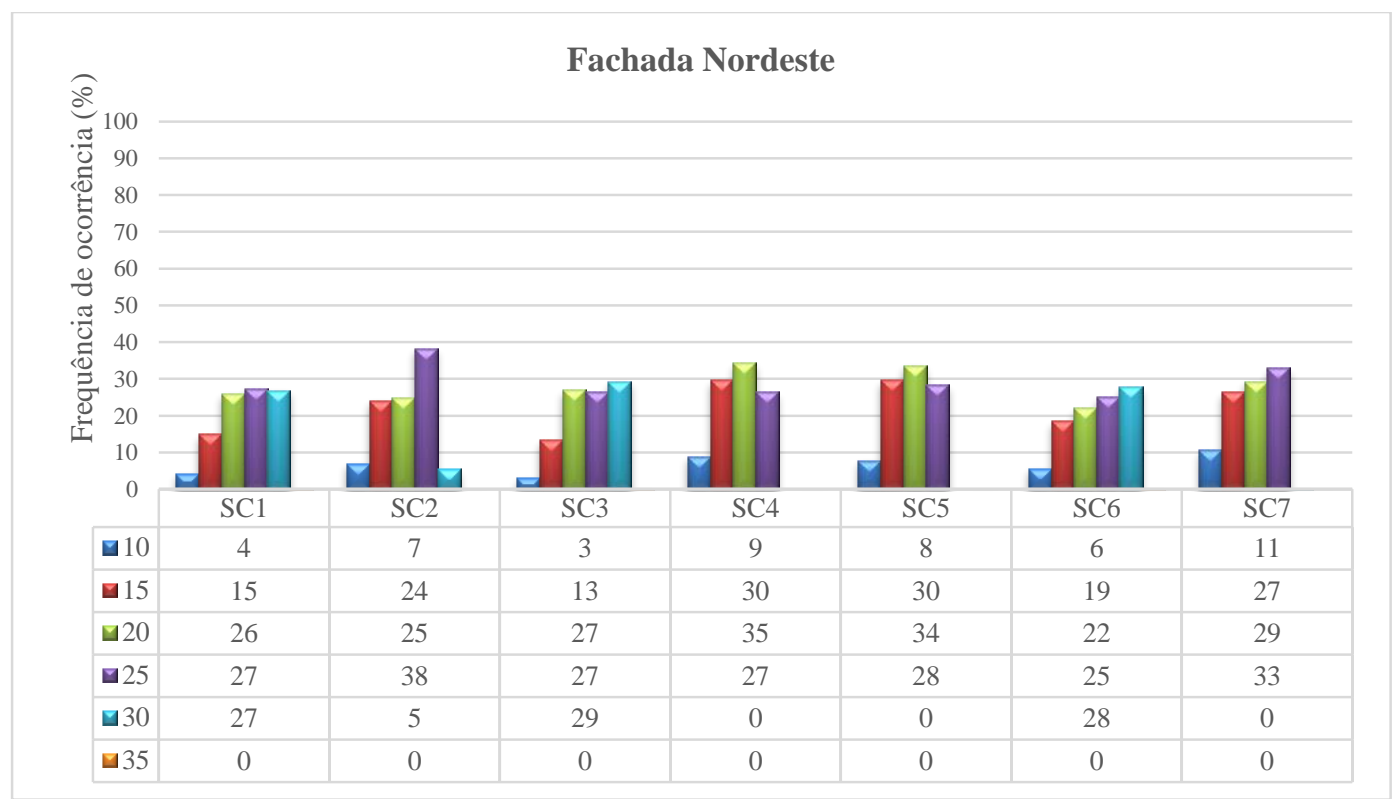

Figura C.2 - Frequência de ocorrência (\%) da amplitude térmica na superfície do sistema construtivo da fachada Nordeste. 


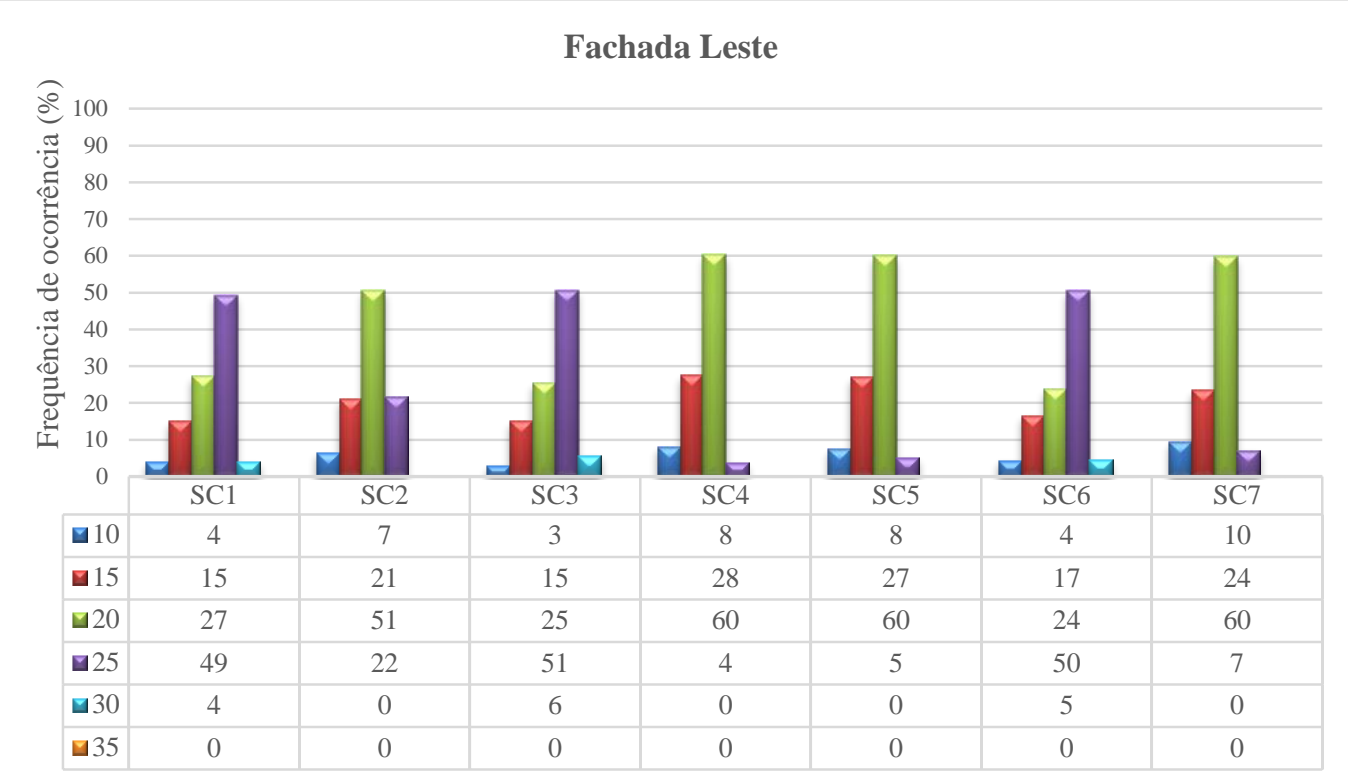

Figura C.3 - Frequência de ocorrência (\%) da amplitude térmica na superfície do sistema construtivo da fachada Leste.

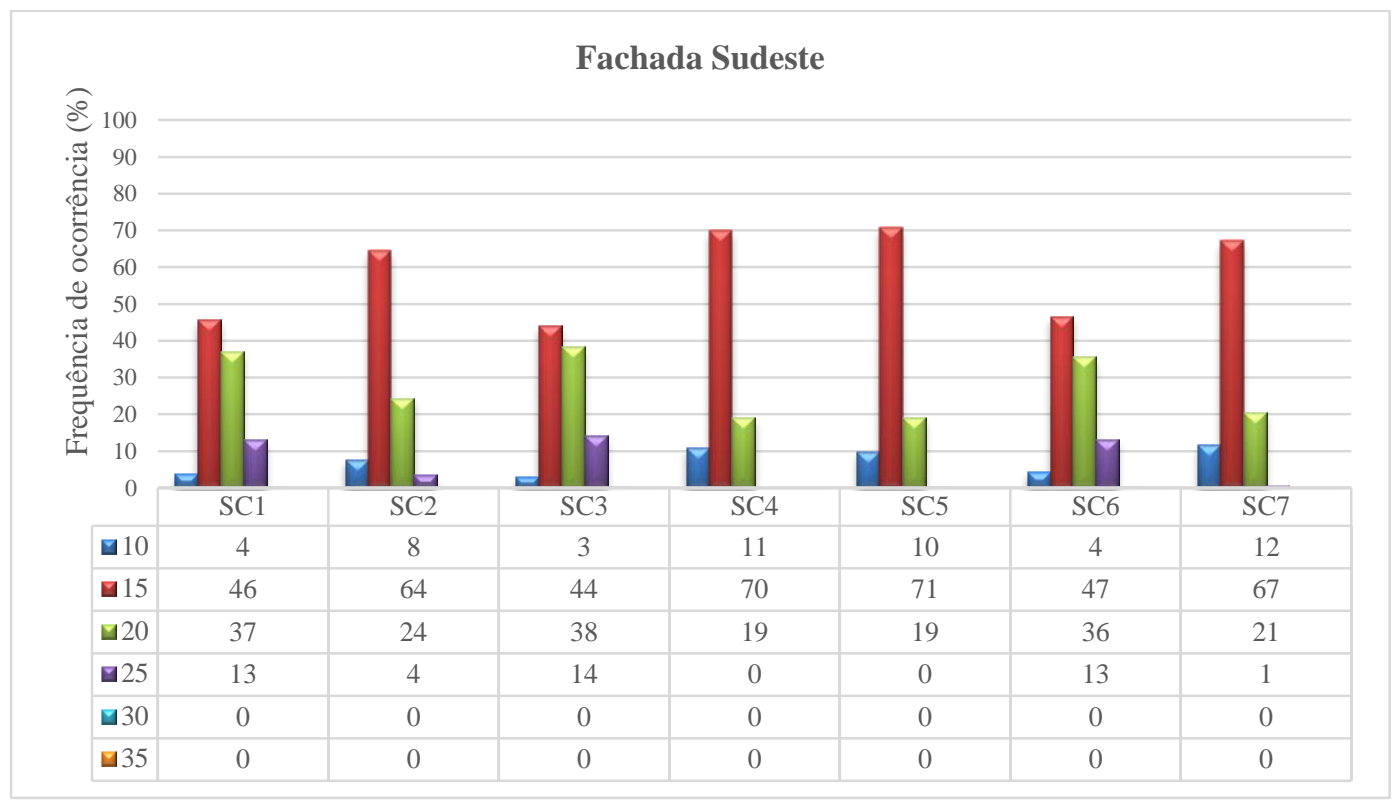

Figura C.4 - Frequência de ocorrência (\%) da amplitude térmica na superfície do sistema construtivo da fachada Sudeste. 


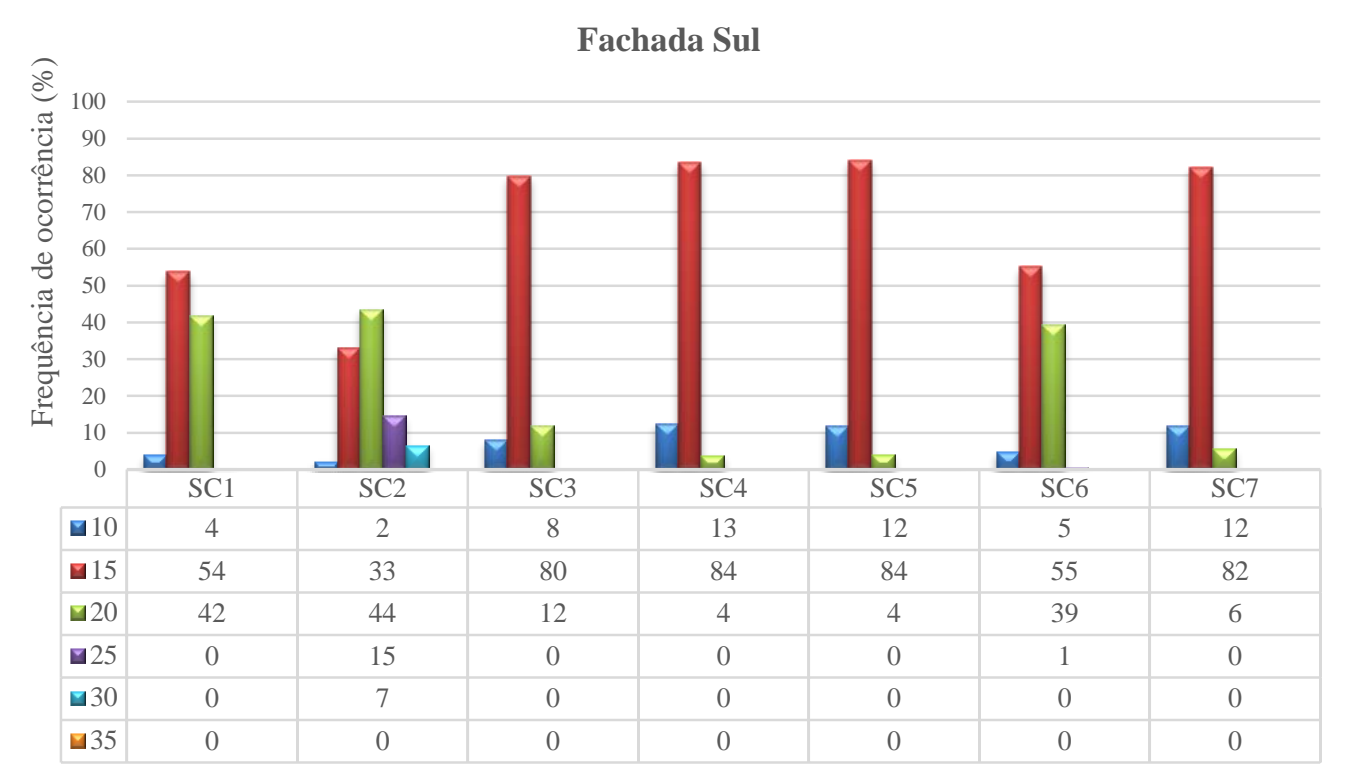

Figura C.5 - Frequência de ocorrência (\%) da amplitude térmica na superfície do sistema construtivo da fachada Sul.

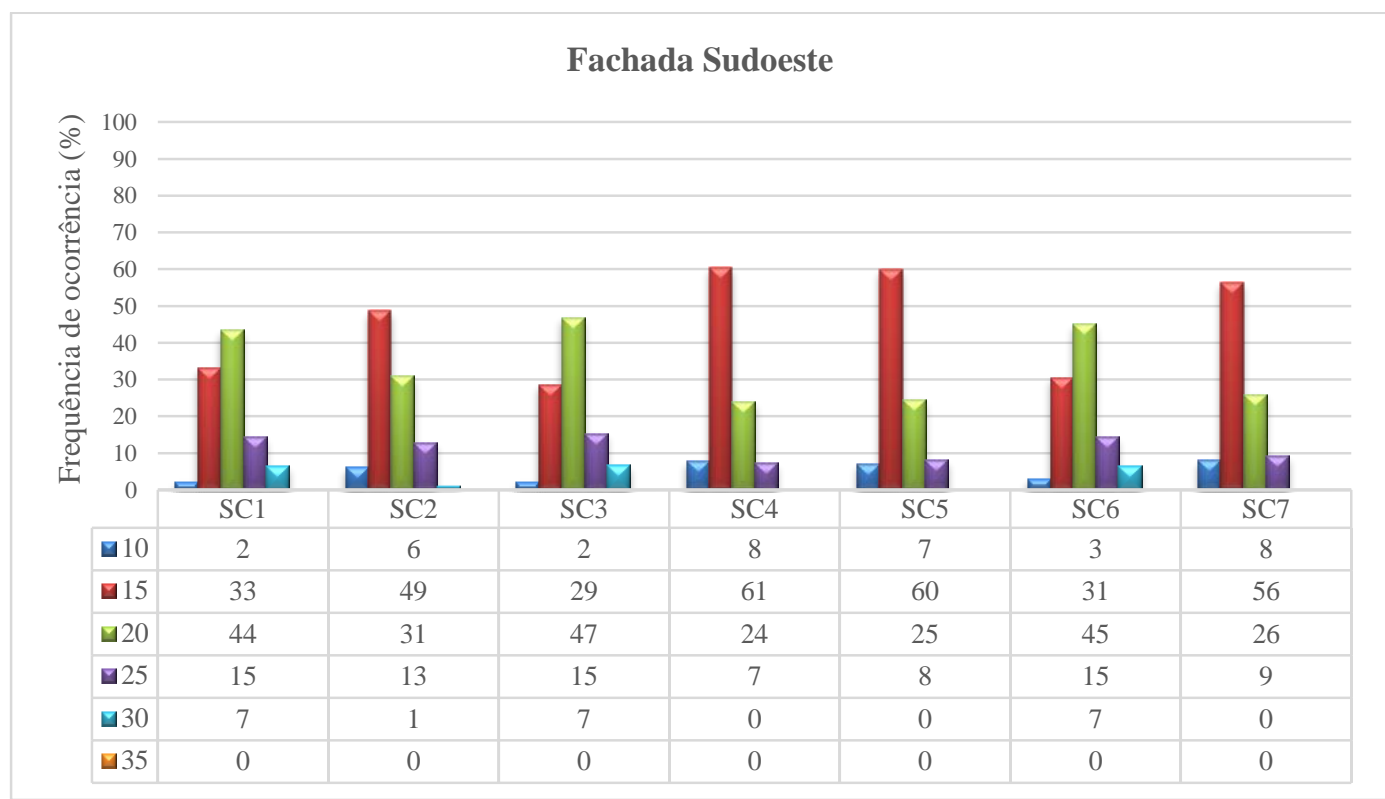

Figura C.6 - Frequência de ocorrência (\%) da amplitude térmica na superfície do sistema construtivo da fachada Sudoeste. 


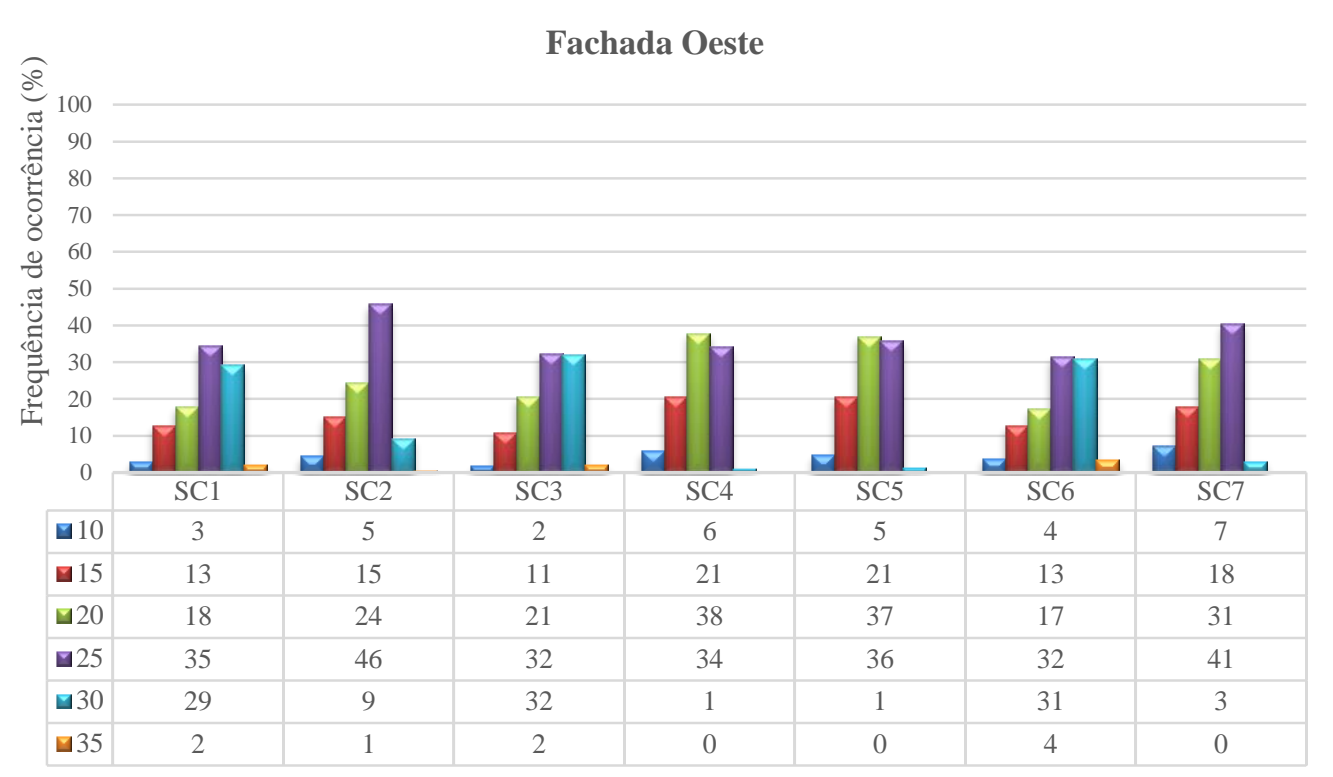

Figura C.7 - Frequência de ocorrência (\%) da amplitude térmica na superfície do sistema construtivo da fachada Oeste.

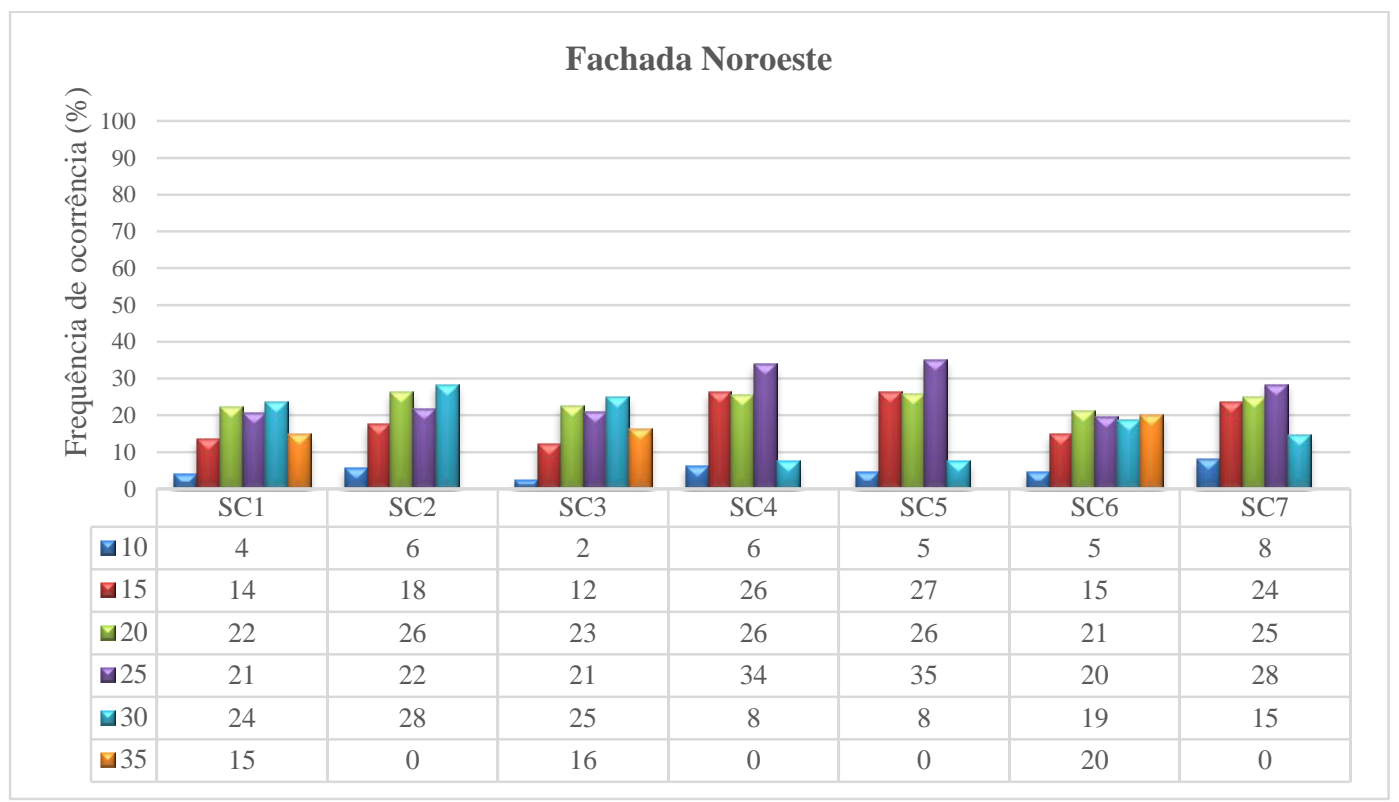

Figura C.8 - Frequência de ocorrência (\%) da amplitude térmica na superfície do sistema construtivo da fachada Noroeste. 
Tabela C.1 - Frequência de ocorrência das variações de temperatura superficial para $\Delta$ Tch $>8$, em intervalos de tempo de 1 hora, para cada orientação de fachada ao longo de um ano típico.

\begin{tabular}{ccccccccc}
\hline & Norte & Nordeste & Leste & Sudeste & Sul & Sudoeste & Oeste & Noroeste \\
\hline \hline SC1 & $0,87 \%$ & $2,47 \%$ & $2,41 \%$ & $0,56 \%$ & $0,13 \%$ & $0,48 \%$ & $2,55 \%$ & $2,39 \%$ \\
SC2 & $0,33 \%$ & $1,38 \%$ & $1,42 \%$ & $0,33 \%$ & $0,06 \%$ & $0,46 \%$ & $2,56 \%$ & $2,43 \%$ \\
SC3 & $0,99 \%$ & $2,66 \%$ & $2,56 \%$ & $0,59 \%$ & $0,13 \%$ & $0,64 \%$ & $2,80 \%$ & $2,51 \%$ \\
SC4 & $0,03 \%$ & $0,24 \%$ & $0,42 \%$ & $0,11 \%$ & $0,03 \%$ & $0,17 \%$ & $1,20 \%$ & $1,43 \%$ \\
SC5 & $0,07 \%$ & $0,26 \%$ & $0,47 \%$ & $0,16 \%$ & $0,05 \%$ & $0,19 \%$ & $1,34 \%$ & $1,52 \%$ \\
SC6 & $1,18 \%$ & $2,57 \%$ & $2,67 \%$ & $0,74 \%$ & $0,11 \%$ & $0,73 \%$ & $3,33 \%$ & $2,64 \%$ \\
SC7 & $0,06 \%$ & $0,65 \%$ & $0,79 \%$ & $0,21 \%$ & $0,05 \%$ & $0,32 \%$ & $1,93 \%$ & $2,17 \%$ \\
\hline
\end{tabular}

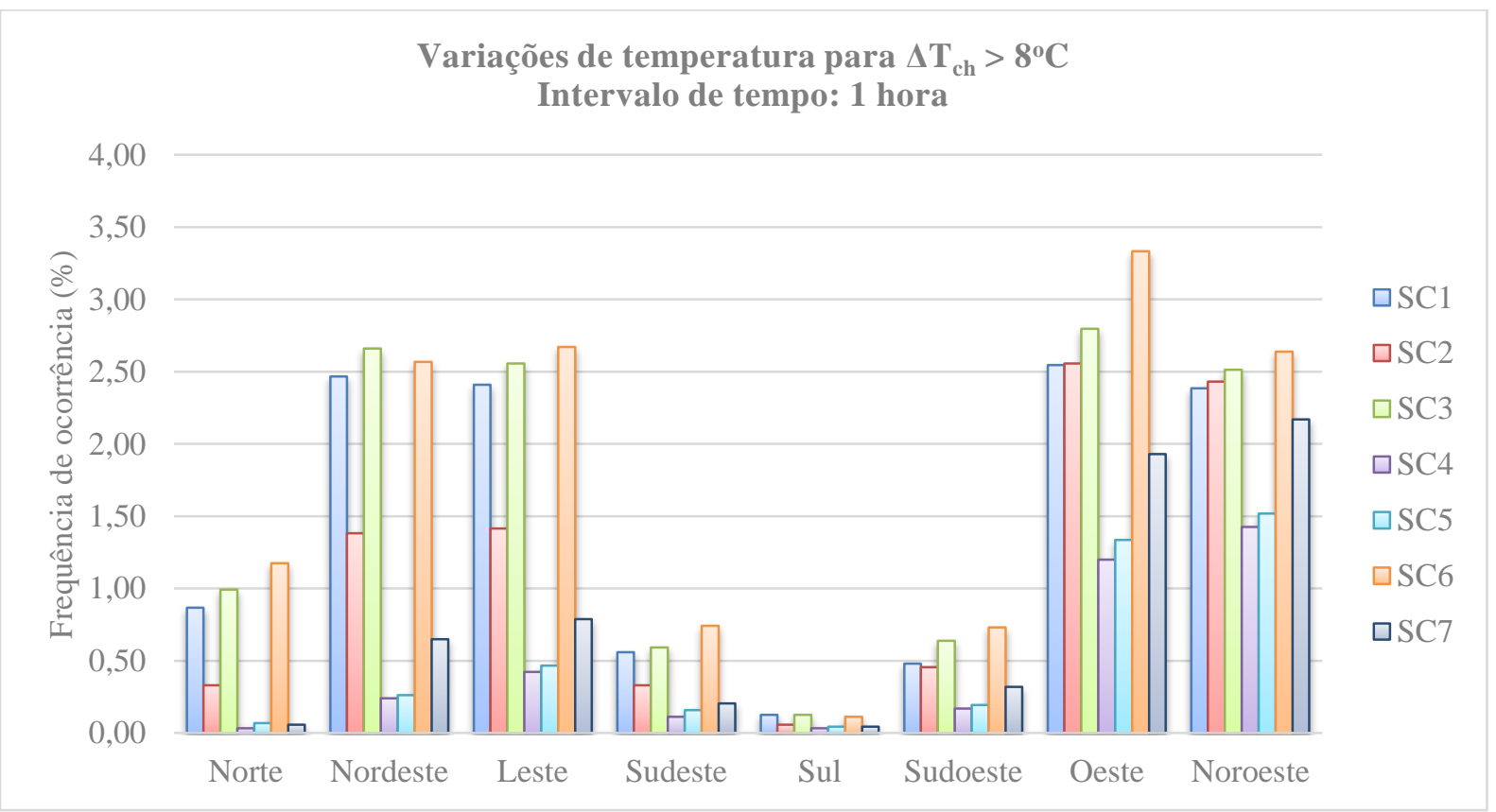

Figura C.9 - Frequência de ocorrência da variação térmica $\Delta \mathrm{T}>8 \circ \mathrm{C}$ para intervalo de tempo de 1 hora, em cada orientação de fachada. 
Tabela C.2 - Frequência de ocorrência das variações de temperatura superficial para $\Delta$ Tch $>8$, em intervalos de tempo de $\mathbf{2}$ horas, para cada orientação de fachada ao longo de um ano típico.

\begin{tabular}{ccccccccc}
\hline & Norte & Nordeste & Leste & Sudeste & Sul & Sudoeste & Oeste & Noroeste \\
\hline \hline SC1 & $10,90 \%$ & $9,67 \%$ & $8,81 \%$ & $5,39 \%$ & $1,39 \%$ & $3,06 \%$ & $7,83 \%$ & $10,33 \%$ \\
SC2 & $8,30 \%$ & $8,00 \%$ & $7,18 \%$ & $3,67 \%$ & $0,56 \%$ & $2,10 \%$ & $5,91 \%$ & $8,24 \%$ \\
SC3 & $11,38 \%$ & $9,95 \%$ & $8,97 \%$ & $5,63 \%$ & $1,56 \%$ & $3,36 \%$ & $8,48 \%$ & $10,84 \%$ \\
SC4 & $5,74 \%$ & $6,75 \%$ & $6,26 \%$ & $2,66 \%$ & $0,25 \%$ & $1,28 \%$ & $3,94 \%$ & $5,59 \%$ \\
SC5 & $5,87 \%$ & $6,89 \%$ & $6,31 \%$ & $2,76 \%$ & $0,29 \%$ & $1,32 \%$ & $4,13 \%$ & $5,80 \%$ \\
SC6 & $10,85 \%$ & $9,51 \%$ & $8,69 \%$ & $5,34 \%$ & $1,63 \%$ & $3,44 \%$ & $8,44 \%$ & $10,58 \%$ \\
SC7 & $6,57 \%$ & $6,95 \%$ & $6,42 \%$ & $2,98 \%$ & $0,32 \%$ & $1,55 \%$ & $4,66 \%$ & $6,49 \%$ \\
\hline
\end{tabular}

Variações de temperatura para $\Delta \mathrm{Tch}>8^{\circ} \mathrm{C}$

Intervalo de tempo: 2 horas

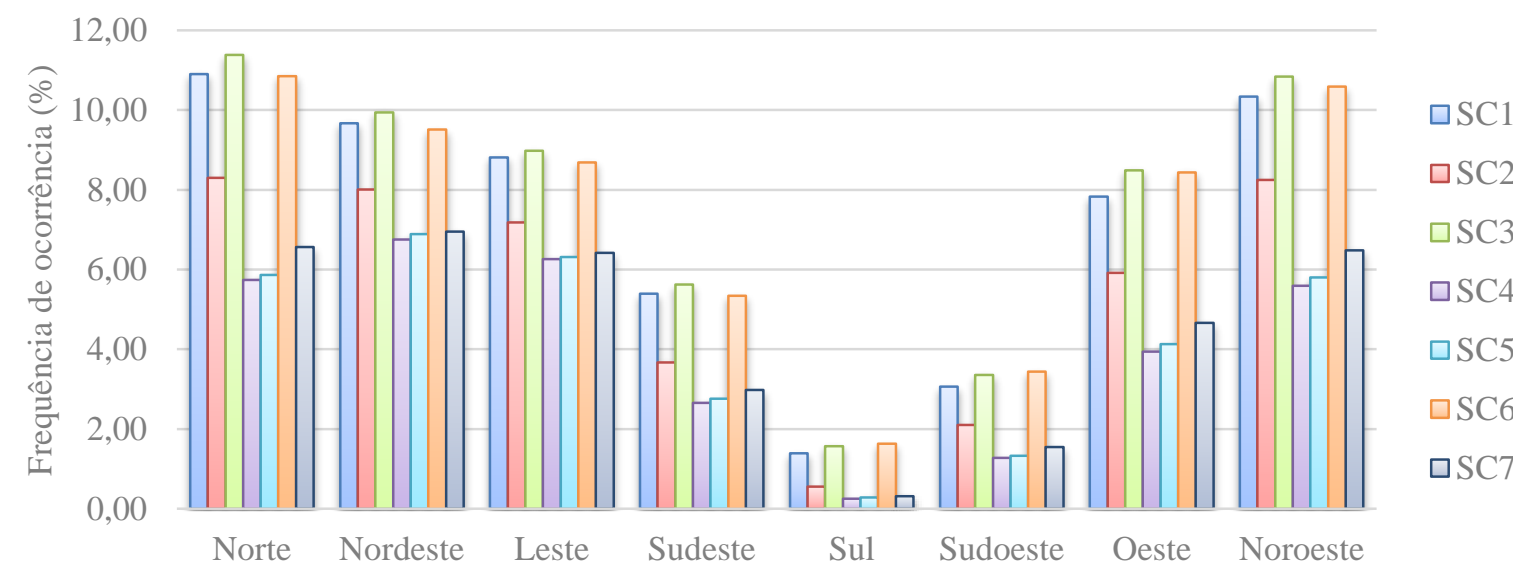

Figura C.10 - Frequência de ocorrência das variações de temperatura superficial para $\Delta$ Tch $>8$, em intervalos de tempo de 2 horas, para cada orientação de fachada ao longo de um ano típico. 
Tabela C.3 - Frequência de ocorrência das variações de temperatura superficial para $\Delta$ Tch $>15$, em intervalos de tempo de $\mathbf{2}$ horas, para cada orientação de fachada ao longo de um ano típico.

\begin{tabular}{ccccccccc}
\hline & Norte & Nordeste & Leste & Sudeste & Sul & Sudoeste & Oeste & Noroeste \\
\hline \hline SC1 & $0,09 \%$ & $1,70 \%$ & $1,34 \%$ & $0,30 \%$ & $0,00 \%$ & $0,08 \%$ & $0,88 \%$ & $1,24 \%$ \\
SC2 & $0,02 \%$ & $0,96 \%$ & $0,50 \%$ & $0,06 \%$ & $0,00 \%$ & $0,05 \%$ & $0,57 \%$ & $0,95 \%$ \\
SC3 & $0,10 \%$ & $1,85 \%$ & $1,75 \%$ & $0,34 \%$ & $0,00 \%$ & $0,09 \%$ & $0,97 \%$ & $1,31 \%$ \\
SC4 & $0,00 \%$ & $0,08 \%$ & $0,10 \%$ & $0,01 \%$ & $0,00 \%$ & $0,01 \%$ & $0,06 \%$ & $0,03 \%$ \\
SC5 & $0,00 \%$ & $0,08 \%$ & $0,13 \%$ & $0,02 \%$ & $0,00 \%$ & $0,01 \%$ & $0,06 \%$ & $0,03 \%$ \\
SC6 & $0,24 \%$ & $1,85 \%$ & $1,79 \%$ & $0,40 \%$ & $0,00 \%$ & $0,15 \%$ & $1,06 \%$ & $1,37 \%$ \\
SC7 & $0,01 \%$ & $0,26 \%$ & $0,18 \%$ & $0,02 \%$ & $0,00 \%$ & $0,02 \%$ & $0,24 \%$ & $0,18 \%$ \\
\hline
\end{tabular}

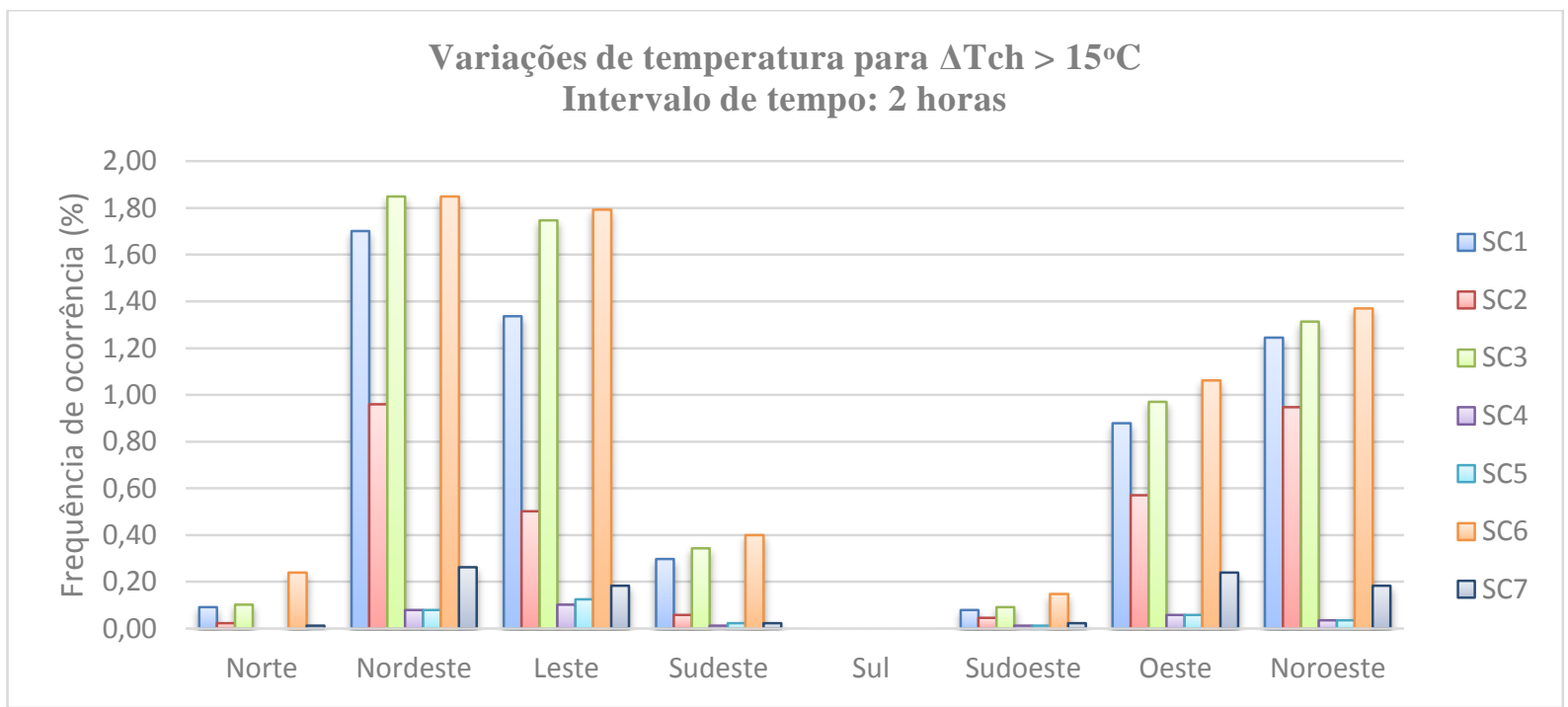

Figura C.11 - Frequência de ocorrência das variações de temperatura superficial para $\Delta$ Tch $>15$, em intervalos de tempo de $\mathbf{2}$ horas, para cada orientação de fachada ao longo de um ano típico. 
Tabela C.4 - Frequência de ocorrência das variações de temperatura superficial para $\Delta$ Tch $>20$, em intervalos de tempo de $\mathbf{2}$ horas, para cada orientação de fachada ao longo de um ano típico.

\begin{tabular}{ccccccccc}
\hline & Norte & Nordeste & Leste & Sudeste & Sul & Sudoeste & Oeste & Noroeste \\
\hline \hline SC1 & $0,00 \%$ & $0,02 \%$ & $0,01 \%$ & $0,00 \%$ & $0,00 \%$ & $0,01 \%$ & $0,02 \%$ & $0,00 \%$ \\
SC2 & $0,00 \%$ & $0,00 \%$ & $0,00 \%$ & $0,00 \%$ & $0,00 \%$ & $0,00 \%$ & $0,02 \%$ & $0,00 \%$ \\
SC3 & $0,00 \%$ & $0,02 \%$ & $0,02 \%$ & $0,01 \%$ & $0,00 \%$ & $0,01 \%$ & $0,02 \%$ & $0,01 \%$ \\
SC4 & $0,00 \%$ & $0,00 \%$ & $0,00 \%$ & $0,00 \%$ & $0,00 \%$ & $0,00 \%$ & $0,00 \%$ & $0,00 \%$ \\
SC5 & $0,00 \%$ & $0,00 \%$ & $0,00 \%$ & $0,00 \%$ & $0,00 \%$ & $0,00 \%$ & $0,00 \%$ & $0,00 \%$ \\
SC6 & $0,00 \%$ & $0,06 \%$ & $0,01 \%$ & $0,00 \%$ & $0,00 \%$ & $0,01 \%$ & $0,05 \%$ & $0,01 \%$ \\
SC7 & $0,00 \%$ & $0,00 \%$ & $0,00 \%$ & $0,00 \%$ & $0,00 \%$ & $0,00 \%$ & $0,00 \%$ & $0,00 \%$ \\
\hline
\end{tabular}

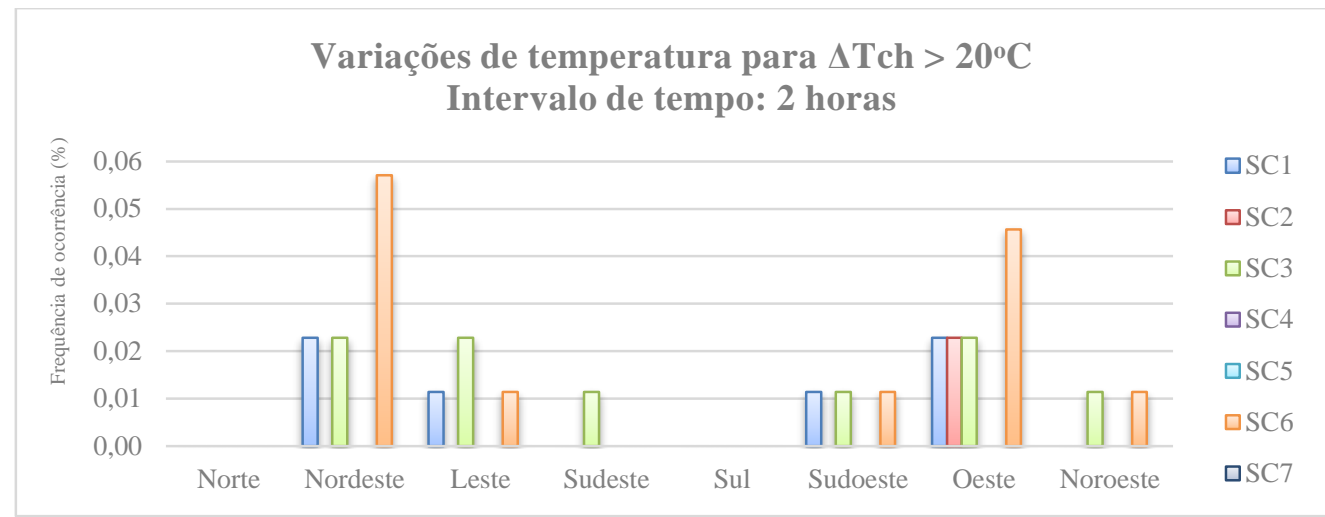

Figura C.12 - Frequência de ocorrência das variações de temperatura superficial para $\Delta$ Tch $>20$, em intervalos de tempo de $\mathbf{2}$ horas, para cada orientação de fachada ao longo de um ano típico. 